\title{
Statistics of Petroleum Exploration in the World Outside the United States and Canada Through 2015
}

Circular 1450 



\section{Statistics of Petroleum Exploration in the World Outside the United States and Canada Through 2015}

By Emil D. Attanasi and Philip A. Freeman

Circular 1450 


\title{
U.S. Department of the Interior \\ DAVID BERNHARDT, Secretary
}

\author{
U.S. Geological Survey \\ James F. Reilly II, Director
}

U.S. Geological Survey, Reston, Virginia: 2019

For more information on the USGS - the Federal source for science about the Earth, its natural and living resources, natural hazards, and the environment-visit https://www.usgs.gov or call 1-888-ASK-USGS.

For an overview of USGS information products, including maps, imagery, and publications,

visit https://store.usgs.gov.

Any use of trade, firm, or product names is for descriptive purposes only and does not imply endorsement by the U.S. Government.

Although this information product, for the most part, is in the public domain, it also may contain copyrighted materials as noted in the text. Permission to reproduce copyrighted items must be secured from the copyright owner.

Suggested citation:

Attanasi, E.D., and Freeman, P.A., 2019, Statistics of petroleum exploration in the world outside the United States and Canada through 2015: U.S. Geological Survey Circular 1450, 237 p., https://doi.org/10.3133/cir1450.

ISSN 2330-5703 (online) 


\section{Contents}

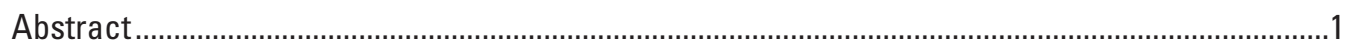

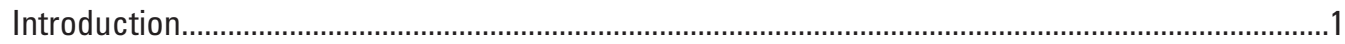

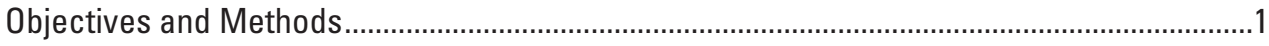

Summary of Findings and Limitations of Study ..................................................................

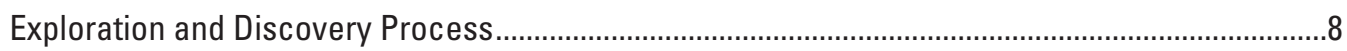

Oil and Gas Exploration: Concepts and Nomenclature …....................................................

Oil and Gas Exploration: Institutional Environment ..............................................................

Inside the United States .............................................................................................

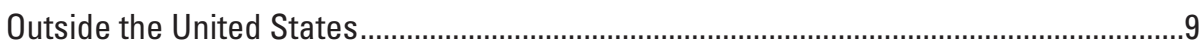

Oil and Gas Discovery Process: Discrete Accumulations ......................................................

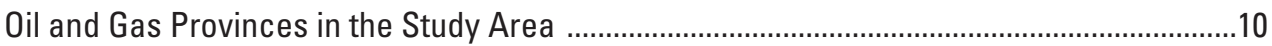

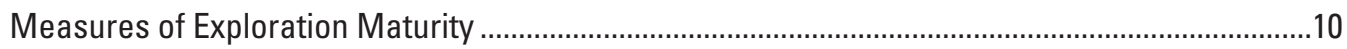

Delineated Prospective Area and Explored Area: Definitions .................................................14

Measuring Productivity of Delineated Prospective Areas .........................................................15

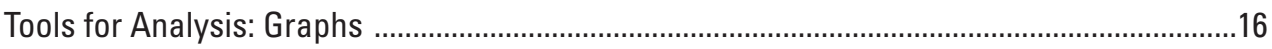

Exploration and Discovery Statistics.........................................................................................

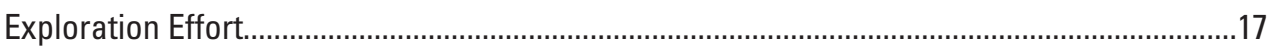

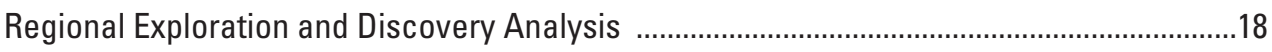

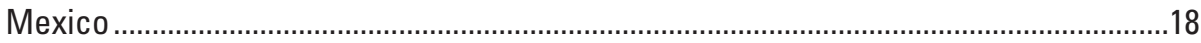

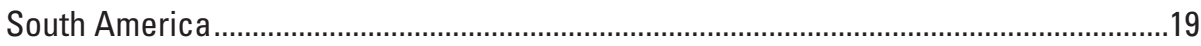

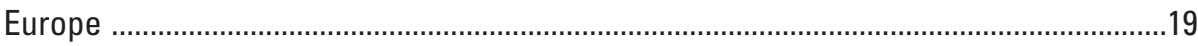

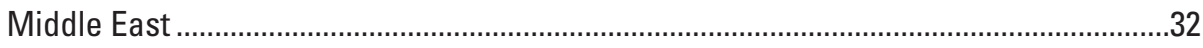

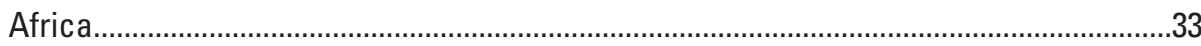

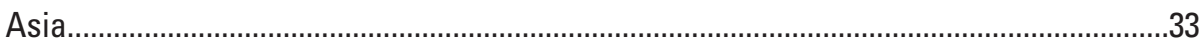

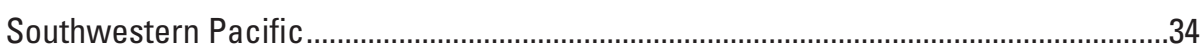

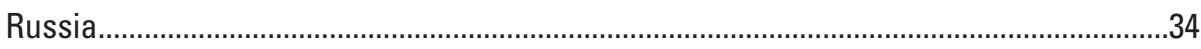

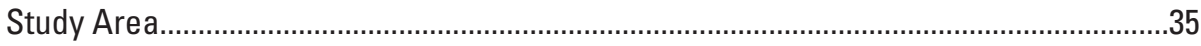

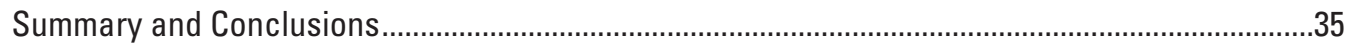

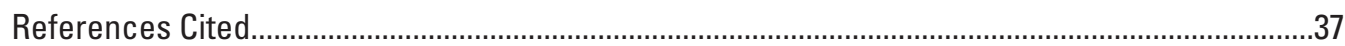

\section{Figures}

[Figures 11-55 follow table 7]

1. Diagram of types of wells leading to additions to reserves in discovered fields .............8

2. Histograms showing the frequency distribution of cumulative recoverable volumes of oil in billions of barrels of oil and natural gas in trillions of cubic feet of gas discovered through 2015 in the 212 significant provinces of the study area, which is the world outside the United States and Canada...........................................................11

3. Diagram for identifying and computing delineated prospective area ..............................14

4. Generalized graphs illustrating the possible profiles of the growth in the cumulative prospective area and the explored area 
5-10 Graphs for seven regions and the whole study area showing-

5. Graphs showing average annual volume of oil discovered offshore and onshore for 5-year intervals from 1951 through 2015

6. Graphs showing average annual volume of gas discovered offshore and onshore for 5 -year intervals from 1951 through 2015 .................................................................22

7. Graphs showing oil discovery rate per wildcat well for 5-year intervals from 1951 through 2015 .

8. Graphs showing growth in delineated prospective area and explored area delineated by wells drilled through 2015

9. Graphs showing cumulative recoverable oil and gas discoveries through 2015 plotted as a function of cumulative delineated prospective area for seven regions and the whole study area

10. Graphs showing the depth distribution of cumulative recoverable oil in oil fields and natural gas in gas fields.

11-55 Maps, graphs, and tables of data for oil and gas exploration through 2015 in-

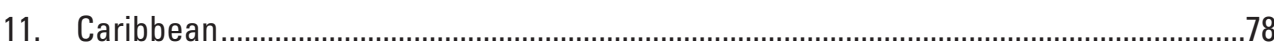

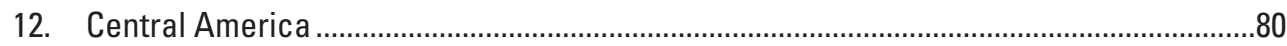

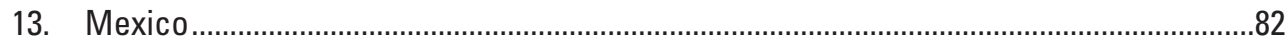

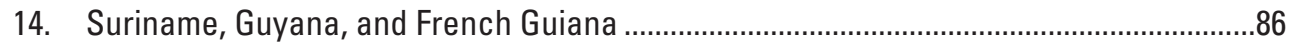

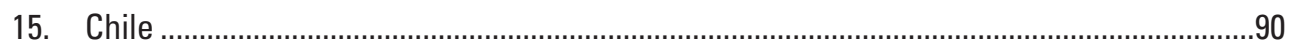

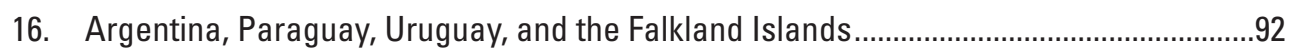

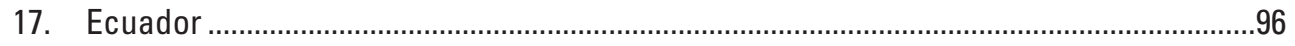

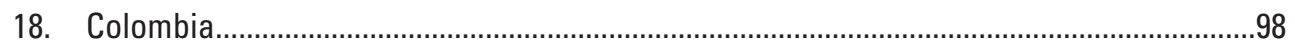

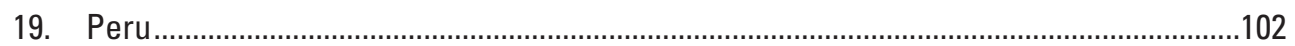

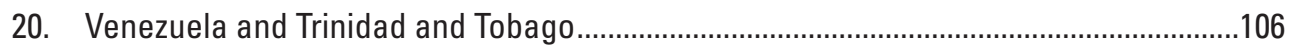

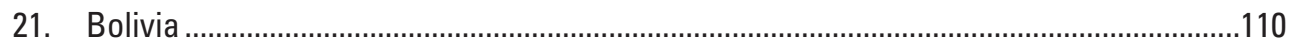

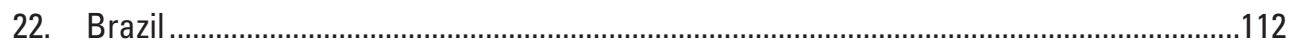

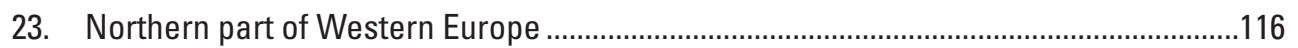

24. Southern part of Western Europe .............................................................................120

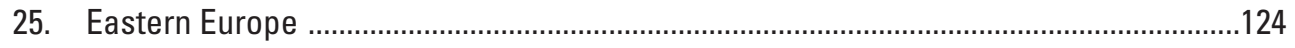

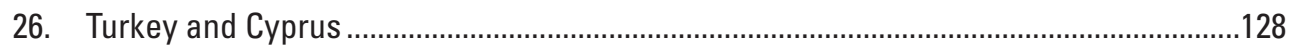

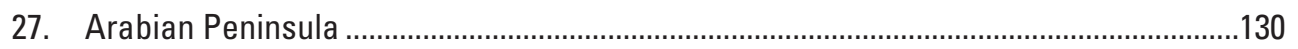

28. Syria, Israel, Jordan, Lebanon, Gaza Strip, and the West Bank ....................................134

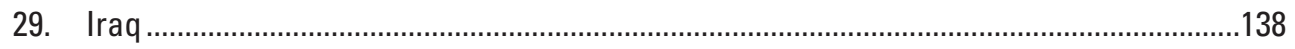

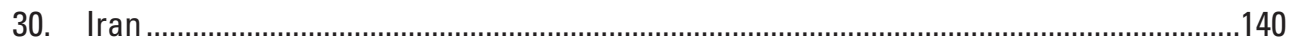

31. Cote d'Ivoire, Ghana, Benin, Guinea-Bissau, Togo, Senegal, The Gambia, Guinea,

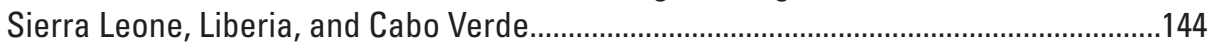

32. Ethiopia, Somalia, Eritrea, Kenya, and Djibouti.........................................................148

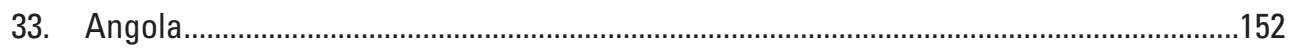

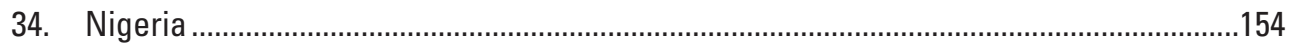

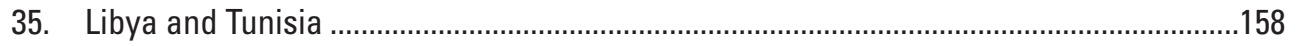

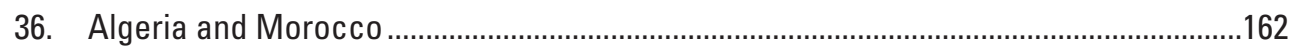

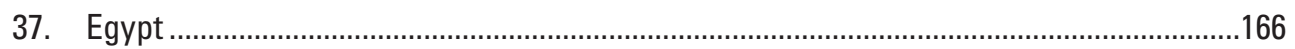

38. Mozambique, Tanzania, Burundi, Malawi, and Rwanda ................................................170

39. South Africa, Namibia, Botswana, Lesotho, Swaziland, Zambia, and Zimbabwe .........174 
40. Gabon, Republic of the Congo (Brazzaville), Cameroon, Equatorial Guinea,

Democratic Republic of the Congo (Kinshasa), Central African Republic, and Sao

Tome and Principe

41. Sudan, South Sudan, Chad, Mauritania, Niger, Burkina Faso, Mali, Uganda, and Western Sahara

42. Madagascar, Comoros, Mauritius, Seychelles, and Reunion ......................................186

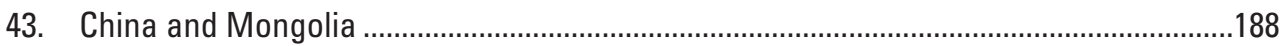

44. Kazakhstan, Azerbaijan, Turkmenistan, Uzbekistan, Georgia, Kyrgyzstan, Tajikistan,

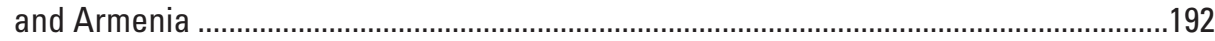

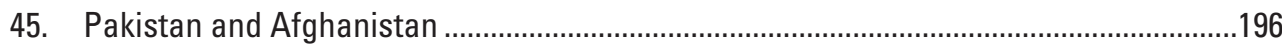

46. India, Bangladesh, Bhutan, Maldives, Nepal, and Sri Lanka .......................................200

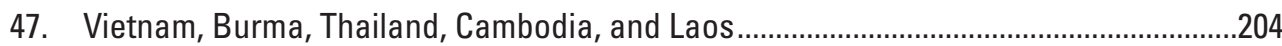

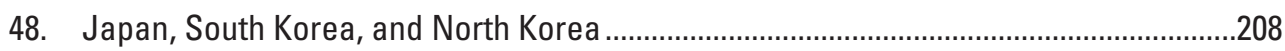

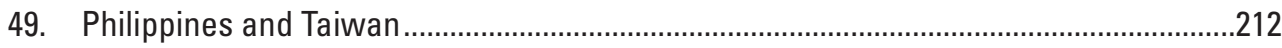

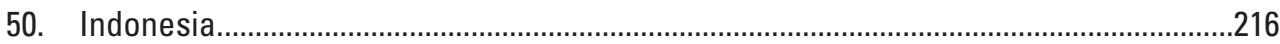

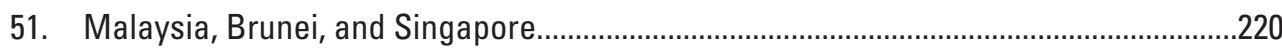

52. Papua New Guinea, Fiji, New Caledonia, Solomon Islands, Vanuatu, French Polynesia, Guam, Marshall Islands, Micronesia, Northern Mariana Islands, and

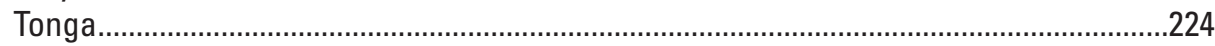

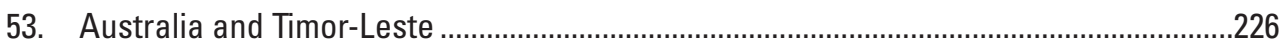

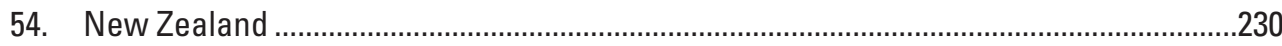

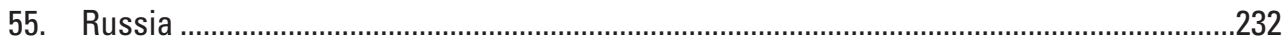

\section{Tables}

\section{[Tables 4-7 follow References Cited]}

1. Estimated world liquid hydrocarbon and natural gas consumption, production, and reserves for 2015.

2. Forty most prolific provinces for oil and gas in the study area and their year of first discovery and cumulative recoverable volumes of oil and gas in their petroleum discoveries through 2015 .

3. Regional distribution in the study area of total and offshore wildcat wells drilled through 2015 and total and offshore estimated cumulative recoverable volumes of oil and gas discovered through 2015

4. Wildcat wells by year, 1961-2015, for the Caribbean, Central America, Mexico, South America, Europe, the Middle East, Africa, Asia, the southwestern Pacific, and Russia

5. Year of first discovery and cumulative recoverable oil and gas discovered through 2015 in the 212 significant provinces in the study area

6. Decadal average discovery size by region of fields discovered at drilling depths of less than 10,000 feet and fields discovered at drilling depths of at least 10,000 feet......74

7. Regional distribution in the study area of land area, delineated prospective area, explored area, cumulative recoverable oil and gas discoveries, and wildcat wells drilled through 2015 and percentages of total delineated prospective area, explored area, cumulative recoverable oil and gas discoveries, and wildcat wells at depths of at least 10,000 feet. 


\section{Conversion Factors}

\begin{tabular}{|c|c|c|}
\hline Multiply & By & To obtain \\
\hline \multicolumn{3}{|c|}{ Length } \\
\hline foot (ft) & 0.3048 & meter $(\mathrm{m})$ \\
\hline mile (mi) & 1.609 & kilometer (km) \\
\hline meter $(\mathrm{m})$ & 3.281 & foot $(\mathrm{ft})$ \\
\hline \multicolumn{3}{|c|}{ Area } \\
\hline square mile $\left(\mathrm{mi}^{2}\right)$ & 2.590 & square kilometer $\left(\mathrm{km}^{2}\right)$ \\
\hline \multicolumn{3}{|c|}{ Volume } \\
\hline cubic foot $\left(\mathrm{ft}^{3}\right)$ & 0.02832 & cubic meter $\left(\mathrm{m}^{3}\right)$ \\
\hline $\begin{array}{l}\text { barrel (bbl; petroleum, } 1 \text { barrel= }=42 \\
\text { gallons) }\end{array}$ & 0.1590 & cubic meter $\left(\mathrm{m}^{3}\right)$ \\
\hline
\end{tabular}

\section{Abbreviations}

$\begin{array}{ll}\mathrm{bbl} & \text { barrel } \\ \mathrm{BBO} & \text { billion barrels of oil }\left(\mathrm{bbl} \times 10^{9}\right) \\ \mathrm{BCF} & \text { billion cubic feet }\left(\mathrm{ft}^{3} \times 10^{9}\right) \\ \mathrm{BOE} & \text { barrel of oil equivalent } \\ \mathrm{CO}_{2} & \text { carbon dioxide } \\ \mathrm{EIA} & \text { U.S. Energy Information Administration } \\ \mathrm{ft} & \text { foot } \\ \mathrm{LNG} & \text { liquefied natural gas } \\ \mathrm{m} & \text { meter } \\ \mathrm{mi} & \text { square mile } \\ \mathrm{MMBO} & \text { million barrels of oil }\left(\mathrm{bbl} \times 10^{6}\right) \\ \mathrm{MMBOE} & \text { million barrels of oil equivalent } \\ \text { OPEC } & \text { Organization of the Petroleum Exporting Countries } \\ \text { TCF } & \text { trillion cubic feet }\left(\mathrm{ft}^{3} \times 10^{12}\right)\end{array}$

\section{Definitions}

$\begin{array}{ll}\text { Thousands } & =10^{3} \\ \text { Millions } & =10^{6} \\ \text { Billions } & =10^{9} \\ \text { Trillions } & =10^{12} \\ 1 \mathrm{BOE} & =1 \text { barrel of crude oil (42 gallons) } \\ & =6,000 \text { cubic feet of natural gas } \\ & =1.5 \text { barrels of natural gas liquids }\end{array}$




\section{Acknowledgments}

The authors gratefully acknowledge the contributions made by the geologists of the U.S. Geological Survey (USGS) who established and published the boundaries of the petroleum provinces used in this Circular (U.S. Geological Survey World Energy Assessment Team, 2000). The authors are grateful to Robert C. Milici and Ricardo A. Olea (both of the USGS) for their technical reviews. We acknowledge permission from IHS Markit ${ }^{\mathrm{TM}}$ to show aggregate data from the "International Petroleum Exploration and Production Database." We are also very grateful for the thorough review work and extensive editorial suggestions from Rachel Gidley (USGS). 



\title{
Statistics of Petroleum Exploration in the World Outside the United States and Canada Through 2015
}

\author{
By Emil D. Attanasi and Philip A. Freeman
}

\section{Abstract}

The world's future oil and gas supplies depend on existing reserves and the additions to those reserves that may result, in part, from ongoing exploration and new discoveries. This Circular summarizes available oil and gas exploration data for the world outside the United States and Canada (the study area) through 2015. It updates U.S. Geological Survey Circulars 981, 1096, and 1288 (by D.H. Root, E.D. Attanasi, and R.L. Turner, 1987; E.D. Attanasi and D.H. Root, 1993; and E.D. Attanasi, P.A. Freeman, and J.A. Glovier, 2007). The exploration measures focus on the search for undiscovered conventional oil and gas accumulations.

The goal of this compilation, presentation, and analysis of exploration and discovery data is to identify, at the reconnaissance level, the areas explored for oil and gas and to characterize their degree of exploration maturity. Maps and graphs provide a visual summary of the exploration maturity of an area. The maps include both land and offshore areas. The maps show delineated prospective areas, which are the industry-defined areas of interest in the search for undiscovered conventional oil and gas accumulations. The maps also show explored areas, which are areas where the density of exploration and development drilling rules out new discoveries of large conventional petroleum accumulations.

Whereas the maps show the static state of oil and gas exploration, the dynamic measures of exploration progress are characterized graphically. The graphs show the growth in the delineated prospective and explored areas as a function of wildcat drilling. The relation between the expansion of the delineated prospective area and the rate of wildcat drilling is determined by the siting of the wildcat wells. Additional graphs show the magnitude of discoveries tied to specific delineated prospective areas. These graphs provide a way to evaluate the quality, in terms of discovered oil and gas, of areas identified by the dates when each area became prospective.

From 2006 through 2015, the delineated prospective area within the study area expanded at a rate of about 48,100 square miles per year. This is slightly above the expansion rate of 46,200 square miles per year from 1996 through 2005. From 2006 through 2015, the explored area expanded at a rate of about 12,900 square miles per year, which is somewhat greater than the rate of 11,300 square miles per year for the period from 1996 through 2005. The delineated prospective area established by 1970 accounts for 35 percent of the delineated prospective area established through 2015 but contains 70 percent of the oil and 52 percent of the natural gas discovered through 2015. From 2006 through 2015, offshore discoveries accounted for 71 percent of the oil and 78 percent of the gas discovered in the study area and 40 percent of the offshore wildcat wells were drilled in deep offshore areas (deeper than 200 meters water depth).

The delineated prospective area and explored area calculated with oil and gas wells and fields at depths of at least 10,000 feet are less than half of the respective areas calculated with all oil and gas wells and fields. The discovery histories of most regions indicate that average discovery sizes are generally larger in deeper geologic horizons. To correctly interpret the exploration maturity of a deep horizon, drilling and discovery data must be considered in the context of the geology of the area. Such analyses should be prepared at the level of the petroleum basin or subbasin.

\section{Introduction}

\section{Objectives and Methods}

The creation of the Cabinet-level U.S. Department of Energy in 1977 and the maintenance of a strategic petroleum reserve during the last two decades of the 20th century demonstrated the U.S. Government's concern about oil supplies after the oil supply disruptions in the 1970s and 1980s. Those disruptions had significant effects on the domestic economy and regulatory environment, as well as on world energy markets. There still is considerable uncertainty with respect to future world oil supplies. One objective of this Circular is to contribute to the analysis of global oil and gas supplies by enhancing the availability of oil and gas exploration statistics for all areas outside the United States and Canada. This compilation of data, which includes tables, figures, and maps, will reduce costly and time-consuming replication of effort and permit researchers and decision makers access to basic exploration statistics for the formulation of energy and environmental policies. 
A second objective is to present a visual summary of world oil and gas exploration at a broad scale. This Circular presents maps for countries outside the United States and Canada to show the spatial distribution of oil and gas exploration. Drilling densities vary immensely across regions. Resulting from this study is a method to characterize an area's level of exploration maturity and to identify areas where the intensity of exploration virtually precludes the possibility of large conventional oil and gas discoveries. Maps and graphs are presented to convey spatially and temporally the productivity of each area of exploration.

Hydrocarbon exploration culminates successfully with economically productive wells. Most of the petroleum exploration in areas outside the United States and Canada still focuses on conventional hydrocarbon accumulations. These accumulations are discrete deposits of oil and (or) gas that have well-defined downdip water contacts from which oil, gas, or natural gas liquids may be commercially extracted by using traditional development practices. This Circular shows the geographic extent of hydrocarbon exploration. The delineated prospective areas have expanded over the extremes of the natural environment, from deep waters to Arctic tundras. The intensity of drilling in areas designated as explored is such that commercial discoveries have likely been identified and developed within their boundaries. Exploration, discovery, and reserve statistics represent a set of indicators that foreshadow the future oil and gas production potential from conventional accumulations in these areas.

The production of oil and gas is from proved reserves. In North America, proved reserves are defined as estimated quantities of crude oil, natural gas, or natural gas liquids that geological and engineering data demonstrate with reasonable certainty to be economically recoverable from known reservoirs under existing economic and operating conditions. Reserves are proved if economic productivity is supported by actual production or conclusive formation tests (drill stem or wireline), or if the economic potential is supported by core analyses and (or) interpretations of electric or other logs (U.S. Energy Information Administration [EIA], 2000). Production at individual wells is physically constrained by the volume of hydrocarbons that may be accessed at any given time, and commonly no more than 10 to 15 percent of the proved reserves of individual fields may be extracted annually without risking reservoir damage and reducing ultimate field recovery (Schanz, 1978).

Currently, most of the world's proved reserves of oil and gas are in conventional accumulations. However, economic production of hydrocarbons in the United States and Canada is no longer tied tightly to conventional accumulations. Continuous-type accumulations are hydrocarbon accumulations that are pervasive throughout large areas and are not significantly affected by hydrodynamic influences (U.S. Geological Survey National Oil and Gas Resource Assessment Team, 1995). Resource plays, or alternatively, continuous accumulations, typically occur in formations that have very low permeability. Continuous accumulations may be identified as the source rocks for the hydrocarbons that migrated into the structural or stratigraphic traps that then became conventional accumulations. The general location and stratigraphic position of these source rocks are commonly identified during the reconstruction of a region's geologic history to justify exploration for associated conventional accumulations.

Continuous accumulations commonly are not fully delineated. In the past, they have not been worth delineating because their contained hydrocarbons could not be produced commercially; however, the use of horizontal well and hydraulic fracture technologies has now made continuous accumulations economic targets for investment. These investments in drilling and the development of new technology are transferring these resources into the proven reserve category. For intensely drilled areas that contain commercial conventional discoveries, it is likely that the geologic literature can provide the general location and strata of the source rocks that charged those accumulations.

Globally, natural gas development and markets have continued to mature, especially in response to increased concerns about global warming and the desire to mitigate carbon dioxide $\left(\mathrm{CO}_{2}\right)$ production by substituting natural gas for coal. Traditionally, natural gas markets were tied to local demand where infrastructure was available to transport the gas from producing areas to consumers. Export of gas from a producing region generally requires a pipeline network that gathers and transports gas to other regions where it is consumed or to liquefaction plants that convert the gas to liquefied natural gas (LNG) for overseas export. In industrialized countries, the development of domestic markets or imports of natural gas have been motivated, in part, by the desire to partially or fully displace coal as a fuel for base-load electricity generation to mitigate the effects of pollution and greenhouse gas emissions. By 2015, the volume of LNG traded outside North America doubled from 2002 levels, and the volume of natural gas traded via pipeline increased by 86 percent during that same period (BP, 2003, 2016). Part of the expansion in gas supplies was from formerly stranded natural gas reservoirs and fields. Stranded gas accumulations are discovered conventional gas accumulations that cannot be commercially produced until markets develop to support building infrastructure and production. Attanasi and Freeman (2013) described in detail volumes of stranded gas in South America, Africa, Russia, Asia, and Australia.

Additional supplies of natural gas have resulted from the introduction of the new technology of hydraulic fracturing gas shales and producing the gas with horizontal wells. In North America, the application of this technology has created a surfeit of producible natural gas. Even with gas displacing coal as a base-load fuel for electric power generation, North America has begun exporting natural gas as LNG. Markets for LNG experienced historically low real prices during 2016, which encouraged the substitution of natural gas for coal in international markets. 
This Circular presents basic statistics of petroleum exploration and discovery in areas outside the United States and Canada. It also presents analytical techniques that were applied to interpret the data. Initially, the Circular presents some background information on the institutional context and practices of modern exploration, and the petroleum discovery process is summarized (figs. 1 and 2; tables 1-4). The discussion then reviews the unique analytical techniques applied to display and interpret the exploration and discovery data at the country and regional levels (figs. 3 and 4). The summary results of the analysis of the exploration and discovery data at the regional level and for the entire study area are described (figs. 5-10; tables 5-7). These results are based upon the data from individual countries or small groups of countries, which are presented as maps, graphs, and tables in figures 11 through 55. The final section of the text considers the implications of the analysis for future discovery and production trends.

This Circular updates U.S. Geological Survey Circulars 981, 1096, and 1288 (Root and others, 1987; Attanasi and Root, 1993; Attanasi and others, 2007). Data reported in the latest Circular, Circular 1288, ended in 2001. This Circular focuses on the world outside the United States and Canada. Since the 1950s, the United States and Canada have accounted for most of the world's oil and gas wildcat wells but represent only a small fraction of the world's conventional oil and gas discoveries. The drilling and field-size data presented here are as of January 2016 and are from IHS Markit ${ }^{\mathrm{TM}}$ (2016). After 2002, IHS Markit added a significant amount of historical data to the database and provided more extensive wildcat well and production well coverage of the study area. For example, the cumulative number of wildcat wells drilled before 2002 in the 2016 version of the database is 35 percent greater than the cumulative number of wells in the 2002 version of the database.

\section{Summary of Findings and Limitations of Study}

For this analysis, the study area is defined as the world outside the United States and Canada. From 2006 through 2015, the delineated prospective area (that is, the search area for oil and gas) within the study area expanded at a rate of about 48,100 square miles per year. This rate is slightly higher than that of the previous decade (1996 through 2005) of 46,200 square miles per year but significantly below the rate of about 65,200 square miles per year for the decade from 1986 through 1995. From 2006 through 2015, the explored area expanded at a rate of about 12,900 square miles per year, which was slightly above the 11,300 square miles per year of the previous decade but significantly below the 19,500 square miles per year for the decade from 1986 through 1995. Expansion of these areas was driven by the number and location of wildcat wells drilled.

Since 1950, the search for oil and gas has moved offshore. In 1965, offshore wildcat wells accounted for 5 percent of the wildcat wells drilled in the study area, but by 2015 , offshore wildcat wells accounted for 29 percent of all wildcat wells in the study area. Through 2015, offshore discoveries accounted for 23 percent of the oil discovered and 40 percent of the gas discovered, but during the decade from 2006 through 2015, offshore discoveries accounted for 71 percent of the oil and 78 percent of the gas discovered in the study area. For that same 10-year period, the average size, in terms of barrels of oil equivalent (BOE), of offshore discoveries was seven times the average onshore discovery size. With the exception of Russia, at least 10 percent of the wildcat wells in each major producing region were drilled offshore.

All oil and gas wells and fields in the study area were used in calculating the delineated prospective areas and the explored areas at the surface. Since 1950, there has been a gradual increase in the average depth of wildcat wells drilled in the study area. The delineated prospective areas and explored areas at a depth of 10,000 feet (ft) reported herein are based on the oil and gas wells and fields that are at least $10,000 \mathrm{ft}$ in depth. For the study area, the delineated prospective area at a depth of $10,000 \mathrm{ft}$ is 44 percent of the delineated prospective area at the surface. The explored area at a depth of $10,000 \mathrm{ft}$ amounts to 36 percent of the explored area at the surface. The explored area is more intensely drilled than the prospective area and is more sensitive to the increased drilling costs associated with deep horizons. Discoveries in the deep horizons, that is, at depths of at least $10,000 \mathrm{ft}$, accounted for 32 percent of the total discovered oil and 49 percent of the discovered gas. From 2006 through 2015, the growth of the prospective area in the deep horizons amounted to about 57 percent of the growth of the prospective area at the surface. During the same decade, the average size, in terms of BOE, of discoveries at least as deep as 10,000 ft was five times the average discovery size in the shallower horizons. This difference is because the greater degree of exploration maturity associated with the shallow interval, that is, the greater number of penetrations than in the deeper horizons, precludes having missed large undiscovered accumulations and because the higher costs associated with deep discoveries increase the threshold size of commercial deposits.

Global estimates of consumption, production, and reserves of liquid hydrocarbons (crude oil, condensate, and natural-gas-plant liquids) and natural gas for 2015 are shown in table 1. According to BP (2016), the reserve estimates were acquired from a combination of official sources, published sources (such as World Oil and the Oil and Gas Journal), and third-party data from the Organization of the Petroleum Exporting Countries (OPEC) Secretariat. The balances between production and consumption for the world show that more oil was consumed than produced, and more natural gas was produced than consumed. The oil deficit may be explained by a drawdown of inventories or by refinery gain. Refinery gain refers to an increase in the volume of liquid hydrocarbon products above the volume of input crude oil. Alternatively, the volume of gas produced but not consumed was probably added to inventories, lost in pipeline transport, or flared. 
Table 1. Estimated world liquid hydrocarbon and natural gas consumption, production, and reserves for 2015.

[For these estimates, liquid hydrocarbon includes crude oil, condensate, and natural-gas-plant liquids. Data are from BP (2016). Region definitions in this table differ from those in the rest of this Circular and follow BP (2016). Because of rounding, some regional totals may differ slightly from the sum of the component estimates shown. Countries are listed alphabetically within each region. bbl/yr, barrels per year; $\mathrm{ft}^{3} / \mathrm{yr}$, cubic feet per year; bbl, barrel; ft ${ }^{3}$, cubic feet]

\begin{tabular}{|c|c|c|c|c|c|c|}
\hline \multirow{2}{*}{ Country } & \multicolumn{2}{|c|}{$\begin{array}{c}\text { Annual } \\
\text { consumption, } 2015\end{array}$} & \multicolumn{2}{|c|}{$\begin{array}{c}\text { Annual } \\
\text { production, } 2015\end{array}$} & \multicolumn{2}{|c|}{$\begin{array}{c}\text { Reserves } \\
\text { at end of } 2015\end{array}$} \\
\hline & $\begin{array}{c}\text { Liquid } \\
\left(10^{6} \mathrm{bbl} / \mathrm{yr}\right)\end{array}$ & $\begin{array}{c}\text { Gas } \\
\left(10^{9} \mathrm{ft}^{3} / \mathrm{yr}\right)\end{array}$ & $\begin{array}{c}\text { Liquid } \\
\left(10^{6} \mathrm{bbl} / \mathrm{yr}\right)\end{array}$ & $\begin{array}{c}\text { Gas } \\
\left(10^{9} \mathrm{ft}^{3} / \mathrm{yr}\right)\end{array}$ & $\begin{array}{l}\text { Liquid } \\
\left(10^{9} \mathrm{bbl}\right)\end{array}$ & $\begin{array}{c}\text { Gas } \\
\left(10^{12} \mathrm{ft}^{3}\right)\end{array}$ \\
\hline \multicolumn{7}{|c|}{ North America } \\
\hline Canada & 847 & 3,618 & 1,601 & 5,775 & 172.2 & 70.2 \\
\hline United States & 7,080 & 27,474 & 4,637 & 27,096 & 55.0 & 368.7 \\
\hline North America subtotal & 8,630 & 34,030 & 7,182 & $\mathbf{3 4 , 7 5 0}$ & 238.0 & 450.3 \\
\hline \multicolumn{7}{|c|}{ South and Central America } \\
\hline Argentina & 248 & 1,679 & 232 & 1,289 & 2.4 & 11.7 \\
\hline Bolivia & $*$ & $*$ & $*$ & 737 & $*$ & 9.9 \\
\hline Ecuador & 92 & 22 & 198 & $*$ & 8.0 & $*$ \\
\hline Peru & 89 & 265 & 41 & 441 & 1.4 & 14.6 \\
\hline Trinidad and Tobago & 14 & 761 & 40 & 1,400 & 0.7 & 11.5 \\
\hline Venezuela & 247 & 1,219 & 959 & 1,145 & 300.9 & 198.4 \\
\hline Other countries & 488 & 272 & 54 & 93 & 0.5 & 2.2 \\
\hline $\begin{array}{l}\text { South and Central America } \\
\text { subtotal }\end{array}$ & 2,585 & 6,172 & 2,815 & 6,302 & 329.3 & 268.1 \\
\hline \multicolumn{7}{|c|}{ Europe and Eurasia } \\
\hline Austria & 96 & 295 & $*$ & $*$ & $*$ & $*$ \\
\hline Denmark & 60 & 112 & 58 & 162 & 0.6 & 1.1 \\
\hline Finland & 64 & 75 & $*$ & $*$ & $*$ & $*$ \\
\hline France & 586 & 1,379 & $*$ & $*$ & * & $*$ \\
\hline Germany & 854 & 2,635 & $*$ & 254 & $*$ & 1.4 \\
\hline Greece & 110 & 100 & $*$ & $*$ & $*$ & $*$ \\
\hline Hungary & 56 & 315 & $*$ & $*$ & $*$ & $*$ \\
\hline Ireland & 52 & 148 & $*$ & * & * & $*$ \\
\hline Italy & 461 & 2,170 & 42 & 218 & 0.6 & 1.6 \\
\hline Kazakhstan & 99 & 304 & 609 & 437 & 30.0 & 33.1 \\
\hline Lithuania & 20 & 81 & $*$ & $*$ & $*$ & $*$ \\
\hline Netherlands & 305 & 1,124 & $*$ & 1,519 & $*$ & 23.8 \\
\hline Norway & 85 & 170 & 711 & 4,137 & 8.0 & 65.6 \\
\hline Poland & 199 & 591 & $*$ & 145 & $*$ & 3.3 \\
\hline Portugal & 89 & 153 & $*$ & $*$ & $*$ & $*$ \\
\hline
\end{tabular}


Table 1. Estimated world liquid hydrocarbon and natural gas consumption, production, and reserves for 2015.—Continued

[For these estimates, liquid hydrocarbon includes crude oil, condensate, and natural-gas-plant liquids. Data are from BP (2016). Region definitions in this table differ from those in the rest of this Circular and follow BP (2016). Because of rounding, some regional totals may differ slightly from the sum of the component estimates shown. Countries are listed alphabetically within each region. bbl/yr, barrels per year; $\mathrm{ft}^{3} / \mathrm{yr}$, cubic feet per year; bbl, barrel; $\mathrm{ft}^{3}$, cubic feet]

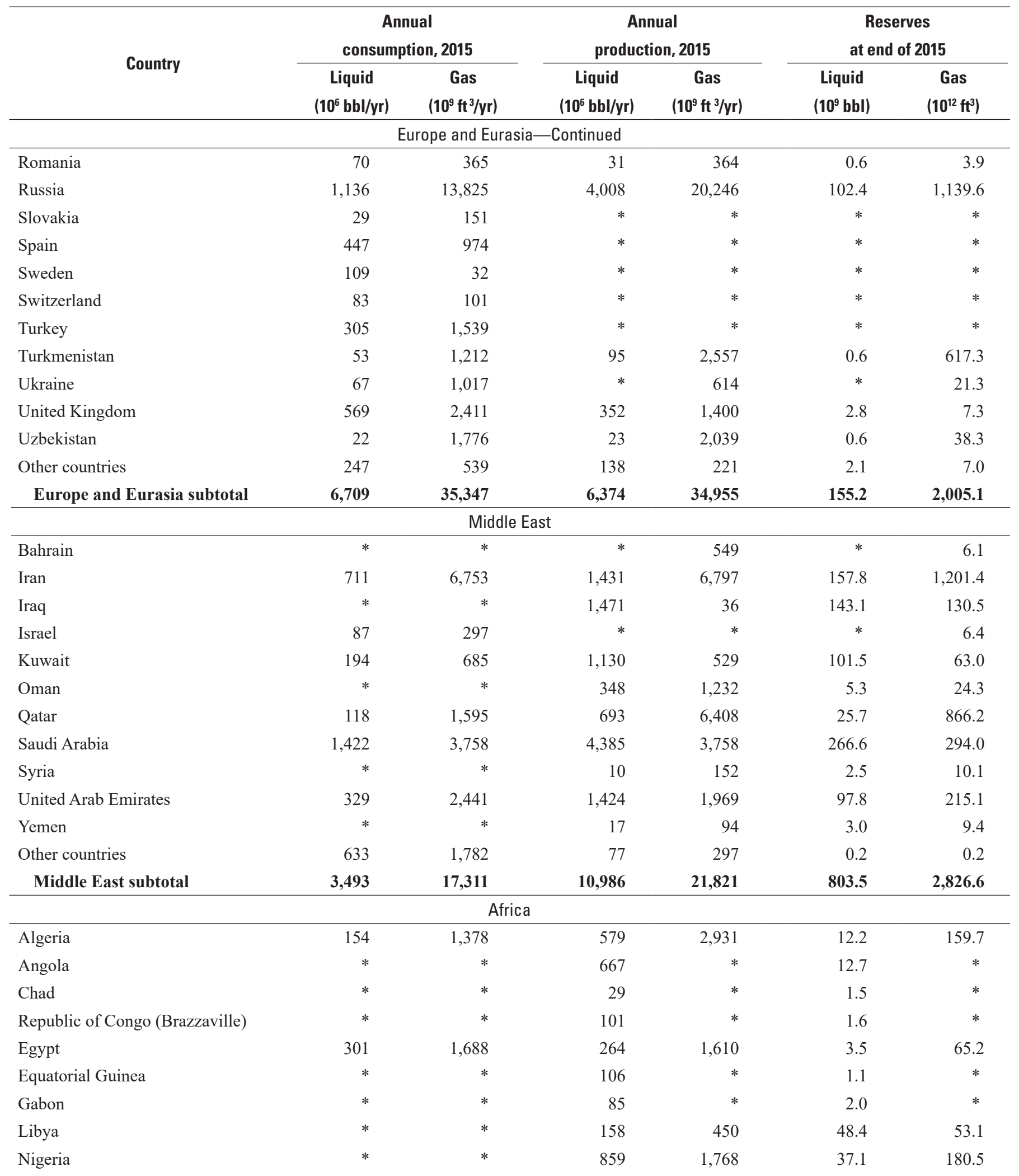


Table 1. Estimated world liquid hydrocarbon and natural gas consumption, production, and reserves for 2015.-Continued

[For these estimates, liquid hydrocarbon includes crude oil, condensate, and natural-gas-plant liquids. Data are from BP (2016). Region definitions in this table differ from those in the rest of this Circular and follow BP (2016). Because of rounding, some regional totals may differ slightly from the sum of the component estimates shown. Countries are listed alphabetically within each region. bbl/yr, barrels per year; $\mathrm{ft}^{3} / \mathrm{yr}$, cubic feet per year; bbl, barrel; $\mathrm{ft}^{3}$, cubic feet]

\begin{tabular}{|c|c|c|c|c|c|c|}
\hline \multirow{2}{*}{ Country } & \multicolumn{2}{|c|}{$\begin{array}{c}\text { Annual } \\
\text { consumption, } 2015\end{array}$} & \multicolumn{2}{|c|}{$\begin{array}{c}\text { Annual } \\
\text { production, } 2015\end{array}$} & \multicolumn{2}{|c|}{$\begin{array}{l}\text { Reserves } \\
\text { at end of } 2015\end{array}$} \\
\hline & $\begin{array}{c}\text { Liquid } \\
\left(10^{6} \mathrm{bbl} / \mathrm{yr}\right)\end{array}$ & $\begin{array}{c}\text { Gas } \\
\left(10^{9} \mathrm{ft}^{3} / \mathrm{yr}\right)\end{array}$ & $\begin{array}{c}\text { Liquid } \\
\left(10^{6} \mathrm{bbl} / \mathrm{yr}\right)\end{array}$ & $\begin{array}{c}\text { Gas } \\
\left(10^{9} \mathrm{ft}^{3} / \mathrm{yr}\right)\end{array}$ & $\begin{array}{l}\text { Liquid } \\
\left(10^{9} \mathrm{bbl}\right)\end{array}$ & $\begin{array}{c}\text { Gas } \\
\left(10^{12} \mathrm{ft}^{3}\right)\end{array}$ \\
\hline \multicolumn{7}{|c|}{ Africa-Continued } \\
\hline South Africa & 237 & 177 & $*$ & $*$ & $*$ & $*$ \\
\hline Sudan & $*$ & $*$ & 38 & $*$ & 1.5 & $*$ \\
\hline Tunisia & $*$ & $*$ & 23 & $*$ & 0.4 & $*$ \\
\hline Other countries & 727 & 1,540 & 96 & 720 & 3.7 & 38.8 \\
\hline Africa subtotal & 1,419 & 4,784 & $\mathbf{3 , 0 5 7}$ & 7,479 & 129.1 & 496.7 \\
\hline \multicolumn{7}{|c|}{ Asia Pacific } \\
\hline Burma & $*$ & $*$ & $*$ & 692 & $*$ & 18.7 \\
\hline China & 4,368 & 6,968 & 1,573 & 4,872 & 18.5 & 135.7 \\
\hline $\begin{array}{l}\text { Hong Kong Special Administrative } \\
\text { Region }\end{array}$ & 134 & 115 & $*$ & $*$ & * & $*$ \\
\hline India & 1518 & 1,787 & 320 & 1,032 & 5.7 & 52.6 \\
\hline Indonesia & 594 & 1,403 & 301 & 2,650 & 3.6 & 100.3 \\
\hline Japan & 1,515 & 4,005 & $*$ & $*$ & $*$ & $*$ \\
\hline Malaysia & 303 & 1,404 & 253 & 2,409 & 3.6 & 41.3 \\
\hline Taiwan & 376 & 649 & $*$ & $*$ & $*$ & $*$ \\
\hline Thailand & 490 & 1,867 & 174 & 1,406 & 0.4 & 7.8 \\
\hline Vietnam & 154 & 376 & 132 & 376 & 4.4 & 21.8 \\
\hline Other countries & 159 & 277 & 107 & 977 & 1.3 & 9.9 \\
\hline Asia Pacific subtotal & 11,842 & 24,761 & 3,046 & 19,658 & 42.6 & 552.6 \\
\hline \multicolumn{7}{|c|}{ World total } \\
\hline World total & 34,678 & 122,494 & 33,460 & 124,966 & $1,697.6$ & $6,599.4$ \\
\hline
\end{tabular}

"The quantity is not listed separately for an individual country but may be included in the "Other countries" category for the region if significant. 
The production data in table 1 include the production of bitumen from Canadian tar sands, extra-heavy oil from Venezuela's Orinoco heavy oil belt, and oil and gas from other unconventional resources. In North America, about 1.4 billion more barrels of liquid hydrocarbons was consumed than produced. Europe, excluding Russia, consumed 4 billion more barrels of liquids than it produced, and the Asia-Pacific region consumed 8 billion more barrels of liquids than it produced. These deficits were offset by imports from South America, the Middle East, Russia, and central Asia. Europe and Asia were the leading importers of both pipeline gas and LNG.

For the study area, that is the world outside the United States and Canada, the data from table 1 indicate that about 26.8 billion barrels of liquid hydrocarbons was consumed and 27.2 billion barrels was produced in 2015; 91.4 trillion cubic feet (TCF) of natural gas was consumed and 92.1 TCF was produced in 2015. During the 30-year period from 1986 through 2015, the average annual volume of oil discovered in conventional accumulations amounted to about 11.4 billion barrels of oil (BBO) and the average annual volume of natural gas discovered in conventional accumulations amounted to 118.4 TCF (IHS Markit, 2016). Even if the resources in these conventional discoveries experience field growth during their productive lifetime, the average annual volume of oil discovered in conventional accumulations falls short of current oil consumption and production levels. The volumes of liquid hydrocarbons produced and consumed and the reserves listed in table 1, however, include both conventional sources of crude oil, condensate, and natural-gas-plant liquids and unconventional sources of oil, such as tar sands, extra-heavy oil, and oil in continuous-type accumulations. Since 2002, world production of liquid hydrocarbons has increased by 24 percent and natural gas production has increased by 40 percent. In 2015 , almost 30 percent of the gas produced was traded internationally, of which roughly two-thirds was transported by pipeline and the remainder was transported by seagoing tankers as LNG (BP, 2016).

Outside the United States and Canada, international gas pipeline trade commonly involves a producer that is a governmental entity. The shipment of gas in international pipelines that traverse countries that are not the ultimate consumers (transit countries) is costly and risky. Transit countries may demand 4 to 6 percent of the gross value of the pipeline gas as transit fees, which add to costs for purchasers and (or) reduce revenues to producers. Risks include transport disruptions because of political instability inside the transit countries and potential contract conflicts with the transit countries. Conversion of gas to LNG and transport in seagoing tankers is not only costly in terms of the capital and operating outlays but also in the amount of gas consumed at liquefaction plants and in transportation processes. Therefore, suppliers that have installed gas transport facilities require long-term commitments in the form of take-or-pay contracts for initial gas purchasers. These provisions have resulted in some imbalances that have led to the emergence of a network of receiving terminals and the relaxation of contract provisions, allowing for the establishment of a sophisticated global spot LNG market (Hayes, 2006).

Before the latter part of the 20th century, natural gas, both associated with oil and in gas reservoirs, was not an economic commodity in most countries. Gas discoveries may have gone unreported, and gas associated with oil discoveries may have been flared. There is no obvious way to estimate the amount of gas that was flared. Drilling records outside the United States and Canada may be incomplete, especially for data prior to 1950. Progress continues to be made in documenting the historical growth of the oil and gas industry, particularly in those countries where drilling information was once considered critical to national security.

The well data used for the analyses presented in this Circular include well location, depth, well classification, spud date, completion date, and, for development wells, producing field (IHS Markit, 2016). The discovery data include field location and estimates of recoverable oil, natural gas, and condensate. The International Field File of the IHS Markit (2016) database was used as the basis for estimating discovered resources at the field level. IHS Markit (2016) documentation notes that, unless otherwise stated, the estimates of recoverable oil and gas volumes are associated with a probability of 50 percent (p50). For a p50 estimate, there is a 50-percent chance that the actual recoverable volume is less than the estimate and a 50-percent chance that the volume exceeds the estimate. By contrast, in the United States and Canada, the proved reserve estimates have a much tighter definition, with a 90-percent probability of the estimate being exceeded and a 10-percent chance of the recoverable volume falling short of the estimate. The phenomenon of field growth, also called reserves appreciation, is a dominant source of the additions to reserves in conventional fields in the United States and Canada because field-size estimates are based on proven reserves.

Estimates of the oil and gas recoveries reported in the International Field File of IHS Markit (2016) for fields outside the United States and Canada are from diverse sources, and revisions are reported on an irregular basis. Accordingly, field growth, if it exists at all, is much more subtle than in the United States and Canada. International oil companies may be constrained by financial regulators to submit estimates that are closer to the ideal of proved reserves, whereas national oil companies are under no such obligation to report the tighter estimates unless they enter capital markets independent of government assistance and must submit to financial regulation. National oil companies now control most of the world's conventional reserves outside the United States and Canada (EIA, 2016b). The instances of field growth that were observed were not sufficiently pervasive to characterize analytically, so no attempt was made to adjust the sizes of recent discoveries for reserve appreciation. However, one should keep in mind that estimates of recoverable oil and gas volumes for new discoveries are likely to change as the discoveries are developed. 


\section{Exploration and Discovery Process}

\section{Oil and Gas Exploration: Concepts and Nomenclature}

As used in this study, exploration is the search for undiscovered discrete oil and gas accumulations that have development and production costs no greater than the costs associated with producing oil and gas from known accumulations and adding to reserves in known accumulations (Adelman, 1970, 1992). Exploration is only one of the methods of adding to reserves. For a given area, the search for hydrocarbons occurs in phases. It commonly begins with reviewing an area's geologic literature, followed by surveying of surface geology, processing and interpreting new or previously collected geophysical data to identify new prospects, acquiring mineral rights, collecting predrilling geophysical data, and finally drilling wells to test the commercial viability of a prospect.

There are no internationally accepted standards for computing and reporting reserves. In countries outside the United States and Canada, government authorities tend to define reserves without reference to economic recoverability; reserves are simply thought of as the inventory of technically recoverable oil and gas in identified reservoirs or fields. A reservoir or pool is a mass of porous, permeable rock that contains a natural accumulation of oil or gas, which is confined by impermeable rock or water barriers. The petroleum is contained by the natural pores of the reservoir rock. A field, as defined by the EIA (2000), is an area consisting of an individual reservoir or multiple reservoirs related to the same geologic structure and (or) stratigraphic condition.

Figure 1 shows different types of wells that lead to additions to reserves. The general categories are (1) shallow pool test well, (2) deep pool test well, (3) infill development well, (4) new pool test well, and (5) extension or outpost well. The risk or probability of a dry hole is highest in the drilling of new pool test wells, somewhat less for deep or shallow pool test wells, and lowest for infill development wells. Nevertheless, some infill development wells fail to contact the producing formation.

The concept of proved reserves (term "proven" was used in previous Circulars) ties the crediting of volumes of oil and gas to the outcome of both wildcat wells and development wells. Consequently, for countries that use this reserve definition, most of the additions to oil and gas reserves are made by drilling development wells in known fields. Inferred reserves are volumes of oil and gas that are expected to be added to proven reserves as fields are developed or as new methods are applied that would increase the recovery of the in-place resource. Alternatively, if reserves are very loosely or broadly defined and estimates are not tied to development wells, as is the case outside of the United States and Canada, reserve estimates are, in part, independent of production wells, so the phenomenon of field growth may not be observed.

At the level of the field, there is some ambiguity as to whether newly discovered accumulations should be classified as new fields or extensions of discovered fields. The definition of an oil or gas field is not exact. The EIA (2000) defined a field as an area consisting of a single reservoir or multiple

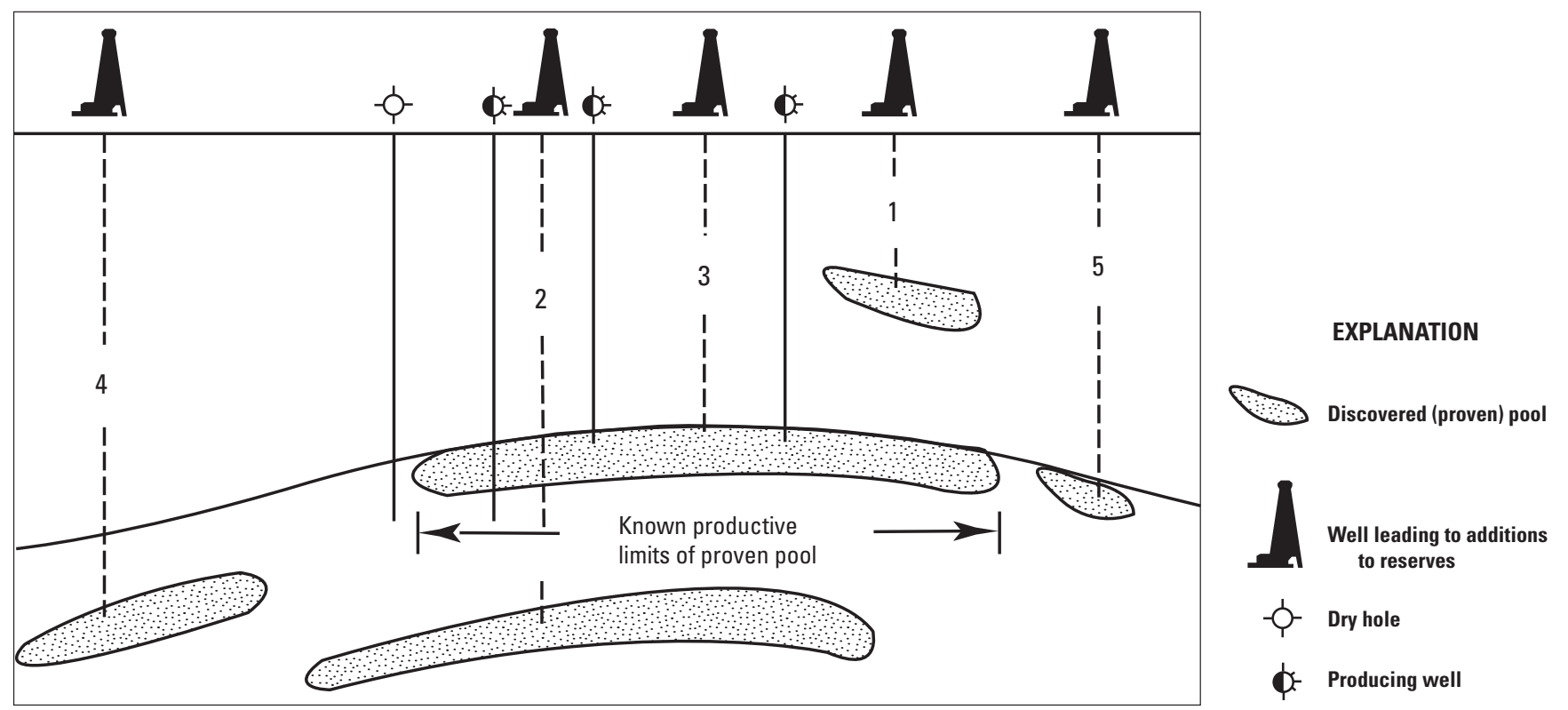

Figure 1. Diagram of types of wells leading to additions to reserves in discovered fields. The wells (represented by derricks) are as follows: (1) shallow pool test well, (2) deep pool test well, (3) infill development well, (4) new pool test well, and (5) extension or outpost well. In practice, the operator or regulatory body may classify the accumulations penetrated by well types 1-5 as a single field or as more than one field. Recognition of the relations among the accumulations can be complicated by the order in which the wells are drilled. From Attanasi and others (2007, fig. 1), which was modified from Drew (1997). 
reservoirs grouped on, or related to, the same geologic structure and (or) stratigraphic condition. In a single field, two or more reservoirs may be separated vertically and (or) laterally by impervious strata. In figure 1 , there could be as many as five possible fields or as few as one field. In practice, the definition of a field may depend on the sequence of discovery, but ultimately it depends on the regulatory authority. The assignment of pools to fields may be based on geology or may simply be a matter of convenience for the regulatory authority.

\section{Oil and Gas Exploration: Institutional Environment}

Oil and gas exploration investments are made by firms attempting to locate unidentified but potentially commercial reservoirs and fields. Exploration may begin with a hypothesis about the formation of accumulations of hydrocarbons in a specific geologic setting. Reviews of the literature, geologic maps, geochemical data, geophysical data, and drilling history may be used to select a target area. Fieldwork in and seismic profiling of the target area may lead to the identification of specific drilling targets. Data are continuously collected and interpreted while drilling to maximize the probability of locating an unidentified accumulation of hydrocarbons. After an accumulation is encountered, tests and data collection continue to determine the potential of a commercial discovery.

\section{Inside the United States}

In the United States, the ownership of mineral rights may reside with private entities, the Federal Government, or State governments. Unless the minerals are in preservation areas, governments commonly transfer rights to the private sector for exploration, commercial evaluation, and production. Although various systems are used to transfer mineral rights to the private sector, their common goal is for the government to capture economic rents that may result from development of the resource. An analysis of these systems is beyond the scope of this study. Currently, however, where significant volumes of hydrocarbons are expected, competitive bidding systems are commonly used to transfer the mineral rights to the private sector.

Private ownership of mineral rights can result in what economists refer to as "market failures," and governments may intervene to remediate the failures. Oil and gas pools commonly extend beyond the boundaries of a single property. Upon the announcement of a discovery, under the rule of capture, competing property owners may quickly drill and produce the hydrocarbons beneath their properties to forestall the pool being drained by a neighbor. This practice results in extremely rapid development and production of the resource. Even if prices drop, production may not decline because owners fear that the resource below their property may be drained by a neighbor. Frequently, the accelerated production reduces the overall quantity of the resource that can be commercially recovered from the pool. Economists call this situation the common property or pool externality. An economic externality occurs when the welfare of an individual depends directly not only on their actions but also on actions of some other economic agent. To remedy the common pool externality, government regulators in leading oil-producing States implemented a pro-rationing system that limited production for each well to an allowable rate per month and set minimum spacing requirements for production wells. For some production methods, regulators require that the extraction be unitized under a single operator to assure production proceeds in an efficient manner.

\section{Outside the United States}

Outside the United States, mineral rights are typically vested in the national governments. The rights to explore a concession area are negotiated with these governments. Although the European countries that owned North Sea mineral rights used an auction system to transfer those rights to the private sector, these countries still maintain strict control of resource development. Other countries such as Venezuela, most Middle Eastern countries, and Asian countries have national oil companies that allow international oil companies to act as minority partners or use international oil companies as contractors to develop and produce discoveries. The exploration and development phases may also be separated and completed by different firms.

National oil companies and government regulators may strive to assure that participation by an international oil company in any project results in the training and employment of local workers, the use of local firms for field infrastructure development, and the provision of social services to the local community. Governments commonly tailor provisions on an individual project basis.

\section{Oil and Gas Discovery Process: Discrete Accumulations}

Within a well-defined sedimentary basin with a single play, well-documented regularity in the oil and gas discovery process (Drew, 1997) enables the use of the discovery history to predict the nature and size distribution of future discoveries. The petroleum industry uses the concept of the petroleum play as a basis for classifying exploration targets (White, 1980; Baker and others, 1984). A play is defined as a set of known or postulated oil and (or) gas accumulations sharing similar geologic, geographic, and temporal properties, such as source rock, migration patterns, timing, trapping mechanism, and hydrocarbon type. Plays include pools related to a specific rock unit that might represent single fields or parts of fields (Gautier and others, 1996).

In this Circular, field size is measured in terms of fluid volumes expressed in barrels of oil or natural gas liquids and in cubic feet of gas. On the basis of calorific heating values, it is assumed that 1 barrel of oil is equivalent (BOE) to 6,000 cubic 
feet $\left(\mathrm{ft}^{3}\right)$ of natural gas; that is, $1 \mathrm{BOE}=1$ barrel $(\mathrm{bbl})$ of crude oil or 6,000 cubic feet of natural gas or 1.5 barrels of natural gas liquids.

The regularity of the discovery process occurs, in part, because the size distribution of accumulations within a confined play or basin is characterized by the likelihood that most of the resource is contained in a few large accumulations and that many small associated accumulations, in total, account for a relatively small share of the total resource. The typical size-frequency distribution is right skewed. The graph of such a distribution has the number of accumulations plotted on the vertical axis and deposit-size class or category on the horizontal axis.

If it is assumed that the planar surface expression of an oil or gas accumulation is proportional to hydrocarbon volume, then with random drilling, the average discovery size of discrete deposits will decline with equal increments of exploratory drilling. This decline will occur because the larger deposits with the larger surface expressions have a greater probability of being found with random drilling (Root and Schuenemeyer, 1980). As the larger accumulations are found and their undiscovered numbers are exhausted, it takes more wildcat wells to locate the smaller accumulations with much smaller surface expressions. Any improvement in exploration efficiency over purely random drilling just accelerates the discovery of the largest fields and the decline of the discovery rate (Root and Schuenemeyer, 1980).

The production of oil and gas generally exhibits substantial economies of scale that affect commercial viability of the discovery. Within a defined geographic and geologic area, the larger accumulations are less costly to find and produce, and their hydrocarbons are less costly, on a unit basis, to transport to market. The typical lifecycle of a multiplay basin is the following: after a large initial discovery, an influx of new competitive explorers creates high rates of drilling, which accelerate a decline in returns. Exploratory drilling will gradually decline as average discovery sizes become marginal. An initial discovery in a different play in the same basin, perhaps in a deeper horizon, if sufficiently large, may ignite another round of intense wildcat drilling in that new play. Again, exploratory drilling will eventually decline as the returns and average discovery sizes decline. Explorers are likely to test multiple horizons in such basins. New discoveries in new plays in the same basin will benefit from the existing oil and gas infrastructure. Eventually, new discoveries in other basins will signal potentially higher returns in plays in other basins, and exploration will shift to those plays.

Factors that affect the order in which plays and basins are explored and produced but not the regularity of the discovery process within a given area or play include exploration access, cost factors, distance from and maturity of markets, political stability, and technology. Distance from markets and the maturity of markets affect the costs and commercial value of oil and gas finds. Technological and legal access affect the feasibility of development if discoveries are identified.

\section{Oil and Gas Provinces in the Study Area}

The U.S. Geological Survey published outlines of 418 petroleum provinces (U.S. Geological Survey World Energy Assessment Team, 2000) in the study area. Fields in the study area were assigned to these provinces based on surface locations. Certain hydrocarbon resources, such as tar sand deposits, extra-heavy oil, oil shale deposits, hydrates, and natural gas in brines, were not included in this analysis of resources in the study area. Provinces were classified as significant if they had at least one discovery that contained 100 million barrels of oil (MMBO) or 600 billion cubic feet (BCF) of natural gas. Of the 418 provinces in the study area, 212 met this threshold. These significant provinces account for 99 percent of the discovered oil and gas reported in the study area. Figure 2 shows histograms of cumulative recoverable oil and gas in the 212 significant provinces.

The data upon which the histograms (fig. 2) are based show that even among this selected group of petroleum provinces, most of the discovered resources are concentrated in relatively few provinces. Table 2 lists the 40 most prolific provinces for oil and the 40 most prolific provinces for natural gas. These provinces account for 92 percent of all discovered oil and 84 percent of all discovered gas in the study area. The 5 and 10 most prolific provinces for oil account for 52 and 67 percent of the discovered oil, respectively, in the study area. Similarly, the 5 and 10 most prolific provinces for gas account for 48 and 59 percent of the discovered gas, respectively, in the study area. Table 2 also shows the year of the first discovery for this selected group of provinces. Overall, the significant provinces having discoveries before 1941 contain 59 percent of all oil and 24 percent of all gas discovered in the study area through 2015. In summary, conventional oil and gas fields discovered in the study area show a high degree of concentration of resource in relatively few provinces. These provinces not only had discoveries early in the history of the global oil and gas industry, but they were also accessible from both legal and technological standpoints.

\section{Measures of Exploration Maturity}

When the planar surface area of discrete deposits is roughly proportional to volume of the recoverable resource, then with random drilling, the average discovery size will decline with successive increments of wildcat drilling. In this study, exploration maturity is defined relative to a drilling density that implies an approximate threshold size of an undiscovered accumulation. An area is mature relative to a specified threshold size if the density of drilling indicates there is little chance that accumulations at least as large as the threshold size remain undiscovered. One motivation for governments to evaluate exploration maturity is to assess the remaining undiscovered conventional resources of a petroleum basin or province to formulate public policy pertaining to its development. 

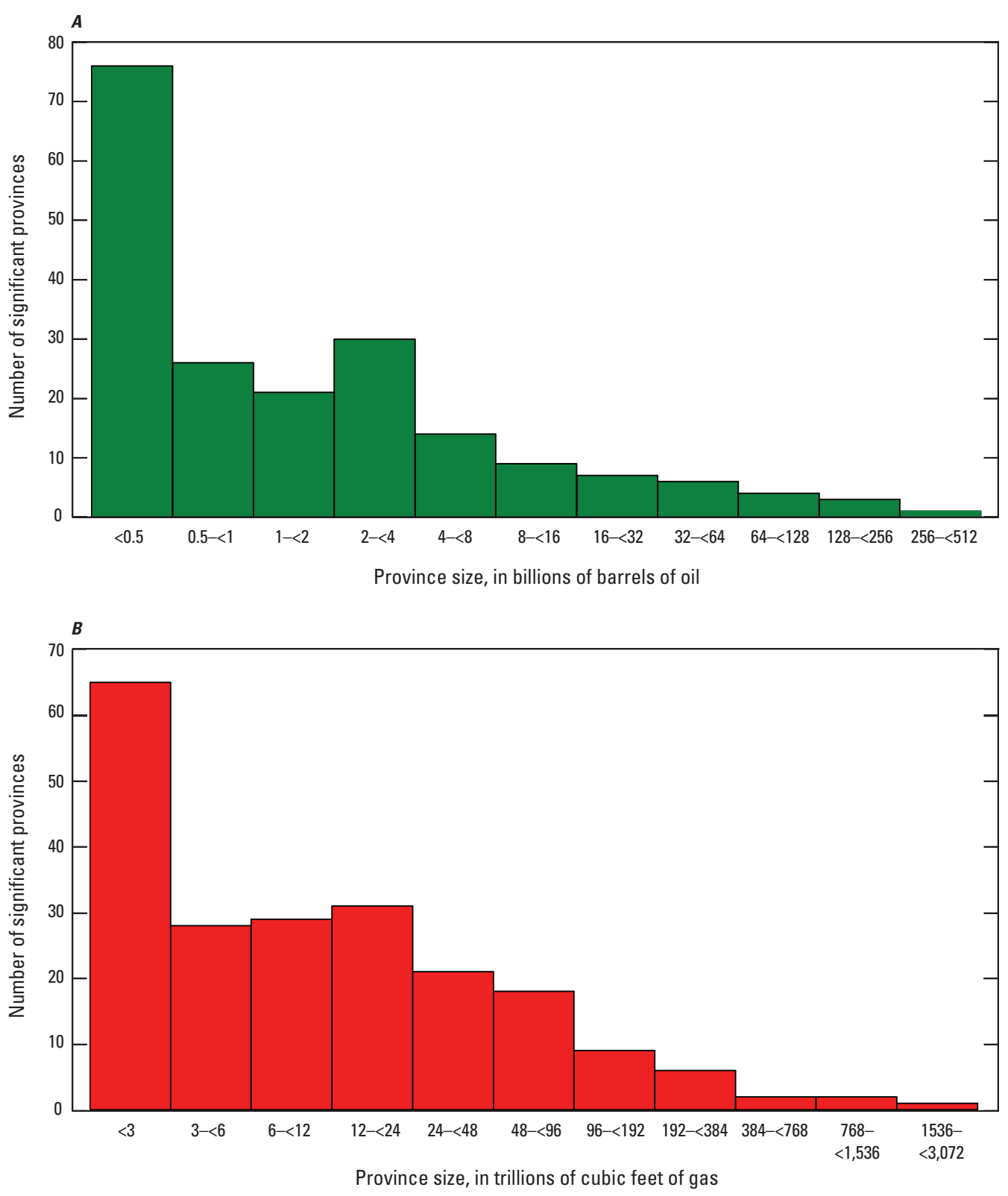

Figure 2. Histograms showing the frequency distribution of cumulative recoverable volumes of $(A)$ oil in billions of barrels of oil and $(B)$ natural gas in trillions of cubic feet of gas discovered through 2015 in the 212 significant provinces of the study area, which is the world outside the United States and Canada. Significant provinces have at least one field containing 100 million barrels of recoverable oil or 600 billion cubic feet of natural gas. In both histograms, the unequal intervals for size classes are defined in powers of 2 to allow all province sizes to fit on the graph. Field data are from IHS Markit (2016); province boundaries are from U.S. Geological Survey World Energy Assessment Team (2000). In the study area, 19 provinces have no reported oil discoveries but have gas discoveries of at least 600 billion cubic feet of gas.
Private sector exploration firms evaluate exploration maturity to facilitate the efficient allocation of exploration assets and efforts over various theaters of operation.

Wildcat or exploration well counts can be misleading measures of exploration maturity. However, the locations of all productive and dry wells and discoveries provide the basic data for developing the measure of maturity used here. Wildcat well locations represent the oil and gas industry's exploration strategy, whereas the discovery data reflect the exploration outcomes. The well location data permit the calculation of distances between wells. A minimum distance between wells is necessary for an accumulation of a given size to remain undetected. The distances between wells convey information about the likelihood of the occurrence of an undetected target accumulation in an area undergoing exploration.

In most countries, petroleum exploration is confined to a small fraction of the total land area. If the petroleum industry sited wildcat wells on a regular grid and confined drilling to a fixed area, then the probability of an undetected accumulation occurring would decline as the drilling density increased and the grid mesh became smaller. Therefore, for any given drilling density (mesh size), the exploration for larger accumulations is more advanced or mature than for smaller accumulations. The measure of exploration maturity for a fixed area is conditional on the distance between wells, the target size, and the spatial arrangement of wells.

While the exploration area is expanding, the discovery rate and average discovery size may not decline. In such areas, discovery rates and average discovery sizes may be highly irregular. Exploration areas may expand because of changes in legal restrictions, technological breakthroughs, or substantially improved economic conditions.

Well locations, field locations, distances between wells and fields, and the arrangement of wells and fields are all used 
Table 2. Forty most prolific provinces for oil and gas in the study area and their year of first discovery and cumulative recoverable volumes of oil and gas in their petroleum discoveries through 2015.

Provinces are ranked by the cumulative recoverable volumes of oil and gas in petroleum discoveries, which are the sum of past production and proved reserves of oil, gas, and natural gas liquids. Years and oil and gas volumes are from IHS Markit (2016); province names and code numbers are from the U.S. Geological Survey (USGS) World Energy Assessment Team (2000). BBO, billion barrels (bbl x 109) of oil; TCF, trillion cubic feet $\left.\left(\mathrm{ft}^{3} \times 10^{12}\right)\right]$

\begin{tabular}{|c|c|c|c|c|c|c|c|c|c|}
\hline $\begin{array}{c}\text { Oil } \\
\text { Rank }\end{array}$ & USGS province name and code number & $\begin{array}{l}\text { Year of first } \\
\text { discovery }\end{array}$ & $\begin{array}{c}\text { Oil } \\
\text { (BBO) }\end{array}$ & $\begin{array}{l}\text { Gas } \\
\text { (TCF) }\end{array}$ & $\begin{array}{l}\text { Gas } \\
\text { rank }\end{array}$ & USGS province name and code number & $\begin{array}{l}\text { Year of first } \\
\text { discovery }\end{array}$ & $\begin{array}{c}\text { Oil } \\
\text { (BBO) }\end{array}$ & $\begin{array}{l}\text { Gas } \\
\text { (TCF) }\end{array}$ \\
\hline 1 & Mesopotamian Foredeep Basin, 2024 & 1938 & 442 & 445 & 1 & West Siberian Basin, 1174 & 1953 & 172 & 1,647 \\
\hline 2 & Zagros Fold Belt, 2030 & 1905 & 175 & 585 & 2 & Qatar Arch, 2022 & 1967 & 5 & 1,523 \\
\hline 3 & West Siberian Basin, 1174 & 1953 & 172 & 1,647 & 3 & Amu-Darya Basin, 1154 & 1953 & 1 & 774 \\
\hline 4 & Greater Ghawar Uplift, 2021 & 1932 & 169 & 229 & 4 & Zagros Fold Belt, 2030 & 1905 & 175 & 585 \\
\hline 5 & Rub Al Khali Basin, 2019 & 1954 & 117 & 290 & 5 & Mesopotamian Foredeep Basin, 2024 & 1938 & 442 & 445 \\
\hline 6 & Volga-Ural Region, 1015 & 1929 & 81 & 102 & 6 & Rub Al Khali Basin, 2019 & 1954 & 117 & 290 \\
\hline 7 & Niger Delta, 7192 & 1954 & 66 & 260 & 7 & Niger Delta, 7192 & 1954 & 66 & 260 \\
\hline 8 & Maracaibo Basin, 6099 & 1914 & 64 & 70 & 8 & Greater Ghawar Uplift, 2021 & 1932 & 169 & 229 \\
\hline 9 & North Sea Graben, 4025 & 1966 & 61 & 206 & 9 & North Sea Graben, 4025 & 1966 & 61 & 206 \\
\hline 10 & Santos Basin, 6036 & 1979 & 50 & 113 & 10 & North Caspian Basin, 1016 & 1892 & 28 & 200 \\
\hline 11 & Sirte Basin, 2043 & 1958 & 46 & 55 & 11 & East Venezuela Basin, 6098 & 1867 & 38 & 192 \\
\hline 12 & Villahermosa Uplift, 5305 & 1954 & 44 & 55 & 12 & Northwest German Basin, 4035 & 1856 & 3 & 160 \\
\hline 13 & East Venezuela Basin, 6098 & 1867 & 38 & 192 & 13 & Northwest Shelf, 3948 & 1954 & 2 & 147 \\
\hline 14 & West-Central Coastal, 7203 & 1951 & 37 & 66 & 14 & Tanzania Coastal, 7273 & 1974 & $<1$ & 145 \\
\hline 15 & Widyan Basin-Interior Platform, 2023 & 1939 & 32 & 21 & 15 & South Barents Basin, 1050 & 1983 & 0 & 126 \\
\hline 16 & Campos Basin, 6035 & 1972 & 29 & 19 & 16 & Grand Erg/Ahnet Basin, 2058 & 1954 & 1 & 126 \\
\hline 17 & North Caspian Basin, 1016 & 1892 & 28 & 200 & 17 & Greater Sarawak Basin, 3702 & 1953 & 1 & 123 \\
\hline 18 & South Caspian Basin, 1112 & 1869 & 25 & 109 & 18 & Santos Basin, 6036 & 1979 & 50 & 113 \\
\hline 19 & Bohaiwan Basin, 3127 & 1961 & 25 & 20 & 19 & South Caspian Basin, 1112 & 1869 & 25 & 109 \\
\hline 20 & Songliao Basin, 3144 & 1959 & 22 & 14 & 20 & Volga-Ural Region, 1015 & 1929 & 81 & 102 \\
\hline 21 & Trias/Ghadames Basin, 2054 & 1956 & 21 & 47 & 21 & Dnieper-Donets Basin, 1009 & 1936 & 3 & 94 \\
\hline 22 & Timan-Pechora Basin, 1008 & 1916 & 16 & 40 & 22 & Anglo-Dutch Basin, 4036 & 1919 & 1 & 91 \\
\hline 23 & Central Sumatra Basin, 3808 & 1939 & 15 & 4 & 23 & Nile Delta Basin, 2035 & 1966 & $<1$ & 89 \\
\hline 24 & Middle Caspian Basin, 1109 & 1893 & 13 & 45 & 24 & Sichuan Basin, 3142 & 1939 & $<1$ & 78 \\
\hline 25 & Putumayo-Oriente-Maranon Basin, 6041 & 1963 & 12 & 3 & 25 & Maracaibo Basin, 6099 & 1914 & 64 & 70 \\
\hline 26 & Red Sea Basin, 2071 & 1907 & 11 & 13 & 26 & Ordos Basin, 3128 & 1907 & 8 & 70 \\
\hline 27 & Tampico-Misantla Basin, 5301 & 1904 & 10 & 18 & 27 & Malay Basin, 3703 & 1969 & 5 & 66 \\
\hline 28 & Baram Delta/Brunei-Sabah Basin, 3701 & 1910 & 9 & 57 & 28 & West-Central Coastal, 7203 & 1951 & 37 & 66 \\
\hline 29 & Bombay, 8043 & 1958 & 9 & 38 & 29 & Tarim Basin, 3154 & 1958 & 3 & 64 \\
\hline
\end{tabular}


Table 2. Forty most prolific provinces for oil and gas in the study area and their year of first discovery and cumulative recoverable volumes of oil and gas in their petroleum discoveries through 2015.-Continued

[Provinces are ranked by the cumulative recoverable volumes of oil and gas in petroleum discoveries, which are the sum of past production and proved reserves of oil, gas, and natural gas liquids. Years and oil and gas volumes are from IHS Markit (2016); province names and code numbers are from the U.S. Geological Survey (USGS) World Energy Assessment Team (2000). BBO, billion barrels (bbl x 10 ${ }^{9}$ ) of oil; TCF, trillion cubic feet $\left.\left(\mathrm{ft}^{3} \times 10^{12}\right)\right]$

\begin{tabular}{|c|c|c|c|c|c|c|c|c|c|}
\hline $\begin{array}{c}\text { Oil } \\
\text { Rank }\end{array}$ & USGS province name and code number & $\begin{array}{c}\text { Year of first } \\
\text { discovery }\end{array}$ & $\begin{array}{c}\text { Oil } \\
\text { (BBO) }\end{array}$ & $\begin{array}{l}\text { Gas } \\
\text { (TCF) }\end{array}$ & $\begin{array}{l}\text { Gas } \\
\text { rank }\end{array}$ & USGS province name and code number & $\begin{array}{l}\text { Year of first } \\
\text { discovery }\end{array}$ & $\begin{array}{c}\text { Oil } \\
\text { (BBO) }\end{array}$ & $\begin{array}{l}\text { Gas } \\
\text { (TCF) }\end{array}$ \\
\hline 30 & Ordos Basin, 3128 & 1907 & 8 & 70 & 30 & Santa Cruz-Tarija Basin, 6045 & 1924 & $<1$ & 62 \\
\hline 31 & Llanos Basin, 6096 & 1948 & 7 & 11 & 31 & Baram Delta/Brunei-Sabah Basin, 3701 & 1910 & 9 & 57 \\
\hline 32 & San Jorge Basin, 6058 & 1907 & 7 & 7 & 32 & Kutei Basin, 3817 & 1897 & 4 & 57 \\
\hline 33 & Interior Homocline-Central Arch, 2020 & 1989 & 7 & 24 & 33 & Villahermosa Uplift, 5305 & 1954 & 44 & 55 \\
\hline 34 & Carpathian-Balkanian Basin, 4061 & 1835 & 7 & 14 & 34 & Sirte Basin, 2043 & 1958 & 46 & 55 \\
\hline 35 & Neuquen Basin, 6055 & 1922 & 6 & 40 & 35 & Bonaparte Gulf Basin, 3910 & 1964 & 1 & 51 \\
\hline 36 & Sud, 7146 & 1975 & 6 & 1 & 36 & Angara-Lena Terrace, 1209 & 1954 & $<1$ & 51 \\
\hline 37 & Junggar Basin, 3115 & 1937 & 6 & 8 & 37 & Illizi Basin, 2056 & 1956 & 5 & 50 \\
\hline 38 & Fahud Salt Basin, 2016 & 1962 & 5 & 14 & 38 & Browse Basin, 3913 & 1971 & $<1$ & 49 \\
\hline 39 & Malay Basin, 3703 & 1969 & 5 & 66 & 39 & Nepa-Botuoba Arch, 1210 & 1962 & 4 & 47 \\
\hline 40 & Qatar Arch, 2022 & 1967 & 5 & 1,523 & 40 & Trias/Ghadames Basin, 2054 & 1956 & 21 & 47 \\
\hline
\end{tabular}


to delineate areas of interest in the search for undiscovered oil and gas accumulations. These characteristics are also used to determine the degree of exploration maturity of the delineated area of interest.

\section{Delineated Prospective Area and Explored Area: Definitions}

Within a country or group of countries, area is described mathematically as a set of grid points in a plane. The grid points are approximately 2.83 miles apart, and the area of each cell having grid points as vertices is approximately 8 square miles. The locations of grid points are identified by longitude and latitude.

The delineated prospective area for oil and gas exploration is represented as the set of all grid points that are within a specified distance to wells (producing and dry) that have penetrated to the depth where hydrocarbons are thought to occur and that are inside the area drilled. The procedure for choosing the grid points that form the delineated prospective area is based on examination of all non-overlapping triangles, (see fig. 3) formed by wells at their vertices. A grid point is classified as being in the delineated prospective area if it is located within a triangle that is small enough to fit inside a circle that has a radius of 20 miles. The delineated prospective area, in square miles, is calculated as the combined (nonoverlapping) area of those triangles having a well at each vertex and fitting inside a circle with a radius of 20 miles (see fig. 3). The delineated prospective areas are displayed on maps as closed polygons.

The 20-mile radius was chosen here and in the earlier editions of this Circular (Root and others, 1987; Attanasi and Root, 1993; Attanasi and others, 2007) because it provides a convenient scale for visual presentation of the area of interest for petroleum exploration. The 20-mile radius was also consistent with the precision of the location data for wells and discoveries. When a radius smaller than 20 miles is used, gaps (data-poor areas) appear in the prospective area; however,

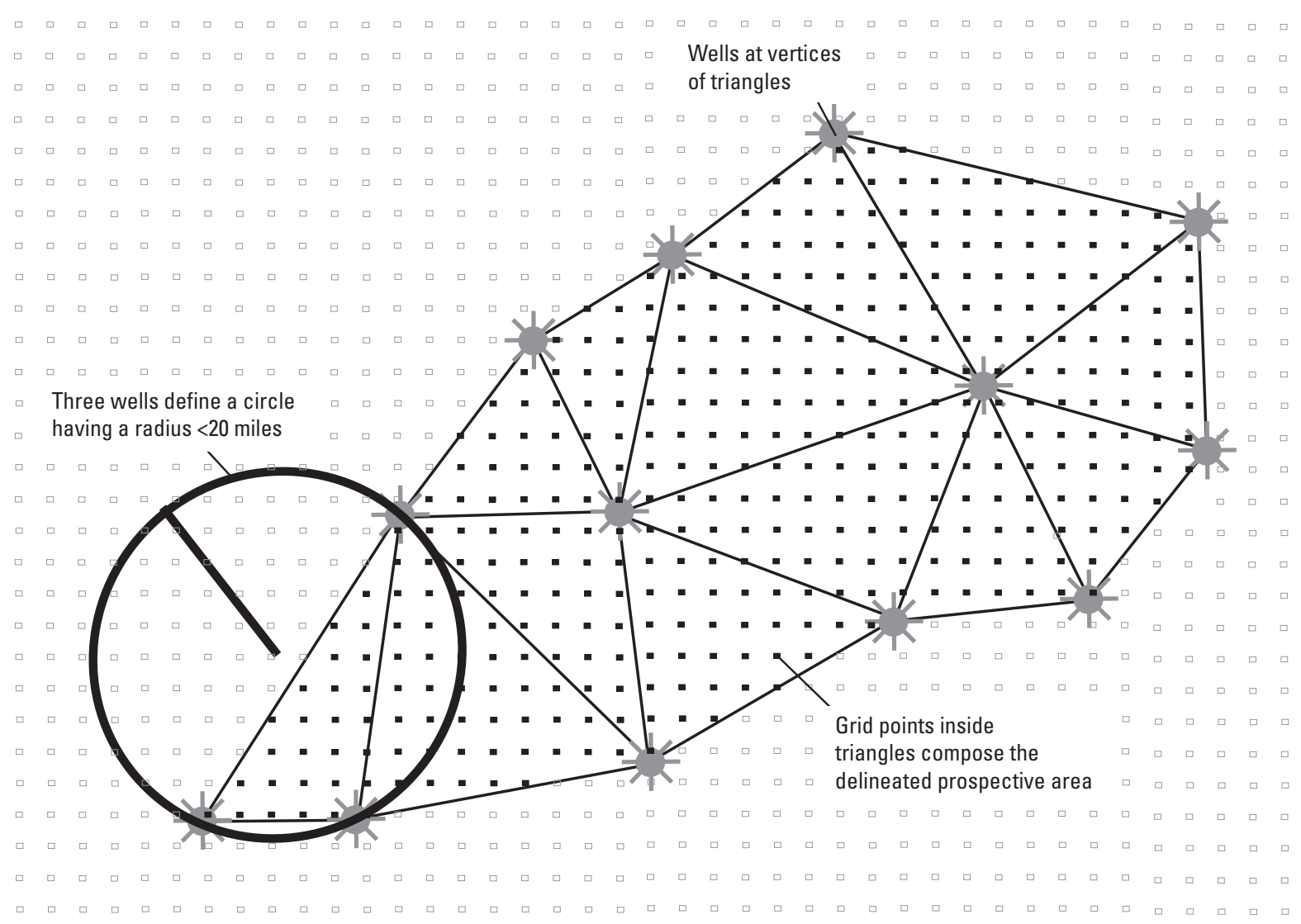

Figure 3. Diagram for identifying and computing delineated prospective area. To facilitate comparisons with Circulars 1288 (Attanasi and others, 2007) and 1096 (Attanasi and Root, 1993), the delineated prospective area was calculated the same way for this Circular from grid points that were evenly spaced 2.83 miles apart. If three non-colinear wells define a triangle that can fit inside a circle having a radius less than 20 miles, then the triangle connecting the wells defines the delineated prospective area. Grid points that lie within such triangles appear as the delineated prospective area on the maps in figures 11-55. Because the grid point symbols in figures 11-55 are too large to be distinguished separately, the area covered by the grid points appears as a continuous area. From Attanasi and others (2007, fig. 5). 
when a larger radius is used, there is a loss of resolution in defining the prospective area.

Data used in calculation of the delineated prospective areas included locations of all wildcat, exploratory, and development wells (both successful and dry), along with the locations of fields. The use of all petroleum well and field locations was intended to compensate for missing data for wildcat wells drilled prior to 1950. The producing wells, dry wells, and field locations may represent the only evidence of early exploration in some areas. Although the use of all the data added redundancy to the computations, it gave some assurance that no area that had been searched was excluded because of missing wildcat wells.

When exploration begins in an area, the delineated prospective area expands rapidly, and then the growth stabilizes to a much slower rate as drilling turns from exploration to development. If there are no discoveries, the area may be abandoned. If the area is not abandoned, wildcat drilling may continue, but this followup drilling may add little additional prospective area because the well locations may be within the existing delineated prospective area. Drilling aimed at extending discoveries or finding new pools near identified fields may increase the delineated prospective area at the margins, if at all.

The explored area is defined as the area in the delineated prospective area that is within 2 miles of a well. For example, if one well is exactly 2 miles from another well, then the explored area is the area covered by a circle between the wells. A circle with a diameter of 2 miles and radius of 1 mile has an area of 3.14 square miles. In this example, the largest field that could occur between the wells and remain undetected has a planar surface area of just less than 3.14 square miles. The recoverable oil expected from pools with a 3.14-square-mile planar surface area would vary with pay thickness and reservoir properties. In the United States, Permian basin (western Texas and eastern New Mexico) conventional fields with planar surface areas of 3.14 square miles averaged less than 12 MMBO (Attanasi and others, 1981). However, for offshore Gulf of Mexico pools, the average recoverable oil may be double that of a pool in the Permian basin with the same planar surface area (Attanasi and Haynes, 1984). According to these data, the largest potential undetected pool in areas designated as explored is estimated to range from 12 to $24 \mathrm{MMBO}$. For some countries, such pool sizes may be important at the local or perhaps national levels, but on a global scale they do not change the resource outlook.

In areas where the delineated prospective area is found to be unproductive and not worth additional evaluation, the size of the explored area will be minimal. A single well can potentially condemn a large area if the well indicates that commercial hydrocarbons were probably not generated or preserved because of a defective trap or seal or the lack of reservoir-quality rock.

The maps for individual countries or groups of countries in the study area show the location of the delineated prospective and explored areas (figs. 11-55). On these maps, exploration maturity is conveyed qualitatively by visually comparing the extent of the delineated prospective and explored areas. The algorithm classifies a grid point as either inside or outside the delineated prospective area, and if the grid point is part of the delineated prospective area, whether it is part of the explored area. The algorithm also attaches years to each grid point in the delineated prospective and explored areas to denote when that location entered the delineated prospective category and when it became part of the explored area category. These data were used to construct the graphs that accompany the maps. In the graphs, a pattern of expanding delineated prospective area with no corresponding growth in explored area suggests unfavorable results to exploration in the new delineated prospective area. The graphs may also be used to represent quantitatively the production potential of discovered hydrocarbons within the delineated prospective areas.

\section{Measuring Productivity of Delineated Prospective Areas}

Discovery rates are commonly expressed in terms of the volume of oil and gas found divided by the number of exploration wells drilled during a specific time interval (yields per unit of exploration effort). For a single play with a fixed boundary, the discovery rate tends to decline as progressively smaller accumulations are discovered. Once a trend is established, it is common to extrapolate the discovery rate to estimate the remaining oil or gas in the play (Drew, 1997). If the petroleum province includes multiple plays in multiple sedimentary basins, discoveries within new areas may offset declining discoveries in old areas, and the discovery rate for the entire province may not decline. In such situations, the extrapolation of discovery rates is not useful for predicting the amounts of undiscovered oil and gas.

The procedure for separating the confounding effects of a declining discovery rate within an existing play or basin and a different, and perhaps increasing, discovery rate in an associated expanding area is to assign discoveries to the nearest grid points in the prospective area. Each grid point in the delineated prospective area was labeled with the year when that grid point became part of the prospective area. The prospective area date is never later than the discovery date of the accumulation. By associating volumes of oil and gas with the delineated prospective area points and prospective area dates, the hydrocarbon potential of the new prospective area can be compared with the hydrocarbon potential of the older areas. This scheme allows one to compare the hydrocarbon volumes yielded from drilling new areas with yields from old areas to decide whether future drilling should target sites already in the prospective area or sites that might open new delineated prospective areas (Attanasi and Root, 1988). 


\section{Tools for Analysis: Graphs}

Two types of graphs are presented along with each of the map figures (figs. 11-55). Figure $4 A$ is a generalized version of the first type of graph, which shows the growth of the cumulative delineated prospective area and the explored area, arranged by the year when the areas first became prospective or explored, plotted against the cumulative number of wildcat wells, which are ordered by drilling date. Increases in the slope of the growth profile of the delineated prospective area may indicate that a larger fraction of the wells were drilled outside the delineated prospective area, thus increasing the size of the area undergoing exploration. A rollover of this profile (decline in slope) suggests that a larger proportion of the newly drilled wildcat wells were sited within the existing prospective area, which is the case if the locations of most of the new wells were based on the results of previous drilling. The closer the 10-year markers at the top of the graph are to each other, the smaller the number of wildcat wells that were drilled in that decade.

The second type of graph (fig. $4 B$ ) shows cumulative recoverable oil and gas discoveries as functions of the cumulative delineated prospective area ordered by time. If all areas are equally productive (and if followup drilling is instantaneous), then the graph of recoverable cumulative oil or gas is a straight line (fig. $4 B$, profile A). If the earlier delineated prospective area is more richly endowed with oil and gas than the later delineated prospective area, then the shape of the graph is concave down (fig. $4 B$, profile B). Alternatively, if the later delineated prospective area is more richly endowed than the earlier delineated prospective area, then the graph is concave up (fig. $4 B$, profile C).

One complication in interpreting graphs such as figure $4 B$ is that an apparent decline in the volume of discoveries per unit area for recently added areas could be exaggerated because of insufficient time for followup drilling required to develop the resources. However, if sufficient time has elapsed without significant resource additions or followup drilling, then the reduced hydrocarbon yields associated with that part of the delineated prospective area probably represent the hydrocarbon endowment accurately.

When technological advances open up entirely new areas, such as the North Sea and the highly productive deepwater areas offshore Brazil, West Africa, and Mozambique, the new areas immediately show high yields of hydrocarbons relative to the areas delineated earlier. In these situations, the graphs of oil and gas yields plotted as a function of the delineated prospective area are concave up (fig. $4 B$, profile $\mathrm{C}$ ).
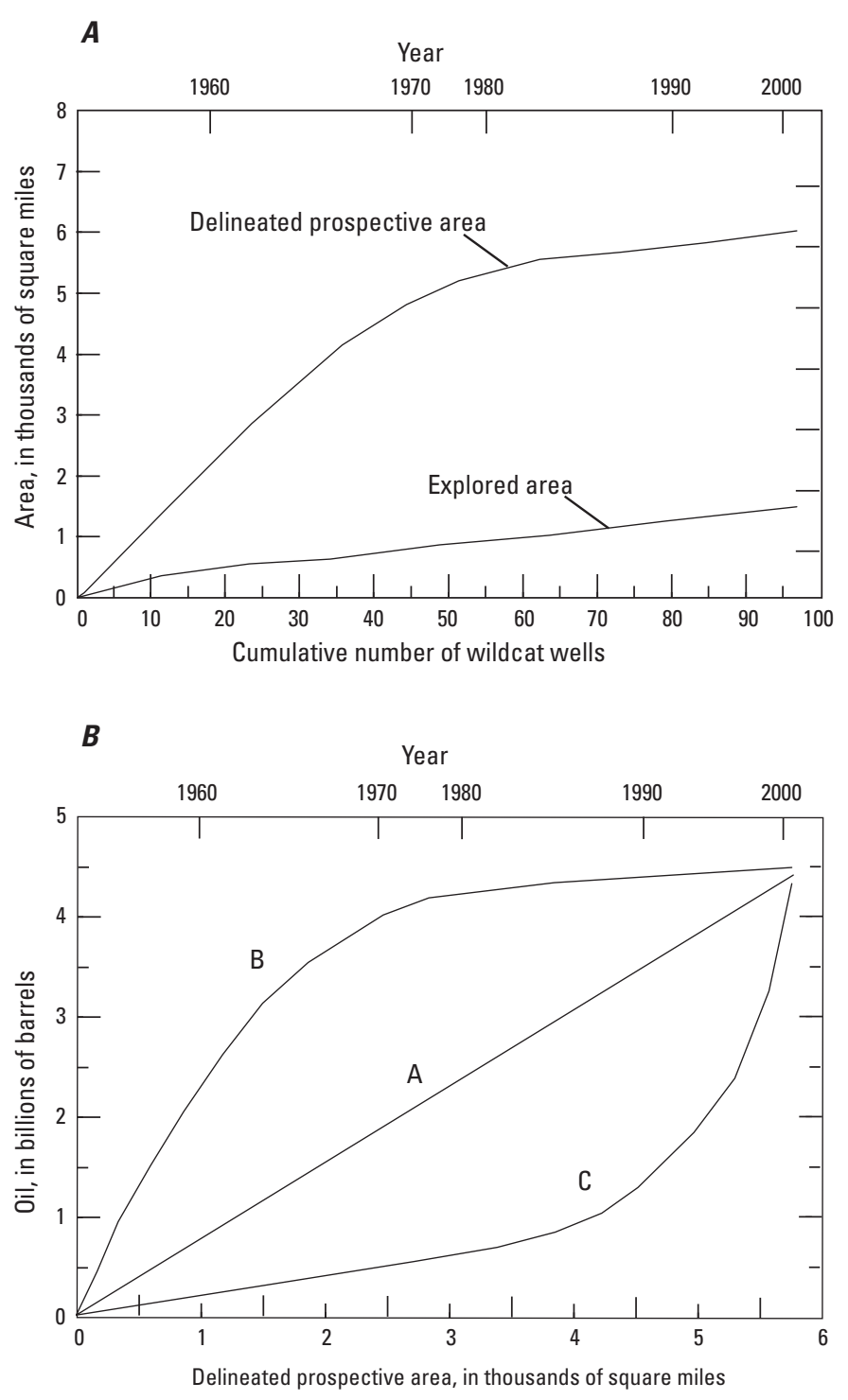

Figure 4. Generalized graphs illustrating the possible profiles of the growth in the cumulative prospective area and the explored area. $A$, Profiles showing the growth in cumulative delineated prospective and explored areas plotted against the cumulative number of wildcat wells drilled, where both the areas and the wildcat wells are ordered by time. The top axis shows 10 -year markers; the closer the markers are to each other, the fewer the wildcat wells that were drilled in that decade. $B$, Profiles $A, B$, and $C$ of the cumulative oil discovered through 2001 and graphed by the year that the field location was classified as part of the delineated prospective area. Profile A is straight line and indicates that the delineated prospective areas identified by early exploration and late exploration are equally productive. Profile B indicates that the delineated prospective area identified by early exploration is more productive than the delineated prospective area identified by late exploration. Profile $\mathrm{C}$ indicates that the delineated prospective area identified by early exploration is less productive than the delineated prospective area identified by late exploration. From Attanasi and others (2007, fig. 6). 


\section{Exploration and Discovery Statistics}

\section{Exploration Effort}

Measures of the quality and value of an exploration effort are not easily quantified. Ideally, the geologic and geographic context of an effort will determine the value, in terms of added information that may be realized by the expenditures on geophysical data or on the drilling of a wildcat well. For example, although some wildcat wells are drilled to test new plays, most wildcat wells are drilled to test for new pools or extensions of existing pools. Risks and costs vary with the characteristics of the geologic target and its geographic location. Consequently, the value and the costs of information generated by an exploration effort are highly dependent on local conditions, as well as on the economic conditions that determine the value of the hydrocarbons.

Table 3 shows the regional distribution of the cumulative number of wildcat wells, as classified by IHS Markit, and the cumulative recoverable volumes of oil and gas discoveries. Table 4 shows the annual totals of wildcat wells drilled in the study area by country and region from 1961 through 2015 (tables 4-7 follow the "References Cited"). The share of worldwide wildcat drilling accounted for by the United States and Canada declined from more than 90 percent in 1930 to less than 50 percent in 2015. For 2015, Europe and Asia (excluding Russia) account for about 24 and 23 percent of the study area's wildcat wells, respectively. South America accounts for 17 percent; Africa and Russia, about 11 percent each; the southwestern Pacific, 5 percent; and the Middle East, 4 percent of all study area wildcat wells.

For offshore wells (table 3), Europe and Asia (excluding Russia) each account for 28 percent of the study area's offshore wildcat wells; Africa, 17 percent; South America,
13 percent; and the southwestern Pacific, 8 percent. The Middle East and Russia account for 2 percent and less than 1 percent, respectively, of the offshore wildcat wells drilled in the study area. The fraction of each region's wildcat wells drilled offshore varies widely (table 3). Less than 1 percent of Russia's wildcat wells are offshore, whereas 29 percent of Asia's wildcat wells are offshore. Overall, offshore wildcat wells accounted for about 17 percent of the wildcat wells drilled in the study area to date. However, for the period from 2006 to 2015, about 26 percent of the wildcat wells drilled in the study area were offshore. During this same period, deepwater wildcat wells, that is, wells sited in waters deeper than 200 meters (m) (656 ft), accounted for 40 percent of the study area's offshore wildcat wells. The movement of exploration from onshore to offshore and then to the deep offshore suggests that operators were willing to incur the extra exploration costs because similar untested prospects were no longer available in less costly exploration areas.

About 29 percent of the wildcat wells in the study area were drilled to target formations at depths of at least $10,000 \mathrm{ft}$ (table 7). However, there is great variability among the regions studied. In Africa, 39 percent of wildcat wells are at least $10,000 \mathrm{ft}$ deep, and for Asia and the Middle East, 33 and 32 percent of the wildcat wells, respectively, were at depths of at least 10,000 feet. For Russia, South America, and Europe, deeper wildcat wells accounted for 29, 26, and 24 percent of the wildcat wells drilled in each region, respectively. Table 6 summarizes the regional average discovery sizes by decade, in terms of BOE, for fields at depths of less than $10,000 \mathrm{ft}$ and for fields at depths of $10,000 \mathrm{ft}$ or more. The six-decade timespan of data shows that average discovery sizes are declining in most regions and that discoveries associated with the deeper horizon are generally larger than shallower fields discovered during the same decade.

Table 3. Regional distribution in the study area of total and offshore wildcat wells drilled through 2015 and total and offshore estimated cumulative recoverable volumes of oil and gas discovered through 2015.

[Data are from IHS Markit (2016). BBO, billion barrels (bbl x 109) of oil; TCF, trillion cubic feet $\left(\mathrm{ft}^{3} \times 10^{12}\right)$ ]

\begin{tabular}{|c|c|c|c|c|c|c|}
\hline \multirow{2}{*}{ Region } & \multicolumn{3}{|c|}{ Total } & \multicolumn{3}{|c|}{ Offshore } \\
\hline & Wildcat wells & Oil (BBO) & Gas (TCF) & Wildcat wells & Oil (BBO) & Gas (TCF) \\
\hline Caribbean & 553 & 0.6 & 0.6 & 51 & 0.3 & 0.1 \\
\hline Central America & 292 & 0.3 & $<0.1$ & 68 & $<0.01$ & $<0.01$ \\
\hline Mexico & 4,478 & 58.7 & 115.3 & 432 & 35.7 & 37.6 \\
\hline South America & 21,916 & 238.3 & 660.2 & 2,884 & 89.3 & 249.2 \\
\hline Europe & 30,861 & 96.3 & 794.0 & 6,318 & 72.7 & 403.2 \\
\hline Middle East & 5,708 & 969.4 & $3,275.2$ & 544 & 123.1 & $1,857.80$ \\
\hline Africa & 13,479 & 213.1 & $1,001.8$ & 3,867 & 84.3 & 538.8 \\
\hline Asia & 30,002 & 210.1 & $2,047.8$ & 6,230 & 68.6 & 647.5 \\
\hline Southwestern Pacific & 6,715 & 9.2 & 349.5 & 1,772 & 7.2 & 252.4 \\
\hline Russia & 14,335 & 288 & $2,231.4$ & 140 & 5.3 & 228.4 \\
\hline Total study area & 128,339 & $2,084.00$ & $10,474.9$ & 22,306 & 486.4 & $4,215.0$ \\
\hline
\end{tabular}




\section{Regional Exploration and Discovery Analysis}

Regional exploration and discovery data are presented in tables 3-7 and figures 5-10. As discussed previously, table 3 shows the regional distribution of total and offshore wildcat wells and volumes of discovered oil and gas. Table 4 lists the annual totals of wildcat wells drilled by country for each region from 1961 through 2015. Table 5 shows the year of first discovery and cumulative recoverable oil and gas discovered through 2015 in the 212 significant provinces within the study area by region. Table 6 shows the decadal average discovery sizes, in millions of barrels of oil equivalent (MMBOE), for fields at depths of less than $10,000 \mathrm{ft}$ and fields at depths of at least 10,000 ft from 1956 through 2015. Table 7 summarizes the regional distribution in the study area of total land area, delineated prospective area, explored area, cumulative recoverable oil and gas discoveries, and wildcat wells and the percentages of total prospective area, explored area, cumulative recoverable oil and gas discoveries, and wildcat wells at depths of $10,000 \mathrm{ft}$ and greater.

The annual discovery rates for oil and gas by 5 -year intervals are shown by region in figures $5 A-G$ and $6 A-G$, respectively, for the period from 1951 through 2015. The figures also show the onshore and offshore volumes of oil and gas discovered. Figure $7 A-G$ shows the regional oil discovery rates calculated on the basis of oil per wildcat well for 5-year intervals from 1951 through 2015. For many areas, natural gas was not commercial before 2000, so reported volumes of discovered gas are likely to be incomplete and understated. Because wildcat well records do not have information on predrilling intent or target, there is no way to definitively distinguish wells targeting oil prospects and those targeting gas prospects.

The regional time profiles of the delineated prospective areas and explored areas are shown in figure $8 A-G$. Figure $9 A-G$ shows regional cumulative recoverable oil and gas discoveries through 2015 plotted as a function of the cumulative delineated prospective area. Data for the Caribbean, Central America, and Mexico are included in the corresponding graphs for the entire study area, figures $8 H$ and $9 H$. These figures show evidence regarding the quality or hydrocarbon yields of additions to the delineated prospective area. However, resource development policies, technology, and economics also influence the trends because these forces influence accessibility to and commercial value of the hydrocarbon resources.

Figure $10 A-G$ shows the regional depth distributions of oil in oil fields and gas in gas fields. For the purposes of this study, a field is classified as either oil or gas on the basis of the gas:oil ratio of the field's estimated recoverable oil and gas. A field having at least 20,000 cubic feet of gas per barrel of crude oil is classified as a gas field; otherwise, the field is classified as an oil field. Although the natural gas found in oil accumulations is substantial, it is most often produced as a byproduct of the oil and will generally be reinjected into the reservoir to maintain pressures. During the life of the oil field, production of associated gas will be constrained by the field's operator if oil production must be shut in for any reason.

The regional delineated prospective areas and explored areas shown in figures 8 and 9 are aggregated from data for individual countries or small groups of countries shown in figures 11-55. Maps and data are provided for the Caribbean (fig. 11) and Central America (fig. 12), but these areas are not discussed as a separate region because discovered petroleum is small. Mexico (fig. 13) is briefly discussed before the sections on the major regions. Data for each region are derived from figures as follows: South America, figures 14-22; Europe, figures 23-25; Middle East, figures 26-30; Africa, figures 31-42; Asia, figures 43-51; southwestern Pacific, figures 52-54; and Russia, figure 55.

In the discussions for each region, the delineated prospective area is described in terms of the early half and the late half. Recall from the previous section that the delineated prospective area is represented by grid points that have dates which signify when the area became prospective. Suppose that half of the delineated prospective area in a region was delineated by 1980 . Then the early half is that part of the prospective area that became prospective before January 1980, and the late half is that part of the prospective area that became prospective during and after January 1980.

\section{Mexico}

In early editions of this Circular (Root and others, 1987; Attanasi and Root, 1993; Attanasi and others, 2007), drilling and discovery data available for Mexico were very incomplete. Consequently, maps of prospective and explored areas in Mexico were not presented. In the years between 2001 and 2016, IHS Markit made significant additions to both the drilling and discovery data available for Mexico. Mexico accounts for about 3 percent of the conventional oil and about 1 percent of conventional gas discovered in the study area through 2015. There are nine significant petroleum provinces in Mexico (table 5). Mexico shares the Yucatan Platform (fig. 13) with the Central American countries of Belize and Guatemala (fig. 12). The four most prolific provinces in terms of discovered oil, Villahermosa Uplift, Tampico-Misantla Basin, Saline-Comalcalco Basin, and Chicontepec Basin, account for 99 percent of the country's discovered oil. The four most prolific provinces in terms of discovered gas, Villahermosa Uplift, Tampico-Misantla Basin, Burgos Basin, and Veracruz Basin, account for 86 percent of the discovered gas.

Available data show that about 90 percent of the oil and gas in Mexico has been discovered since 1951. For the decade from 2006 through 2015, offshore discoveries accounted for about 71 percent of the oil discovered and 75 percent of the gas discovered. During the same period, the prospective area expanded at a rate of about 8,000 square miles per year, which is twice the rate of the previous decade (fig. 13). Half of the prospective area was delineated by 1965 , and the early half 
of the area accounts for 39 percent of the discovered oil and 65 percent of the discovered gas in Mexico. Mexico's later discoveries were primarily in newly explored offshore areas.

Mexico's delineated prospective area at a depth of $10,000 \mathrm{ft}$ is about 68 percent of the delineated prospective area at the surface. Discoveries at 10,000 ft and deeper represent about 54 percent of the discovered oil and 53 percent of the discovered gas. From 2006 through 2015, on a BOE basis, the average size of new fields discovered in the deeper horizons was about nine times the average size of discoveries from horizons above depths of 10,000 ft (table 6).

\section{South America}

South America accounts for 11 percent of the oil and 6 percent of the gas discovered in the study area (table 3 ) with 32 significant provinces (table 5). The provinces with the largest volumes of oil are the Maracaibo Basin (figs. 18 and 20), Santos Basin (fig. 22), East Venezuela Basin (fig. 20), and Campos Basin (fig. 22). Each of these provinces has fields that total more than $20 \mathrm{BBO}$ (table 5), and together they account for 76 percent of the oil discovered in this region. The provinces having the largest volumes of discovered gas are the East Venezuela Basin (fig. 20), Santos Basin (fig. 22), Maracaibo Basin (figs. 18 and 20), and Santa Cruz-Tarija Basin (figs. 16 and 21), which together account for 67 percent of the gas discovered in South America. In addition to the 38.5 BBO of conventional oil discoveries in the East Venezuela Basin (fig. 20), an estimated $270 \mathrm{BBO}$ of extra-heavy oil associated with the Orinoco heavy oil belt was discovered in the province (IHS Markit, 2016).

Though many of South America's most prolific basins have discoveries made prior to 1951 , discoveries made after 1951 account for 70 percent of the oil and 78 percent of the gas in conventional fields. These discoveries followed the development of the international oil industry after World War II, which provided export markets for previously developed and newly discovered oil fields. The giant deepwater discoveries in the Campos and Santos Basins (fig. 22) occurred because improved technology for the exploration, discovery, and production of deepwater accumulations had become available and economic since the latter 1980s. Figures $5 \mathrm{~A}$ and $6 \mathrm{~A}$ show that the highest 5 -year annual average discovery rates for oil and gas occurred in the period from 2006 through 2010. For that period, the annual oil discovery rate was $8.2 \mathrm{BBO}$ per year and the gas discovery rate was 21.5 TCF per year. During the period from 1996 through 2015, offshore discoveries accounted for 92 percent of the oil and 74 percent of the gas discovered. Figure $7 A$ shows that the 5-year period from 2006 to 2010 had the highest rate of oil discovered per wildcat well, 28.3 MMBO per wildcat well.

South America accounts for 11 percent of the study area's total prospective area. By the end of 2015, the explored area of this region constituted about 26 percent of the delineated prospective area. The delineated prospective area for South
America doubled between 1977 and 2015 (fig. 8A). Despite the prolific offshore areas added since 1977, discoveries in the early half of the prospective area (before 1977) accounted for 62 percent of the oil and 61 percent of the natural gas discovered through 2015 (fig. $9 A$ ). Figure $9 A$ shows that the prospective areas added between 1995 and 2010 are much more productive than the areas added between 1970 and 1985. The later prospective areas are in deep offshore waters where exploration targeted deeper formations.

For South America, the size of the delineated prospective area at a $10,000-\mathrm{ft}$ drilling depth is about 45 percent of the delineated prospective area at the surface. About 49 percent of the oil in oil fields and 60 percent of the gas in gas fields are at depths of 10,000 ft or greater (fig. 10A). On a BOE basis, the average size of discoveries in the deep $(10,000-\mathrm{ft}$ depth and greater) drilling horizon from 2006 through 2015 was 25 times greater than the average size of discoveries in the shallow drilling horizon (depths less than 10,000 ft) (table 6). Brazil is the most prolific area for deepwater discoveries. Although Brazil's prospective area at a depth of $10,000 \mathrm{ft}$ is about 56 percent of the prospective area measured at the surface, 87 percent of the oil discovered in oil fields and 69 percent of the gas discovered in gas fields are at depths of $10,000 \mathrm{ft}$ and greater (fig. 22).

The maps in figures 14-22 show the 200- and 1,000-m (656- and 3,280-ft) bathymetric contours illustrating that the prospective areas along the coast of Brazil (fig. 22), Guyana, Suriname, and French Guiana (fig. 14) are deeper than prospective areas in other countries of South America.

\section{Europe}

In this study, Europe includes the British Isles, continental Europe, and several nearby islands (figs. 23-25) and excludes Greenland, Iceland, Russia, Cyprus, and Turkey. Greenland has 47 wells and Iceland has 22 wildcat wells, but their prospective areas were excluded from the European totals, and maps of these areas are not included herein. Although seven of Greenland's wells had oil or gas shows, no new discoveries were declared. All wells in Iceland were dry. Cyprus and Turkey are considered part of the Middle East, and Russia represents a single region.

Of the 31 significant provinces in Europe, 6 are shared with other regions (table 5). In table 5, the European oil and gas volume totals for these shared provinces do not include the oil and gas volumes within the other regions. For example, figure 25 shows the European parts of the Azov-Kuban Basin and Dnieper-Donets Basin, but the data for Europe exclude the parts of these provinces in Russia (fig. 55). Figure 23 shows the Central Barents Platform but does not include data for the part of the province in Russia (fig. 55). Similarly, the Pelagian Basin and Sicily provinces are shared with Africa (fig. 35), and the Aegean province is shared with Turkey and Cyprus in the Middle East (fig. 26). 


\section{A. South America}

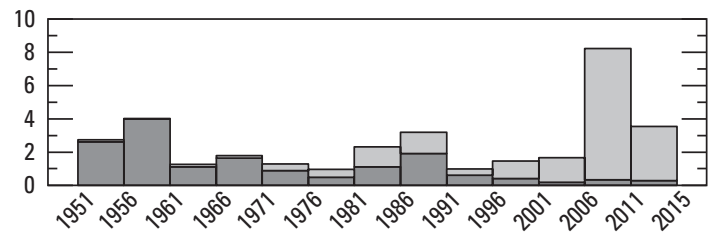

\section{B. Europe}

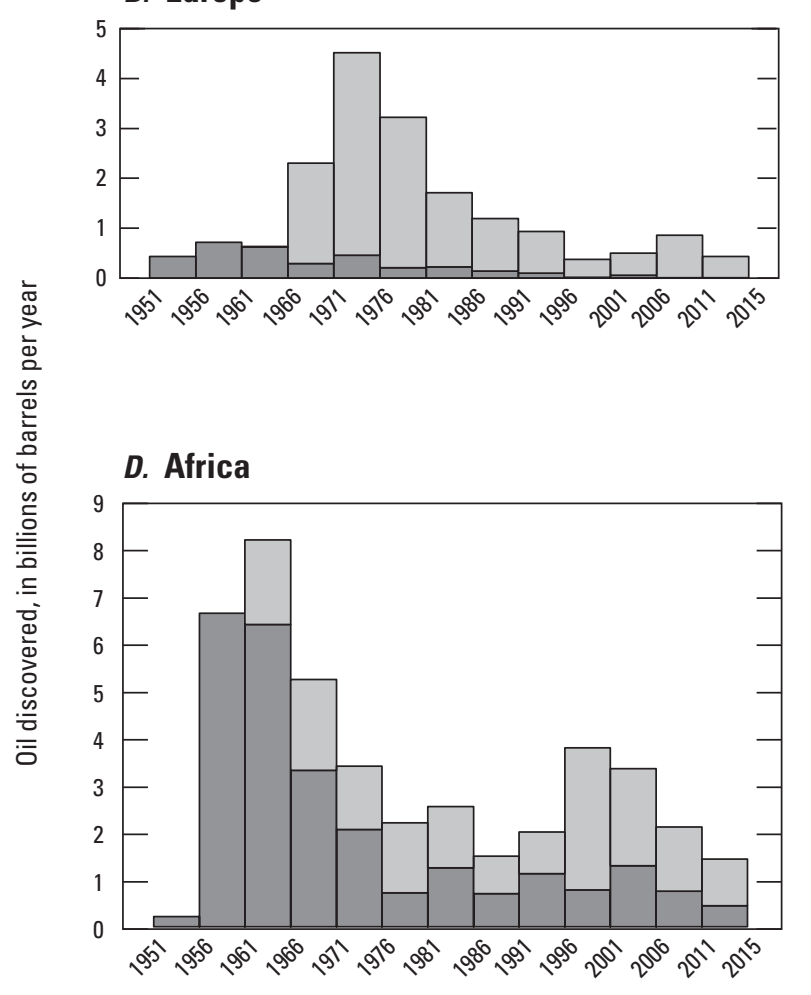

\section{Middle East}

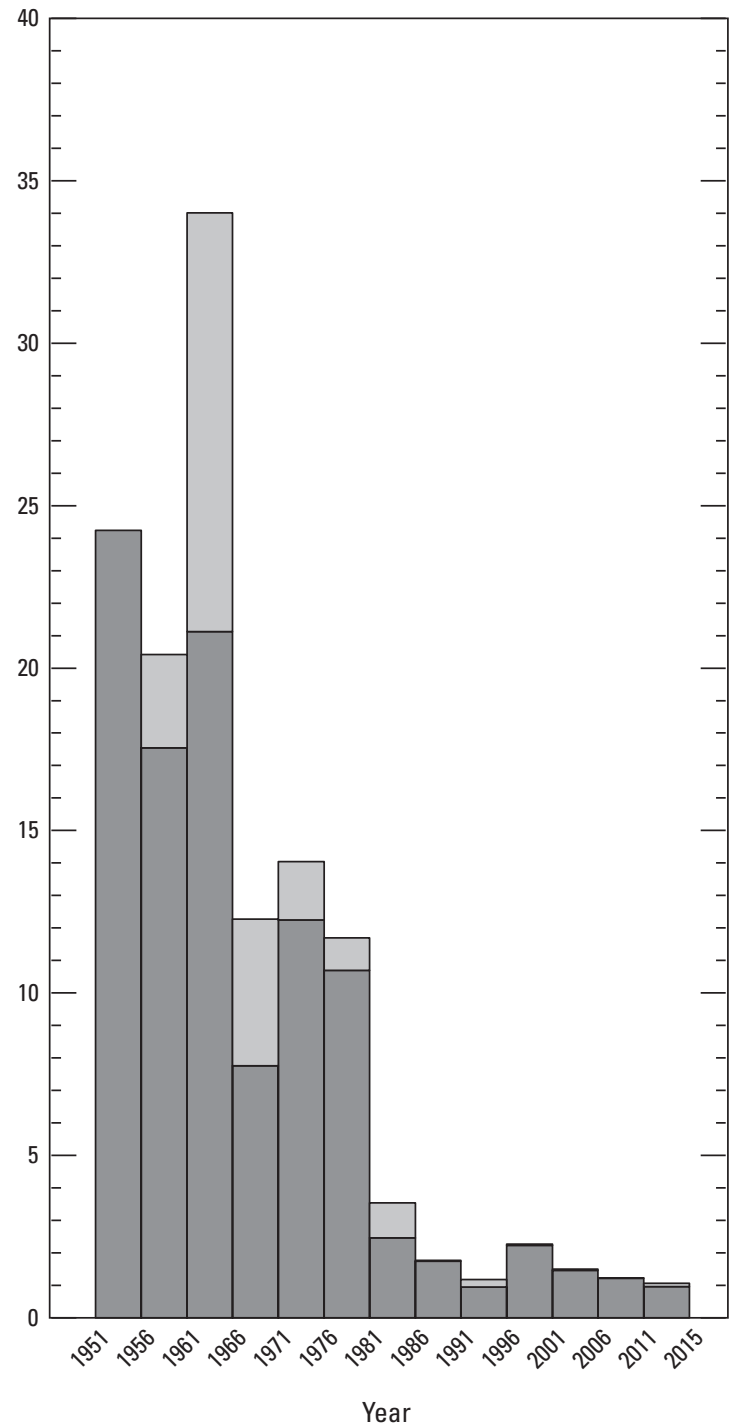

\section{E. Asia}

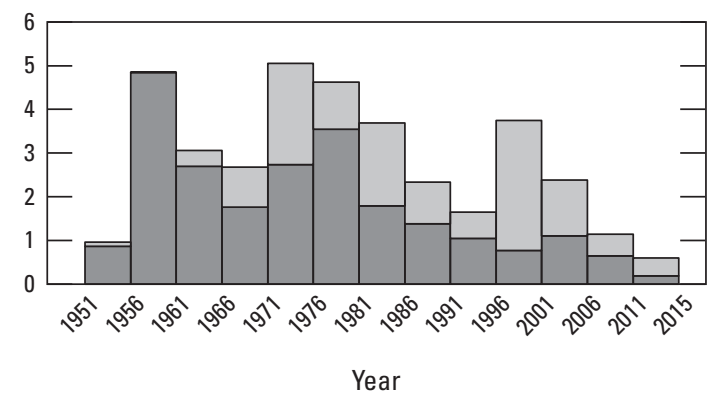

EXPLANATION

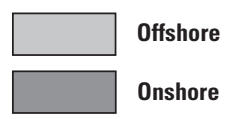

Figure 5. Graphs showing average annual volume of oil discovered offshore and onshore for 5-year intervals from 1951 through 2015 for seven regions and the whole study area: $A$, South America; $B$, Europe; $C$, Middle East; $D$, Africa; $E$, Asia; $F$, Southwestern Pacific; $G$, Russia; and $H$, Study area. The study area graph (fig. $5 H$ ) includes data for the Caribbean, Central America, and Mexico, as well as for the seven regions for which data are graphed in figure $5 A-G$. Discovery size estimates are from IHS Markit (2016). Note the change in vertical scale between graphs. 
F. Southwestern Pacific

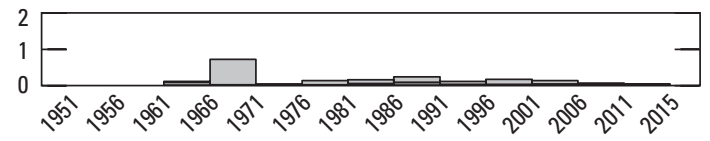

\section{G. Russia}

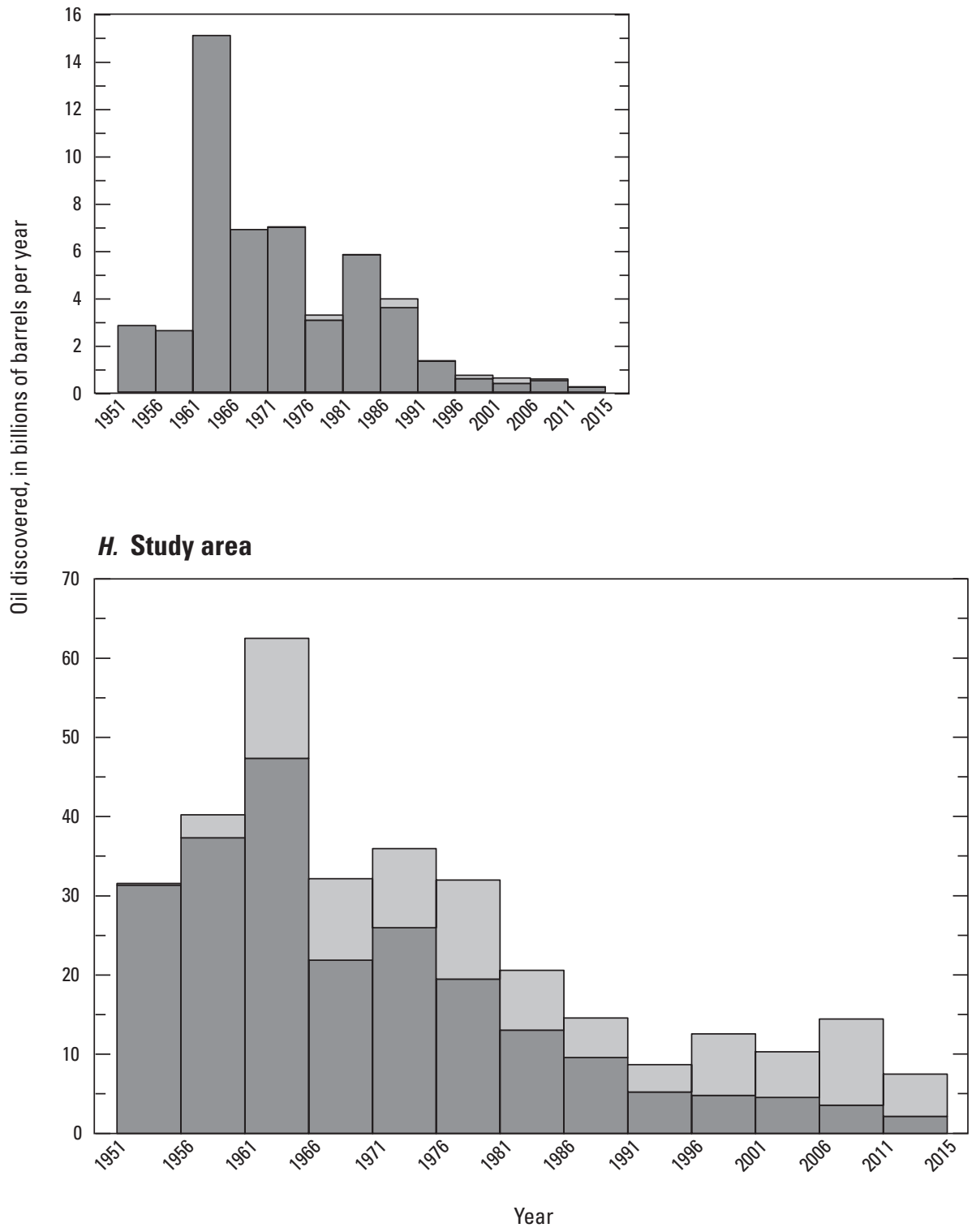

Figure 5. Continued. 


\section{A. South America}

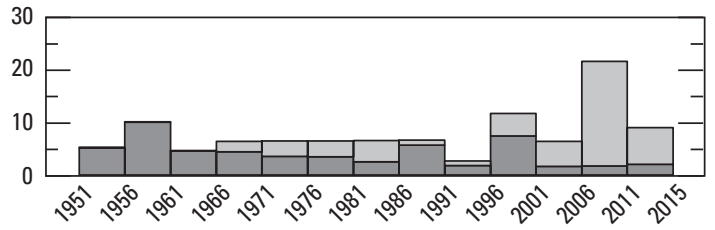

B. Europe

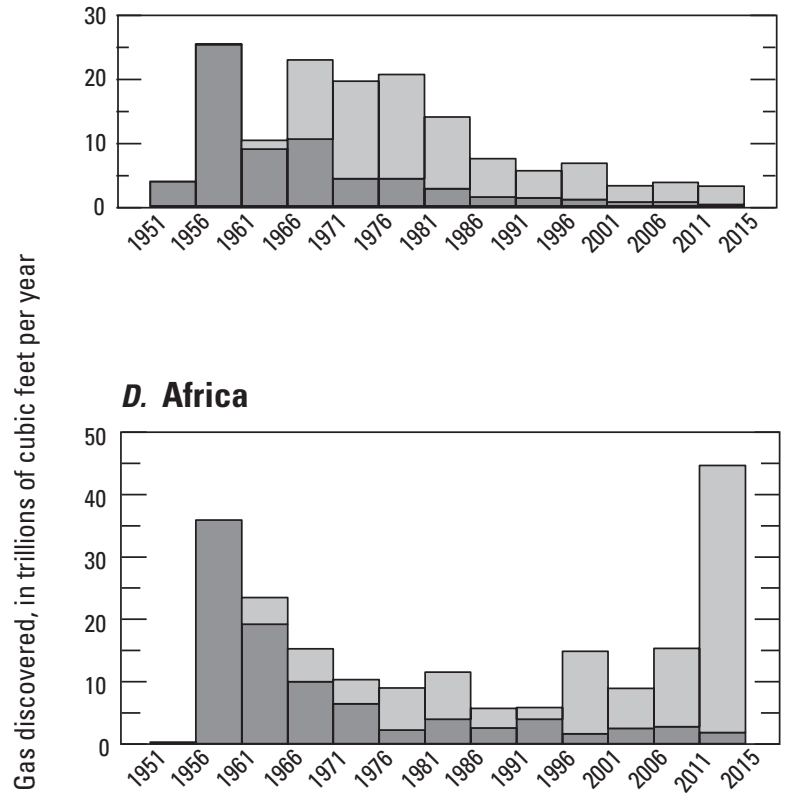

E. Asia

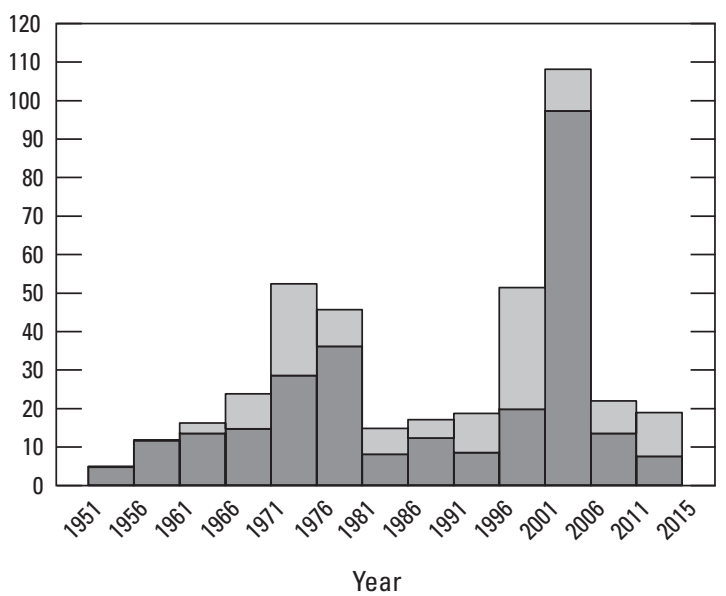

\section{Middle East}

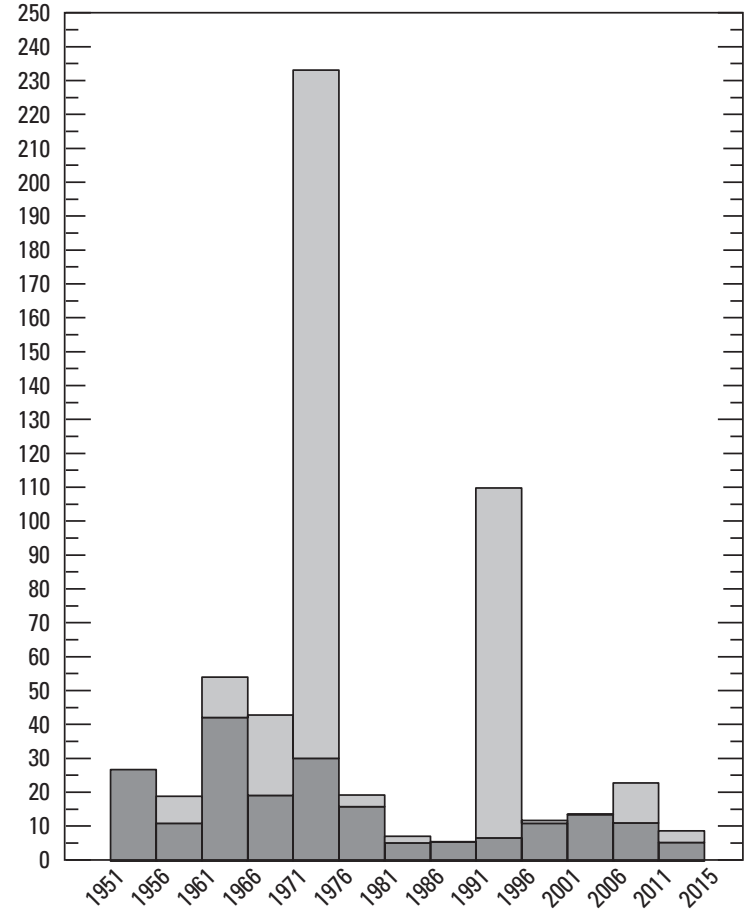

F. Southwestern Pacific

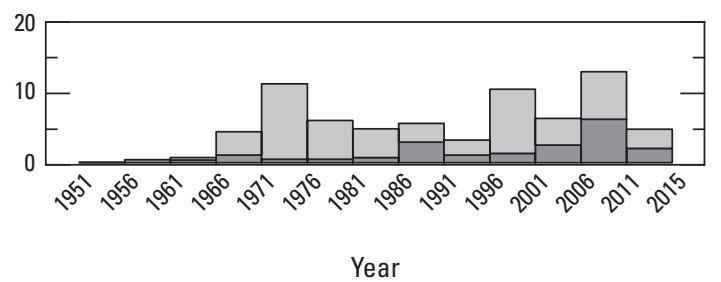

EXPLANATION

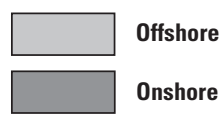

Figure 6. Graphs showing average annual volume of gas discovered offshore and onshore for 5-year intervals from 1951 through 2015 for seven regions and the whole study area: $A$, South America; $B$, Europe; $C$, Middle East; $D$, Africa; $E$, Asia; $F$, Southwestern Pacific; G, Russia; and $H$, Study area. The study area graph (fig. $6 H$ ) includes data for the Caribbean, Central America, and Mexico, as well as for the seven regions for which data are graphed in figure 6A-G. Discovery size estimates are from IHS Markit (2016). Note the change in vertical scale between graphs. 


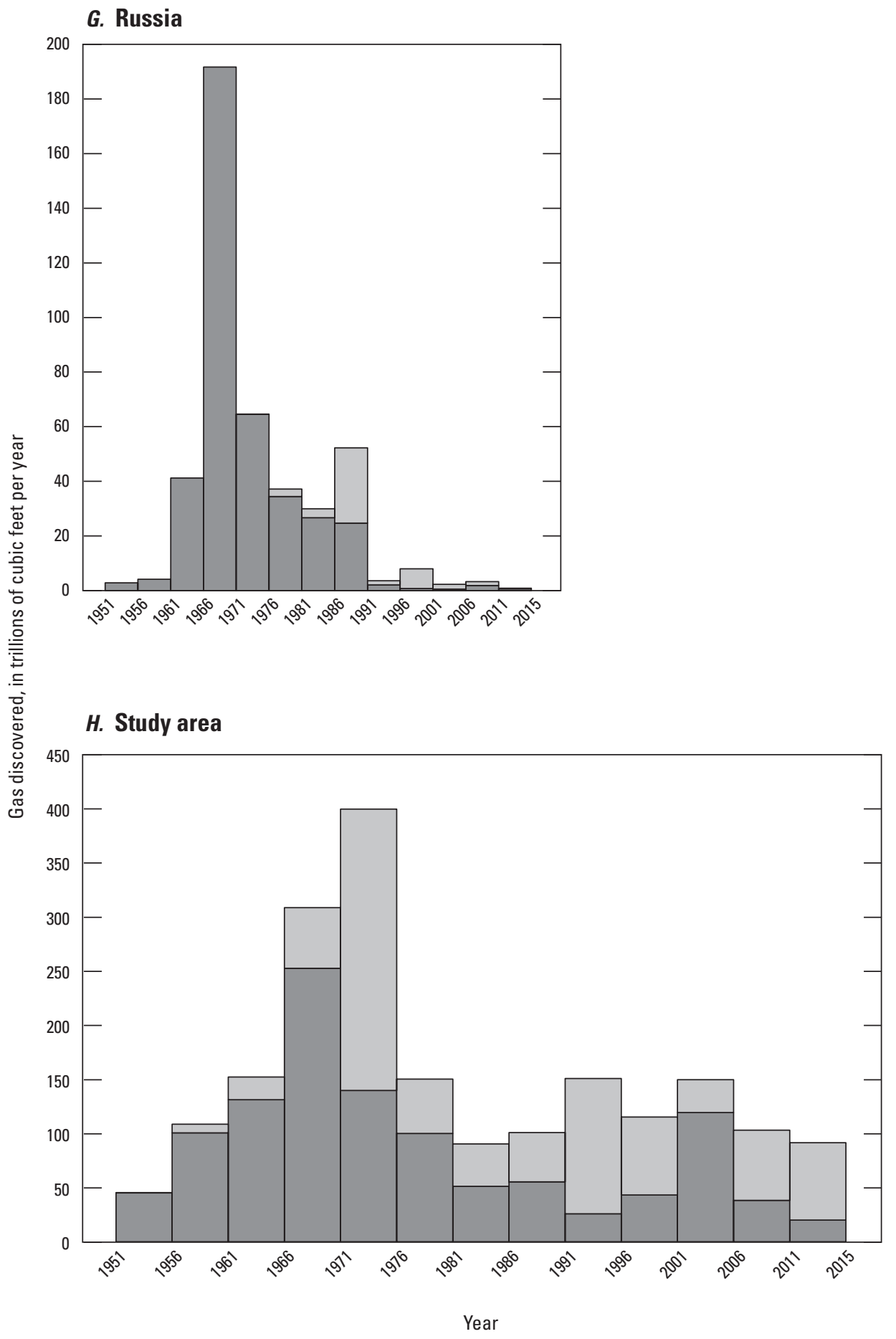

Figure 6. Continued. 


\section{A. South America}

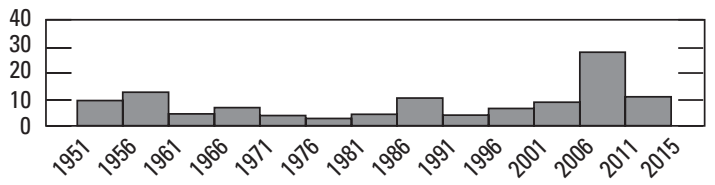

\section{B. Europe}

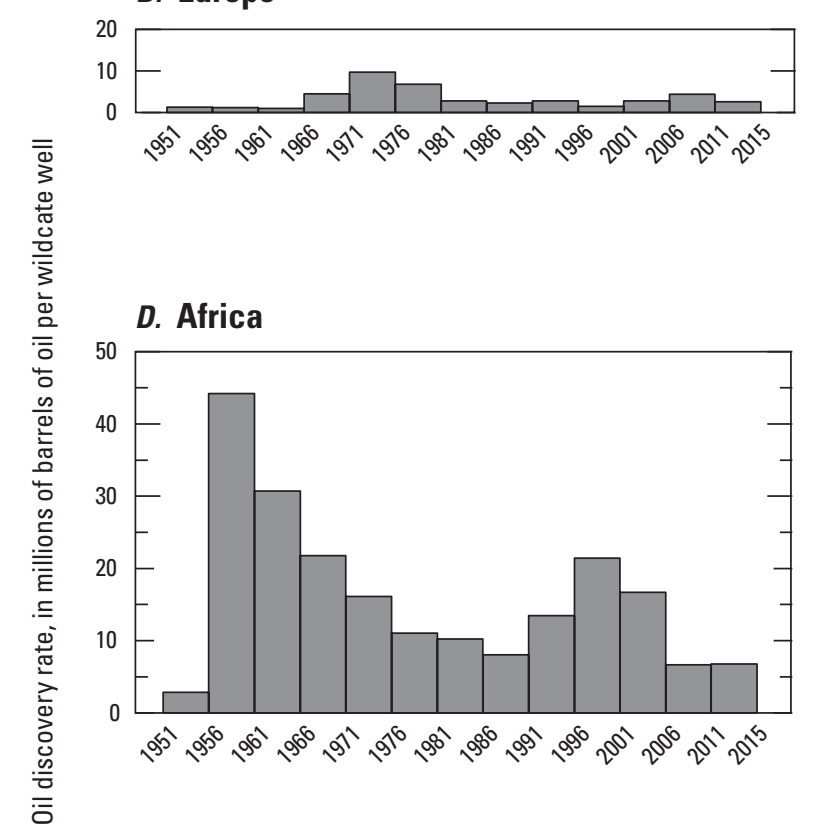

\section{E. Asia}

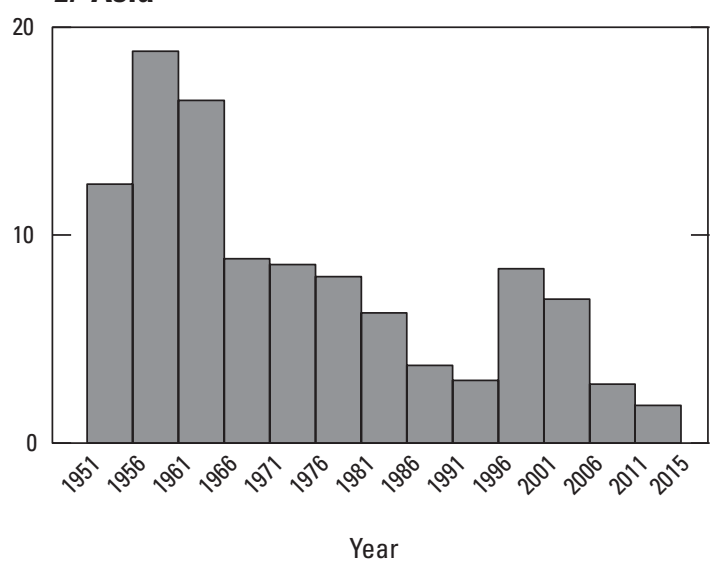

\section{Middle East}

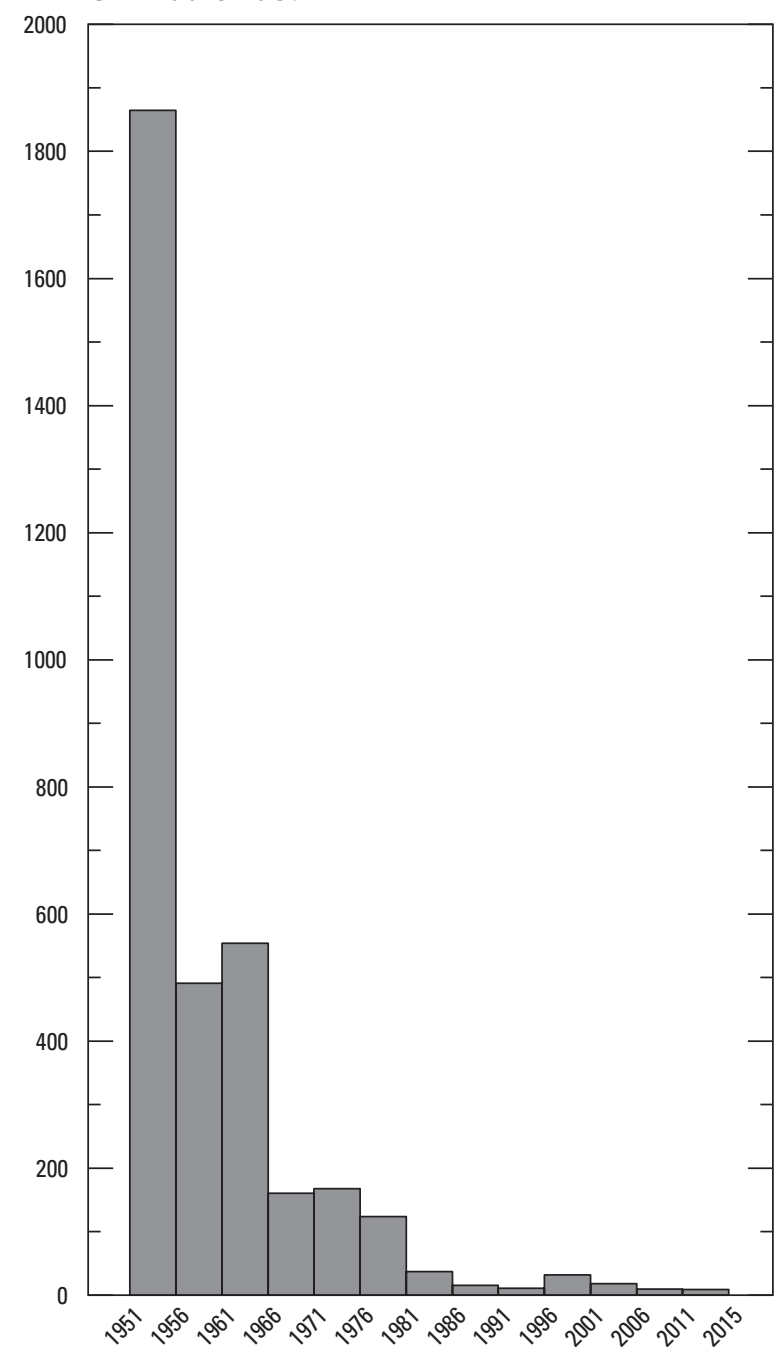

F. Southwestern Pacific

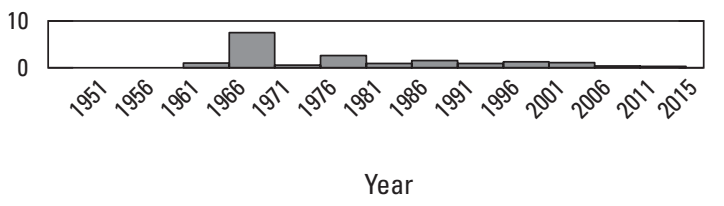

Figure 7. Graphs showing oil discovery rate per wildcat well for 5-year intervals from 1951 through 2015 for seven regions and the whole study area: $A$, South America; $B$, Europe; $C$, Middle East; $D$, Africa; $E$, Asia; F, Southwestern Pacific; $G$, Russia; and $H$, Study area. The study area graph (fig. $7 H$ ) includes data for the Caribbean, Central America, and Mexico, as well as for the seven regions for which data are graphed in figure $7 A-G$. Wildcat well data and discovery size estimates are from IHS Markit (2016). Discovery rates reflect data for all wildcat wells and discoveries both onshore and offshore. Note the change in vertical scale between the graphs. 


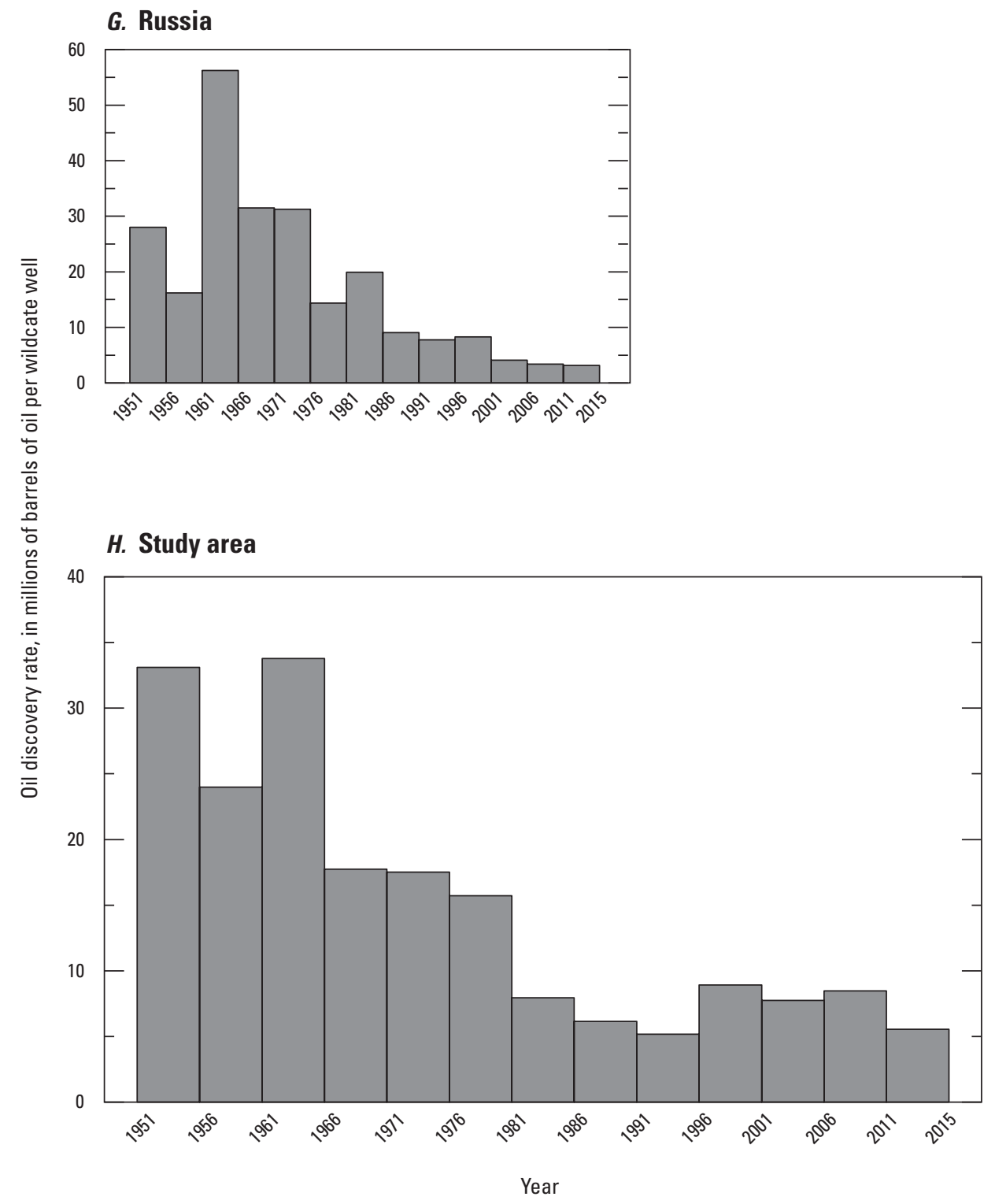

Figure 7. Continued. 


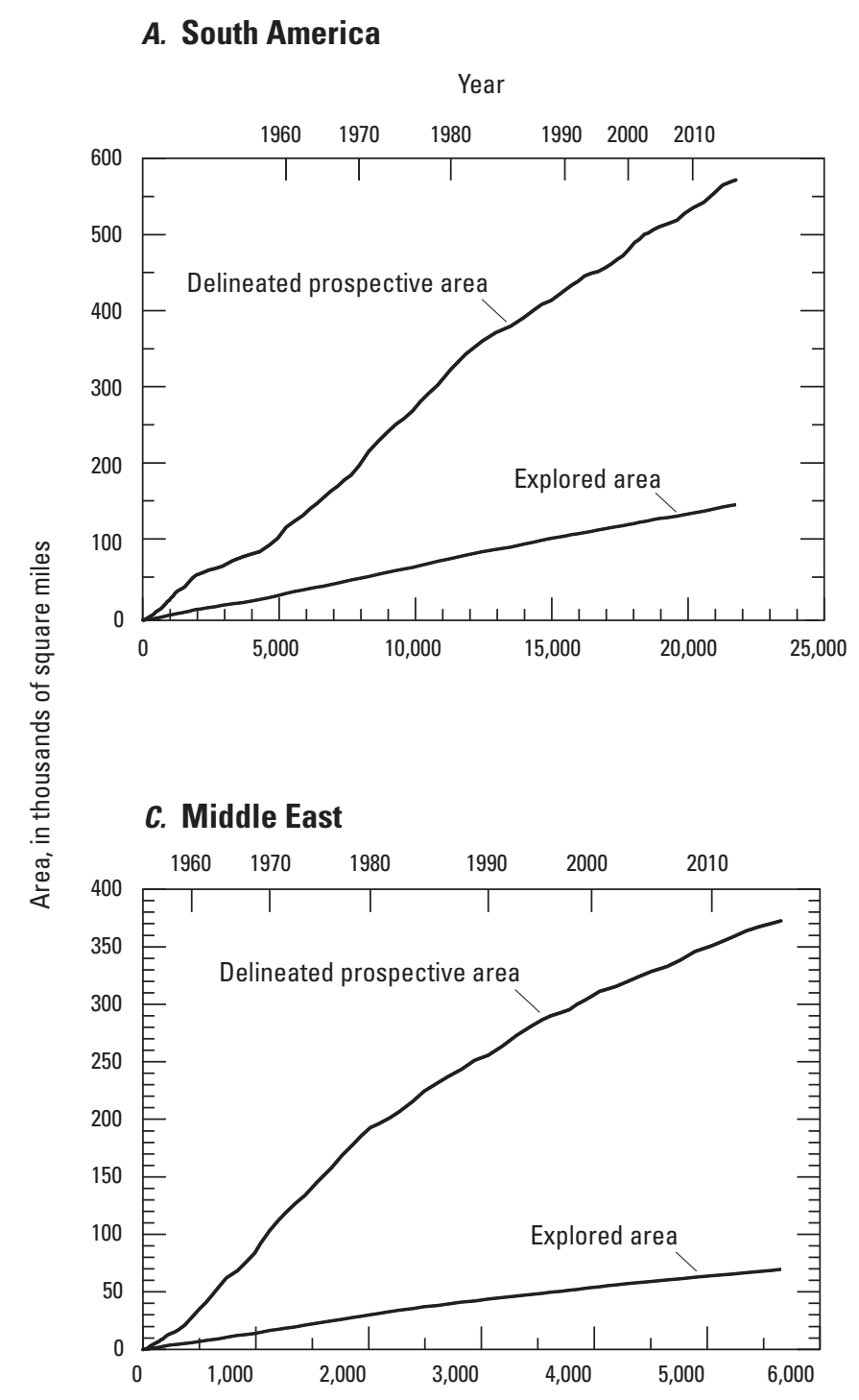

\section{B. Europe}

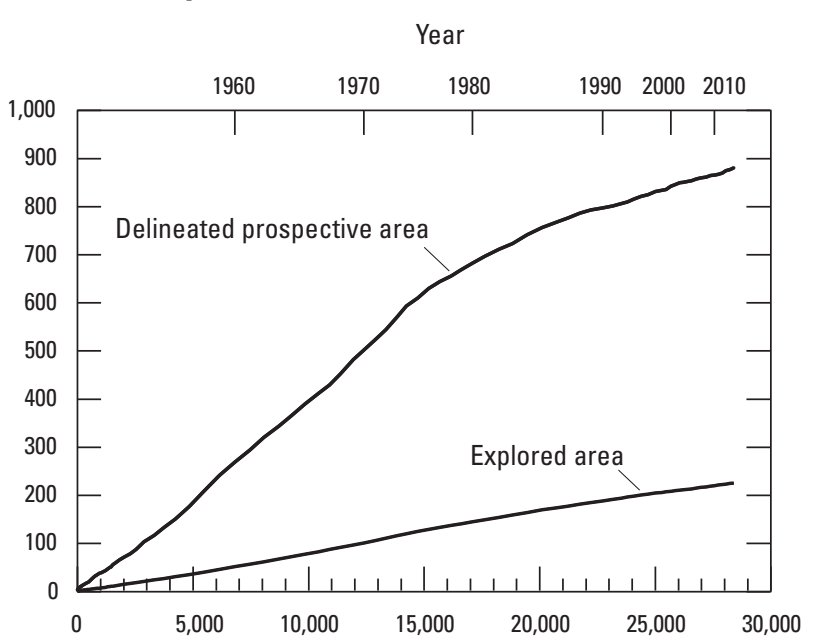

\section{Africa}

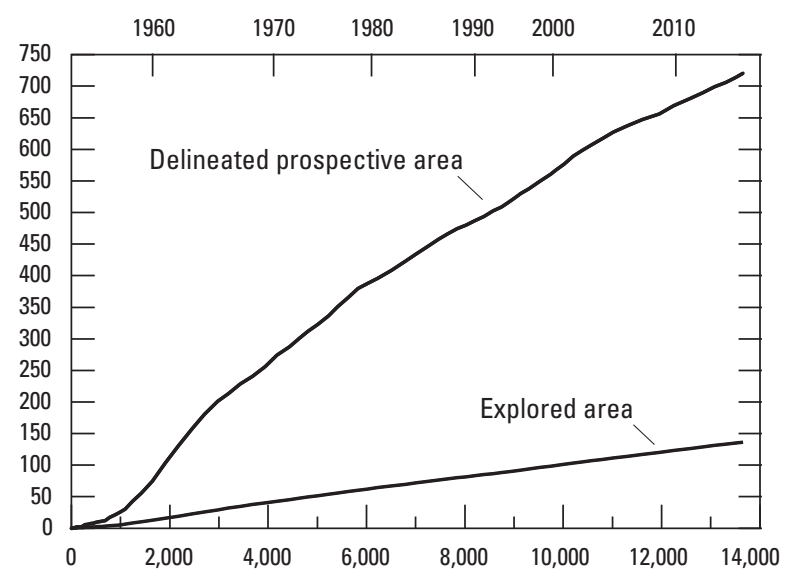

Cummulative number of wildcat wells

Figure 8. Graphs showing growth in delineated prospective area and explored area delineated by wells drilled through 2015 for seven regions and the whole study area: $A$, South America; $B$, Europe; $C$, Middle East; $D$, Africa; $E$, Asia; $F$, Southwestern Pacific; $G$, Russia; and $H$, Study area. The study area graph (fig. $8 H$ ) includes data for the Caribbean, Central America, and Mexico, as well as for the seven regions for which data are graphed in figure $8 A-G$. The regional graphs are at different scales and are derived from graphs in figures $14-55$. The areas are arranged by the year they became prospective or explored, and the wells are also ordered by time. At the top axis of the graphs, the closer the 10-year markers are to each other, the smaller the number of the wildcat wells that were drilled in that decade. Calculations of delineated prospective and explored areas are explained in the text. Well data are from IHS Markit (2016). Only wildcat wells that have spud or completion dates and that have longitude and latitude coordinates are used in the growth calculations for this figure. 
E. Asia

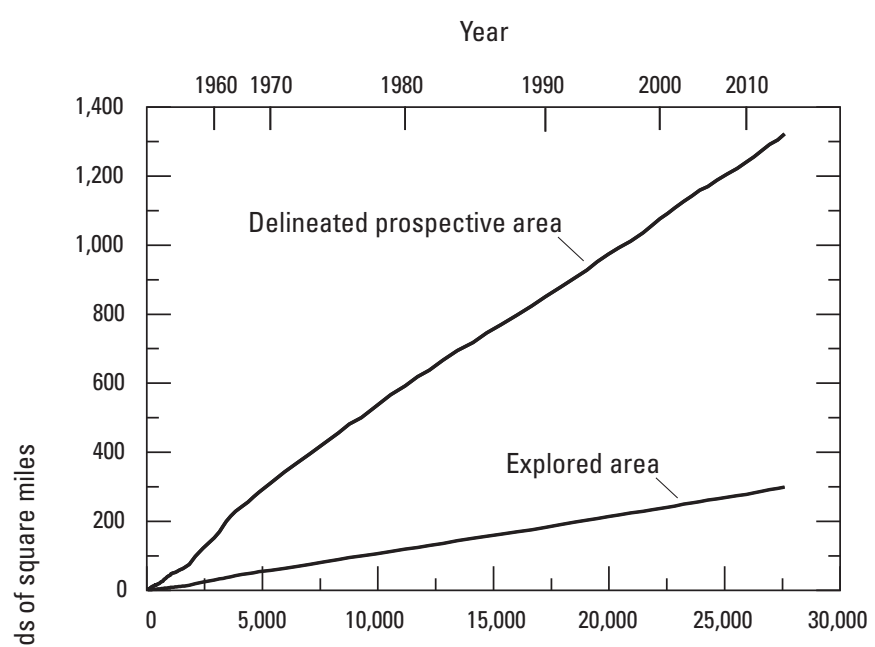

\section{G. Russia}

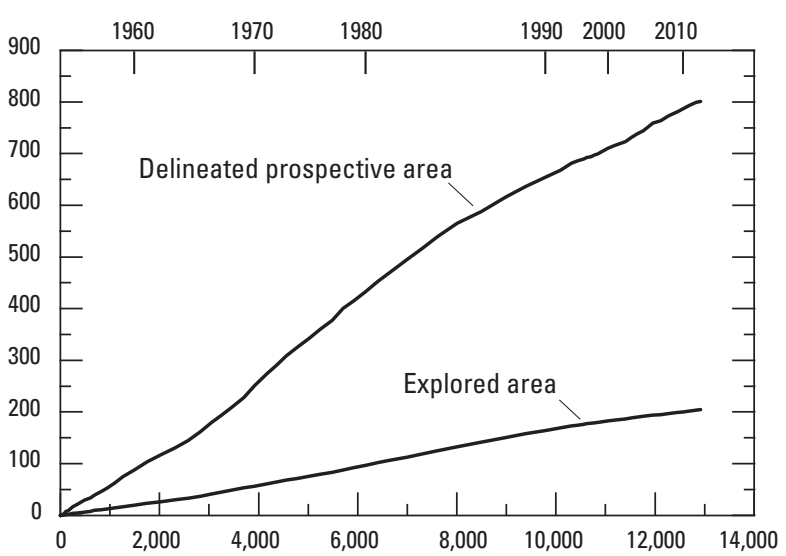

F. Southwestern Pacific

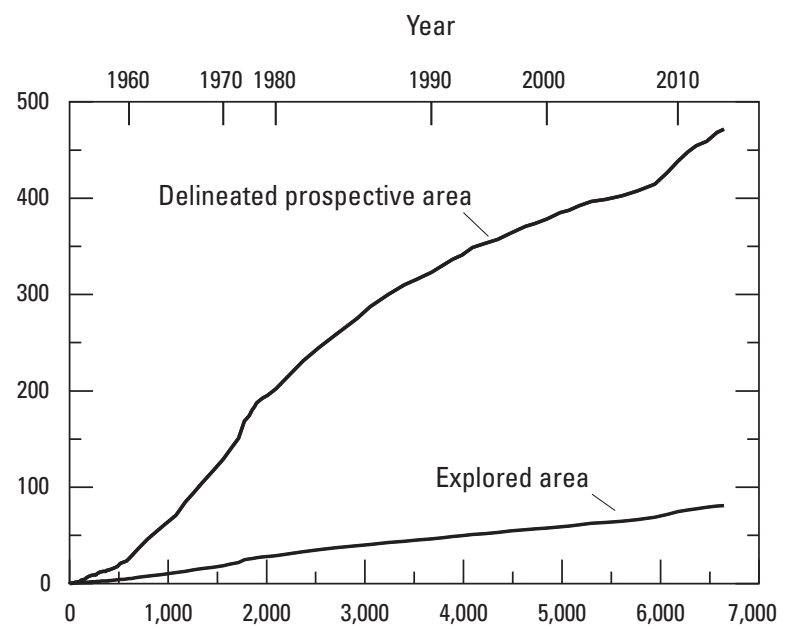

\section{H. Study area}

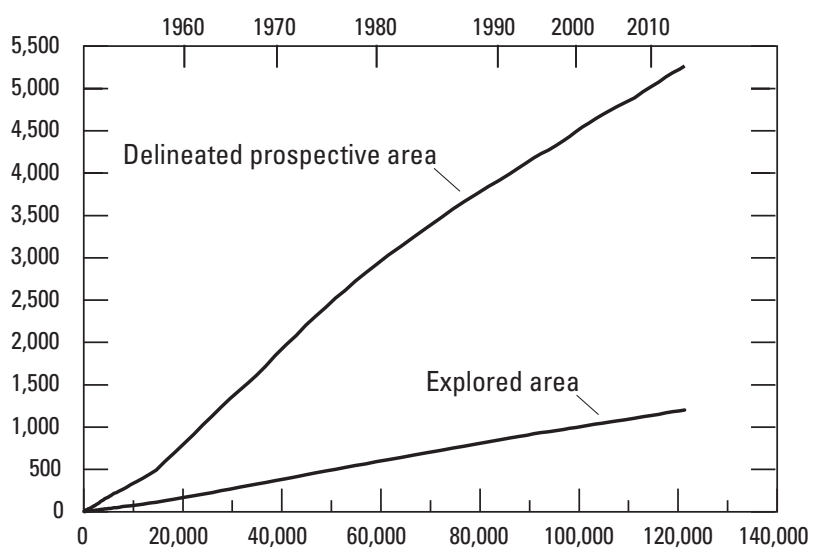

Cummulative number of wildcat wells

Figure 8. Continued. 


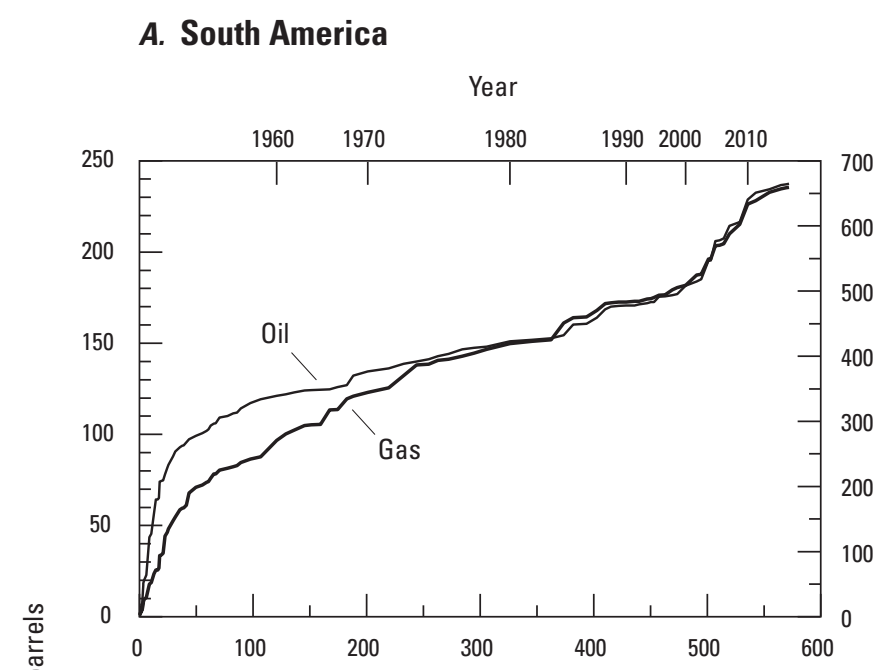

\section{B. Europe}

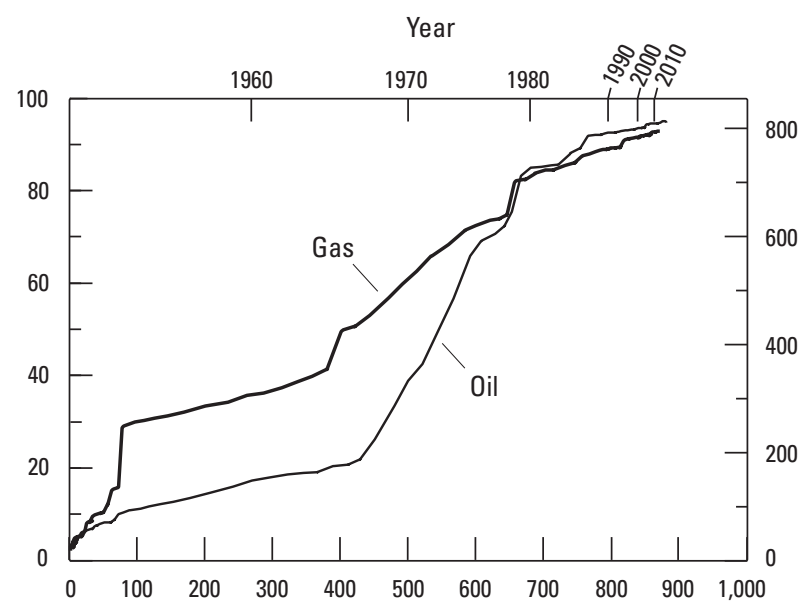

\section{Middle East}

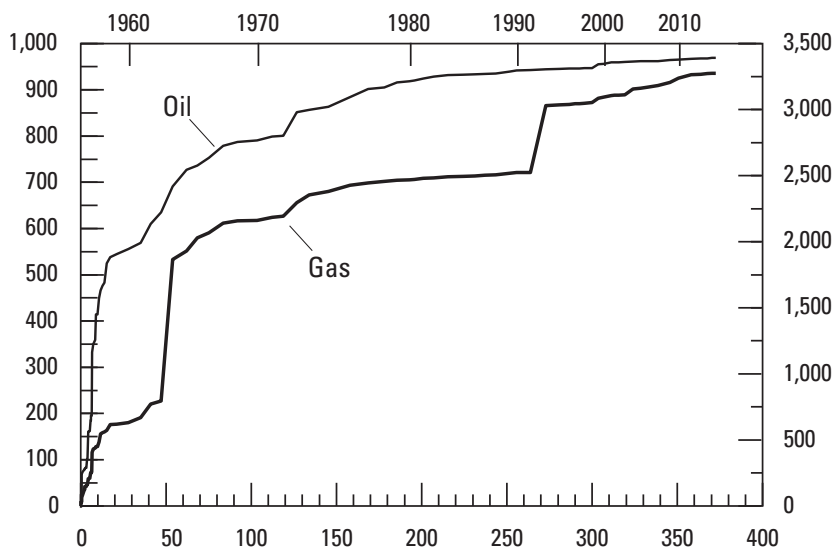

\section{Africa}

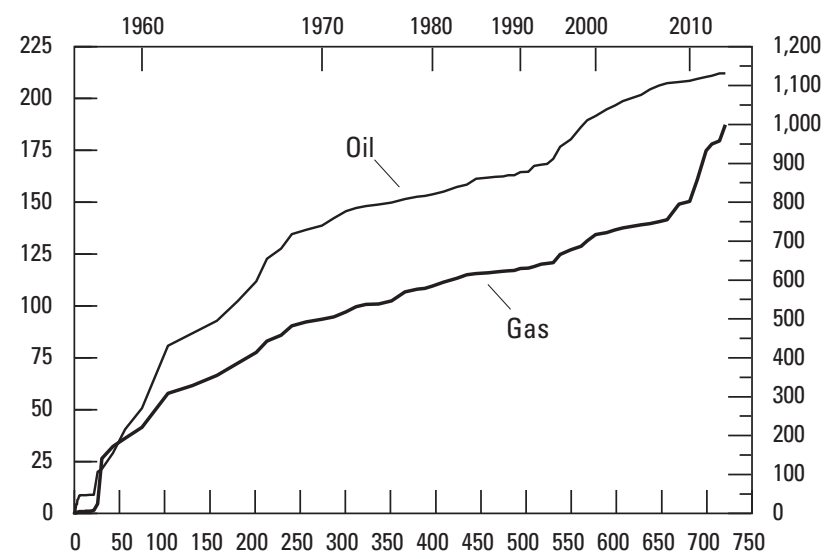

Delineated prospective area, in thousands of square miles

Figure 9. Graphs showing cumulative recoverable oil and gas discoveries through 2015 plotted as a function of cumulative delineated prospective area for seven regions and the whole study area: $A$, South America; $B$, Europe; $C$, Middle East; $D$, Africa; $E$, Asia;

F, Southwestern Pacific; $G$, Russia; and $H$, Study area. The study area graph (fig. $9 H$ ) includes data for the Caribbean, Central America, and Mexico, as well as for the seven regions for which data are graphed in figure $9 A-G$. The regional graphs are at different scales and are derived from graphs in figures $14-55$. The oil and gas discoveries are graphed by the year that the field location was classified as part of the delineated prospective area, and the increments of prospective area are ordered by time. At the top axis of the graphs, the closer the 10-year markers are to each other, the lower the rate at which prospective area was added in that decade. Calculation of delineated prospective area is explained in the text. Discovery size estimates are from IHS Markit (2016). 
E. Asia
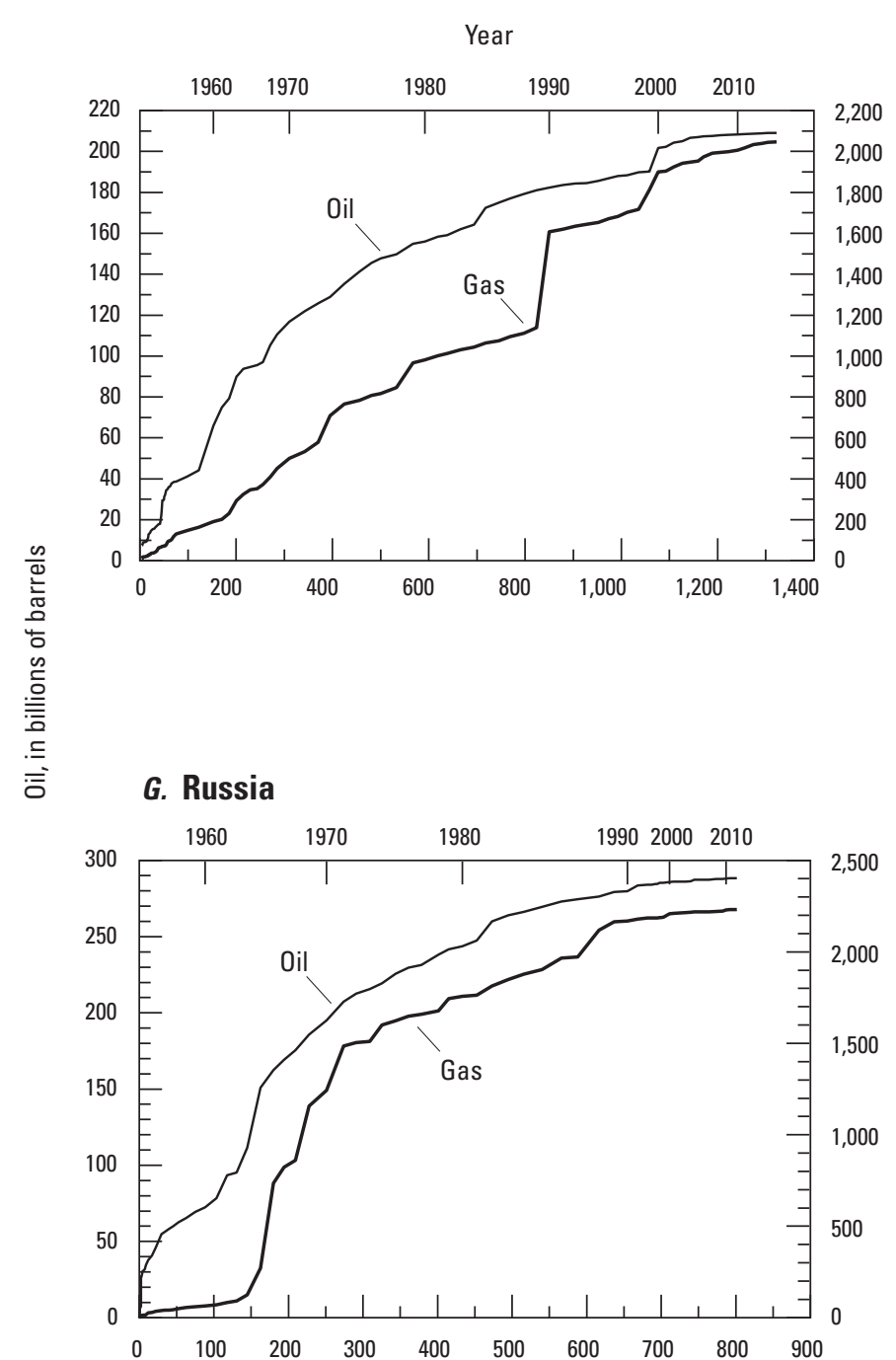

\section{F. Southwestern Pacific}

Year

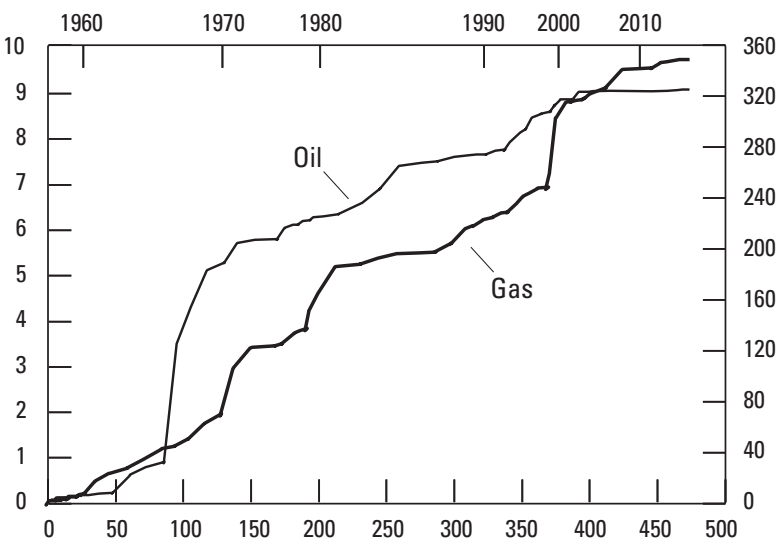

H. Study area

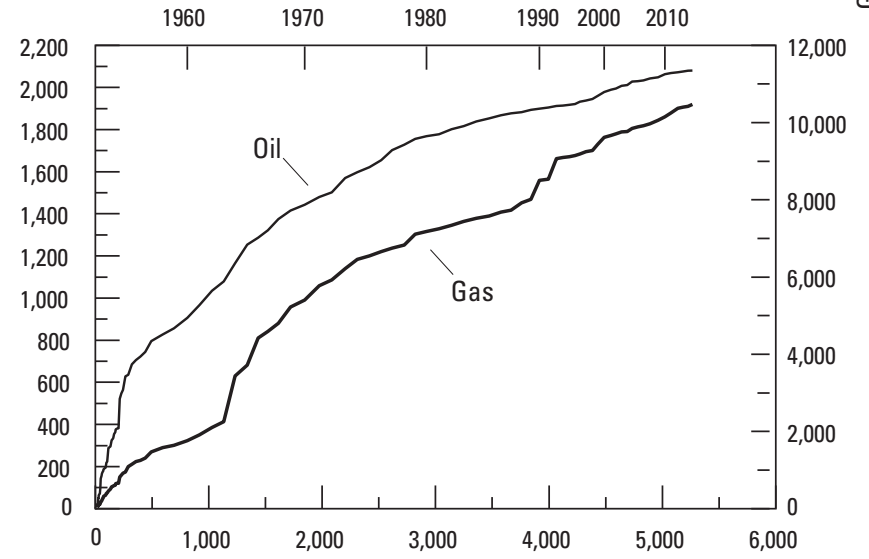

Delineated prospective area, in thousands of square miles

Figure 9. Continued. 

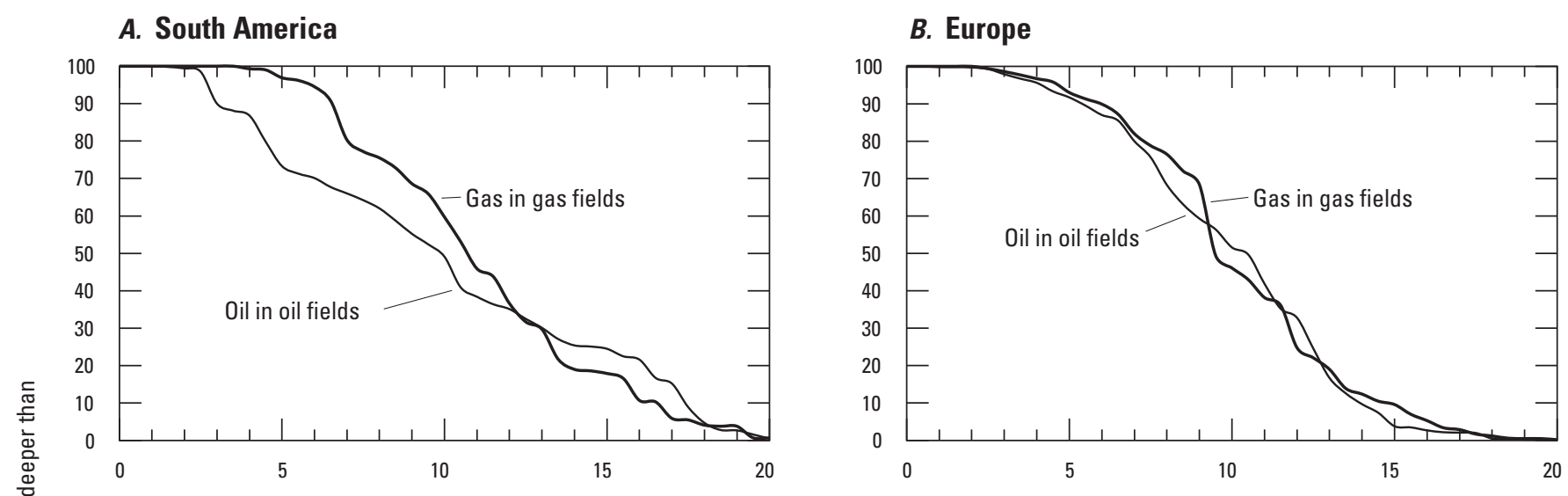

\section{c. Middle East}
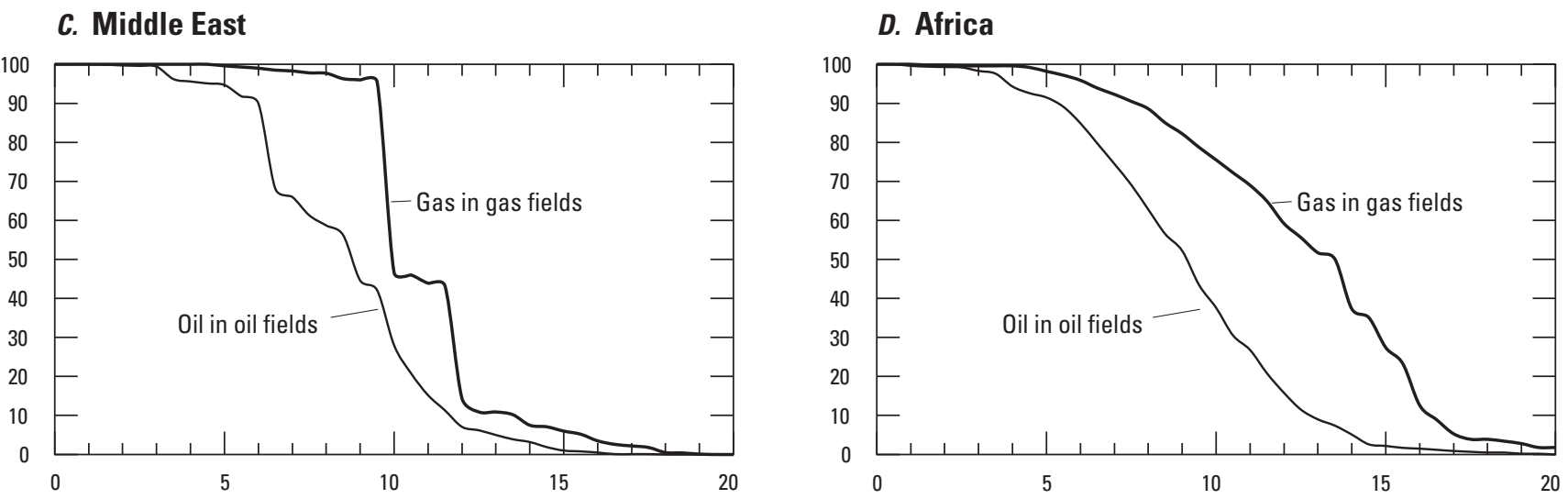

Depth, in thousands of feet

Figure 10. Graphs showing the depth distribution of cumulative recoverable oil in oil fields and natural gas in gas fields for seven regions and the whole study area: $A$, South America; $B$, Europe; $C$, Middle East; $D$, Africa; $E$, Asia; $F$, Southwestern Pacific; $G$, Russia; and $H$, Study area. The study area graph (fig. 10H) includes data for the Caribbean, Central America, and Mexico, as well as for the seven regions for which data are graphed in figure $10 A-G$. The graphs show the percentages of oil and gas volumes below (deeper than) each depth on the horizontal axis. Depths and discovery size estimates are from IHS Markit (2016). 

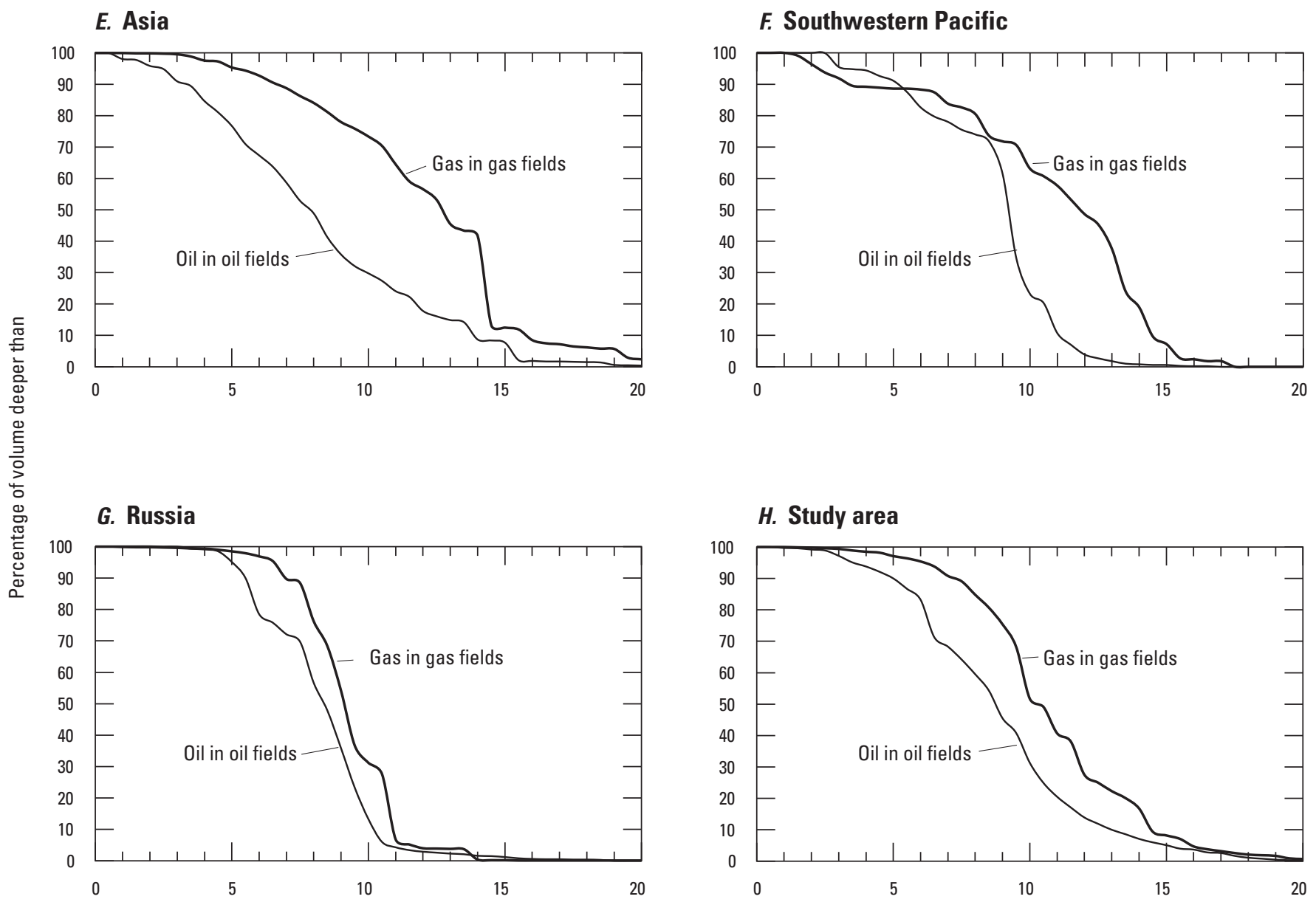

Depth, in thousands of feet

Figure 10. Continued. 
Europe accounts for about 5 percent of the oil and 8 percent of the natural gas discovered in the study area through 2015 (table 3). The North Sea Graben (fig. 23) accounts for 64 percent of the oil discovered in Europe through 2015 and 27 percent of the natural gas. The next most prolific provinces for oil are the Carpathian-Balkanian Basin (fig. 25), which accounts for only 6.9 percent of the oil, followed by VestfordHelgeland (fig. 23) and Dnieper-Donets Basin (fig. 25). For natural gas, the Northwest German Basin (fig. 23) is the second most prolific province with 21 percent of the gas discovered in Europe, followed by the Dnieper-Donets Basin (fig. 25) and Anglo-Dutch Basin (fig. 23). The four most prolific oil provinces account for 78 percent of the discovered oil, and the four most prolific gas provinces account for 71 percent of the discovered gas.

About 92 percent of the oil discovered in Europe through 2015 has been discovered since 1951 . The 5 -year average annual oil discovery rate peaked at $4.5 \mathrm{BBO}$ per year during the period from 1971 through 1975 (fig. 5B), and the 5-year average annual gas discovery rate peaked at $25.2 \mathrm{TCF}$ per year during the period from 1956 to 1960 (fig. 6B). Figure $7 B$ shows that the period from 1971 to 1975 had the highest discovery rate per wildcat well at 9.7 MMBO per wildcat well. During the decade from 2006 through 2015, offshore discoveries accounted for 92 percent of the discovered oil and 85 percent of the discovered natural gas.

Europe accounts for 17 percent of the study area's total prospective area. By the end of 2015, the explored area of Europe constituted about 26 percent of its delineated prospective area. The annual rate of expansion of the delineated prospective area declined by 25 percent between 2006 and 2015 (fig. $8 B$ ), primarily because of a slowdown in wildcat drilling. Figure $9 B$ shows that the prospective area added during the period from 1967 through about 1978 yielded the greatest volumes of oil. This expansion was associated with the delineation of the North Sea Graben. Half of Europe's delineated prospective area was delineated by the end of 1966 . The early half of the prospective area accounted for 23 percent of the oil and 55 percent of the natural gas discovered through 2015. According to the data that support figure $9 B$, the most productive part of the North Sea Graben was delineated after 1966.

For Europe, the delineated prospective area at a depth of $10,000 \mathrm{ft}$ is about 42 percent of the delineated prospective area at the surface (table 7). Discoveries in deep horizons account for 52 percent of the oil in oil fields and 46 percent of the natural gas in gas fields (fig. 10B). For the period from 2006 to 2015, the average discovery sizes in shallow and deep horizons were about the same (table 6). During the previous ten-year period (1996-2005), deeper discoveries were more than twice the size of discoveries in the shallower horizons (table 6).

Figures 23, 24, and 25 show the northern part of Western Europe, the southern part of Western Europe, and Eastern Europe, respectively. For the southern part of Western Europe and Eastern Europe, the graphs tracking the productivity of additions to the prospective area show that the areas added since 1970 have yielded relatively small oil and gas volumes. Although the prospective area added to the northern part of Western Europe since 1980 was not as productive as the area added between 1966 and 1979, the northern part of Western Europe probably accounted for most of the newly discovered oil in Europe (fig. 23), as is evidenced by the high proportion of offshore discoveries since 1980 (figs. $5 B$ and $6 B$ ).

\section{Middle East}

In this study, the Middle East is defined as the Arabian Peninsula, Iran, Iraq, Turkey, Cyprus, Lebanon, Jordon, Syria, Israel, Gaza Strip, and the West Bank (figs. 26-30). The following significant provinces are shared with other regions: Aegean, Levantine Basin, Red Sea Basin, South Caspian Basin, Kura Basin, and Amu-Darya Basin. The tables and figures for the Middle East do not include data for the part of each province located outside the Middle East.

The Middle East accounts for 47 percent of the oil and 31 percent of the natural gas discovered through 2015 in the study area (table 3). Of the 25 significant provinces in the Middle East, 4 provinces, Mesopotamian Foredeep Basin (figs. 27, 29, and 30), Zagros Fold Belt (figs. 26, 28, 29, and 30), Greater Ghawar Uplift (fig. 27), and Rub Al Khali Basin (figs. 27 and 30), account for 93 percent of the oil discovered in the Middle East through 2015. The earliest discoveries in these oil provinces were reported before 1955 (table 5). The four leading provinces for natural gas are Qatar Arch (figs. 27 and 29), Zagros Fold Belt (figs. 26, 28, 29, and 30), Mesopotamian Foredeep Basin (figs. 27, 29, and 30), and Rub Al Khali Basin (figs. 27 and 30). These four provinces account for 87 percent of the discovered natural gas in this region. The most prolific oil and gas provinces in the Middle East are some of the most prolific oil and gas provinces in the entire study area (table 2).

In the Middle East, discoveries since 1951 represent 67 percent of the oil and 88 percent of the gas discovered through 2015 . The annual oil discovery rate peaked at 34 BBO per year from 1961 through 1965 (fig. 5C), and the annual natural gas discovery rate was highest in the period from 1971 to 1975 at 233 TCF per year (fig. 6C). In both cases, the graphs show that the volumes of oil and gas discovered offshore constituted significant portions of the volumes of oil and gas reported. In terms of oil discovered per wildcat well, the peak period was from 1951 to 1955 (fig. 7C). The discovery of natural gas in Qatar's North Field in 1971 and the extension of the field into Iranian waters as the Pars South field in 1991 account for the spikes in the 5-year natural gas discovery rate (fig. 6C). The gas discovered during the period from 2006 to 2010 is from fields in the Levantine Basin offshore Israel (fig. 28). Although this volume of gas is dwarfed by the gas discovered in Iran and Qatar, gas in the Levantine Basin is extremely important to the smaller non-producing countries in the region. The maps (figs. 27, 28, and 30) show that the offshore discoveries are in close proximity to land. 
Figure $8 C$ shows that half of the prospective area was added after 1979; however, the late half of the prospective area accounts for 5 percent of the oil discovered and 25 percent of the natural gas discovered. The rollover of the oil yield curve indicates that the prospective area added after 1970 was much less productive than the earlier area. Although the 1,000-TCF North Field was discovered in 1971, the area became prospective in the early 1960s. By the end of 2015, the explored area of the Middle East represented about 19 percent of the prospective area. This low percentage may reflect the controlled nature of oil development by the primary members of OPEC that are in this region.

For the Middle East, the delineated prospective area at a depth of $10,000 \mathrm{ft}$ is 53 percent of the delineated prospective area at the surface. Discoveries at depths of at least $10,000 \mathrm{ft}$ represent about 28 percent of the oil discovered in oil fields and 47 percent of the gas discovered in gas fields (fig. 10C). During the period from 2006 to 2015, the average discovery size, on a BOE basis, at depths of 10,000 ft and below was about nine times larger than the average size of discoveries at shallower depths (table 6).

\section{Africa}

Africa accounts for about 10 percent of the discovered oil and gas in the study area (table 3). Africa has 31 significant provinces (table 5 and figs. 31-42). Although the Levantine Basin and Red Sea Basin are shared with the Middle East (figs. 26, 28, and 30) and Pelagian Basin and Sicily are shared with Europe (fig. 24), the tables and figures for Africa include only data for the part of each province in Africa. As shown in table 5, only two of the significant provinces of Africa had discoveries prior to 1951. The search for oil and gas in Africa began in earnest after World War II. The four most prolific provinces for oil, Niger Delta (figs. 34 and 40), Sirte Basin (fig. 35), West-Central Coastal (figs. 33, 39, and 40), and Trias/ Ghadames Basin (figs. 35 and 36) account for 81 percent of Africa's discovered oil. The leading provinces for natural gas are Niger Delta (figs. 34 and 40), Tanzania Coastal (figs. 32 and 38), Grand Erg/Ahnet Basin (fig. 36), and Nile Delta Basin (fig. 37). These four provinces account for 66 percent of the natural gas discovered in Africa.

Figures $5 D$ and $6 D$ show that offshore discoveries have accounted for increasing fractions of annual oil and natural gas discoveries. The peak 5-year period for oil discoveries was from 1961 through 1965, and the peak 5-year period for natural gas discoveries was from 2011 to 2015 . The very large natural gas discoveries associated with this peak were in offshore waters of Mozambique in the Tanzania Coastal province (fig. 38). The oil discovery rate per wildcat well peaked in the 5-year period from 1956 through 1960 (fig. 7D). Almost all oil and gas discovered in Africa has been discovered since the beginning of 1951. Over the last 20 years (1996-2015), offshore discoveries accounted for two-thirds of the oil and more than 90 percent of the natural gas discovered.
Africa accounts for 13 percent of the study area's prospective area. The explored area constitutes about 19 percent of Africa's prospective area. Half of the prospective area was added after 1976 (fig. 8D). Discoveries in the early half of the prospective area account for 71 percent of the oil and 55 percent of the natural gas discovered through 2015 . The areas added after 1995, which improved the yields for oil discoveries (fig. 9D), were in the deep offshore waters of west Africa. The shape of the natural gas yield curve is similar to the oil yield curve but increases dramatically after 2010 because exploration in the newly prospective deepwater areas in the Tanzania Coastal province offshore east Africa resulted in the discovery of large nonassociated gas fields (figs. 9D, 37, and 38).

For Africa, the size of the delineated prospective area at a depth of $10,000 \mathrm{ft}$ represents 48 percent of the delineated prospective area measured at the surface (table 7). Discoveries at depths of 10,000 ft and greater account for 38 percent of the oil in oil fields and 76 percent of the gas in gas fields (fig. 10D). During the period from 2006 to 2015, the average size of deep-horizon discoveries was almost four times the average size of shallow-horizon discoveries (table 6).

\section{Asia}

For this study, Asia includes countries of central Asia, China, Mongolia, Southeast Asia, the Indian subcontinent, and the Far East (figs. 43-51) but excludes Russia. Asia accounts for 10 percent of the oil and 20 percent of the natural gas discovered in the study area (table 3 ). The countries of central Asia account for 32 percent of the oil and 50 percent of the natural gas discovered in Asia (fig. 44), and China accounts for 35 percent of the oil and 15 percent of the natural gas (fig. 43).

There are 68 significant provinces in Asia (table 5). Although several significant provinces (Volga-Ural Region, North Caspian Basin, Middle Caspian Basin, South Caspian Basin, Kura Basin, Amu-Darya Basin, and Bonaparte Gulf Basin) have hydrocarbon resources both in Asia and in other regions, the tables and figures for Asia exclude the data for the part of each province outside Asia.

The four most prolific provinces for oil are the North Caspian Basin (fig. 44), Bohaiwan Basin (fig. 43), South Caspian Basin (fig. 44), and Songliao Basin (fig. 43). These four provinces account for 49 percent of the oil discovered in Asia. The four most prolific provinces for natural gas, AmuDarya Basin (fig. 44), North Caspian Basin (fig. 44), Greater Sarawak Basin (figs. 47, 50, and 51), and South Caspian Basin (fig. 44), account for 56 percent of the natural gas discovered in Asia. Fifteen of the significant provinces had evidence of oil or gas before 1900 (table 5).

Discoveries prior to 1951 account for about 88 percent of the oil and nearly all the natural gas discovered in this region. Figure $5 E$ shows that annual oil discoveries have been sustained by the increasing share of offshore discoveries. Although the average annual volume of oil discovered was near the maximum during several 5-year periods, the peak 
period was from 1971 through 1975 . The average annual rate of discovery of natural gas peaked during the period from 2001 through 2005 (fig. $6 E$ ). Figure $7 E$ shows that the oil discovery rate per wildcat well peaked during the period from 1956 through 1960. Offshore discoveries represent about twothirds of the oil and one-third of the gas discovered in Asia since 1996. The large natural gas discoveries of central Asia were in onshore fields.

Asia accounts for about one-fourth of the delineated prospective area in the study area (table 7). The region's explored area is 23 percent of its prospective area. Half of the prospective area was added after 1983 (fig. 8E). The early half of the prospective area has yielded about 75 percent of the oil and 50 percent of the gas discovered through 2015. Figure $9 E$ shows the oil yields in the prospective areas added after 2000 declining dramatically as the plot rolls over. However, these areas were still productive in terms of additional natural gas discoveries (fig. 9E).

For Asia, the prospective area at a depth of $10,000 \mathrm{ft}$ represents about 45 percent of the prospective area at the surface. Discoveries at depths of at least $10,000 \mathrm{ft}$ account for about 30 percent of the oil in oil fields and 73 percent of the gas in gas fields (fig. 10E). Since 2006, on a BOE basis, the average size of fields discovered in the deeper horizons was about three times the average size of discoveries at depths of less than 10,000 ft (table 6).

\section{Southwestern Pacific}

For this study, the southwestern Pacific region includes Australia, New Zealand, Timor-Leste, and Papua New Guinea, along with several South Pacific island nations (figs. 52-54). Of the 12 significant provinces in this region, only the Bonaparte Gulf Basin is shared with another region. The southwestern Pacific accounts for less than 1 percent of the oil and about 3 percent of natural gas discovered in the study area through 2015 (table 3). The amount of oil discovered is small, and the Gippsland Basin (fig. 53), the region's most prolific oil province, accounts for 46 percent of the discovered oil. The Northwest Shelf province (fig. 53) accounts for 42 percent of the natural gas discovered in the region.

Nearly all the oil and gas discoveries were reported after 1951. Discoveries in offshore fields represent about 79 percent of the oil and 72 percent of the discovered gas. The peak 5 -year interval for average annual oil discoveries and average annual oil discovered per wildcat well was from 1966 through 1970 (figs. $5 F$ and $7 F$ ). The peak 5 -year period for annual natural gas discoveries was from 2006 through 2010 (fig. 6F). From 2006 through 2015, offshore discoveries accounted for half of the oil and gas discovered.

Figure $8 F$ shows the growth in the prospective area, and figure $9 F$ shows the oil and gas yields by prospective area. The explored area accounts for 17 percent of the prospective area. Figure $9 F$ shows that prospective areas added after 2000 have resulted in additional natural gas discoveries but have yielded virtually no additional crude oil discoveries. Half of the prospective area was added after 1982. The early half of the prospective area accounts for 72 percent of the discovered oil and 54 percent of the discovered natural gas.

The prospective area at a depth of $10,000 \mathrm{ft}$ is only 16 percent of the prospective area at the surface (table 7). Though the prospective area at $10,000 \mathrm{ft}$ is small, the deeper horizons account for 24 percent of the oil in oil fields and 63 percent of natural gas in gas fields (fig. 10F). From 2006 through 2015, on a BOE basis, the average size of new fields discovered in the deeper horizons was about four times the average size of discoveries at depths of less than $10,000 \mathrm{ft}$ (table 6).

\section{Russia}

Russia accounts for 14 percent of the oil and 21 percent of the gas discovered in the study area (table 3). Russia extends from Europe eastward to the tip of Alaska in North America. The part of Russia in Europe and the part of Russia in Asia are shown on separate maps (fig. 55). Of its 18 significant provinces, Russia shares 6 provinces with other regions (table 5). The Azov-Kuban Basin, Dnieper-Donets Basin, and Central Barents Platform are shared with Europe (figs. 23 and 25). The Middle Caspian Basin, Volga-Ural Region, and North Caspian Basin are shared with Asia (fig. 44).

The most prolific oil and gas province, the West Siberian Basin, accounts for 60 percent of the oil and 74 percent of the natural gas discovered in Russia (table 5). The next most prolific oil provinces are Volga-Ural Region, TimanPechora Basin, and Middle Caspian Basin. Together with the West Siberian Basin, these provinces account for about 96 percent of Russia's discovered oil. The next most prolific gas provinces are the South Barents Basin, Volga-Ural Region, and North Caspian Basin. The four most prolific gas provinces account for about 87 percent of Russia's discovered natural gas.

About 88 percent of Russia's oil and 99 percent of its natural gas were discovered after the beginning of 1951 . Figures $5 G$ and $7 G$ show that the 5-year period from 1961 through 1965 had the highest average annual oil discovery rate and the highest rate of oil discovered per wildcat well. The average annual natural gas discovery rate was highest during the period from 1966 to 1970 (fig. 6G). Offshore discoveries account for less than 2 percent of Russia's discovered oil and about 10 percent of its discovered gas. Very few offshore areas are part of the delineated prospective area. Russia's vast coastal areas are commonly at high latitudes, implying a hostile environment for exploration and development of oil and gas resources.

Russia's prospective area represents 15 percent of the prospective area of the study area (table 7). Russia's explored area is 26 percent of its prospective area. Growth in the prospective area slowed after the beginning of the 1990s (fig. 8G). The rollover of the oil and gas yield curves suggests that the areas added after 1990 are much less productive than the areas that became prospective earlier (fig. $9 G$ ). Half of Russia's 
prospective area was added after 1978. The prospective area delineated before 1978 (the early half of the area) accounts for 83 percent of Russia's discovered oil and 75 percent of the discovered natural gas. The percentages of oil and gas in the early half of the prospective area are the highest of any region in the study area.

The prospective area at a depth of $10,000 \mathrm{ft}$ is about 47 percent of Russia's prospective area at the surface (table 7). However, only 13 percent of the oil in oil fields and 31 percent of the gas in gas fields are at depths of 10,000 ft and greater (fig. 10G). From 2006 through 2015, on a BOE basis, the average size of new fields discovered in the deeper horizons was only slightly larger than the average size of discoveries in horizons less than 10,000 ft deep (table 6).

\section{Study Area}

Table 3 shows cumulative wildcat wells, total oil and gas discoveries, offshore wells, and offshore oil and gas discoveries for the study area. Overall, offshore discoveries account for 23 percent of the oil and 40 percent of the natural gas discovered in the study area. For the study area, the four most prolific oil provinces are Mesopotamian Foredeep Basin, Zagros Fold Belt, West Siberian Basin, and Greater Ghawar Uplift (table 2). These four provinces account for 46 percent of the oil discovered in the study area. The four most prolific natural gas provinces, West Siberian Basin, Qatar Arch, Amu-Darya Basin, and Zagros Fold Belt, account for 43 percent of the gas discovered in the study area.

For the entire study area, discoveries after 1951 account for about 78 percent of the oil and 94 percent of the natural gas discovered through 2015 . The highest 5-year average annual rates of oil discovered and oil discovered per wildcat well occurred in the period from 1961 through 1965 (figs. 5H and $7 H$ ), which reflects the high rates of oil discovery in the Middle East (fig. 5C) and Russia (fig. 5G) during that period. The natural gas discovery rate peaked during the period from 1971 through 1975 (fig. 6H). Large gas discoveries in the Middle East (fig. 6C), Asia (fig. 6E), and Russia (fig. 6G) contributed to the peak. From 2006 through 2015, offshore discoveries accounted for 71 percent of the oil discovered and 78 percent of the gas discovered. During that decade, the offshore oil and gas discoveries amounted to $81 \mathrm{BBO}$ and $680 \mathrm{TCF}$ of gas, of which the offshore discoveries of Africa and South America accounted for $67 \mathrm{BBO}$ and 421 TCF of gas (IHS Markit, 2016).

The estimates of the delineated prospective area, explored area, and cumulative oil and gas were summed across the 10 regions shown in table 3 to obtain the area and yield graphs for the study area (figs. $8 H$ and $9 H$ ). The rate of additions to the prospective area has slowed since the early 1990 s (fig. $8 H$ ). The slight rollover in the oil and gas yield curves in the 1980s (fig. 9H) indicates that the newly delineated prospective areas are slightly less productive than the earlier delineated prospective areas. It should be kept in mind that the oil and gas yields of the recently delineated prospective areas will likely increase as these areas become more intensively explored. For the entire study area, half of the delineated prospective area was added after 1977. The prospective area delineated through 1977, or the early half of the area, accounts for 82 percent of the oil discovered and 64 percent of the natural gas discovered in the study area.

Table 7 summarizes the data for the total land area, prospective area, explored area, cumulative recoverable oil and gas discoveries, and wildcat wells. The table also lists the percentages of prospective and explored areas, oil and gas discoveries, and wildcat wells at depths of at least 10,000 ft. For the study area, 31 percent of the oil in oil fields and 52 percent of the gas in gas fields are at depths of $10,000 \mathrm{ft}$ and greater (fig. 10H). From 2006 through 2015, on a BOE basis, the average size of new fields discovered in deep horizons was about five times the average size of discoveries at depths of less than $10,000 \mathrm{ft}$ (table 6).

\section{Summary and Conclusions}

This Circular summarizes available data pertaining to oil and gas exploration for the world outside the United States and Canada, that is, the study area. The exploration data are principally for wildcat wells that have targeted conventional discrete oil and gas accumulations. The goal of the compilation, presentation, and analysis is to identify, at a reconnaissance level, the areas explored for oil and gas and to characterize their degree of exploration maturity. The maps show the delineated prospective areas, which are the industry-defined areas of interest in the search for undiscovered conventional oil and gas accumulations. The maps also show the explored areas, which are the areas where sufficient exploration and development drilling have occurred to virtually preclude the possibility of new large discoveries. The maps show all the significant onshore and offshore areas of interest for exploration. The bathymetric contours at 200 and 1,000 m (656 and $3,280 \mathrm{ft}$ ) below sea level show the extent of offshore drilling.

The delineated prospective area is generally only a small part of a country's land area. Over the entire study area, the explored area is only 23 percent of the prospective area (table 7). Although the exploration effort is measured in terms of wildcat wells, the measure of exploration maturity used in this Circular takes into account all oil and gas wells that penetrated the depth interval of interest, as well as known field locations. This procedure augments information for areas where records for wells drilled early in the industry's history are missing. In order not to overstate the degree of exploration maturity of the deeper formations, the analysis was repeated using only wells and fields at least as deep as 10,000 ft. In the study area, 29 percent of the wildcat wells were drilled to depths of at least $10,000 \mathrm{ft}$.

Table 7 shows the regional variation in the percentage of deep prospective area at a depth of 10,000 ft. With the exception of the Caribbean, Central America, and the southwestern 
Pacific, the proportion ranges from 42 to 68 percent and the percentage of deep explored area ranges from 34 to 55 percent. On a map, the prospective and explored areas at $10,000 \mathrm{ft}$ would be overlain by the prospective and explored areas at the surface. The calculations show that substantially less than half of the delineated and explored areas can be considered delineated or explored at depths of 10,000 ft and greater.

There may be several reasons for the disparity between the total and deep prospective and explored areas. In certain areas, the depths of conventional discrete accumulations may be constrained by shallow basement rocks. Alternatively, if deep formations are perceived to be prone to gas accumulations rather than oil, and if gas markets are nonexistent or immature, there is an economic incentive to avoid drilling wildcat wells to deep formations. For the study area, 31 percent of the discovered gas is at depths of at least $10,000 \mathrm{ft}$ (table 7) and 52 percent of the gas in gas fields is at least as deep as $10,000 \mathrm{ft}$. Table 7 shows that 32 percent of the oil in both oil and gas fields and 42 percent of the gas in both oil and gas fields are at least as deep at 10,000 ft. In order to properly interpret the intensity of exploration at various depths by using the prospective and explored area concepts, the calculations should be prepared with multiple depth cutoffs at the level of the petroleum basin or subbasin areas.

The maps show a static state of hydrocarbon exploration. The dynamic measures of exploration progress are shown in the graphs that depict the growth in delineated prospective and explored areas as a function of the number of wildcat wells. The relation between the expansion of the delineated prospective area and the associated rate of wildcat drilling is determined by the nature of the wildcat wells. Successful wildcat drilling that finds accumulations in new plays (extensive margin and higher risk) will likely lead to followup wildcat wells and produce a larger incremental expansion in the prospective area than wildcat wells drilled to verify new pools within an operating field (intensive margin and lower risk). Economic factors tend to drive the rate of wildcat drilling, as well as the risk-taking behavior of exploration firms, which in turn affects the siting of new wildcat wells and other petroleum wells that result in reserve additions. By risk classification, these wells range from new pool wildcat wells to infill development wells. The rate of drilling and mix of wells determines the rate of increase in the size of the delineated prospective area.

Another aspect of the dynamic measures of exploration progress is the assignment of discoveries to specific additions to the prospective area. Discoveries are organized spatially and assigned dates that indicate when the area became prospective. The graphs of oil and gas discoveries as functions of delineated prospective area provide a way to evaluate an area's petroleum potential in terms of the amount of oil and gas discovered. Several basin- and play-level empirical studies confirmed that on average, large accumulations are discovered early in the exploration and discovery process (Drew, 1997; Attanasi and others, 2007). Although a prospective area may be only partially explored, the early discoveries provide valuable information about its ultimate yields from a global perspective.

Empirical data show that relatively few of the most prolific provinces contain an overwhelming percentage of the oil and gas discovered to date. More than 400 provinces are in the study area (U.S. Geological Survey World Energy Assessment Team, 2000). According to the data presented in table 2 , the 21 provinces with at least $20 \mathrm{BBO}$ discovered through 2015 account for 85 percent of all oil discovered in the study area. Similarly, the 17 provinces having at least 120 TCF of gas discovered through 2015 account for 69 percent of all gas discovered in the study area. The data in table 3 show the regional distribution of discovered oil and gas.

Not only are the discoveries concentrated in a few provinces, they are also concentrated regionally and among political entities. Table 1 shows that the world's oil and gas reserves are also concentrated by geographical areas. The Middle East alone accounts for about 47 percent of the world's oil reserves and 43 percent of the natural gas reserves.

At various times since the 1970s, OPEC members have restricted oil production to manipulate crude oil prices with varying degrees of success. The conventional wisdom of prices reflecting resource scarcity may not hold. In order to predict the potential magnitude of oil production, some analysts have used exploration and discovery data in place of the unreliable price and economic signals with some success (Hubbert, 1967). However, for such analysis to be reliable, exploration and discovery data must be sufficiently complete and the exploration process far enough along that the analyst can correctly interpret the trends.

One effect of global, short-term, high crude oil prices was to make it profitable to develop oil in offshore fields, deep offshore waters, and environments with extreme climates. During the period from 2006 to 2015, offshore wildcat wells accounted for 26 percent of the wildcat wells drilled in the study area. Of these offshore wells, 40 percent were sited in waters deeper than $200 \mathrm{~m}$. During the same period, offshore discoveries accounted for 71 percent of the oil and 78 percent of the gas discovered in the study area.

Inflated prices also made it profitable to develop the unconventional resources of extra-heavy oil and tar sands. In these accumulations, extraction costs are higher than those of comparable conventional accumulations and the produced oil generally requires some upgrading to be used as feedstock in conventional oil refineries. Finally, higher prices permitted the commercial development of technology to extract oil (tight oil) and gas (shale gas) in reservoirs with very low permeability. The application of hydraulic fracturing in combination with horizontal wells resulted in the ability to produce the oil in such reservoirs at commercial rates. As the oil industry has improved its techniques, unit extraction costs have fallen to levels comparable to the extraction costs of conventional accumulations. According to the U.S. Energy Information Administration (EIA, 2016a), tight oil accounted for 35 percent of the oil produced in the United States in 2015 and gas from shales accounted for 62 percent of 2015 gas production. Currently, 
production of tight oil and shale gas outside the United States and Canada is very limited, although favorable geologic conditions have been identified in several countries (EIA, 2013). In the future, worldwide oil and gas supply streams are expected to increasingly include unconventional resources.

The limitations of this study relate to the data and methods used for appraising the productivity of newly added prospective areas. Although for a given area, on average, the largest accumulations are discovered early in the discovery process, newly prospective areas that have not undergone a threshold level of exploration may be undervalued. Fieldsize data provided by IHS Markit are periodically verified, although some of the data undoubtedly come from secondary sources. Without internationally accepted standards for reserve estimation, there may be some ambiguity in the interpretations of the data.

The magnitudes of the prospective and explored areas at a depth of 10,000 $\mathrm{ft}$ are much smaller than the prospective and explored areas at the surface. However, the interpretation of these disparities should be within the context of the geology of petroleum basins and subbasins rather than at a broad regional scale. The data and methods presented are useful to identify the industry's search area for undiscovered oil and gas and to assess the degree of exploration maturity of an area with respect to discovery of discrete conventional oil and gas accumulations. Although the development and production of large continuous-type oil and gas accumulations in the study area are still in their infancy, the technology to develop those resources is available. Such accumulations will likely make significant contributions to the future oil and gas supply stream from the study area.

\section{References Cited}

Adelman, M.A., 1970, Economics of exploration for petroleum and other minerals: Geoexploration, v. 8, nos. 3-4, p. 131-150. [Also available at https://doi.org/10.1016/0016-7142(70)90030-X.]

Adelman, M.A., 1992, Finding and developing costs in the United States 1945-1986, in Moroney, J.R., ed., Advances in the economics of energy and resources: Greenwich, Conn., JAI Press, v. 7, p. 11-58.

Attanasi, E.D., and Freeman, P.A., 2013, Role of stranded gas in increasing global gas supplies: U.S. Geological Survey Open-File Report 2013-1044, 57 p., accessed September 2016, at http://pubs.usgs.gov/of/2013/1044.

Attanasi, E.D., Freeman, P.A., and Glovier, J.A., 2007, Statistics of petroleum exploration in the world outside the United States and Canada: U.S. Geological Survey Circular 1288, 167 p. [Also available at https://doi.org/10.3133/cir1288.]
Attanasi, E.D., Garland, T.M., Wood, J.H., Dietzman, W.D., and Hicks, J.N., 1981, Economics and resource appraisalThe case of the Permian basin: Journal of Petroleum Technology, v. 33, no. 4, p. 603-616. [Also available at https://doi.org/10.2118/7738-PA.]

Attanasi, E.D., and Haynes, J.L., 1984, Economics and appraisal of conventional oil and gas in the western Gulf of Mexico: Journal of Petroleum Technology, v. 36, no. 12, p. 12711280. [Also available at https://doi.org/10.2118/11297-PA.]

Attanasi, E.D., and Root, D.H., 1988, Forecasting petroleum discoveries in sparsely drilled areas-Nigeria and the North Sea: Mathematical Geology, v. 20, no. 7, p. 763-776. [Also available at https://doi.org/10.1007/BF00890190.]

Attanasi, E.D., and Root, D.H., 1993, Statistics of petroleum exploration in the Caribbean, Latin America, Western Europe, the Middle East, Africa, non-Communist Asia, and the southwestern Pacific: U.S. Geological Survey Circular 1096, 129 p. [Also available at https://doi.org/10.3133/ cir1096.]

Baker, R.A., Gehman, H.M., James, W.R., and White, D.A., 1984, Geologic field number and size assessments of oil and gas plays: American Association of Petroleum Geologists Bulletin, v. 68, no. 4, p. 426-432. [Also available at http://archives.datapages.com/data/bulletns/1984-85/data/ pg/0068/0004/0400/0426.htm.]

BP, 2003, BP statistical review of world energy, June 2003: London, BP, 40 p., accessed June 2003, at http://bp.com/ subsection.do? categoryId=95\&contentId $=2006480$.

BP, 2016, BP statistical review of world energy, June 2016 [dataset]: London, BP, accessed June 8, 2016, at http://www.bp.com/content/dam/bp/excel/energy-economics/ statistical-review-2016/bp-statistical-review-of-worldenergy-2016-workbook.xlsx.

Drew, L.J., 1997, Undiscovered petroleum and mineral resources-Assessment and controversy: New York, Plenum Press, 210 p.

Environmental Systems Research Institute, Inc. [ESRI], 1992, Rivers and water bodies [coverage], in ArcWorld 1:3M [database]: Redlands, Calif., ESRI, on CD-ROM.

Environmental Systems Research Institute, Inc. [ESRI], 1998, Cntry98/Country [shape file for country and land mass boundaries], in World, Mexico, Canada, and European countries, and general U.S. data, CD 1 of ESRI data \& maps 1998: Redlands, Calif., ESRI, on CD-ROM.

Gautier, D.L., Dolton, G.L., Takahashi, K.I., and Varnes, K.L., eds., 1996, 1995 National assessment of United States oil and gas resources-Results, methodology, and supporting data (ver. 2): U.S. Geological Survey Digital Data Series 30, 1 CD-ROM. 
Hayes, M.H., 2006, Flexible LNG supply and gas market integration-Simulation approach for valuing the market arbitrage option, in World Gas Conference, 23d, Amsterdam, 2006, Proceedings: Hoersholm, Denmark, International Gas Union, v. 4, p. 2130-2147, accessed October 17, 2009, at http://www.igu.org/html/wgc2006/.

Hubbert, M.K., 1967, Degree of advancement of petroleum exploration in United States: American Association of Petroleum Geologists Bulletin, v. 51, no. 11, p. 2207-2227. [Also available at http://archives.datapages.com/data/ bulletns/1965-67/data/pg/0051/0011/2200/2207.htm.]

IHS Markit, 2016, International petroleum exploration and production database: London, IHS Markit.

National Geophysical Data Center, 1988, ETOPO5 5-minute gridded elevation data [release publicized by Data Announcement 88-MGG-02, Digital relief of the surface of the Earth]: Boulder, Colo., National Geophysical Data Center, accessed August 11, 2000, at http://www.ngdc.noaa.gov/mgg/global/ etopo5.HTML.

Natural Earth, 2016, ne_10m_admin_0_countries (ver. 3.1.0) [shape file for country boundaries]: Natural Earth, accessed October 18, 2016, at http://www.naturalearthdata.com/ downloads/10m-cultural-vectors/.

Root, D.H., Attanasi, E.D., and Turner, R.L., 1987, Statistics of petroleum exploration in the non-Communist world outside the United States and Canada: U.S. Geological Survey Circular 981, 132 p. [Also available at https://doi. org/10.3133/cir981.]

Root, D.H., and Schuenemeyer, J.H., 1980, Petroleumresource appraisal and discovery rate forecasting in partially explored regions-Mathematical foundations: U.S. Geological Survey Professional Paper 1138-B, p. B1-B9. [Also available at https://doi.org/10.3133/ pp1138AC.]

Schanz, J.J., Jr., 1978, Oil and gas resources-Welcome to uncertainty: Resources, v. 58, p. 1-16.

U.S. Central Intelligence Agency [CIA], 2001, The world factbook 2001: Washington, D.C., U.S. Central Intelligence Agency, 670 p. [Also available at https:/www.cia.gov/ library/publications/download/download-2001/index.html.]

U.S. Central Intelligence Agency [CIA], 2016, The world factbook 2016: Washington, D.C., U.S. Central Intelligence Agency, accessed December 28, 2016, at https:/www.cia.gov/library/publications/the-worldfactbook/index.html.
U.S. Energy Information Administration [EIA], 2000, U.S. crude oil, natural gas, and natural gas liquids reserves - 1999 annual report: U.S. Energy Information Administration [Report] DOE/EIA-0216(99), 156 p. [Also available at https://www.eia.gov/naturalgas/ crudeoilreserves/archive/1999/full.pdf.]

U.S. Energy Information Administration [EIA], 2013, Technically recoverable shale oil and shale gas resources-An assessment of 137 shale formations in 41 countries outside the United States: Washington, D.C., U.S. Energy Information Administration, [variously paged], accessed December 22, 2016, at http://www.eia.gov/analysis/studies/ worldshalegas/archive/2013/pdf/fullreport_2013.pdf.

U.S. Energy Information Administration [EIA], 2016a, U.S. crude oil, and natural gas proved reserves, year-end 2015: Washington, D.C., U.S. Energy Information Administration, 46 p., accessed December 20, 2016, at https://www.eia.gov/ naturalgas/crudeoilreserves/.

U.S. Energy Information Administration [EIA], 2016b, Who are the major players supplying the world oil market?: Washington, D.C., U.S. Energy Information Administration, accessed September 20, 2016, at http:/www.eia.gov/ energy_in_brief/article/world_oil_market.cfm.]

U.S. Geological Survey National Oil and Gas Resource Assessment Team, 1995, 1995 national assessment of United States oil and gas resources: U.S. Geological Survey Circular 1118, 20 p. [Also available at https://doi.org/10.3133/cir1118.]

U.S. Geological Survey World Energy Assessment Team, 2000, U.S. Geological Survey world petroleum assessment 2000_Description and results: U.S. Geological Survey Digital Data Series DDS-60, 4 CD-ROMs. [Also available at https://doi.org/10.3133/ds60.]

White, D.A., 1980, Assessing oil and gas plays in facies-cycles wedges: American Association of Petroleum Geologists Bulletin, v. 64, no. 8, p. 1158-1178. [Also available at http://archives.datapages.com/data/bulletns/1980-81/data/ pg/0064/0008/1150/1158.htm.] 


\section{Tables 4-7}

[Figures 11-55 follow table 7] 
Table 4. Wildcat wells by year, 1961-2015, for the Caribbean, Central America, Mexico, South America, Europe, the Middle East, Africa, Asia, the southwestern Pacific, and Russia.

[Data are from IHS Markit (2016). Some entries in this table differ from entries in table 2 of Circular 1096 (Attanasi and Root, 1993) and table 5 of Circular 1288 (Attanasi and others, 2007) because (1) the well classification system changed in 1996 and (2) historical wildcat well data were added to the database by IHS Markit. The column denoted "Unkn" means year unknown; these wells are not plotted on graphs in figures 11-55. The computation of the delineated prospective and explored areas mapped in figures 11-55 used all wildcat, exploration, and development wells, both successful and dry, except for wells with a missing or obviously incorrect location]

\begin{tabular}{|c|c|c|c|c|c|c|c|c|c|c|c|c|c|c|c|c|c|c|c|c|}
\hline Area & $\begin{array}{l}\text { Pre- } \\
1961\end{array}$ & 1961 & 62 & 63 & 64 & 65 & 66 & 67 & 68 & 69 & 70 & 71 & 72 & 73 & 74 & 75 & 76 & 77 & 78 & 79 \\
\hline \multicolumn{21}{|c|}{ Caribbean $^{1}$} \\
\hline Cuba & 212 & 6 & 1 & 0 & 4 & 1 & 0 & 0 & 1 & 0 & 0 & 3 & 2 & 1 & 1 & 1 & 7 & 5 & 0 & 1 \\
\hline Bahamas & 4 & 0 & 0 & 0 & 0 & 0 & 0 & 0 & 0 & 0 & 1 & 1 & 0 & 0 & 0 & 0 & 0 & 0 & 0 & 0 \\
\hline Barbados & 7 & 0 & 0 & 0 & 0 & 0 & 8 & 2 & 0 & 0 & 1 & 2 & 0 & 0 & 0 & 0 & 0 & 0 & 1 & 0 \\
\hline Haiti & 8 & 0 & 0 & 0 & 0 & 0 & 0 & 0 & 0 & 0 & 0 & 0 & 0 & 0 & 0 & 0 & 0 & 3 & 0 & 0 \\
\hline Dominican Republic & 21 & 3 & 0 & 0 & 0 & 0 & 0 & 2 & 0 & 6 & 1 & 0 & 0 & 0 & 0 & 0 & 0 & 0 & 0 & 3 \\
\hline Jamaica & 4 & 0 & 0 & 0 & 0 & 0 & 0 & 0 & 0 & 0 & 1 & 1 & 0 & 1 & 0 & 0 & 0 & 0 & 0 & 0 \\
\hline Puerto Rico & 4 & 0 & 0 & 0 & 0 & 0 & 0 & 0 & 0 & 0 & 0 & 0 & 0 & 0 & 0 & 0 & 0 & 0 & 0 & 0 \\
\hline Bonaire, Sint Eustatius, and Saba & 0 & 0 & 0 & 0 & 0 & 0 & 0 & 0 & 0 & 0 & 0 & 0 & 0 & 0 & 0 & 0 & 0 & 1 & 0 & 0 \\
\hline British Virgin Islands & 0 & 0 & 0 & 0 & 0 & 0 & 0 & 0 & 0 & 0 & 0 & 0 & 0 & 0 & 0 & 0 & 0 & 0 & 0 & 0 \\
\hline Aruba & 0 & 0 & 0 & 0 & 0 & 0 & 0 & 0 & 0 & 0 & 0 & 0 & 0 & 0 & 0 & 0 & 0 & 0 & 0 & 0 \\
\hline Total & 260 & 9 & 1 & $\mathbf{0}$ & 4 & 1 & 8 & 4 & 1 & 6 & 4 & 7 & 2 & 2 & 1 & 1 & 7 & 9 & 1 & 4 \\
\hline \multicolumn{21}{|c|}{ Central America² } \\
\hline Guatemala & 9 & 2 & 1 & 0 & 0 & 0 & 0 & 0 & 0 & 0 & 4 & 2 & 2 & 0 & 1 & 2 & 3 & 4 & 0 & 0 \\
\hline Belize & 11 & 1 & 1 & 1 & 0 & 0 & 0 & 2 & 0 & 0 & 0 & 0 & 5 & 2 & 1 & 4 & 0 & 2 & 0 & 2 \\
\hline Costa Rica & 18 & 0 & 1 & 2 & 0 & 0 & 0 & 0 & 0 & 0 & 0 & 0 & 0 & 0 & 0 & 1 & 0 & 0 & 0 & 0 \\
\hline Honduras & 6 & 0 & 0 & 1 & 0 & 2 & 4 & 1 & 0 & 1 & 0 & 1 & 3 & 3 & 0 & 1 & 0 & 0 & 2 & 0 \\
\hline Nicaragua & 7 & 0 & 0 & 0 & 0 & 0 & 0 & 1 & 2 & 4 & 8 & 3 & 0 & 0 & 3 & 2 & 0 & 2 & 3 & 0 \\
\hline Panama & 18 & 1 & 4 & 0 & 0 & 0 & 0 & 0 & 0 & 0 & 0 & 1 & 0 & 0 & 2 & 0 & 0 & 0 & 1 & 1 \\
\hline Total & 69 & 4 & 7 & 4 & 0 & 2 & 4 & 4 & 2 & 5 & 12 & 7 & 10 & 5 & 7 & 10 & 3 & 8 & 6 & 3 \\
\hline \multicolumn{21}{|c|}{ Mexico } \\
\hline Mexico & 852 & 93 & 87 & 72 & 66 & 111 & 117 & 86 & 121 & 100 & 92 & 87 & 107 & 83 & 73 & 53 & 66 & 65 & 83 & 67 \\
\hline
\end{tabular}


Table 4. Wildcat wells by year, 1961-2015, for the Caribbean, Central America, Mexico, South America, Europe, the Middle East, Africa, Asia, the southwestern Pacific, and Russia.-Continued

\begin{tabular}{|c|c|c|c|c|c|c|c|c|c|c|c|c|c|c|c|c|c|c|c|c|}
\hline Area & 1980 & 81 & 82 & 83 & 84 & 85 & 86 & 87 & 88 & 89 & 90 & 91 & 92 & 93 & 94 & 95 & 96 & 97 & 98 & 1999 \\
\hline \multicolumn{21}{|c|}{ Caribbean'-Continued } \\
\hline Cuba & 7 & 0 & 0 & 0 & 0 & 2 & 3 & 1 & 0 & 3 & 1 & 1 & 2 & 0 & 4 & 1 & 3 & 3 & 7 & 3 \\
\hline Bahamas & 0 & 0 & 0 & 0 & 0 & 0 & 1 & 0 & 0 & 0 & 0 & 0 & 0 & 0 & 0 & 0 & 0 & 0 & 0 & 0 \\
\hline Barbados & 0 & 0 & 0 & 0 & 8 & 5 & 1 & 0 & 0 & 2 & 3 & 1 & 0 & 0 & 0 & 0 & 0 & 0 & 0 & 0 \\
\hline Haiti & 0 & 0 & 0 & 0 & 0 & 0 & 0 & 0 & 0 & 0 & 0 & 0 & 0 & 0 & 0 & 0 & 0 & 0 & 0 & 0 \\
\hline Dominican Republic & 0 & 2 & 1 & 0 & 0 & 0 & 0 & 0 & 0 & 0 & 0 & 0 & 0 & 0 & 0 & 1 & 2 & 0 & 0 & 0 \\
\hline Jamaica & 0 & 0 & 4 & 0 & 0 & 0 & 0 & 0 & 0 & 0 & 0 & 0 & 0 & 0 & 0 & 0 & 0 & 0 & 0 & 0 \\
\hline Puerto Rico & 0 & 0 & 0 & 0 & 0 & 0 & 0 & 0 & 0 & 0 & 0 & 0 & 0 & 0 & 0 & 0 & 0 & 0 & 0 & 0 \\
\hline Bonaire, Sint Eustatius, and Saba & 0 & 0 & 1 & 0 & 0 & 0 & 0 & 0 & 0 & 0 & 0 & 0 & 0 & 0 & 0 & 0 & 0 & 0 & 0 & 0 \\
\hline British Virgin Islands & 0 & 1 & 0 & 0 & 0 & 0 & 0 & 0 & 0 & 0 & 0 & 0 & 0 & 0 & 0 & 0 & 0 & 0 & 0 & 0 \\
\hline Aruba & 0 & 0 & 0 & 0 & 0 & 0 & 0 & 0 & 0 & 2 & 4 & 0 & 0 & 0 & 0 & 0 & 0 & 0 & 0 & 0 \\
\hline Total & 7 & 3 & 6 & $\mathbf{0}$ & 8 & 7 & 5 & 1 & $\mathbf{0}$ & 7 & 8 & 2 & 2 & $\mathbf{0}$ & 4 & 2 & 5 & 3 & 7 & 3 \\
\hline \multicolumn{21}{|c|}{ Central America ${ }^{2}$-Continued } \\
\hline Guatemala & 4 & 5 & 9 & 3 & 3 & 1 & 0 & 0 & 4 & 2 & 0 & 0 & 0 & 0 & 1 & 1 & 0 & 1 & 4 & 1 \\
\hline Belize & 0 & 3 & 2 & 1 & 1 & 2 & 0 & 0 & 0 & 0 & 2 & 1 & 0 & 0 & 1 & 0 & 0 & 2 & 0 & 0 \\
\hline Costa Rica & 0 & 0 & 0 & 1 & 0 & 0 & 1 & 0 & 0 & 0 & 0 & 0 & 0 & 0 & 0 & 0 & 0 & 0 & 0 & 0 \\
\hline Honduras & 2 & 0 & 0 & 2 & 0 & 0 & 0 & 0 & 0 & 0 & 0 & 0 & 1 & 1 & 0 & 0 & 0 & 0 & 0 & 0 \\
\hline Nicaragua & 0 & 0 & 0 & 0 & 0 & 0 & 0 & 0 & 0 & 0 & 0 & 0 & 0 & 0 & 0 & 0 & 0 & 0 & 0 & 0 \\
\hline Panama & 0 & 1 & 0 & 0 & 0 & 0 & 0 & 0 & 0 & 3 & 0 & 0 & 0 & 0 & 0 & 0 & 0 & 0 & 0 & 0 \\
\hline Total & 6 & 9 & 11 & 7 & 4 & 3 & 1 & 0 & 4 & 5 & 2 & 1 & 1 & 1 & 2 & 1 & 0 & 3 & 4 & 1 \\
\hline \multicolumn{21}{|c|}{ Mexico-Continued } \\
\hline Mexico & 59 & 47 & 45 & 49 & 38 & 57 & 40 & 31 & 24 & 31 & 23 & 34 & 35 & 16 & 8 & 12 & 6 & 4 & 20 & 18 \\
\hline
\end{tabular}


Table 4. Wildcat wells by year, 1961-2015, for the Caribbean, Central America, Mexico, South America, Europe, the Middle East, Africa, Asia, the southwestern Pacific, and Russia.-Continued

\begin{tabular}{|c|c|c|c|c|c|c|c|c|c|c|c|c|c|c|c|c|c|c|}
\hline Area & 2000 & 2001 & 2002 & 2003 & 2004 & 2005 & 2006 & 2007 & 2008 & 2009 & 2010 & 2011 & 2012 & 2013 & 2014 & 2015 & Unkn & Total \\
\hline \multicolumn{19}{|c|}{ Caribbean'1-Continued } \\
\hline Cuba & 1 & 3 & 4 & 0 & 2 & 0 & 2 & 3 & 2 & 0 & 2 & 0 & 3 & 0 & 0 & 1 & 70 & 380 \\
\hline Bahamas & 0 & 0 & 0 & 0 & 0 & 0 & 0 & 0 & 0 & 0 & 0 & 0 & 0 & 0 & 0 & 0 & 0 & 7 \\
\hline Barbados & 0 & 1 & 2 & 0 & 0 & 0 & 0 & 0 & 0 & 0 & 0 & 0 & 1 & 0 & 0 & 0 & 30 & 75 \\
\hline Haiti & 0 & 0 & 0 & 0 & 0 & 0 & 0 & 0 & 0 & 0 & 0 & 0 & 0 & 0 & 0 & 0 & 0 & 11 \\
\hline Dominican Republic & 1 & 3 & 1 & 6 & 0 & 1 & 0 & 0 & 0 & 0 & 0 & 0 & 0 & 0 & 0 & 0 & 2 & 56 \\
\hline Jamaica & 0 & 0 & 0 & 0 & 0 & 0 & 0 & 0 & 0 & 0 & 0 & 0 & 0 & 0 & 0 & 0 & 0 & 11 \\
\hline Puerto Rico & 0 & 0 & 0 & 0 & 0 & 0 & 0 & 0 & 0 & 0 & 0 & 0 & 0 & 0 & 0 & 0 & 0 & 4 \\
\hline Bonaire, Sint Eustatius, and Saba & 0 & 0 & 0 & 0 & 0 & 0 & 0 & 0 & 0 & 0 & 0 & 0 & 0 & 0 & 0 & 0 & 0 & 2 \\
\hline British Virgin Islands & 0 & 0 & 0 & 0 & 0 & 0 & 0 & 0 & 0 & 0 & 0 & 0 & 0 & 0 & 0 & 0 & 0 & 1 \\
\hline Aruba & 0 & 0 & 0 & 0 & 0 & 0 & 0 & 0 & 0 & 0 & 0 & 0 & 0 & 0 & 0 & 0 & 0 & 6 \\
\hline Total & 2 & 7 & 7 & 6 & 2 & 1 & 2 & 3 & 2 & $\mathbf{0}$ & 2 & $\mathbf{0}$ & 4 & $\mathbf{0}$ & $\mathbf{0}$ & 1 & 102 & 553 \\
\hline \multicolumn{19}{|c|}{ Central America ${ }^{2}$ - Continued } \\
\hline Guatemala & 1 & 0 & 0 & 0 & 1 & 0 & 0 & 0 & 0 & 0 & 1 & 0 & 0 & 0 & 1 & 0 & 0 & 73 \\
\hline Belize & 0 & 0 & 0 & 0 & 0 & 1 & 1 & 7 & 11 & 4 & 9 & 2 & 3 & 6 & 0 & 1 & 0 & 92 \\
\hline Costa Rica & 0 & 0 & 0 & 0 & 0 & 0 & 0 & 0 & 0 & 0 & 0 & 0 & 0 & 0 & 0 & 0 & 0 & 24 \\
\hline Honduras & 0 & 0 & 0 & 0 & 0 & 0 & 0 & 0 & 0 & 0 & 0 & 0 & 0 & 0 & 0 & 0 & 0 & 31 \\
\hline Nicaragua & 0 & 0 & 0 & 0 & 0 & 0 & 0 & 1 & 1 & 0 & 1 & 0 & 0 & 1 & 0 & 0 & 1 & 40 \\
\hline Panama & 0 & 0 & 0 & 0 & 0 & 0 & 0 & 0 & 0 & 0 & 0 & 0 & 0 & 0 & 0 & 0 & 0 & 32 \\
\hline Total & 1 & $\mathbf{0}$ & $\mathbf{0}$ & $\mathbf{0}$ & 1 & 1 & 1 & 8 & 12 & 4 & 11 & 2 & 3 & 7 & 1 & 1 & 1 & 292 \\
\hline \multicolumn{19}{|c|}{ Mexico-Continued } \\
\hline Mexico & 44 & 56 & 49 & 96 & 101 & 75 & 52 & 64 & 53 & 73 & 36 & 29 & 35 & 44 & 25 & 32 & 536 & 4,478 \\
\hline
\end{tabular}

${ }^{1}$ No wildcat wells were reported for Bermuda, Cayman Islands, Navassa Island, and Turks and Caicos Islands. Bonaire, Sint Eustatius, and Saba belong to the Netherlands and are part of the Lesser Antilles. No wildcat wells were reported for other parts of the Lesser Antilles.

${ }^{2}$ No wildcat wells were reported for El Salvador. 
Table 4. Wildcat wells by year, 1961-2015, for the Caribbean, Central America, Mexico, South America, Europe, the Middle East, Africa, Asia, the southwestern Pacific, and Russia.-Continued

\begin{tabular}{|c|c|c|c|c|c|c|c|c|c|c|c|c|c|c|c|c|c|c|c|c|}
\hline Area & $\begin{array}{l}\text { Pre- } \\
1961\end{array}$ & 1961 & 62 & 63 & 64 & 65 & 66 & 67 & 68 & 69 & 70 & 71 & 72 & 73 & 74 & 75 & 76 & 77 & 78 & 79 \\
\hline \multicolumn{21}{|c|}{ South America } \\
\hline Guyana & 1 & 0 & 0 & 0 & 0 & 0 & 0 & 2 & 0 & 0 & 0 & 1 & 0 & 0 & 2 & 3 & 1 & 0 & 0 & 0 \\
\hline Suriname & 2 & 0 & 0 & 0 & 1 & 1 & 10 & 1 & 6 & 2 & 5 & 1 & 0 & 0 & 0 & 1 & 0 & 0 & 1 & 0 \\
\hline French Guiana $^{3}$ & 0 & 0 & 0 & 0 & 0 & 0 & 0 & 0 & 0 & 0 & 0 & 0 & 0 & 0 & 0 & 1 & 0 & 0 & 1 & 0 \\
\hline Chile & 140 & 10 & 16 & 15 & 17 & 14 & 18 & 15 & 18 & 20 & 18 & 20 & 32 & 16 & 24 & 19 & 19 & 6 & 14 & 9 \\
\hline Argentina & 706 & 78 & 94 & 56 & 45 & 73 & 71 & 81 & 67 & 61 & 100 & 118 & 92 & 121 & 92 & 64 & 73 & 93 & 59 & 56 \\
\hline Paraguay & 9 & 0 & 0 & 0 & 0 & 0 & 1 & 2 & 0 & 0 & 0 & 11 & 5 & 0 & 0 & 1 & 2 & 2 & 3 & 1 \\
\hline Uruguay & 18 & 0 & 0 & 0 & 0 & 0 & 1 & 0 & 0 & 0 & 0 & 0 & 0 & 0 & 0 & 0 & 2 & 0 & 1 & 0 \\
\hline Falkland Islands & 0 & 0 & 0 & 0 & 0 & 0 & 0 & 0 & 0 & 0 & 0 & 0 & 0 & 0 & 0 & 0 & 0 & 0 & 0 & 0 \\
\hline Ecuador & 73 & 2 & 0 & 1 & 1 & 2 & 1 & 3 & 6 & 6 & 12 & 10 & 18 & 8 & 6 & 1 & 1 & 3 & 4 & 8 \\
\hline Colombia & 414 & 27 & 18 & 23 & 23 & 18 & 21 & 16 & 20 & 27 & 19 & 18 & 20 & 19 & 17 & 11 & 14 & 17 & 26 & 24 \\
\hline Peru & 547 & 14 & 13 & 15 & 4 & 24 & 15 & 21 & 15 & 17 & 21 & 20 & 17 & 18 & 17 & 39 & 13 & 8 & 10 & 1 \\
\hline Venezuela & 2,956 & 112 & 97 & 73 & 60 & 64 & 50 & 30 & 32 & 47 & 48 & 67 & 83 & 79 & 107 & 69 & 70 & 68 & 70 & 107 \\
\hline Trinidad and Tobago & 111 & 7 & 5 & 14 & 11 & 14 & 3 & 3 & 8 & 6 & 8 & 23 & 20 & 9 & 9 & 5 & 12 & 4 & 5 & 6 \\
\hline Bolivia & 59 & 13 & 18 & 10 & 9 & 9 & 13 & 17 & 12 & 3 & 6 & 3 & 7 & 4 & 6 & 7 & 14 & 9 & 9 & 11 \\
\hline Brazil & 243 & 49 & 52 & 59 & 46 & 53 & 55 & 69 & 61 & 53 & 50 & 57 & 57 & 59 & 59 & 71 & 85 & 73 & 97 & 114 \\
\hline Total & 5,279 & 312 & 313 & 266 & 217 & 272 & 259 & 260 & 245 & 242 & 287 & 349 & 351 & 333 & 339 & 292 & 306 & 283 & 300 & 337 \\
\hline
\end{tabular}


Table 4. Wildcat wells by year, 1961-2015, for the Caribbean, Central America, Mexico, South America, Europe, the Middle East, Africa, Asia, the southwestern Pacific, and Russia.-Continued

\begin{tabular}{|c|c|c|c|c|c|c|c|c|c|c|c|c|c|c|c|c|c|c|c|c|}
\hline Area & 1980 & 81 & 82 & 83 & 84 & 85 & 86 & 87 & 88 & 89 & 90 & 91 & 92 & 93 & 94 & 95 & 96 & 97 & 98 & 1999 \\
\hline \multicolumn{21}{|c|}{ South America-Continued } \\
\hline Guyana & 0 & 0 & 2 & 0 & 0 & 0 & 0 & 0 & 0 & 0 & 0 & 1 & 0 & 1 & 0 & 0 & 0 & 0 & 0 & 0 \\
\hline Suriname & 0 & 0 & 3 & 6 & 0 & 1 & 2 & 0 & 0 & 0 & 0 & 0 & 0 & 0 & 0 & 0 & 0 & 0 & 0 & 0 \\
\hline French Guiana $^{3}$ & 0 & 0 & 0 & 0 & 0 & 0 & 0 & 0 & 0 & 0 & 0 & 0 & 0 & 0 & 0 & 0 & 0 & 0 & 0 & 0 \\
\hline Chile & 13 & 26 & 14 & 5 & 8 & 2 & 10 & 13 & 8 & 14 & 10 & 5 & 8 & 8 & 2 & 10 & 6 & 1 & 5 & 0 \\
\hline Argentina & 71 & 81 & 71 & 115 & 119 & 134 & 76 & 72 & 78 & 74 & 77 & 73 & 45 & 59 & 100 & 122 & 88 & 89 & 66 & 66 \\
\hline Paraguay & 0 & 1 & 1 & 0 & 0 & 0 & 1 & 1 & 1 & 1 & 0 & 0 & 0 & 1 & 2 & 1 & 0 & 0 & 0 & 0 \\
\hline Uruguay & 0 & 0 & 0 & 0 & 0 & 1 & 2 & 2 & 0 & 0 & 0 & 0 & 0 & 0 & 0 & 0 & 0 & 0 & 0 & 0 \\
\hline Falkland Islands & 0 & 0 & 0 & 0 & 0 & 0 & 0 & 0 & 0 & 0 & 0 & 0 & 0 & 0 & 0 & 0 & 0 & 0 & 6 & 0 \\
\hline Ecuador & 5 & 1 & 4 & 9 & 3 & 1 & 4 & 6 & 13 & 8 & 3 & 17 & 5 & 7 & 4 & 4 & 4 & 5 & 8 & 7 \\
\hline Colombia & 29 & 52 & 64 & 28 & 35 & 50 & 45 & 57 & 81 & 51 & 43 & 35 & 30 & 37 & 28 & 17 & 10 & 17 & 29 & 15 \\
\hline Peru & 10 & 10 & 8 & 19 & 20 & 4 & 1 & 7 & 2 & 4 & 0 & 0 & 3 & 2 & 2 & 5 & 4 & 9 & 10 & 6 \\
\hline Venezuela & 200 & 186 & 169 & 107 & 154 & 156 & 100 & 16 & 41 & 32 & 20 & 38 & 34 & 33 & 28 & 38 & 50 & 42 & 32 & 25 \\
\hline Trinidad and Tobago & 2 & 6 & 13 & 2 & 0 & 3 & 1 & 4 & 3 & 7 & 4 & 5 & 2 & 1 & 7 & 8 & 7 & 3 & 9 & 9 \\
\hline Bolivia & 3 & 14 & 13 & 6 & 8 & 6 & 2 & 3 & 6 & 8 & 6 & 20 & 12 & 10 & 11 & 7 & 9 & 5 & 14 & 20 \\
\hline Brazil & 139 & 182 & 237 & 202 & 199 & 130 & 112 & 114 & 103 & 80 & 74 & 74 & 70 & 77 & 56 & 50 & 71 & 53 & 59 & 52 \\
\hline Total & 472 & 559 & 599 & 499 & 546 & 488 & 356 & 295 & 336 & 279 & 237 & 268 & 209 & 236 & 240 & 262 & 249 & 224 & 238 & 200 \\
\hline
\end{tabular}


Table 4. Wildcat wells by year, 1961-2015, for the Caribbean, Central America, Mexico, South America, Europe, the Middle East, Africa, Asia, the southwestern Pacific, and Russia.-Continued

\begin{tabular}{|c|c|c|c|c|c|c|c|c|c|c|c|c|c|c|c|c|c|c|}
\hline Area & 2000 & 2001 & 2002 & 2003 & 2004 & 2005 & 2006 & 2007 & 2008 & 2009 & 2010 & 2011 & 2012 & 2013 & 2014 & 2015 & Unkn & Total \\
\hline \multicolumn{19}{|c|}{ South America-Continued } \\
\hline Guyana & 1 & 0 & 0 & 0 & 0 & 3 & 0 & 0 & 0 & 0 & 0 & 0 & 2 & 0 & 0 & 1 & 1 & 22 \\
\hline Suriname & 0 & 1 & 1 & 1 & 0 & 0 & 1 & 5 & 12 & 4 & 0 & 3 & 5 & 2 & 3 & 2 & 7 & 90 \\
\hline French Guiana ${ }^{3}$ & 0 & 0 & 0 & 0 & 0 & 0 & 0 & 0 & 0 & 0 & 0 & 5 & 0 & 3 & 0 & 0 & 0 & 10 \\
\hline Chile & 2 & 0 & 0 & 0 & 0 & 0 & 1 & 6 & 10 & 8 & 23 & 19 & 17 & 22 & 36 & 14 & 15 & 801 \\
\hline Argentina & 64 & 72 & 47 & 38 & 54 & 49 & 47 & 54 & 91 & 58 & 40 & 73 & 65 & 85 & 65 & 62 & 55 & 4,895 \\
\hline Uruguay & 0 & 0 & 0 & 0 & 0 & 0 & 0 & 0 & 0 & 0 & 0 & 0 & 0 & 0 & 0 & 0 & 3 & 30 \\
\hline Falkland Islands & 0 & 0 & 0 & 0 & 0 & 0 & 0 & 0 & 0 & 0 & 7 & 3 & 4 & 0 & 0 & 3 & 0 & 23 \\
\hline Ecuador & 11 & 4 & 10 & 7 & 4 & 7 & 4 & 1 & 5 & 3 & 3 & 2 & 10 & 12 & 24 & 1 & 3 & 395 \\
\hline Colombia & 22 & 17 & 15 & 33 & 22 & 35 & 54 & 71 & 96 & 63 & 91 & 115 & 113 & 82 & 91 & 33 & 23 & 2,521 \\
\hline Peru & 3 & 3 & 5 & 3 & 6 & 4 & 4 & 7 & 6 & 7 & 6 & 11 & 9 & 6 & 17 & 2 & 9 & 1,083 \\
\hline Venezuela & 27 & 12 & 17 & 9 & 6 & 9 & 9 & 13 & 3 & 7 & 6 & 2 & 3 & 7 & 6 & 15 & 5 & 5,946 \\
\hline Bolivia & 18 & 11 & 5 & 9 & 8 & 4 & 2 & 2 & 1 & 5 & 3 & 5 & 3 & 2 & 11 & 6 & 0 & 517 \\
\hline Brazil & 47 & 113 & 54 & 73 & 53 & 53 & 80 & 116 & 144 & 127 & 115 & 155 & 142 & 94 & 51 & 38 & 0 & 5,051 \\
\hline Total & 200 & 240 & 162 & 183 & 159 & 171 & 213 & 284 & 376 & 283 & 295 & 396 & 380 & 319 & 308 & 181 & 132 & 21,916 \\
\hline
\end{tabular}

${ }^{3}$ French Guiana is listed separately although it is an overseas department of France. 
Table 4. Wildcat wells by year, 1961-2015, for the Caribbean, Central America, Mexico, South America, Europe, the Middle East, Africa, Asia, the southwestern Pacific, and Russia.-Continued

\begin{tabular}{|c|c|c|c|c|c|c|c|c|c|c|c|c|c|c|c|c|c|c|c|c|}
\hline Area & $\begin{array}{l}\text { Pre- } \\
1961\end{array}$ & 1961 & 62 & 63 & 64 & 65 & 66 & 67 & 68 & 69 & 70 & 71 & 72 & 73 & 74 & 75 & 76 & 77 & 78 & 79 \\
\hline \multicolumn{21}{|c|}{ Europe $^{4}$} \\
\hline United Kingdom & 254 & 9 & 6 & 7 & 9 & 28 & 31 & 42 & 43 & 55 & 30 & 31 & 35 & 69 & 81 & 87 & 76 & 84 & 45 & 50 \\
\hline Norway & 0 & 0 & 0 & 0 & 0 & 0 & 1 & 5 & 10 & 12 & 8 & 12 & 14 & 14 & 16 & 15 & 20 & 11 & 14 & 14 \\
\hline Germany & 2,466 & 153 & 122 & 123 & 129 & 104 & 119 & 81 & 68 & 80 & 70 & 73 & 53 & 42 & 50 & 34 & 57 & 55 & 66 & 50 \\
\hline Denmark & 29 & 0 & 0 & 0 & 0 & 0 & 3 & 2 & 7 & 2 & 4 & 2 & 0 & 4 & 3 & 3 & 7 & 5 & 3 & 1 \\
\hline Netherlands & 168 & 3 & 5 & 2 & 38 & 37 & 11 & 2 & 18 & 41 & 36 & 33 & 28 & 23 & 24 & 29 & 24 & 35 & 21 & 25 \\
\hline Ireland & 0 & 0 & 2 & 3 & 0 & 0 & 0 & 0 & 0 & 0 & 0 & 3 & 2 & 3 & 3 & 7 & 5 & 7 & 18 & 11 \\
\hline Sweden & 1 & 0 & 0 & 0 & 0 & 0 & 0 & 1 & 2 & 0 & 0 & 4 & 10 & 13 & 14 & 27 & 6 & 6 & 32 & 11 \\
\hline Belgium & 1 & 0 & 2 & 0 & 1 & 0 & 0 & 0 & 0 & 0 & 0 & 0 & 0 & 0 & 0 & 0 & 0 & 0 & 0 & 0 \\
\hline Faroe Islands ${ }^{5}$ & 0 & 0 & 0 & 0 & 0 & 0 & 0 & 0 & 0 & 0 & 0 & 0 & 0 & 0 & 0 & 0 & 0 & 0 & 0 & 0 \\
\hline Svalbard and Jan Mayen ${ }^{6}$ & 0 & 0 & 0 & 0 & 0 & 0 & 1 & 1 & 0 & 0 & 0 & 1 & 2 & 2 & 2 & 1 & 0 & 1 & 0 & 0 \\
\hline Isle of Man & 0 & 0 & 0 & 0 & 0 & 0 & 0 & 0 & 0 & 0 & 0 & 0 & 0 & 0 & 0 & 0 & 0 & 0 & 0 & 0 \\
\hline Italy & 754 & 83 & 105 & 95 & 78 & 51 & 55 & 28 & 31 & 46 & 34 & 41 & 46 & 28 & 22 & 25 & 29 & 26 & 62 & 41 \\
\hline Austria & 249 & 13 & 17 & 13 & 19 & 17 & 20 & 10 & 13 & 18 & 16 & 25 & 16 & 16 & 20 & 35 & 22 & 27 & 20 & 25 \\
\hline France & 808 & 106 & 94 & 101 & 78 & 62 & 31 & 21 & 12 & 25 & 12 & 7 & 11 & 10 & 9 & 11 & 13 & 13 & 16 & 22 \\
\hline Spain & 109 & 14 & 17 & 23 & 11 & 15 & 18 & 13 & 16 & 10 & 8 & 13 & 5 & 18 & 7 & 17 & 20 & 15 & 18 & 15 \\
\hline Portugal & 40 & 1 & 1 & 4 & 0 & 0 & 0 & 0 & 0 & 0 & 0 & 0 & 0 & 0 & 3 & 7 & 9 & 1 & 0 & 2 \\
\hline Switzerland & 11 & 2 & 1 & 2 & 2 & 3 & 0 & 0 & 0 & 0 & 0 & 0 & 0 & 1 & 0 & 0 & 0 & 1 & 1 & 0 \\
\hline Malta & 1 & 0 & 0 & 0 & 0 & 0 & 0 & 0 & 0 & 0 & 0 & 0 & 3 & 1 & 0 & 0 & 0 & 0 & 0 & 0 \\
\hline San Marino & 1 & 0 & 0 & 0 & 0 & 0 & 0 & 0 & 0 & 0 & 0 & 0 & 0 & 0 & 0 & 0 & 0 & 0 & 0 & 0 \\
\hline Romania & 163 & 23 & 13 & 19 & 17 & 21 & 28 & 17 & 23 & 34 & 16 & 21 & 10 & 13 & 13 & 15 & 16 & 15 & 10 & 12 \\
\hline Ukraine & 68 & 11 & 12 & 14 & 9 & 13 & 12 & 20 & 8 & 14 & 9 & 6 & 9 & 5 & 8 & 10 & 17 & 14 & 10 & 14 \\
\hline Belarus & 0 & 0 & 0 & 1 & 2 & 1 & 1 & 4 & 3 & 1 & 2 & 2 & 13 & 4 & 9 & 4 & 6 & 4 & 4 & 3 \\
\hline Hungary & 522 & 46 & 53 & 55 & 58 & 32 & 34 & 15 & 12 & 22 & 20 & 21 & 20 & 17 & 16 & 23 & 37 & 19 & 34 & 23 \\
\hline Albania & 36 & 11 & 11 & 8 & 8 & 6 & 3 & 5 & 4 & 3 & 14 & 12 & 10 & 11 & 12 & 14 & 11 & 12 & 4 & 8 \\
\hline Serbia & 81 & 17 & 9 & 11 & 6 & 8 & 6 & 3 & 7 & 5 & 8 & 15 & 17 & 12 & 10 & 22 & 9 & 28 & 25 & 13 \\
\hline Montenegro & 7 & 0 & 0 & 6 & 1 & 0 & 0 & 0 & 0 & 0 & 0 & 0 & 0 & 0 & 0 & 0 & 1 & 0 & 0 & 0 \\
\hline Poland & 473 & 67 & 63 & 59 & 61 & 117 & 172 & 150 & 140 & 150 & 143 & 131 & 124 & 90 & 71 & 56 & 47 & 49 & 43 & 46 \\
\hline
\end{tabular}


Table 4. Wildcat wells by year, 1961-2015, for the Caribbean, Central America, Mexico, South America, Europe, the Middle East, Africa, Asia, the southwestern Pacific, and Russia.-Continued

\begin{tabular}{|c|c|c|c|c|c|c|c|c|c|c|c|c|c|c|c|c|c|c|c|c|}
\hline Area & $\begin{array}{l}\text { Pre- } \\
1961\end{array}$ & 1961 & 62 & 63 & 64 & 65 & 66 & 67 & 68 & 69 & 70 & 71 & 72 & 73 & 74 & 75 & 76 & 77 & 78 & 79 \\
\hline \multicolumn{21}{|c|}{ Europe ${ }^{4}$-Continued } \\
\hline Czech Republic & 22 & 3 & 4 & 2 & 5 & 10 & 6 & 4 & 8 & 6 & 4 & 3 & 3 & 13 & 6 & 5 & 8 & 15 & 7 & 7 \\
\hline Greece & 23 & 6 & 11 & 6 & 3 & 2 & 0 & 8 & 0 & 0 & 2 & 1 & 1 & 3 & 3 & 0 & 2 & 5 & 2 & 5 \\
\hline Bulgaria & 337 & 61 & 53 & 54 & 10 & 22 & 14 & 17 & 9 & 14 & 10 & 16 & 15 & 12 & 22 & 17 & 11 & 13 & 18 & 11 \\
\hline Lithuania & 1 & 0 & 0 & 1 & 2 & 1 & 3 & 2 & 1 & 1 & 5 & 5 & 5 & 4 & 4 & 7 & 5 & 3 & 4 & 4 \\
\hline Slovakia & 22 & 1 & 4 & 6 & 6 & 10 & 3 & 7 & 2 & 8 & 5 & 5 & 5 & 1 & 0 & 1 & 1 & 0 & 2 & 1 \\
\hline Slovenia & 41 & 2 & 2 & 0 & 0 & 0 & 0 & 2 & 1 & 1 & 0 & 0 & 0 & 0 & 0 & 0 & 2 & 1 & 4 & 3 \\
\hline Latvia & 0 & 0 & 0 & 0 & 1 & 1 & 0 & 6 & 5 & 4 & 2 & 2 & 0 & 1 & 0 & 0 & 0 & 0 & 0 & 0 \\
\hline Moldova & 11 & 1 & 1 & 0 & 1 & 0 & 0 & 0 & 0 & 0 & 0 & 0 & 0 & 0 & 0 & 0 & 0 & 0 & 0 & 0 \\
\hline Bosnia and Herzegovina & 1 & 0 & 0 & 0 & 0 & 1 & 0 & 0 & 0 & 0 & 0 & 0 & 0 & 0 & 0 & 0 & 0 & 0 & 0 & 0 \\
\hline Croatia & 125 & 4 & 14 & 20 & 10 & 5 & 18 & 14 & 13 & 10 & 3 & 7 & 9 & 18 & 11 & 10 & 14 & 13 & 17 & 17 \\
\hline Macedonia & 0 & 0 & 0 & 0 & 0 & 0 & 0 & 0 & 0 & 1 & 0 & 0 & 0 & 0 & 0 & 0 & 0 & 0 & 0 & 0 \\
\hline Total & 6,825 & 637 & 622 & 635 & 565 & 567 & 590 & 480 & 456 & 563 & 461 & 492 & 466 & 448 & 439 & 482 & 475 & 478 & 500 & 434 \\
\hline
\end{tabular}


Table 4. Wildcat wells by year, 1961-2015, for the Caribbean, Central America, Mexico, South America, Europe, the Middle East, Africa, Asia, the southwestern Pacific, and Russia.-Continued

\begin{tabular}{|c|c|c|c|c|c|c|c|c|c|c|c|c|c|c|c|c|c|c|c|c|}
\hline Area & 1980 & 81 & 82 & 83 & 84 & 85 & 86 & 87 & 88 & 89 & 90 & 91 & 92 & 93 & 94 & 95 & 96 & 97 & 98 & 1999 \\
\hline \multicolumn{21}{|c|}{ Europe ${ }^{4}$-Continued } \\
\hline United Kingdom & 45 & 71 & 95 & 95 & 149 & 133 & 148 & 90 & 108 & 118 & 169 & 148 & 114 & 61 & 79 & 70 & 81 & 76 & 53 & 38 \\
\hline Norway & 24 & 22 & 32 & 26 & 28 & 28 & 30 & 21 & 17 & 16 & 28 & 32 & 32 & 24 & 21 & 21 & 21 & 38 & 21 & 13 \\
\hline Germany & 42 & 66 & 81 & 59 & 60 & 54 & 46 & 37 & 25 & 20 & 30 & 19 & 16 & 9 & 9 & 17 & 20 & 11 & 11 & 6 \\
\hline Denmark & 4 & 2 & 4 & 10 & 5 & 14 & 3 & 5 & 3 & 4 & 1 & 4 & 6 & 1 & 0 & 0 & 1 & 6 & 3 & 2 \\
\hline Netherlands & 37 & 39 & 52 & 43 & 44 & 55 & 41 & 36 & 35 & 39 & 44 & 49 & 32 & 27 & 17 & 26 & 35 & 35 & 35 & 18 \\
\hline Ireland & 3 & 14 & 4 & 6 & 7 & 6 & 7 & 3 & 5 & 3 & 3 & 1 & 2 & 3 & 3 & 4 & 2 & 4 & 0 & 2 \\
\hline Sweden & 12 & 14 & 14 & 12 & 11 & 15 & 0 & 4 & 10 & 1 & 7 & 5 & 0 & 1 & 0 & 0 & 0 & 0 & 0 & 0 \\
\hline Belgium & 0 & 0 & 0 & 0 & 0 & 0 & 0 & 0 & 0 & 0 & 0 & 0 & 0 & 0 & 0 & 0 & 0 & 0 & 0 & 0 \\
\hline Faroe Islands ${ }^{5}$ & 0 & 0 & 0 & 0 & 0 & 0 & 0 & 0 & 0 & 0 & 0 & 0 & 0 & 0 & 0 & 0 & 0 & 0 & 0 & 0 \\
\hline Svalbard and Jan Mayen ${ }^{6}$ & 0 & 0 & 0 & 0 & 0 & 0 & 0 & 1 & 1 & 1 & 0 & 1 & 1 & 0 & 0 & 0 & 0 & 0 & 0 & 0 \\
\hline Isle of Man & 0 & 0 & 1 & 0 & 0 & 0 & 0 & 0 & 0 & 0 & 0 & 0 & 0 & 0 & 0 & 0 & 1 & 1 & 0 & 0 \\
\hline Italy & 55 & 75 & 77 & 55 & 63 & 52 & 87 & 75 & 71 & 34 & 33 & 47 & 36 & 26 & 21 & 28 & 31 & 28 & 28 & 14 \\
\hline Austria & 16 & 24 & 23 & 20 & 31 & 26 & 12 & 13 & 15 & 6 & 12 & 5 & 7 & 4 & 6 & 6 & 7 & 13 & 9 & 4 \\
\hline France & 25 & 38 & 46 & 32 & 41 & 55 & 73 & 26 & 34 & 36 & 25 & 30 & 10 & 5 & 8 & 7 & 7 & 0 & 5 & 0 \\
\hline Spain & 21 & 23 & 10 & 20 & 10 & 24 & 17 & 12 & 9 & 10 & 4 & 7 & 0 & 4 & 2 & 3 & 1 & 5 & 3 & 5 \\
\hline Portugal & 0 & 1 & 2 & 3 & 0 & 1 & 0 & 0 & 3 & 0 & 2 & 0 & 2 & 4 & 0 & 1 & 0 & 0 & 1 & 1 \\
\hline Switzerland & 1 & 1 & 3 & 0 & 0 & 0 & 0 & 0 & 0 & 1 & 0 & 0 & 0 & 0 & 0 & 0 & 0 & 0 & 0 & 0 \\
\hline Malta & 1 & 0 & 2 & 0 & 0 & 1 & 0 & 0 & 0 & 0 & 0 & 0 & 1 & 1 & 0 & 0 & 0 & 0 & 0 & 1 \\
\hline San Marino & 0 & 0 & 0 & 0 & 0 & 0 & 0 & 0 & 0 & 0 & 0 & 0 & 0 & 0 & 0 & 0 & 0 & 0 & 0 & 0 \\
\hline Romania & 13 & 7 & 9 & 14 & 13 & 7 & 10 & 8 & 11 & 12 & 10 & 6 & 11 & 16 & 27 & 26 & 15 & 30 & 22 & 17 \\
\hline Ukraine & 9 & 10 & 7 & 12 & 20 & 11 & 3 & 11 & 8 & 6 & 9 & 8 & 10 & 7 & 2 & 6 & 0 & 4 & 7 & 17 \\
\hline Belarus & 4 & 1 & 3 & 4 & 5 & 2 & 1 & 4 & 0 & 3 & 1 & 2 & 2 & 3 & 3 & 5 & 1 & 0 & 0 & 3 \\
\hline Hungary & 29 & 25 & 31 & 28 & 13 & 25 & 30 & 20 & 20 & 34 & 24 & 10 & 19 & 15 & 4 & 14 & 16 & 13 & 13 & 12 \\
\hline Albania & 18 & 11 & 12 & 10 & 6 & 8 & 11 & 12 & 5 & 14 & 9 & 2 & 0 & 3 & 2 & 3 & 1 & 3 & 0 & 0 \\
\hline Serbia & 13 & 11 & 9 & 12 & 7 & 12 & 12 & 9 & 9 & 13 & 4 & 7 & 5 & 6 & 7 & 8 & 6 & 7 & 11 & 2 \\
\hline Montenegro & 1 & 0 & 1 & 0 & 0 & 0 & 0 & 0 & 1 & 0 & 0 & 0 & 0 & 0 & 0 & 0 & 1 & 0 & 0 & 0 \\
\hline Poland & 50 & 41 & 67 & 55 & 52 & 55 & 54 & 47 & 63 & 73 & 57 & 37 & 36 & 23 & 36 & 55 & 39 & 38 & 25 & 35 \\
\hline
\end{tabular}


Table 4. Wildcat wells by year, 1961-2015, for the Caribbean, Central America, Mexico, South America, Europe, the Middle East, Africa, Asia, the southwestern Pacific, and Russia.-Continued

\begin{tabular}{|c|c|c|c|c|c|c|c|c|c|c|c|c|c|c|c|c|c|c|c|c|}
\hline Area & 1980 & 81 & 82 & 83 & 84 & 85 & 86 & 87 & 88 & 89 & 90 & 91 & 92 & 93 & 94 & 95 & 96 & 97 & 98 & 1999 \\
\hline \multicolumn{21}{|c|}{ Europe ${ }^{4}$-Continued } \\
\hline Czech Republic & 9 & 7 & 7 & 10 & 11 & 6 & 5 & 4 & 5 & 5 & 2 & 4 & 4 & 2 & 3 & 2 & 3 & 2 & 5 & 5 \\
\hline Greece & 5 & 8 & 11 & 7 & 7 & 5 & 6 & 7 & 4 & 3 & 1 & 0 & 1 & 0 & 1 & 0 & 0 & 0 & 2 & 0 \\
\hline Bulgaria & 10 & 6 & 9 & 18 & 13 & 16 & 24 & 18 & 16 & 9 & 6 & 1 & 4 & 7 & 10 & 4 & 5 & 0 & 3 & 1 \\
\hline Lithuania & 4 & 5 & 6 & 5 & 5 & 5 & 4 & 5 & 6 & 1 & 4 & 2 & 1 & 2 & 2 & 0 & 1 & 1 & 0 & 2 \\
\hline Slovakia & 1 & 0 & 0 & 1 & 2 & 0 & 0 & 0 & 0 & 0 & 1 & 4 & 6 & 0 & 2 & 3 & 4 & 0 & 1 & 2 \\
\hline Slovenia & 2 & 0 & 2 & 0 & 0 & 1 & 2 & 1 & 2 & 0 & 1 & 4 & 0 & 1 & 0 & 0 & 0 & 0 & 0 & 0 \\
\hline Latvia & 0 & 0 & 0 & 0 & 1 & 0 & 0 & 0 & 1 & 1 & 0 & 1 & 0 & 2 & 1 & 0 & 0 & 0 & 0 & 0 \\
\hline Moldova & 0 & 0 & 0 & 0 & 0 & 0 & 0 & 0 & 0 & 0 & 0 & 0 & 0 & 0 & 0 & 0 & 0 & 0 & 0 & 0 \\
\hline Bosnia and Herzegovina & 0 & 0 & 0 & 0 & 2 & 2 & 1 & 1 & 0 & 0 & 0 & 0 & 0 & 0 & 0 & 0 & 0 & 0 & 0 & 0 \\
\hline Croatia & 15 & 18 & 13 & 11 & 20 & 29 & 20 & 17 & 15 & 23 & 21 & 8 & 4 & 7 & 10 & 4 & 3 & 6 & 4 & 0 \\
\hline Macedonia & 0 & 0 & 0 & 0 & 0 & 0 & 0 & 0 & 0 & 0 & 0 & 0 & 0 & 0 & 0 & 0 & 0 & 0 & 0 & 0 \\
\hline Total & 469 & 540 & 633 & 568 & 626 & 648 & 647 & 487 & 502 & 486 & 508 & 444 & 362 & 264 & 276 & 313 & 302 & 321 & 262 & 200 \\
\hline
\end{tabular}


Table 4. Wildcat wells by year, 1961-2015, for the Caribbean, Central America, Mexico, South America, Europe, the Middle East, Africa, Asia, the southwestern Pacific, and Russia.-Continued

\begin{tabular}{|c|c|c|c|c|c|c|c|c|c|c|c|c|c|c|c|c|c|c|}
\hline Area & 2000 & 2001 & 2002 & 2003 & 2004 & 2005 & 2006 & 2007 & 2008 & 2009 & 2010 & 2011 & 2012 & 2013 & 2014 & 2015 & Unkn & Total \\
\hline \multicolumn{19}{|c|}{ Europe ${ }^{4}$-Continued } \\
\hline United Kingdom & 37 & 41 & 30 & 25 & 35 & 40 & 43 & 51 & 62 & 46 & 37 & 26 & 35 & 31 & 31 & 20 & 12 & 3,615 \\
\hline Norway & 19 & 23 & 21 & 17 & 8 & 13 & 16 & 21 & 36 & 49 & 33 & 39 & 28 & 40 & 44 & 40 & 0 & 1,108 \\
\hline Germany & 3 & 5 & 10 & 6 & 6 & 8 & 6 & 8 & 6 & 10 & 4 & 10 & 9 & 1 & 10 & 10 & 39 & 4,784 \\
\hline Denmark & 6 & 6 & 3 & 5 & 3 & 1 & 3 & 1 & 1 & 3 & 1 & 5 & 2 & 3 & 4 & 2 & 0 & 202 \\
\hline Netherlands & 6 & 18 & 23 & 9 & 16 & 10 & 15 & 16 & 14 & 11 & 11 & 20 & 18 & 8 & 22 & 19 & 0 & 1,578 \\
\hline Ireland & 0 & 5 & 1 & 2 & 2 & 0 & 2 & 1 & 2 & 1 & 1 & 0 & 0 & 1 & 0 & 1 & 0 & 165 \\
\hline Sweden & 0 & 0 & 0 & 0 & 0 & 0 & 0 & 0 & 0 & 0 & 0 & 0 & 4 & 0 & 0 & 1 & 11 & 249 \\
\hline Belgium & 0 & 0 & 0 & 0 & 0 & 0 & 0 & 0 & 0 & 0 & 0 & 0 & 0 & 0 & 0 & 0 & 3 & 7 \\
\hline Faroe Islands ${ }^{5}$ & 0 & 4 & 0 & 1 & 0 & 0 & 1 & 0 & 2 & 0 & 1 & 0 & 0 & 0 & 2 & 0 & 0 & 11 \\
\hline Svalbard and Jan Mayen ${ }^{6}$ & 0 & 0 & 0 & 0 & 0 & 0 & 0 & 0 & 0 & 0 & 0 & 0 & 0 & 0 & 0 & 0 & 0 & 16 \\
\hline Isle of Man & 0 & 0 & 0 & 0 & 0 & 0 & 0 & 0 & 0 & 0 & 0 & 0 & 0 & 0 & 0 & 0 & 0 & 3 \\
\hline Italy & 17 & 12 & 6 & 5 & 6 & 6 & 7 & 8 & 7 & 4 & 2 & 0 & 2 & 3 & 1 & 2 & 43 & 2,747 \\
\hline Austria & 10 & 4 & 8 & 5 & 14 & 16 & 17 & 9 & 8 & 8 & 3 & 4 & 8 & 5 & 0 & 6 & 31 & 1,026 \\
\hline France & 2 & 0 & 0 & 2 & 3 & 3 & 3 & 4 & 4 & 2 & 3 & 5 & 8 & 5 & 5 & 2 & 11 & 2,027 \\
\hline Spain & 6 & 3 & 2 & 2 & 1 & 2 & 0 & 3 & 0 & 1 & 1 & 0 & 0 & 0 & 0 & 2 & 4 & 599 \\
\hline Portugal & 0 & 0 & 0 & 0 & 0 & 11 & 0 & 0 & 0 & 0 & 0 & 1 & 2 & 0 & 0 & 0 & 0 & 103 \\
\hline Switzerland & 0 & 0 & 0 & 0 & 1 & 0 & 0 & 0 & 0 & 0 & 2 & 0 & 0 & 0 & 0 & 0 & 0 & 33 \\
\hline Malta & 0 & 0 & 1 & 0 & 0 & 0 & 0 & 0 & 0 & 0 & 0 & 0 & 0 & 0 & 1 & 0 & 0 & 14 \\
\hline San Marino & 0 & 0 & 0 & 0 & 0 & 0 & 0 & 0 & 0 & 0 & 0 & 0 & 0 & 0 & 0 & 0 & 0 & 1 \\
\hline Romania & 9 & 10 & 15 & 17 & 12 & 19 & 17 & 30 & 27 & 22 & 22 & 16 & 8 & 7 & 8 & 11 & 1,117 & 2,150 \\
\hline Ukraine & 19 & 6 & 5 & 6 & 9 & 8 & 8 & 6 & 2 & 2 & 1 & 2 & 4 & 2 & 2 & 0 & 984 & 1,516 \\
\hline Belarus & 3 & 1 & 1 & 1 & 2 & 2 & 2 & 3 & 3 & 0 & 0 & 3 & 0 & 1 & 1 & 1 & 3 & 138 \\
\hline Hungary & 8 & 11 & 6 & 11 & 6 & 10 & 11 & 16 & 18 & 18 & 11 & 11 & 14 & 9 & 7 & 6 & 16 & 1,663 \\
\hline Albania & 0 & 2 & 0 & 2 & 1 & 0 & 1 & 0 & 0 & 0 & 0 & 0 & 2 & 1 & 1 & 0 & 13 & 356 \\
\hline Serbia & 4 & 5 & 5 & 7 & 5 & 5 & 2 & 7 & 4 & 7 & 6 & 2 & 3 & 2 & 0 & 0 & 2 & 548 \\
\hline Montenegro & 0 & 0 & 0 & 0 & 0 & 0 & 0 & 0 & 0 & 0 & 0 & 0 & 0 & 0 & 0 & 0 & 4 & 23 \\
\hline Poland & 31 & 41 & 31 & 24 & 27 & 25 & 15 & 19 & 20 & 12 & 9 & 17 & 12 & 22 & 32 & 19 & 97 & 3,643 \\
\hline
\end{tabular}


Table 4. Wildcat wells by year, 1961-2015, for the Caribbean, Central America, Mexico, South America, Europe, the Middle East, Africa, Asia, the southwestern Pacific, and Russia.-Continued

\begin{tabular}{|c|c|c|c|c|c|c|c|c|c|c|c|c|c|c|c|c|c|c|}
\hline Area & 2000 & 2001 & 2002 & 2003 & 2004 & 2005 & 2006 & 2007 & 2008 & 2009 & 2010 & 2011 & 2012 & 2013 & 2014 & 2015 & Unkn & Total \\
\hline \multicolumn{19}{|c|}{ Europe ${ }^{4}$-Continued } \\
\hline Czech Republic & 4 & 8 & 4 & 5 & 2 & 0 & 0 & 5 & 2 & 1 & 0 & 2 & 5 & 15 & 3 & 3 & 9 & 310 \\
\hline Bulgaria & 0 & 1 & 2 & 2 & 2 & 2 & 4 & 5 & 3 & 0 & 3 & 3 & 0 & 2 & 0 & 2 & 26 & 973 \\
\hline Lithuania & 1 & 0 & 0 & 2 & 2 & 3 & 1 & 1 & 0 & 1 & 1 & 0 & 3 & 0 & 1 & 2 & 0 & 137 \\
\hline Slovakia & 4 & 0 & 2 & 2 & 2 & 1 & 1 & 2 & 0 & 2 & 2 & 2 & 1 & 4 & 4 & 0 & 0 & 146 \\
\hline Slovenia & 0 & 1 & 0 & 0 & 0 & 0 & 2 & 0 & 0 & 0 & 1 & 0 & 0 & 0 & 0 & 0 & 15 & 94 \\
\hline Latvia & 0 & 0 & 0 & 0 & 0 & 0 & 0 & 0 & 0 & 0 & 0 & 0 & 0 & 1 & 0 & 0 & 8 & 38 \\
\hline Moldova & 0 & 0 & 0 & 0 & 0 & 0 & 1 & 0 & 0 & 0 & 0 & 0 & 0 & 0 & 0 & 0 & 6 & 21 \\
\hline Bosnia and Herzegovina & 0 & 0 & 0 & 0 & 0 & 0 & 0 & 0 & 0 & 0 & 0 & 0 & 0 & 1 & 1 & 0 & 0 & 10 \\
\hline Croatia & 4 & 3 & 3 & 0 & 2 & 0 & 4 & 0 & 2 & 1 & 1 & 0 & 1 & 0 & 1 & 5 & 17 & 644 \\
\hline Macedonia & 0 & 0 & 0 & 0 & 0 & 0 & 0 & 0 & 0 & 0 & 0 & 0 & 0 & 0 & 0 & 0 & 3 & 4 \\
\hline Total & 197 & 212 & 180 & 158 & 168 & 185 & 182 & 216 & 223 & 201 & 156 & 168 & 169 & 164 & 181 & 154 & 2,474 & 30,861 \\
\hline
\end{tabular}

${ }^{4}$ No wildcat wells were reported for Andorra, Estonia, Finland, Gibraltar, Kosovo, Liechentenstein, Luxembourg, or Monaco. Greenland (which is part of part of

Denmark) has 15 wildcat wells, and Iceland has 7 stratigraphic test wells.

${ }^{5}$ Faroe Islands are part of Denmark.

${ }^{6}$ Svalbard is a group of islands in the Artic Ocean north of and belonging to Norway. Jan Mayen is an island in the Artic Ocean north of and belonging to Norway. 
Table 4. Wildcat wells by year, 1961-2015, for the Caribbean, Central America, Mexico, South America, Europe, the Middle East, Africa, Asia, the southwestern Pacific, and Russia.-Continued

\begin{tabular}{|c|c|c|c|c|c|c|c|c|c|c|c|c|c|c|c|c|c|c|c|c|}
\hline Area & $\begin{array}{l}\text { Pre- } \\
1961\end{array}$ & 1961 & 62 & 63 & 64 & 65 & 66 & 67 & 68 & 69 & 70 & 71 & 72 & 73 & 74 & 75 & 76 & 77 & 78 & 79 \\
\hline \multicolumn{21}{|c|}{ Middle East } \\
\hline Turkey & 97 & 35 & 18 & 11 & 13 & 31 & 30 & 19 & 27 & 12 & 33 & 20 & 24 & 28 & 36 & 43 & 42 & 21 & 20 & 10 \\
\hline Cyprus & 0 & 0 & 0 & 0 & 0 & 0 & 0 & 0 & 0 & 1 & 1 & 0 & 0 & 0 & 0 & 0 & 0 & 0 & 0 & 0 \\
\hline Saudi Arabia & 22 & 0 & 0 & 4 & 1 & 2 & 5 & 8 & 7 & 3 & 6 & 9 & 5 & 4 & 5 & 11 & 7 & 5 & 7 & 6 \\
\hline Kuwait & 11 & 1 & 2 & 10 & 3 & 2 & 5 & 2 & 0 & 0 & 2 & 1 & 2 & 0 & 0 & 0 & 1 & 1 & 2 & 1 \\
\hline Abu Dhabi ${ }^{7}$ & 3 & 0 & 3 & 0 & 4 & 1 & 3 & 3 & 8 & 8 & 11 & 9 & 1 & 8 & 10 & 5 & 7 & 1 & 6 & 6 \\
\hline${ }^{\prime} \operatorname{Ajman}^{7}$ & 0 & 0 & 0 & 0 & 0 & 0 & 0 & 0 & 0 & 0 & 0 & 0 & 0 & 0 & 0 & 0 & 0 & 0 & 0 & 0 \\
\hline Dubai $^{7}$ & 1 & 0 & 0 & 0 & 2 & 1 & 1 & 0 & 1 & 0 & 0 & 1 & 1 & 0 & 0 & 0 & 3 & 1 & 0 & 3 \\
\hline Al Fujayrah ${ }^{7}$ & 0 & 0 & 0 & 0 & 0 & 0 & 0 & 0 & 0 & 1 & 0 & 0 & 0 & 0 & 0 & 0 & 0 & 1 & 0 & 0 \\
\hline Umm al Qaywayn ${ }^{7}$ & 0 & 0 & 0 & 0 & 0 & 1 & 0 & 0 & 0 & 0 & 0 & 1 & 0 & 0 & 0 & 0 & 2 & 1 & 0 & 0 \\
\hline Ra's al Khaymah & 0 & 0 & 0 & 0 & 0 & 0 & 1 & 0 & 0 & 1 & 0 & 1 & 1 & 0 & 0 & 0 & 1 & 0 & 0 & 0 \\
\hline Sharjah $^{7}$ & 1 & 0 & 0 & 1 & 1 & 1 & 0 & 1 & 0 & 0 & 0 & 1 & 0 & 1 & 1 & 1 & 0 & 0 & 2 & 0 \\
\hline Former Neutral Zone ${ }^{8}$ & 12 & 3 & 7 & 4 & 3 & 1 & 3 & 2 & 0 & 0 & 0 & 0 & 0 & 1 & 0 & 0 & 1 & 0 & 0 & 0 \\
\hline Oman & 26 & 1 & 3 & 3 & 5 & 2 & 8 & 2 & 3 & 6 & 2 & 11 & 11 & 11 & 4 & 10 & 10 & 9 & 8 & 13 \\
\hline Qatar & 10 & 1 & 5 & 3 & 3 & 1 & 1 & 4 & 3 & 2 & 1 & 2 & 2 & 0 & 0 & 0 & 3 & 1 & 0 & 4 \\
\hline Yemen & 0 & 0 & 3 & 0 & 1 & 1 & 0 & 0 & 0 & 0 & 0 & 0 & 0 & 0 & 1 & 0 & 4 & 2 & 1 & 2 \\
\hline Bahrain & 4 & 1 & 1 & 0 & 0 & 1 & 1 & 0 & 0 & 0 & 0 & 0 & 1 & 1 & 0 & 1 & 0 & 0 & 2 & 1 \\
\hline Syria & 17 & 0 & 3 & 5 & 1 & 0 & 1 & 0 & 3 & 0 & 0 & 0 & 0 & 2 & 5 & 5 & 9 & 11 & 15 & 9 \\
\hline Lebanon & 3 & 1 & 0 & 2 & 0 & 0 & 0 & 1 & 0 & 0 & 0 & 0 & 0 & 0 & 0 & 0 & 0 & 0 & 0 & 0 \\
\hline Israel $^{9}$ & 62 & 5 & 4 & 4 & 12 & 11 & 14 & 8 & 8 & 5 & 8 & 7 & 3 & 3 & 1 & 9 & 9 & 12 & 4 & 5 \\
\hline Jordan & 4 & 0 & 0 & 1 & 0 & 0 & 0 & 0 & 0 & 0 & 2 & 5 & 1 & 0 & 0 & 0 & 0 & 0 & 1 & 0 \\
\hline Iraq & 88 & 6 & 2 & 0 & 0 & 0 & 0 & 0 & 0 & 0 & 1 & 2 & 1 & 2 & 4 & 2 & 9 & 10 & 14 & 9 \\
\hline Iran & 74 & 13 & 9 & 6 & 9 & 12 & 23 & 22 & 21 & 15 & 13 & 9 & 11 & 20 & 21 & 20 & 21 & 18 & 16 & 3 \\
\hline Total & 435 & 67 & 60 & 54 & 58 & 68 & 96 & 72 & 81 & 54 & 80 & 79 & 64 & 81 & 88 & 107 & 129 & 94 & 98 & 72 \\
\hline
\end{tabular}


Table 4. Wildcat wells by year, 1961-2015, for the Caribbean, Central America, Mexico, South America, Europe, the Middle East, Africa, Asia, the southwestern Pacific, and Russia.-Continued

\begin{tabular}{|c|c|c|c|c|c|c|c|c|c|c|c|c|c|c|c|c|c|c|c|c|}
\hline Area & 1980 & 81 & 82 & 83 & 84 & 85 & 86 & 87 & 88 & 89 & 90 & 91 & 92 & 93 & 94 & 95 & 96 & 97 & 98 & 1999 \\
\hline \multicolumn{21}{|c|}{ Middle East-Continued } \\
\hline Turkey & 24 & 21 & 30 & 25 & 19 & 23 & 24 & 27 & 35 & 34 & 30 & 28 & 22 & 24 & 21 & 13 & 14 & 11 & 14 & 14 \\
\hline Cyprus & 0 & 0 & 0 & 0 & 0 & 0 & 0 & 0 & 0 & 0 & 0 & 0 & 0 & 0 & 0 & 0 & 0 & 0 & 0 & 0 \\
\hline Saudi Arabia & 5 & 2 & 3 & 5 & 2 & 0 & 0 & 1 & 0 & 2 & 5 & 2 & 5 & 7 & 3 & 2 & 3 & 5 & 4 & 3 \\
\hline Kuwait & 0 & 1 & 1 & 1 & 3 & 3 & 0 & 1 & 2 & 1 & 2 & 0 & 0 & 0 & 0 & 1 & 0 & 0 & 0 & 0 \\
\hline Abu Dhabi ${ }^{7}$ & 1 & 5 & 10 & 13 & 12 & 9 & 7 & 2 & 1 & 7 & 2 & 1 & 3 & 4 & 3 & 1 & 2 & 0 & 0 & 0 \\
\hline${ }^{6} \operatorname{Ajman}^{7}$ & 0 & 0 & 0 & 1 & 0 & 0 & 0 & 0 & 0 & 0 & 0 & 0 & 0 & 0 & 0 & 0 & 0 & 0 & 0 & 0 \\
\hline Dubai $^{7}$ & 3 & 1 & 1 & 0 & 6 & 5 & 0 & 1 & 2 & 1 & 1 & 2 & 1 & 2 & 0 & 0 & 1 & 0 & 0 & 0 \\
\hline Al Fujayrah ${ }^{7}$ & 1 & 0 & 0 & 0 & 0 & 0 & 0 & 0 & 0 & 0 & 0 & 0 & 0 & 0 & 0 & 0 & 0 & 0 & 0 & 0 \\
\hline Umm al Qaywayn $^{7}$ & 0 & 1 & 1 & 1 & 0 & 0 & 1 & 0 & 0 & 0 & 0 & 0 & 0 & 0 & 0 & 0 & 0 & 0 & 0 & 0 \\
\hline Ra's al Khaymah ${ }^{7}$ & 1 & 0 & 2 & 0 & 2 & 2 & 1 & 0 & 1 & 0 & 0 & 0 & 0 & 1 & 0 & 0 & 0 & 0 & 1 & 0 \\
\hline Sharjah $^{7}$ & 2 & 1 & 1 & 2 & 2 & 4 & 0 & 1 & 0 & 0 & 0 & 0 & 1 & 0 & 3 & 0 & 1 & 0 & 2 & 0 \\
\hline Former Neutral Zone ${ }^{8}$ & 0 & 1 & 2 & 0 & 0 & 0 & 0 & 0 & 0 & 0 & 0 & 0 & 0 & 0 & 2 & 0 & 0 & 1 & 2 & 0 \\
\hline Oman & 14 & 15 & 20 & 19 & 37 & 24 & 37 & 24 & 23 & 22 & 30 & 40 & 16 & 18 & 18 & 18 & 28 & 29 & 17 & 23 \\
\hline Qatar & 0 & 0 & 2 & 1 & 0 & 0 & 0 & 1 & 6 & 2 & 5 & 4 & 2 & 0 & 0 & 0 & 3 & 3 & 4 & 0 \\
\hline Yemen & 3 & 4 & 3 & 1 & 3 & 12 & 18 & 21 & 15 & 15 & 11 & 20 & 35 & 34 & 22 & 19 & 13 & 10 & 9 & 7 \\
\hline Bahrain & 1 & 0 & 0 & 0 & 0 & 0 & 3 & 0 & 0 & 0 & 0 & 0 & 2 & 1 & 0 & 0 & 0 & 0 & 0 & 0 \\
\hline Syria & 5 & 8 & 5 & 2 & 6 & 16 & 20 & 10 & 22 & 21 & 27 & 24 & 32 & 26 & 15 & 11 & 13 & 13 & 7 & 10 \\
\hline Lebanon & 0 & 0 & 0 & 0 & 0 & 0 & 0 & 0 & 0 & 0 & 0 & 0 & 0 & 0 & 0 & 0 & 0 & 0 & 0 & 0 \\
\hline Israel $^{9}$ & 8 & 5 & 14 & 9 & 11 & 3 & 3 & 1 & 2 & 3 & 3 & 1 & 2 & 6 & 8 & 5 & 3 & 3 & 3 & 7 \\
\hline Jordan & 1 & 0 & 3 & 4 & 5 & 1 & 1 & 3 & 7 & 7 & 4 & 3 & 1 & 2 & 5 & 0 & 0 & 1 & 2 & 1 \\
\hline Iraq & 7 & 3 & 3 & 4 & 6 & 2 & 0 & 2 & 1 & 0 & 0 & 0 & 0 & 0 & 1 & 1 & 0 & 0 & 1 & 1 \\
\hline Iran & 3 & 1 & 1 & 1 & 1 & 0 & 0 & 0 & 3 & 2 & 1 & 2 & 4 & 2 & 0 & 2 & 3 & 3 & 2 & 5 \\
\hline Total & 79 & 69 & 102 & 89 & 115 & 104 & 115 & 95 & 120 & 117 & 121 & 127 & 126 & 127 & 101 & 73 & 84 & 79 & 68 & 71 \\
\hline
\end{tabular}


Table 4. Wildcat wells by year, 1961-2015, for the Caribbean, Central America, Mexico, South America, Europe, the Middle East, Africa, Asia, the southwestern Pacific, and Russia.-Continued

[Data are from IHS Markit (2016). Some entries in this table differ from entries in table 2 of Circular 1096 (Attanasi and Root, 1993) and table 5 of Circular 1288 (Attanasi and others, 2007) because (1) the well classification system changed in 1996 and (2) historical wildcat well data were added to the database by IHS Markit. The column denoted "Unkn" means year unknown; these wells are not plotted on graphs in figures 11-55. The computation of the delineated prospective and explored areas mapped in figures 11-55 used all wildcat, exploration, and development wells, both successful and dry, except for wells with a missing or obviously incorrect location]

\begin{tabular}{|c|c|c|c|c|c|c|c|c|c|c|c|c|c|c|c|c|c|c|}
\hline Area & 2000 & 2001 & 2002 & 2003 & 2004 & 2005 & 2006 & 2007 & 2008 & 2009 & 2010 & 2011 & 2012 & 2013 & 2014 & 2015 & Unkn & Total \\
\hline \multicolumn{19}{|c|}{ Middle East_-Continued } \\
\hline Turkey & 14 & 21 & 14 & 23 & 19 & 23 & 40 & 51 & 46 & 50 & 76 & 78 & 71 & 55 & 44 & 24 & 0 & 1,672 \\
\hline Cyprus & 0 & 0 & 0 & 0 & 0 & 0 & 0 & 0 & 0 & 0 & 0 & 1 & 1 & 0 & 1 & 1 & 0 & 6 \\
\hline Saudi Arabia & 5 & 1 & 2 & 4 & 6 & 5 & 5 & 8 & 11 & 6 & 7 & 3 & 3 & 9 & 13 & 0 & 35 & 299 \\
\hline Kuwait & 0 & 1 & 5 & 1 & 5 & 2 & 5 & 1 & 0 & 0 & 0 & 0 & 2 & 1 & 4 & 1 & 3 & 93 \\
\hline Abu Dhabi ${ }^{7}$ & 2 & 0 & 0 & 0 & 1 & 0 & 1 & 0 & 1 & 0 & 3 & 3 & 1 & 0 & 0 & 0 & 0 & 192 \\
\hline${ }^{4} \operatorname{Ajman}^{7}$ & 0 & 0 & 0 & 0 & 0 & 0 & 0 & 0 & 0 & 0 & 0 & 0 & 0 & 0 & 0 & 0 & 0 & 1 \\
\hline Dubai $^{7}$ & 0 & 0 & 0 & 0 & 0 & 1 & 0 & 0 & 0 & 0 & 1 & 0 & 1 & 0 & 1 & 0 & 0 & 46 \\
\hline Al Fujayrah ${ }^{7}$ & 0 & 0 & 0 & 0 & 0 & 0 & 0 & 0 & 0 & 1 & 0 & 0 & 0 & 0 & 0 & 0 & 0 & 4 \\
\hline Umm al Qaywayn? & 0 & 0 & 0 & 0 & 0 & 0 & 0 & 0 & 0 & 0 & 0 & 0 & 0 & 0 & 0 & 0 & 0 & 9 \\
\hline Ra's al Khaymah ${ }^{7}$ & 0 & 0 & 0 & 0 & 0 & 0 & 1 & 0 & 0 & 0 & 0 & 1 & 0 & 0 & 0 & 0 & 0 & 18 \\
\hline Sharjah $^{7}$ & 1 & 0 & 0 & 0 & 0 & 0 & 0 & 0 & 0 & 1 & 0 & 1 & 0 & 0 & 1 & 0 & 0 & 35 \\
\hline Former Neutral Zone ${ }^{8}$ & 0 & 0 & 0 & 0 & 0 & 1 & 0 & 0 & 0 & 0 & 0 & 0 & 0 & 0 & 0 & 0 & 0 & 46 \\
\hline Oman & 9 & 17 & 17 & 15 & 17 & 27 & 10 & 18 & 19 & 17 & 15 & 28 & 18 & 21 & 26 & 30 & 1 & 925 \\
\hline Qatar & 1 & 4 & 2 & 2 & 0 & 1 & 4 & 0 & 2 & 3 & 0 & 2 & 0 & 3 & 0 & 2 & 0 & 105 \\
\hline Yemen & 12 & 15 & 20 & 15 & 24 & 23 & 32 & 33 & 19 & 15 & 18 & 9 & 0 & 4 & 1 & 1 & 1 & 532 \\
\hline Bahrain & 0 & 0 & 1 & 2 & 2 & 1 & 0 & 0 & 0 & 0 & 0 & 1 & 4 & 0 & 1 & 1 & 1 & 35 \\
\hline Syria & 3 & 4 & 5 & 8 & 5 & 15 & 10 & 15 & 12 & 15 & 17 & 20 & 3 & 0 & 0 & 3 & 2 & 516 \\
\hline Lebanon & 0 & 0 & 0 & 0 & 0 & 0 & 0 & 0 & 0 & 0 & 0 & 0 & 0 & 0 & 0 & 0 & 0 & 7 \\
\hline Israel $^{9}$ & 7 & 2 & 3 & 1 & 2 & 1 & 1 & 3 & 0 & 2 & 1 & 2 & 8 & 4 & 4 & 3 & 1 & 339 \\
\hline Jordan & 0 & 0 & 1 & 0 & 0 & 3 & 0 & 0 & 0 & 2 & 0 & 0 & 0 & 0 & 0 & 0 & 0 & 71 \\
\hline Iraq & 0 & 0 & 1 & 1 & 0 & 0 & 0 & 3 & 2 & 3 & 4 & 12 & 14 & 16 & 17 & 8 & 6 & 269 \\
\hline Iran & 4 & 6 & 2 & 2 & 10 & 6 & 5 & 8 & 6 & 11 & 10 & 7 & 10 & 4 & 1 & 4 & 0 & 488 \\
\hline Total & 58 & 71 & 73 & 74 & 91 & 109 & 114 & 140 & 118 & 126 & 152 & 168 & 136 & 117 & 114 & 78 & 50 & 5,708 \\
\hline
\end{tabular}

${ }^{7}$ One of the seven United Arab Emirates.

${ }^{8}$ The former Neutral Zone was located between Kuwait and SaudiAarabia.

${ }^{9}$ No wildcat wells were reported for Gaza Strip or West Bank by IHS Markit (2016), although wells may have been included with the data for Israel. 
Table 4. Wildcat wells by year, 1961-2015, for the Caribbean, Central America, Mexico, South America, Europe, the Middle East, Africa, Asia, the southwestern Pacific, and Russia.-Continued

\begin{tabular}{|c|c|c|c|c|c|c|c|c|c|c|c|c|c|c|c|c|c|c|c|c|}
\hline Area & $\begin{array}{l}\text { Pre- } \\
1961\end{array}$ & 1961 & 62 & 63 & 64 & 65 & 66 & 67 & 68 & 69 & 70 & 71 & 72 & 73 & 74 & 75 & 76 & 77 & 78 & 79 \\
\hline \multicolumn{21}{|c|}{ Africa $a^{10}$} \\
\hline Cote d'Ivoire & 8 & 1 & 0 & 0 & 0 & 0 & 0 & 0 & 0 & 0 & 0 & 0 & 2 & 1 & 1 & 2 & 1 & 8 & 5 & 3 \\
\hline Ghana & 4 & 0 & 0 & 0 & 0 & 0 & 0 & 3 & 0 & 0 & 9 & 1 & 1 & 1 & 1 & 5 & 0 & 1 & 1 & 2 \\
\hline Benin & 0 & 0 & 0 & 0 & 0 & 0 & 0 & 0 & 1 & 1 & 4 & 0 & 0 & 2 & 0 & 0 & 0 & 0 & 0 & 0 \\
\hline Guinea-Bissau & 1 & 3 & 0 & 0 & 0 & 0 & 0 & 0 & 2 & 3 & 0 & 0 & 0 & 1 & 0 & 0 & 0 & 0 & 0 & 0 \\
\hline Guinea-Bissau/Senegal JEZ ${ }^{11}$ & 0 & 0 & 0 & 0 & 0 & 0 & 0 & 1 & 0 & 0 & 3 & 2 & 0 & 0 & 0 & 0 & 0 & 0 & 0 & 0 \\
\hline Togo & 0 & 0 & 0 & 0 & 0 & 0 & 0 & 0 & 0 & 0 & 1 & 0 & 0 & 0 & 0 & 0 & 0 & 0 & 0 & 0 \\
\hline Senegal & 24 & 9 & 3 & 0 & 0 & 1 & 2 & 2 & 2 & 3 & 1 & 1 & 1 & 0 & 0 & 1 & 2 & 1 & 0 & 0 \\
\hline The Gambia & 1 & 1 & 0 & 0 & 0 & 0 & 0 & 0 & 0 & 0 & 0 & 0 & 0 & 0 & 0 & 0 & 0 & 0 & 0 & 1 \\
\hline Guinea & 0 & 0 & 0 & 0 & 0 & 0 & 0 & 0 & 0 & 0 & 0 & 0 & 0 & 0 & 0 & 0 & 0 & 1 & 0 & 0 \\
\hline Sierra Leone & 0 & 0 & 0 & 0 & 0 & 0 & 0 & 0 & 0 & 0 & 0 & 0 & 0 & 0 & 0 & 0 & 0 & 0 & 0 & 0 \\
\hline Liberia & 0 & 0 & 0 & 0 & 0 & 0 & 0 & 0 & 0 & 0 & 0 & 4 & 0 & 0 & 0 & 0 & 0 & 0 & 0 & 0 \\
\hline Ethiopia & 18 & 0 & 0 & 1 & 0 & 1 & 0 & 0 & 0 & 0 & 0 & 0 & 1 & 3 & 3 & 0 & 0 & 0 & 0 & 0 \\
\hline Somalia & 21 & 3 & 2 & 3 & 1 & 3 & 1 & 1 & 2 & 2 & 0 & 0 & 0 & 1 & 1 & 1 & 1 & 1 & 0 & 0 \\
\hline Eritrea & 11 & 0 & 0 & 0 & 0 & 0 & 2 & 0 & 0 & 2 & 1 & 0 & 0 & 2 & 0 & 0 & 0 & 1 & 0 & 0 \\
\hline Kenya & 2 & 1 & 1 & 1 & 1 & 0 & 0 & 1 & 1 & 0 & 0 & 2 & 0 & 0 & 0 & 1 & 2 & 0 & 1 & 0 \\
\hline Angola & 78 & 12 & 4 & 11 & 4 & 19 & 10 & 15 & 43 & 23 & 12 & 27 & 11 & 6 & 28 & 9 & 0 & 3 & 3 & 2 \\
\hline Angola/Congo Unitized Area ${ }^{12}$ & 0 & 0 & 0 & 0 & 0 & 0 & 0 & 0 & 0 & 0 & 0 & 0 & 0 & 0 & 0 & 0 & 0 & 0 & 0 & 0 \\
\hline Nigeria & 96 & 16 & 7 & 19 & 31 & 58 & 62 & 77 & 35 & 21 & 22 & 52 & 54 & 41 & 49 & 33 & 18 & 29 & 27 & 34 \\
\hline $\begin{array}{l}\text { Nigeria/Sao Tome and Principe } \\
\text { JDZ }^{13}\end{array}$ & 0 & 0 & 0 & 0 & 0 & 0 & 0 & 0 & 0 & 0 & 0 & 0 & 0 & 0 & 0 & 0 & 0 & 0 & 0 & 0 \\
\hline Libya & 142 & 96 & 112 & 150 & 136 & 118 & 64 & 42 & 83 & 76 & 52 & 43 & 31 & 24 & 28 & 45 & 30 & 35 & 36 & 24 \\
\hline Libya/Tunisia JEZ $^{14}$ & 0 & 0 & 0 & 0 & 0 & 0 & 0 & 0 & 0 & 0 & 0 & 0 & 0 & 0 & 0 & 1 & 0 & 1 & 0 & 0 \\
\hline Tunisia & 77 & 1 & 7 & 4 & 5 & 7 & 6 & 12 & 6 & 4 & 4 & 11 & 13 & 8 & 16 & 6 & 8 & 7 & 7 & 12 \\
\hline Algeria & 333 & 59 & 55 & 56 & 43 & 18 & 10 & 19 & 16 & 30 & 36 & 27 & 12 & 9 & 15 & 21 & 26 & 22 & 23 & 17 \\
\hline Morocco & 243 & 16 & 10 & 2 & 8 & 6 & 12 & 11 & 6 & 13 & 1 & 6 & 4 & 3 & 3 & 5 & 5 & 3 & 4 & 7 \\
\hline Egypt & 156 & 10 & 7 & 11 & 9 & 8 & 17 & 10 & 23 & 29 & 38 & 24 & 22 & 15 & 15 & 21 & 38 & 44 & 29 & 32 \\
\hline Mozambique & 5 & 1 & 3 & 0 & 0 & 5 & 1 & 14 & 0 & 0 & 11 & 6 & 2 & 0 & 0 & 0 & 0 & 0 & 0 & 0 \\
\hline
\end{tabular}


Table 4. Wildcat wells by year, 1961-2015, for the Caribbean, Central America, Mexico, South America, Europe, the Middle East, Africa, Asia, the southwestern Pacific, and Russia.-Continued

\begin{tabular}{|c|c|c|c|c|c|c|c|c|c|c|c|c|c|c|c|c|c|c|c|c|}
\hline Area & $\begin{array}{l}\text { Pre- } \\
1961\end{array}$ & 1961 & 62 & 63 & 64 & 65 & 66 & 67 & 68 & 69 & 70 & 71 & 72 & 73 & 74 & 75 & 76 & 77 & 78 & 79 \\
\hline \multicolumn{21}{|c|}{ Africa ${ }^{10}$ - Continued } \\
\hline Tanzania & 3 & 0 & 1 & 0 & 0 & 0 & 0 & 0 & 0 & 0 & 0 & 0 & 0 & 0 & 2 & 0 & 2 & 0 & 0 & 1 \\
\hline Burundi & 0 & 0 & 0 & 0 & 0 & 0 & 0 & 0 & 0 & 0 & 0 & 0 & 0 & 0 & 0 & 0 & 0 & 0 & 0 & 0 \\
\hline South Africa & 2 & 0 & 0 & 0 & 0 & 5 & 3 & 5 & 4 & 11 & 13 & 18 & 11 & 19 & 4 & 21 & 17 & 13 & 10 & 5 \\
\hline Namibia & 1 & 0 & 0 & 0 & 0 & 0 & 0 & 0 & 0 & 0 & 4 & 1 & 0 & 0 & 1 & 0 & 0 & 0 & 0 & 0 \\
\hline Botswana & 0 & 0 & 0 & 0 & 0 & 0 & 0 & 0 & 0 & 0 & 0 & 0 & 0 & 0 & 0 & 0 & 0 & 0 & 0 & 0 \\
\hline Lesotho & 0 & 0 & 0 & 0 & 0 & 0 & 0 & 0 & 0 & 0 & 0 & 0 & 0 & 0 & 0 & 1 & 0 & 0 & 0 & 0 \\
\hline Zambia & 0 & 0 & 0 & 0 & 0 & 0 & 0 & 0 & 0 & 0 & 0 & 0 & 0 & 0 & 0 & 0 & 0 & 0 & 0 & 0 \\
\hline Zimbabwe & 0 & 0 & 0 & 0 & 0 & 0 & 0 & 0 & 0 & 0 & 1 & 0 & 0 & 0 & 0 & 0 & 0 & 0 & 0 & 0 \\
\hline Gabon & 102 & 9 & 14 & 5 & 1 & 8 & 9 & 10 & 11 & 21 & 12 & 11 & 17 & 13 & 15 & 16 & 16 & 17 & 12 & 16 \\
\hline Congo (Brazzaville) & 11 & 1 & 3 & 2 & 0 & 0 & 0 & 0 & 0 & 1 & 2 & 2 & 6 & 6 & 6 & 4 & 0 & 0 & 5 & 6 \\
\hline Cameroon & 21 & 0 & 0 & 0 & 0 & 1 & 0 & 4 & 0 & 1 & 6 & 2 & 3 & 2 & 3 & 6 & 4 & 24 & 16 & 16 \\
\hline Equatorial Guinea & 0 & 0 & 0 & 0 & 0 & 0 & 0 & 1 & 5 & 0 & 0 & 1 & 0 & 0 & 0 & 0 & 0 & 0 & 0 & 0 \\
\hline Central African Republic & 0 & 0 & 0 & 0 & 0 & 0 & 0 & 0 & 0 & 0 & 0 & 0 & 0 & 0 & 0 & 0 & 0 & 0 & 0 & 0 \\
\hline Congo (Kinshasa) & 2 & 0 & 0 & 0 & 1 & 1 & 0 & 0 & 0 & 0 & 0 & 1 & 6 & 4 & 0 & 3 & 2 & 1 & 2 & 1 \\
\hline Sudan & 0 & 1 & 3 & 3 & 0 & 0 & 0 & 0 & 0 & 0 & 0 & 0 & 0 & 0 & 0 & 1 & 2 & 1 & 2 & 5 \\
\hline South Sudan & 0 & 0 & 0 & 0 & 0 & 0 & 0 & 0 & 0 & 0 & 0 & 0 & 0 & 0 & 0 & 0 & 0 & 0 & 2 & 0 \\
\hline Chad & 0 & 0 & 0 & 0 & 0 & 0 & 0 & 0 & 0 & 0 & 0 & 0 & 0 & 0 & 4 & 2 & 4 & 3 & 5 & 1 \\
\hline Mauritania & 0 & 0 & 1 & 1 & 0 & 0 & 0 & 0 & 0 & 2 & 2 & 0 & 1 & 1 & 3 & 0 & 0 & 0 & 0 & 0 \\
\hline Niger & 0 & 0 & 6 & 1 & 2 & 0 & 0 & 0 & 0 & 0 & 0 & 0 & 0 & 0 & 0 & 7 & 0 & 0 & 0 & 3 \\
\hline Mali & 0 & 0 & 0 & 0 & 0 & 0 & 0 & 0 & 0 & 0 & 0 & 0 & 0 & 0 & 0 & 0 & 0 & 0 & 0 & 1 \\
\hline Uganda & 1 & 0 & 0 & 0 & 0 & 0 & 0 & 0 & 0 & 0 & 0 & 0 & 0 & 0 & 0 & 0 & 0 & 0 & 0 & 0 \\
\hline Western Sahara & 0 & 8 & 15 & 7 & 4 & 3 & 4 & 6 & 0 & 1 & 1 & 0 & 1 & 1 & 0 & 0 & 0 & 0 & 0 & 0 \\
\hline Madagascar & 49 & 0 & 0 & 1 & 1 & 1 & 0 & 0 & 0 & 0 & 1 & 8 & 1 & 2 & 5 & 1 & 0 & 0 & 0 & 0 \\
\hline Mauritius & 0 & 0 & 0 & 0 & 0 & 0 & 0 & 0 & 0 & 0 & 0 & 0 & 0 & 0 & 0 & 2 & 0 & 0 & 0 & 0 \\
\hline Seychelles & 0 & 0 & 0 & 0 & 0 & 0 & 0 & 0 & 0 & 0 & 0 & 0 & 0 & 0 & 0 & 0 & 0 & 0 & 0 & 0 \\
\hline Total & 1,412 & 248 & 254 & 278 & 247 & 263 & 203 & 234 & 240 & 244 & 237 & 250 & 200 & 165 & 203 & 215 & 178 & 216 & 190 & 189 \\
\hline
\end{tabular}


Table 4. Wildcat wells by year, 1961-2015, for the Caribbean, Central America, Mexico, South America, Europe, the Middle East, Africa, Asia, the southwestern Pacific, and Russia.-Continued

\begin{tabular}{|c|c|c|c|c|c|c|c|c|c|c|c|c|c|c|c|c|c|c|c|c|}
\hline Area & 1980 & 81 & 82 & 83 & 84 & 85 & 86 & 87 & 88 & 89 & 90 & 91 & 92 & 93 & 94 & 95 & 96 & 97 & 98 & 1999 \\
\hline \multicolumn{21}{|c|}{ Africa ${ }^{10}$ - Continued } \\
\hline Cote d'Ivoire & 1 & 7 & 9 & 2 & 6 & 2 & 0 & 0 & 0 & 0 & 0 & 0 & 0 & 0 & 0 & 0 & 5 & 4 & 4 & 2 \\
\hline Ghana & 1 & 0 & 1 & 0 & 0 & 2 & 0 & 1 & 0 & 3 & 1 & 0 & 0 & 0 & 0 & 0 & 0 & 1 & 1 & 0 \\
\hline Benin & 0 & 0 & 0 & 0 & 0 & 0 & 0 & 0 & 0 & 0 & 0 & 0 & 0 & 0 & 0 & 0 & 0 & 1 & 0 & 0 \\
\hline Guinea-Bissau & 0 & 0 & 0 & 0 & 1 & 0 & 0 & 0 & 0 & 0 & 3 & 0 & 0 & 0 & 0 & 0 & 0 & 0 & 0 & 0 \\
\hline Guinea-Bissau/Senegal JEZ ${ }^{11}$ & 0 & 0 & 0 & 0 & 0 & 0 & 0 & 0 & 0 & 0 & 0 & 0 & 0 & 0 & 0 & 0 & 1 & 0 & 0 & 0 \\
\hline Togo & 0 & 0 & 0 & 0 & 0 & 1 & 1 & 0 & 0 & 0 & 0 & 0 & 0 & 0 & 0 & 0 & 0 & 0 & 0 & 0 \\
\hline Senegal & 0 & 0 & 1 & 0 & 1 & 0 & 0 & 0 & 1 & 2 & 0 & 0 & 0 & 4 & 0 & 0 & 0 & 0 & 1 & 0 \\
\hline The Gambia & 0 & 0 & 0 & 0 & 0 & 0 & 0 & 0 & 0 & 0 & 0 & 0 & 0 & 0 & 0 & 0 & 0 & 0 & 0 & 0 \\
\hline Guinea & 0 & 0 & 0 & 0 & 0 & 0 & 0 & 0 & 0 & 0 & 0 & 0 & 0 & 0 & 0 & 0 & 0 & 0 & 0 & 0 \\
\hline Sierra Leone & 0 & 0 & 1 & 0 & 0 & 1 & 0 & 0 & 0 & 0 & 0 & 0 & 0 & 0 & 0 & 0 & 0 & 0 & 0 & 0 \\
\hline Liberia & 0 & 0 & 0 & 0 & 0 & 3 & 0 & 0 & 0 & 0 & 0 & 0 & 0 & 0 & 0 & 0 & 0 & 0 & 0 & 0 \\
\hline Ethiopia & 0 & 0 & 0 & 1 & 1 & 1 & 0 & 2 & 0 & 0 & 0 & 0 & 0 & 0 & 0 & 1 & 0 & 0 & 0 & 0 \\
\hline Somalia & 1 & 0 & 3 & 0 & 2 & 2 & 0 & 1 & 2 & 0 & 3 & 0 & 0 & 0 & 0 & 0 & 0 & 0 & 0 & 0 \\
\hline Eritrea & 0 & 0 & 0 & 0 & 0 & 0 & 0 & 0 & 0 & 0 & 0 & 0 & 0 & 0 & 0 & 0 & 0 & 0 & 2 & 1 \\
\hline Kenya & 0 & 2 & 1 & 0 & 0 & 1 & 1 & 0 & 3 & 4 & 1 & 0 & 1 & 1 & 0 & 0 & 0 & 0 & 0 & 0 \\
\hline Angola & 4 & 9 & 21 & 23 & 11 & 18 & 14 & 15 & 19 & 9 & 20 & 20 & 12 & 12 & 12 & 7 & 16 & 16 & 23 & 14 \\
\hline Angola/Congo Unitized Area ${ }^{12}$ & 0 & 0 & 0 & 0 & 0 & 0 & 0 & 0 & 0 & 0 & 0 & 0 & 0 & 0 & 0 & 0 & 0 & 0 & 0 & 0 \\
\hline Nigeria & 30 & 29 & 27 & 25 & 16 & 15 & 18 & 16 & 26 & 28 & 36 & 24 & 28 & 29 & 15 & 21 & 29 & 28 & 24 & 9 \\
\hline $\begin{array}{l}\text { Nigeria/Sao Tome and Principe } \\
\text { JDZ }^{13}\end{array}$ & 0 & 0 & 0 & 0 & 0 & 0 & 0 & 0 & 0 & 0 & 0 & 0 & 0 & 0 & 0 & 0 & 0 & 0 & 0 & 0 \\
\hline Libya & 17 & 34 & 37 & 37 & 41 & 38 & 21 & 17 & 14 & 15 & 12 & 8 & 20 & 28 & 24 & 13 & 10 & 19 & 15 & 7 \\
\hline Libya/Tunisia JEZ ${ }^{14}$ & 0 & 0 & 0 & 0 & 0 & 0 & 0 & 0 & 0 & 0 & 0 & 0 & 0 & 0 & 0 & 0 & 0 & 0 & 0 & 1 \\
\hline Tunisia & 13 & 28 & 18 & 10 & 12 & 14 & 5 & 12 & 7 & 8 & 6 & 9 & 12 & 9 & 7 & 13 & 9 & 11 & 11 & 6 \\
\hline Algeria & 25 & 19 & 20 & 21 & 11 & 25 & 18 & 26 & 9 & 14 & 11 & 18 & 17 & 18 & 21 & 18 & 19 & 23 & 30 & 14 \\
\hline Morocco & 9 & 11 & 8 & 5 & 4 & 5 & 4 & 8 & 2 & 0 & 1 & 2 & 2 & 3 & 0 & 0 & 0 & 0 & 2 & 0 \\
\hline Egypt & 37 & 57 & 62 & 42 & 37 & 67 & 60 & 47 & 47 & 37 & 38 & 43 & 36 & 25 & 25 & 27 & 51 & 69 & 65 & 31 \\
\hline Mozambique & 0 & 0 & 0 & 0 & 0 & 0 & 1 & 0 & 1 & 0 & 0 & 0 & 0 & 0 & 0 & 0 & 0 & 2 & 0 & 0 \\
\hline
\end{tabular}


Table 4. Wildcat wells by year, 1961-2015, for the Caribbean, Central America, Mexico, South America, Europe, the Middle East, Africa, Asia, the southwestern Pacific, and Russia.-Continued

\begin{tabular}{|c|c|c|c|c|c|c|c|c|c|c|c|c|c|c|c|c|c|c|c|c|}
\hline Area & 1980 & 81 & 82 & 83 & 84 & 85 & 86 & 87 & 88 & 89 & 90 & 91 & 92 & 93 & 94 & 95 & 96 & 97 & 98 & 1999 \\
\hline \multicolumn{21}{|c|}{ Africa $^{10}$-Continued } \\
\hline Tanzania & 0 & 0 & 1 & 2 & 2 & 2 & 1 & 2 & 0 & 0 & 2 & 1 & 0 & 0 & 0 & 0 & 1 & 1 & 0 & 0 \\
\hline Burundi & 0 & 0 & 0 & 0 & 0 & 0 & 0 & 2 & 0 & 0 & 0 & 0 & 0 & 0 & 0 & 0 & 0 & 0 & 0 & 0 \\
\hline South Africa & 7 & 9 & 15 & 8 & 11 & 13 & 15 & 15 & 17 & 19 & 21 & 8 & 5 & 3 & 5 & 3 & 0 & 1 & 4 & 0 \\
\hline Namibia & 0 & 0 & 0 & 0 & 0 & 0 & 0 & 0 & 0 & 0 & 0 & 1 & 0 & 0 & 1 & 3 & 1 & 0 & 1 & 1 \\
\hline Botswana & 0 & 0 & 0 & 0 & 0 & 0 & 0 & 0 & 0 & 0 & 0 & 0 & 0 & 0 & 0 & 0 & 0 & 0 & 0 & 0 \\
\hline Lesotho & 0 & 0 & 0 & 0 & 0 & 0 & 0 & 0 & 0 & 0 & 0 & 0 & 0 & 0 & 0 & 0 & 0 & 0 & 0 & 0 \\
\hline Zambia & 0 & 0 & 0 & 0 & 0 & 0 & 0 & 1 & 1 & 0 & 0 & 0 & 0 & 0 & 0 & 0 & 0 & 0 & 0 & 0 \\
\hline Zimbabwe & 0 & 0 & 0 & 0 & 0 & 0 & 0 & 0 & 0 & 0 & 0 & 0 & 0 & 0 & 0 & 0 & 0 & 0 & 0 & 0 \\
\hline Gabon & 16 & 23 & 19 & 15 & 16 & 15 & 7 & 6 & 17 & 28 & 25 & 32 & 13 & 2 & 5 & 9 & 9 & 17 & 7 & 2 \\
\hline Congo (Brazzaville) & 8 & 10 & 11 & 4 & 3 & 9 & 3 & 8 & 4 & 3 & 7 & 10 & 19 & 2 & 1 & 2 & 1 & 4 & 6 & 4 \\
\hline Cameroon & 19 & 19 & 8 & 2 & 5 & 2 & 3 & 0 & 3 & 1 & 0 & 0 & 2 & 1 & 0 & 2 & 2 & 3 & 3 & 2 \\
\hline Equatorial Guinea & 0 & 0 & 2 & 0 & 1 & 1 & 1 & 0 & 1 & 0 & 0 & 1 & 1 & 0 & 2 & 2 & 8 & 9 & 6 & 1 \\
\hline Central African Republic & 0 & 0 & 0 & 0 & 0 & 0 & 1 & 0 & 0 & 0 & 0 & 0 & 0 & 0 & 0 & 0 & 0 & 0 & 0 & 0 \\
\hline Congo (Kinshasa) & 0 & 3 & 4 & 4 & 4 & 1 & 1 & 0 & 3 & 1 & 1 & 0 & 0 & 0 & 1 & 0 & 1 & 0 & 0 & 0 \\
\hline Sudan & 1 & 7 & 6 & 7 & 3 & 7 & 2 & 1 & 0 & 4 & 0 & 0 & 0 & 0 & 0 & 0 & 1 & 6 & 4 & 4 \\
\hline South Sudan & 0 & 3 & 5 & 3 & 0 & 0 & 0 & 0 & 0 & 0 & 0 & 0 & 0 & 0 & 1 & 1 & 3 & 5 & 5 & 9 \\
\hline Chad & 0 & 0 & 0 & 0 & 0 & 3 & 3 & 0 & 0 & 0 & 2 & 1 & 0 & 0 & 2 & 0 & 0 & 0 & 0 & 0 \\
\hline Mauritania & 1 & 0 & 0 & 0 & 1 & 0 & 0 & 0 & 0 & 1 & 0 & 0 & 1 & 0 & 0 & 0 & 0 & 0 & 0 & 0 \\
\hline Niger & 2 & 0 & 2 & 0 & 0 & 0 & 0 & 0 & 0 & 0 & 2 & 0 & 0 & 0 & 3 & 0 & 0 & 0 & 3 & 0 \\
\hline Mali & 0 & 0 & 1 & 0 & 0 & 1 & 0 & 0 & 0 & 0 & 0 & 0 & 0 & 0 & 0 & 0 & 0 & 0 & 0 & 0 \\
\hline Uganda & 0 & 0 & 0 & 0 & 0 & 0 & 0 & 0 & 0 & 0 & 0 & 0 & 0 & 0 & 0 & 0 & 0 & 0 & 0 & 0 \\
\hline Western Sahara & 0 & 0 & 0 & 0 & 0 & 0 & 0 & 0 & 0 & 0 & 0 & 0 & 0 & 0 & 0 & 0 & 0 & 0 & 0 & 0 \\
\hline Madagascar & 0 & 0 & 0 & 0 & 0 & 4 & 3 & 2 & 0 & 0 & 1 & 1 & 2 & 1 & 0 & 0 & 0 & 0 & 0 & 0 \\
\hline Mauritius & 0 & 0 & 0 & 0 & 0 & 0 & 0 & 0 & 0 & 0 & 0 & 0 & 0 & 0 & 0 & 0 & 0 & 0 & 0 & 0 \\
\hline Seychelles & 1 & 2 & 0 & 0 & 0 & 0 & 0 & 0 & 0 & 0 & 0 & 0 & 0 & 0 & 0 & 1 & 0 & 0 & 0 & 0 \\
\hline Total & 193 & 272 & 283 & 211 & 189 & 253 & 183 & 182 & 177 & 177 & 193 & 179 & 171 & 138 & 125 & 123 & 167 & 220 & 217 & 108 \\
\hline
\end{tabular}


Table 4. Wildcat wells by year, 1961-2015, for the Caribbean, Central America, Mexico, South America, Europe, the Middle East, Africa, Asia, the southwestern Pacific, and Russia.-Continued

\begin{tabular}{|c|c|c|c|c|c|c|c|c|c|c|c|c|c|c|c|c|c|c|}
\hline Area & 2000 & 2001 & 2002 & 2003 & 2004 & 2005 & 2006 & 2007 & 2008 & 2009 & 2010 & 2011 & 2012 & 2013 & 2014 & 2015 & Unkn & Total \\
\hline \multicolumn{19}{|c|}{ Africa $^{10}$-Continued } \\
\hline Cote d'Ivoire & 1 & 1 & 2 & 1 & 0 & 3 & 0 & 2 & 0 & 2 & 3 & 3 & 4 & 2 & 5 & 2 & 0 & 105 \\
\hline Benin & 0 & 0 & 0 & 2 & 0 & 1 & 0 & 1 & 0 & 0 & 0 & 0 & 0 & 0 & 3 & 0 & 0 & 16 \\
\hline Guinea-Bissau & 0 & 0 & 1 & 0 & 1 & 0 & 0 & 2 & 0 & 0 & 0 & 0 & 0 & 0 & 0 & 0 & 0 & 18 \\
\hline Guinea-Bissau/Senegal JEZ ${ }^{11}$ & 0 & 0 & 0 & 0 & 0 & 0 & 0 & 0 & 0 & 0 & 0 & 1 & 0 & 0 & 0 & 0 & 0 & 8 \\
\hline Senegal & 2 & 0 & 0 & 0 & 0 & 1 & 0 & 0 & 0 & 0 & 0 & 0 & 2 & 0 & 2 & 0 & 12 & 82 \\
\hline The Gambia & 0 & 0 & 0 & 0 & 0 & 0 & 0 & 0 & 0 & 0 & 0 & 0 & 0 & 0 & 0 & 0 & 0 & 3 \\
\hline Guinea & 0 & 0 & 0 & 0 & 0 & 0 & 0 & 0 & 0 & 0 & 0 & 0 & 1 & 0 & 0 & 0 & 0 & 2 \\
\hline Sierra Leone & 0 & 0 & 0 & 0 & 0 & 0 & 0 & 0 & 0 & 1 & 1 & 0 & 2 & 1 & 0 & 0 & 0 & 7 \\
\hline Liberia & 0 & 0 & 0 & 0 & 0 & 0 & 0 & 0 & 0 & 0 & 0 & 2 & 3 & 1 & 3 & 0 & 0 & 16 \\
\hline Ethiopia & 0 & 0 & 0 & 0 & 0 & 0 & 1 & 1 & 0 & 0 & 1 & 0 & 0 & 3 & 2 & 0 & 0 & 41 \\
\hline Eritrea & 0 & 0 & 0 & 0 & 0 & 0 & 0 & 0 & 0 & 0 & 0 & 0 & 0 & 0 & 0 & 0 & 1 & 23 \\
\hline Kenya & 0 & 0 & 0 & 0 & 0 & 0 & 0 & 1 & 0 & 0 & 1 & 0 & 1 & 5 & 12 & 5 & 0 & 54 \\
\hline Angola & 21 & 10 & 16 & 18 & 9 & 14 & 14 & 26 & 15 & 18 & 16 & 9 & 9 & 11 & 21 & 9 & 5 & 856 \\
\hline Angola/Congo Unitized Area ${ }^{12}$ & 0 & 0 & 0 & 1 & 1 & 0 & 0 & 1 & 0 & 0 & 0 & 0 & 0 & 0 & 0 & 0 & 0 & 3 \\
\hline Nigeria & 13 & 16 & 17 & 16 & 19 & 13 & 20 & 15 & 12 & 13 & 6 & 11 & 13 & 11 & 10 & 9 & 1 & 1,469 \\
\hline $\begin{array}{l}\text { Nigeria/Sao Tome and Principe } \\
\text { JDZ }^{13}\end{array}$ & 0 & 0 & 0 & 0 & 0 & 0 & 1 & 0 & 0 & 4 & 1 & 0 & 1 & 0 & 0 & 0 & 0 & 7 \\
\hline Libya & 14 & 19 & 10 & 11 & 19 & 22 & 33 & 50 & 48 & 44 & 57 & 15 & 4 & 24 & 18 & 2 & 77 & 2,261 \\
\hline Libya/Tunisia JEZ ${ }^{14}$ & 0 & 0 & 2 & 0 & 0 & 0 & 0 & 0 & 0 & 0 & 0 & 0 & 0 & 0 & 0 & 0 & 0 & 5 \\
\hline Tunisia & 6 & 4 & 5 & 10 & 6 & 6 & 7 & 17 & 18 & 6 & 13 & 8 & 11 & 9 & 4 & 5 & 6 & 582 \\
\hline Algeria & 15 & 28 & 22 & 22 & 37 & 37 & 34 & 39 & 39 & 35 & 22 & 8 & 30 & 18 & 4 & 2 & 36 & 1,652 \\
\hline Morocco & 3 & 1 & 0 & 1 & 5 & 1 & 3 & 2 & 3 & 3 & 8 & 6 & 0 & 3 & 7 & 12 & 57 & 549 \\
\hline Egypt & 49 & 45 & 50 & 50 & 49 & 61 & 91 & 87 & 118 & 101 & 111 & 99 & 92 & 72 & 64 & 49 & 4 & 2,653 \\
\hline Mozambique & 2 & 0 & 0 & 1 & 4 & 0 & 0 & 5 & 6 & 3 & 7 & 5 & 7 & 8 & 6 & 1 & 0 & 107 \\
\hline
\end{tabular}


Table 4. Wildcat wells by year, 1961-2015, for the Caribbean, Central America, Mexico, South America, Europe, the Middle East, Africa, Asia, the southwestern Pacific, and Russia.-Continued

\begin{tabular}{|c|c|c|c|c|c|c|c|c|c|c|c|c|c|c|c|c|c|c|}
\hline Area & 2000 & 2001 & 2002 & 2003 & 2004 & 2005 & 2006 & 2007 & 2008 & 2009 & 2010 & 2011 & 2012 & 2013 & 2014 & 2015 & Unkn & Total \\
\hline \multicolumn{19}{|c|}{ Africa ${ }^{10}$ - Continued } \\
\hline Tanzania & 0 & 1 & 0 & 0 & 0 & 0 & 0 & 1 & 3 & 2 & 5 & 4 & 8 & 6 & 9 & 4 & 0 & 67 \\
\hline Burundi & 0 & 0 & 0 & 0 & 0 & 0 & 0 & 0 & 0 & 0 & 0 & 0 & 0 & 0 & 0 & 0 & 0 & 2 \\
\hline South Africa & 2 & 3 & 0 & 6 & 1 & 0 & 0 & 0 & 1 & 2 & 0 & 0 & 0 & 1 & 1 & 0 & 97 & 454 \\
\hline Namibia & 0 & 0 & 2 & 0 & 0 & 0 & 0 & 0 & 1 & 0 & 0 & 0 & 2 & 3 & 2 & 0 & 0 & 25 \\
\hline Botswana & 0 & 0 & 0 & 0 & 0 & 0 & 0 & 0 & 0 & 0 & 0 & 1 & 0 & 1 & 0 & 0 & 0 & 2 \\
\hline Lesotho & 0 & 0 & 0 & 0 & 0 & 0 & 0 & 0 & 0 & 0 & 0 & 0 & 0 & 0 & 0 & 0 & 0 & 1 \\
\hline Zambia & 0 & 0 & 0 & 0 & 0 & 0 & 0 & 0 & 0 & 0 & 0 & 0 & 0 & 0 & 0 & 0 & 0 & 2 \\
\hline Zimbabwe & 0 & 0 & 0 & 0 & 0 & 0 & 0 & 0 & 0 & 0 & 0 & 0 & 0 & 0 & 0 & 0 & 0 & 1 \\
\hline Gabon & 6 & 12 & 9 & 10 & 8 & 15 & 13 & 4 & 13 & 16 & 14 & 10 & 6 & 12 & 12 & 2 & 9 & 789 \\
\hline Congo (Brazzaville) & 5 & 4 & 1 & 1 & 2 & 7 & 6 & 7 & 1 & 6 & 5 & 4 & 3 & 5 & 3 & 2 & 0 & 236 \\
\hline Cameroon & 1 & 0 & 2 & 3 & 2 & 2 & 2 & 4 & 5 & 2 & 1 & 7 & 3 & 3 & 4 & 6 & 0 & 233 \\
\hline Equatorial Guinea & 4 & 10 & 12 & 8 & 9 & 6 & 1 & 6 & 5 & 1 & 4 & 1 & 2 & 2 & 2 & 2 & 0 & 118 \\
\hline Central African Republic & 0 & 0 & 0 & 0 & 0 & 0 & 0 & 0 & 0 & 0 & 0 & 0 & 0 & 0 & 0 & 0 & 0 & 1 \\
\hline Congo (Kinshasa) & 1 & 1 & 0 & 0 & 1 & 0 & 0 & 0 & 0 & 0 & 3 & 1 & 0 & 1 & 0 & 0 & 0 & 56 \\
\hline Sudan & 8 & 12 & 12 & 3 & 13 & 12 & 8 & 5 & 0 & 4 & 4 & 7 & 1 & 1 & 1 & 1 & 0 & 163 \\
\hline South Sudan & 7 & 11 & 16 & 7 & 15 & 17 & 25 & 26 & 17 & 12 & 13 & 4 & 0 & 0 & 0 & 0 & 0 & 207 \\
\hline Chad & 0 & 0 & 5 & 0 & 3 & 5 & 8 & 5 & 0 & 5 & 25 & 4 & 1 & 3 & 4 & 3 & 0 & 101 \\
\hline Mauritania & 0 & 3 & 2 & 2 & 7 & 6 & 5 & 2 & 1 & 0 & 0 & 3 & 0 & 1 & 3 & 2 & 0 & 52 \\
\hline Niger & 3 & 0 & 0 & 0 & 1 & 2 & 0 & 2 & 0 & 6 & 10 & 11 & 15 & 4 & 1 & 11 & 0 & 97 \\
\hline Mali & 0 & 0 & 0 & 0 & 0 & 0 & 0 & 0 & 0 & 0 & 0 & 0 & 0 & 0 & 0 & 0 & 0 & 3 \\
\hline Uganda & 0 & 0 & 0 & 1 & 2 & 0 & 3 & 1 & 5 & 8 & 4 & 4 & 5 & 4 & 0 & 0 & 0 & 38 \\
\hline Western Sahara & 0 & 0 & 0 & 0 & 0 & 0 & 0 & 0 & 0 & 0 & 0 & 0 & 0 & 0 & 0 & 0 & 1 & 52 \\
\hline Madagascar & 1 & 0 & 0 & 0 & 0 & 0 & 0 & 0 & 17 & 1 & 0 & 3 & 0 & 0 & 0 & 0 & 0 & 106 \\
\hline Mauritius & 0 & 0 & 0 & 0 & 0 & 0 & 0 & 0 & 0 & 0 & 0 & 0 & 0 & 0 & 0 & 0 & 0 & 2 \\
\hline Seychelles & 0 & 0 & 0 & 0 & 0 & 0 & 0 & 0 & 0 & 0 & 0 & 0 & 0 & 0 & 0 & 0 & 0 & 4 \\
\hline Total & 166 & 185 & 186 & 176 & 214 & 232 & 275 & 312 & 332 & 297 & 341 & 237 & 239 & 220 & 205 & 129 & 306 & 13,479 \\
\hline
\end{tabular}

${ }^{10}$ No wildcat wells were reported for Burkina Faso, Cabo Verde, Comoros, Djibouti, Malawi, Reunion, Rwanda, Sao Tome and Principe, or Swaziland.

${ }^{11}$ Guinea-Bissau and Senegal share the Guinea-Bissau/Senegal Joint Economic Zone (JEZ).

${ }^{12}$ Angola and Congo (Brazzaville) share the Angola/Congo Unitized Area.

${ }^{13}$ Nigeria and Sao Tome and Principe share the Nigeria/Sao Tome and Principe Joint Development Zone (JDZ).

${ }^{14}$ Libya and Tunisia share the Libya/Tunisia Joint Exploration Zone (JEZ). 
Table 4. Wildcat wells by year, 1961-2015, for the Caribbean, Central America, Mexico, South America, Europe, the Middle East, Africa, Asia, the southwestern Pacific, and Russia.-Continued

\begin{tabular}{|c|c|c|c|c|c|c|c|c|c|c|c|c|c|c|c|c|c|c|c|c|}
\hline Area & $\begin{array}{l}\text { Pre- } \\
1961\end{array}$ & 1961 & 62 & 63 & 64 & 65 & 66 & 67 & 68 & 69 & 70 & 71 & 72 & 73 & 74 & 75 & 76 & 77 & 78 & 79 \\
\hline \multicolumn{21}{|c|}{ Asia $^{15}$} \\
\hline China & 982 & 132 & 48 & 39 & 46 & 73 & 146 & 125 & 66 & 62 & 230 & 334 & 299 & 218 & 245 & 274 & 181 & 272 & 343 & 324 \\
\hline Mongolia & 1 & 0 & 0 & 0 & 0 & 0 & 0 & 0 & 0 & 0 & 0 & 0 & 0 & 0 & 0 & 0 & 0 & 0 & 0 & 0 \\
\hline Kazakhstan & 217 & 5 & 10 & 10 & 17 & 23 & 18 & 14 & 36 & 25 & 15 & 20 & 10 & 15 & 20 & 47 & 19 & 20 & 28 & 30 \\
\hline Azerbaijan & 233 & 6 & 8 & 7 & 15 & 10 & 19 & 14 & 8 & 11 & 13 & 12 & 12 & 8 & 6 & 7 & 10 & 9 & 9 & 13 \\
\hline Turkmenistan & 78 & 18 & 10 & 13 & 20 & 42 & 23 & 18 & 30 & 19 & 25 & 17 & 19 & 22 & 21 & 13 & 18 & 27 & 22 & 25 \\
\hline Uzbekistan & 54 & 11 & 6 & 11 & 8 & 9 & 12 & 12 & 11 & 7 & 14 & 9 & 2 & 13 & 17 & 17 & 9 & 10 & 12 & 11 \\
\hline Georgia & 116 & 4 & 16 & 18 & 19 & 13 & 20 & 18 & 19 & 20 & 20 & 25 & 17 & 25 & 34 & 25 & 15 & 24 & 12 & 15 \\
\hline Kyrgyzstan & 16 & 1 & 3 & 2 & 2 & 2 & 2 & 1 & 3 & 3 & 1 & 0 & 1 & 2 & 1 & 2 & 3 & 0 & 3 & 0 \\
\hline Tajikistan & 5 & 3 & 2 & 0 & 1 & 0 & 1 & 1 & 1 & 3 & 2 & 0 & 0 & 1 & 1 & 0 & 1 & 3 & 1 & 2 \\
\hline Armenia & 12 & 10 & 11 & 5 & 4 & 3 & 5 & 7 & 2 & 3 & 6 & 1 & 6 & 1 & 2 & 0 & 0 & 0 & 0 & 0 \\
\hline Pakistan & 86 & 2 & 2 & 1 & 3 & 2 & 2 & 2 & 2 & 3 & 1 & 4 & 2 & 4 & 4 & 4 & 2 & 3 & 2 & 3 \\
\hline Afghanistan & 5 & 3 & 4 & 6 & 6 & 4 & 2 & 3 & 3 & 0 & 4 & 1 & 1 & 5 & 2 & 10 & 5 & 2 & 6 & 5 \\
\hline India & 25 & 2 & 13 & 4 & 8 & 13 & 9 & 7 & 10 & 8 & 15 & 10 & 11 & 5 & 7 & 11 & 19 & 15 & 23 & 13 \\
\hline Bangladesh & 16 & 0 & 2 & 1 & 0 & 1 & 0 & 1 & 0 & 2 & 1 & 0 & 0 & 0 & 0 & 0 & 6 & 3 & 1 & 0 \\
\hline Maldives & 0 & 0 & 0 & 0 & 0 & 0 & 0 & 0 & 0 & 0 & 0 & 0 & 0 & 0 & 0 & 0 & 1 & 0 & 0 & 0 \\
\hline Nepal & 0 & 0 & 0 & 0 & 0 & 0 & 0 & 0 & 0 & 0 & 0 & 0 & 0 & 0 & 0 & 0 & 0 & 0 & 0 & 0 \\
\hline Sri Lanka & 0 & 0 & 0 & 0 & 0 & 0 & 0 & 0 & 0 & 0 & 0 & 0 & 0 & 0 & 1 & 1 & 3 & 0 & 0 & 0 \\
\hline Vietnam & 0 & 0 & 0 & 0 & 0 & 0 & 0 & 0 & 0 & 0 & 0 & 0 & 0 & 0 & 2 & 4 & 2 & 0 & 0 & 8 \\
\hline Burma & 107 & 4 & 6 & 0 & 2 & 1 & 0 & 0 & 1 & 1 & 1 & 2 & 6 & 5 & 8 & 10 & 14 & 5 & 5 & 2 \\
\hline Thailand & 1 & 0 & 0 & 1 & 0 & 0 & 0 & 0 & 0 & 3 & 2 & 2 & 5 & 6 & 15 & 6 & 15 & 0 & 1 & 1 \\
\hline Cambodia & 0 & 0 & 0 & 0 & 0 & 0 & 0 & 0 & 0 & 0 & 0 & 0 & 1 & 0 & 2 & 0 & 0 & 0 & 0 & 0 \\
\hline Laos & 0 & 0 & 0 & 0 & 0 & 0 & 0 & 0 & 0 & 0 & 0 & 0 & 0 & 0 & 0 & 0 & 0 & 0 & 0 & 0 \\
\hline Japan & 33 & 5 & 3 & 5 & 4 & 3 & 4 & 4 & 8 & 3 & 0 & 5 & 8 & 12 & 19 & 23 & 16 & 21 & 25 & 14 \\
\hline Japan/South Korea JDZ ${ }^{16}$ & 0 & 0 & 0 & 0 & 0 & 0 & 0 & 0 & 0 & 0 & 0 & 0 & 0 & 0 & 0 & 0 & 0 & 0 & 0 & 0 \\
\hline South Korea & 0 & 0 & 0 & 0 & 0 & 0 & 0 & 6 & 1 & 0 & 0 & 0 & 1 & 4 & 0 & 2 & 0 & 0 & 0 & 0 \\
\hline North Korea & 0 & 0 & 0 & 0 & 0 & 0 & 0 & 0 & 0 & 0 & 0 & 0 & 0 & 0 & 0 & 0 & 0 & 0 & 0 & 1 \\
\hline Philippines & 80 & 8 & 6 & 3 & 12 & 0 & 0 & 0 & 0 & 0 & 1 & 13 & 7 & 10 & 8 & 12 & 8 & 12 & 12 & 18 \\
\hline
\end{tabular}


Table 4. Wildcat wells by year, 1961-2015, for the Caribbean, Central America, Mexico, South America, Europe, the Middle East, Africa, Asia, the southwestern Pacific, and Russia.-Continued

\begin{tabular}{|c|c|c|c|c|c|c|c|c|c|c|c|c|c|c|c|c|c|c|c|c|}
\hline Area & $\begin{array}{l}\text { Pre- } \\
1961\end{array}$ & 1961 & 62 & 63 & 64 & 65 & 66 & 67 & 68 & 69 & 70 & 71 & 72 & 73 & 74 & 75 & 76 & 77 & 78 & 79 \\
\hline \multicolumn{21}{|c|}{ Asia ${ }^{15}$-Continued } \\
\hline Taiwan & 18 & 1 & 2 & 1 & 4 & 3 & 8 & 7 & 5 & 10 & 6 & 7 & 3 & 15 & 11 & 16 & 8 & 7 & 8 & 7 \\
\hline Indonesia & 1,062 & 5 & 1 & 10 & 16 & 10 & 7 & 10 & 24 & 28 & 78 & 134 & 114 & 145 & 143 & 131 & 106 & 81 & 98 & 113 \\
\hline Malaysia & 68 & 7 & 5 & 3 & 1 & 0 & 2 & 11 & 16 & 25 & 44 & 21 & 26 & 20 & 10 & 23 & 2 & 10 & 17 & 34 \\
\hline Malaysia/Thailand JDA ${ }^{17}$ & 0 & 0 & 0 & 0 & 0 & 0 & 0 & 0 & 0 & 0 & 0 & 1 & 0 & 0 & 0 & 0 & 1 & 0 & 0 & 0 \\
\hline Brunei & 11 & 1 & 1 & 1 & 0 & 0 & 0 & 0 & 2 & 4 & 2 & 1 & 6 & 4 & 1 & 7 & 4 & 2 & 4 & 3 \\
\hline Total & 3,226 & 228 & 159 & 141 & 188 & 212 & 280 & 261 & 248 & 240 & 481 & 619 & 557 & 540 & 580 & 645 & 468 & 526 & 632 & 642 \\
\hline \multicolumn{21}{|c|}{ Southwestern Pacific ${ }^{18}$} \\
\hline Papua New Guinea & 56 & 0 & 1 & 1 & 1 & 1 & 0 & 3 & 8 & 3 & 2 & 2 & 1 & 5 & 1 & 4 & 2 & 1 & 1 & 0 \\
\hline Fiji & 0 & 0 & 0 & 0 & 0 & 0 & 0 & 0 & 0 & 0 & 0 & 0 & 0 & 0 & 0 & 0 & 0 & 0 & 0 & 0 \\
\hline New Caledonia ${ }^{19}$ & 0 & 0 & 0 & 0 & 0 & 0 & 0 & 0 & 0 & 0 & 0 & 0 & 0 & 0 & 0 & 0 & 0 & 0 & 0 & 0 \\
\hline Tonga & 0 & 0 & 0 & 0 & 0 & 0 & 0 & 0 & 0 & 0 & 0 & 0 & 0 & 0 & 0 & 0 & 0 & 0 & 3 & 0 \\
\hline Australia & 481 & 16 & 64 & 96 & 132 & 139 & 92 & 79 & 74 & 91 & 92 & 54 & 72 & 54 & 44 & 23 & 14 & 15 & 52 & 49 \\
\hline Timor-Leste & 3 & 2 & 0 & 0 & 0 & 0 & 0 & 0 & 0 & 2 & 3 & 4 & 3 & 0 & 0 & 1 & 0 & 0 & 0 & 0 \\
\hline Timor Sea JPDA ${ }^{20}$ & 0 & 0 & 0 & 0 & 0 & 0 & 0 & 0 & 0 & 0 & 0 & 1 & 0 & 0 & 0 & 0 & 0 & 0 & 0 & 0 \\
\hline New Zealand & 91 & 3 & 3 & 3 & 12 & 5 & 3 & 4 & 4 & 9 & 9 & 10 & 10 & 2 & 1 & 5 & 6 & 3 & 9 & 1 \\
\hline Total & 631 & 21 & 68 & 100 & 145 & 145 & 95 & 86 & 86 & 105 & 106 & 71 & 86 & 61 & 46 & 33 & 22 & 19 & 65 & 50 \\
\hline \multicolumn{21}{|c|}{ Russia } \\
\hline Russia & 1,488 & 264 & 283 & 273 & 272 & 246 & 230 & 196 & 207 & 245 & 212 & 248 & 200 & 193 & 219 & 253 & 217 & 245 & 218 & 209 \\
\hline \multicolumn{21}{|c|}{ Grand total for study area } \\
\hline Grand total & 20,477 & 1,883 & 1,854 & 1,823 & 1,762 & 1,887 & 1,882 & 1,683 & 1,687 & 1,804 & 1,972 & 2,209 & 2,043 & 1,911 & 1,995 & 2,091 & 1,871 & 1,943 & 2,093 & 2,007 \\
\hline
\end{tabular}


Table 4. Wildcat wells by year, 1961-2015, for the Caribbean, Central America, Mexico, South America, Europe, the Middle East, Africa, Asia, the southwestern Pacific, and Russia.-Continued

\begin{tabular}{|c|c|c|c|c|c|c|c|c|c|c|c|c|c|c|c|c|c|c|c|c|}
\hline Area & 1980 & 81 & 82 & 83 & 84 & 85 & 86 & 87 & 88 & 89 & 90 & 91 & 92 & 93 & 94 & 95 & 96 & 97 & 98 & 1999 \\
\hline \multicolumn{21}{|c|}{ Asia ${ }^{15}$-Continued } \\
\hline China & 301 & 184 & 172 & 228 & 313 & 343 & 299 & 344 & 339 & 308 & 231 & 234 & 227 & 236 & 201 & 248 & 229 & 272 & 274 & 215 \\
\hline Mongolia & 0 & 0 & 0 & 0 & 0 & 0 & 0 & 0 & 0 & 0 & 0 & 0 & 0 & 0 & 0 & 1 & 3 & 1 & 1 & 0 \\
\hline Kazakhstan & 31 & 31 & 40 & 39 & 23 & 34 & 49 & 50 & 72 & 41 & 48 & 68 & 54 & 52 & 18 & 10 & 11 & 3 & 10 & 16 \\
\hline Azerbaijan & 9 & 8 & 11 & 7 & 3 & 5 & 9 & 4 & 7 & 8 & 2 & 0 & 3 & 5 & 2 & 3 & 7 & 2 & 3 & 6 \\
\hline Turkmenistan & 27 & 24 & 25 & 24 & 21 & 25 & 27 & 36 & 23 & 33 & 27 & 24 & 19 & 16 & 9 & 6 & 1 & 8 & 7 & 7 \\
\hline Uzbekistan & 12 & 17 & 9 & 8 & 9 & 4 & 5 & 11 & 10 & 10 & 9 & 18 & 13 & 11 & 9 & 14 & 2 & 1 & 13 & 14 \\
\hline Georgia & 21 & 17 & 26 & 33 & 35 & 30 & 29 & 20 & 27 & 24 & 14 & 10 & 7 & 2 & 0 & 2 & 0 & 0 & 0 & 1 \\
\hline Kyrgyzstan & 0 & 1 & 0 & 1 & 0 & 0 & 0 & 1 & 1 & 0 & 1 & 0 & 0 & 0 & 0 & 0 & 0 & 0 & 0 & 0 \\
\hline Tajikistan & 3 & 3 & 1 & 2 & 3 & 4 & 7 & 5 & 1 & 1 & 0 & 0 & 0 & 0 & 0 & 0 & 0 & 0 & 0 & 0 \\
\hline Armenia & 0 & 0 & 1 & 0 & 0 & 0 & 0 & 1 & 0 & 1 & 1 & 0 & 0 & 0 & 0 & 0 & 0 & 0 & 12 & 0 \\
\hline Pakistan & 2 & 8 & 4 & 10 & 16 & 15 & 12 & 7 & 18 & 18 & 15 & 11 & 16 & 25 & 17 & 26 & 26 & 21 & 27 & 14 \\
\hline Afghanistan & 0 & 0 & 2 & 2 & 1 & 0 & 0 & 0 & 0 & 1 & 0 & 0 & 5 & 0 & 0 & 0 & 0 & 0 & 0 & 0 \\
\hline India & 25 & 23 & 11 & 25 & 32 & 36 & 44 & 47 & 47 & 75 & 95 & 93 & 93 & 50 & 53 & 53 & 55 & 36 & 54 & 38 \\
\hline Bangladesh & 0 & 5 & 2 & 0 & 0 & 1 & 1 & 0 & 4 & 2 & 1 & 0 & 0 & 0 & 1 & 0 & 0 & 1 & 3 & 2 \\
\hline Maldives & 0 & 0 & 0 & 0 & 0 & 0 & 0 & 0 & 0 & 0 & 0 & 1 & 0 & 0 & 0 & 0 & 0 & 0 & 0 & 0 \\
\hline Nepal & 0 & 0 & 0 & 0 & 0 & 0 & 0 & 0 & 0 & 1 & 0 & 0 & 0 & 0 & 0 & 0 & 0 & 0 & 0 & 0 \\
\hline Sri Lanka & 0 & 2 & 0 & 0 & 0 & 0 & 0 & 0 & 0 & 0 & 0 & 0 & 0 & 0 & 0 & 0 & 0 & 0 & 0 & 0 \\
\hline Vietnam & 5 & 0 & 0 & 0 & 0 & 1 & 1 & 0 & 1 & 3 & 6 & 11 & 3 & 17 & 21 & 18 & 20 & 11 & 3 & 1 \\
\hline Burma & 2 & 11 & 8 & 7 & 15 & 10 & 8 & 4 & 3 & 4 & 4 & 9 & 10 & 5 & 6 & 8 & 7 & 4 & 4 & 2 \\
\hline Thailand & 3 & 11 & 15 & 26 & 17 & 12 & 2 & 15 & 13 & 2 & 10 & 8 & 11 & 11 & 10 & 4 & 7 & 15 & 10 & 9 \\
\hline Cambodia & 0 & 0 & 0 & 0 & 0 & 0 & 0 & 0 & 0 & 0 & 0 & 0 & 0 & 0 & 5 & 0 & 4 & 0 & 1 & 0 \\
\hline Laos & 0 & 0 & 0 & 0 & 0 & 0 & 0 & 0 & 0 & 0 & 0 & 0 & 0 & 0 & 0 & 0 & 0 & 1 & 1 & 0 \\
\hline Japan & 10 & 13 & 9 & 7 & 8 & 9 & 10 & 7 & 7 & 5 & 6 & 8 & 5 & 6 & 3 & 1 & 5 & 3 & 5 & 4 \\
\hline Japan/South Korea JDZ16 & 2 & 1 & 0 & 0 & 1 & 2 & 1 & 0 & 0 & 0 & 0 & 0 & 0 & 0 & 0 & 0 & 0 & 0 & 0 & 0 \\
\hline South Korea & 0 & 0 & 0 & 1 & 0 & 0 & 0 & 1 & 0 & 3 & 2 & 4 & 0 & 2 & 0 & 0 & 0 & 0 & 1 & 0 \\
\hline North Korea & 1 & 1 & 4 & 0 & 3 & 1 & 0 & 1 & 1 & 1 & 1 & 1 & 0 & 0 & 0 & 0 & 0 & 0 & 0 & 1 \\
\hline Philippines & 22 & 12 & 15 & 3 & 0 & 0 & 0 & 3 & 7 & 5 & 3 & 6 & 3 & 3 & 5 & 3 & 4 & 2 & 4 & 2 \\
\hline
\end{tabular}


Table 4. Wildcat wells by year, 1961-2015, for the Caribbean, Central America, Mexico, South America, Europe, the Middle East, Africa, Asia, the southwestern Pacific, and Russia.-Continued

\begin{tabular}{|c|c|c|c|c|c|c|c|c|c|c|c|c|c|c|c|c|c|c|c|c|}
\hline Area & 1980 & 81 & 82 & 83 & 84 & 85 & 86 & 87 & 88 & 89 & 90 & 91 & 92 & 93 & 94 & 95 & 96 & 97 & 98 & 1999 \\
\hline \multicolumn{21}{|c|}{ Asia ${ }^{15}$-Continued } \\
\hline Taiwan & 10 & 8 & 6 & 7 & 2 & 3 & 3 & 1 & 1 & 0 & 0 & 3 & 1 & 6 & 2 & 2 & 6 & 2 & 5 & 0 \\
\hline Indonesia & 116 & 126 & 130 & 145 & 117 & 120 & 72 & 56 & 91 & 70 & 81 & 104 & 91 & 77 & 60 & 62 & 73 & 92 & 81 & 64 \\
\hline Malaysia & 19 & 29 & 12 & 3 & 7 & 12 & 4 & 8 & 7 & 19 & 33 & 42 & 29 & 21 & 25 & 15 & 3 & 5 & 9 & 9 \\
\hline Malaysia/Thailand JDA ${ }^{17}$ & 0 & 0 & 0 & 0 & 0 & 0 & 0 & 0 & 0 & 0 & 0 & 0 & 0 & 0 & 0 & 2 & 4 & 9 & 2 & 0 \\
\hline Brunei & 1 & 6 & 5 & 3 & 12 & 3 & 1 & 2 & 4 & 4 & 7 & 3 & 2 & 2 & 3 & 0 & 1 & 6 & 4 & 2 \\
\hline Total & 622 & 541 & 508 & 581 & 638 & 670 & 584 & 624 & 684 & 639 & 597 & 658 & 592 & 547 & 450 & 478 & 468 & 495 & 534 & 407 \\
\hline \multicolumn{21}{|c|}{ Southwestern Pacific ${ }^{18}$ —Continued } \\
\hline Papua New Guinea & 1 & 0 & 1 & 1 & 7 & 3 & 2 & 2 & 5 & 11 & 19 & 7 & 3 & 2 & 5 & 6 & 5 & 2 & 1 & 3 \\
\hline Fiji & 2 & 1 & 4 & 0 & 0 & 0 & 0 & 0 & 0 & 0 & 0 & 0 & 0 & 0 & 0 & 0 & 0 & 0 & 0 & 0 \\
\hline New Caledonia ${ }^{19}$ & 0 & 0 & 0 & 0 & 0 & 0 & 0 & 0 & 0 & 0 & 0 & 0 & 0 & 0 & 0 & 0 & 0 & 0 & 0 & 0 \\
\hline Tonga & 0 & 0 & 0 & 0 & 0 & 0 & 0 & 0 & 0 & 0 & 0 & 0 & 0 & 0 & 0 & 0 & 0 & 0 & 0 & 0 \\
\hline Australia & 81 & 104 & 166 & 147 & 152 & 191 & 114 & 173 & 144 & 103 & 130 & 109 & 89 & 80 & 84 & 106 & 116 & 118 & 136 & 88 \\
\hline Timor-Leste & 0 & 0 & 0 & 0 & 0 & 0 & 0 & 0 & 0 & 0 & 0 & 0 & 0 & 0 & 0 & 0 & 0 & 0 & 0 & 0 \\
\hline Timor Sea JPDA ${ }^{20}$ & 0 & 0 & 0 & 0 & 0 & 0 & 0 & 0 & 0 & 0 & 0 & 0 & 0 & 4 & 13 & 5 & 5 & 7 & 4 & 2 \\
\hline New Zealand & 4 & 5 & 2 & 8 & 17 & 20 & 15 & 10 & 14 & 5 & 6 & 6 & 5 & 8 & 4 & 4 & 8 & 7 & 8 & 5 \\
\hline Total & 88 & 110 & 173 & 156 & 176 & 214 & 131 & 185 & 163 & 119 & 155 & 122 & 97 & 94 & 106 & 121 & 134 & 134 & 149 & 98 \\
\hline \multicolumn{21}{|c|}{ Russia-Continued } \\
\hline Russia & 244 & 238 & 284 & 311 & 290 & 333 & 391 & 485 & 500 & 396 & 396 & 307 & 219 & 136 & 111 & 67 & 85 & 79 & 54 & 51 \\
\hline \multicolumn{21}{|c|}{ Grand total for study area-Continued } \\
\hline Grand total & 2,239 & 2,388 & 2,644 & 2,471 & 2,630 & 2,777 & 2,453 & 2,385 & 2,510 & 2,256 & 2,240 & 2,142 & 1,814 & 1,559 & 1,423 & 1,452 & 1,500 & 1,562 & 1,553 & 1,157 \\
\hline
\end{tabular}


Table 4. Wildcat wells by year, 1961-2015, for the Caribbean, Central America, Mexico, South America, Europe, the Middle East, Africa, Asia, the southwestern Pacific, and Russia.-Continued

\begin{tabular}{|c|c|c|c|c|c|c|c|c|c|c|c|c|c|c|c|c|c|c|}
\hline Area & 2000 & 2001 & 2002 & 2003 & 2004 & 2005 & 2006 & 2007 & 2008 & 2009 & 2010 & 2011 & 2012 & 2013 & 2014 & 2015 & Unkn & Total \\
\hline \multicolumn{19}{|c|}{ Asia ${ }^{15}$-Continued } \\
\hline China & 82 & 83 & 88 & 166 & 88 & 79 & 77 & 99 & 138 & 115 & 96 & 85 & 87 & 75 & 71 & 55 & 445 & 11,566 \\
\hline Mongolia & 2 & 0 & 2 & 3 & 0 & 2 & 0 & 0 & 0 & 0 & 2 & 1 & 2 & 0 & 0 & 0 & 53 & 74 \\
\hline Kazakhstan & 9 & 9 & 18 & 14 & 8 & 15 & 28 & 23 & 26 & 8 & 20 & 21 & 21 & 16 & 10 & 12 & 470 & 2,027 \\
\hline Azerbaijan & 4 & 7 & 5 & 2 & 9 & 2 & 0 & 0 & 2 & 1 & 1 & 2 & 1 & 2 & 1 & 1 & 192 & 766 \\
\hline Turkmenistan & 7 & 7 & 4 & 9 & 16 & 12 & 6 & 10 & 7 & 14 & 1 & 5 & 1 & 2 & 3 & 1 & 393 & 1,367 \\
\hline Georgia & 2 & 1 & 1 & 0 & 1 & 0 & 1 & 2 & 3 & 0 & 0 & 1 & 0 & 2 & 0 & 0 & 69 & 856 \\
\hline Kyrgyzstan & 1 & 3 & 0 & 0 & 1 & 1 & 0 & 0 & 0 & 3 & 0 & 1 & 0 & 0 & 0 & 0 & 1 & 64 \\
\hline Tajikistan & 0 & 0 & 0 & 0 & 0 & 0 & 1 & 0 & 0 & 0 & 0 & 2 & 0 & 0 & 1 & 0 & 37 & 99 \\
\hline Armenia & 0 & 1 & 0 & 0 & 0 & 0 & 0 & 0 & 1 & 0 & 0 & 0 & 0 & 0 & 0 & 0 & 4 & 100 \\
\hline Pakistan & 17 & 14 & 19 & 31 & 25 & 24 & 31 & 31 & 28 & 27 & 25 & 15 & 27 & 33 & 45 & 61 & 0 & 895 \\
\hline Afghanistan & 0 & 0 & 0 & 0 & 0 & 0 & 0 & 0 & 0 & 0 & 0 & 0 & 0 & 0 & 0 & 0 & 2 & 90 \\
\hline Bangladesh & 3 & 0 & 0 & 0 & 2 & 1 & 0 & 1 & 1 & 0 & 0 & 4 & 5 & 2 & 2 & 1 & 0 & 79 \\
\hline Maldives & 0 & 0 & 0 & 0 & 0 & 0 & 0 & 0 & 0 & 0 & 0 & 0 & 0 & 0 & 0 & 0 & 0 & 2 \\
\hline Nepal & 0 & 0 & 0 & 0 & 0 & 0 & 0 & 0 & 0 & 0 & 0 & 0 & 0 & 0 & 0 & 0 & 0 & 1 \\
\hline Sri Lanka & 0 & 0 & 0 & 0 & 0 & 0 & 0 & 0 & 0 & 0 & 0 & 3 & 0 & 0 & 0 & 0 & 0 & 10 \\
\hline Vietnam & 9 & 5 & 8 & 11 & 14 & 8 & 7 & 15 & 18 & 14 & 9 & 12 & 9 & 12 & 13 & 4 & 50 & 356 \\
\hline Burma & 8 & 8 & 3 & 3 & 4 & 11 & 11 & 11 & 18 & 9 & 3 & 9 & 6 & 3 & 7 & 9 & 36 & 470 \\
\hline Thailand & 14 & 14 & 5 & 4 & 13 & 8 & 7 & 7 & 7 & 27 & 25 & 21 & 17 & 32 & 21 & 21 & 0 & 512 \\
\hline Cambodia & 0 & 0 & 0 & 1 & 3 & 2 & 0 & 0 & 1 & 0 & 1 & 0 & 2 & 0 & 0 & 0 & 0 & 23 \\
\hline Laos & 0 & 0 & 0 & 0 & 0 & 0 & 0 & 0 & 0 & 0 & 1 & 0 & 0 & 0 & 0 & 0 & 0 & 3 \\
\hline Japan & 3 & 5 & 1 & 1 & 1 & 1 & 0 & 0 & 1 & 0 & 0 & 0 & 1 & 1 & 0 & 0 & 20 & 381 \\
\hline Japan/South Korea JDZ ${ }^{16}$ & 0 & 0 & 0 & 0 & 0 & 0 & 0 & 0 & 0 & 0 & 0 & 0 & 0 & 0 & 0 & 0 & 0 & 7 \\
\hline South Korea & 0 & 0 & 0 & 0 & 1 & 2 & 2 & 0 & 0 & 0 & 0 & 0 & 1 & 0 & 0 & 2 & 0 & 36 \\
\hline North Korea & 0 & 0 & 0 & 0 & 0 & 0 & 0 & 0 & 0 & 0 & 0 & 0 & 0 & 0 & 0 & 0 & 0 & 17 \\
\hline
\end{tabular}


Table 4. Wildcat wells by year, 1961-2015, for the Caribbean, Central America, Mexico, South America, Europe, the Middle East, Africa, Asia, the southwestern Pacific, and Russia.-Continued

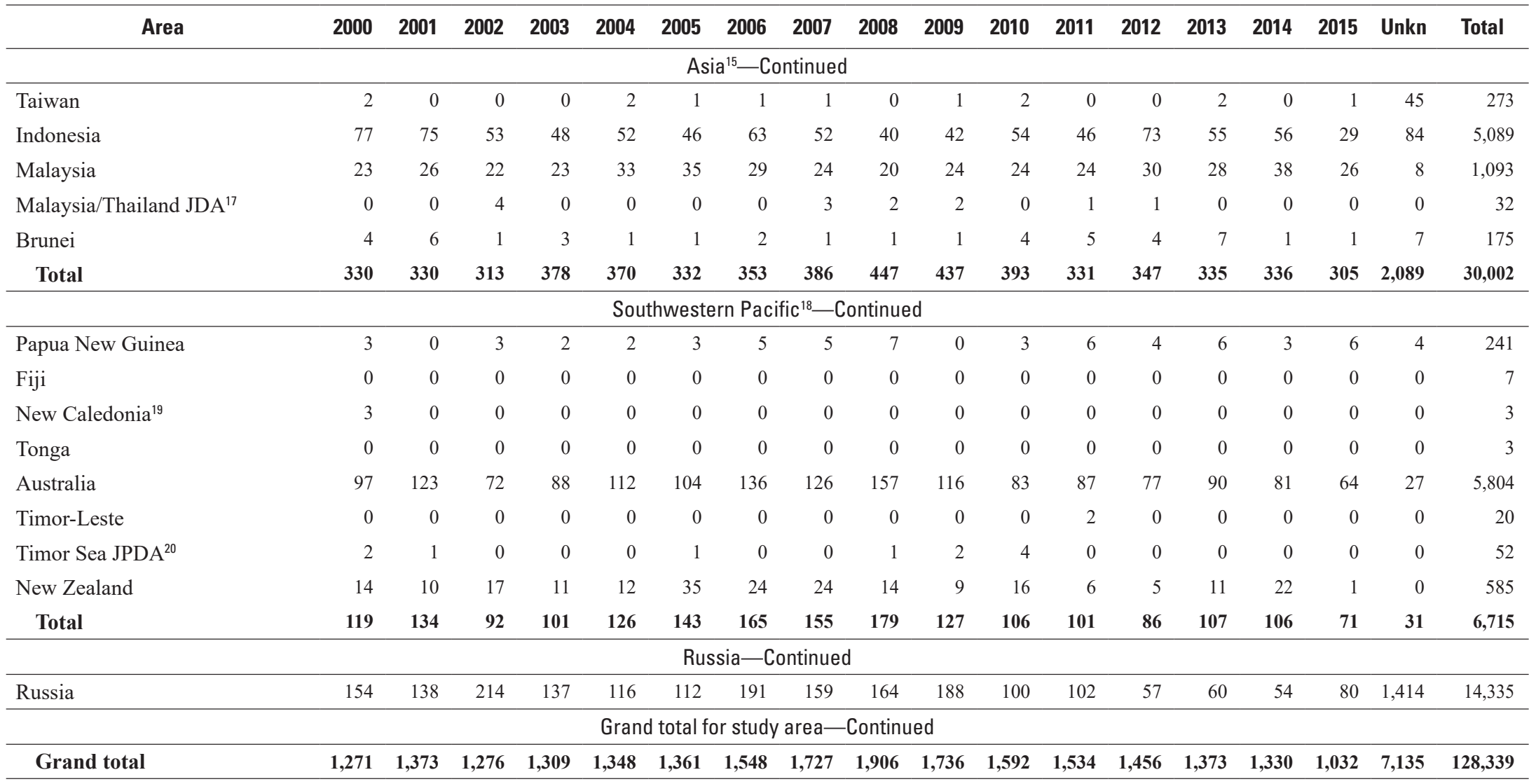

${ }^{15}$ No wildcat wells were reported for Bhutan or Singapore.

${ }^{16} J a p a n$ and South Korea share the Japan/South Korea Joint Development Zone (JDZ).

${ }^{17}$ Malaysia and Thailand share the Malaysia/Thailand Joint Development Area (JDA).

${ }^{18}$ No wildcat wells were reported for French Polynesia, Guam, Kiribati, Marshall Islands, Micronesia, Nauru, Northern Mariana Islands, Samoa, Solomon Islands, Tuvalu, or Vanuatu.

${ }^{19} \mathrm{New}$ Caledonia is listed separately although it is an overseas territory of France.

${ }^{20}$ Australia and Timor-Leste share the Timor Sea Joint Petroleum Development Area (JPDA). 
Table 5. Year of first discovery and cumulative recoverable oil and gas discovered through 2015 in the 212 significant provinces in the study area.

[Each significant province has at least one field containing 100 million barrels of recoverable oil or 600 billion cubic feet of recoverable gas. Some provinces (marked by an asterisk) have resources in more than one region, and the petroleum in each part of the province is apportioned to the correct region. Data are from IHS Markit (2016). Province names and code numbers are from U.S. Geological Survey World Energy Assessment Team (2000). The provinces in this table are listed within each region by year of first discovery. Province boundaries are mapped and data on oil and gas discoveries in significant provinces are given in figures 11-55 for all regions. MMBO, million barrels ( $\left.\mathrm{bbl} \mathrm{x} 10^{6}\right)$ of oil; BCF, billion cubic feet $\left(\mathrm{ft}^{3}{ }^{3} 1^{9}\right)$; OCS, Outer Continental Shelf]

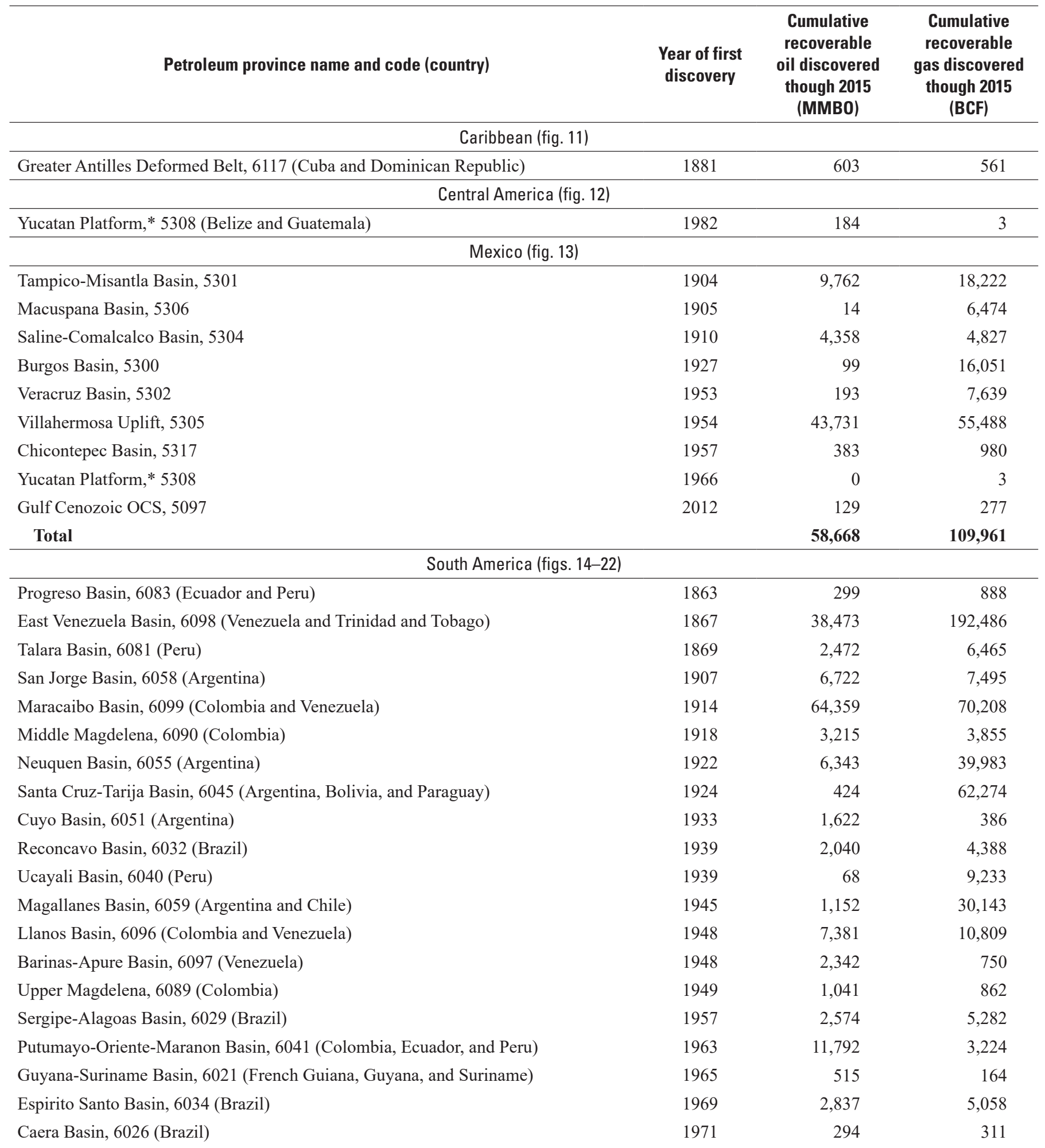


Table 5. Year of first discovery and cumulative recoverable oil and gas discovered through 2015 in the 212 significant provinces in the study area.-Continued

[Each significant province has at least one field containing 100 million barrels of recoverable oil or 600 billion cubic feet of recoverable gas. Some provinces (marked by an asterisk) have resources in more than one region, and the petroleum in each part of the province is apportioned to the correct region. Data are from IHS Markit (2016). Province names and code numbers are from U.S. Geological Survey World Energy Assessment Team (2000). The provinces in this table are listed within each region by year of first discovery. Province boundaries are mapped and data on oil and gas discoveries in significant provinces are

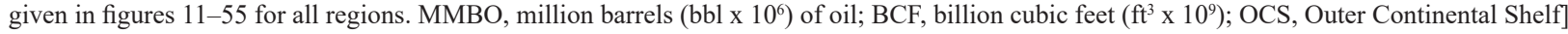

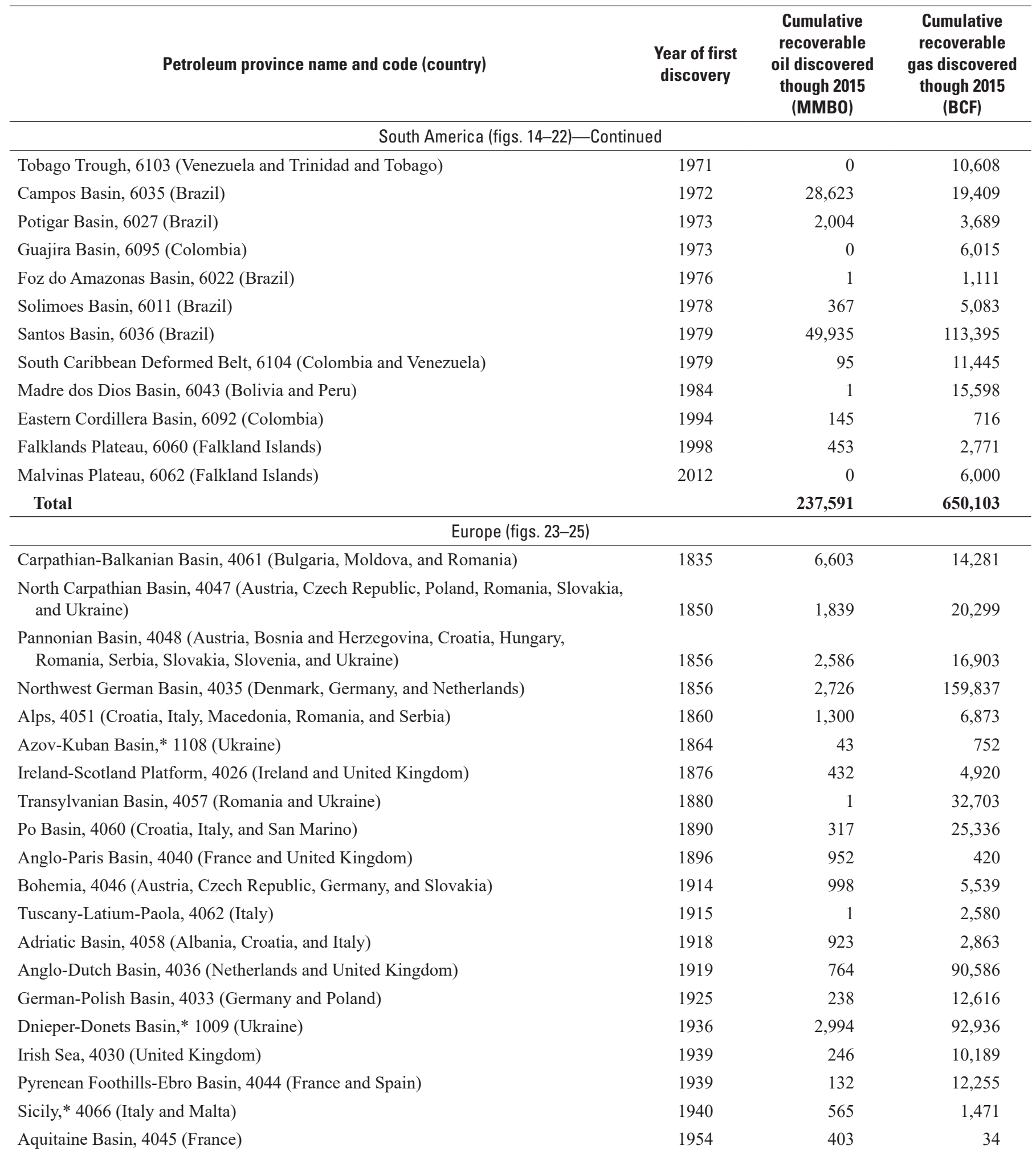


Table 5. Year of first discovery and cumulative recoverable oil and gas discovered through 2015 in the 212 significant provinces in the study area.-Continued

[Each significant province has at least one field containing 100 million barrels of recoverable oil or 600 billion cubic feet of recoverable gas. Some provinces (marked by an asterisk) have resources in more than one region, and the petroleum in each part of the province is apportioned to the correct region. Data are from IHS Markit (2016). Province names and code numbers are from U.S. Geological Survey World Energy Assessment Team (2000). The provinces in this table are listed within each region by year of first discovery. Province boundaries are mapped and data on oil and gas discoveries in significant provinces are

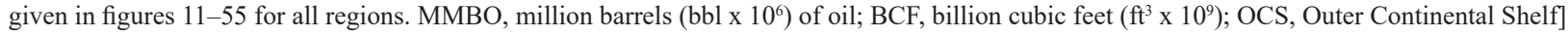

\begin{tabular}{|c|c|c|c|}
\hline Petroleum province name and code (country) & $\begin{array}{l}\text { Year of first } \\
\text { discovery }\end{array}$ & $\begin{array}{l}\text { Cumulative } \\
\text { recoverable } \\
\text { oil discovered } \\
\text { though } 2015 \\
\text { (MMBO) }\end{array}$ & $\begin{array}{l}\text { Cumulative } \\
\text { recoverable } \\
\text { gas discovered } \\
\text { though } 2015 \\
\text { (BCF) }\end{array}$ \\
\hline \multicolumn{4}{|c|}{ Europe (figs. 23-25)—Continued } \\
\hline Pripyat Basin, 1010 (Belarus) & 1963 & 1,241 & 669 \\
\hline $\begin{array}{l}\text { North Sea Graben, } 4025 \text { (Denmark, Germany, Netherlands, Norway, and } \\
\text { United Kingdom) }\end{array}$ & 1966 & 60,829 & 205,732 \\
\hline Iberic Cordillera, 4083 (Spain) & 1967 & 293 & 241 \\
\hline Aegean,* 4075 (Greece) & 1971 & 173 & 156 \\
\hline Horda-Norwegian-Danish Basin, 4023 (Denmark and Norway) & 1972 & 360 & 291 \\
\hline Faeroes-Shetland-Orkney Basin, 4019 (Faroe Islands and United Kingdom) & 1977 & 2,961 & 6,618 \\
\hline Hammerfest-Varanger Basin, 4015 (Norway) & 1981 & 264 & 11,420 \\
\hline Vestford-Helgeland, 4017 (Norway) & 1981 & 4,546 & 35,589 \\
\hline Pelagian Basin,* 2048 (Italy) & 1988 & 15 & 2 \\
\hline Central Barents Platform,* 4012 (Norway) & 2008 & 976 & 2,698 \\
\hline Black Sea Continental Slope, 1107 (Romania) & 2012 & 0 & 3,200 \\
\hline Total & & $\mathbf{9 5 , 5 5 4}$ & 780,985 \\
\hline \multicolumn{4}{|c|}{ Middle East (figs. 26-30) } \\
\hline Zagros Fold Belt, 2030 (Iran, Iraq, Syria, and Turkey) & 1905 & 175,325 & 585,247 \\
\hline Greater Ghawar Uplift, 2021 (Bahrain, Qatar, and Saudi Arabia) & 1932 & 168,940 & 229,070 \\
\hline $\begin{array}{l}\text { Mesopotamian Foredeep Basin, } 2024 \text { (Iran, Iraq, Kuwait, former Kuwait-Sat } \\
\text { Arabia Neutral Zone, and Saudi Arabia) }\end{array}$ & 1938 & 441,861 & 445,175 \\
\hline Widyan Basin-Interior Platform, 2023 (Iraq, Kuwait, and Saudi Arabia) & 1939 & 31,762 & 20,510 \\
\hline Euphrates/Mardin, 2075 (Syria and Turkey) & 1940 & 1,350 & 3,893 \\
\hline $\begin{array}{l}\text { Rub Al Khali Basin, } 2019 \text { (Iran, Oman, Qatar, Saudi Arabia, and United } \\
\text { Arab Emirates) }\end{array}$ & 1954 & 116,743 & 289,766 \\
\hline Levantine Basin,* 2032 (Cyprus, Gaza Strip, and Israel) & 1955 & 161 & 40,571 \\
\hline South Oman Salt Basin, 2011 (Oman) & 1956 & 3,532 & 4,139 \\
\hline South Caspian Basin,* 1112 (Iran) & 1960 & 492 & 1,200 \\
\hline Fahud Salt Basin, 2016 (Oman) & 1962 & 5,353 & 13,863 \\
\hline Ghaba Salt Basin, 2014 (Oman) & 1964 & 2,025 & 28,857 \\
\hline Central Oman Platform, 2015 (Oman) & 1966 & 344 & 15,839 \\
\hline Kura Basin,* 1113 (Iran) & 1967 & 3 & 1 \\
\hline Qatar Arch, 2022 (Iran and Qatar) & 1967 & 4,850 & $1,522,941$ \\
\hline Kopet-Dag Foldbelt, 1155 (Iran) & 1967 & 0 & 2,000 \\
\hline Amu-Darya Basin,* 1154 (Iran) & 1968 & 0 & 17,305 \\
\hline Palmyra Zone, 2077 (Syria) & 1968 & 241 & 6,147 \\
\hline Red Sea Basin,* 2071 (Saudi Arabia) & 1969 & 99 & 4,090 \\
\hline East Flank Oman Sub-basin, 2012 (Oman) & 1973 & 3,232 & 187 \\
\hline Anah Graben, 2089 (Syria) & 1982 & 440 & 280 \\
\hline
\end{tabular}


Table 5. Year of first discovery and cumulative recoverable oil and gas discovered through 2015 in the 212 significant provinces in the study area.-Continued

[Each significant province has at least one field containing 100 million barrels of recoverable oil or 600 billion cubic feet of recoverable gas. Some provinces (marked by an asterisk) have resources in more than one region, and the petroleum in each part of the province is apportioned to the correct region. Data are from IHS Markit (2016). Province names and code numbers are from U.S. Geological Survey World Energy Assessment Team (2000). The provinces in this table are listed within each region by year of first discovery. Province boundaries are mapped and data on oil and gas discoveries in significant provinces are given in figures 11-55 for all regions. MMBO, million barrels (bbl x 10 $0^{6}$ of oil; BCF, billion cubic feet ( $\left.\mathrm{ft}^{3} \times 10^{9}\right)$; OCS, Outer Continental Shelf]

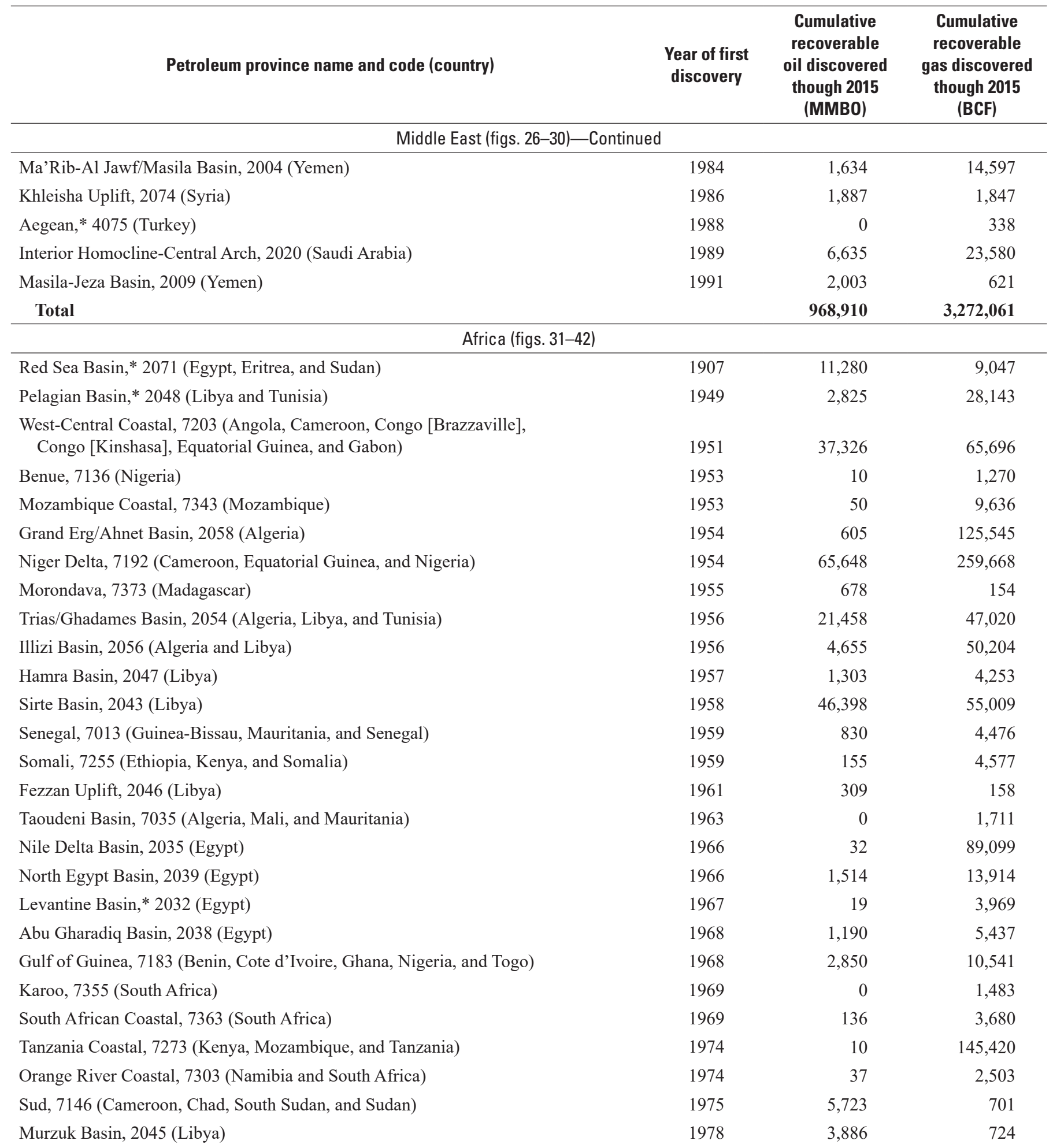


Table 5. Year of first discovery and cumulative recoverable oil and gas discovered through 2015 in the 212 significant provinces in the study area.-Continued

[Each significant province has at least one field containing 100 million barrels of recoverable oil or 600 billion cubic feet of recoverable gas. Some provinces (marked by an asterisk) have resources in more than one region, and the petroleum in each part of the province is apportioned to the correct region. Data are from IHS Markit (2016). Province names and code numbers are from U.S. Geological Survey World Energy Assessment Team (2000). The provinces in this table are listed within each region by year of first discovery. Province boundaries are mapped and data on oil and gas discoveries in significant provinces are

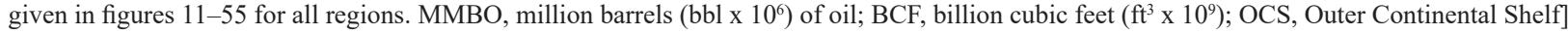

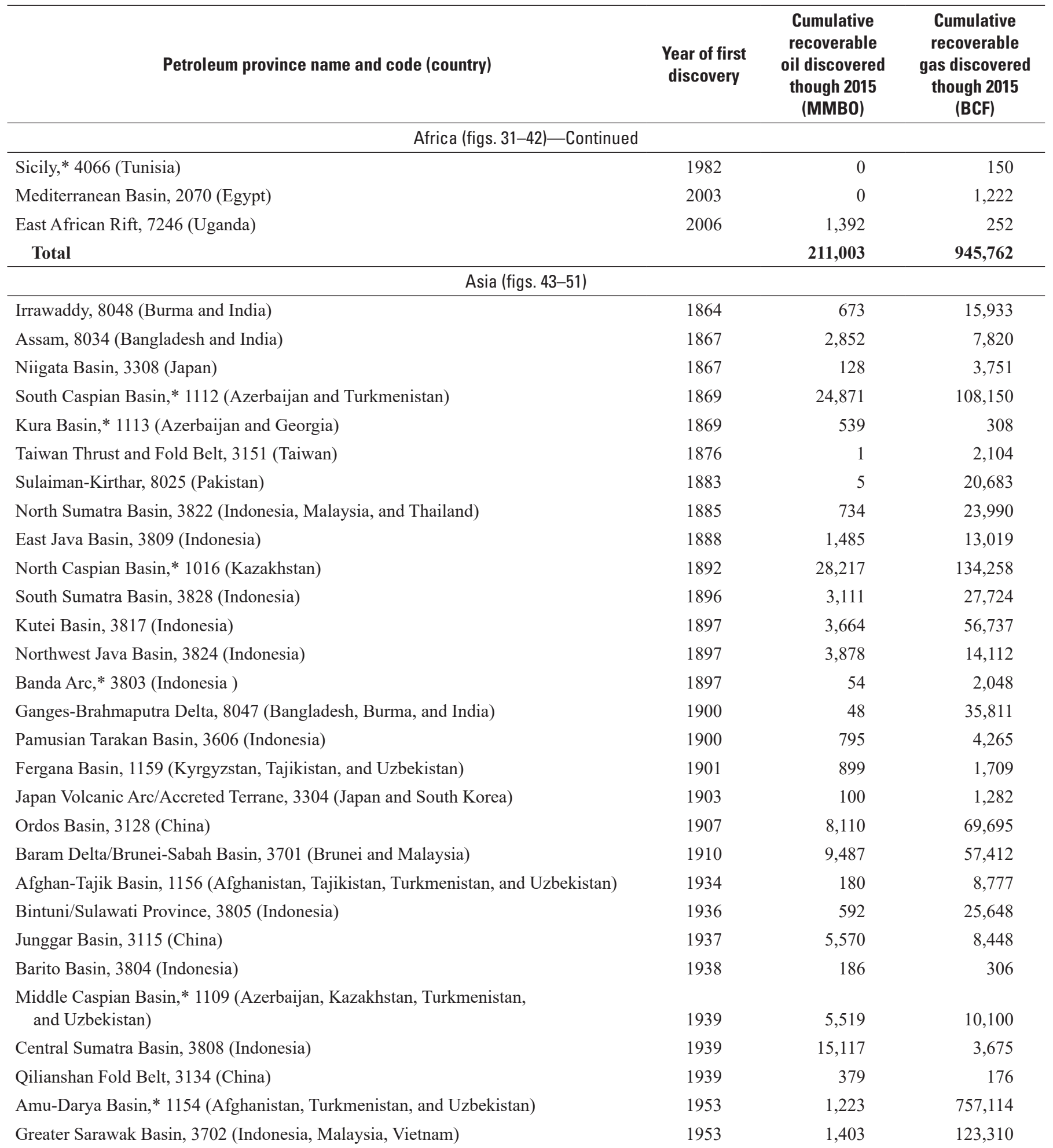




\section{Statistics of Petroleum Exploration in the World Outside the United States and Canada Through 2015}

Table 5. Year of first discovery and cumulative recoverable oil and gas discovered through 2015 in the 212 significant provinces in the study area.-Continued

[Each significant province has at least one field containing 100 million barrels of recoverable oil or 600 billion cubic feet of recoverable gas. Some provinces (marked by an asterisk) have resources in more than one region, and the petroleum in each part of the province is apportioned to the correct region. Data are from IHS Markit (2016). Province names and code numbers are from U.S. Geological Survey World Energy Assessment Team (2000). The provinces in this table are listed within each region by year of first discovery. Province boundaries are mapped and data on oil and gas discoveries in significant provinces are given in figures 11-55 for all regions. MMBO, million barrels ( $\left.\mathrm{bbl} \times 10^{6}\right)$ of oil; BCF, billion cubic feet ( $\left.\mathrm{ft}^{3} \times 10^{9}\right)$; OCS, Outer Continental Shelf]

\begin{tabular}{|c|c|c|c|}
\hline Petroleum province name and code (country) & $\begin{array}{l}\text { Year of first } \\
\text { discovery }\end{array}$ & $\begin{array}{l}\text { Cumulative } \\
\text { recoverable } \\
\text { oil discovered } \\
\text { though 2015 } \\
\text { (MMBO) }\end{array}$ & $\begin{array}{l}\text { Cumulative } \\
\text { recoverable } \\
\text { gas discovered } \\
\text { though } 2015 \\
\text { (BCF) }\end{array}$ \\
\hline \multicolumn{4}{|c|}{ Asia (figs. 43-51)—Continued } \\
\hline Qaidam Basin, 3131 (China) & 1955 & 1,021 & 9,635 \\
\hline Indus, 8042 (India and Pakistan) & 1957 & 474 & 32,711 \\
\hline Tarim Basin, 3154 (China) & 1958 & 3,487 & 63,948 \\
\hline Bombay, 8043 (India) & 1958 & 8,676 & 38,176 \\
\hline Turpan Basin, 3156 (China) & 1958 & 751 & 2,349 \\
\hline Northern Irian Jaya Waropen Basin, 3823 (Indonesia) & 1958 & 0 & 1,100 \\
\hline Songliao Basin, 3144 (China) & 1959 & 22,456 & 13,753 \\
\hline Bohaiwan Basin, 3127 (China) & 1961 & 24,915 & 19,572 \\
\hline Temtsag Hailar Basin, 3207 (China and Mongolia) & 1961 & 666 & 177 \\
\hline Indian Shield, 8003 (India) & 1963 & 1,060 & 2,147 \\
\hline North Ustyurt Basin, 1150 (Kazakhstan and Uzbekistan) & 1964 & 2,708 & 9,916 \\
\hline Jianghan Basin, 3112 (China) & 1965 & 397 & 64 \\
\hline Malay Basin, 3703 (Cambodia, Indonesia, Malaysia, Thailand, and Vietnam) & 1969 & 5,318 & 66,063 \\
\hline East China Sea Basin, 3109 (China and Taiwan) & 1969 & 102 & 8,196 \\
\hline Cauvery, 8044 (India and Sri Lanka) & 1969 & 131 & 4,614 \\
\hline Nanyang Basin, 3126 (China) & 1971 & 608 & 66 \\
\hline Penyu/West Natuna Basin, 3825 (Indonesia and Malaysia) & 1972 & 984 & 6,378 \\
\hline Thai Basin, 3507 (Thailand) & 1973 & 971 & 21,417 \\
\hline Luxi Jiaoliao Uplift, 3124 (China) & 1973 & 1,659 & 357 \\
\hline Saigon Basin, 3505 (Vietnam) & 1974 & 356 & 7,771 \\
\hline Yinggehai Basin, 3159 (China and Vietnam) & 1975 & 21 & 13,581 \\
\hline Mekong/Cuulong/Vung Tau Basin, 3503 (Vietnam) & 1975 & 3,941 & 5,709 \\
\hline Palawan Shelf, 3605 (Philippines) & 1976 & 168 & 3,649 \\
\hline Reed Bank Basin, 3609 (Philippines) & 1976 & 0 & 1,822 \\
\hline Krishna-Godavari, 8045 (India) & 1979 & 788 & 25,763 \\
\hline Pearl River Mouth Basin, 3130 (China) & 1979 & 2,350 & 3,656 \\
\hline Volga-Ural Region,* 1015 (Kazakhstan) & 1979 & 202 & 2,615 \\
\hline Qiongdongnan Basin, 3136 (China and Vietnam) & 1979 & 2 & 1,961 \\
\hline Thailand Mesozoic Basin Belt, 3508 (Thailand) & 1981 & 374 & 775 \\
\hline Shanxi Plateau, 3140 (China) & 1982 & 0 & 7,771 \\
\hline Khorat Platform, 3502 (Thailand) & 1982 & 0 & 2,322 \\
\hline South China Continental Shelf Slope, 3181 (China and Vietnam) & 1984 & 409 & 7,700 \\
\hline South Turgay Basin, 1167 (Kazakhstan) & 1984 & 1,936 & 1,443 \\
\hline Sulawesi Accretionary Prism, 3829 (Indonesia) & 1986 & 21 & 2,680 \\
\hline Altay-Sayan Folded Region, 1219 (China) & 1992 & 148 & 2,097 \\
\hline
\end{tabular}


Table 5. Year of first discovery and cumulative recoverable oil and gas discovered through 2015 in the 212 significant provinces in the study area.-Continued

[Each significant province has at least one field containing 100 million barrels of recoverable oil or 600 billion cubic feet of recoverable gas. Some provinces (marked by an asterisk) have resources in more than one region, and the petroleum in each part of the province is apportioned to the correct region. Data are from IHS Markit (2016). Province names and code numbers are from U.S. Geological Survey World Energy Assessment Team (2000). The provinces in this table are listed within each region by year of first discovery. Province boundaries are mapped and data on oil and gas discoveries in significant provinces are

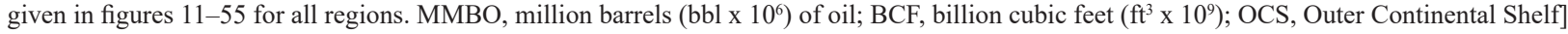

\begin{tabular}{|c|c|c|c|}
\hline Petroleum province name and code (country) & $\begin{array}{l}\text { Year of first } \\
\text { discovery }\end{array}$ & $\begin{array}{l}\text { Cumulative } \\
\text { recoverable } \\
\text { oil discovered } \\
\text { though } 2015 \\
\text { (MMBO) }\end{array}$ & $\begin{array}{c}\text { Cumulative } \\
\text { recoverable } \\
\text { gas discovered } \\
\text { though } 2015 \\
\text { (BCF) }\end{array}$ \\
\hline \multicolumn{4}{|c|}{ Asia (figs. 43-51)—Continued } \\
\hline Bonaparte Gulf Basin, ${ }^{*} 3910$ (Indonesia) & 2000 & 0 & 18,470 \\
\hline Mahanadi, 8046 (India) & 2006 & 0 & 2,697 \\
\hline Total & & 207,045 & $2,027,924$ \\
\hline \multicolumn{4}{|c|}{ Southwestern Pacific (figs. 52-54) } \\
\hline Taranaki Basin, 3031 (New Zealand) & 1867 & 267 & 9,052 \\
\hline Surat Basin, 3958 (Australia) & 1900 & 39 & 26,201 \\
\hline Bowen Basin, 3911 (Australia) & 1955 & 0 & 7,570 \\
\hline Papuan Basin-Shelf Platform, 3969 (Papua New Guinea) & 1958 & $<1$ & 4,928 \\
\hline Bonaparte Gulf Basin,*3910 (Australia) & 1964 & 588 & 32,811 \\
\hline Eromanga Basin, 3924 (Australia) & 1964 & 497 & 21,129 \\
\hline Perth Basin, 3952 (Australia) & 1964 & 49 & 4,333 \\
\hline Clarence-Moreton Basin, 3919 (Australia) & 1968 & 0 & 2,675 \\
\hline Browse Basin, 3913 (Australia) & 1971 & 169 & 49,092 \\
\hline Total & & 9,081 & 343,910 \\
\hline \multicolumn{4}{|c|}{ Russia (fig. 55) } \\
\hline West Siberian Basin, 1174 & 1953 & 172,142 & $1,647,065$ \\
\hline Angara-Lena Terrace, 1209 & 1954 & 2 & 50,681 \\
\hline Lena-Vilyuy Basin, 1214 & 1956 & 0 & 15,528 \\
\hline Nepa-Botuoba Arch, 1210 & 1962 & 3,754 & 47,140 \\
\hline Dnieper-Donets Basin,* 1009 & 1963 & 6 & 796 \\
\hline North Caspian Basin,* 1016 & 1963 & 143 & 65,618 \\
\hline Yenisey-Khatanga Basin, 1175 & 1965 & 38 & 18,549 \\
\hline Baykit Arch, 1207 & 1974 & 1,820 & 12,613 \\
\hline South Barents Basin, 1050 & 1983 & 0 & 126,034 \\
\hline Central Barents Platform,* 4012 & 1984 & 0 & 156 \\
\hline Ludlov Saddle, 1059 & 1990 & 0 & 2,470 \\
\hline
\end{tabular}


Table 5. Year of first discovery and cumulative recoverable oil and gas discovered through 2015 in the 212 significant provinces in the study area.-Continued

[Each significant province has at least one field containing 100 million barrels of recoverable oil or 600 billion cubic feet of recoverable gas. Some provinces (marked by an asterisk) have resources in more than one region, and the petroleum in each part of the province is apportioned to the correct region. Data are from IHS Markit (2016). Province names and code numbers are from U.S. Geological Survey World Energy Assessment Team (2000). The provinces in this table are listed within each region by year of first discovery. Province boundaries are mapped and data on oil and gas discoveries in significant provinces are given in figures 11-55 for all regions. MMBO, million barrels ( $\left.\mathrm{bbl} \times 10^{6}\right)$ of oil; BCF, billion cubic feet ( $\left.\mathrm{ft}^{3} \times 10^{9}\right)$; OCS, Outer Continental Shelf]

\begin{tabular}{|c|c|c|c|}
\hline Petroleum province name and code (country) & $\begin{array}{l}\text { Year of first } \\
\text { discovery }\end{array}$ & $\begin{array}{l}\text { Cumulative } \\
\text { recoverable } \\
\text { oil discovered } \\
\text { though } 2015 \\
\text { (MMBO) }\end{array}$ & $\begin{array}{l}\text { Cumulative } \\
\text { recoverable } \\
\text { gas discovered } \\
\text { though } 2015 \\
\text { (BCF) }\end{array}$ \\
\hline \multicolumn{4}{|c|}{ Russia (fig. 55)—Continued } \\
\hline Deryugin Basin, 1321 & 2006 & 133 & 5,593 \\
\hline Kempendiay Region, 1212 & 2009 & 0 & 700 \\
\hline Total & & 287,501 & $2,228,904$ \\
\hline
\end{tabular}

Table 6. Decadal average discovery size by region of fields discovered at drilling depths of less than 10,000 feet and fields discovered at drilling depths of at least 10,000 feet.

[Data are from IHS Markit (2016). The "Study area" column includes data for the Caribbean and Central America, as well as for the eight regions listed in the table. On the basis of calorific heating values, it is assumed that 1 barrel of oil is equivalent to 6,000 cubic feet of natural gas; that is, $1 \mathrm{BOE}=1 \mathrm{barrel}$ of crude oil or 6,000 cubic feet of natural gas or 1.5 barrels of natural gas liquids]

Average discovery size in millions of barrels of oil equivalent (MMBOE)

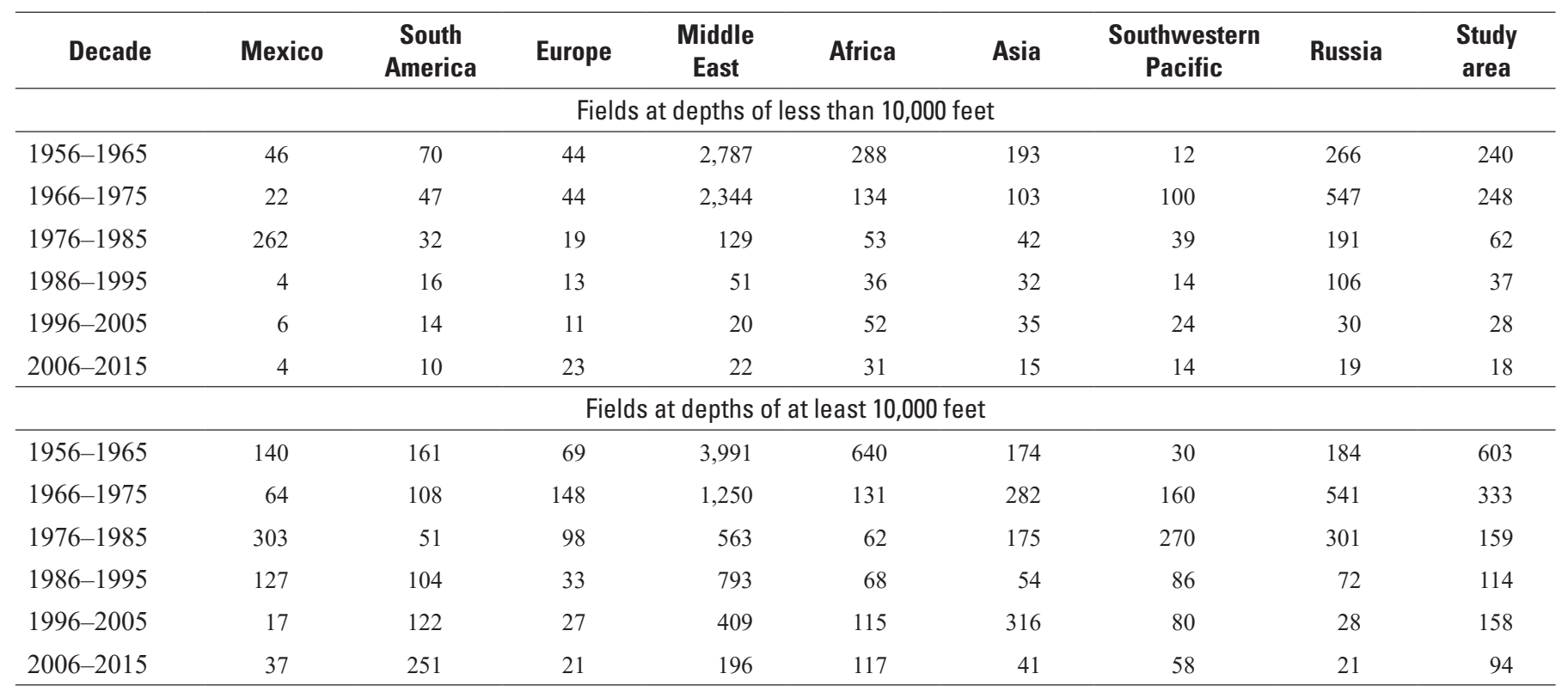


Table 7. Regional distribution in the study area of land area, delineated prospective area, explored area, cumulative recoverable oil and gas discoveries, and wildcat wells drilled through 2015 and percentages of total delineated prospective area, explored area, cumulative recoverable oil and gas discoveries, and wildcat wells at depths of at least 10,000 feet.

[Data are from IHS Markit (2016). Land areas in square miles ( $\left.\mathrm{mi}^{2}\right)$ are converted from areas in square kilometers in "The World Factbook 2001" (U.S. Central Intelligence Agency, 2001) and "The World Factbook 2016" (U.S. Central Intelligence Agency, 2016). ft, foot; BBO, billion barrels (bbl x 109) of oil; TCF, trillion cubic feet $\left(\mathrm{ft}^{3} \times 10^{12}\right)$ ]

\begin{tabular}{|c|c|c|c|c|c|c|c|c|c|c|c|}
\hline \multirow[b]{2}{*}{ Region } & \multirow[b]{2}{*}{$\begin{array}{l}\text { Land area } \\
\qquad\left(\mathrm{mi}^{2}\right)\end{array}$} & \multicolumn{2}{|c|}{ Delineated prospective area } & \multicolumn{2}{|c|}{ Explored area } & \multicolumn{2}{|c|}{ Oil } & \multicolumn{2}{|c|}{ Natural gas } & \multicolumn{2}{|c|}{ Wildcat wells } \\
\hline & & $\begin{array}{l}\text { At surface } \\
\qquad\left(\mathrm{mi}^{2}\right)\end{array}$ & $\begin{array}{c}\text { At depth of } \\
10,000 \mathrm{ft} \\
\text { (percent) }\end{array}$ & $\begin{array}{l}\text { At surface } \\
\qquad\left(\mathrm{mi}^{2}\right)\end{array}$ & $\begin{array}{c}\text { At depth of } \\
10,000 \mathrm{ft} \\
\text { (percent) }\end{array}$ & $\begin{array}{l}\text { Total } \\
\text { (BBO) }\end{array}$ & $\begin{array}{l}\text { At depth of } \\
\geq 10,000 \mathrm{ft} \\
\text { (percent) }\end{array}$ & $\begin{array}{l}\text { Total } \\
\text { (TCF) }\end{array}$ & $\begin{array}{l}\text { At depth of } \\
\geq 10,000 \mathrm{ft} \\
\text { (percent) }\end{array}$ & Total & $\begin{array}{l}\text { At depth of } \\
\geq 10,000 \mathrm{ft} \\
\text { (percent) }\end{array}$ \\
\hline Caribbean & 86,524 & 20,863 & 32 & 3,736 & 25 & 1 & 49 & 1 & 74 & 553 & 14 \\
\hline \multicolumn{12}{|l|}{ Central } \\
\hline America & 196,127 & 17,025 & 21 & 2,292 & 22 & $<1$ & 0 & $<1$ & 0 & 292 & 22 \\
\hline Mexico & 750,561 & 103,090 & 68 & 32,295 & 55 & 59 & 54 & 115 & 53 & 4,478 & 38 \\
\hline \multicolumn{12}{|l|}{ South } \\
\hline America & $6,769,307$ & 572,056 & 45 & 150,269 & 36 & 238 & 49 & 660 & 56 & 21,916 & 26 \\
\hline Europe & $2,186,167$ & 878,761 & 42 & 224,990 & 34 & 96 & 52 & 794 & 46 & 30,861 & 24 \\
\hline Middle East & $2,377,520$ & 372,542 & 53 & 69,660 & 41 & 969 & 28 & 3,275 & 44 & 5,708 & 32 \\
\hline Africa & $11,495,615$ & 720,482 & 48 & 136,329 & 45 & 213 & 42 & 1,000 & 57 & 13,479 & 39 \\
\hline Asia & $9,537,566$ & $1,322,373$ & 45 & 299,181 & 37 & 210 & 30 & 2,048 & 70 & 30,002 & 33 \\
\hline \multicolumn{12}{|l|}{ Southwestern } \\
\hline Pacific & $3,282,520$ & 471,586 & 16 & 80,964 & 16 & 9 & 24 & 350 & 61 & 6,715 & 17 \\
\hline Russia & $6,323,482$ & 801,354 & 47 & 204,997 & 34 & 288 & 13 & 2,231 & 31 & 14,335 & 29 \\
\hline $\begin{array}{l}\text { Total study } \\
\text { area }\end{array}$ & $43,003,681$ & $5,280,132$ & 43 & $1,204,713$ & 36 & 2,084 & 32 & 10,475 & 42 & 128,339 & 29 \\
\hline
\end{tabular}




\section{Figures 11-55}

Introduction.- Figures 11-55 show delineated prospective area, explored area, and known petroleum provinces of the study area regions - the Caribbean (fig. 11), Central America (fig. 12), Mexico (fig. 13), South America (figs. 14-22), Europe (figs. 23-25), the Middle East (figs. 26-30), Africa (figs. 31-42), Asia (figs. 43-51), the southwestern Pacific (figs. 52-54), and Russia (fig. 55). Each figure includes a map, two graphs, and a summary of the exploration data. If significant provinces occur in the mapped area, then a table provides information on each significant province. Definitions of terms are provided below.

Maps.-All maps in Circular 1288 (Attanasi and others, 2007) were drawn by using ArcView software (version 3.2, created by Environmental Systems Research Institute, Inc. [ESRI]) and were edited in Adobe Illustrator (version 10). If possible, only the delineated prospective areas and explored areas were revised for use in this Circular; otherwise, new maps with new map extents were drawn by using ArcGIS software (version 10.3.1, created by ESRI) and were edited in Adobe Illustrator (version CS6). Each map is shown in unprojected geographic coordinates, except for the northern part of Western Europe (fig. 23) and Russia (two maps in fig. 55). These three maps are shown in equidistant conic projection to minimize distortion of distance over the nearpolar areas. Scales are not provided, as the scale varies on unprojected maps.

Methods for computing and identifying delineated prospective areas and explored areas are explained in the text and are the same methods as those used in Attanasi and Root (1993). Recall that the delineated prospective area is described as the set of all (grid) points that are reasonably close to wells (producing or dry) and that are also inside the area drilled. Also recall that the explored area is defined as the area consisting of the points in the delineated prospective area that are within 2 miles of a well. The computation of delineated prospective area and explored area used locations of all wildcat, exploration, and development wells, both successful and dry, along with the locations of fields. All data except data for wells with a missing or obviously incorrect location were used because, for some areas, most of the wildcat well history, particularly prior to 1950 , is missing. The dry and producing well locations and field locations may represent the only evidence of prior exploration. Use of all the data added some redundancy to the computations but assured that no area that had been searched was excluded because of missing wildcat or exploration wells.

Landmass outlines and country boundaries are from the "Data \& Maps Series Cntry98 File" (ESRI, 1998). The countries of Kosovo and South Sudan have been recognized since the publication of Circular 1288 (Attanasi and others, 2007), so country boundaries separating South Sudan from Sudan and Kosovo from Serbia are from the "ne_10m_admin_0_countries" file (Natural Earth, 2016). Exclusive economic zones are shared by multiple countries. In such situations, neighboring countries have agreed to joint economic zones (JEZs), joint development zones (JDZs), or joint development areas (JDAs). These areas are not delineated on the maps because standard boundaries were not available. However, the general location of an exclusive economic zone may be labeled where IHS Markit (2016) assigned discoveries to that zone. Country names are from the "The World Factbook 2016" (U.S. Central Intelligence Agency [CIA], 2016). If only part of the country is shown, then no delineated prospective area was identified in the rest of the country. Selected major rivers and lakes are from the "ArcWorld 1:3M Rivers and Water Bodies Coverage" (ESRI, 1992).

Generalized bathymetric contour lines are shown at 200 and 1,000 meters (656 and 3,280 feet) below sea level. Contour lines were generated from the "ETOPO5 5-MinuteGridded Elevation Data" (National Geophysical Data Center, 1988) by using ESRI's Arc/Info software (version 8.2). ETOPO5 is a raster dataset of worldwide land and sea-floor elevations at 5-minute spacing. Contour lines were then generalized in Arc/Info to smooth the lines and to reduce jagged features.

Petroleum province names, boundaries, and code numbers are from the "U.S. Geological Survey World Petroleum Assessment 2000" (U.S. Geological Survey World Energy Assessment Team, 2000). Of all the known petroleum provinces shown in figures 11-55, 212 are classified as significant because, by the end of 2015, they had at least one field containing 100 million barrels of crude oil or 600 billion cubic feet of gas (table 5).

Tables of significant petroleum provinces through 2015. - In figures 11-55, tables facing the maps provide information on the part of each significant province in a country, if there are reported discoveries for that significant province in that country. (Table 5 gives the total cumulative recoverable oil and gas volumes in each significant province in all the countries it occupies.) Data are from the "International Petroleum Exploration and Production Database" (IHS Markit, 2016), and the country order in the significant province tables follows the order in that database. Within each country, provinces are listed alphabetically. The tables show year of first discovery, oil in large oil fields (containing at least 100 million barrels), oil in all oil fields, gas in oil fields, gas in gas fields, and gas in all fields. A field is classified as either oil or gas on the basis of its gas:oil ratio. A field having at least 20,000 cubic feet of gas per barrel of crude oil is classified as a gas field; otherwise, the field is classified as an oil field.

Graphs.- Two graphs are shown with each map in figures 11-55; the two types of graphs are described in the text section "Tools for Analysis: Graphs," and generalized graphs are shown in figure 4 . The first graph shows the growth 
of cumulative delineated prospective area and explored area, arranged by the year when the areas became prospective or explored, plotted against the cumulative number of wildcat wells drilled in the country or country group through 2015 , where the wells are also ordered by time. The second graph shows cumulative recoverable oil and gas discoveries as functions of cumulative delineated prospective area, where the increments of prospective area are ordered by time. Dates are shown at the top of each graph. Data plotted are from IHS Markit (2016).

Only wildcat wells that have spud or completion dates and complete data indicating a location within the country or country group were used to construct graphs. Thus, cumulative wildcat well counts in the graphs are typically less than those in table 4, which includes wells without dates or coordinates.

For many wildcat wells drilled before 1950, data were not available, and, therefore, the delineated prospective areas and explored areas as of 1950 are underestimated in the graphs. Records of followup drilling after 1950 probably result in an overestimate of the rate of increase in the delineated prospective area. Nonetheless, the growth in delineated prospective area after 1970 is probably real and not an artifact of missing data.

\section{EXPLANATION FOR MAPS IN FIGURES 11-55}

\section{Delineated prospective area}

Explored area

- Petroleum province boundary; province names, codes, and boundaries are from U.S. Geological Survey World Energy Assessment Team (2000)

Country boundary from Environmental Systems Research Institute (ESRI, 1998), except for South Sudan and Kosovo (Natural Earth, 2016); country names are

from U.S. Central Intelligence Agency (2016)

\section{River from ESRI (1992)}

Bathymetry contour at 200 meters (656 feet) from

National Geophysical Data Center (1988)

Bathymetry contour at 1,000 meters (3,280 feet) from

National Geophysical Data Center (1988)
Summaries of exploration data.-Land areas for the overseas departments of France (Reunion, Guadeloupe, Martinique, and French Guiana) are from "The World Factbook 2001" (CIA, 2001), and all other land areas are from "The World Factbook 2016" (CIA, 2016). Land areas from the CIA $(2001,2016)$ in square kilometers were converted to square miles for ease in comparing this Circular with Circular 1288 (Attanasi and others, 2007). The conversion factor was 2.589988110336 square kilometers per square mile. Land areas for country groups may not add to the totals shown because of rounding. Computation of the delineated prospective area and the explored area is explained in the text. Wildcat wells and cumulative recoverable oil and gas discoveries through 2015 are from IHS Markit (2016).

Field depths were calculated from the average vertical depths of a field's production wells, and the field's oil and gas volumes were assigned that depth. Reported discoveries of oil and gas in conventional fields are provided for each country or country group. The percentages of oil and gas assigned to fields at depths of at least 10,000 feet are also provided, along with the percentages of oil in oil fields and gas in gas fields assigned to fields at 10,000 feet or deeper.

\section{UNITS USED IN FIGURES 11-55}

$\begin{array}{ll}\text { BBO } & \text { billion barrels of oil }\left(\mathrm{bbl} \times 10^{9}\right) \\ \mathrm{BCF} & \text { billion cubic feet }\left(\mathrm{ft}^{3} \times 10^{9)}\right. \\ \mathrm{ft} & \text { foot } \\ \mathrm{mi}^{2} & \text { square mile } \\ \mathrm{MMBO} & \text { million barrels of oil }\left(\mathrm{bbl} \times 10^{6}\right) \\ \mathrm{TCF} & \text { trillion cubic feet }\left(\mathrm{ft}^{3} \times 10^{12}\right)\end{array}$




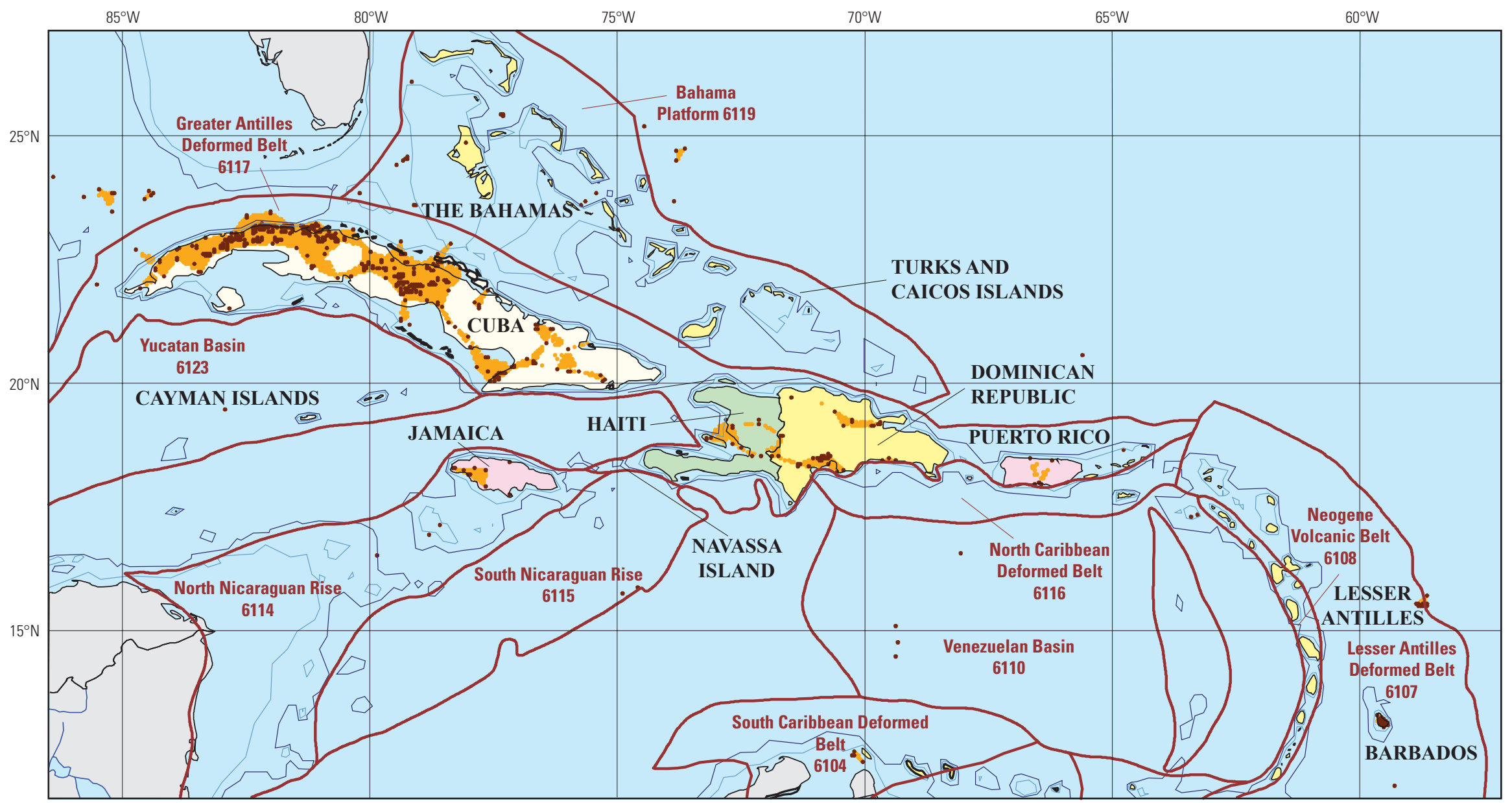

Figure 11. Map, graphs, and tables of data for oil and gas exploration through 2015 in the Caribbean. Parts of the Caribbean are Cuba, Barbados, The Bahamas, Turks and Caicos Islands, Navassa Island, Bermuda, Cayman Islands, Dominican Republic, Haiti, Jamaica, Puerto Rico, and the Lesser Antilles. Bermuda is not shown on the map; it lacks delineated prospective area. For this study, the Lesser Antilles are considered to include the former Netherlands Antilles, British Virgin Islands, Martinique (an overseas department of France), Dominica, Grenada, Virgin Islands, Saint Kitts and Nevis, Antigua and Barbuda, Anguilla, Montserrat, Guadeloupe (an overseas department of France), Saint Lucia, Saint Vincent and the Grenadines, and Aruba. 
Growth in delineated prospective area and explored area through 2015, graphed by the year the areas became prospective or explored

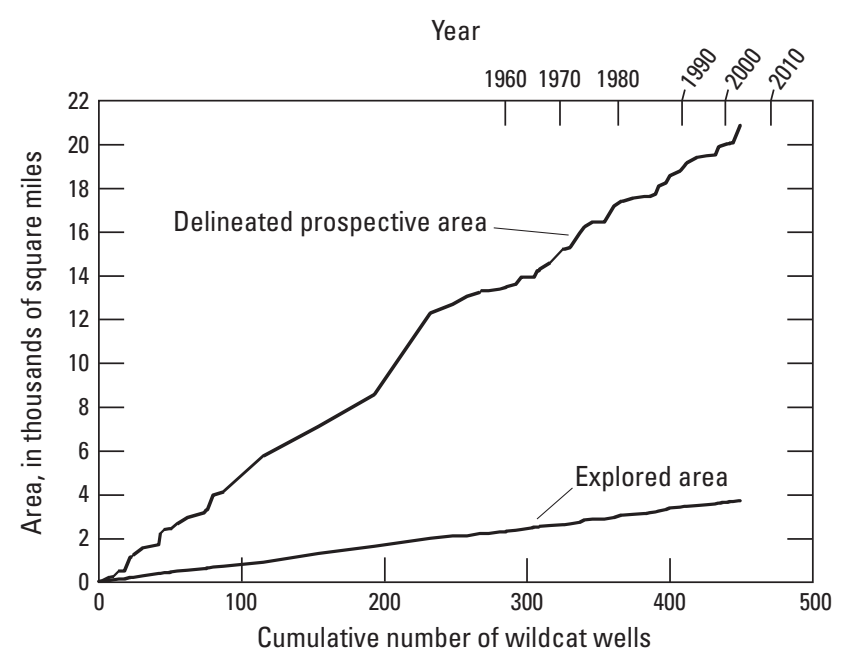

Cumulative recoverable oil and gas discoveries in all provinces through 2015, graphed by the year the field location became part of the delineated prospective area

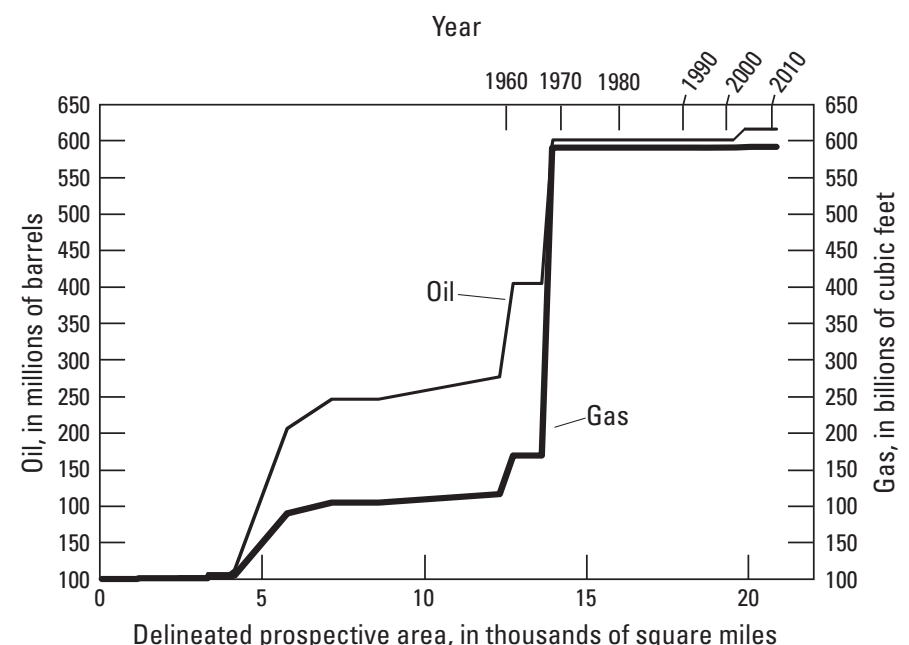

Significant petroleum provinces_-Year of first discovery and cumulative recoverable oil and gas discovered through 2015

\begin{tabular}{lcccccc}
\hline $\begin{array}{c}\text { Significant petroleum } \\
\text { province }\end{array}$ & $\begin{array}{c}\text { Year of } \\
\text { first } \\
\text { discovery }\end{array}$ & $\begin{array}{c}\text { Oil in } \\
\text { large } \\
\text { fields } \\
\text { (MMB0) }\end{array}$ & $\begin{array}{c}\text { Oil in all } \\
\text { fields } \\
\text { (MMBO) }\end{array}$ & $\begin{array}{c}\text { Gas in oil } \\
\text { fields } \\
\text { (BCF) }\end{array}$ & $\begin{array}{c}\text { Gas } \\
\text { in gas } \\
\text { fields } \\
\text { (BCF) }\end{array}$ & $\begin{array}{c}\text { Gas in all } \\
\text { fields } \\
\text { (BCF) }\end{array}$ \\
\hline $\begin{array}{c}\text { Cuba } \\
\text { Greater Antilles Deformed } \\
\text { Belt, } 6117\end{array}$ & 1881 & 185 & 603 & 561 & 0 & 561 \\
\hline & & Dominican Republic & & \\
\hline $\begin{array}{c}\text { Greater Antilles Deformed } \\
\text { Belt, } 6117\end{array}$ & 1905 & 0 & $<1$ & 0 & 0 & 0 \\
\hline
\end{tabular}

Exploration data

\begin{tabular}{|c|c|c|}
\hline Country & $\begin{array}{l}\text { Land } \\
\text { area } \\
\left(\mathrm{mi}^{2}\right)\end{array}$ & 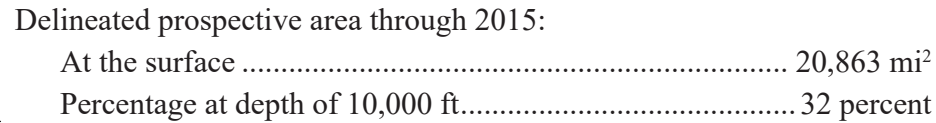 \\
\hline Cuba & 42,402 & Explored area through 2015: \\
\hline Barbados & 166 & At the surface \\
\hline Bahamas & 3,865 & 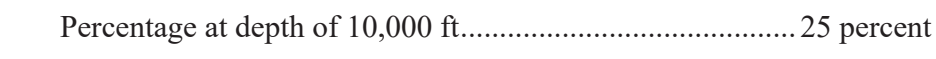 \\
\hline $\begin{array}{l}\text { Turks and Caicos } \\
\text { Islands }\end{array}$ & 369 & 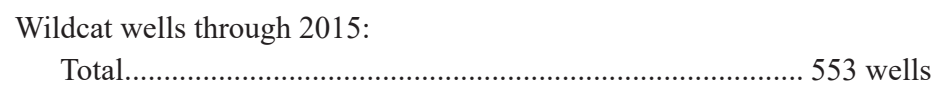 \\
\hline Navassa Island & 2 & 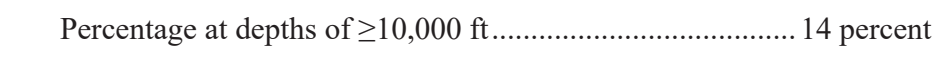 \\
\hline $\begin{array}{l}\text { Bermuda (not } \\
\text { shown on map) }\end{array}$ & 21 & $\begin{array}{l}\text { Reported discoveries through } 2015 \text { of cumulative recoverable crude oil } \\
\text { and gas in all provinces: }\end{array}$ \\
\hline Cayman Islands & 102 & Oil \\
\hline $\begin{array}{r}\text { Dominican } \\
\text { Republic }\end{array}$ & 18,656 & Percentage of oil at depths of $\geq 10,000 \mathrm{ft}$ \\
\hline $\begin{array}{l}\text { Haiti } \\
\text { Jamaica }\end{array}$ & $\begin{array}{r}10,641 \\
4,182\end{array}$ & 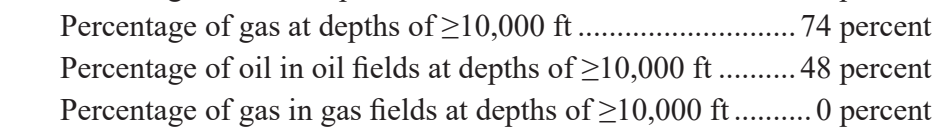 \\
\hline Puerto Rico & 3,425 & \\
\hline Lesser Antilles & 2,696 & \\
\hline Total & 86,524 & \\
\hline
\end{tabular}

Figure 11. Continued. 


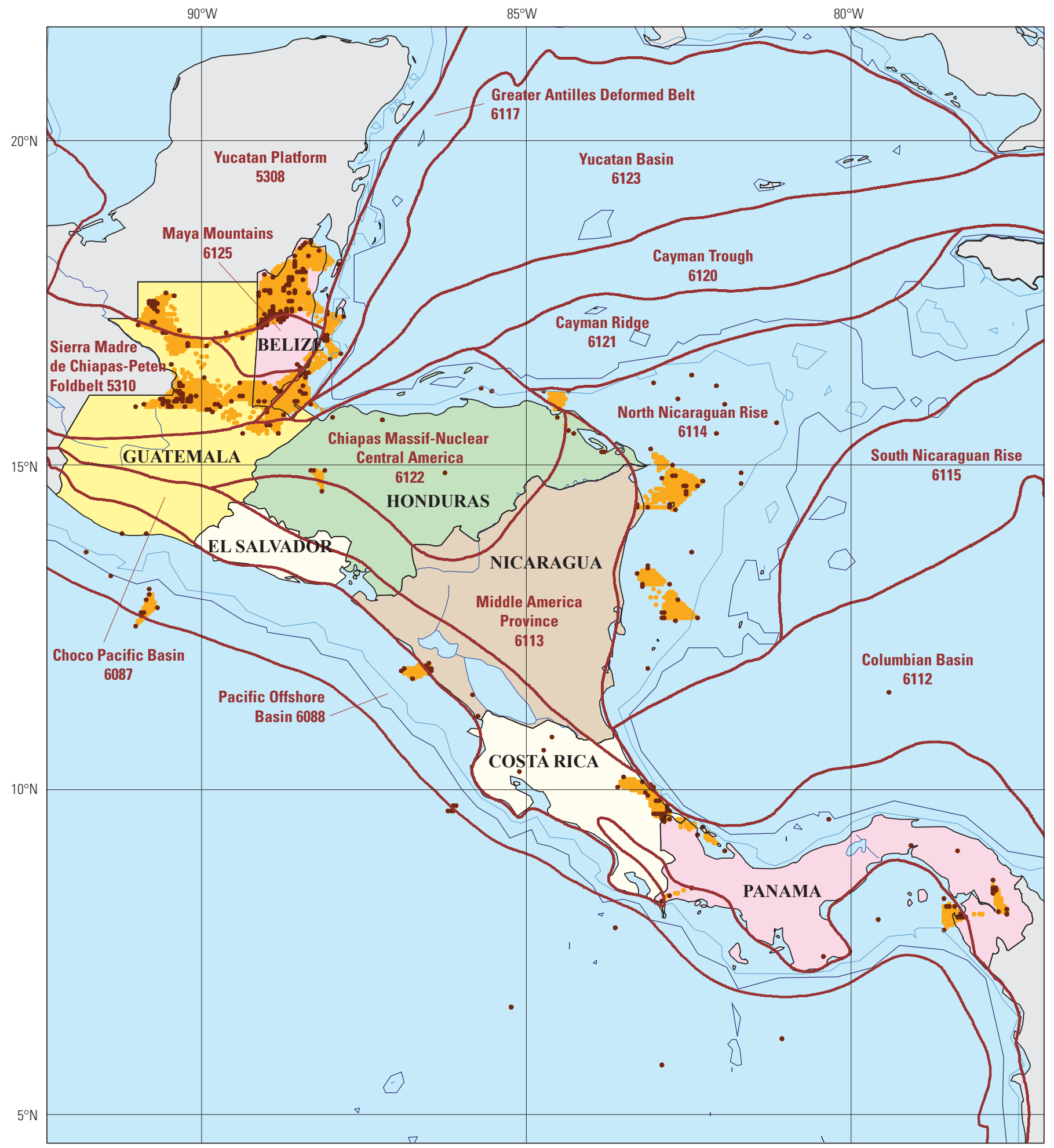

Figure 12. Map, graphs, and tables of data for oil and gas exploration through 2015 in Central America. Countries of Central America are Guatemala, Belize, Costa Rica, Honduras, Nicaragua, Panama, and El Salvador. 
Growth in delineated prospective area and explored area through 2015, graphed by the year the areas became prospective or explored

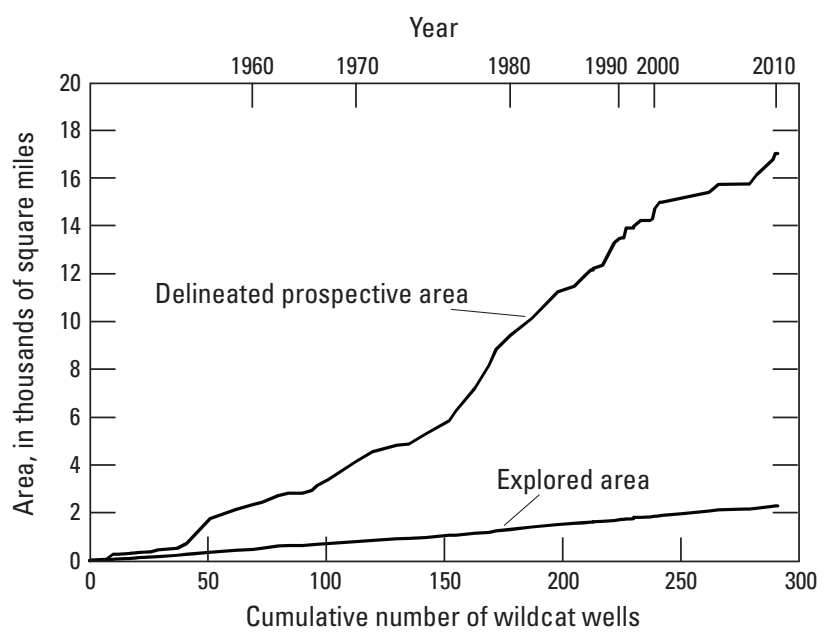

Cumulative recoverable oil and gas discoveries in all provinces through 2015, graphed by the year the field location became part of the delineated prospective area

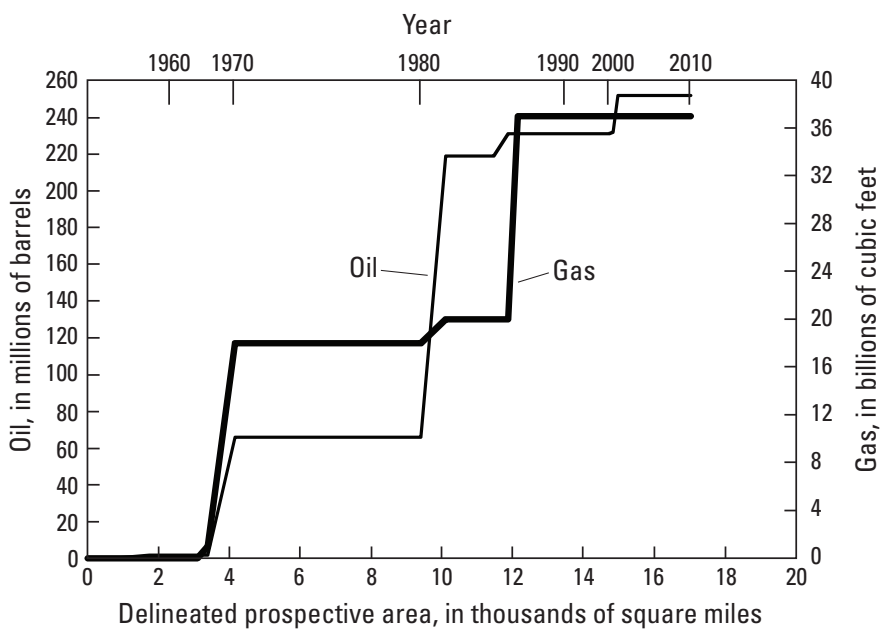

Significant petroleum provinces-Year of first discovery and cumulative recoverable oil and gas discovered through 2015

\begin{tabular}{|c|c|c|c|c|c|c|}
\hline Significant petroleum province & $\begin{array}{c}\text { Year of } \\
\text { first } \\
\text { discovery }\end{array}$ & $\begin{array}{l}\text { Oil in large } \\
\text { fields } \\
\text { (MMBO) }\end{array}$ & $\begin{array}{l}\text { Oil in all } \\
\text { fields } \\
\text { (MMBO) }\end{array}$ & $\begin{array}{l}\text { Gas in oil } \\
\text { fields } \\
\text { (BCF) }\end{array}$ & $\begin{array}{c}\text { Gas in gas } \\
\text { fields } \\
\text { (BCF) }\end{array}$ & $\begin{array}{l}\text { Gas in all } \\
\text { fields } \\
\text { (BCF) }\end{array}$ \\
\hline \multicolumn{7}{|c|}{ Belize } \\
\hline Yucatan Platform, 5308 & 2005 & 0 & 22 & 1 & 0 & 1 \\
\hline \multicolumn{7}{|c|}{ Guatemala } \\
\hline Yucatan Platform, 5308 & 1981 & 151 & 163 & 2 & 0 & 2 \\
\hline
\end{tabular}

\section{Exploration data}

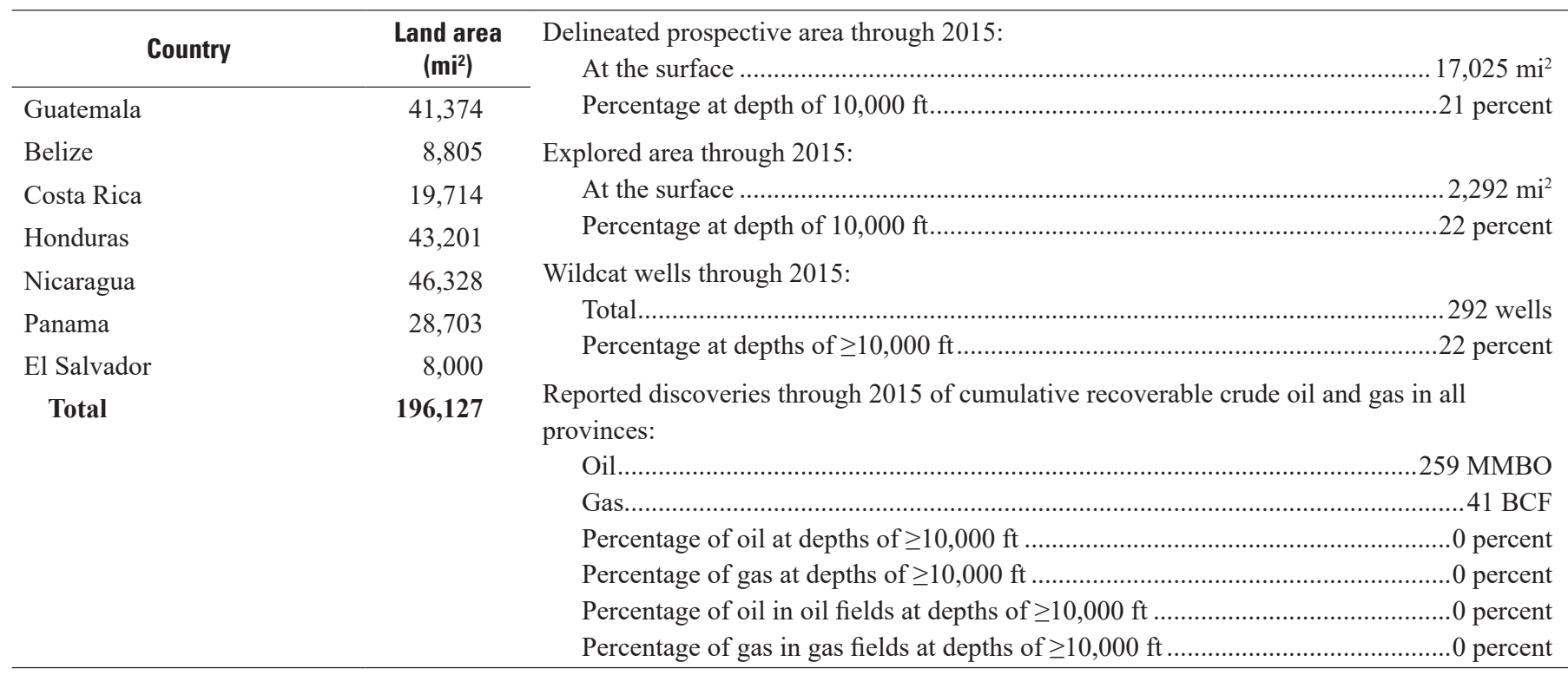

Figure 12. Continued. 


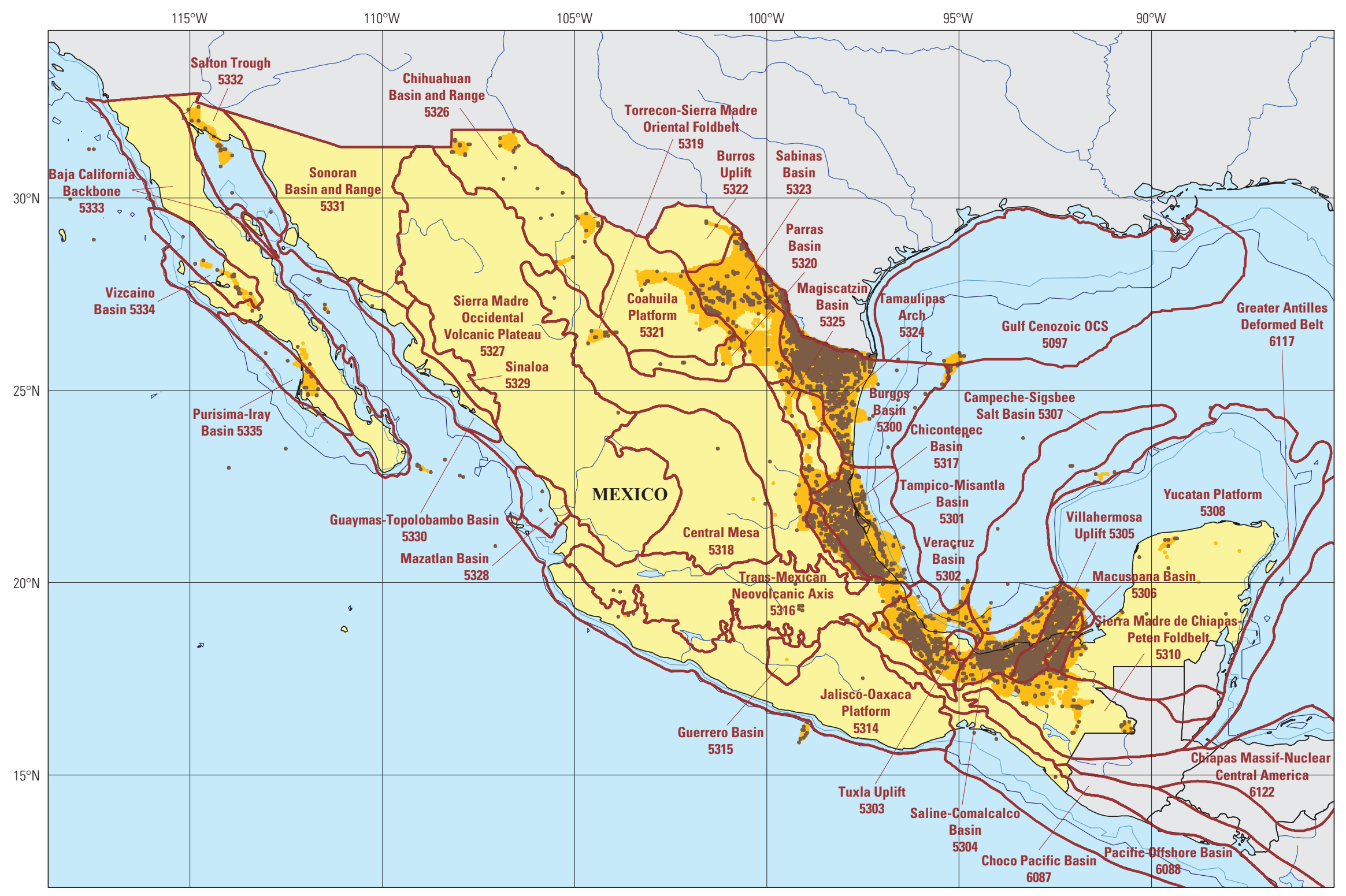

Figure 13. Map, graphs, and tables of data for oil and gas exploration through 2015 in Mexico. OCS, Outer Continental Shelf. 
Growth in delineated prospective area and explored

area through 2015, graphed by the year the areas became

prospective or explored

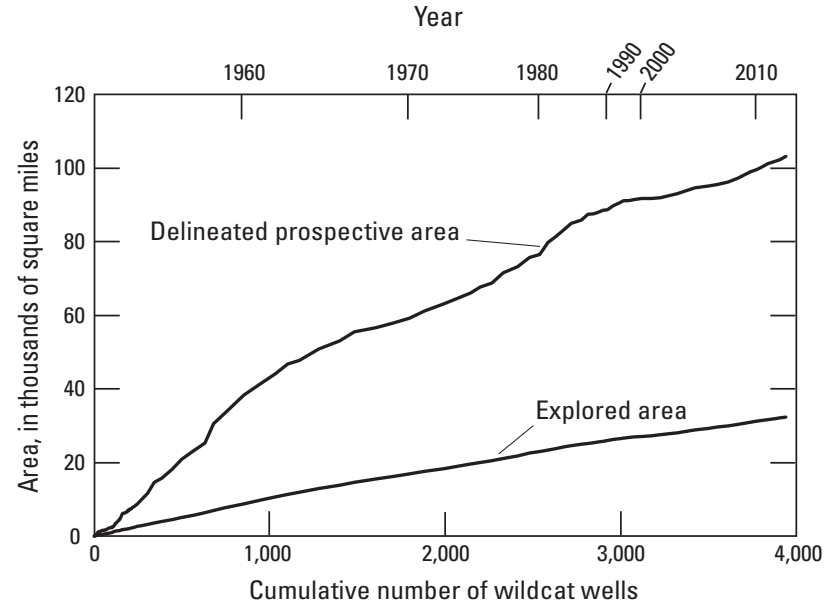

Cumulative recoverable oil and gas discoveries in all provinces through 2015, graphed by the year the field location became part of the delineated prospective area

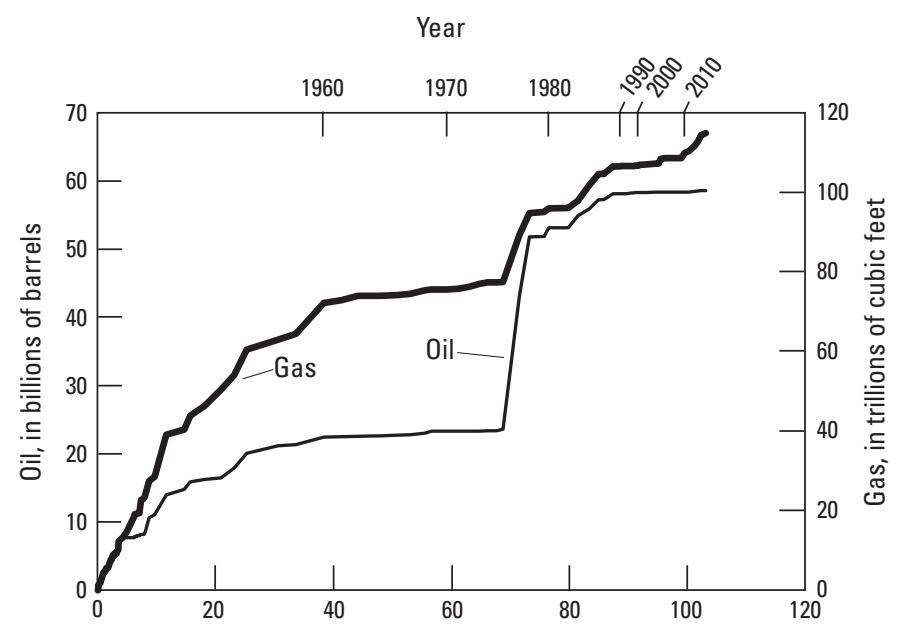

Delineated prospective area, in thousands of square miles

Figure 13. Continued. 

discovered through 2015

\begin{tabular}{|c|c|c|c|c|c|c|}
\hline $\begin{array}{c}\text { Significant petroleum } \\
\text { province }\end{array}$ & $\begin{array}{c}\text { Year of } \\
\text { first } \\
\text { discovery }\end{array}$ & $\begin{array}{l}\text { Oil in } \\
\text { large } \\
\text { fields } \\
\text { (MMBO) }\end{array}$ & $\begin{array}{l}\text { Oil in all } \\
\text { fields } \\
\text { (MMBO) }\end{array}$ & $\begin{array}{l}\text { Gas in oil } \\
\text { fields } \\
\text { (BCF) }\end{array}$ & $\begin{array}{c}\text { Gas in } \\
\text { gas fields } \\
\text { (BCF) }\end{array}$ & $\begin{array}{c}\text { Gas in all } \\
\text { fields } \\
\text { (BCF) }\end{array}$ \\
\hline \multicolumn{7}{|c|}{ Mexico } \\
\hline Burgos Basin, 5300 & 1927 & 0 & 99 & 151 & 15,900 & 16,051 \\
\hline Chicontepec Basin, 5317 & 1957 & 133 & 383 & 978 & 2 & 980 \\
\hline Gulf Cenozoic OCS, 5097 & 2012 & 115 & 129 & 277 & 0 & 277 \\
\hline Macuspana Basin, 5306 & 1905 & 0 & 14 & 47 & 6,427 & 6,474 \\
\hline $\begin{array}{l}\text { Saline-Comalcalco Basin, } \\
5304\end{array}$ & 1910 & 2,777 & 4,358 & 4,729 & 98 & 4,827 \\
\hline Tampico-Misantla Basin, 5301 & 1904 & 8,064 & 9,762 & 17,801 & 421 & 18,222 \\
\hline Veracruz Basin, 5302 & 1953 & 0 & 193 & 449 & 7,191 & 7,639 \\
\hline Villahermosa Uplift, 5305 & 1954 & 41,410 & 43,731 & 53,285 & 2,203 & 55,488 \\
\hline Yucatan Platform, 5308 & 1966 & 0 & 0 & 0 & 3 & 3 \\
\hline Undesignated offshore area & & 0 & 8 & 0 & 3,613 & 3,613 \\
\hline Total & & 52,498 & 58,677 & 77,717 & 35,857 & 113,573 \\
\hline
\end{tabular}

Figure 13. Continued. 


\section{Exploration data}

\begin{tabular}{|c|c|c|}
\hline Country & $\begin{array}{l}\text { Land } \\
\text { area } \\
\left(\mathrm{mi}^{2}\right)\end{array}$ & 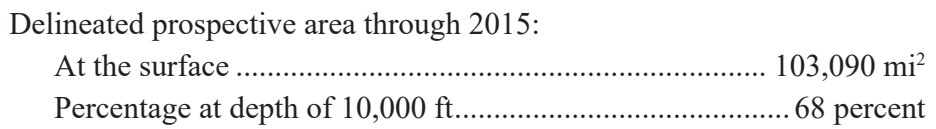 \\
\hline \multirow[t]{9}{*}{ Mexico } & 750,561 & 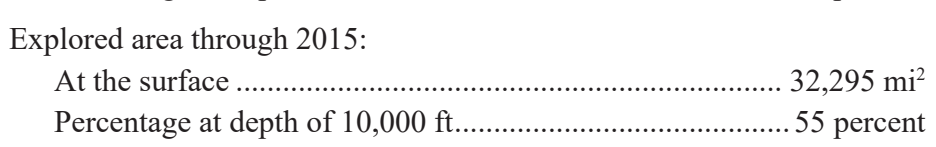 \\
\hline & & 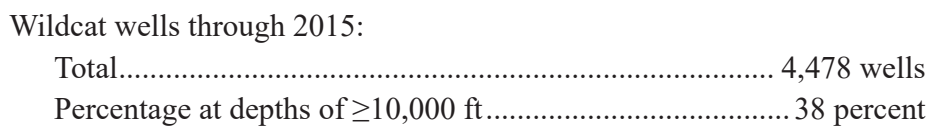 \\
\hline & & $\begin{array}{l}\text { Reported discoveries through } 2015 \text { of cumulative recoverable crude oil } \\
\text { and gas in all provinces: }\end{array}$ \\
\hline & & 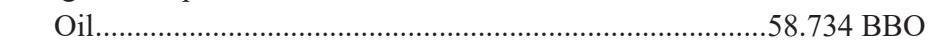 \\
\hline & & .............................. TCF \\
\hline & & 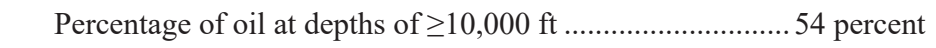 \\
\hline & & 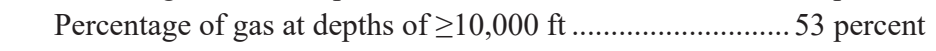 \\
\hline & & Percentage of oil in oil fields at depths of $\geq 10,000 \mathrm{ft} \ldots \ldots \ldots . .54$ percent \\
\hline & & Percentage of gas in gas fields at depths of $\geq 10,000 \mathrm{ft} \ldots \ldots . .35$ percent \\
\hline
\end{tabular}

Figure 13. Continued. 


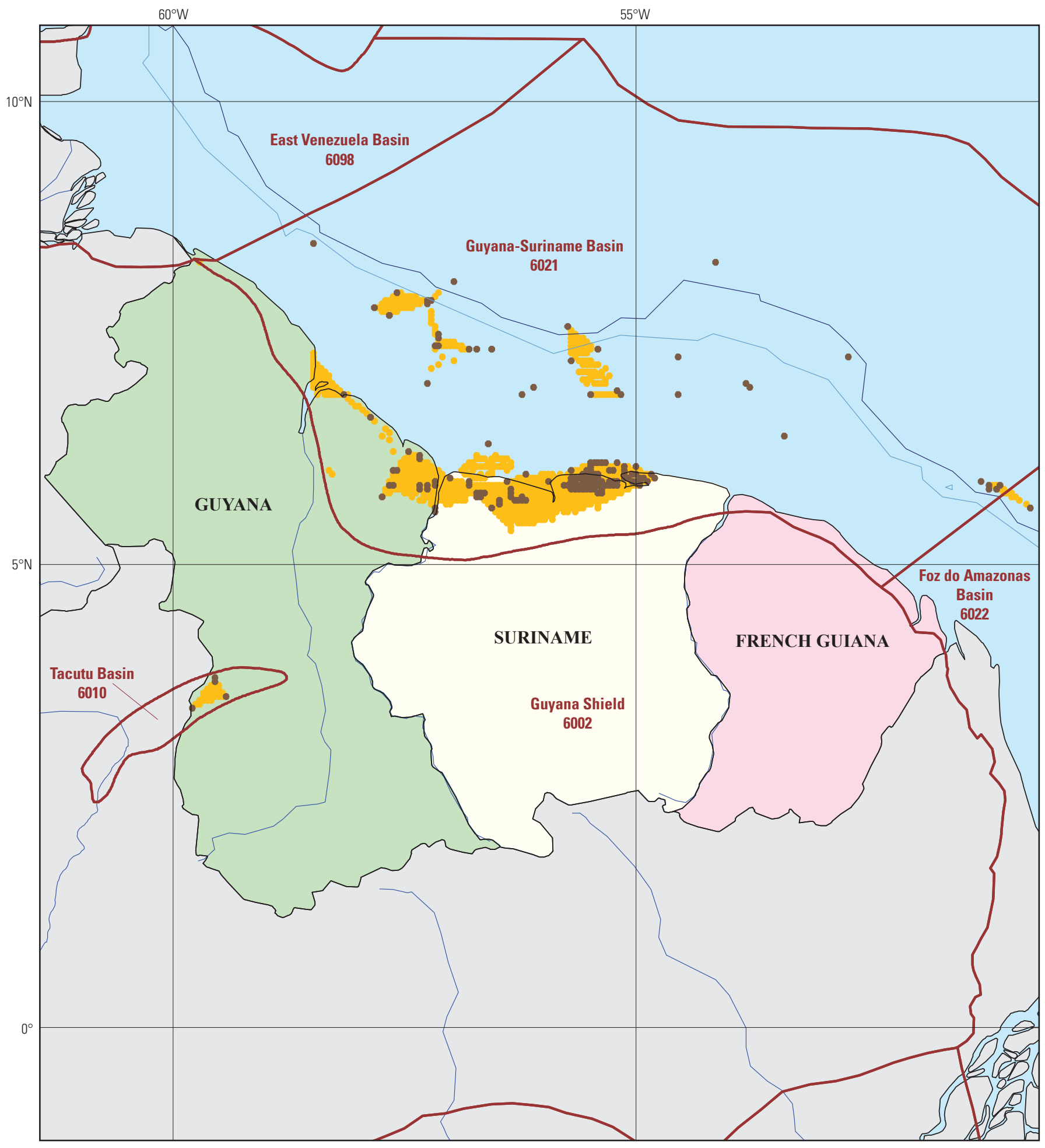

Figure 14. Map, graphs, and tables of data for oil and gas exploration through 2015 in Suriname, Guyana, and French Guiana (an overseas department of France). 
Growth in delineated prospective area and explored area through 2015 , graphed by the year the areas became prospective or explored

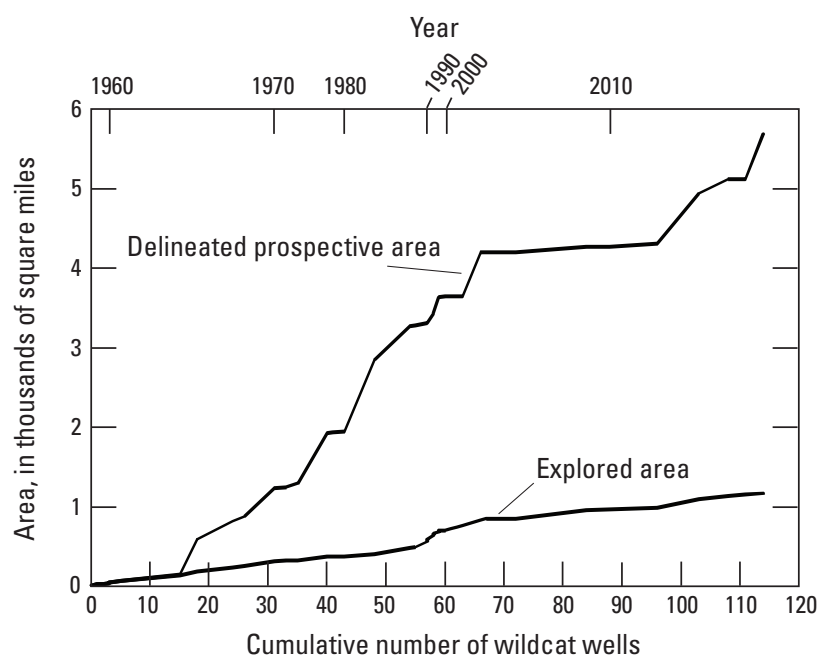

Cumulative recoverable oil and gas discoveries in all provinces through 2015, graphed by the year the field location became part of the delineated prospective area

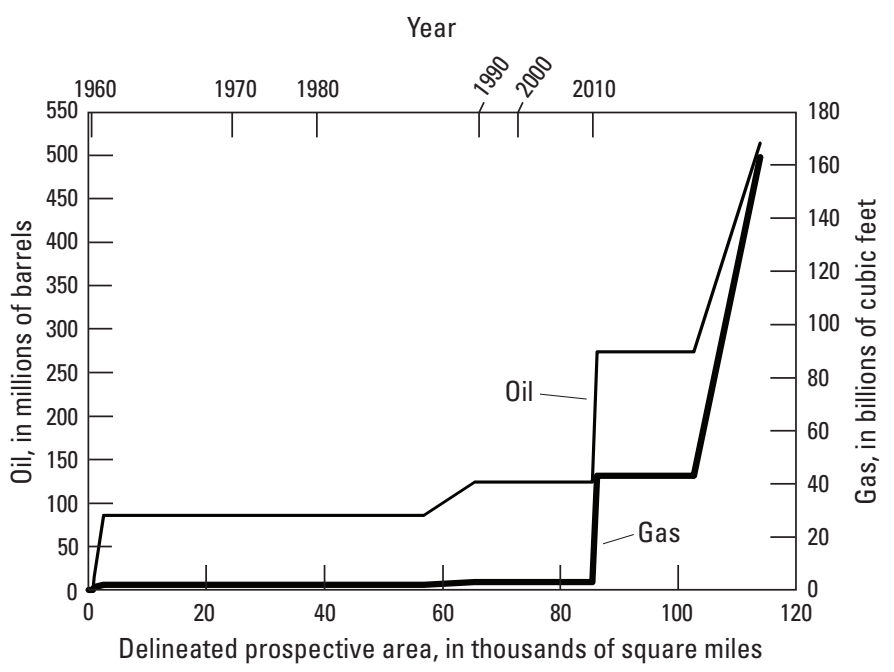

Figure 14. Continued. 
Significant petroleum provinces_-Year of first discovery and cumulative recoverable oil and gas discovered through 2015

\begin{tabular}{|c|c|c|c|c|c|c|}
\hline Significant petroleum province & $\begin{array}{c}\text { Year of } \\
\text { first } \\
\text { discovery }\end{array}$ & $\begin{array}{l}\text { Oil in large } \\
\text { fields } \\
\text { (MMBO) }\end{array}$ & $\begin{array}{l}\text { Oil in all } \\
\text { fields } \\
\text { (MMBO) }\end{array}$ & $\begin{array}{c}\text { Gas in oil } \\
\text { fields } \\
\text { (BCF) }\end{array}$ & $\begin{array}{l}\text { Gas in gas } \\
\text { fields } \\
\text { (BCF) }\end{array}$ & $\begin{array}{c}\text { Gas in all } \\
\text { fields } \\
\text { (BCF) }\end{array}$ \\
\hline \multicolumn{7}{|c|}{ French Guiana } \\
\hline Guyana-Suriname Basin, 6021 & 2011 & 150 & 150 & 40 & 0 & 40 \\
\hline \multicolumn{7}{|c|}{ Guyana } \\
\hline \multicolumn{7}{|c|}{ Suriname } \\
\hline Guyana-Suriname Basin, 6021 & 1965 & 0 & 125 & 4 & 0 & 4 \\
\hline
\end{tabular}

Figure 14. Continued. 


\section{Exploration data}

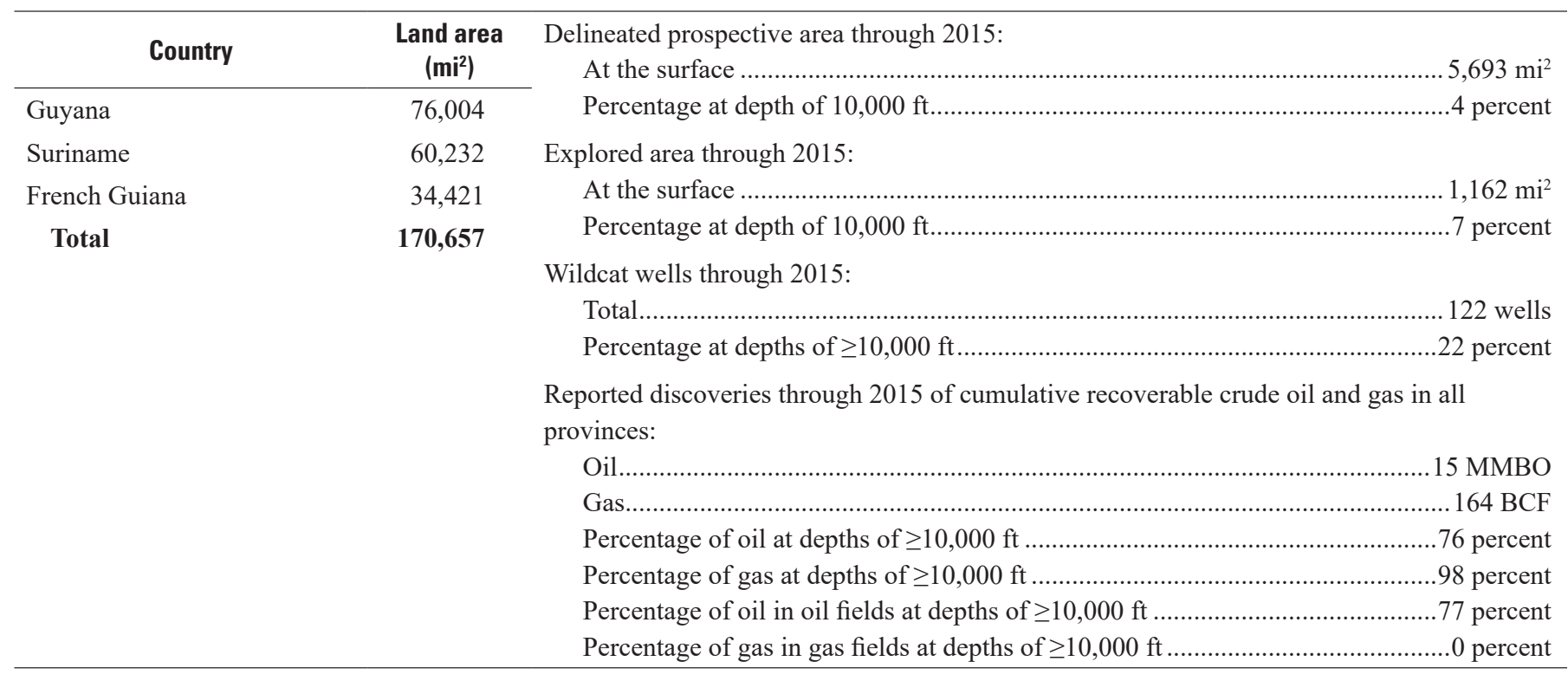

Figure 14. Continued. 


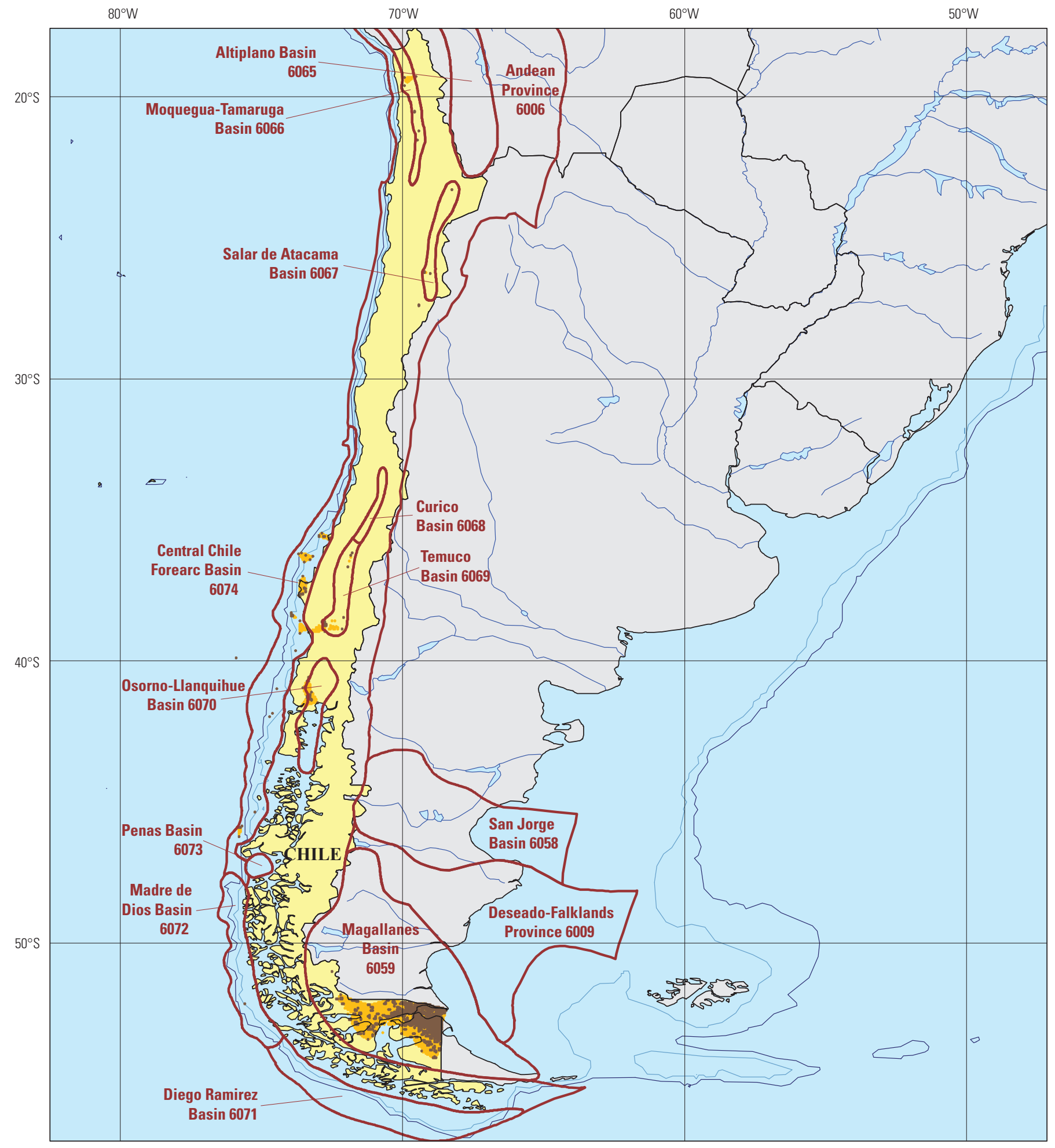

Figure 15. Map, graphs, and tables of data for oil and gas exploration through 2015 in Chile. 
Growth in delineated prospective area and explored area through 2015 , graphed by the year the areas became prospective or explored

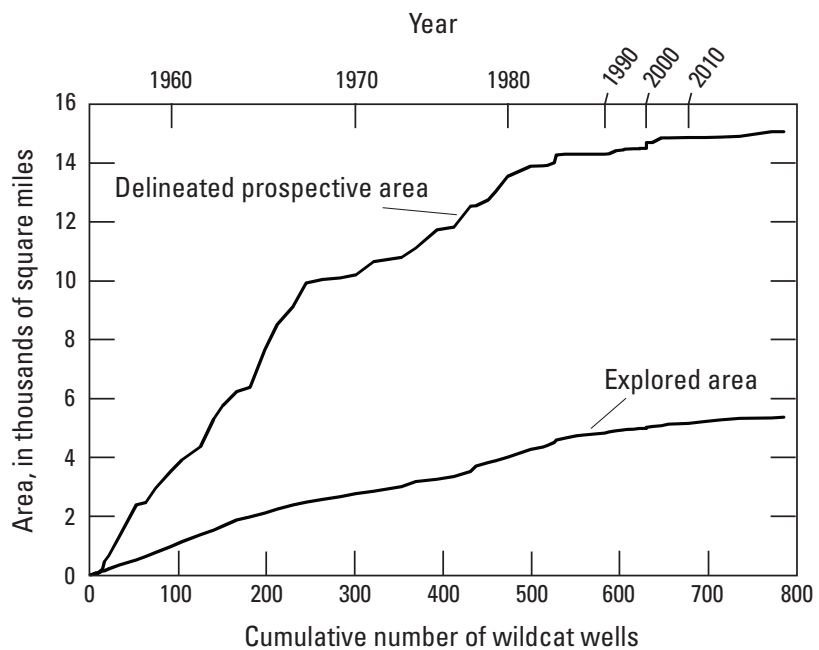

Cumulative recoverable oil and gas discoveries in all provinces through 2015, graphed by the year the field location became part of the delineated prospective area

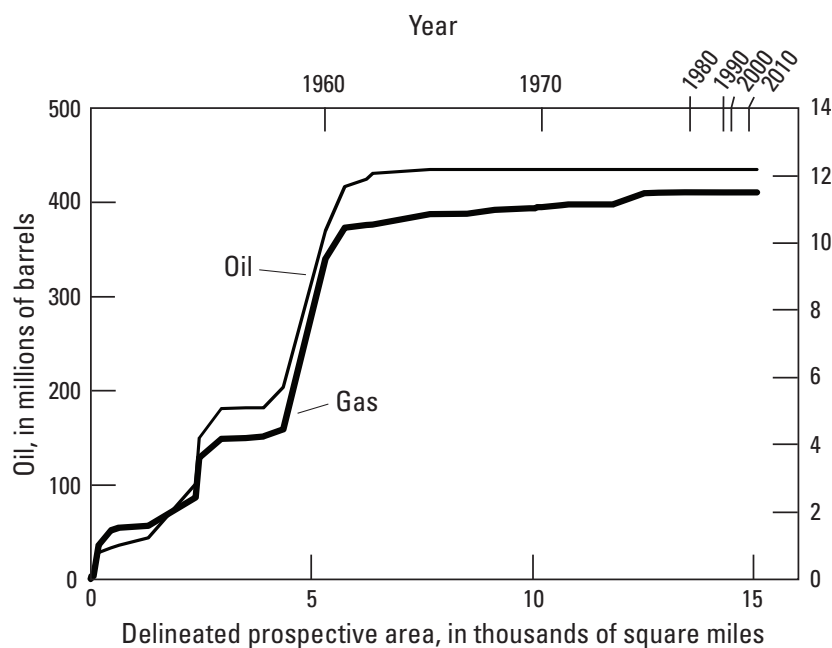

Significant petroleum province-Year of first discovery and cumulative recoverable oil and gas discovered through 2015

\begin{tabular}{lcccccc}
\hline Significant petroleum province & $\begin{array}{c}\text { Year of } \\
\text { first } \\
\text { discovery }\end{array}$ & $\begin{array}{c}\text { Oil in large } \\
\text { fields } \\
\text { (MMB0) }\end{array}$ & $\begin{array}{c}\text { Oil in all } \\
\text { fields } \\
\text { (MMBO) }\end{array}$ & $\begin{array}{c}\text { Gas in oil } \\
\text { fields } \\
\text { (BCF) }\end{array}$ & $\begin{array}{c}\text { Gas in gas } \\
\text { fields } \\
\text { (BCF) }\end{array}$ & $\begin{array}{c}\text { Gas in all } \\
\text { fields } \\
\text { (BCF) }\end{array}$ \\
\hline Magallanes Basin, 6059 & Chile & 0 & 469 & 1,890 & 9,601 \\
\hline
\end{tabular}

\section{Exploration data}

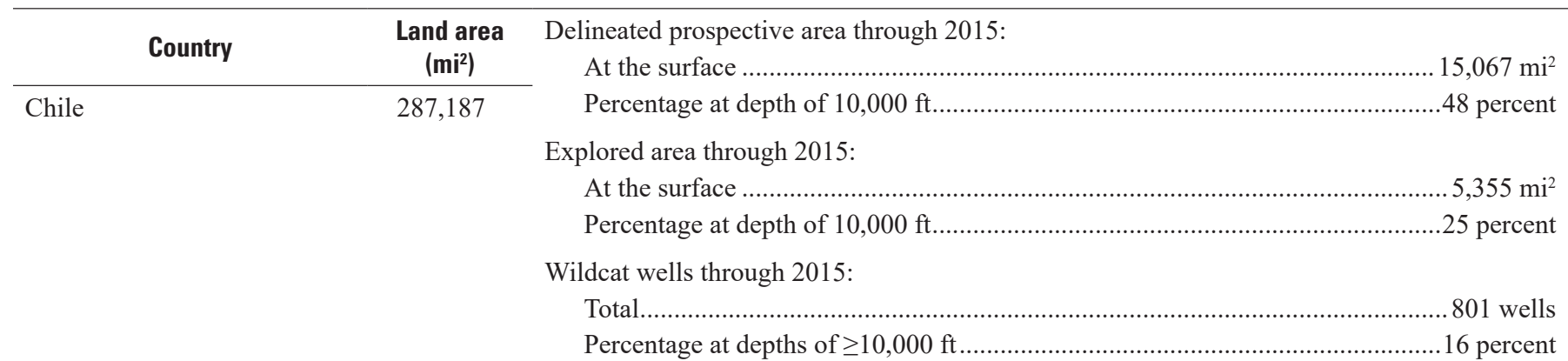

Reported discoveries through 2015 of cumulative recoverable crude oil and gas in all provinces:

Oil $469 \mathrm{MMBO}$

Gas 11.532 BCF

Percentage of oil at depths of $\geq 10,000 \mathrm{ft}$

4 percent

Percentage of gas at depths of $\geq 10,000 \mathrm{ft}$ .5 percent

Percentage of oil in oil fields at depths of $\geq 10,000 \mathrm{ft}$ 7 percent

Percentage of gas in gas fields at depths of $\geq 10,000 \mathrm{ft}$ 10 percent

Figure 15. Continued. 


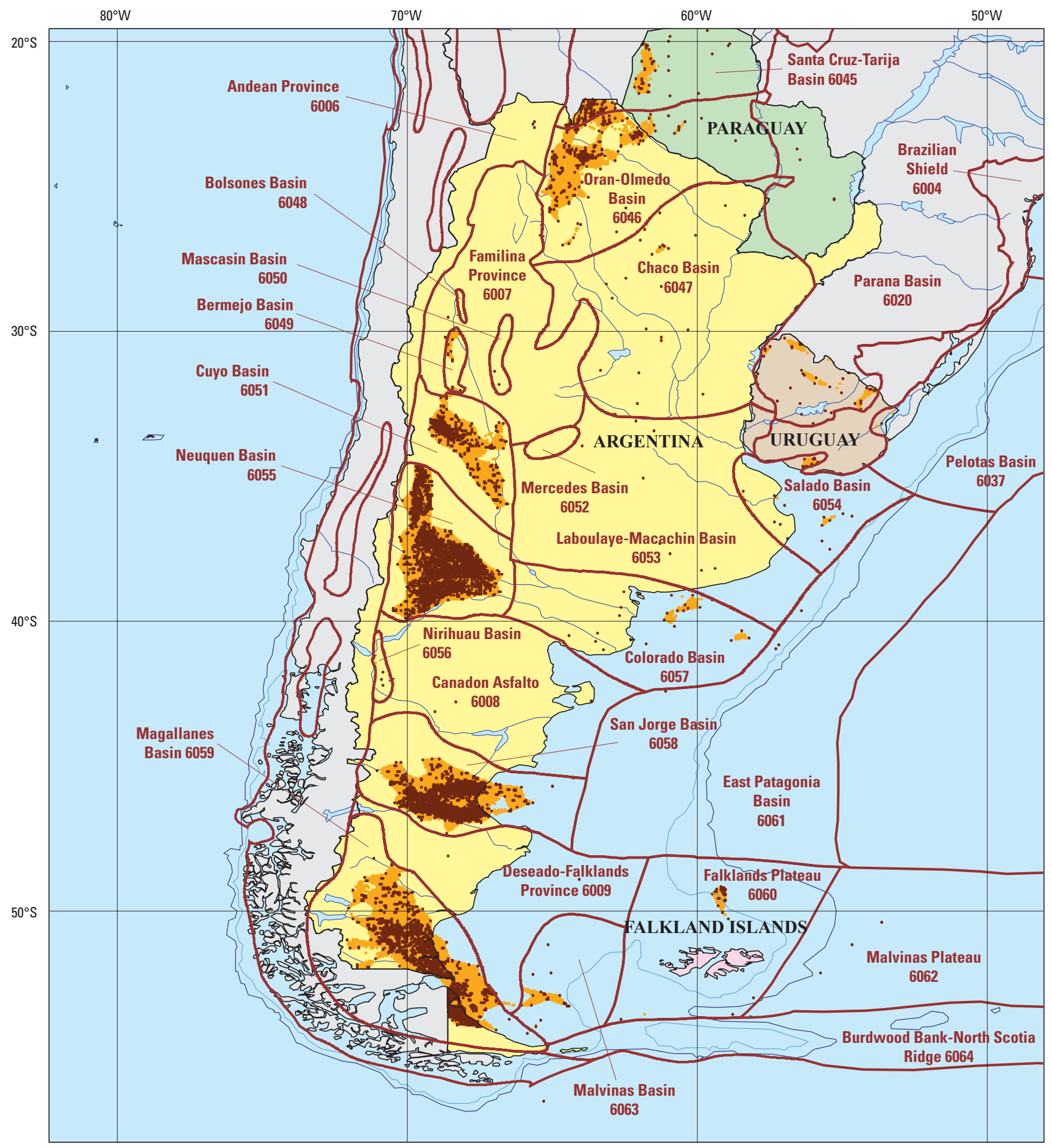

Figure 16. Map, graphs, and tables of data for oil and gas exploration through 2015 in Argentina, Paraguay, Uruguay, and the Falkland Islands. 
Growth in delineated prospective area and explored area through 2015, graphed by the year the areas became prospective or explored

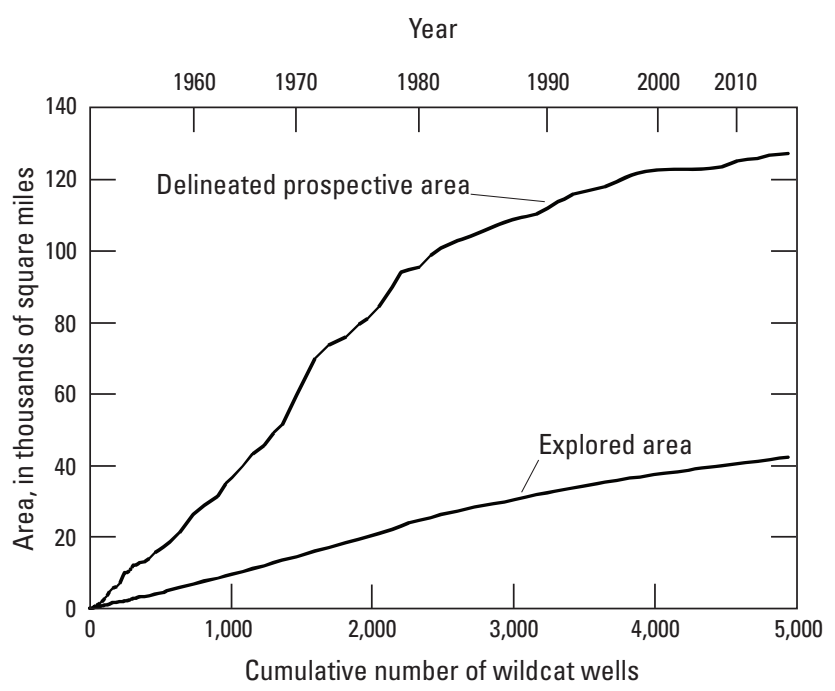

Cumulative recoverable oil and gas discoveries in all provinces through 2015, graphed by the year the field location became part of the delineated prospective area

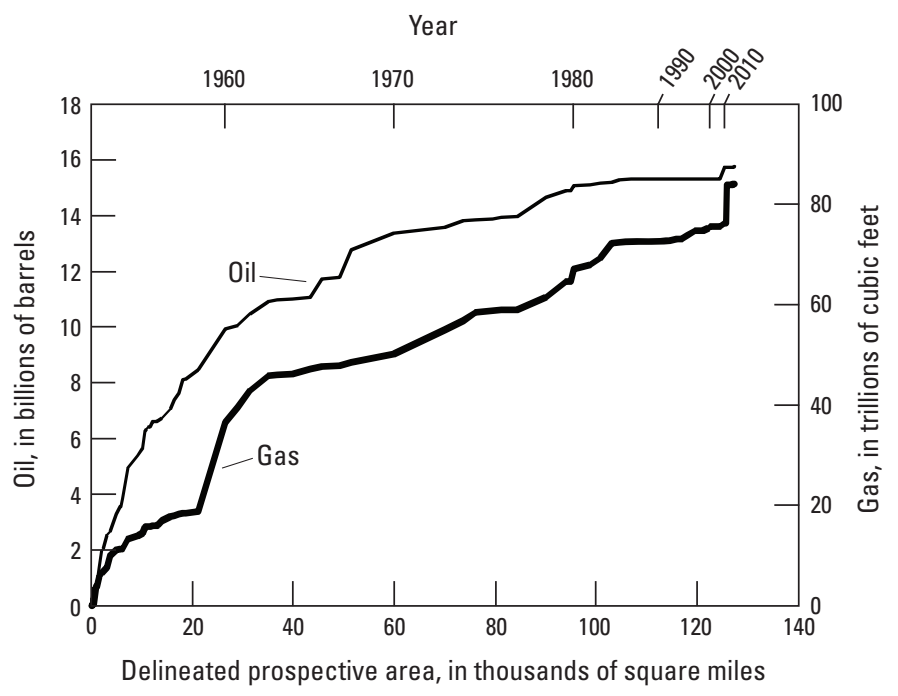

Figure 16. Continued. 
94 Statistics of Petroleum Exploration in the World Outside the United States and Canada Through 2015

Significant petroleum provinces-Year of first discovery and cumulative recoverable oil and gas discovered through 2015

\begin{tabular}{|c|c|c|c|c|c|c|}
\hline Significant petroleum province & $\begin{array}{c}\text { Year of } \\
\text { first } \\
\text { discovery }\end{array}$ & $\begin{array}{l}\text { Oil in large } \\
\text { fields } \\
\text { (MMBO) }\end{array}$ & $\begin{array}{c}\text { Oil in all } \\
\text { fields } \\
\text { (MMBO) }\end{array}$ & $\begin{array}{l}\text { Gas in oil } \\
\text { fields } \\
\text { (BCF) }\end{array}$ & $\begin{array}{c}\text { Gas in gas } \\
\text { fields } \\
\text { (BCF) }\end{array}$ & $\begin{array}{c}\text { Gas in all } \\
\text { fields } \\
\text { (BCF) }\end{array}$ \\
\hline \multicolumn{7}{|c|}{ Argentina } \\
\hline Cuyo Basin, 6051 & 1933 & 1,089 & 1,622 & 384 & 2 & 386 \\
\hline Magallanes Basin, 6059 & 1949 & 0 & 683 & 2,319 & 16,333 & 18,652 \\
\hline Neuquen Basin, 6055 & 1922 & 4,079 & 6,343 & 22,840 & 17,143 & 39,983 \\
\hline San Jorge Basin, 6058 & 1907 & 4,853 & 6,722 & 7,178 & 317 & 7,495 \\
\hline Santa Cruz-Tarija Basin, 6045 & 1926 & 0 & 44 & 18 & 8,215 & 8,233 \\
\hline Total & & 10,021 & 15,415 & 32,738 & 42,010 & 74,749 \\
\hline \multicolumn{7}{|c|}{ Paraguay } \\
\hline Santa Cruz-Tarija Basin, 6045 & 1959 & 0 & 0 & 0 & 26 & 26 \\
\hline \multicolumn{7}{|c|}{ Falkland Islands } \\
\hline Falklands Plateau, 6060 & 1998 & 353 & 453 & 445 & 2,326 & 2,771 \\
\hline Malvinas Plateau, 6062 & 2012 & 0 & 0 & 0 & 6,000 & 6,000 \\
\hline Total & & 353 & 453 & 445 & 8,326 & 8,771 \\
\hline
\end{tabular}

Figure 16. Continued. 


\section{Exploration data}

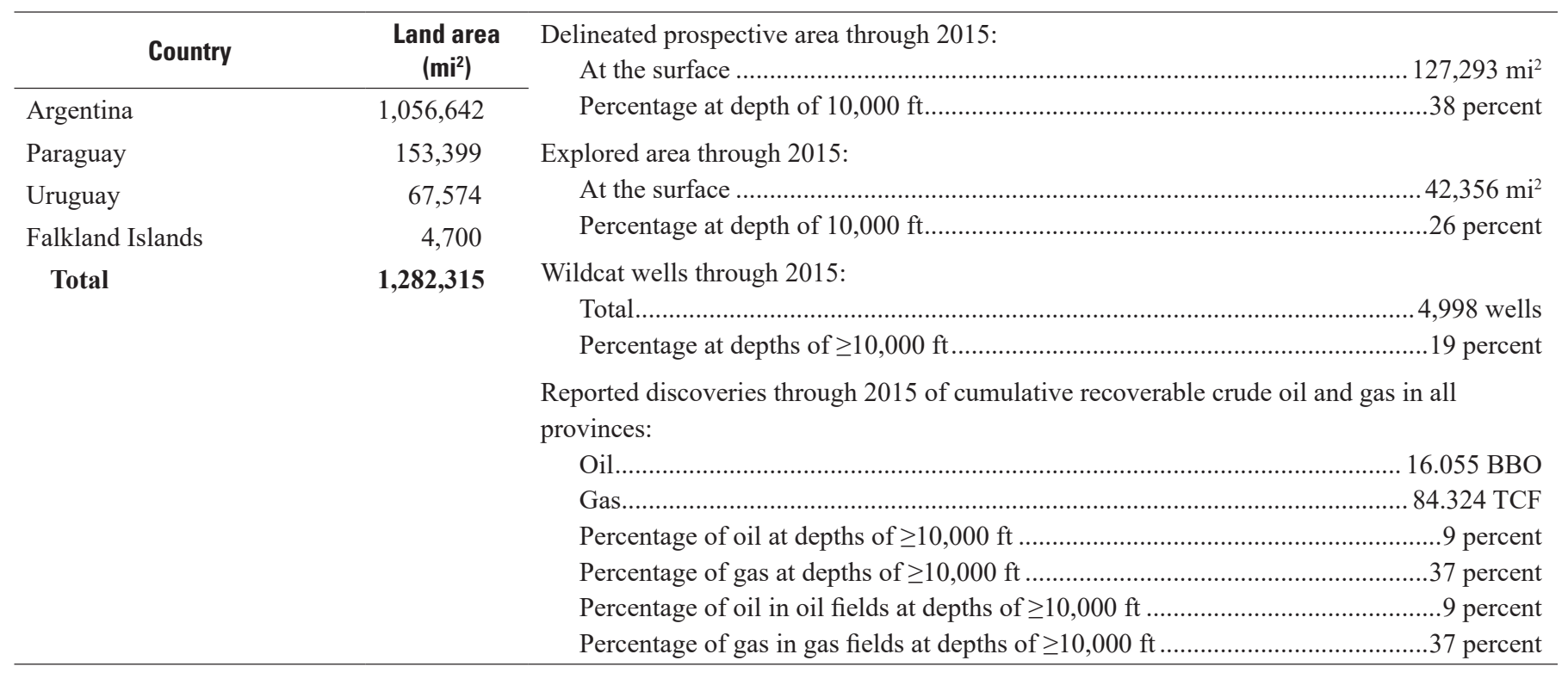

Figure 16. Continued. 


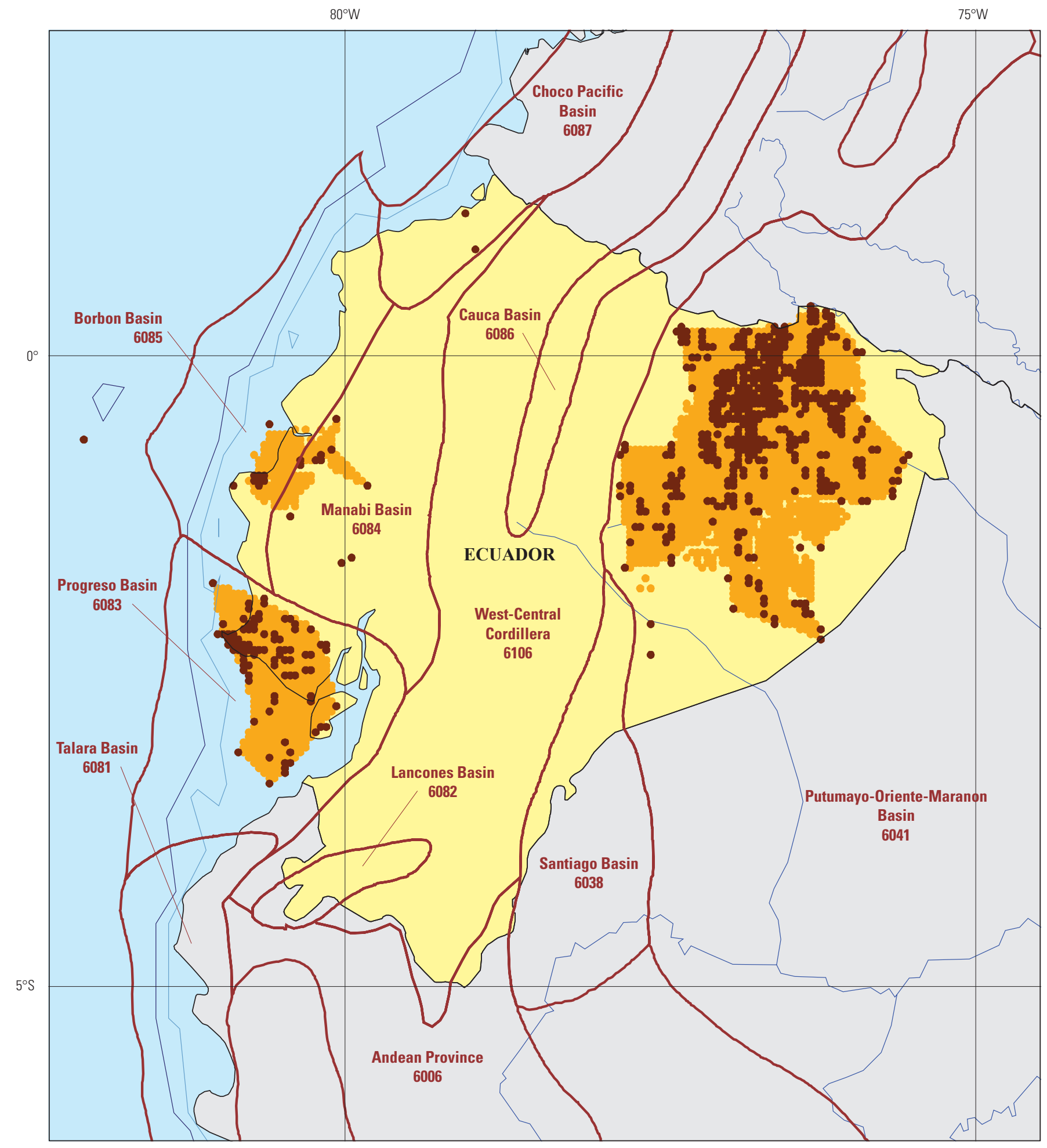

Figure 17. Map, graphs, and tables of data for oil and gas exploration through 2015 in Ecuador. 
Growth in delineated prospective area and explored area through 2015, graphed by the year the areas became prospective or explored

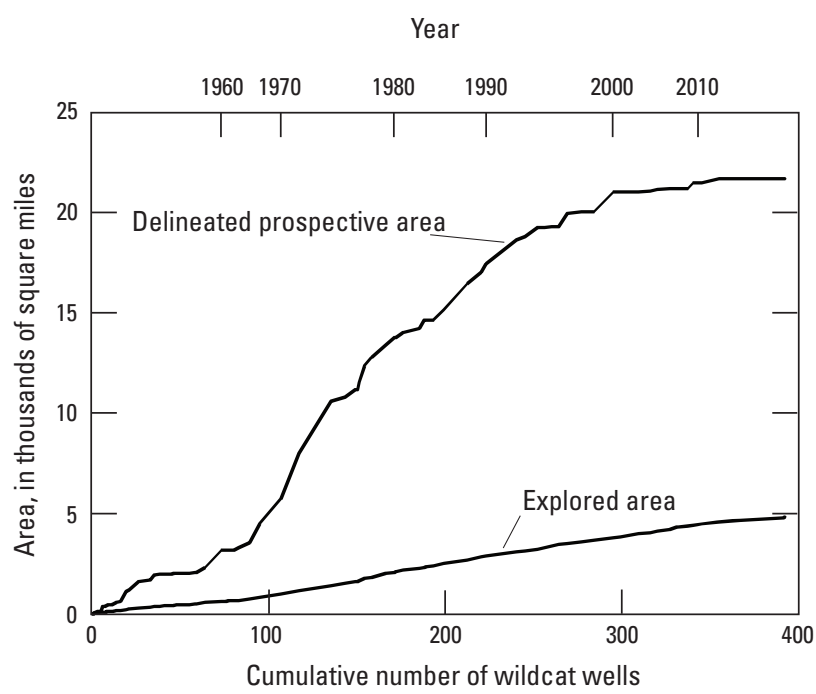

Cumulative recoverable oil and gas discoveries in all provinces through 2015, graphed by the year the field location became part of the delineated prospective area

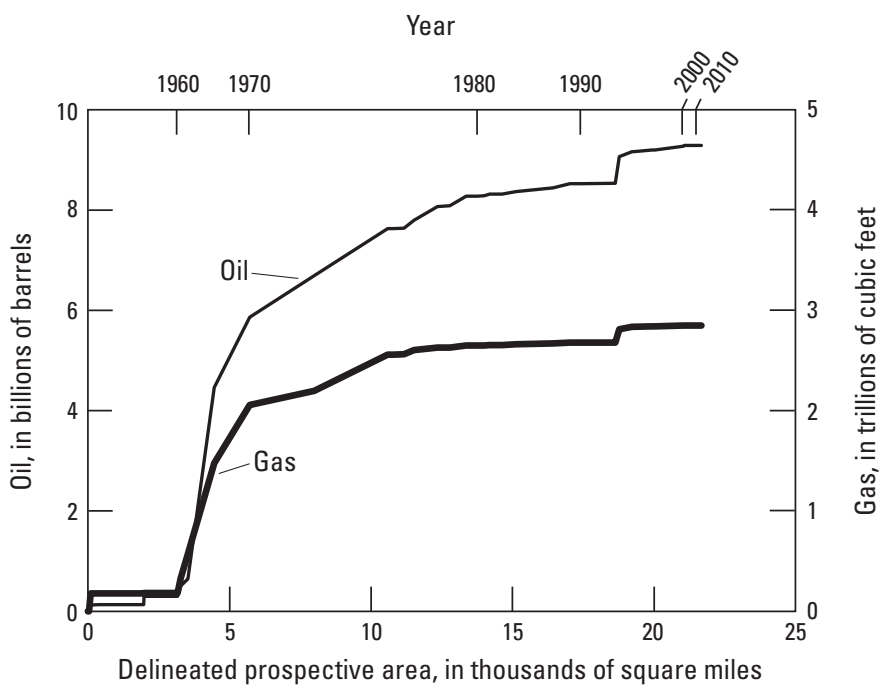

Significant petroleum provinces-Year of first discovery and cumulative recoverable oil and gas discovered through 2015

\begin{tabular}{|c|c|c|c|c|c|c|}
\hline Significant petroleum province & $\begin{array}{c}\text { Year of } \\
\text { first } \\
\text { discovery }\end{array}$ & $\begin{array}{l}\text { Oil in large } \\
\text { fields } \\
\text { (MMBO) }\end{array}$ & $\begin{array}{l}\text { Oil in all } \\
\text { fields } \\
\text { (MMBO) }\end{array}$ & $\begin{array}{c}\text { Gas in oil } \\
\text { fields } \\
\text { (BCF) }\end{array}$ & $\begin{array}{l}\text { Gas in gas } \\
\text { fields } \\
\text { (BCF) }\end{array}$ & $\begin{array}{c}\text { Gas in al } \\
\text { fields } \\
\text { (BCF) }\end{array}$ \\
\hline \multicolumn{7}{|c|}{ Ecuador } \\
\hline Progreso Basin, 6083 & 1918 & 120 & 134 & 181 & 364 & 545 \\
\hline $\begin{array}{l}\text { Putumayo-Oriente-Maranon Basin, } \\
\quad 6041\end{array}$ & 1967 & 6,617 & 9,207 & 2,348 & 0 & 2,348 \\
\hline Total & & 6,737 & 9,341 & 2,529 & 364 & 2,893 \\
\hline
\end{tabular}

\section{Exploration data}

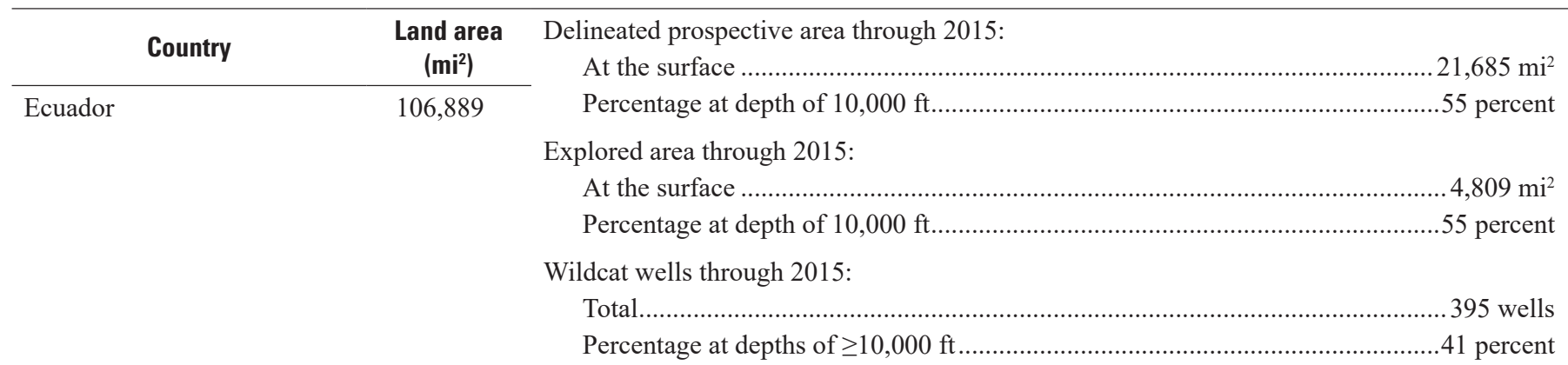

Reported discoveries through 2015 of cumulative recoverable crude oil and gas in all provinces:

Oil.

9.341 BBO

Gas.

$2.893 \mathrm{TCF}$

Percentage of oil at depths of $\geq 10,000 \mathrm{ft}$

42 percent

Percentage of gas at depths of $\geq 10,000 \mathrm{ft}$

35 percent

Percentage of oil in oil fields at depths of $\geq 10,000 \mathrm{ft}$........................................42 percent

Percentage of gas in gas fields at depths of $\geq 10,000 \mathrm{ft}$....................................... percent

Figure 17. Continued. 


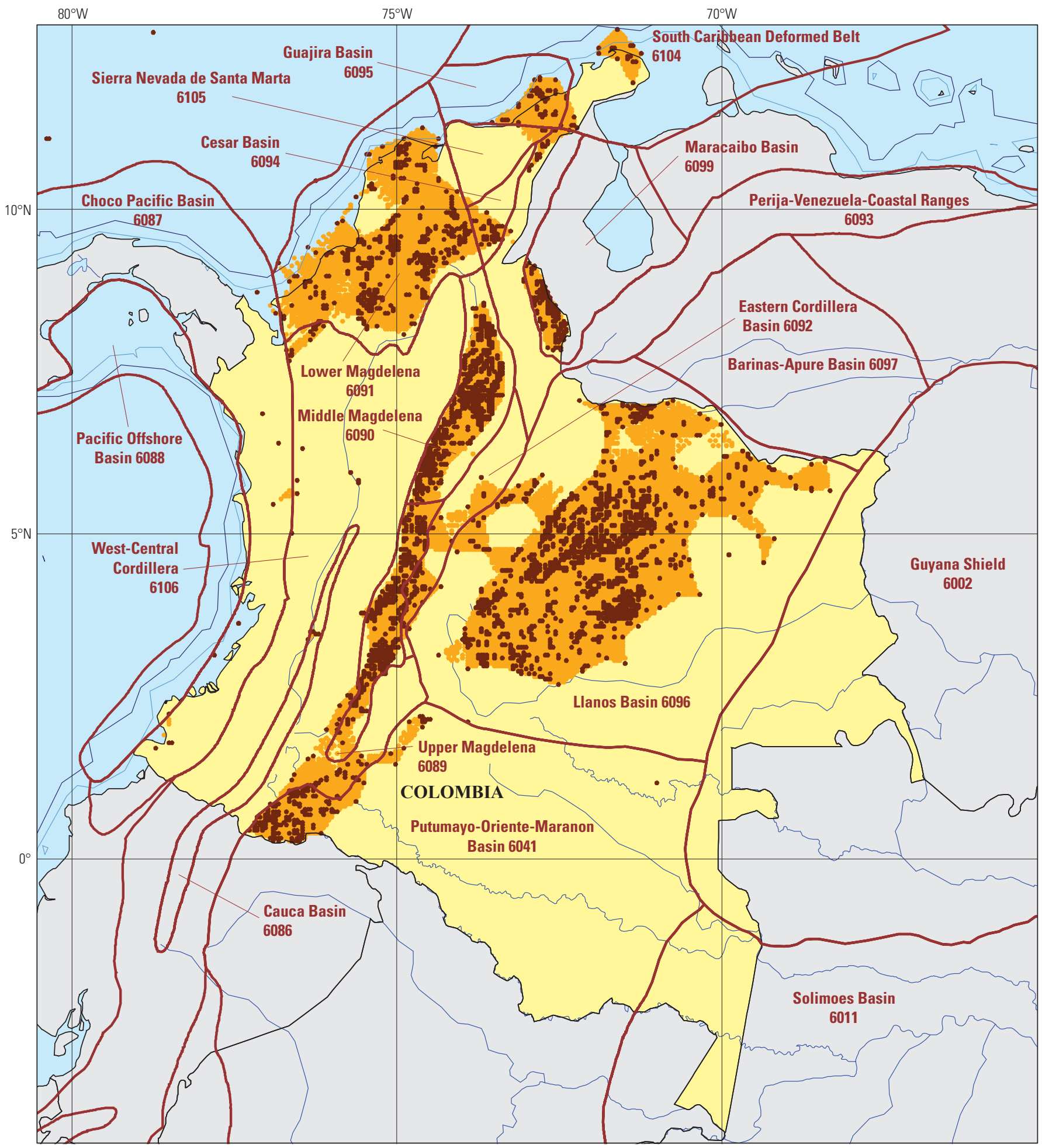

Figure 18. Map, graphs, and tables of data for oil and gas exploration through 2015 in Colombia. 
Growth in delineated prospective area and explored area through 2015, graphed by the year the areas became prospective or explored

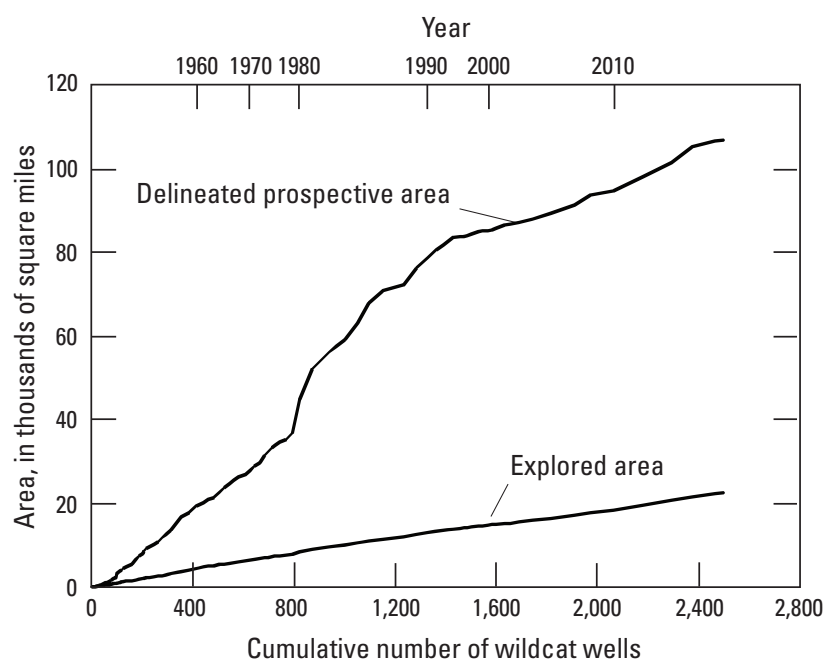

Cumulative recoverable oil and gas discoveries in all provinces through 2015, graphed by the year the field location became part of the delineated prospective area

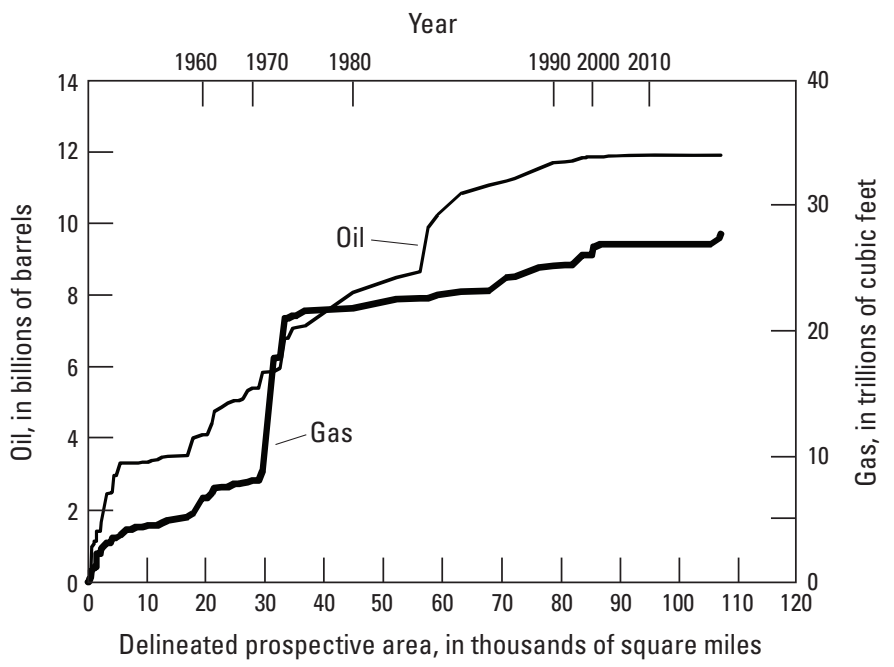

Figure 18. Continued. 
Significant petroleum provinces-Year of first discovery and cumulative recoverable oil and gas discovered through 2015

\begin{tabular}{lcrrrrr}
\hline \multicolumn{1}{c}{ Significant petroleum province } & $\begin{array}{c}\text { Year of } \\
\text { first } \\
\text { discovery }\end{array}$ & $\begin{array}{c}\text { 0il in large } \\
\text { fields } \\
\text { (MMBO) }\end{array}$ & $\begin{array}{c}\text { Oil in all } \\
\text { fields } \\
\text { (MMB0) }\end{array}$ & $\begin{array}{c}\text { Gas in oil } \\
\text { fields } \\
\text { (BCF) }\end{array}$ & $\begin{array}{c}\text { Gas in gas } \\
\text { fields } \\
\text { (BCF) }\end{array}$ & $\begin{array}{c}\text { Gas in all } \\
\text { fields } \\
\text { (BCF) }\end{array}$ \\
\hline Eastern Cordillera Basin, 6092 & \multicolumn{7}{c}{ Colombia } \\
Guajira Basin, 6095 & 1994 & 130 & 145 & 711 & 5 & 716 \\
Llanos Basin, 6096 & 1973 & 0 & 0 & 0 & 6,015 & 6,015 \\
Maracaibo Basin, 6099 & 1948 & 4,498 & 6,427 & 3,808 & 6,962 & 10,770 \\
Middle Magdelena, 6090 & 1920 & 410 & 490 & 567 & 332 & 898 \\
Putumayo-Oriente-Maranon Basin, & 1918 & 2,583 & 3,215 & 3,646 & 210 & 3,855 \\
$\quad$ 6041 & 1963 & 292 & 634 & 638 & 0 & 638 \\
South Caribbean Deformed Belt, 6104 & 1979 & 0 & 0 & 0 & 825 & 825 \\
Upper Magdelena, 6089 & 1949 & 323 & 1,041 & 822 & 40 & 862 \\
$\quad$ Total & & $\mathbf{8 , 2 3 5}$ & $\mathbf{1 1 , 9 5 2}$ & $\mathbf{1 0 , 1 9 2}$ & $\mathbf{1 4 , 3 8 8}$ & $\mathbf{2 4 , 5 8 0}$ \\
\hline
\end{tabular}

Figure 18. Continued. 


\section{Exploration data}

\begin{tabular}{|c|c|c|}
\hline Country & $\begin{array}{l}\text { Land area } \\
\qquad\left(\mathrm{mi}^{2}\right)\end{array}$ & 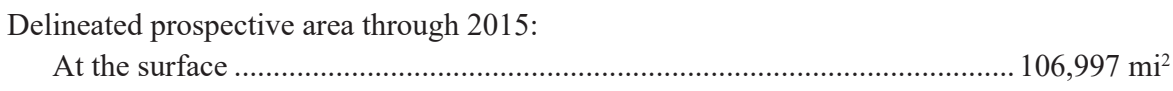 \\
\hline \multirow[t]{9}{*}{ Colombia } & 401,044 & 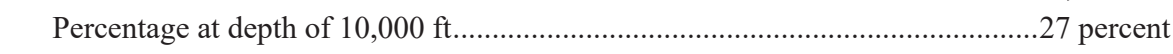 \\
\hline & & At the surface \\
\hline & & 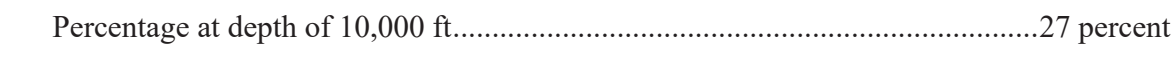 \\
\hline & & Wildcat wells through 2015: \\
\hline & & Percentage at depths of $\geq 10,000 \mathrm{ft}$ \\
\hline & & $\begin{array}{l}\text { Reported discoveries through } 2015 \text { of cumulative recoverable crude oil and gas in all } \\
\text { provinces: }\end{array}$ \\
\hline & & Oill. \\
\hline & & Gas \\
\hline & & 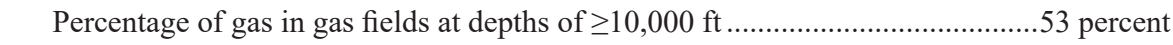 \\
\hline
\end{tabular}

Figure 18. Continued. 


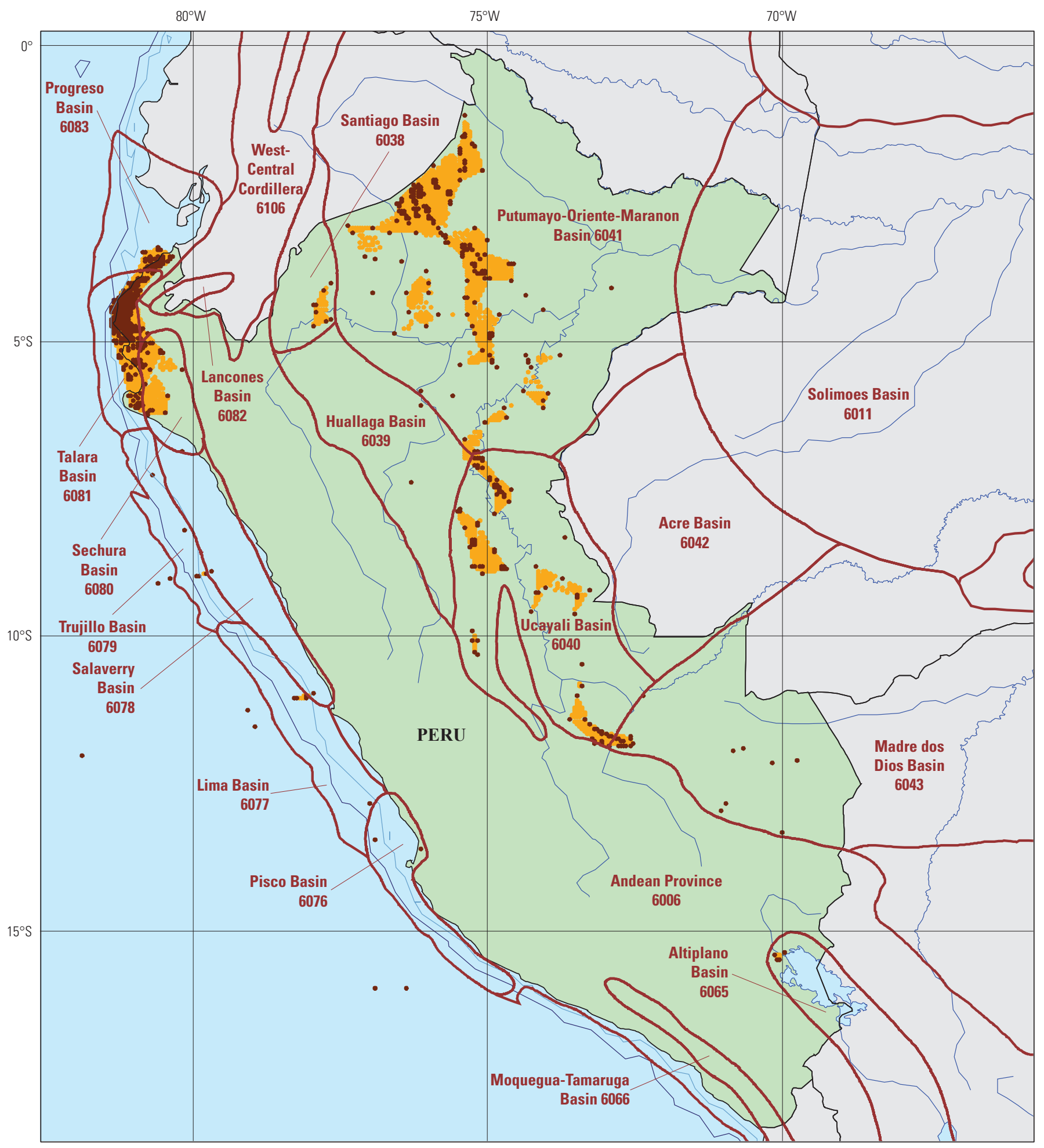

Figure 19. Map, graphs, and tables of data for oil and gas exploration through 2015 in Peru. 
Growth in delineated prospective area and explored area through 2015, graphed by the year the areas became prospective or explored

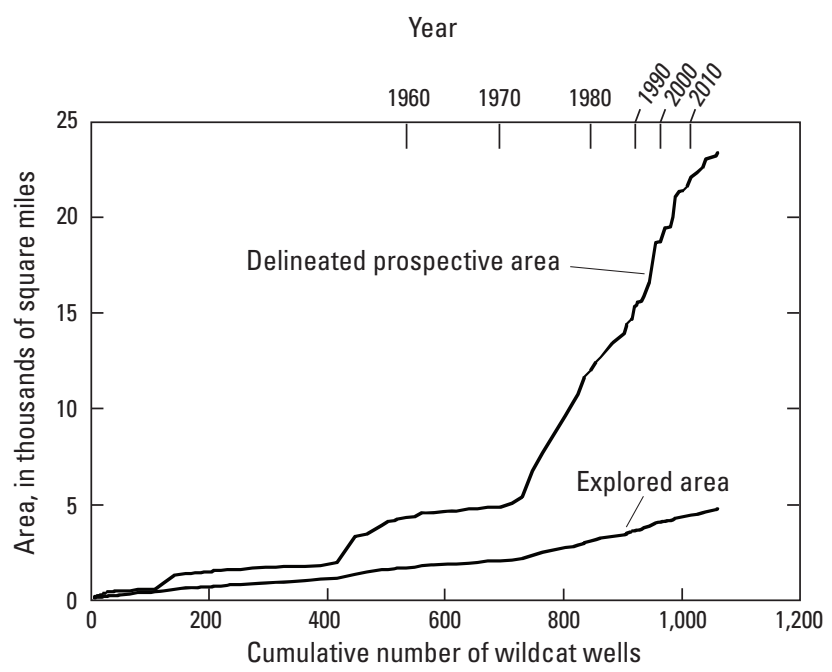

Cumulative recoverable oil and gas discoveries in all provinces through 2015, graphed by the year the field location became part of the delineated prospective area

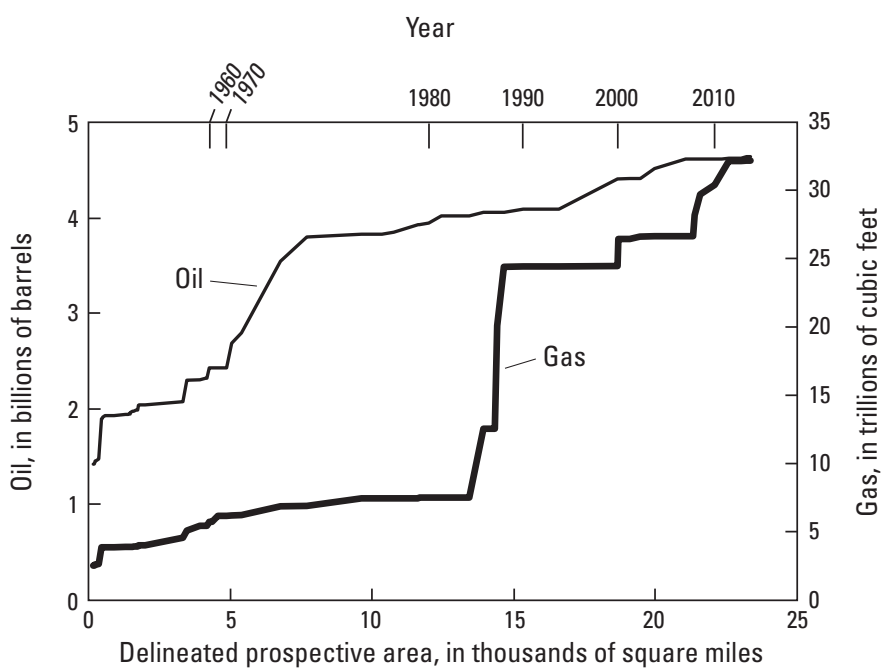

Figure 19. Continued. 
Significant petroleum provinces-Year of first discovery and cumulative recoverable oil and gas discovered through 2015

\begin{tabular}{|c|c|c|c|c|c|c|}
\hline Significant petroleum province & $\begin{array}{c}\text { Year of } \\
\text { first } \\
\text { discovery }\end{array}$ & $\begin{array}{l}\text { Oil in large } \\
\text { fields } \\
\text { (MMBO) }\end{array}$ & $\begin{array}{l}\text { Oil in all } \\
\text { fields } \\
\text { (MMBO) }\end{array}$ & $\begin{array}{l}\text { Gas in oil } \\
\text { fields } \\
\text { (BCF) }\end{array}$ & $\begin{array}{c}\text { Gas in gas } \\
\text { fields } \\
\text { (BCF) }\end{array}$ & $\begin{array}{c}\text { Gas in all } \\
\text { fields } \\
\text { (BCF) }\end{array}$ \\
\hline Madre dos Dios Basin, 6043 & 1984 & 0 & 0 & 0 & 15,598 & 15,598 \\
\hline Progreso Basin, 6083 & 1863 & 0 & 165 & 292 & 51 & 343 \\
\hline Talara Basin, 6081 & 1869 & 2,066 & 2,472 & 5,047 & 1,418 & 6,465 \\
\hline Ucayali Basin, 6040 & 1939 & 0 & 68 & 19 & 9,213 & 9,233 \\
\hline Total & & 2,772 & 4,656 & 5,596 & 26,280 & 31,876 \\
\hline
\end{tabular}

Figure 19. Continued. 


\section{Exploration data}

\begin{tabular}{|c|c|c|c|}
\hline & Country & $\begin{array}{l}\text { Land area } \\
\qquad\left(\mathrm{mi}^{2}\right)\end{array}$ & $\begin{array}{l}\text { Delineated prospective area through 2015: } \\
\text { At the surface }\end{array}$ \\
\hline \multirow[t]{13}{*}{ Peru } & & 494,209 & 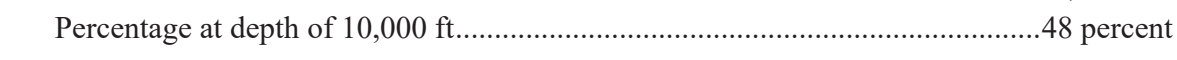 \\
\hline & & & Explored area through 2015: \\
\hline & & & 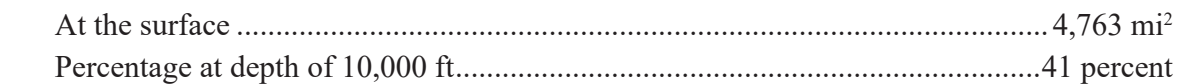 \\
\hline & & & Wildcat wells through 2015: \\
\hline & & & 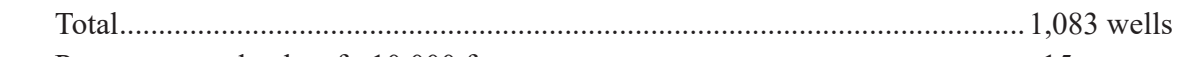 \\
\hline & & & Percentage at depths of $\geq 10,000 \mathrm{ft}$ \\
\hline & & & $\begin{array}{l}\text { Reported discoveries through } 2015 \text { of cumulative recoverable crude oil and gas in all } \\
\text { provinces: }\end{array}$ \\
\hline & & & 슨․․… $4.657 \mathrm{BBO}$ \\
\hline & & & Gas. \\
\hline & & & Percentage of oil at depths of $\geq 10,000 \mathrm{ft}$ \\
\hline & & & 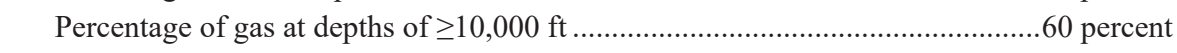 \\
\hline & & & Percentage of oil in oil fields at depths of $\geq 10,000 \mathrm{ft}$ \\
\hline & & & 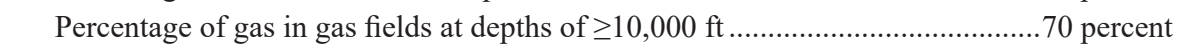 \\
\hline
\end{tabular}

Figure 19. Continued. 


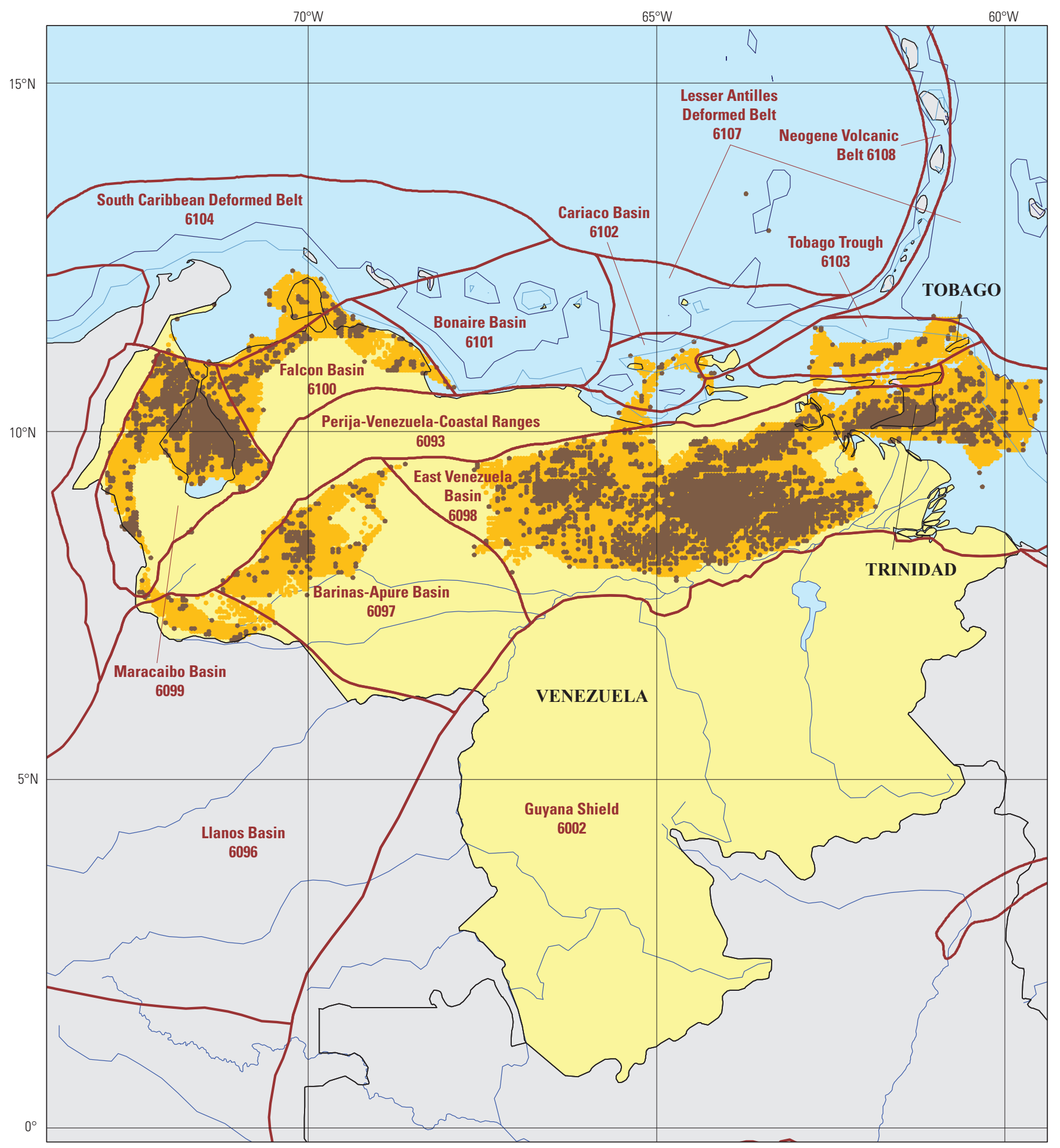

Figure 20. Map, graphs, and tables of data for oil and gas exploration through 2015 in Venezuela and Trinidad and Tobago. 
Growth in delineated prospective area and explored area through 2015, graphed by the year the areas became prospective or explored

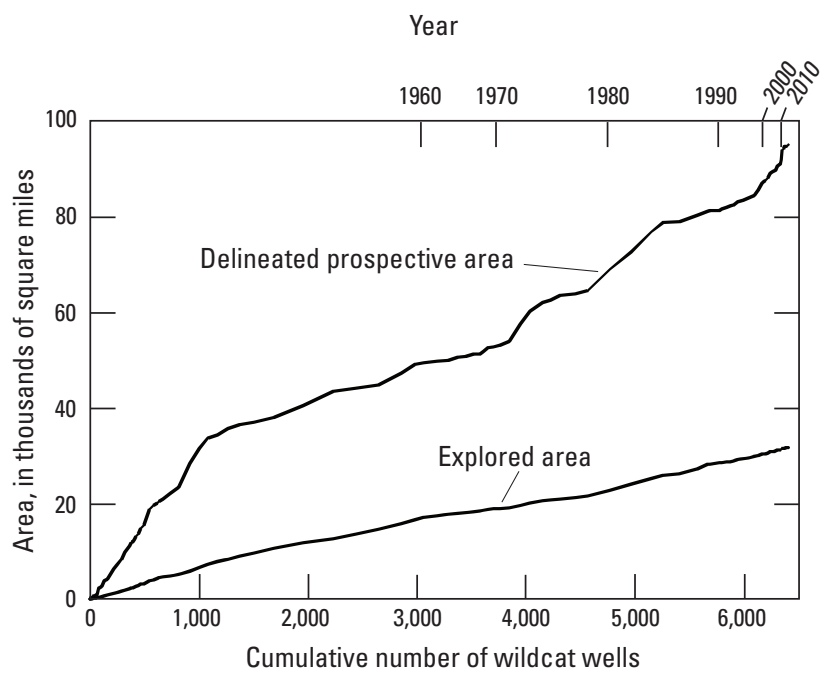

Cumulative recoverable oil and gas discoveries in all provinces through 2015, graphed by the year the field location became part of the delineated prospective area

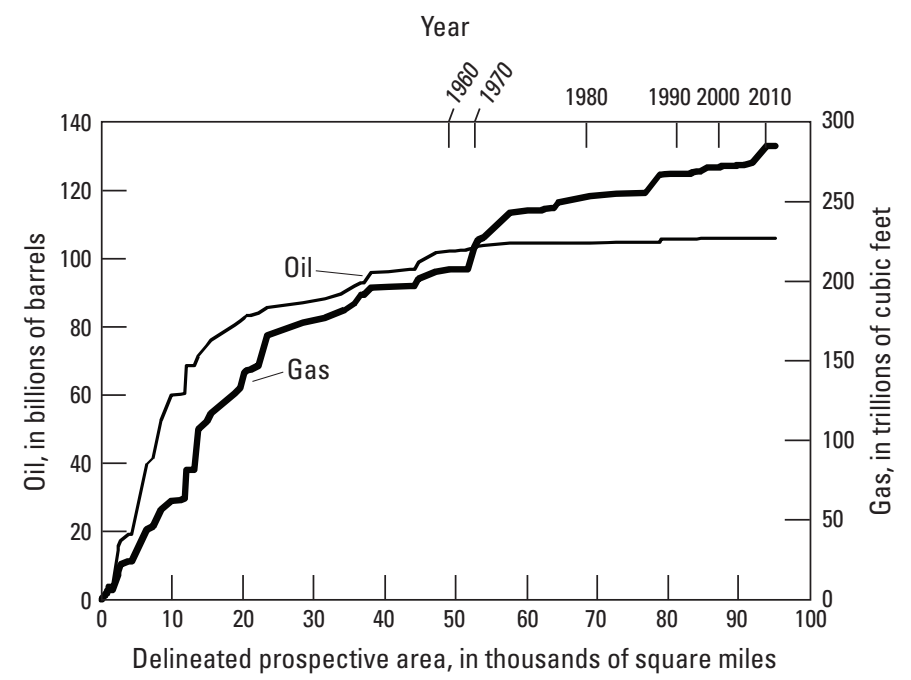

Figure 20. Continued. 
Significant petroleum provinces-Year of first discovery and cumulative recoverable oil and gas discovered through 2015

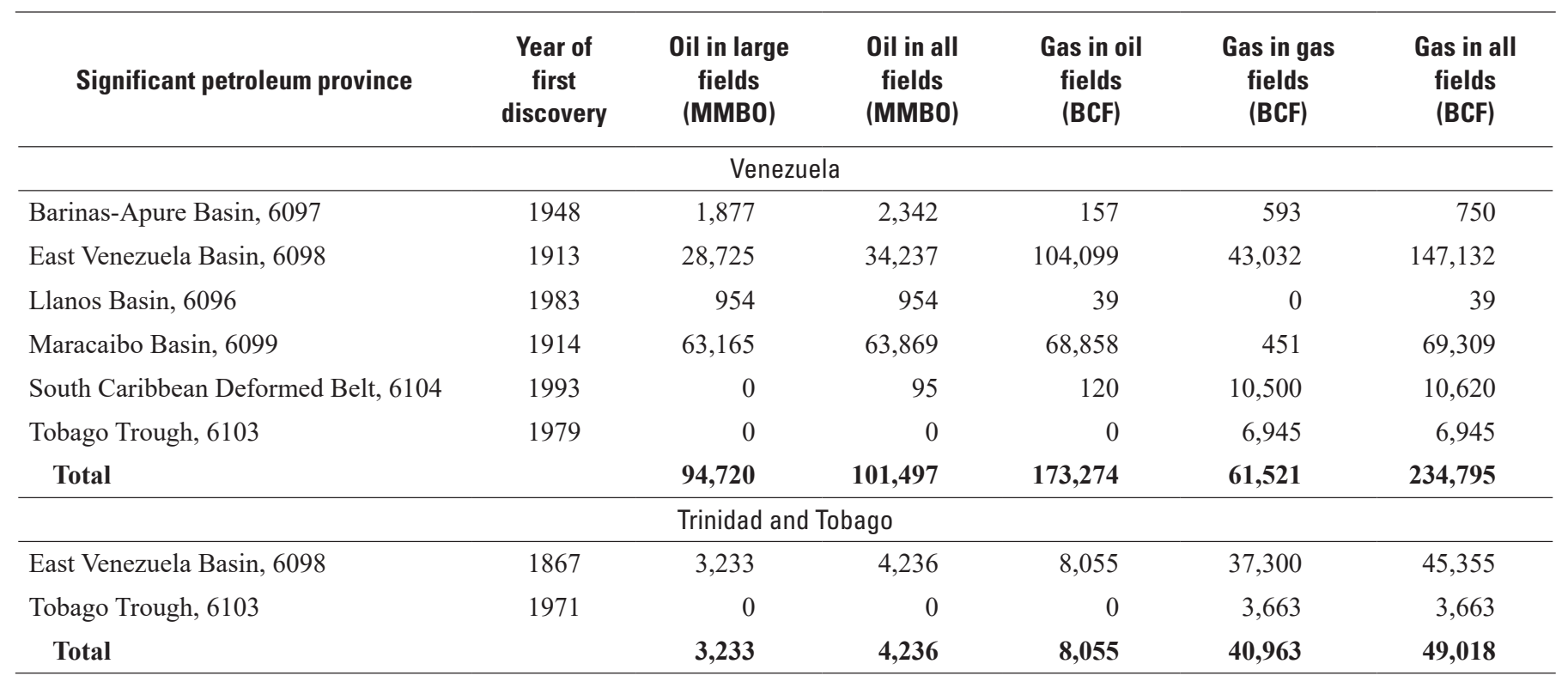

Figure 20. Continued. 


\section{Exploration data}

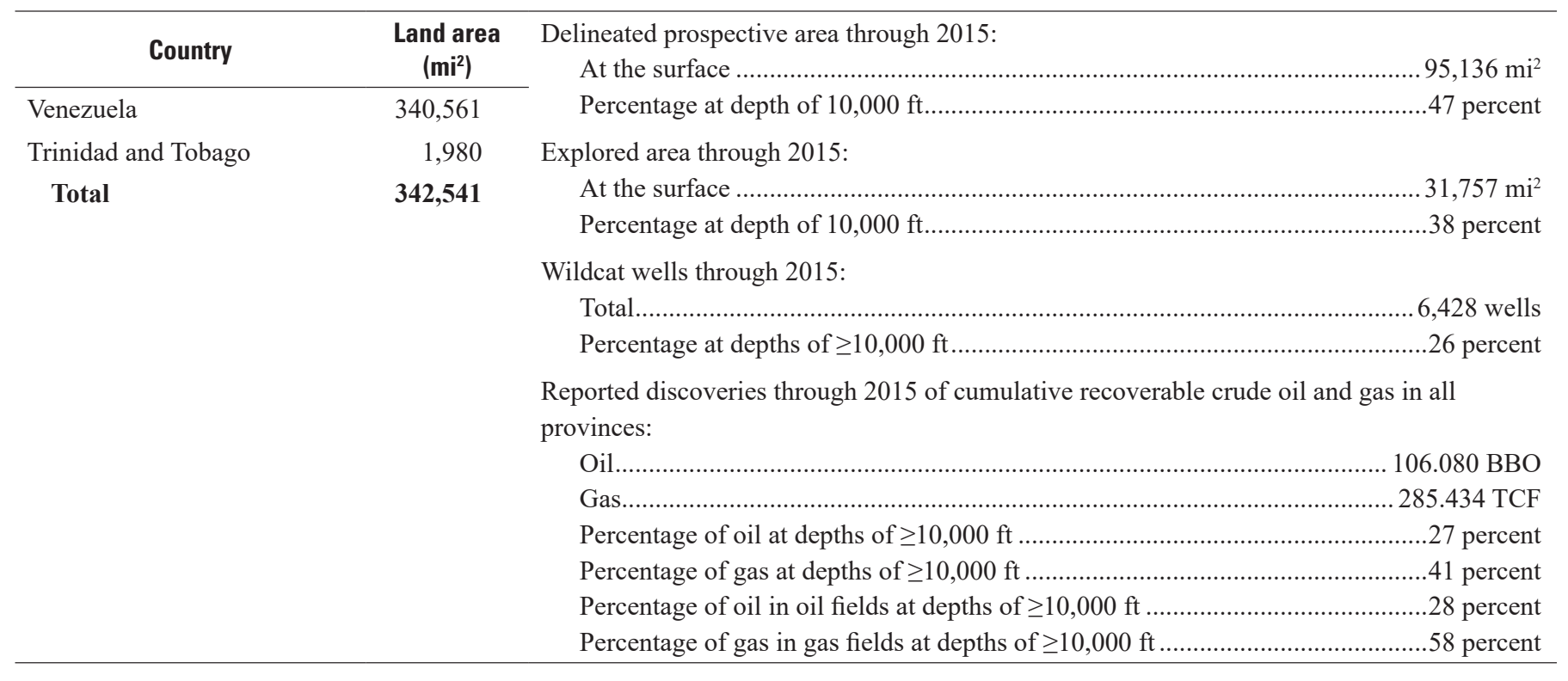

Figure 20. Continued. 


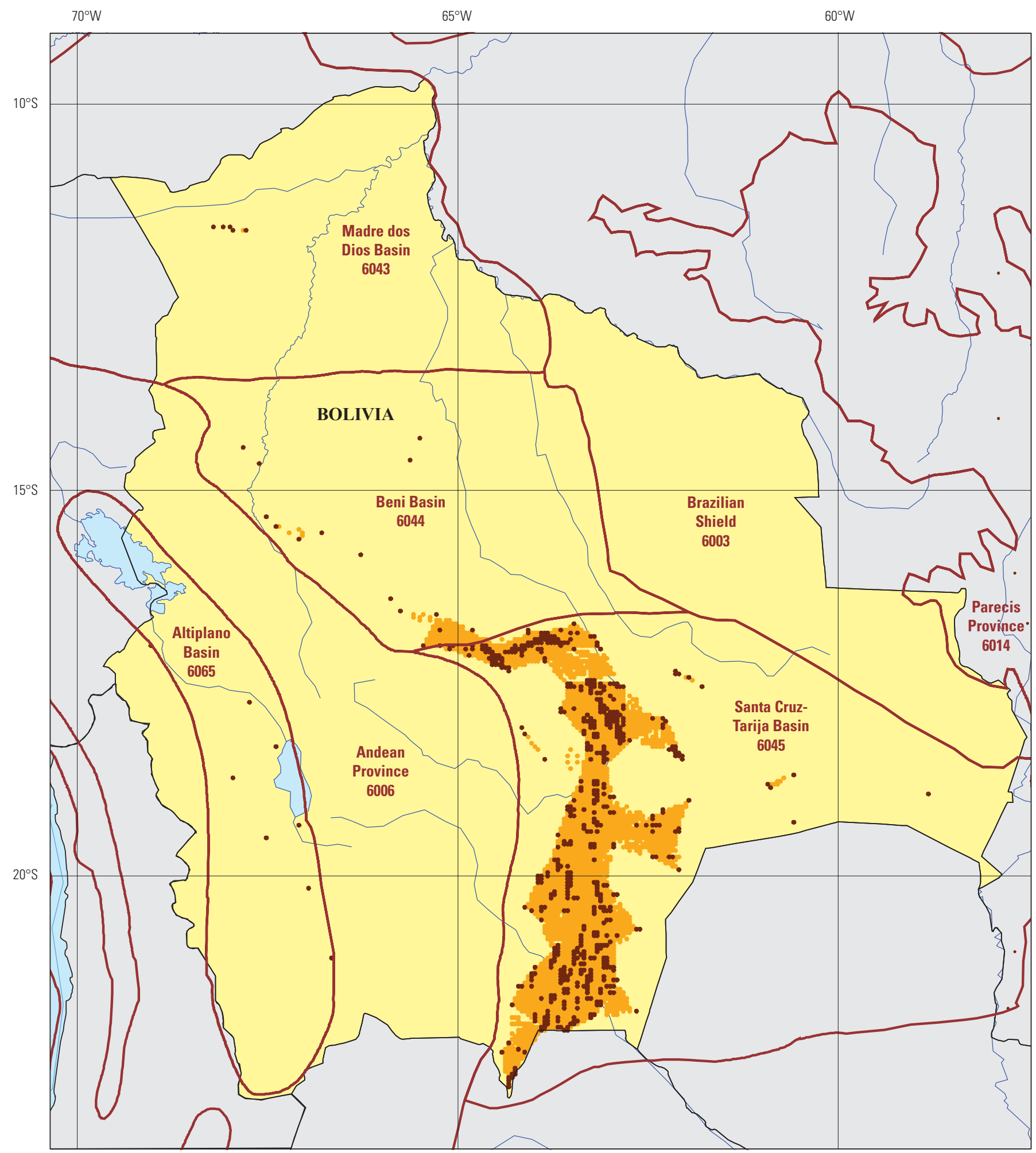

Figure 21. Map, graphs, and tables of data for oil and gas exploration through 2015 in Bolivia. 
Growth in delineated prospective area and explored area through 2015, graphed by the year the areas became prospective or explored

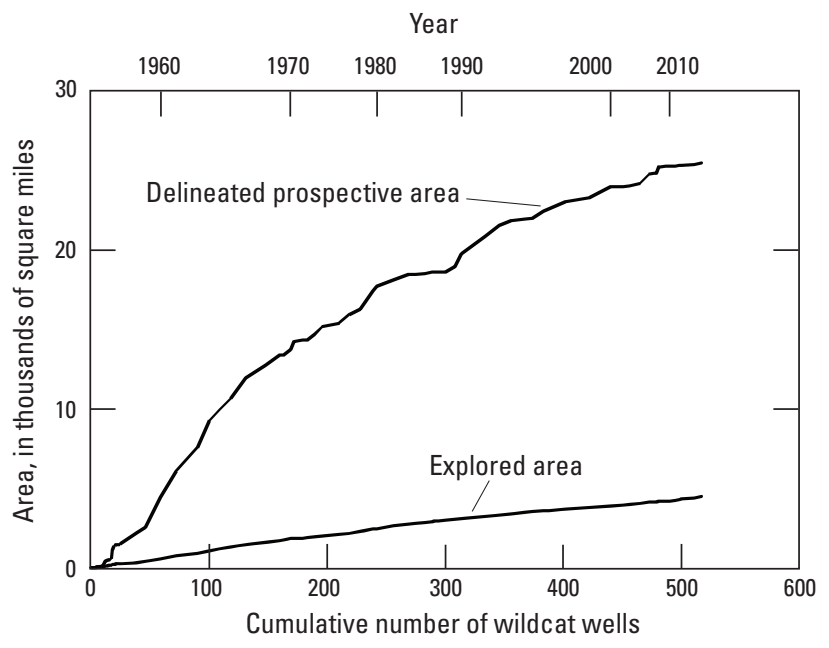

Cumulative recoverable oil and gas discoveries in all provinces through 2015, graphed by the year the field location became part of the delineated prospective area

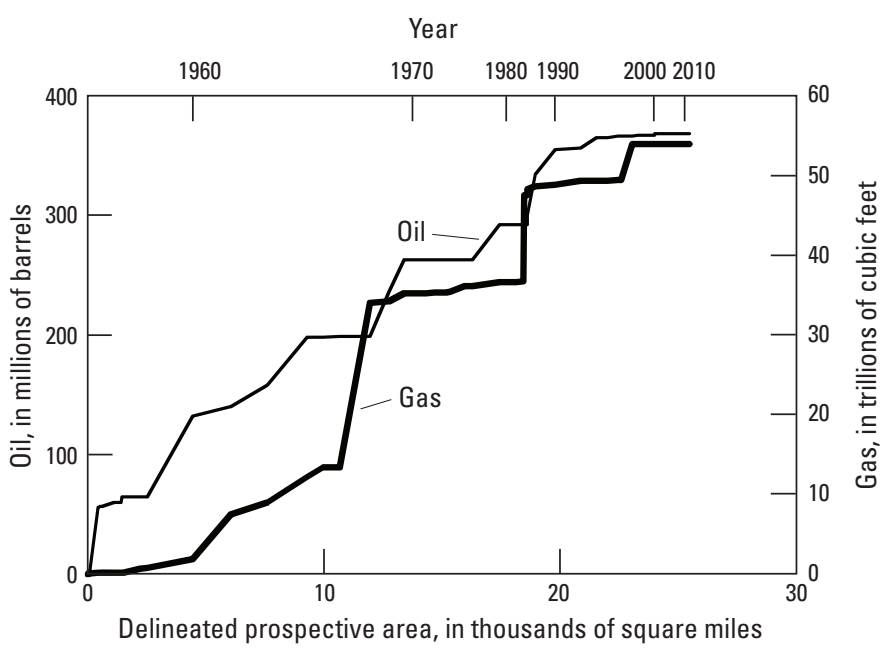

Significant petroleum provinces-Year of first discovery and cumulative recoverable oil and gas discovered through 2015

\begin{tabular}{lcccccr}
\hline Significant petroleum province & $\begin{array}{c}\text { Year of } \\
\text { first } \\
\text { discovery }\end{array}$ & $\begin{array}{c}\text { 0il in large } \\
\text { fields } \\
\text { (MMBO) }\end{array}$ & $\begin{array}{c}\text { Oil in all } \\
\text { fields } \\
\text { (MMB0) }\end{array}$ & $\begin{array}{c}\text { Gas in oil } \\
\text { fields } \\
\text { (BCF) }\end{array}$ & $\begin{array}{c}\text { Gas in gas } \\
\text { fields } \\
\text { (BCF) }\end{array}$ & $\begin{array}{c}\text { Gas in all } \\
\text { fields } \\
\text { (BCF) }\end{array}$ \\
\hline Madre dos Dios Basin, 6043 & 1991 & 0 & 1 & $<1$ & 0 & $<1$ \\
Santa Cruz-Tarija Basin, 6045 & 1924 & 0 & 380 & 1,668 & 52,347 & 54,015 \\
$\quad$ Total & & $\mathbf{0}$ & $\mathbf{3 8 1}$ & $\mathbf{1 , 6 6 8}$ & $\mathbf{5 2 , 3 4 7}$ & $\mathbf{5 4 , 0 1 5}$ \\
\hline
\end{tabular}

\section{Exploration data}

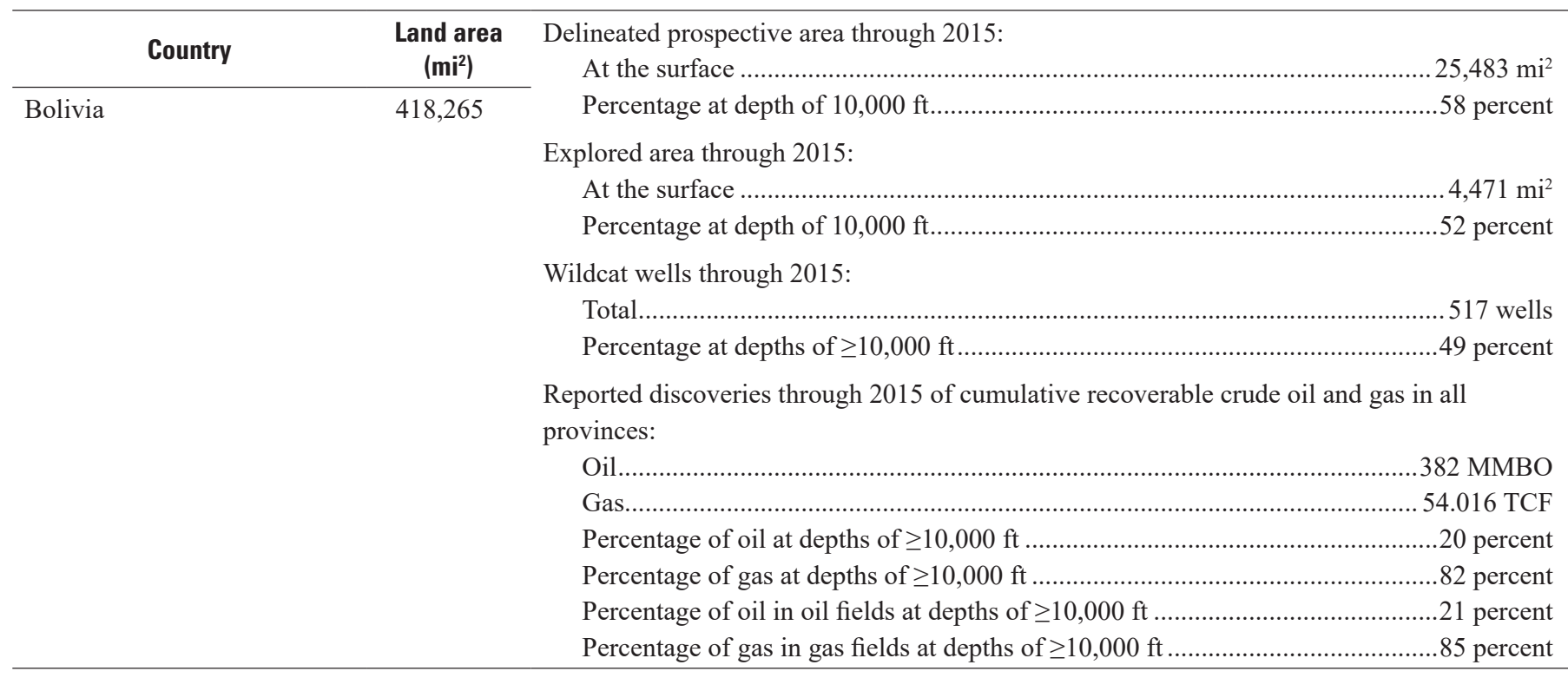

Figure 21. Continued. 


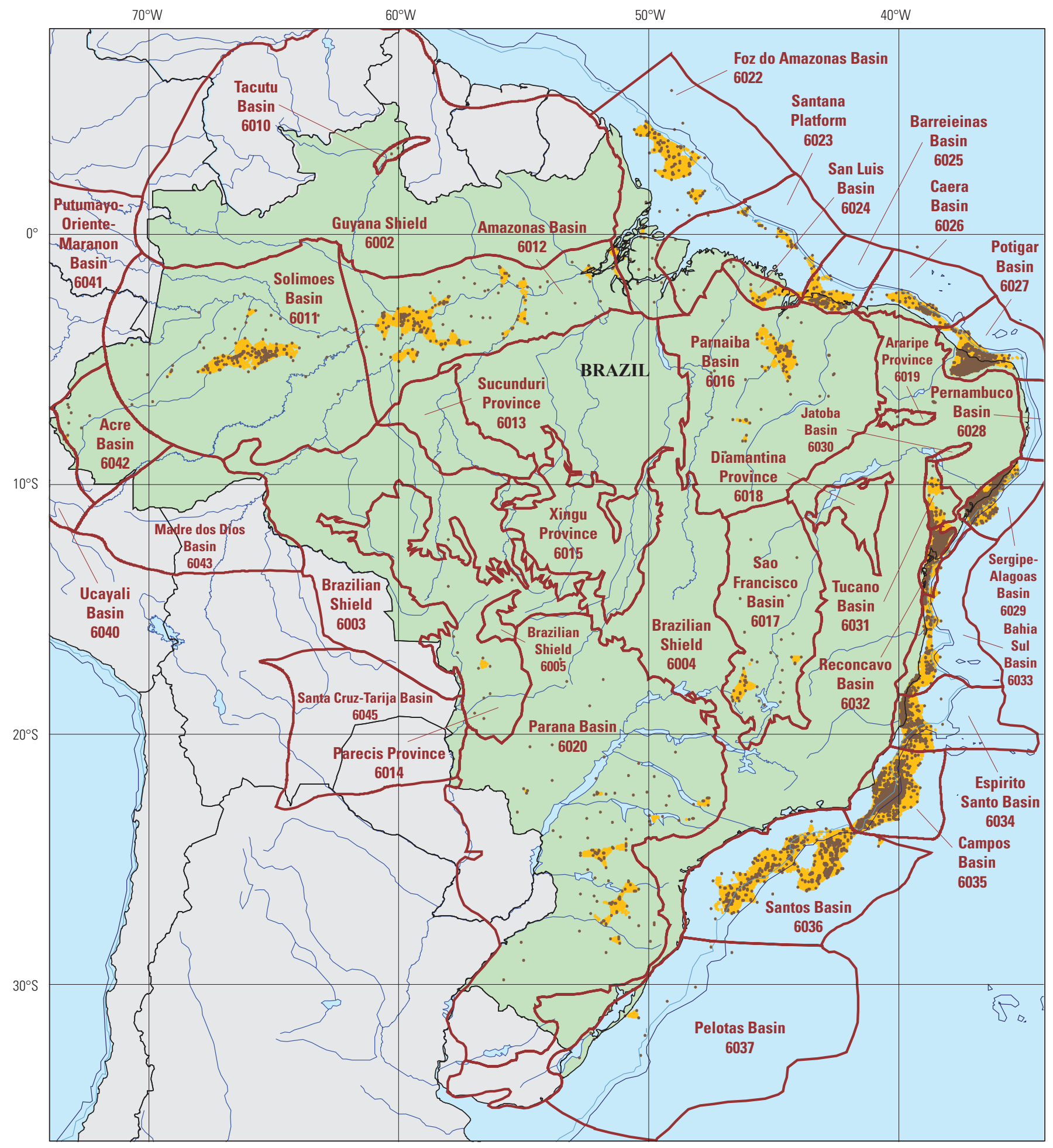

Figure 22. Map, graphs, and tables of data for oil and gas exploration through 2015 in Brazil. 
Growth in delineated prospective area and explored area through 2015, graphed by the year the areas became prospective or explored

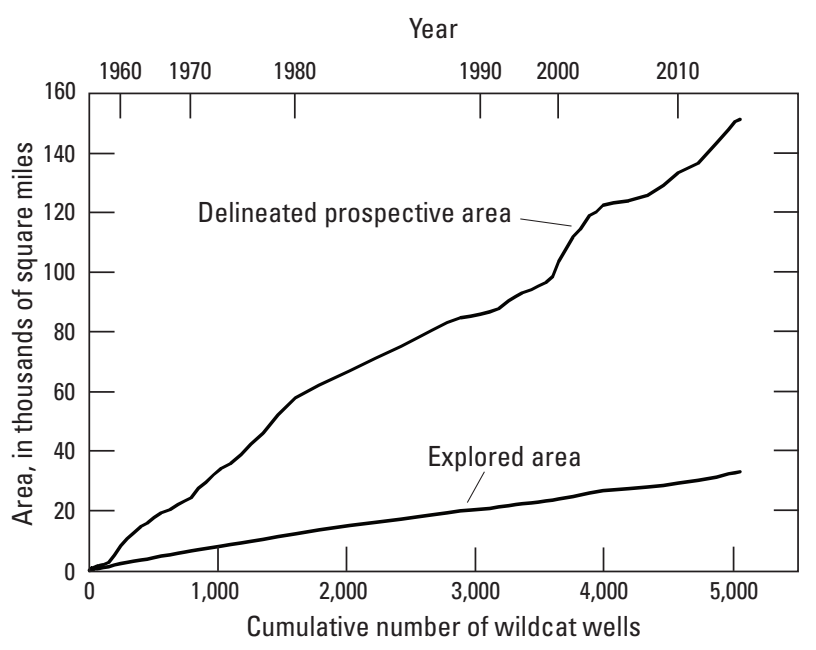

Cumulative recoverable oil and gas discoveries in all provinces through 2015, graphed by the year the field location became part of the delineated prospective area

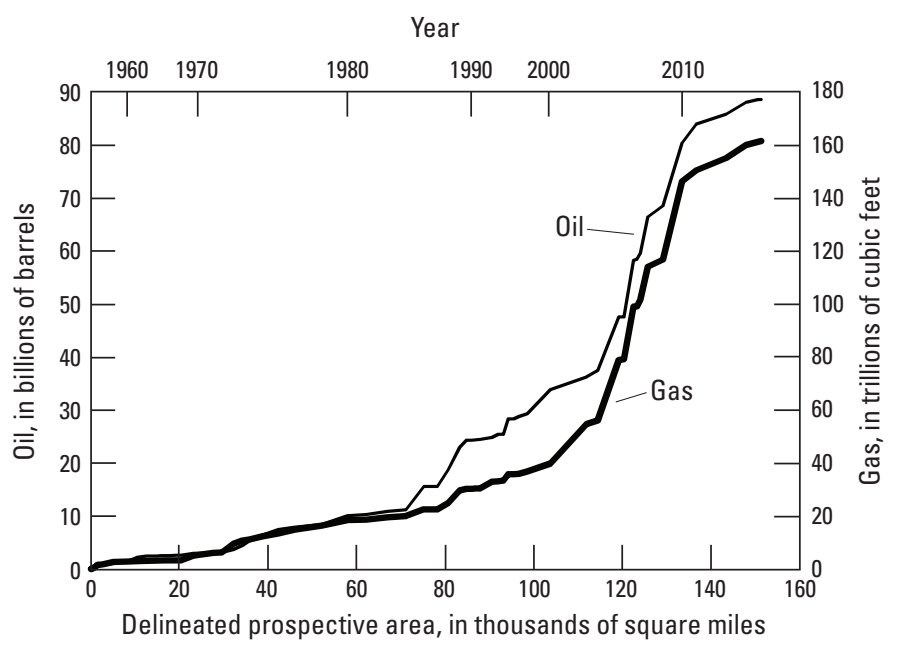

Figure 22. Continued. 
Significant petroleum provinces-Year of first discovery and cumulative recoverable oil and gas discovered through 2015

\begin{tabular}{|c|c|c|c|c|c|c|}
\hline Significant petroleum province & $\begin{array}{c}\text { Year of } \\
\text { first } \\
\text { discovery }\end{array}$ & $\begin{array}{c}\text { Oil in large } \\
\text { fields } \\
\text { (MMBO) } \\
\end{array}$ & $\begin{array}{l}\text { Oil in all } \\
\text { fields } \\
\text { (MMBO) }\end{array}$ & $\begin{array}{c}\text { Gas in oil } \\
\text { fields } \\
\text { (BCF) }\end{array}$ & $\begin{array}{c}\text { Gas in gas } \\
\text { fields } \\
\text { (BCF) } \\
\end{array}$ & $\begin{array}{c}\text { Gas in all } \\
\text { fields } \\
\text { (BCF) }\end{array}$ \\
\hline \multicolumn{7}{|c|}{ Brazil } \\
\hline Caera Basin, 6026 & 1971 & 100 & 294 & 204 & 107 & 311 \\
\hline Campos Basin, 6035 & 1972 & 25,017 & 28,623 & 16,960 & 2,449 & 19,409 \\
\hline Espirito Santo Basin, 6034 & 1969 & 1,953 & 2,837 & 2,101 & 2,957 & 5,058 \\
\hline Potigar Basin, 6027 & 1973 & 1,181 & 2,004 & 2,373 & 1,316 & 3,689 \\
\hline Reconcavo Basin, 6032 & 1939 & 1,311 & 2,040 & 2,678 & 1,710 & 4,388 \\
\hline Santos Basin, 6036 & 1979 & 48,170 & 49,935 & 98,365 & 15,030 & 113,395 \\
\hline Sergipe-Alagoas Basin, 6029 & 1957 & 1,761 & 2,574 & 4,377 & 905 & 5,282 \\
\hline
\end{tabular}

Figure 22. Continued. 


\section{Exploration data}

\begin{tabular}{|c|c|c|}
\hline & $\begin{array}{l}\text { Land area } \\
\qquad\left(\mathrm{mi}^{2}\right)\end{array}$ & 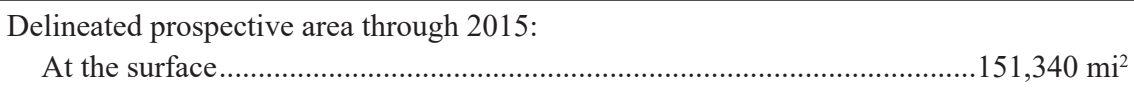 \\
\hline \multirow[t]{10}{*}{ Brazil } & $3,266,199$ & Percentage at depth of $10,000 \mathrm{ft}$ \\
\hline & & Explored area through 2015: \\
\hline & & At the surface...................... \\
\hline & & 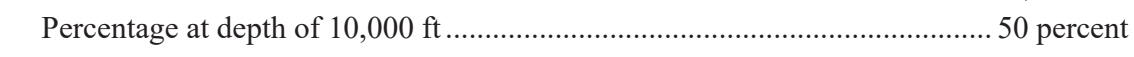 \\
\hline & & Wildcat wells through 2015: \\
\hline & & Percentage at depths of $\geq 10,000 \mathrm{ft}$ \\
\hline & & $\begin{array}{l}\text { Reported discoveries through } 2015 \text { of cumulative recoverable crude oil and gas in all } \\
\text { provinces: }\end{array}$ \\
\hline & & Oil \\
\hline & & Gas \\
\hline & & 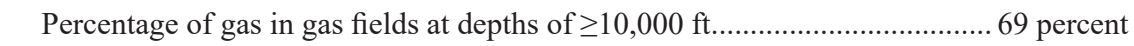 \\
\hline
\end{tabular}

Figure 22. Continued. 


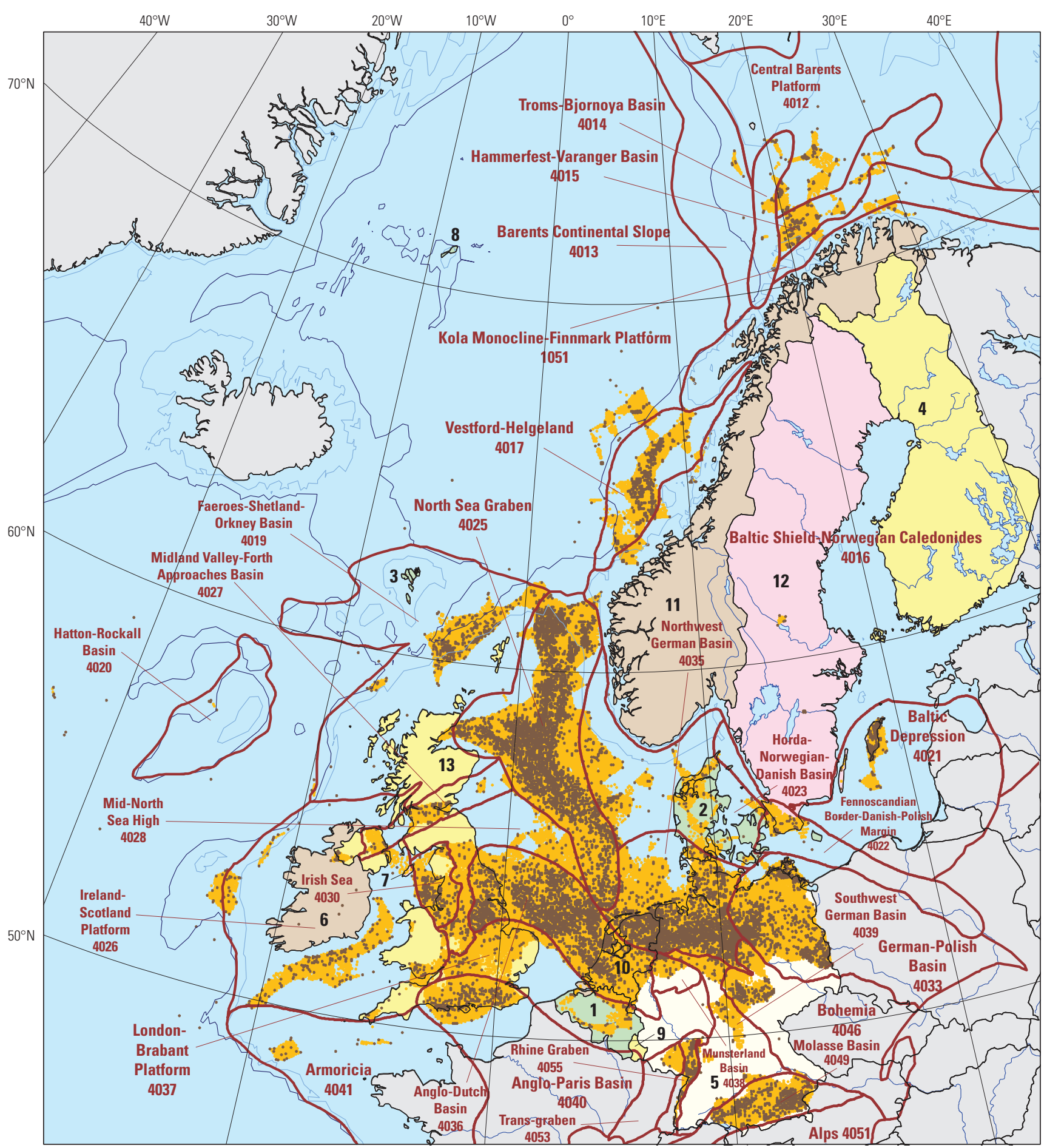

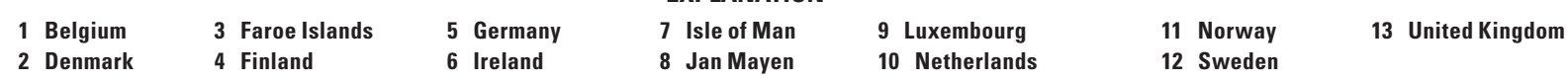

Figure 23. Maps, graphs, and tables of data for oil and gas exploration through 2015 in the northern part of Western Europe. For this figure, the parts mapped are the United Kingdom, Norway, Germany, Denmark, Netherlands, Ireland, Sweden, Belgium, Faroe Islands, Finland, Luxembourg, Svalbard, Jan Mayen, and the Isle of Man. The Faroe Islands are a self-governing overseas administrative division of Denmark. Svalbard (a territory of Norway) is a group of islands in the Arctic Ocean; see the separate small map. Data for Greenland and Iceland are not mapped and are not included in the exploration data; they had no discoveries through 2015. 


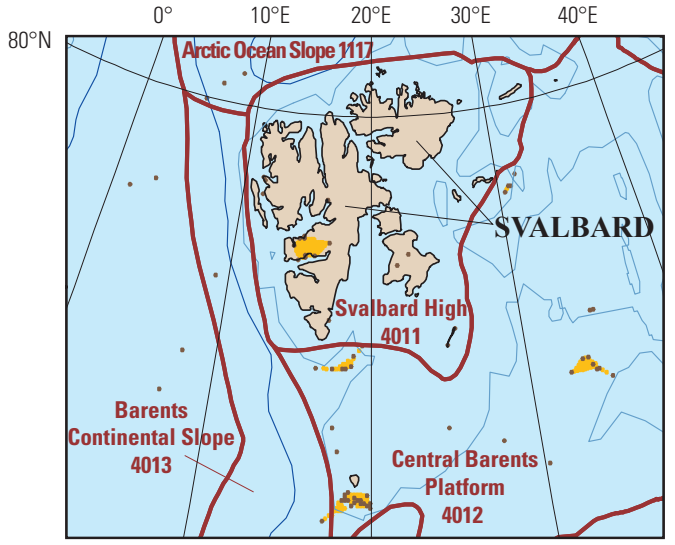

Map of oil and gas exploration through 2015 in Svalbard.

Growth in delineated prospective area and explored area through 2015, graphed by the year the areas became prospective or explored

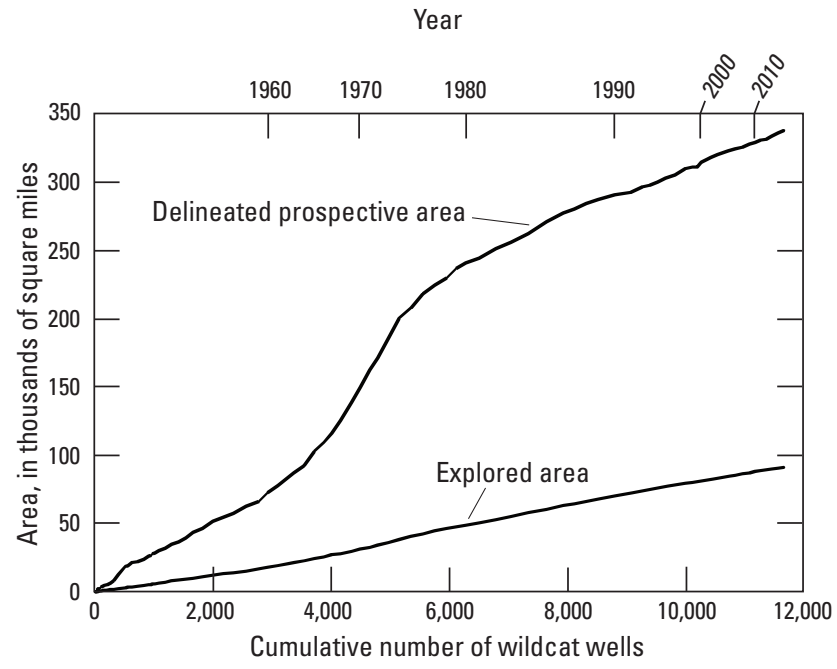

Figure 23. Continued.
Cumulative recoverable oil and gas discoveries in all provinces through 2015, graphed by the year the field location became part of the delineated prospective area

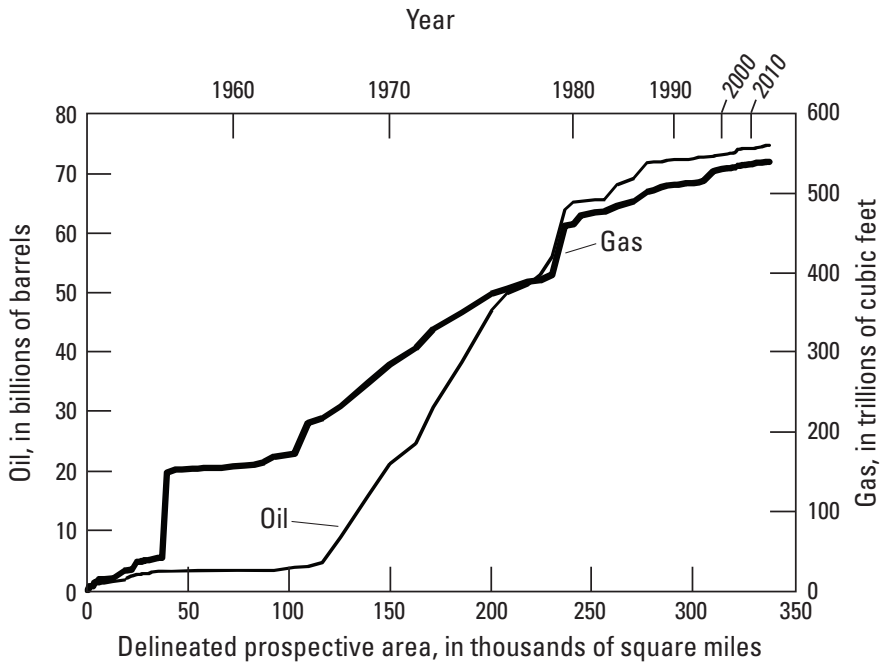


Significant petroleum provinces-Year of first discovery and cumulative recoverable oil and gas discovered through 2015

\begin{tabular}{|c|c|c|c|c|c|c|}
\hline Significant petroleum province & $\begin{array}{c}\text { Year of } \\
\text { first } \\
\text { discovery }\end{array}$ & $\begin{array}{l}\text { Oil in large } \\
\text { fields } \\
\text { (MMBO) }\end{array}$ & $\begin{array}{l}\text { Oil in all } \\
\text { fields } \\
\text { (MMBO) }\end{array}$ & $\begin{array}{l}\text { Gas in oil } \\
\text { fields } \\
\text { (BCF) }\end{array}$ & $\begin{array}{c}\text { Gas in gas } \\
\text { fields } \\
\text { (BCF) }\end{array}$ & $\begin{array}{c}\text { Gas in all } \\
\text { fields } \\
\text { (BCF) }\end{array}$ \\
\hline \multicolumn{7}{|c|}{ United Kingdom } \\
\hline Anglo-Dutch Basin, 4036 & 1919 & 0 & 88 & 35 & 61,577 & 61,612 \\
\hline Anglo-Paris Basin, 4040 & 1896 & 515 & 613 & 219 & 93 & 313 \\
\hline Faeroes-Shetland-Orkney Basin, 4019 & 1977 & 2,497 & 2,941 & 2,412 & 4,200 & 6,612 \\
\hline Irish Sea, 4030 & 1939 & 115 & 246 & 425 & 9,764 & 10,189 \\
\hline North Sea Graben, 4025 & 1969 & 22,703 & 28,965 & 35,086 & 31,772 & 66,858 \\
\hline Total & & 25,830 & 32,852 & 38,177 & 107,884 & 146,061 \\
\hline \multicolumn{7}{|c|}{ Norway } \\
\hline North Sea Graben, 4025 & 1967 & 23,649 & 28,791 & 42,132 & 80,368 & 122,500 \\
\hline Vestford-Helgeland, 4017 & 1981 & 3,819 & 4,546 & 11,086 & 24,503 & 35,589 \\
\hline Undesignated offshore area & & 0 & 1 & 0 & 4,721 & 4,721 \\
\hline Total & & 28,523 & 34,750 & 55,164 & 121,890 & 177,054 \\
\hline \multicolumn{7}{|c|}{ Germany } \\
\hline Bohemia, 4046 & 1930 & 0 & 1 & $<1$ & 330 & 331 \\
\hline German-Polish Basin, 4033 & 1925 & 0 & 29 & 49 & 3,698 & 3,746 \\
\hline North Sea Graben, 4025 & 1974 & 0 & 0 & 0 & 450 & 450 \\
\hline Northwest German Basin, 4035 & 1856 & 1,090 & 2,313 & 1,245 & 32,373 & 33,618 \\
\hline \multicolumn{7}{|c|}{ Netherlands } \\
\hline Anglo-Dutch Basin, 4036 & 1952 & 0 & 675 & 361 & 28,613 & 28,974 \\
\hline North Sea Graben, 4025 & 1968 & 0 & 186 & 792 & 5,592 & 6,384 \\
\hline Northwest German Basin, 4035 & 1943 & 411 & 413 & 369 & 125,850 & 126,219 \\
\hline Total & & 411 & 1,274 & 1,522 & 160,055 & 161,577 \\
\hline \multicolumn{7}{|c|}{ Ireland } \\
\hline Ireland-Scotland Platform, 4026 & 1963 & 327 & 432 & 267 & 4,175 & 4,442 \\
\hline Undesignated offshore area & & 0 & 0 & 0 & 325 & 325 \\
\hline Total & & 327 & 432 & 267 & 4,500 & 4,767 \\
\hline \multicolumn{7}{|c|}{ Faroe Islands } \\
\hline Faeroes-Shetland-Orkney Basin, 4019 & 2001 & 0 & 20 & 6 & 0 & 6 \\
\hline
\end{tabular}

Figure 23. Continued. 


\section{Exploration data}

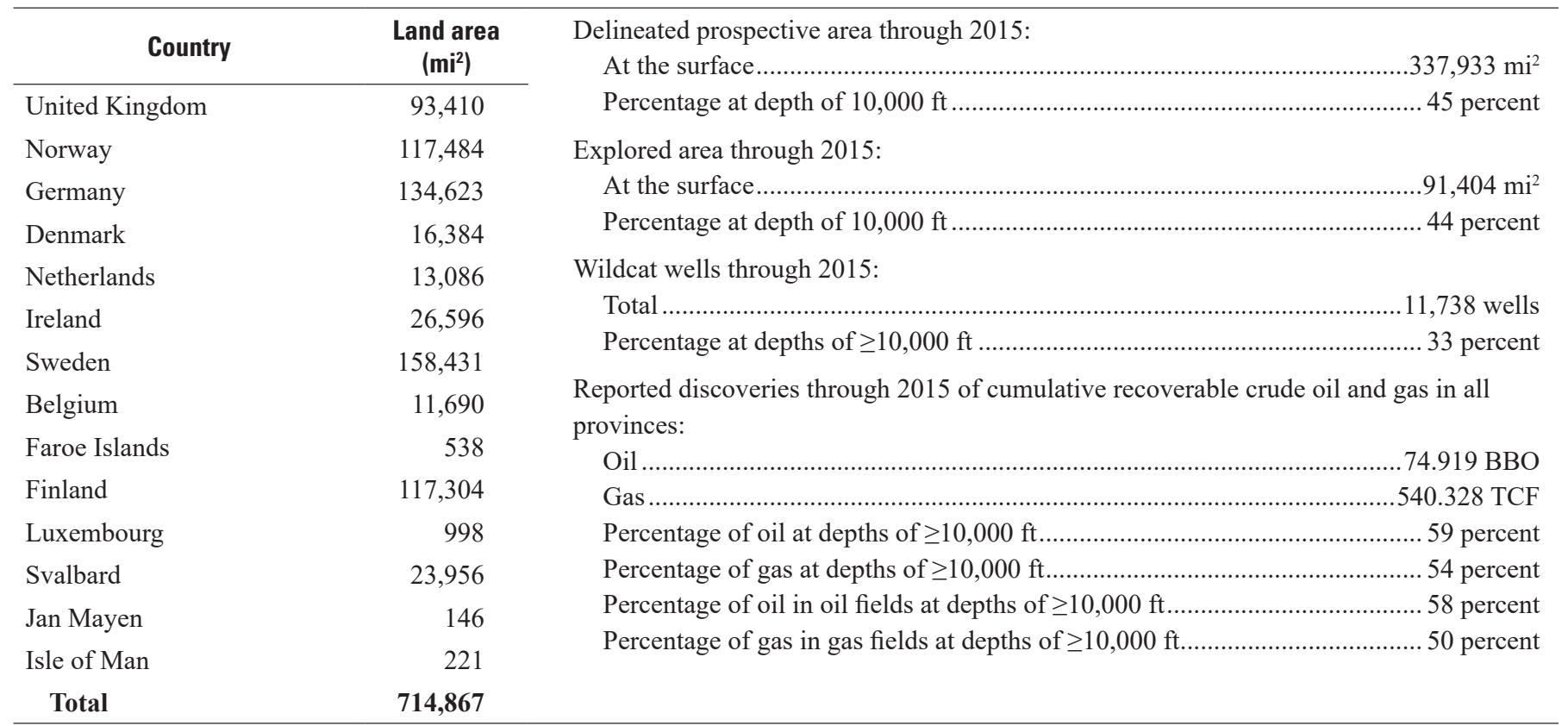

Figure 23. Continued. 


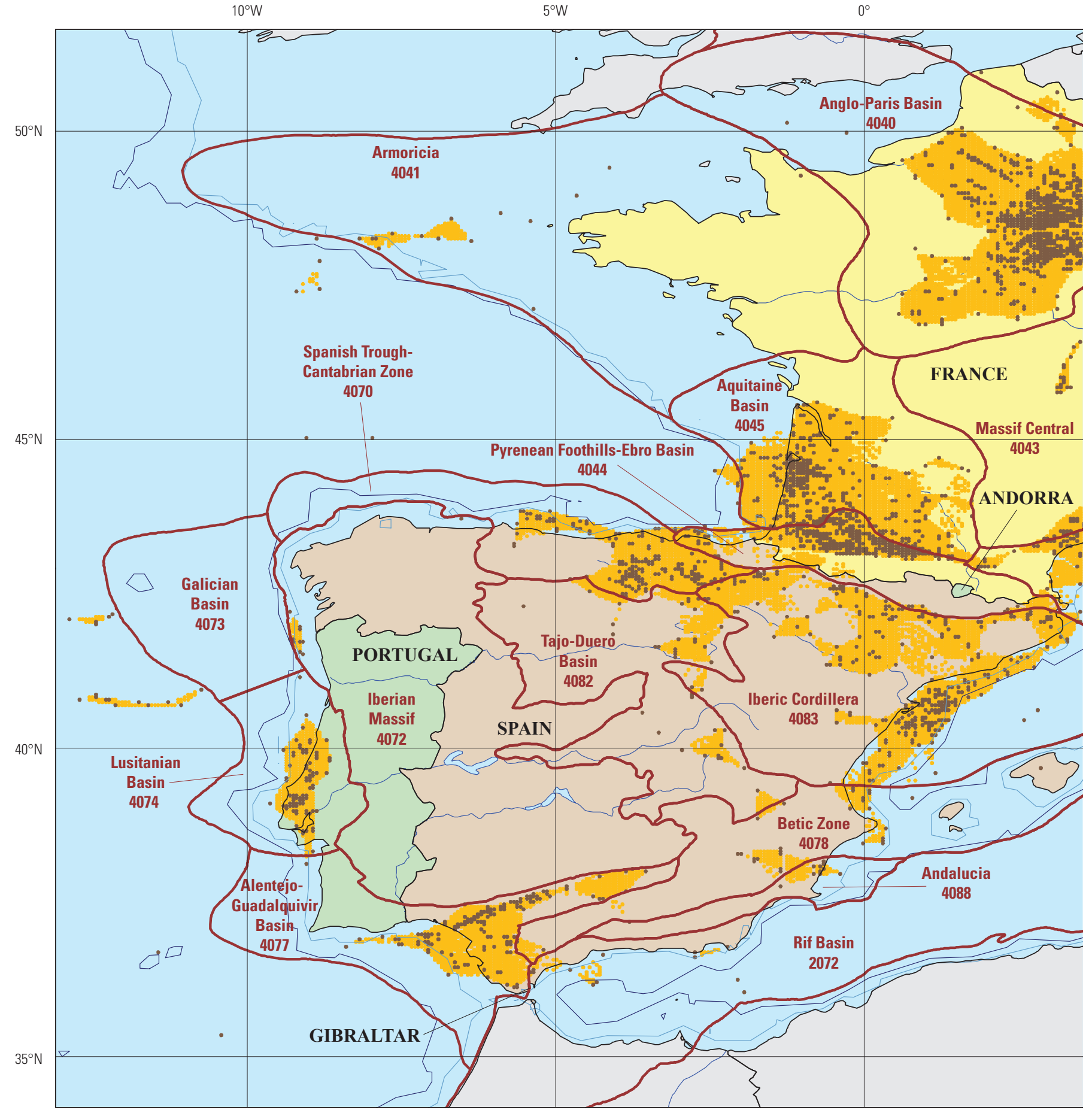

Figure 24. Map, graphs, and tables of data for oil and gas exploration through 2015 in the southern part of Western Europe. For this figure, the parts mapped are Italy, Austria, France, Spain, Portugal, Switzerland, Andorra, Liechtenstein, Malta, Monaco, San Marino, and Gibraltar (an overseas territory of the United Kingdom). 


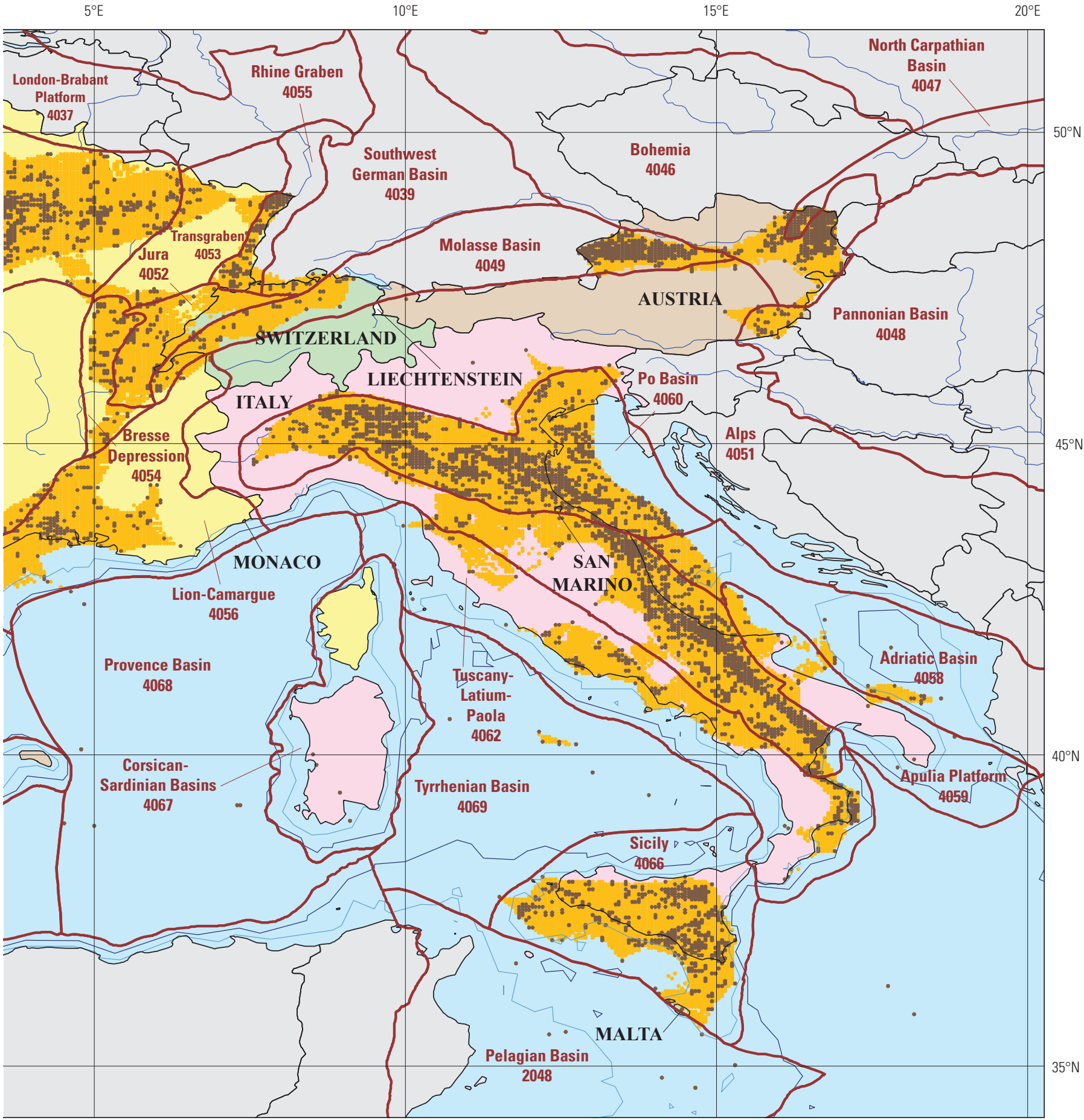

Figure 24. Continued. 
Growth in delineated prospective area and explored area through 2015 , graphed by the year the areas became prospective or explored

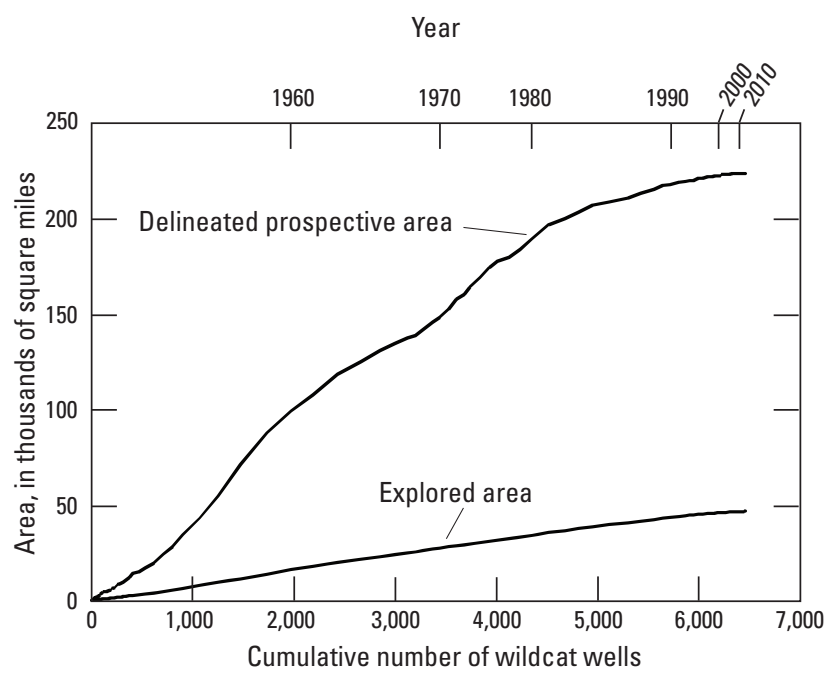

Cumulative recoverable oil and gas discoveries in all provinces through 2015, graphed by the year the field location became part of the delineated prospective area

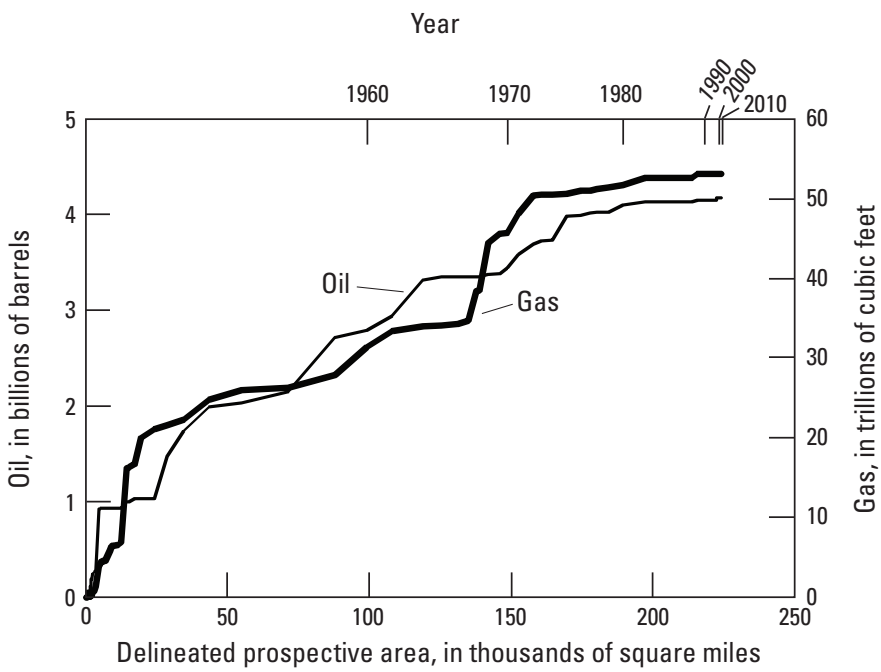

Significant petroleum provinces - Year of first discovery and cumulative recoverable oil and gas discovered through 2015

\begin{tabular}{|c|c|c|c|c|c|c|}
\hline Significant petroleum province & $\begin{array}{c}\text { Year of } \\
\text { first } \\
\text { discovery }\end{array}$ & $\begin{array}{l}\text { Oil in large } \\
\text { fields } \\
\text { (MMBO) }\end{array}$ & $\begin{array}{l}\text { Oil in all } \\
\text { fields } \\
\text { (MMBO) }\end{array}$ & $\begin{array}{l}\text { Gas in oil } \\
\text { fields } \\
\text { (BCF) }\end{array}$ & $\begin{array}{l}\text { Gas in gas } \\
\text { fields } \\
\text { (BCF) }\end{array}$ & $\begin{array}{c}\text { Gas in all } \\
\text { fields } \\
\text { (BCF) }\end{array}$ \\
\hline \multicolumn{7}{|c|}{ Italy } \\
\hline Adriatic Basin, 4058 & 1978 & 0 & 82 & 34 & 200 & 234 \\
\hline Alps, 4051 & 1860 & 740 & 1,090 & 1,067 & 5,793 & 6,859 \\
\hline Sicily, 4066 & 1940 & 348 & 565 & 110 & 1,361 & 1,471 \\
\hline Tuscany-Latium-Paola, 4062 & 1915 & 0 & 1 & 1 & 2,579 & 2,580 \\
\hline Total & & 1,353 & 2,070 & 1,390 & 33,701 & 35,091 \\
\hline \multicolumn{7}{|c|}{ Austria } \\
\hline Total & & 590 & 873 & 2,218 & 1,917 & 4,136 \\
\hline \multicolumn{7}{|c|}{ France } \\
\hline Anglo-Paris Basin, 4040 & 1954 & 0 & 339 & 24 & 83 & 107 \\
\hline Aquitaine Basin, 4045 & 1954 & 237 & 403 & 34 & 0 & 34 \\
\hline Pyrenean Foothills-Ebro Basin, 4044 & 1939 & 0 & 132 & 138 & 11,818 & 11,956 \\
\hline Total & & 237 & 874 & 197 & 11,901 & 12,098 \\
\hline
\end{tabular}

Figure 24. Continued. 
Significant petroleum provinces-Year of first discovery and cumulative recoverable oil and gas discovered through 2015—Continued

\begin{tabular}{|c|c|c|c|c|c|c|}
\hline Significant petroleum province & $\begin{array}{c}\text { Year of } \\
\text { first } \\
\text { discovery }\end{array}$ & $\begin{array}{l}\text { Oil in large } \\
\text { fields } \\
\text { (MMBO) }\end{array}$ & $\begin{array}{l}\text { Oil in all } \\
\text { fields } \\
\text { (MMBO) }\end{array}$ & $\begin{array}{l}\text { Gas in oil } \\
\text { fields } \\
\text { (BCF) }\end{array}$ & $\begin{array}{l}\text { Gas in gas } \\
\text { fields } \\
\text { (BCF) }\end{array}$ & $\begin{array}{l}\text { Gas in all } \\
\text { fields } \\
\text { (BCF) }\end{array}$ \\
\hline \multicolumn{7}{|c|}{ Spain } \\
\hline Iberic Cordillera, 4083 & 1967 & 160 & 293 & 115 & 126 & 241 \\
\hline Pyrenean Foothills-Ebro Basin, 4044 & 1980 & 0 & 0 & 0 & 299 & 299 \\
\hline Total & & 160 & 293 & 115 & 425 & 540 \\
\hline \multicolumn{7}{|c|}{ Malta } \\
\hline Sicily, 4066 & 1999 & 0 & 0 & 0 & $<1$ & $<1$ \\
\hline \multicolumn{7}{|c|}{ San Marino } \\
\hline Po Basin, 4060 & 1960 & 0 & 0 & 0 & 1 & 1 \\
\hline
\end{tabular}

\section{Exploration data}

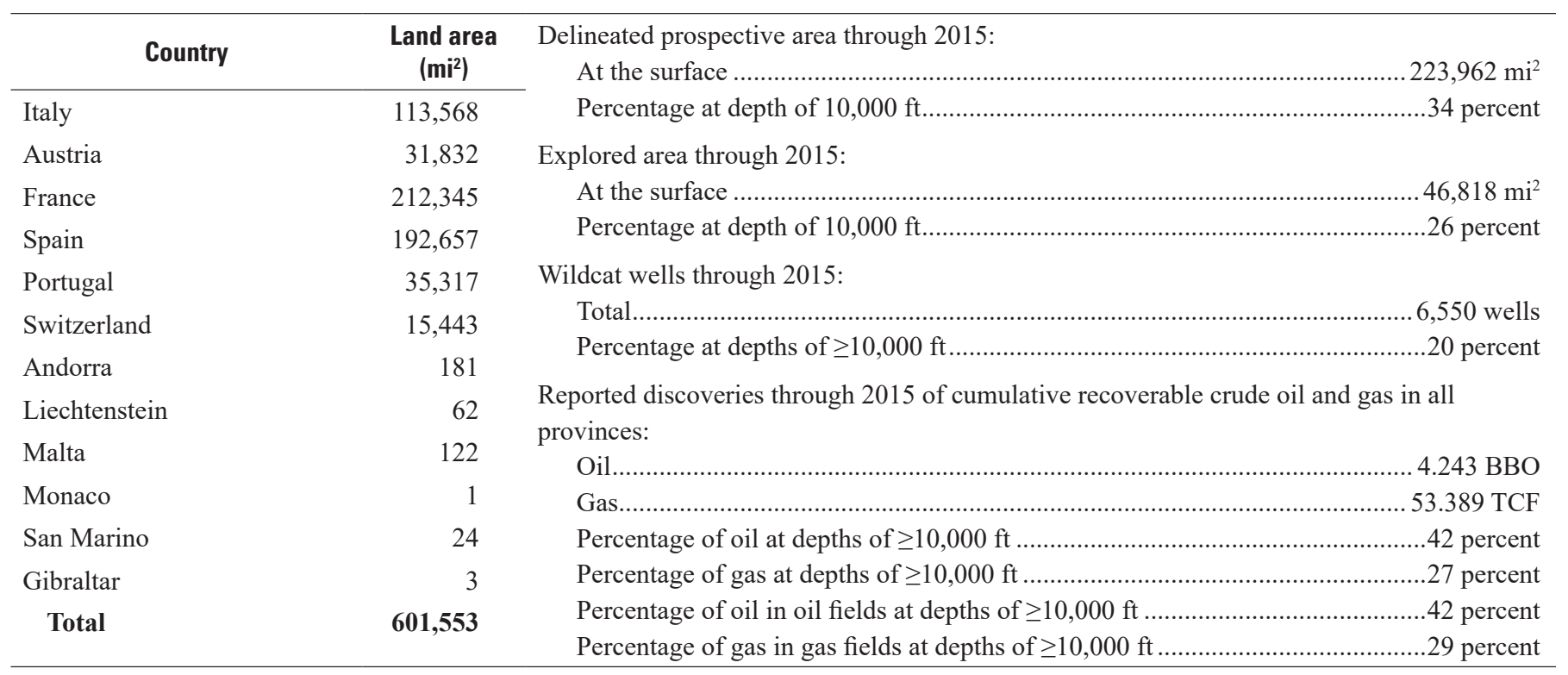

Figure 24. Continued. 


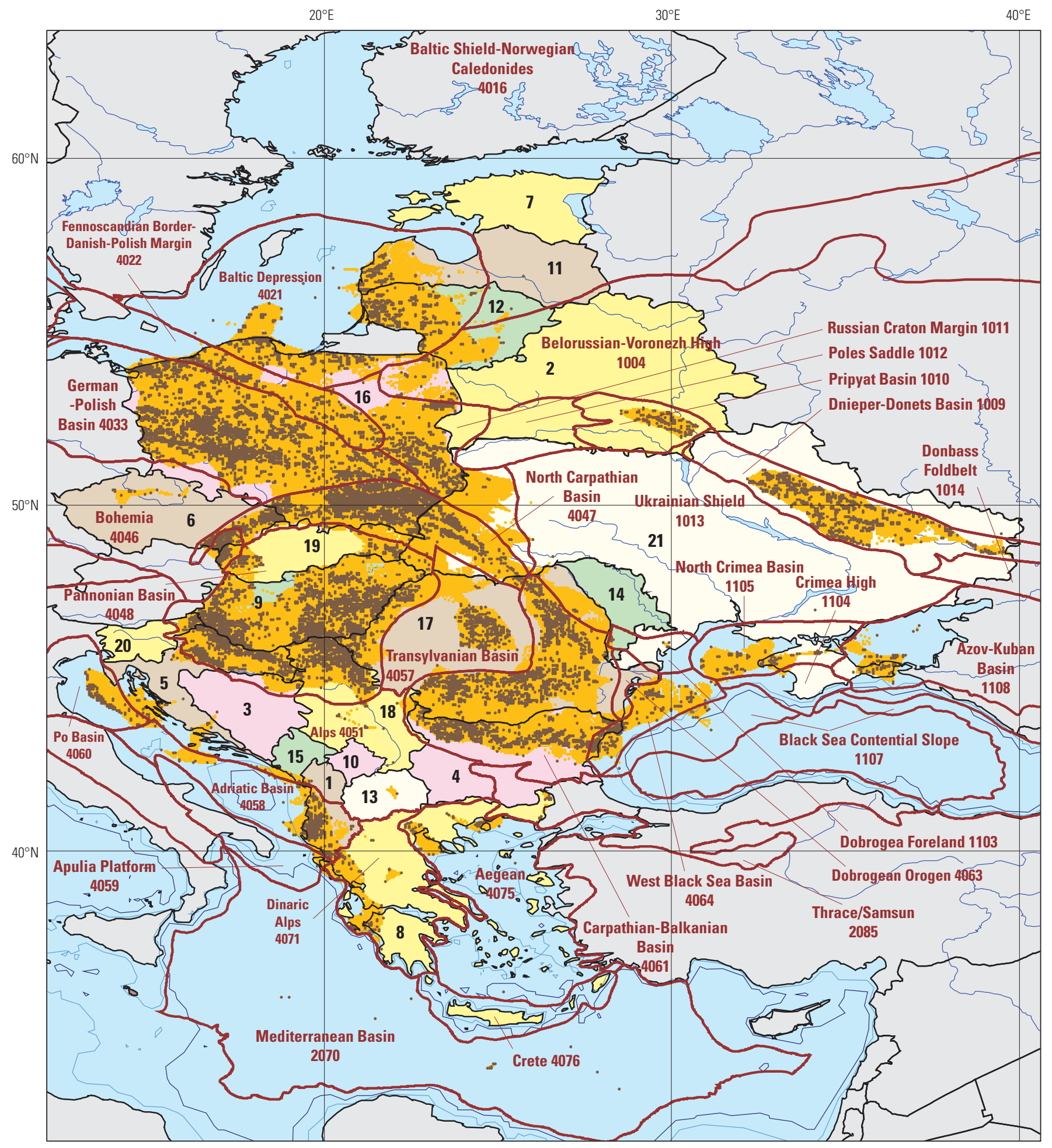

\section{EXPLANATION}

\begin{tabular}{|c|c|c|c|c|c|c|c|}
\hline 1 Albania & 6 Czech Republic & 10 & Kosovo & 14 & Moldova & 18 & Serbia \\
\hline 2 Belarus & 7 Estonia & 11 & Latvia & 15 & Montenegro & 19 & Slovakia \\
\hline Bosnia and Herzegovina & 8 Greece & 12 & Lithuania & 16 & Poland & 20 & Slovenia \\
\hline $\begin{array}{ll}4 & \text { Bulgaria } \\
5 & \text { Croatia }\end{array}$ & 9 Hungary & 13 & Macedonia & 17 & Romania & 21 & Ukraine \\
\hline
\end{tabular}

Figure 25. Map, graphs, and tables of data for oil and gas exploration through 2015 in Eastern Europe. For this figure, the parts mapped are Romania, Ukraine, Belarus, Hungary, Albania, Serbia, Montenegro, Kosovo, Croatia, Poland, Czech Republic, Greece, Bulgaria, Slovakia, Slovenia, Moldova, Lithuania, Latvia, Bosnia and Herzegovina, Estonia, and Macedonia. 
Growth in delineated prospective area and explored area through 2015, graphed by the year the areas became prospective or explored

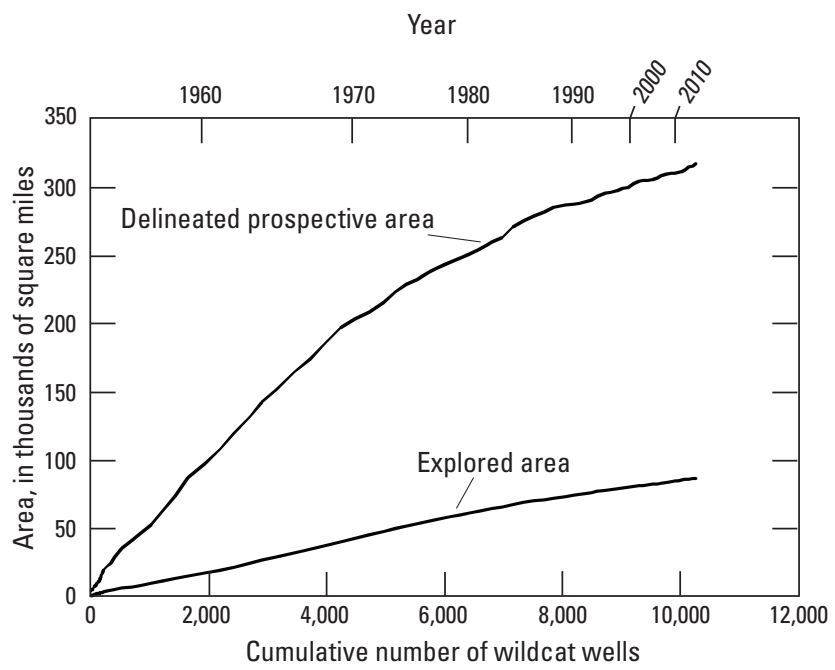

Cumulative recoverable oil and gas discoveries in all provinces through 2015, graphed by the year the field location became part of the delineated prospective area

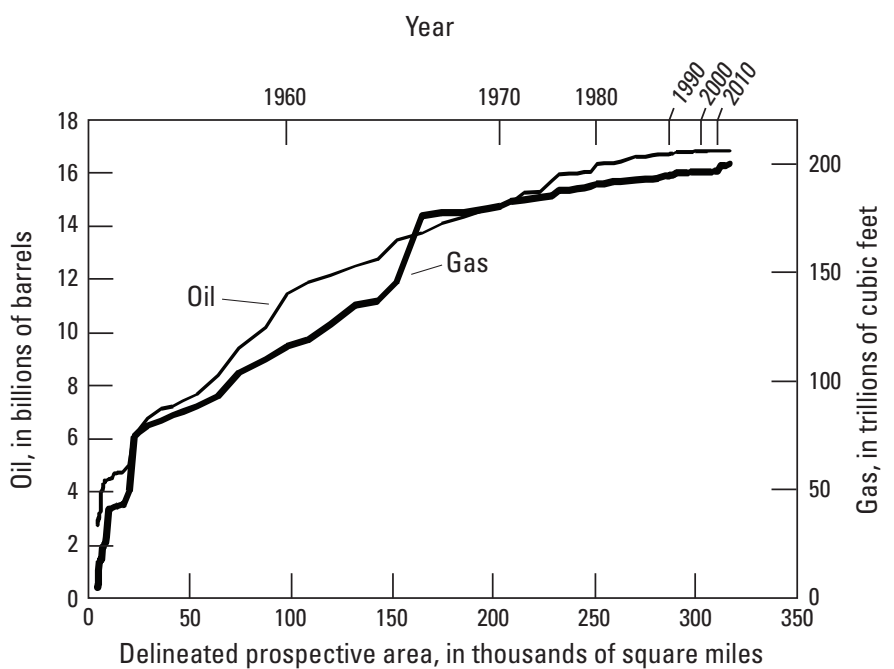

Figure 25. Continued. 
Significant petroleum provinces-Year of first discovery and cumulative recoverable oil and gas discovered through 2015

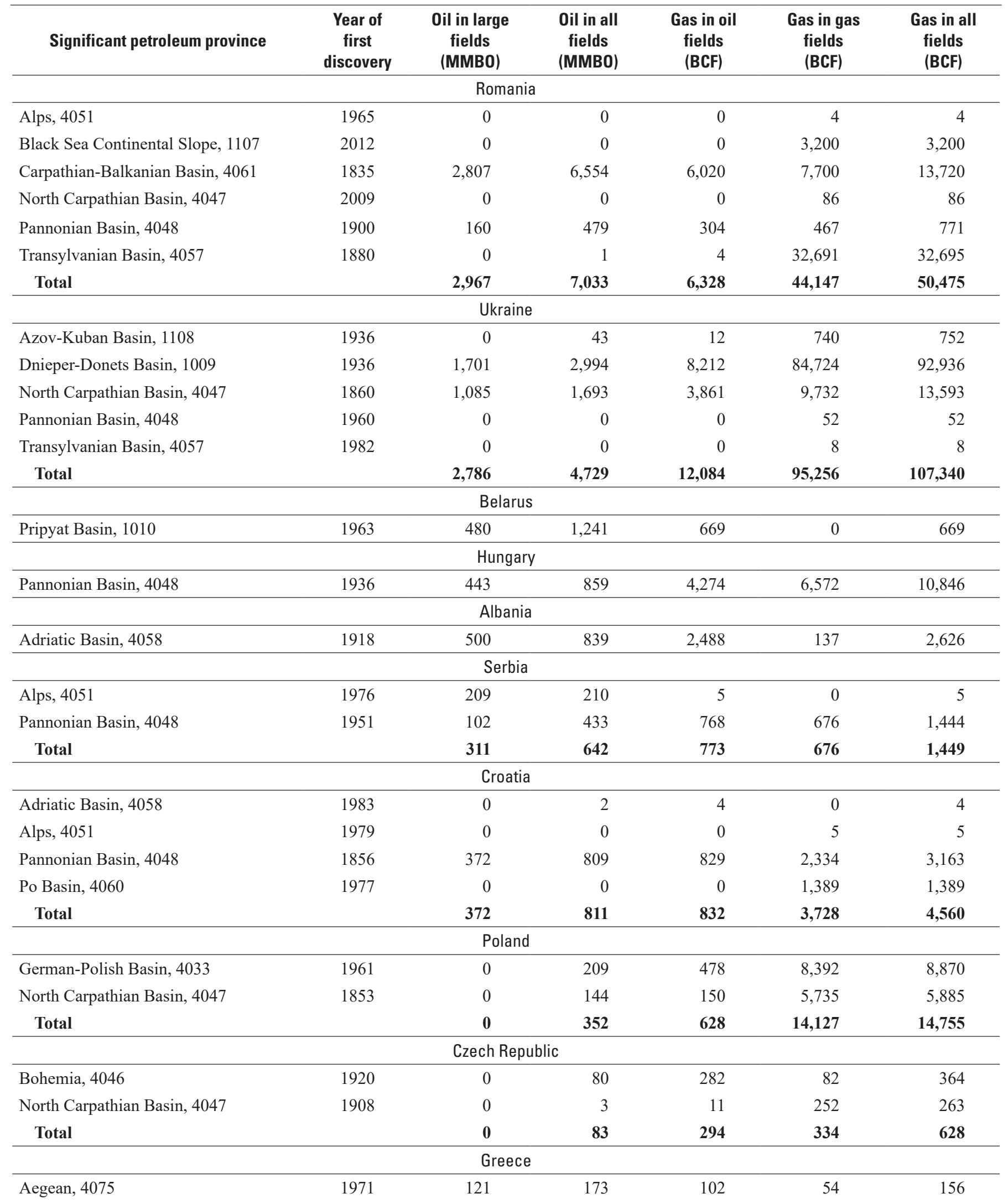

Figure 25. Continued. 
Significant petroleum provinces—Year of first discovery and cumulative recoverable oil and gas discovered through 2015—Continued

\begin{tabular}{|c|c|c|c|c|c|c|}
\hline Significant petroleum province & $\begin{array}{c}\text { Year of } \\
\text { first } \\
\text { discovery }\end{array}$ & $\begin{array}{l}\text { Oil in large } \\
\text { fields } \\
\text { (MMBO) }\end{array}$ & $\begin{array}{c}\text { Oil in all } \\
\text { fields } \\
\text { (MMBO) }\end{array}$ & $\begin{array}{l}\text { Gas in oil } \\
\text { fields } \\
\text { (BCF) }\end{array}$ & $\begin{array}{l}\text { Gas in gas } \\
\text { fields } \\
\text { (BCF) }\end{array}$ & $\begin{array}{c}\text { Gas in all } \\
\text { fields } \\
\text { (BCF) }\end{array}$ \\
\hline \multicolumn{7}{|c|}{ Bulgaria } \\
\hline Carpathian-Balkanian Basin, 4061 & 1949 & 0 & 47 & 52 & 509 & 561 \\
\hline \multicolumn{7}{|c|}{ Slovakia } \\
\hline Bohemia, 4046 & 1914 & 0 & 44 & 42 & 1,137 & 1,179 \\
\hline North Carpathian Basin, 4047 & 1850 & 0 & 0 & 0 & 2 & 2 \\
\hline Pannonian Basin, 4048 & 1958 & 0 & $<1$ & 1 & 527 & 528 \\
\hline Total & & $\mathbf{0}$ & 45 & 44 & 1,666 & 1,709 \\
\hline \multicolumn{7}{|c|}{ Slovenia } \\
\hline Pannonian Basin, 4048 & 1943 & 0 & 6 & 23 & 74 & 97 \\
\hline \multicolumn{7}{|c|}{ Moldova } \\
\hline Carpathian-Balkanian Basin, 4061 & 1957 & 0 & 3 & $<1$ & 0 & $<1$ \\
\hline \multicolumn{7}{|c|}{ Bosnia and Herzegovina } \\
\hline Pannonian Basin, 4048 & 1934 & 0 & $<1$ & 0 & 0 & 0 \\
\hline \multicolumn{7}{|c|}{ Macedonia } \\
\hline Alps, 4051 & 1969 & 0 & $<1$ & $<1$ & 0 & $<1$ \\
\hline
\end{tabular}

\section{Exploration data}

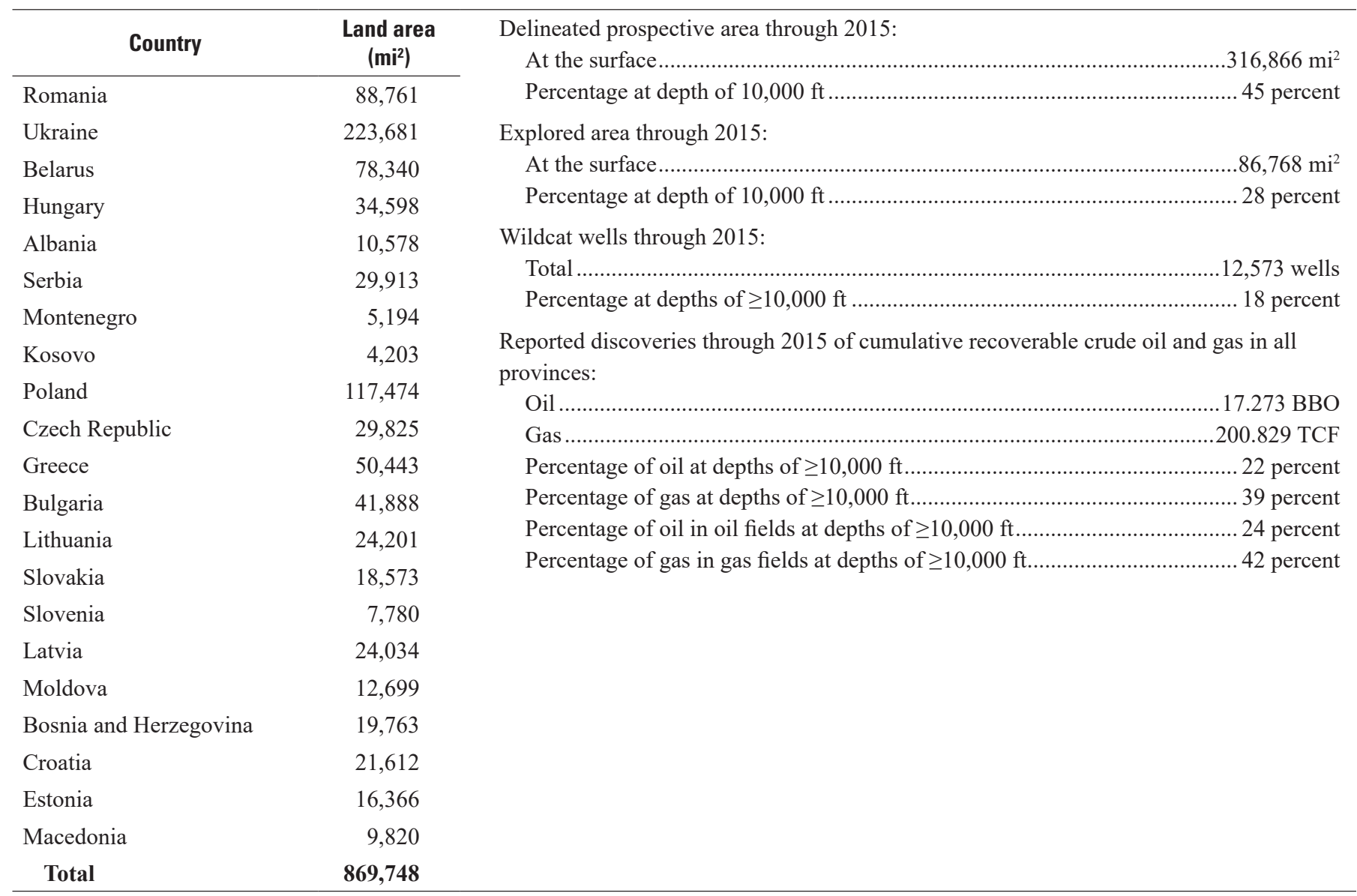

Figure 25. Continued. 


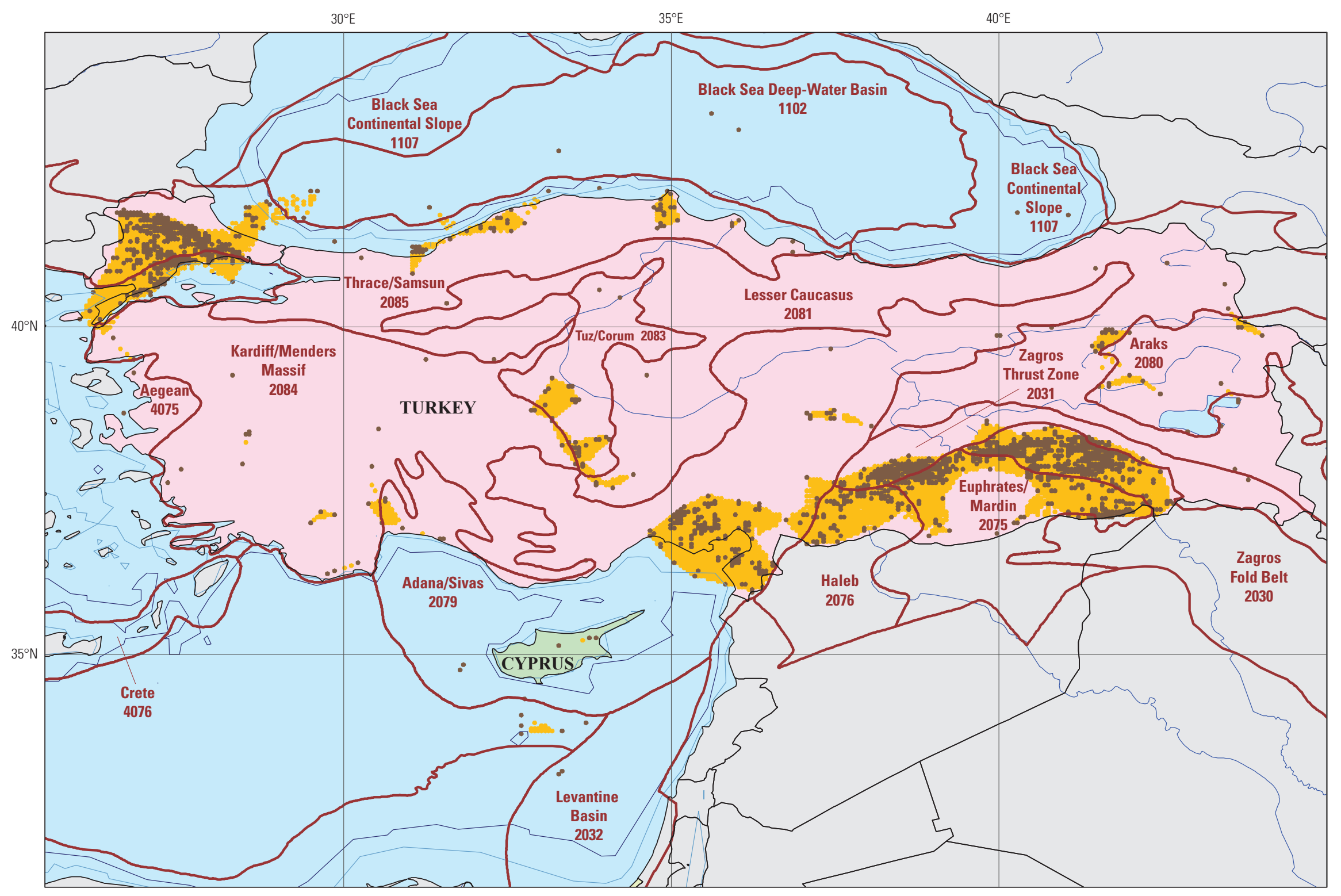

Figure 26. Map, graphs, and tables of data for oil and gas exploration through 2015 in Turkey and Cyprus. 
Growth in delineated prospective area and explored area through 2015, graphed by the year the areas became prospective or explored

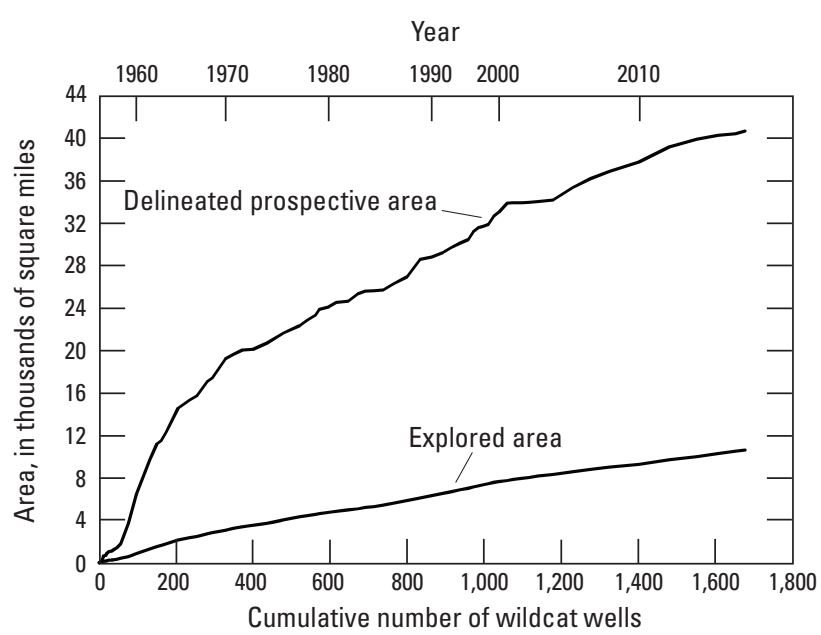

Cumulative recoverable oil and gas discoveries in all provinces through 2015, graphed by the year the field location became part of the delineated prospective area

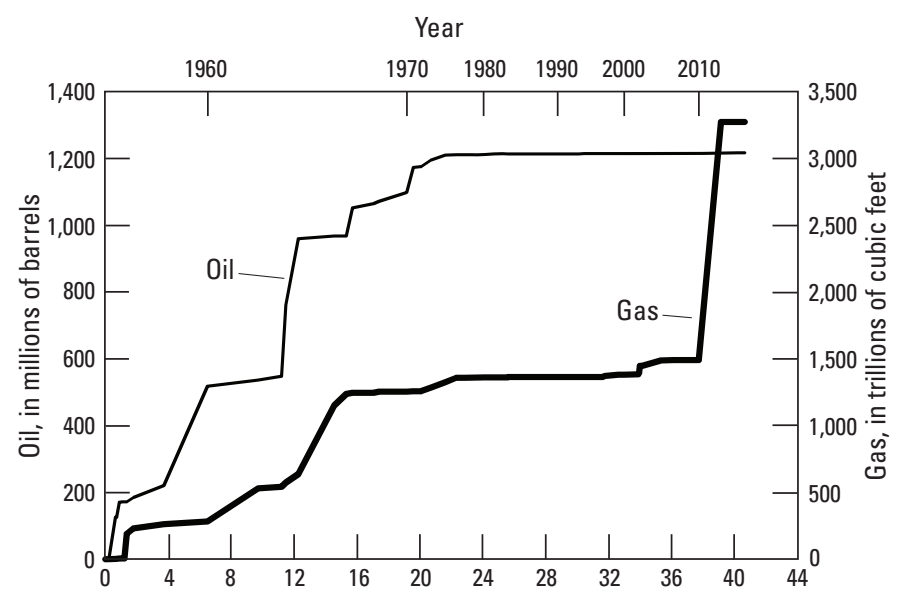

Delineated prospective area, in thousands of square miles
Significant petroleum provinces-Year of first discovery and cumulative recoverable oil and gas discovered through 2015

\begin{tabular}{|c|c|c|c|c|c|c|}
\hline $\begin{array}{c}\text { Significant petroleum } \\
\text { province }\end{array}$ & $\begin{array}{c}\text { Year of } \\
\text { first } \\
\text { discovery }\end{array}$ & $\begin{array}{l}\text { Oil in } \\
\text { large } \\
\text { fields } \\
\text { (MMBO) }\end{array}$ & $\begin{array}{c}\text { Oil in all } \\
\text { fields } \\
\text { (MMBO) }\end{array}$ & $\begin{array}{l}\text { Gas in oil } \\
\text { fields } \\
\text { (BCF) }\end{array}$ & $\begin{array}{c}\text { Gas } \\
\text { in gas } \\
\text { fields } \\
\text { (BCF) }\end{array}$ & $\begin{array}{c}\text { Gas in all } \\
\text { fields } \\
\text { (BCF) }\end{array}$ \\
\hline \multicolumn{7}{|c|}{ Turkey } \\
\hline Aegean, 4075 & 1988 & 0 & 0 & 0 & 338 & 338 \\
\hline Euphrates/Mardin, 2075 & 1958 & 0 & 75 & 43 & 14 & 57 \\
\hline Zagros Fold Belt, 2030 & 1945 & 310 & 966 & 44 & 267 & 311 \\
\hline Total & & 310 & 1,041 & 87 & 618 & 705 \\
\hline \multicolumn{7}{|c|}{ Cyprus } \\
\hline Levantine Basin, 2032 & 2011 & 0 & 0 & 0 & 1,786 & 1,786 \\
\hline
\end{tabular}

Exploration data

\begin{tabular}{|c|c|c|}
\hline Country & $\begin{array}{l}\text { Land } \\
\text { area } \\
\left(\mathrm{mi}^{2}\right)\end{array}$ & 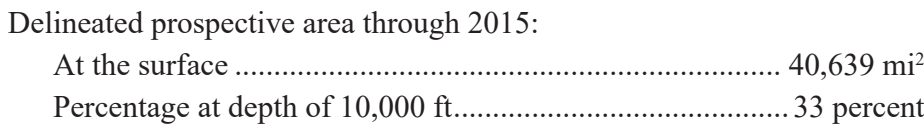 \\
\hline Turkey & 297,157 & Explored area through 2015: \\
\hline Cyprus & 3,568 & 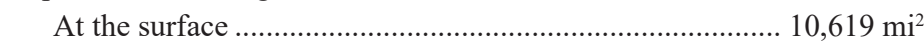 \\
\hline Total & 300,725 & 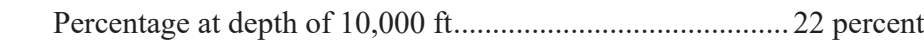 \\
\hline & & 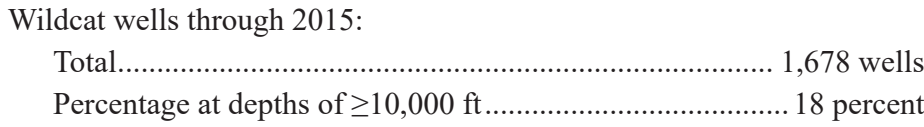 \\
\hline
\end{tabular}

Reported discoveries through 2015 of cumulative recoverable crude oil and gas in all provinces:

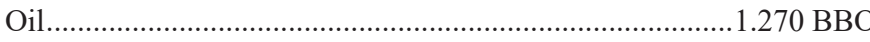

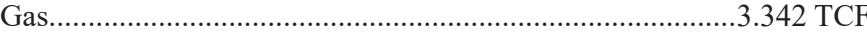

Percentage of oil at depths of $\geq 10,000 \mathrm{ft}$............................. 3 percent Percentage of gas at depths of $\geq 10,000 \mathrm{ft}$......................... 55 percent

Percentage of oil in oil fields at depths of $\geq 10,000 \mathrm{ft}$............ 3 percent Percentage of gas in gas fields at depths of $\geq 10,000 \mathrm{ft}$....... 67 percent

Figure 26. Continued. 


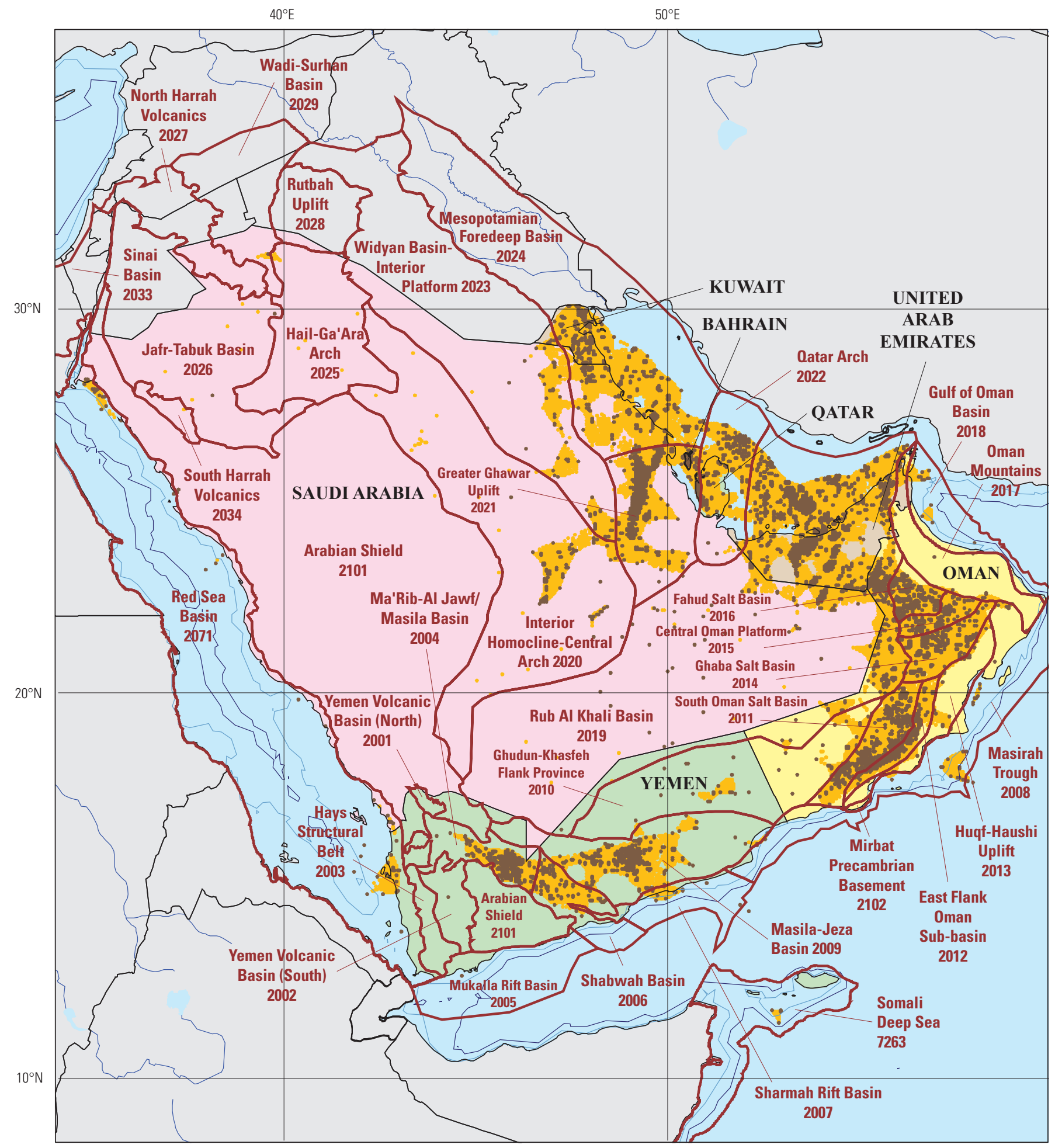

Figure 27. Map, graphs, and tables of data for oil and gas exploration through 2015 in the Arabian Peninsula. For this figure, the parts mapped are Saudi Arabia, Kuwait, United Arab Emirates, Oman, Oatar, Yemen, and Bahrain. Outlines of the seven individual emirates of the United Arab Emirates (UAE) are not shown on the map, but significant provinces are listed for six of them; the seven are Abu Dhabi, Dubai, Sharjah, Ra's al Khaymah, Umm al Qaywayn, 'Ajman, and Al Fujayrah. The former Kuwait-Saudi Arabia Neutral Zone contains resources according to the IHS Markit (2016), and so it is listed in the significant provinces table, but it is not mapped because it is not mentioned in "The World Factbook 2016" (CIA, 2016). 
Growth in delineated prospective area and explored area through 2015, graphed by the year the areas became prospective or explored

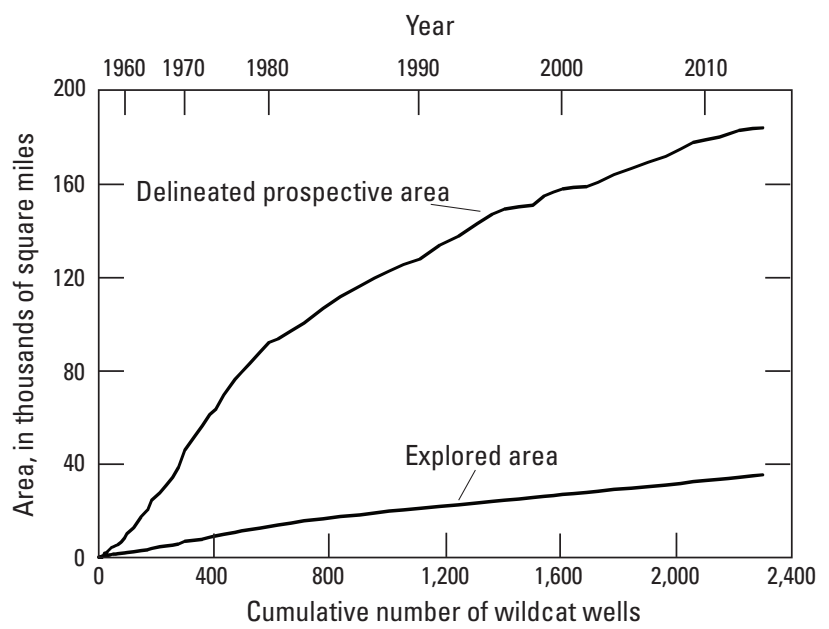

Figure 27. Continued.
Cumulative recoverable oil and gas discoveries in all provinces through 2015, graphed by the year the field location became part of the delineated prospective area

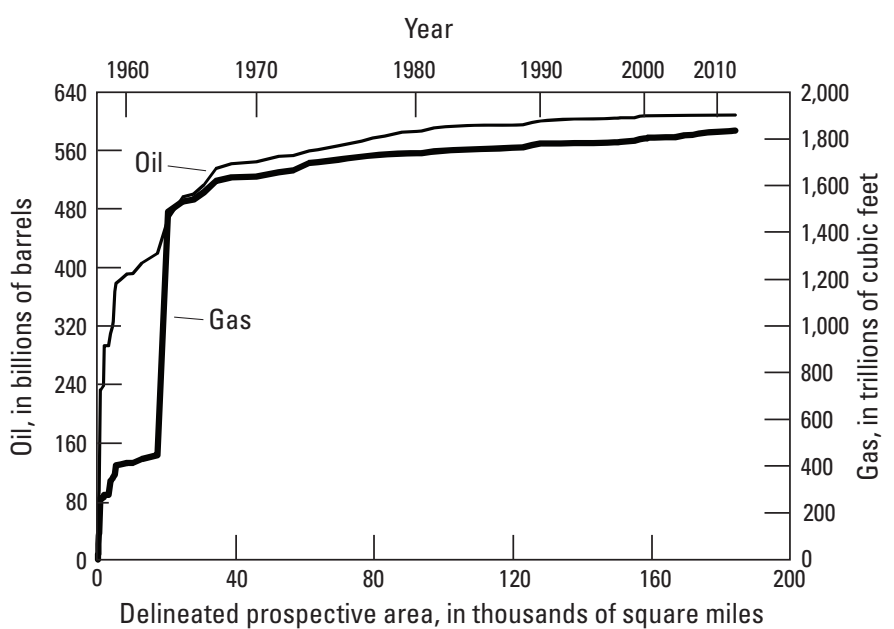


Significant petroleum provinces-Year of first discovery and cumulative recoverable oil and gas discovered through 2015

\begin{tabular}{|c|c|c|c|c|c|c|}
\hline Significant petroleum province & $\begin{array}{c}\text { Year of } \\
\text { first } \\
\text { discovery }\end{array}$ & $\begin{array}{c}\text { Oil in large } \\
\text { fields } \\
\text { (MMBO) }\end{array}$ & $\begin{array}{l}\text { Oil in all } \\
\text { fields } \\
\text { (MMBO) }\end{array}$ & $\begin{array}{l}\text { Gas in oil } \\
\text { fields } \\
\text { (BCF) }\end{array}$ & $\begin{array}{l}\text { Gas in gas } \\
\text { fields } \\
\text { (BCF) }\end{array}$ & $\begin{array}{c}\text { Gas in all } \\
\text { fields } \\
\text { (BCF) }\end{array}$ \\
\hline \multicolumn{7}{|c|}{ Saudi Arabia } \\
\hline Greater Ghawar Uplift, 2021 & 1938 & 161,552 & 161,637 & 192,560 & 4,950 & 197,510 \\
\hline Interior Homocline-Central Arch, 2020 & 1989 & 6,210 & 6,635 & 17,450 & 6,130 & 23,580 \\
\hline Mesopotamian Foredeep Basin, 2024 & 1940 & 161,545 & 161,756 & 100,672 & 8,625 & 109,297 \\
\hline Rub Al Khali Basin, 2019 & 1967 & 22,950 & 23,287 & 45,106 & 11,340 & 56,446 \\
\hline Widyan Basin-Interior Platform, 2023 & 1957 & 30,734 & 31,049 & 10,471 & 3,400 & 13,871 \\
\hline Total & & 382,991 & 384,463 & 366,274 & 38,520 & 404,794 \\
\hline \multicolumn{7}{|c|}{ Kuwait } \\
\hline \multicolumn{7}{|c|}{ UAE - Abu Dhabi } \\
\hline Rub Al Khali Basin, 2019 & 1954 & 75,738 & 77,250 & 178,268 & 5,831 & 184,099 \\
\hline \multicolumn{7}{|c|}{ UAE - Dubai } \\
\hline Rub Al Khali Basin, 2019 & 1966 & 4,124 & 4,253 & 3,248 & 4,000 & 7,248 \\
\hline \multicolumn{7}{|c|}{ UAE - Sharjah } \\
\hline Rub Al Khali Basin, 2019 & 1972 & 110 & 110 & 900 & 5,492 & 6,392 \\
\hline \multicolumn{7}{|c|}{ UAE - Ra's al Khaymah } \\
\hline Rub Al Khali Basin, 2019 & 1972 & 0 & 6 & 115 & 200 & 315 \\
\hline \multicolumn{7}{|c|}{ UAE - Umm al Qaywayn } \\
\hline \multicolumn{7}{|c|}{ UAE - 'Ajman } \\
\hline \multicolumn{7}{|c|}{ Former Kuwait-Saudi Arabia Neutral Zone } \\
\hline Central Oman Platform, 2015 & 1966 & 239 & 344 & 216 & 15,623 & 15,839 \\
\hline East Flank Oman Sub-basin, 2012 & 1973 & 2,448 & 3,232 & 187 & 0 & 187 \\
\hline Fahud Salt Basin, 2016 & 1962 & 5,121 & 5,353 & 8,468 & 5,395 & 13,863 \\
\hline Ghaba Salt Basin, 2014 & 1964 & 675 & 2,025 & 220 & 28,636 & 28,857 \\
\hline Rub Al Khali Basin, 2019 & 1969 & 975 & 1,528 & 2,201 & 1,184 & 3,384 \\
\hline South Oman Salt Basin, 2011 & 1956 & 2,398 & 3,532 & 1,889 & 2,250 & 4,139 \\
\hline Total & & 11,856 & 16,013 & 13,180 & 53,088 & 66,268 \\
\hline \multicolumn{7}{|c|}{ Qatar } \\
\hline Greater Ghawar Uplift, 2021 & 1940 & 5,800 & 5,803 & 10,800 & 0 & 10,800 \\
\hline Qatar Arch, 2022 & 1971 & 3,920 & 3,944 & 3,756 & $1,002,775$ & $1,006,531$ \\
\hline Rub Al Khali Basin, 2019 & 1960 & 5,015 & 5,109 & 12,494 & 0 & 12,494 \\
\hline Total & & 14,735 & 14,856 & 27,050 & $1,002,775$ & $1,029,825$ \\
\hline
\end{tabular}

Figure 27. Continued. 
Figure 27. Arabian Peninsula

Significant petroleum provinces—Year of first discovery and cumulative recoverable oil and gas discovered through 2015—Continued

\begin{tabular}{|c|c|c|c|c|c|c|}
\hline Significant petroleum province & $\begin{array}{c}\text { Year of } \\
\text { first } \\
\text { discovery }\end{array}$ & $\begin{array}{c}\text { Oil in large } \\
\text { fields } \\
\text { (MMBO) }\end{array}$ & $\begin{array}{l}\text { Oil in all } \\
\text { fields } \\
\text { (MMBO) }\end{array}$ & $\begin{array}{l}\text { Gas in oil } \\
\text { fields } \\
\text { (BCF) }\end{array}$ & $\begin{array}{c}\text { Gas in gas } \\
\text { fields } \\
\text { (BCF) }\end{array}$ & $\begin{array}{c}\text { Gas in al } \\
\text { fields } \\
\text { (BCF) }\end{array}$ \\
\hline \multicolumn{7}{|c|}{ Yemen } \\
\hline Ma'Rib-Al Jawf/Masila Basin, 2004 & 1984 & 1,285 & 1,634 & 8,549 & 6,048 & 14,597 \\
\hline Masila-Jeza Basin, 2009 & 1991 & 1,330 & 2,003 & 521 & 100 & 621 \\
\hline Total & & 2,615 & 3,637 & 9,070 & 6,148 & 15,218 \\
\hline Greater Ghawar Uplift, 2021 & 1932 & 1,500 & 1,500 & 20,760 & 0 & 20,760 \\
\hline
\end{tabular}

\section{Exploration data}

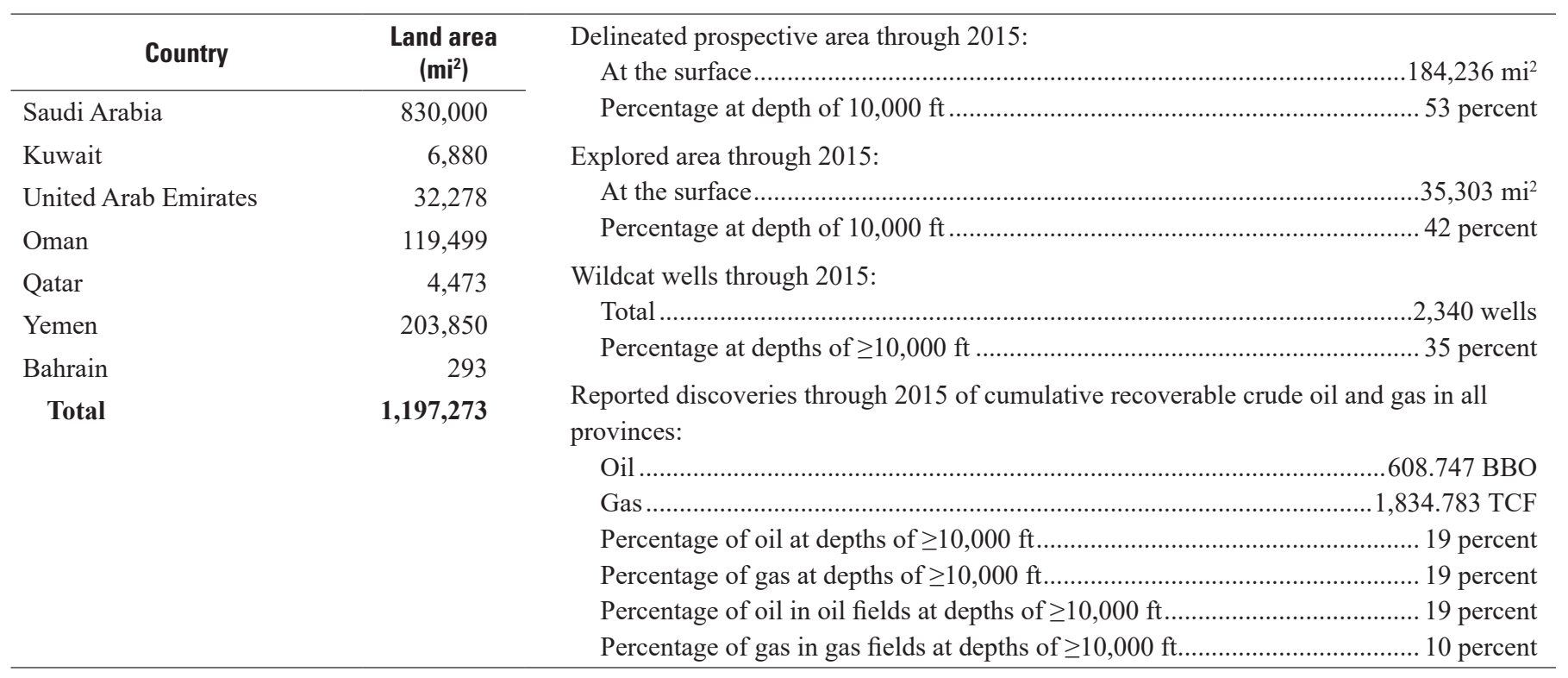

Figure 27. Continued. 


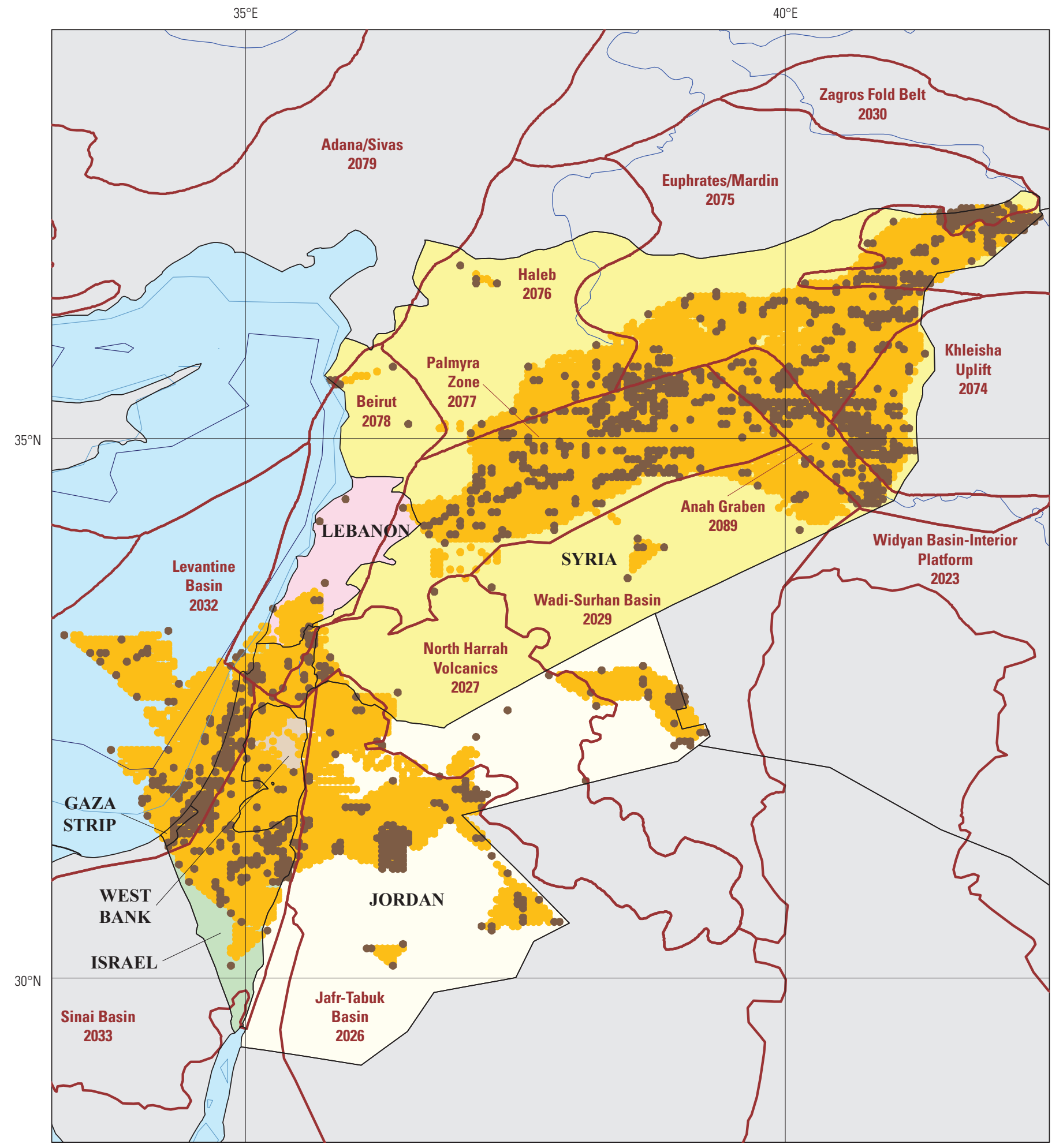

Figure 28. Map, graphs, and tables of data for oil and gas exploration through 2015 in Syria, Israel, Jordan, Lebanon, Gaza Strip, and the West Bank. 
Growth in delineated prospective area and explored area through 2015, graphed by the year the areas became prospective or explored

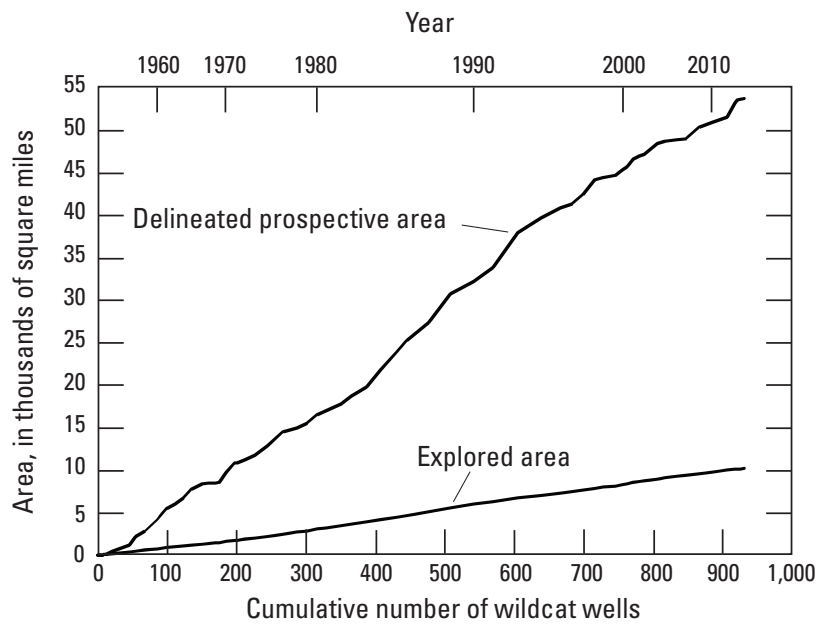

Cumulative recoverable oil and gas discoveries in all provinces through 2015, graphed by the year the field location became part of the delineated prospective area

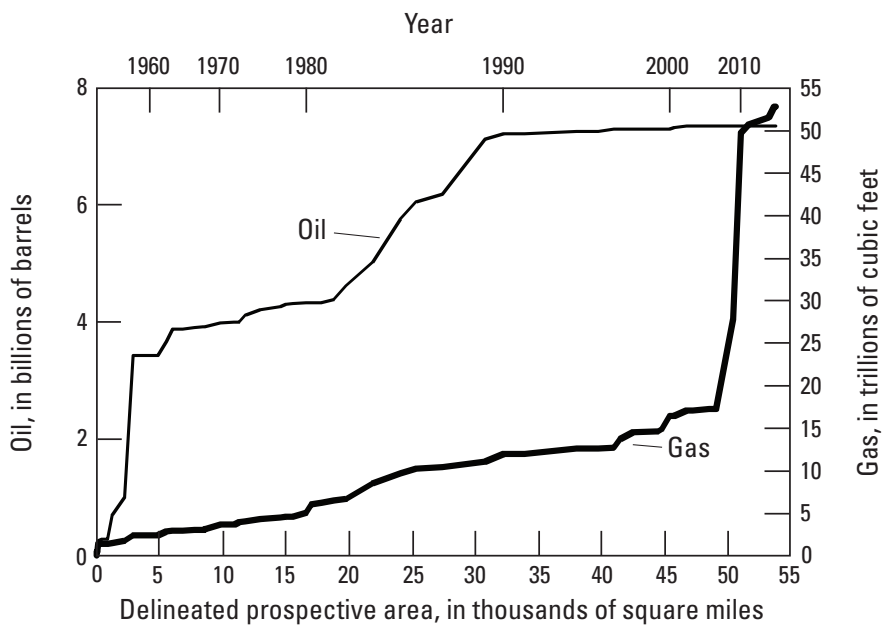

Figure 28. Continued. 
Significant petroleum provinces-Year of first discovery and cumulative recoverable oil and gas discovered through 2015

\begin{tabular}{|c|c|c|c|c|c|c|}
\hline Significant petroleum province & $\begin{array}{c}\text { Year of } \\
\text { first } \\
\text { discovery }\end{array}$ & $\begin{array}{c}\text { Oil in large } \\
\text { fields } \\
\text { (MMBO) }\end{array}$ & $\begin{array}{l}\text { Oil in all } \\
\text { fields } \\
\text { (MMBO) }\end{array}$ & $\begin{array}{c}\text { Gas in oil } \\
\text { fields } \\
\text { (BCF) }\end{array}$ & $\begin{array}{c}\text { Gas in gas } \\
\text { fields } \\
\text { (BCF) }\end{array}$ & $\begin{array}{c}\text { Gas in all } \\
\text { fields } \\
\text { (BCF) }\end{array}$ \\
\hline \multicolumn{7}{|c|}{ Syria } \\
\hline Anah Graben, 2089 & 1982 & 218 & 440 & 255 & 25 & 280 \\
\hline Euphrates/Mardin, 2075 & 1940 & 872 & 1,274 & 2,656 & 1,180 & 3,836 \\
\hline Khleisha Uplift, 2074 & 1986 & 1,043 & 1,887 & 1,826 & 21 & 1,847 \\
\hline Zagros Fold Belt, 2030 & 1956 & 3,098 & 3,364 & 1,518 & 36 & 1,554 \\
\hline Total & & 5,230 & 7,207 & 6,668 & 6,994 & 13,663 \\
\hline \multicolumn{7}{|c|}{ Israel } \\
\hline Levantine Basin, 2032 & 1955 & 110 & 161 & 173 & 38,612 & 38,785 \\
\hline
\end{tabular}

Figure 28. Continued. 


\section{Exploration data}

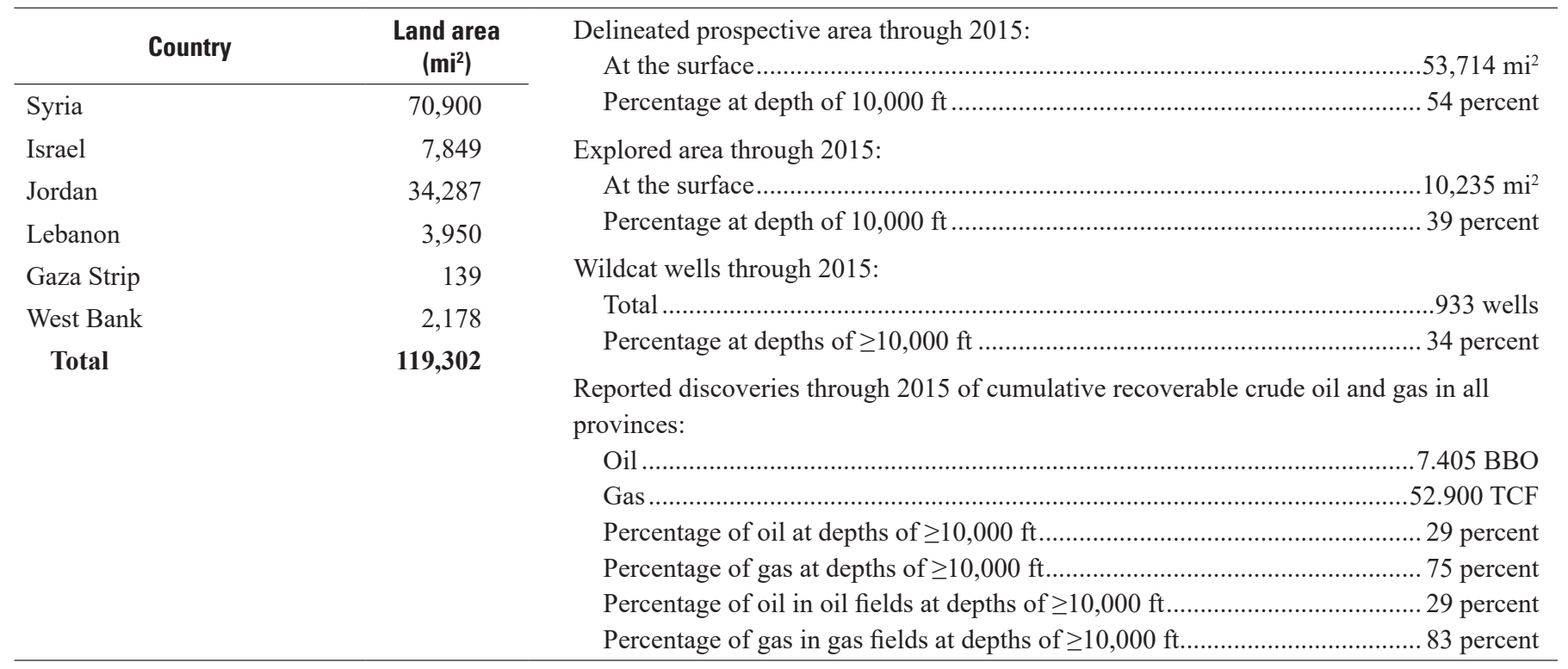

Figure 28. Continued. 


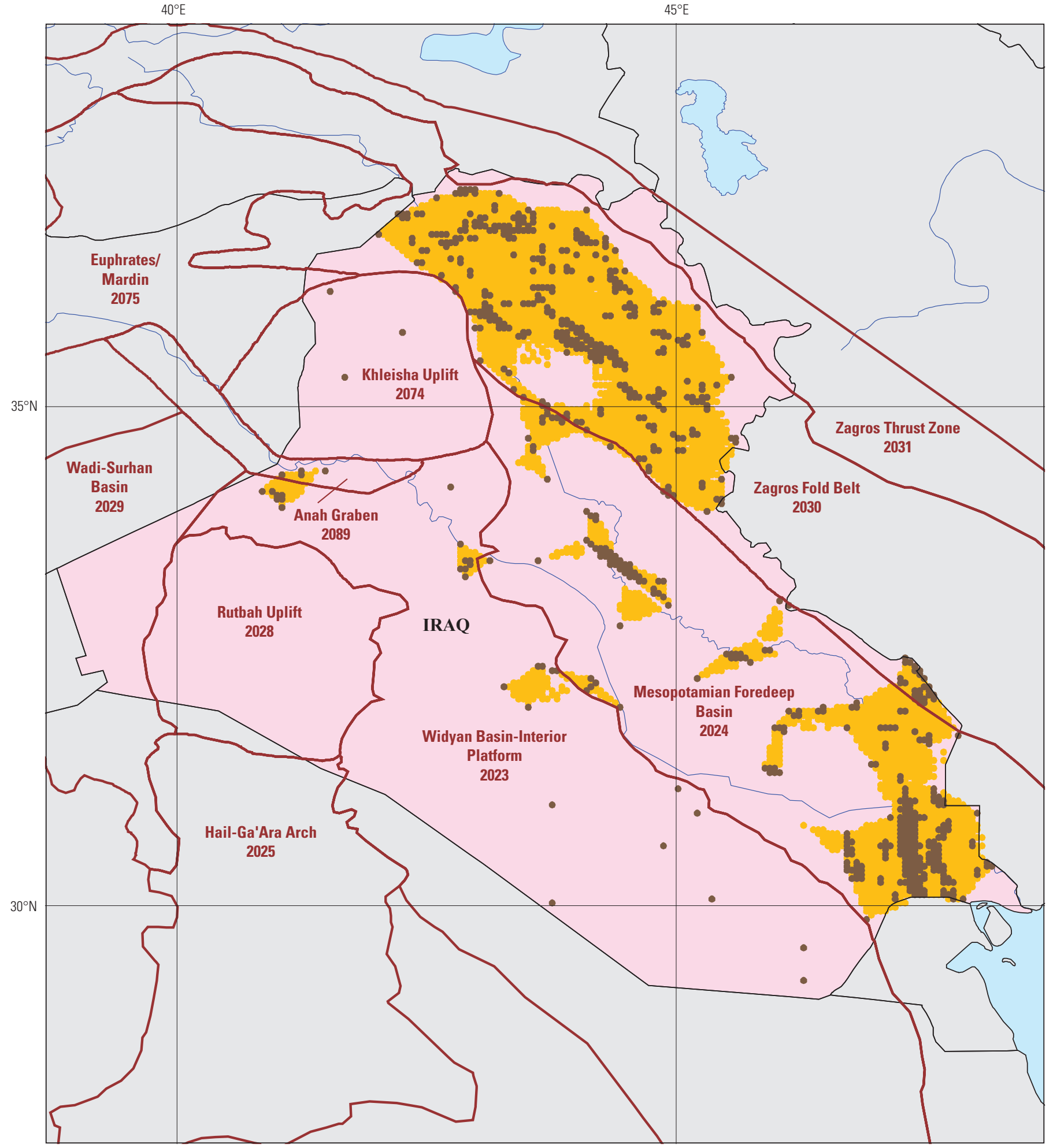

Figure 29. Map, graphs, and tables of data for oil and gas exploration through 2015 in Iraq. 
Growth in delineated prospective area and explored area through 2015, graphed by the year the areas became prospective or explored

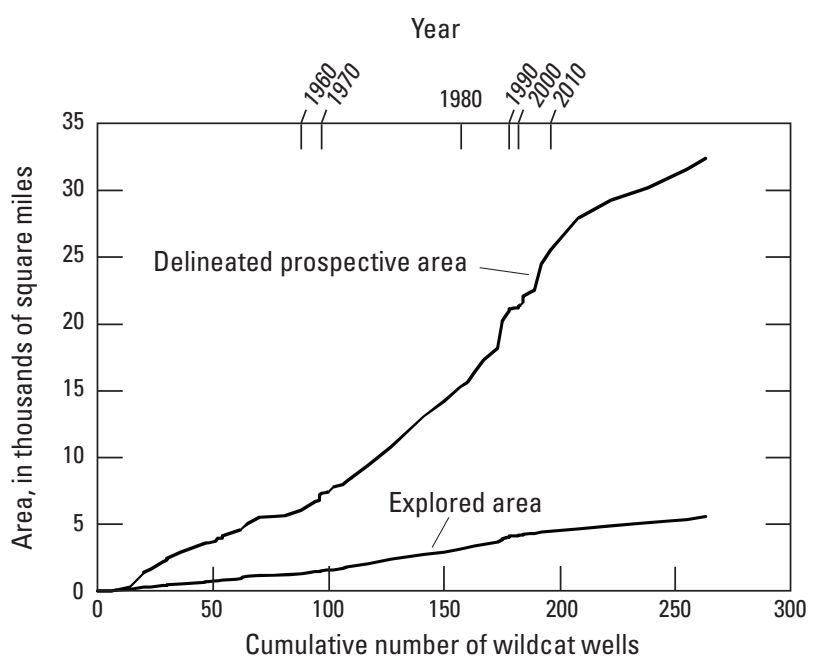

Cumulative recoverable oil and gas discoveries in all provinces through 2015, graphed by the year the field location became part of the delineated prospective area

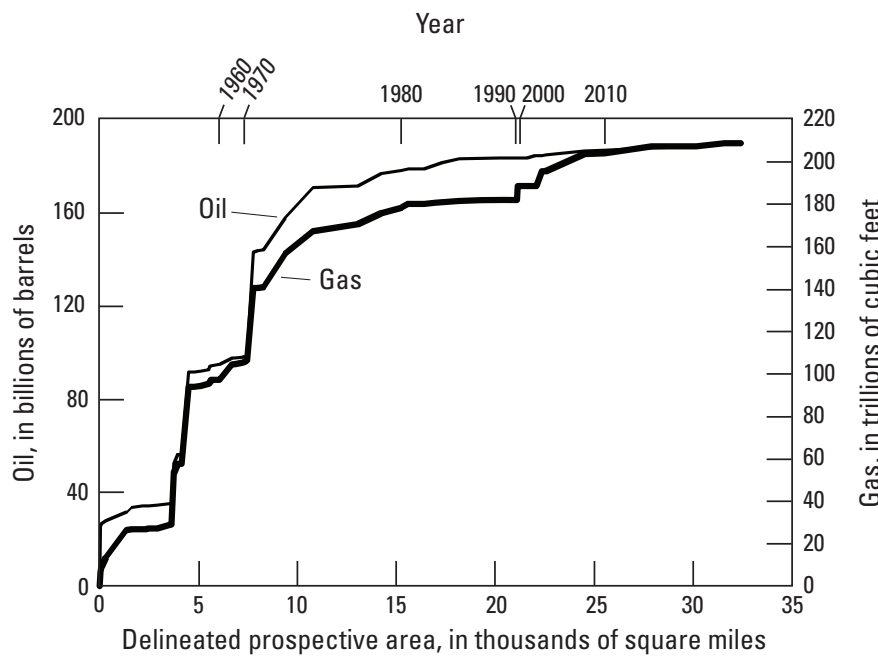

Significant petroleum provinces-Year of first discovery and cumulative recoverable oil and gas discovered through 2015

\begin{tabular}{lccrrrr}
\hline \multicolumn{1}{c}{ Significant petroleum province } & $\begin{array}{c}\text { Year of } \\
\text { first } \\
\text { discovery }\end{array}$ & $\begin{array}{c}\text { 0il in large } \\
\text { fields } \\
\text { (MMBO) }\end{array}$ & $\begin{array}{c}\text { 0il in all } \\
\text { fields } \\
\text { (MMBO) }\end{array}$ & $\begin{array}{c}\text { Gas in oil } \\
\text { fields } \\
\text { (BCF) }\end{array}$ & $\begin{array}{c}\text { Gas in gas } \\
\text { fields } \\
\text { (BCF) }\end{array}$ & $\begin{array}{c}\text { Gas in all } \\
\text { fields } \\
\text { (BCF) }\end{array}$ \\
\hline Mesopotamian Foredeep Basin, 2024 & 1938 & 142,181 & 142,697 & 132,694 & 38 & 132,732 \\
Widyan Basin-Interior Platform, 2023 & 1939 & 526 & 713 & 328 & 6,310 & 6,638 \\
Zagros Fold Belt, 2030 & 1905 & 44,495 & 46,233 & 40,351 & 29,098 & 69,449 \\
$\quad$ Total & & $\mathbf{1 8 7 , 2 0 2}$ & $\mathbf{1 8 9 , 6 4 3}$ & $\mathbf{1 7 3 , 3 7 3}$ & $\mathbf{3 5 , 4 4 6}$ & $\mathbf{2 0 8 , 8 1 9}$ \\
\hline
\end{tabular}

\section{Exploration data}

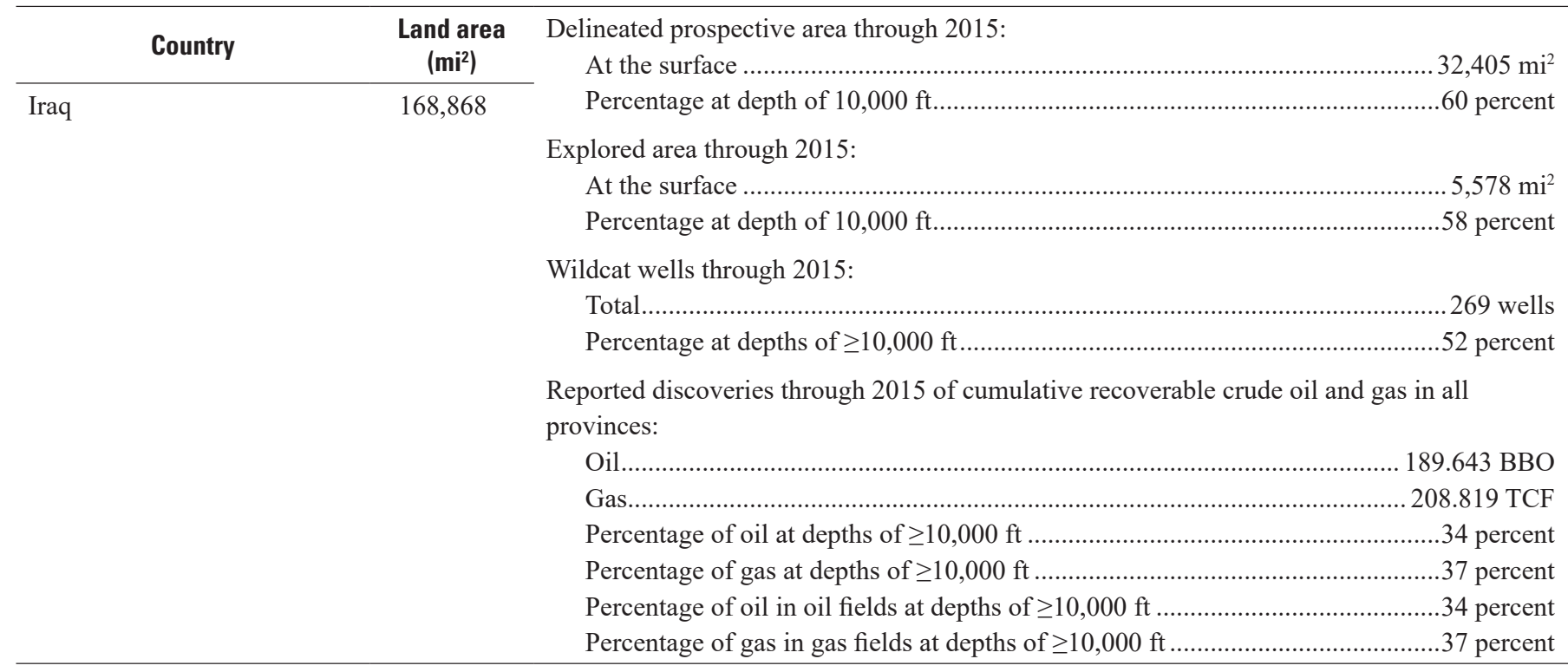

Figure 29. Continued. 


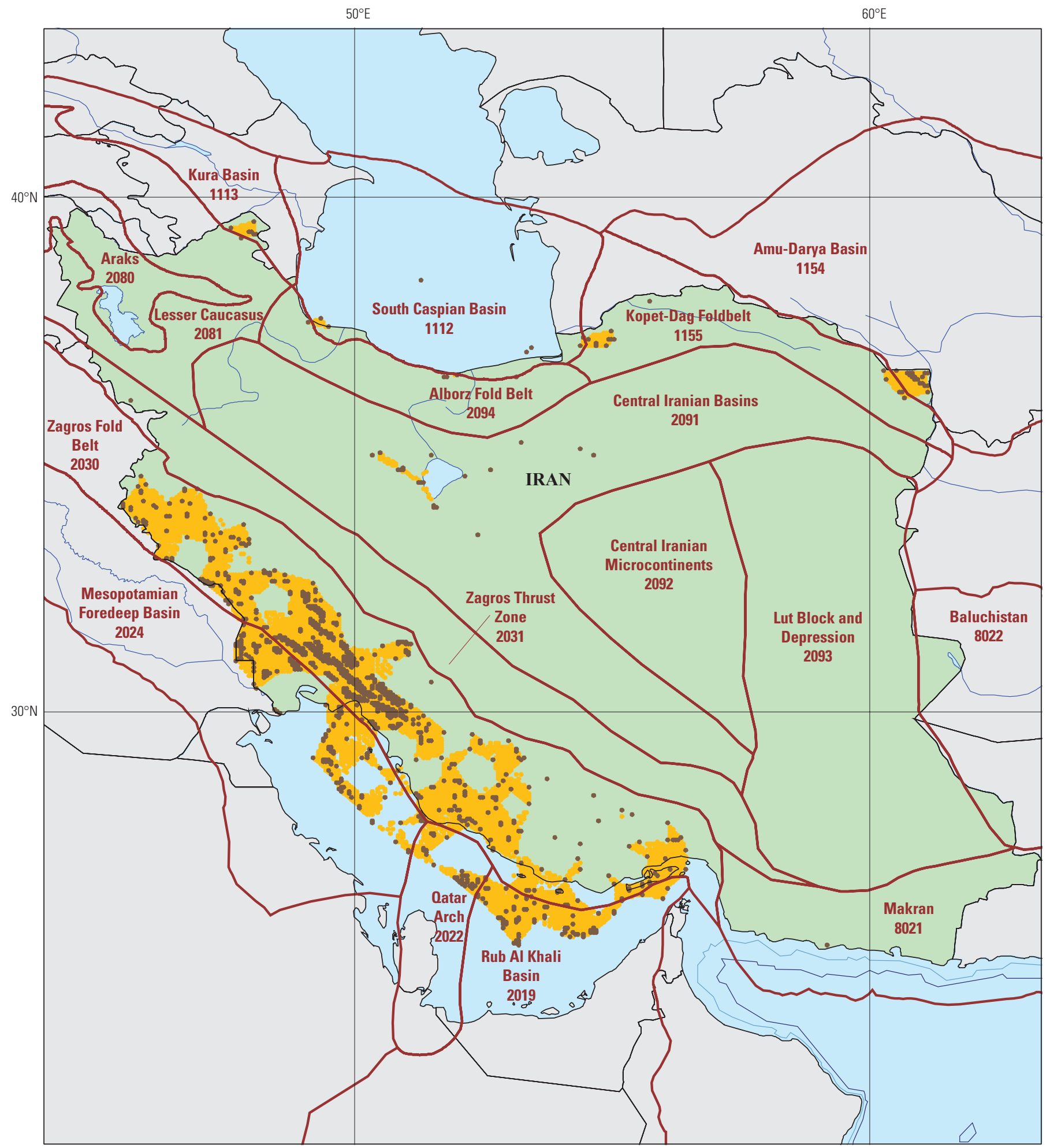

Figure 30. Map, graphs, and tables of data for oil and gas exploration through 2015 in Iran. 
Growth in delineated prospective area and explored area through 2015, graphed by the year the areas became prospective or explored

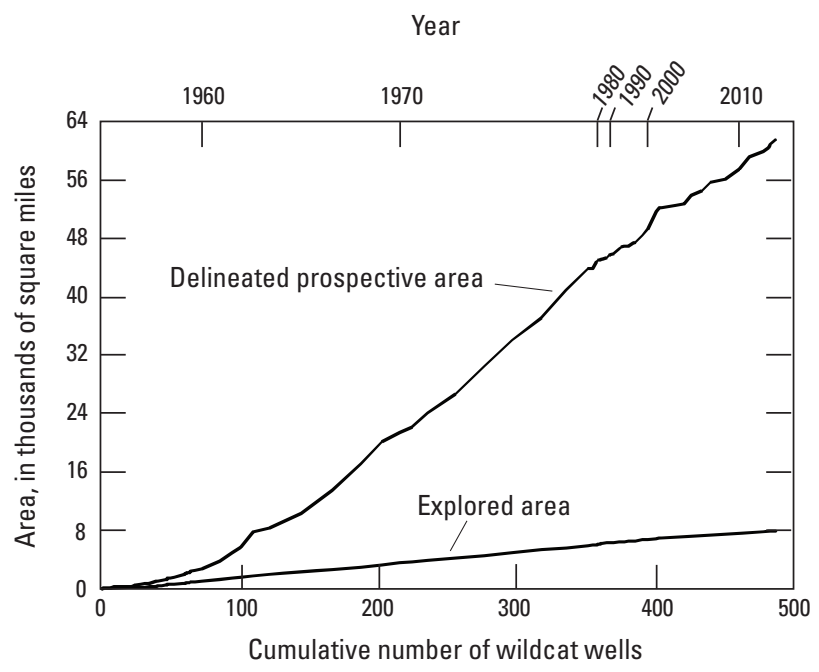

Cumulative recoverable oil and gas discoveries in all provinces through 2015, graphed by the year the field location became part of the delineated prospective area

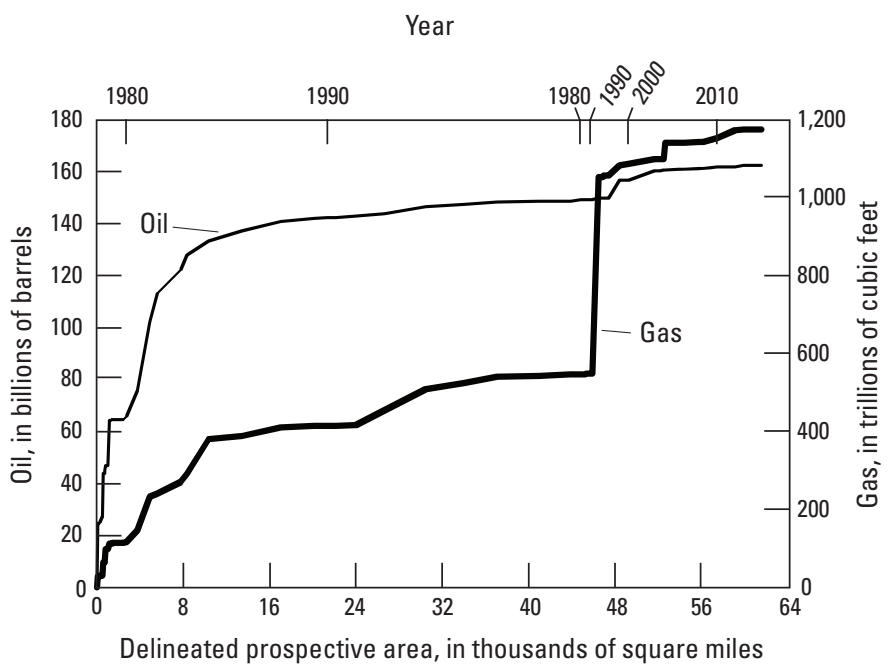

Figure 30. Continued. 
Significant petroleum provinces-Year of first discovery and cumulative recoverable oil and gas discovered through 2015

\begin{tabular}{|c|c|c|c|c|c|c|}
\hline Significant petroleum province & $\begin{array}{c}\text { Year of } \\
\text { first } \\
\text { discovery }\end{array}$ & $\begin{array}{c}\text { Oil in large } \\
\text { fields } \\
\text { (MMBO) }\end{array}$ & $\begin{array}{c}\text { Oil in all } \\
\text { fields } \\
\text { (MMBO) }\end{array}$ & $\begin{array}{l}\text { Gas in oil } \\
\text { fields } \\
\text { (BCF) }\end{array}$ & $\begin{array}{c}\text { Gas in gas } \\
\text { fields } \\
\text { (BCF) }\end{array}$ & $\begin{array}{c}\text { Gas in all } \\
\text { fields } \\
\text { (BCF) }\end{array}$ \\
\hline \multicolumn{7}{|c|}{ Iran } \\
\hline Amu-Darya Basin, 1154 & 1968 & 0 & 0 & 0 & 17,305 & 17,305 \\
\hline Kopet-Dag Foldbelt, 1155 & 1967 & 0 & 0 & 0 & 2,000 & 2,000 \\
\hline Kura Basin, 1113 & 1967 & 0 & 3 & 1 & 0 & 1 \\
\hline Qatar Arch, 2022 & 1967 & 0 & 906 & 0 & 516,409 & 516,409 \\
\hline Rub Al Khali Basin, 2019 & 1965 & 4,798 & 5,200 & 13,552 & 5,441 & 18,993 \\
\hline South Caspian Basin, 1112 & 1960 & 492 & 492 & 500 & 700 & 1,200 \\
\hline Zagros Fold Belt, 2030 & 1908 & 123,003 & 124,761 & 272,129 & 241,804 & 513,933 \\
\hline
\end{tabular}

Figure 30. Continued. 


\section{Exploration data}

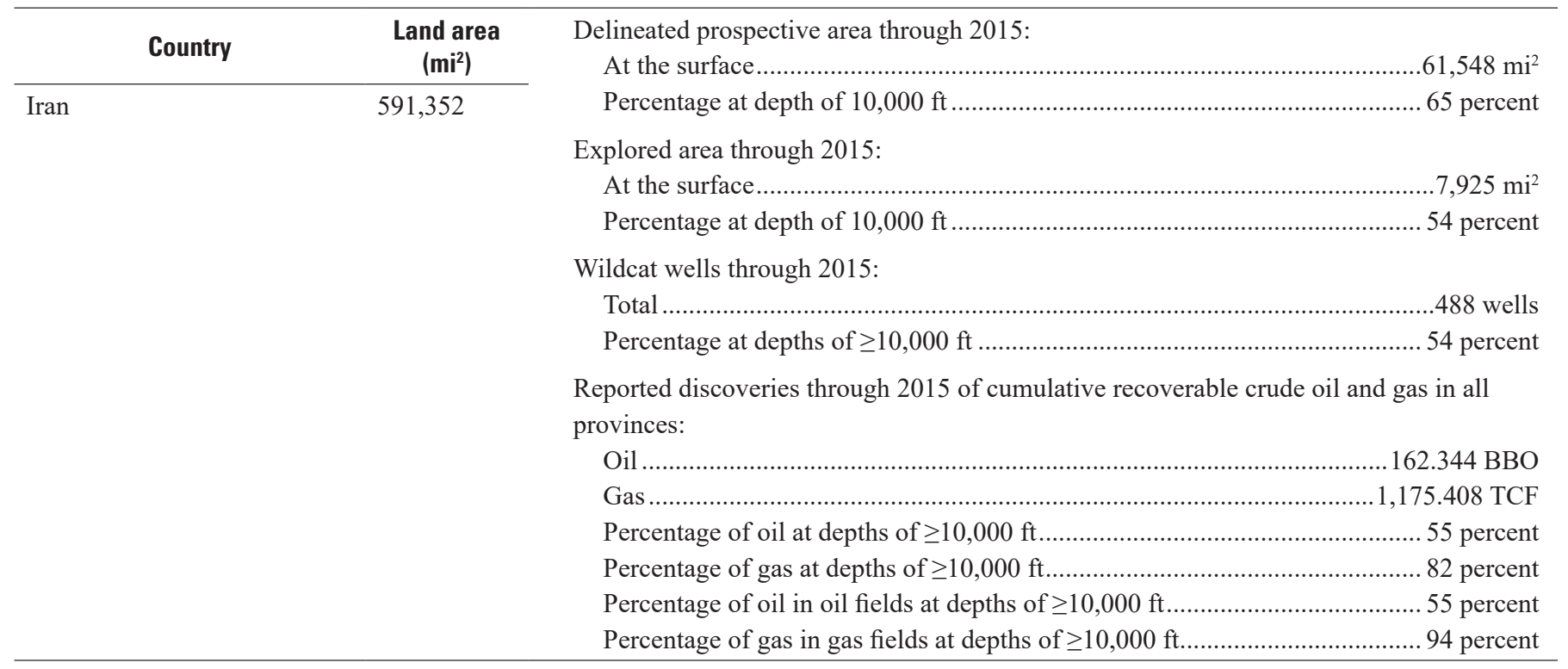

Figure 30. Continued. 


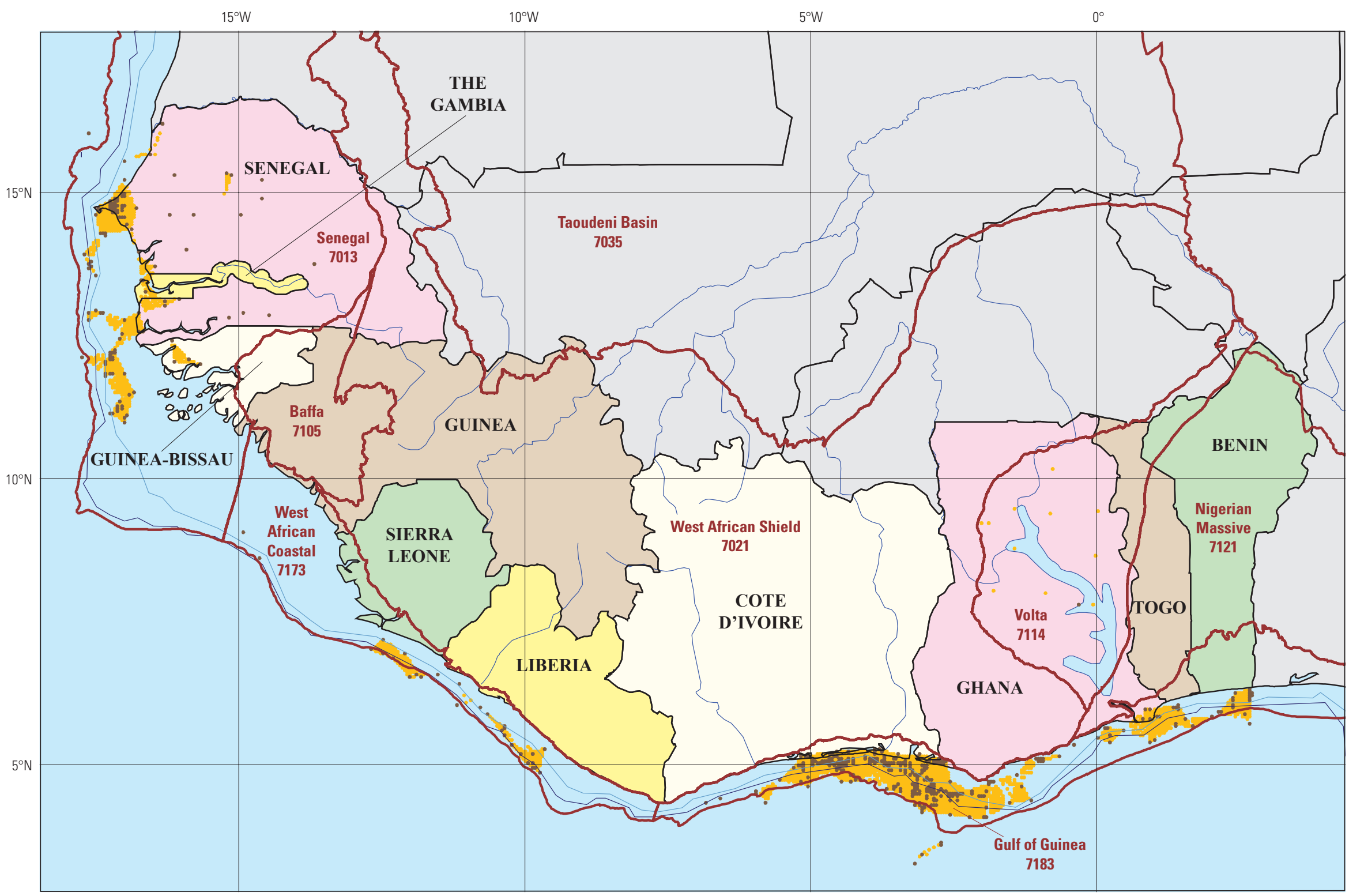

Figure 31. Map, graphs, and tables of data for oil and gas exploration through 2015 in Cote d'Ivoire, Ghana, Benin, Guinea-Bissau, Togo, Senegal, The Gambia, Guinea, Sierra Leone, Liberia, and Cabo Verde (not mapped). The Guinea-Bissau/Senegal Joint Economic Zone (JEZ) is not delineated on the map because a standard boundary was not available. 
Growth in delineated prospective area and explored

area through 2015, graphed by the year the areas became

prospective or explored

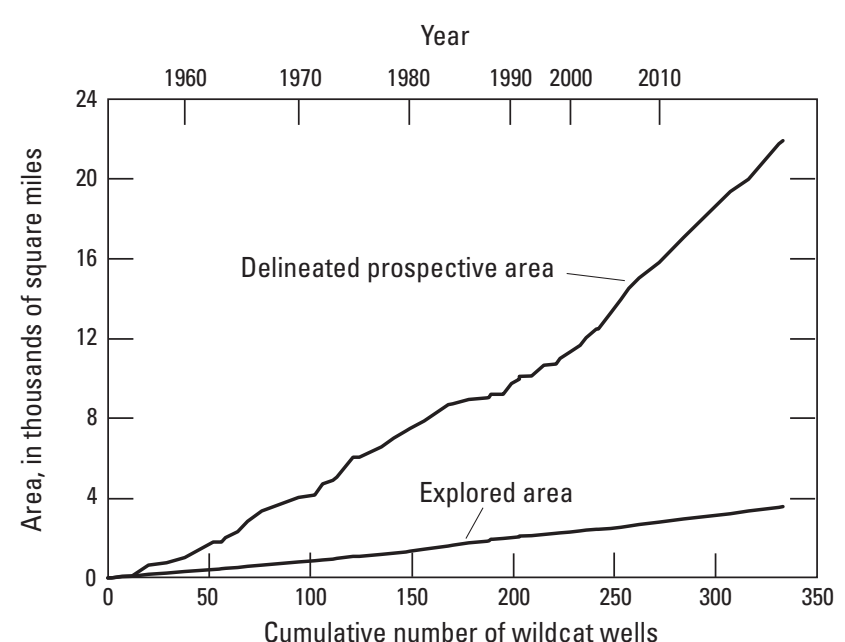

Cumulative recoverable oil and gas discoveries in all provinces through 2015, graphed by the year the field location became part of the delineated prospective area

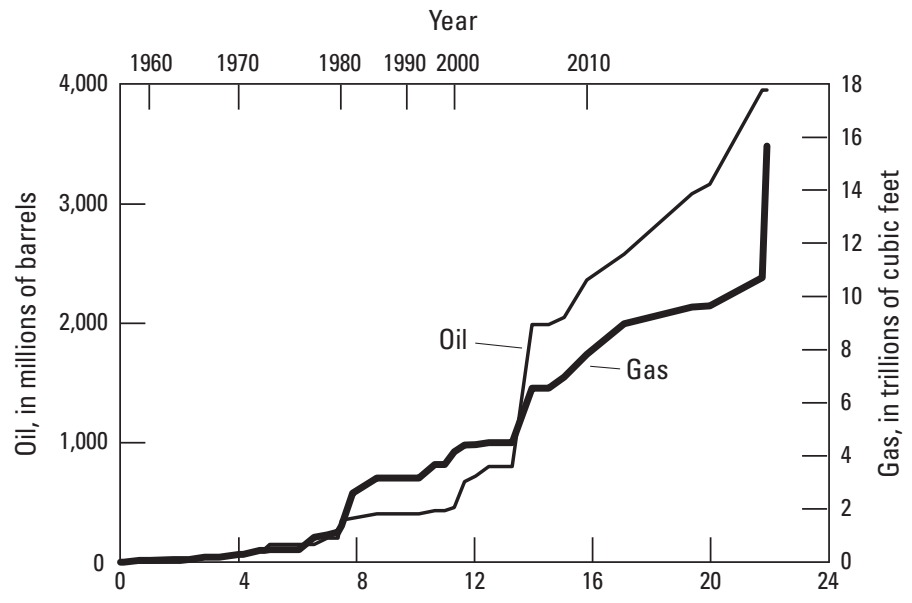

Delineated prospective area, in thousands of square miles

Figure 31. Continued. 


\begin{tabular}{|c|c|c|c|c|c|c|}
\hline $\begin{array}{c}\text { Significant petroleum } \\
\text { province }\end{array}$ & $\begin{array}{c}\text { Year of } \\
\text { first } \\
\text { discovery }\end{array}$ & $\begin{array}{c}\text { Oil in } \\
\text { large } \\
\text { fields } \\
\text { (MMBO) }\end{array}$ & $\begin{array}{l}\text { Oil in all } \\
\text { fields } \\
\text { (MMBO) }\end{array}$ & $\begin{array}{l}\text { Gas in oil } \\
\text { fields } \\
\text { (BCF) }\end{array}$ & $\begin{array}{l}\text { Gas in } \\
\text { gas fields } \\
\text { (BCF) }\end{array}$ & $\begin{array}{l}\text { Gas in all } \\
\text { fields } \\
\text { (BCF) }\end{array}$ \\
\hline \multicolumn{7}{|c|}{ Cote d'Ivoire } \\
\hline Gulf of Guinea, 7183 & 1972 & 477 & 781 & 1,343 & 2,311 & 3,654 \\
\hline Undesignated offshore area & & 180 & 185 & 123 & 30 & 153 \\
\hline Total & & 657 & 966 & 1,465 & 2,341 & 3,806 \\
\hline \multicolumn{7}{|c|}{ Ghana } \\
\hline Gulf of Guinea, 7183 & 1970 & 990 & 1,722 & 4,498 & 837 & 5,335 \\
\hline Undesignated offshore area & & 0 & 165 & 180 & 0 & 180 \\
\hline Total & & 990 & 1,887 & 4,678 & 837 & 5,515 \\
\hline \multicolumn{7}{|c|}{ Benin } \\
\hline Gulf of Guinea, 7183 & 1968 & 0 & 91 & 161 & 0 & 161 \\
\hline Undesignated offshore area & & 0 & 30 & 15 & 0 & 15 \\
\hline Total & & $\mathbf{0}$ & 121 & 176 & $\mathbf{0}$ & 176 \\
\hline \multicolumn{7}{|c|}{ Guinea-Bissau } \\
\hline Senegal, 7013 & 2004 & 0 & 13 & 4 & 0 & 4 \\
\hline \multicolumn{7}{|c|}{ Togo } \\
\hline Gulf of Guinea, 7183 & 1970 & 0 & 7 & 2 & 0 & 2 \\
\hline \multicolumn{7}{|c|}{ Senegal } \\
\hline Senegal, 7013 & 1959 & 658 & 658 & 861 & 94 & 955 \\
\hline \multicolumn{7}{|c|}{ Guinea-Bissau/Senegal JEZ } \\
\hline Senegal, 7013 & 1967 & 0 & 10 & 1 & 0 & 1 \\
\hline
\end{tabular}

Figure 31. Continued. 


\section{Exploration data}

\begin{tabular}{|c|c|c|}
\hline Country & $\begin{array}{l}\text { Land } \\
\text { area } \\
\left(\mathrm{mi}^{2}\right)\end{array}$ & 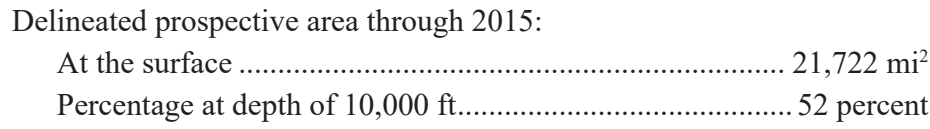 \\
\hline Cote d'Ivoire & 122,782 & Explored area through 2015: \\
\hline Ghana & 87,851 & 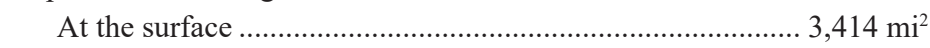 \\
\hline Benin & 42,711 & 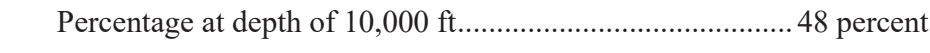 \\
\hline Guinea-Bissau & 10,857 & Wildcat wells through 2015: \\
\hline Togo & 20,998 & Total................................................... \\
\hline Senegal & 74,336 & 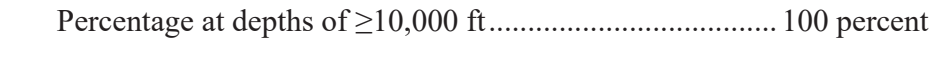 \\
\hline The Gambia & 3,861 & Reported discoveries through 2015 of cumulative recoverable crude oil \\
\hline Guinea & 94,872 & and gas in all provinces: \\
\hline Sierra Leone & 27,653 & 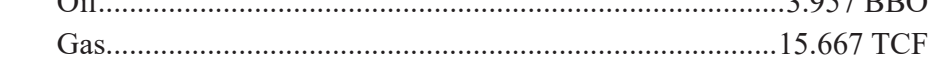 \\
\hline Liberia & 37,189 & Percentage of oil at depths of $\geq 10,000 \mathrm{ft} \ldots \ldots \ldots \ldots \ldots \ldots \ldots \ldots \ldots . . .79$ percent \\
\hline $\begin{array}{l}\text { Cabo Verde (not } \\
\text { shown on map) }\end{array}$ & 1,557 & $\begin{array}{l}\text { Percentage of gas at depths of } \geq 10,000 \mathrm{ft} \ldots \ldots \ldots \ldots \ldots \ldots \ldots \ldots \ldots \\
\text { Percentage of oil in oil fields at depths of } \geq 10,000 \mathrm{ft} \ldots \ldots \ldots . . . \\
\text { percent }\end{array}$ \\
\hline Total & 524,668 & Percentage of gas in gas fields at depths of $\geq 10,000 \mathrm{ft} \ldots \ldots .67$ percent \\
\hline
\end{tabular}

Figure 31. Continued. 


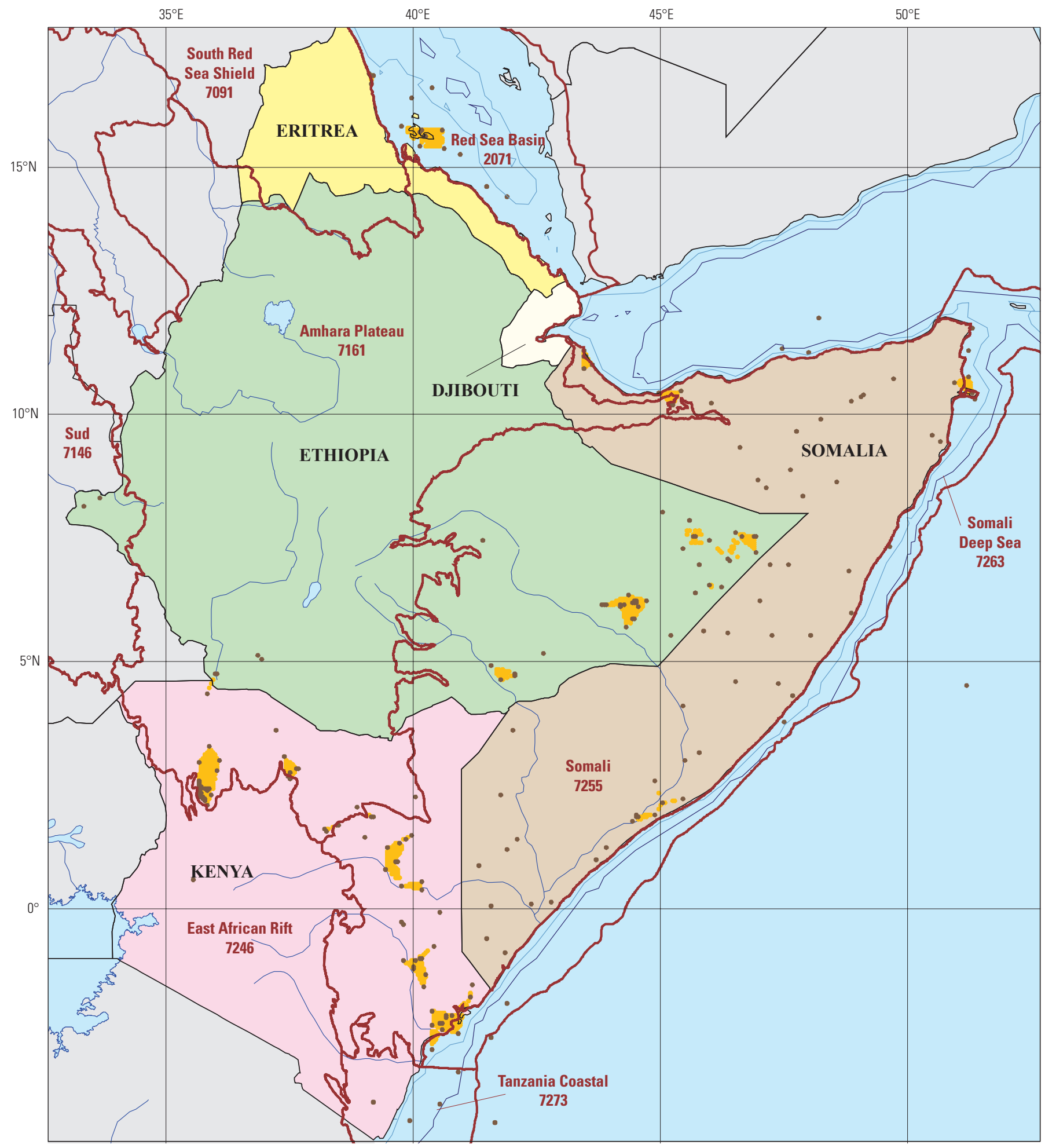

Figure 32. Map, graphs, and tables of data for oil and gas exploration through 2015 in Ethiopia, Somalia, Eritrea, Kenya, and Djibouti. 
Growth in delineated prospective area and explored area through 2015, graphed by the year the areas became prospective or explored

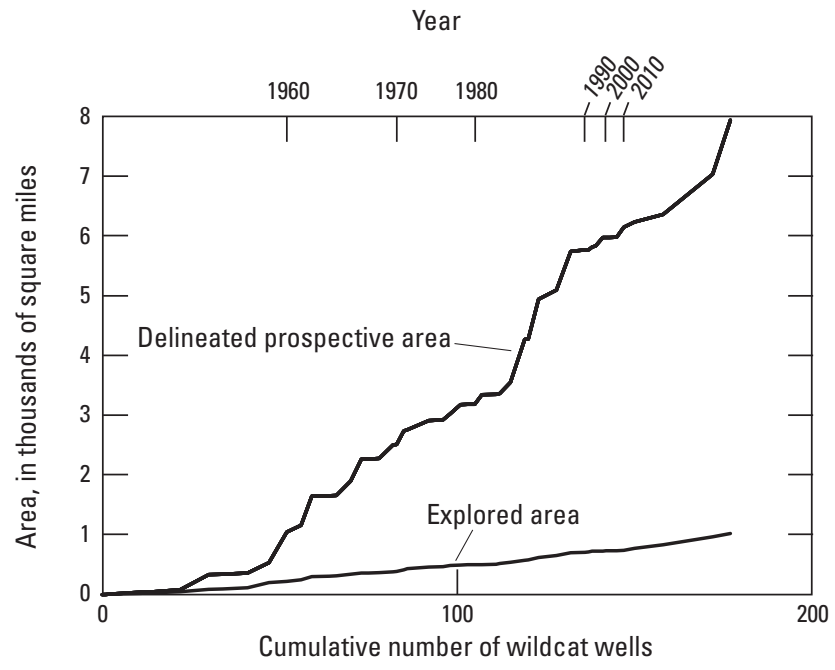

Cumulative recoverable oil and gas discoveries in all provinces through 2015, graphed by the year the field location became part of the delineated prospective area

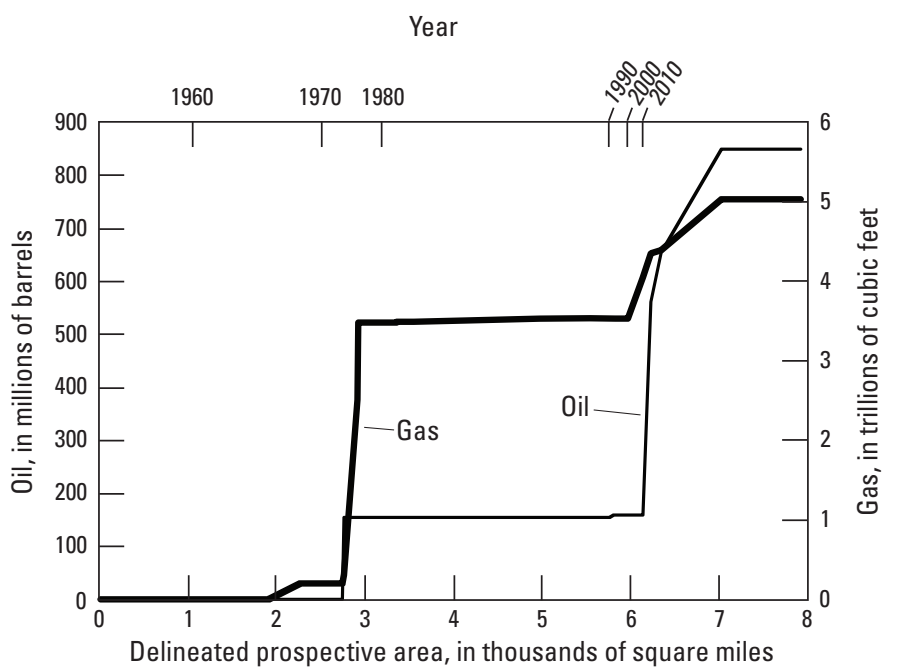

Figure 32. Continued. 
Significant petroleum provinces-Year of first discovery and cumulative recoverable oil and gas discovered through 2015

\begin{tabular}{|c|c|c|c|c|c|c|}
\hline Significant petroleum province & $\begin{array}{c}\text { Year of } \\
\text { first } \\
\text { discovery }\end{array}$ & $\begin{array}{l}\text { Oil in large } \\
\text { fields } \\
\text { (MMBO) }\end{array}$ & $\begin{array}{l}\text { Oil in all } \\
\text { fields } \\
\text { (MMBO) }\end{array}$ & $\begin{array}{l}\text { Gas in oil } \\
\text { fields } \\
\text { (BCF) }\end{array}$ & $\begin{array}{l}\text { Gas in gas } \\
\text { fields } \\
\text { (BCF) }\end{array}$ & $\begin{array}{l}\text { Gas in all } \\
\text { fields } \\
\text { (BCF) }\end{array}$ \\
\hline \multicolumn{7}{|c|}{ Ethiopia } \\
\hline Somali, 7255 & 1972 & 155 & 155 & 106 & 3,685 & 3,791 \\
\hline \multicolumn{7}{|c|}{ Somalia } \\
\hline Somali, 7255 & 1959 & 0 & 0 & 0 & 200 & 200 \\
\hline \multicolumn{7}{|c|}{ Eritrea } \\
\hline Red Sea Basin, 2071 & 1970 & 0 & 0 & 0 & 5 & 5 \\
\hline \multicolumn{7}{|c|}{ Kenya } \\
\hline Amhara Plateau, 7161 & 1993 & 458 & 686 & 101 & 0 & 101 \\
\hline Somali, 7255 & 1960 & 0 & 0 & 0 & 585 & 585 \\
\hline Tanzania Coastal, 7273 & 1974 & 0 & 10 & 95 & 260 & 355 \\
\hline Total & & 458 & 696 & 196 & 845 & 1,041 \\
\hline
\end{tabular}

Figure 32. Continued. 


\section{Exploration data}

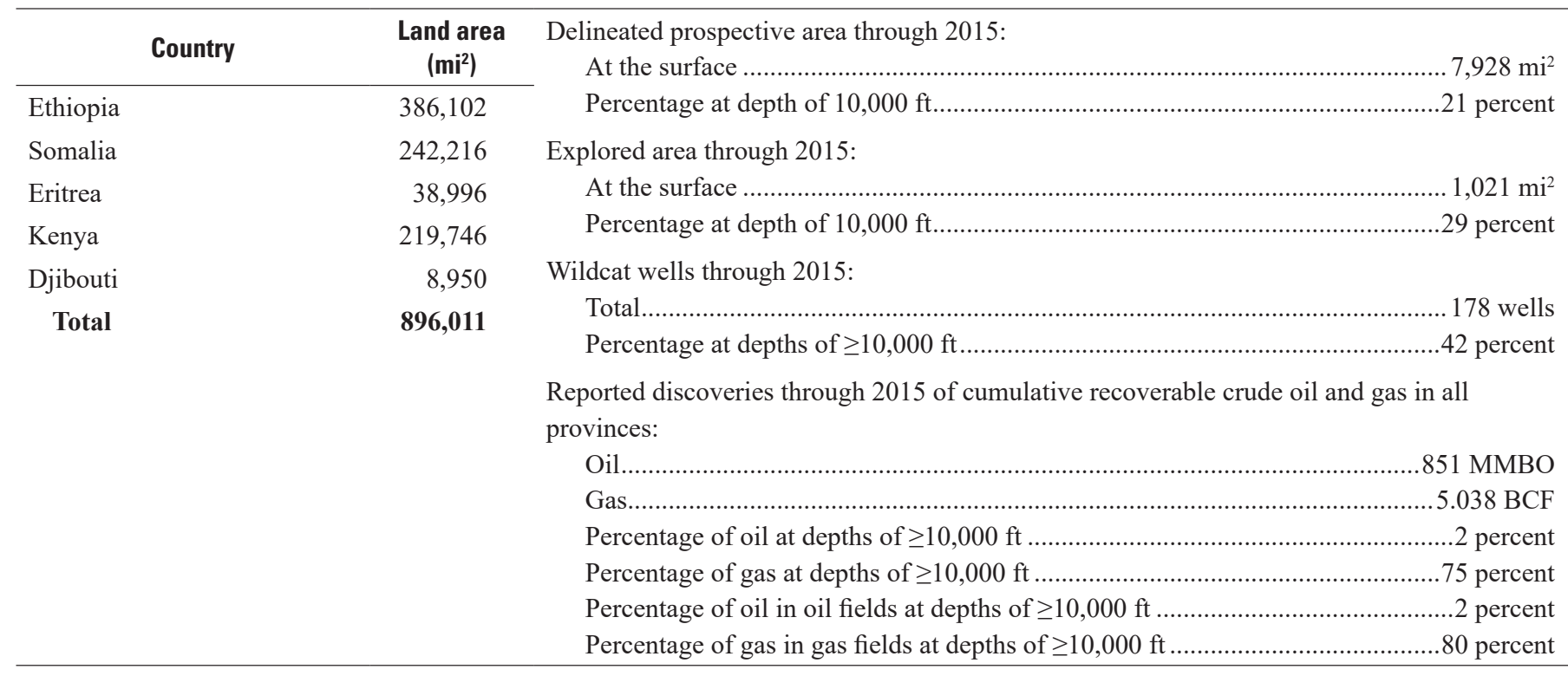

Figure 32. Continued. 


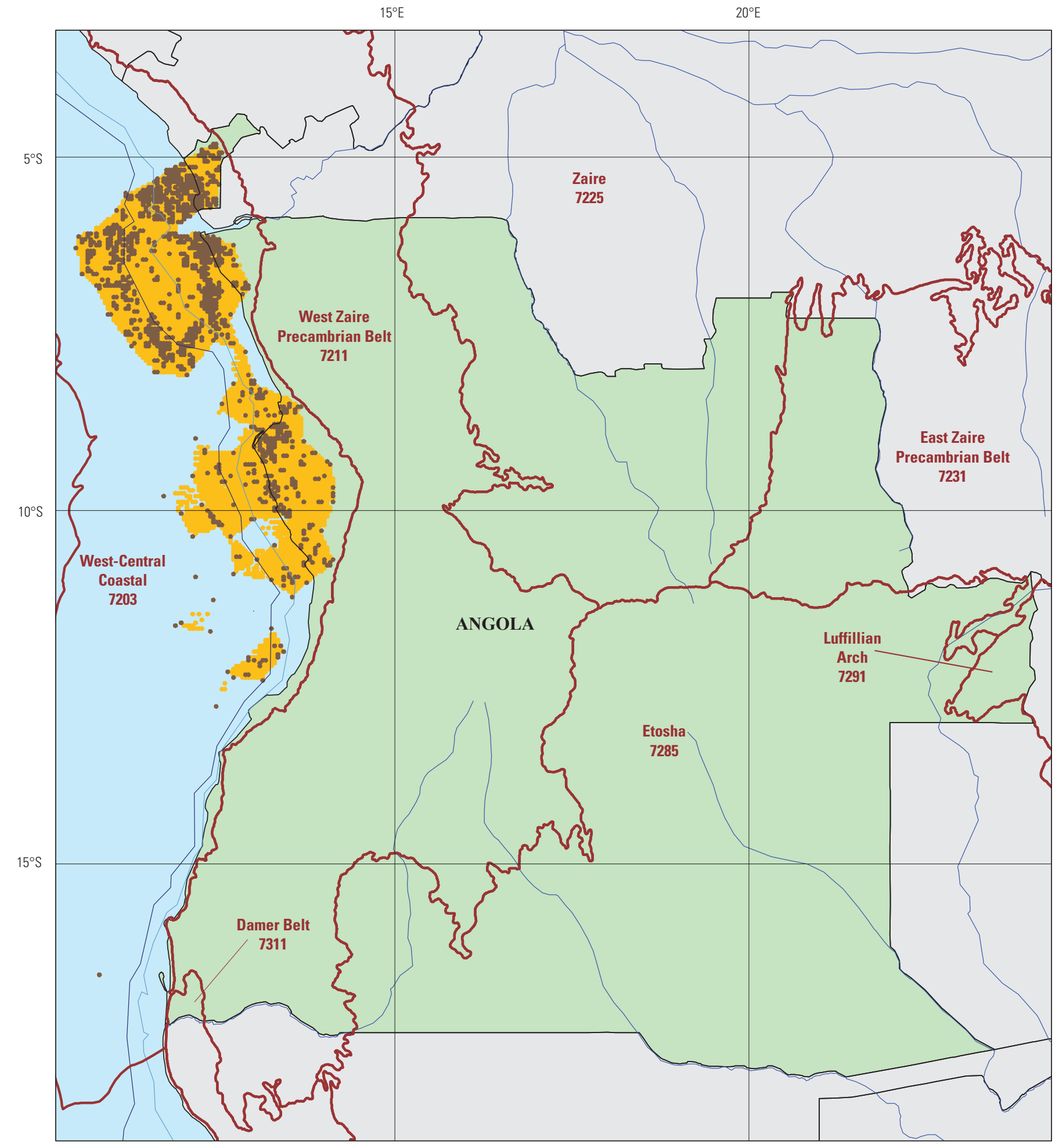

Figure 33. Map, graphs, and tables of data for oil and gas exploration through 2015 in Angola. The Angola/Congo Unitized Area is not delineated on the map because a standard boundary was not available. 
Growth in delineated prospective area and explored area through 2015, graphed by the year the areas became prospective or explored

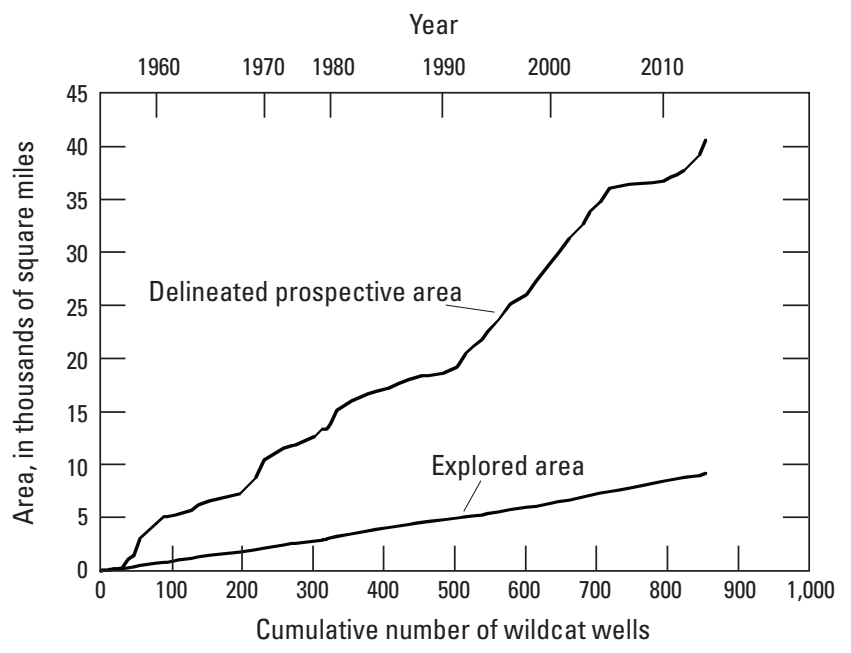

Cumulative recoverable oil and gas discoveries in all provinces through 2015, graphed by the year the field location became part of the delineated prospective area

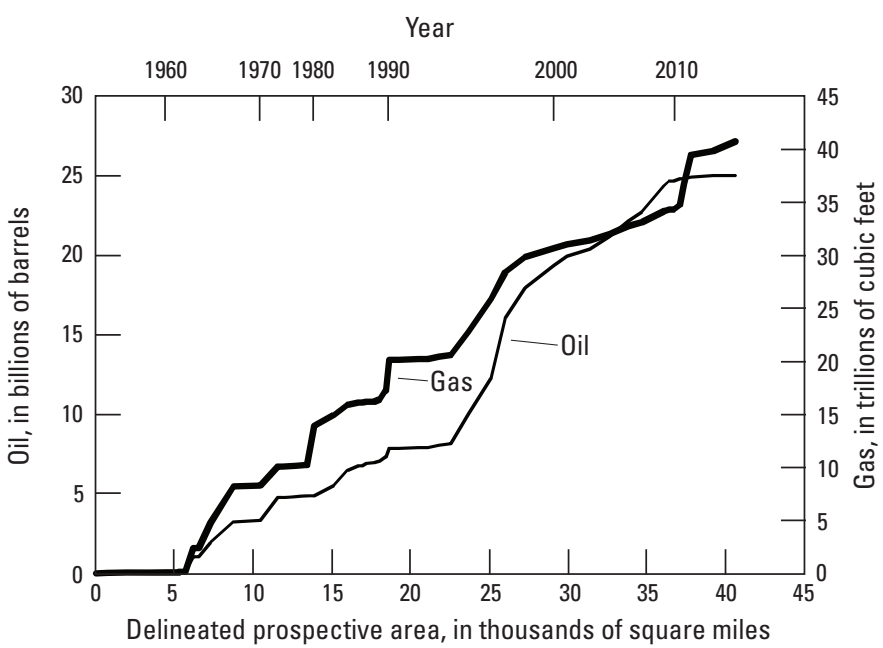

Significant petroleum provinces-Year of first discovery and cumulative recoverable oil and gas discovered through 2015

\begin{tabular}{|c|c|c|c|c|c|c|}
\hline Significant petroleum province & $\begin{array}{c}\text { Year of } \\
\text { first } \\
\text { discovery }\end{array}$ & $\begin{array}{l}\text { Oil in large } \\
\text { fields } \\
\text { (MMBO) }\end{array}$ & $\begin{array}{l}\text { Oil in all } \\
\text { fields } \\
\text { (MMBO) }\end{array}$ & $\begin{array}{c}\text { Gas in oil } \\
\text { fields } \\
\text { (BCF) }\end{array}$ & $\begin{array}{l}\text { Gas in gas } \\
\text { fields } \\
\text { (BCF) }\end{array}$ & $\begin{array}{l}\text { Gas in all } \\
\text { fields } \\
\text { (BCF) }\end{array}$ \\
\hline \multicolumn{7}{|c|}{ Angola } \\
\hline West-Central Coastal, 7203 & 1955 & 19,056 & 24,926 & 26,672 & 13,981 & 40,653 \\
\hline \multicolumn{7}{|c|}{ Angola/Congo Unitized Area } \\
\hline West-Central Coastal, 7203 & 2003 & 0 & 90 & 90 & 0 & 90 \\
\hline
\end{tabular}

\section{Exploration data}

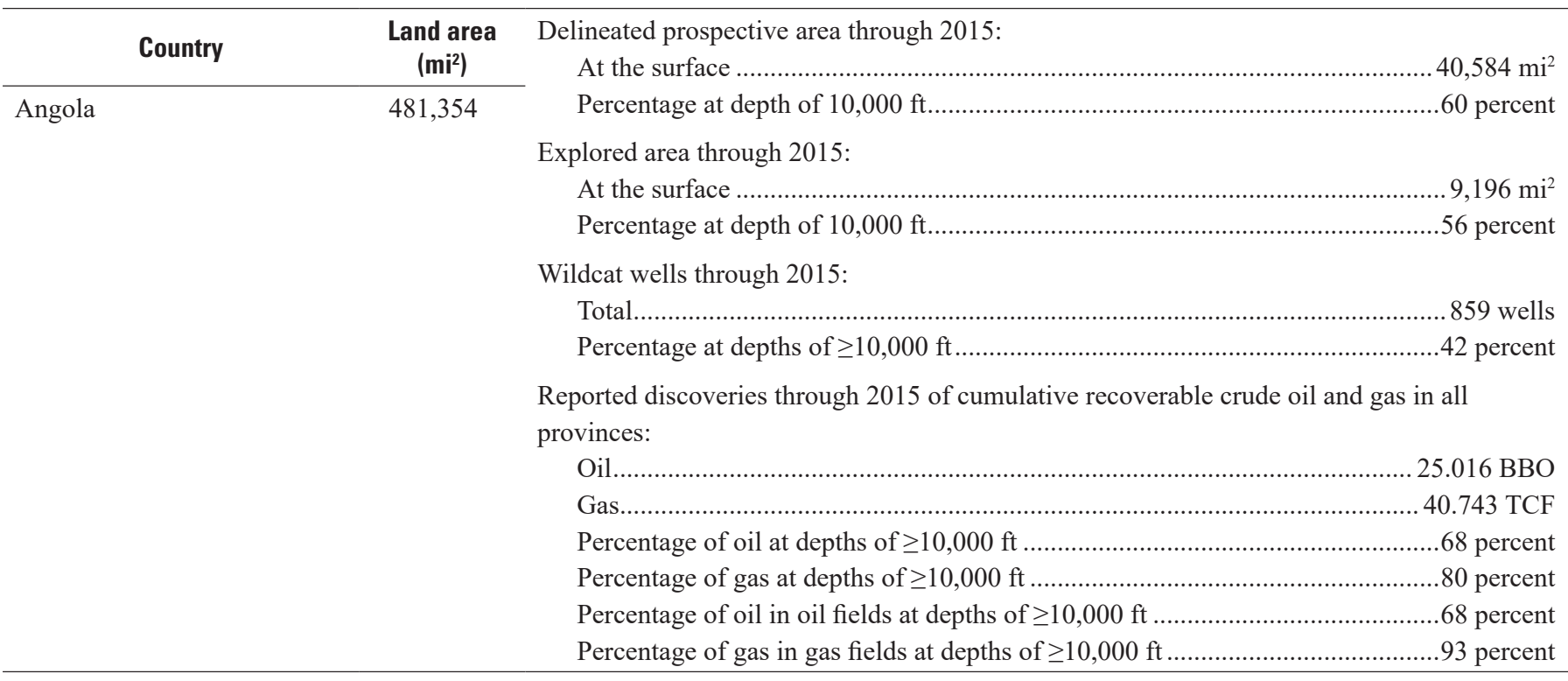

Figure 33. Continued. 


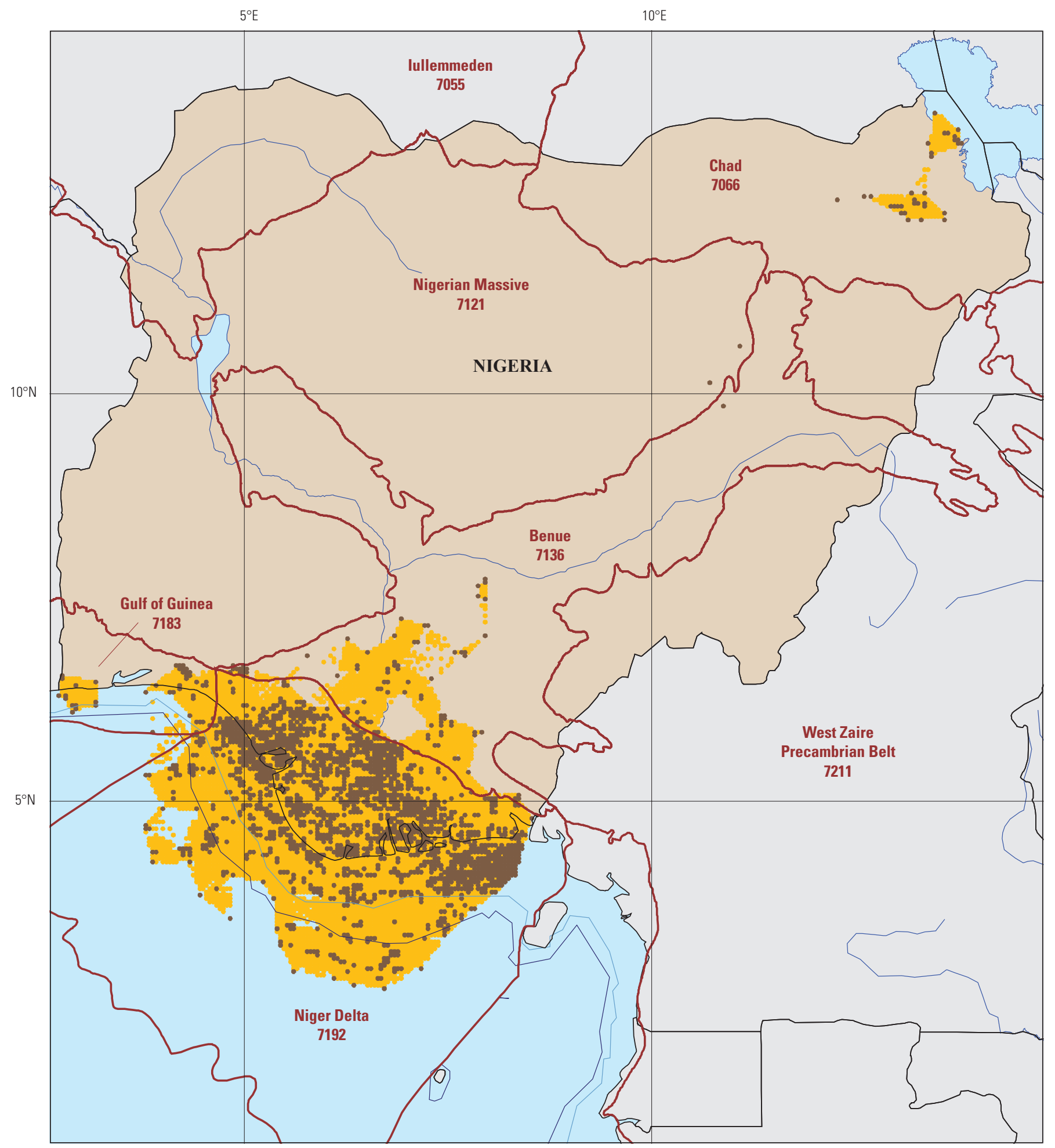

Figure 34. Map, graphs, and tables of data for oil and gas exploration through 2015 in Nigeria. The Nigeria/Sao Tome and Principe Joint Development Zone (JDZ) is not delineated on the map because a standard boundary was not available. 
Growth in delineated prospective area and explored area through 2015, graphed by the year the areas became prospective or explored

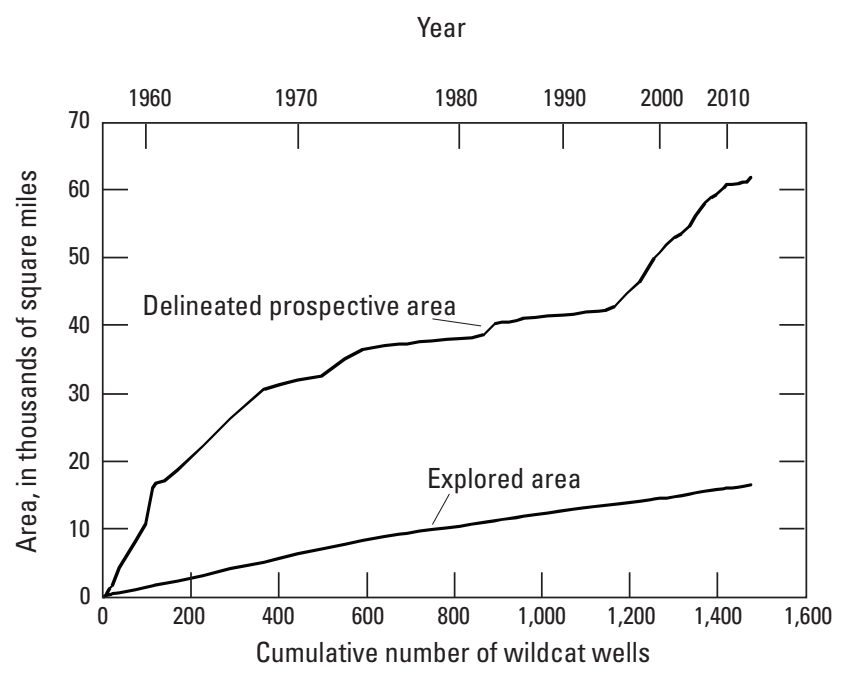

Cumulative recoverable oil and gas discoveries in all provinces through 2015, graphed by the year the field location became part of the delineated prospective area

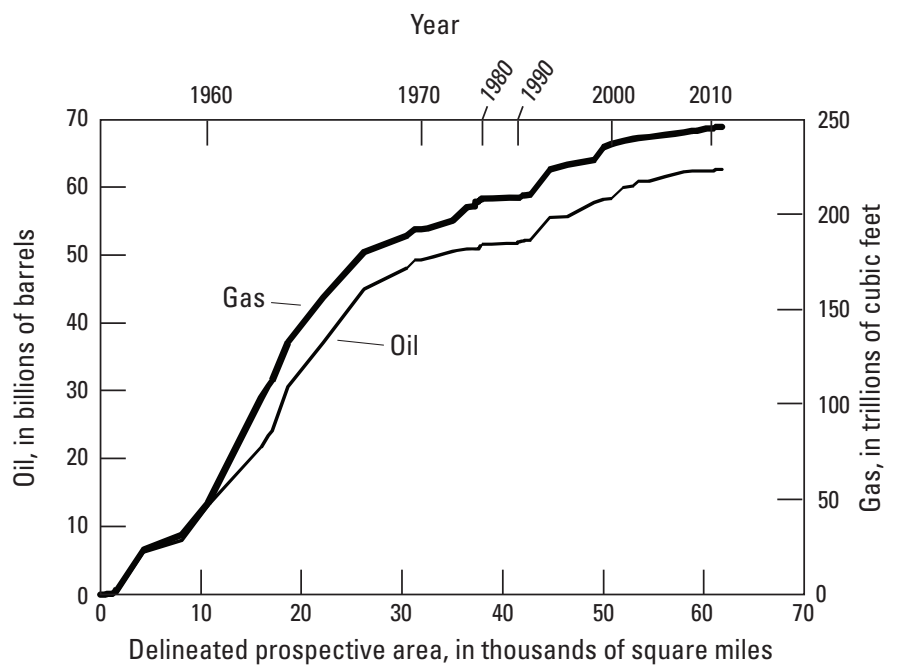

Figure 34. Continued. 
Significant petroleum provinces-Year of first discovery and cumulative recoverable oil and gas discovered through 2015

\begin{tabular}{|c|c|c|c|c|c|c|}
\hline Significant petroleum province & $\begin{array}{c}\text { Year of } \\
\text { first } \\
\text { discovery }\end{array}$ & $\begin{array}{c}\text { Oil in large } \\
\text { fields } \\
\text { (MMBO) }\end{array}$ & $\begin{array}{l}\text { Oil in all } \\
\text { fields } \\
\text { (MMBO) }\end{array}$ & $\begin{array}{l}\text { Gas in oil } \\
\text { fields } \\
\text { (BCF) }\end{array}$ & $\begin{array}{c}\text { Gas in gas } \\
\text { fields } \\
\text { (BCF) }\end{array}$ & $\begin{array}{c}\text { Gas in all } \\
\text { fields } \\
\text { (BCF) }\end{array}$ \\
\hline \multicolumn{7}{|c|}{ Nigeria } \\
\hline Benue, 7136 & 1953 & 0 & 10 & 40 & 1,230 & 1,270 \\
\hline Gulf of Guinea, 7183 & 1981 & 190 & 249 & 1,390 & 0 & 1,390 \\
\hline Total & & 49,931 & 62,596 & 173,431 & 71,081 & 244,512 \\
\hline \multicolumn{7}{|c|}{ Nigeria/Sao Tome and Principe JDZ } \\
\hline Niger Delta, 7192 & 2006 & 0 & 110 & 205 & 1,200 & 1,405 \\
\hline
\end{tabular}

Figure 34. Continued. 


\section{Exploration data}

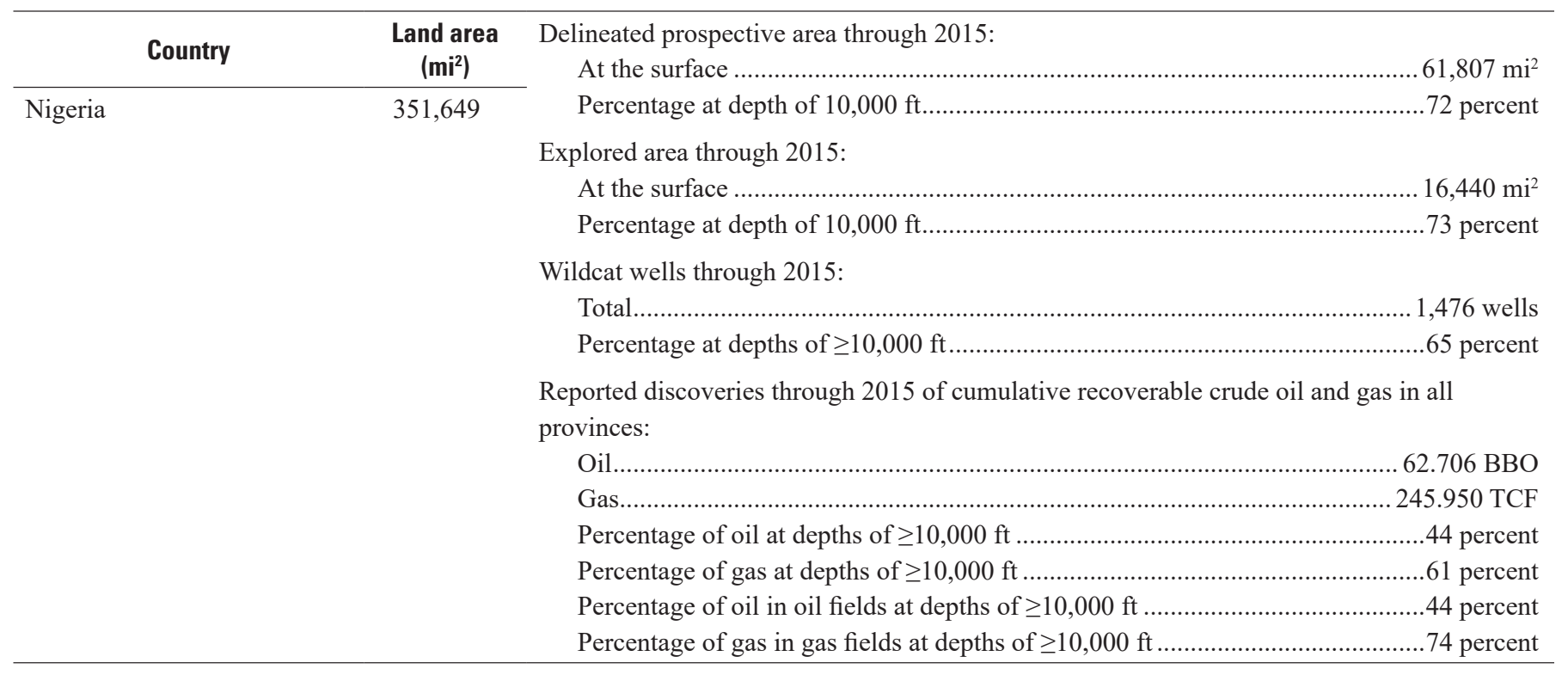

Figure 34. Continued. 


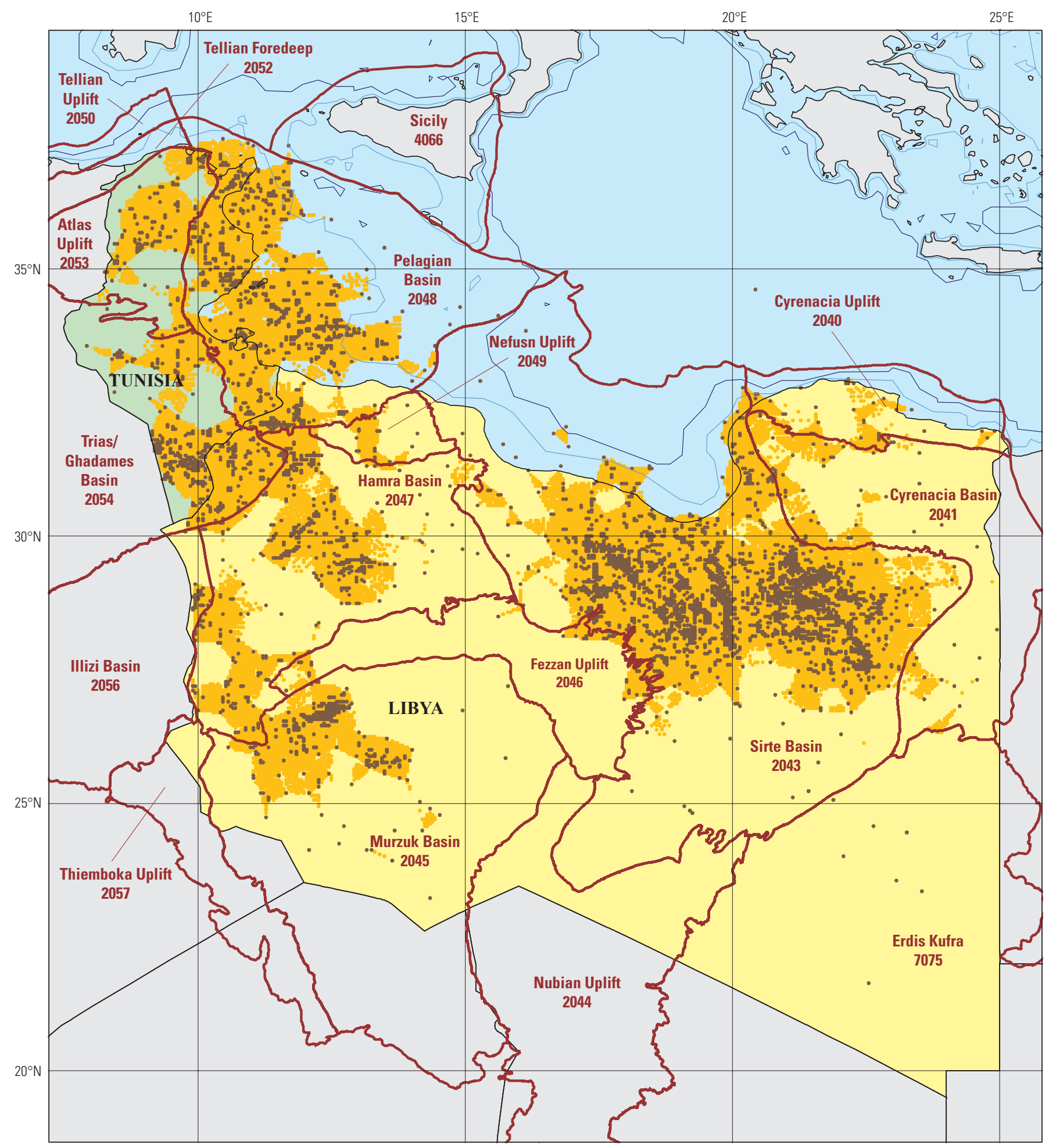

Figure 35. Map, graphs, and tables of data for oil and gas exploration through 2015 in Libya and Tunisia. The Libya/Tunisia Joint Economic Zone (JEZ) is not delineated on the map because a standard boundary was not available. 
Growth in delineated prospective area and explored area through 2015, graphed by the year the areas became prospective or explored

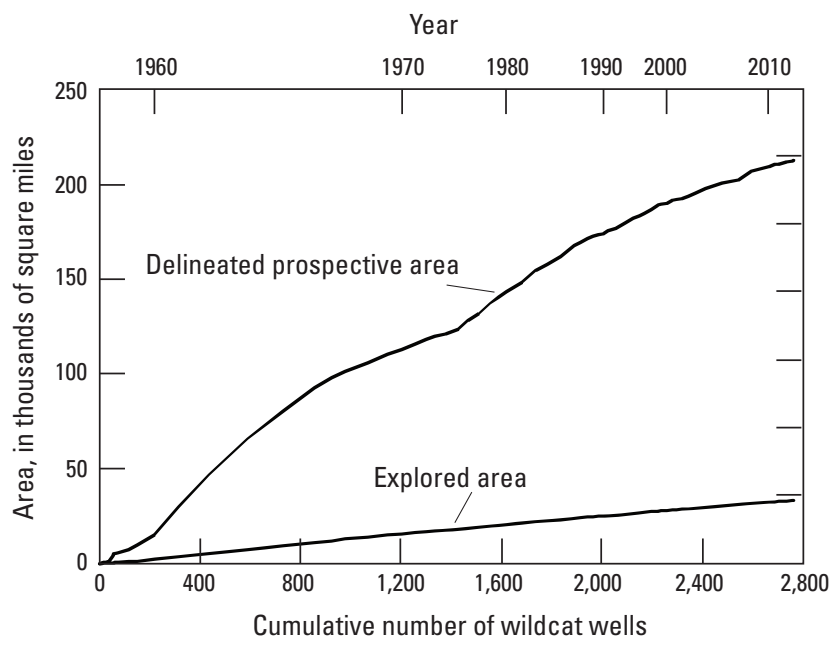

Cumulative recoverable oil and gas discoveries in all provinces through 2015, graphed by the year the field location became part of the delineated prospective area

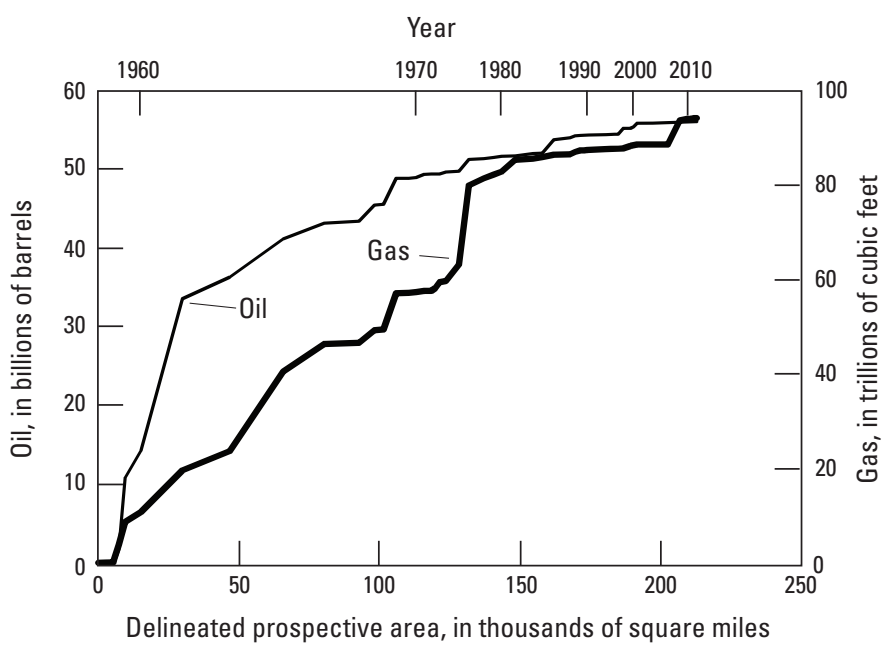

Figure 35. Continued. 
Significant petroleum provinces-Year of first discovery and cumulative recoverable oil and gas discovered through 2015

\begin{tabular}{|c|c|c|c|c|c|c|}
\hline Significant petroleum province & $\begin{array}{c}\text { Year of } \\
\text { first } \\
\text { discovery }\end{array}$ & $\begin{array}{l}\text { Oil in large } \\
\text { fields } \\
\text { (MMBO) }\end{array}$ & $\begin{array}{l}\text { Oil in all } \\
\text { fields } \\
\text { (MMBO) }\end{array}$ & $\begin{array}{l}\text { Gas in oil } \\
\text { fields } \\
\text { (BCF) }\end{array}$ & $\begin{array}{l}\text { Gas in gas } \\
\text { fields } \\
\text { (BCF) }\end{array}$ & $\begin{array}{l}\text { Gas in all } \\
\text { fields } \\
\text { (BCF) }\end{array}$ \\
\hline \multicolumn{7}{|c|}{ Libya } \\
\hline Fezzan Uplift, 2046 & 1961 & 224 & 309 & 158 & 0 & 158 \\
\hline Hamra Basin, 2047 & 1957 & 730 & 1,303 & 1,720 & 2,534 & 4,253 \\
\hline Illizi Basin, 2056 & 1964 & 0 & 40 & 0 & 2,721 & 2,721 \\
\hline Murzuk Basin, 2045 & 1978 & 3,003 & 3,886 & 689 & 35 & 724 \\
\hline Pelagian Basin, 2048 & 1959 & 1,335 & 1,918 & 4,564 & 19,399 & 23,963 \\
\hline Sirte Basin, 2043 & 1958 & 42,417 & 46,398 & 32,235 & 22,775 & 55,009 \\
\hline Trias/Ghadames Basin, 2054 & 1961 & 0 & 268 & 334 & 96 & 430 \\
\hline Total & & 47,709 & 54,121 & 39,699 & 47,558 & 87,257 \\
\hline \multicolumn{7}{|c|}{ Tunisia } \\
\hline Pelagian Basin, 2048 & 1949 & 330 & 901 & 656 & 3,454 & 4,110 \\
\hline Sicily, 4066 & 1982 & 0 & 0 & 0 & 150 & 150 \\
\hline Trias/Ghadames Basin, 2054 & 1964 & 750 & 1,017 & 1,514 & 1,123 & 2,636 \\
\hline Total & & 1,080 & 1,918 & 2,170 & 4,726 & 6,896 \\
\hline \multicolumn{7}{|c|}{ Libya/Tunisia JEZ } \\
\hline Pelagian Basin, 2048 & 1992 & 0 & 7 & 71 & 0 & 71 \\
\hline
\end{tabular}

Figure 35. Continued. 


\section{Exploration data}

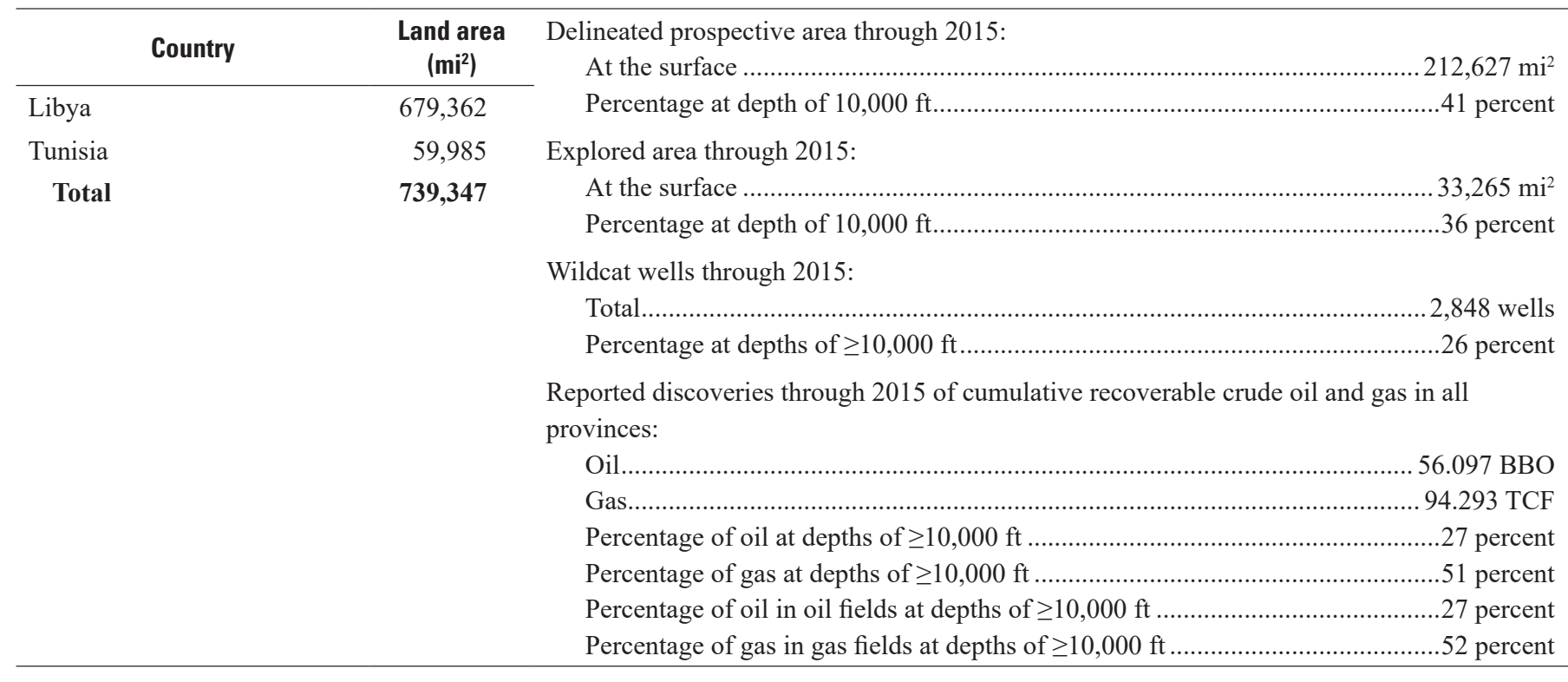

Figure 35. Continued. 


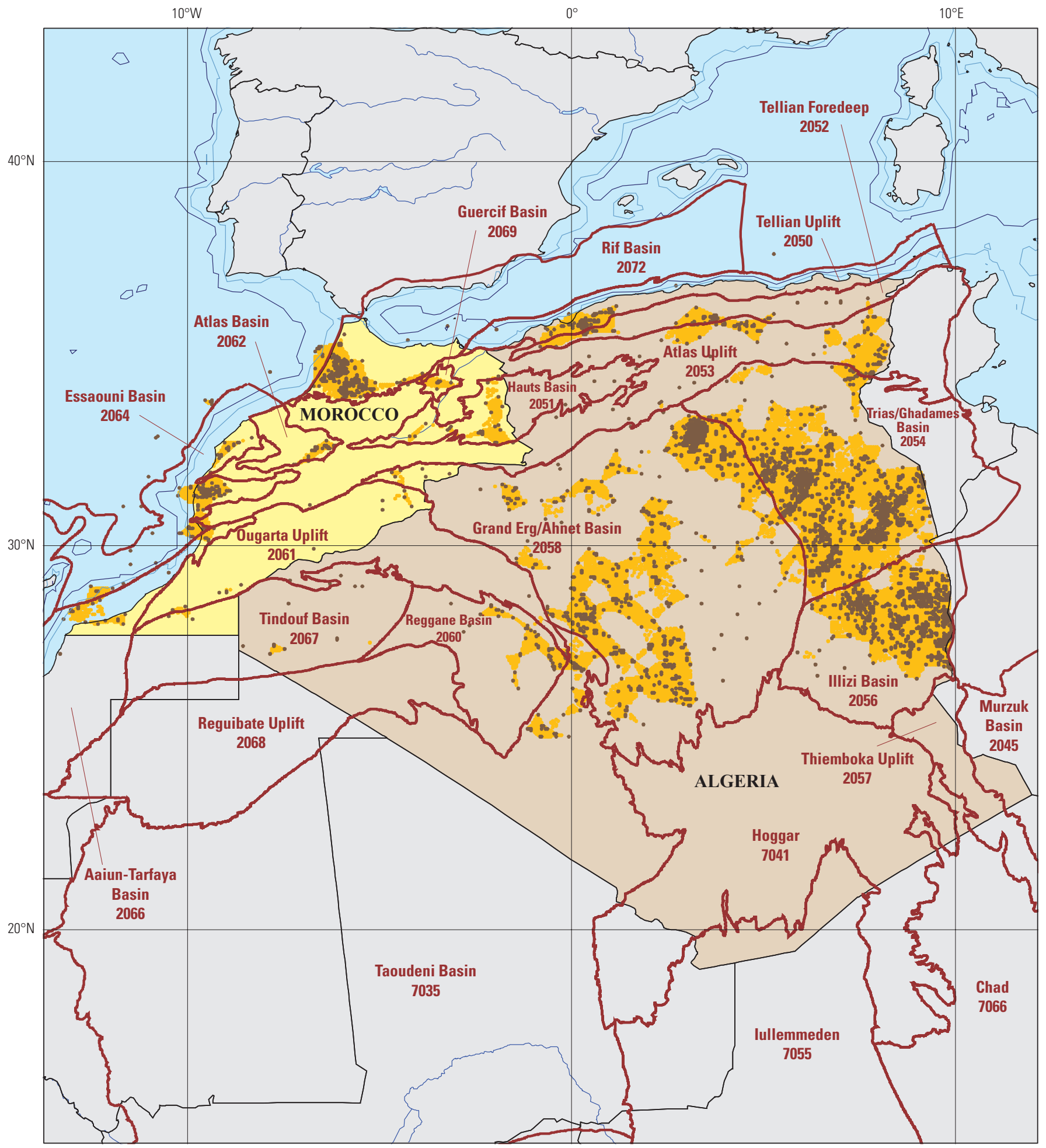

Figure 36. Map, graphs, and tables of data for oil and gas exploration through 2015 in Algeria and Morocco. 
Growth in delineated prospective area and explored area through 2015, graphed by the year the areas became prospective or explored

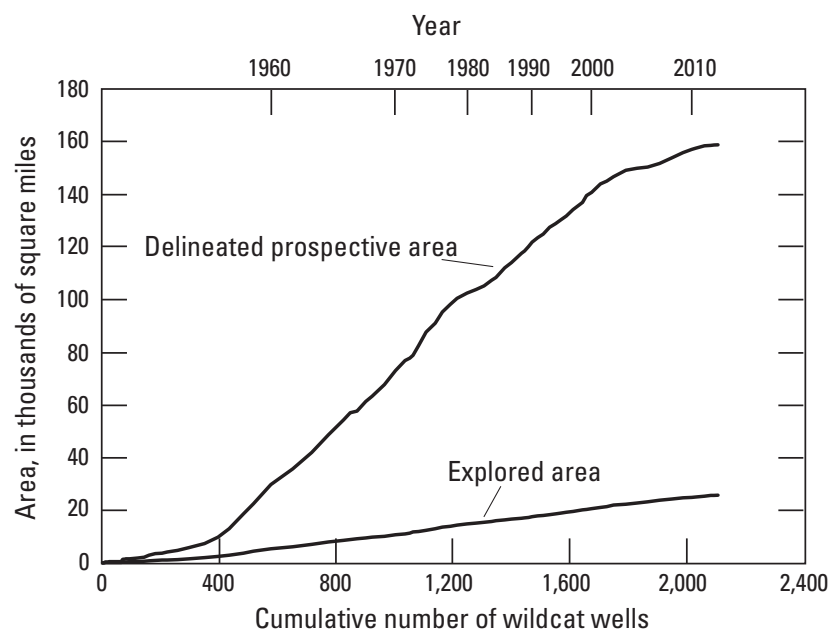

Cumulative recoverable oil and gas discoveries in all provinces through 2015, graphed by the year the field location became part of the delineated prospective area

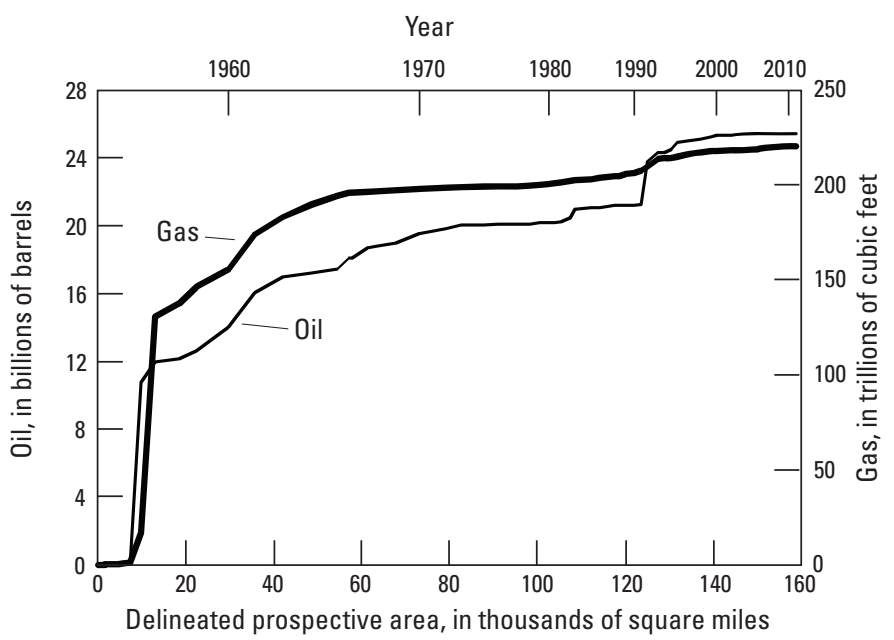

Figure 36. Continued. 
Significant petroleum provinces-Year of first discovery and cumulative recoverable oil and gas discovered through 2015

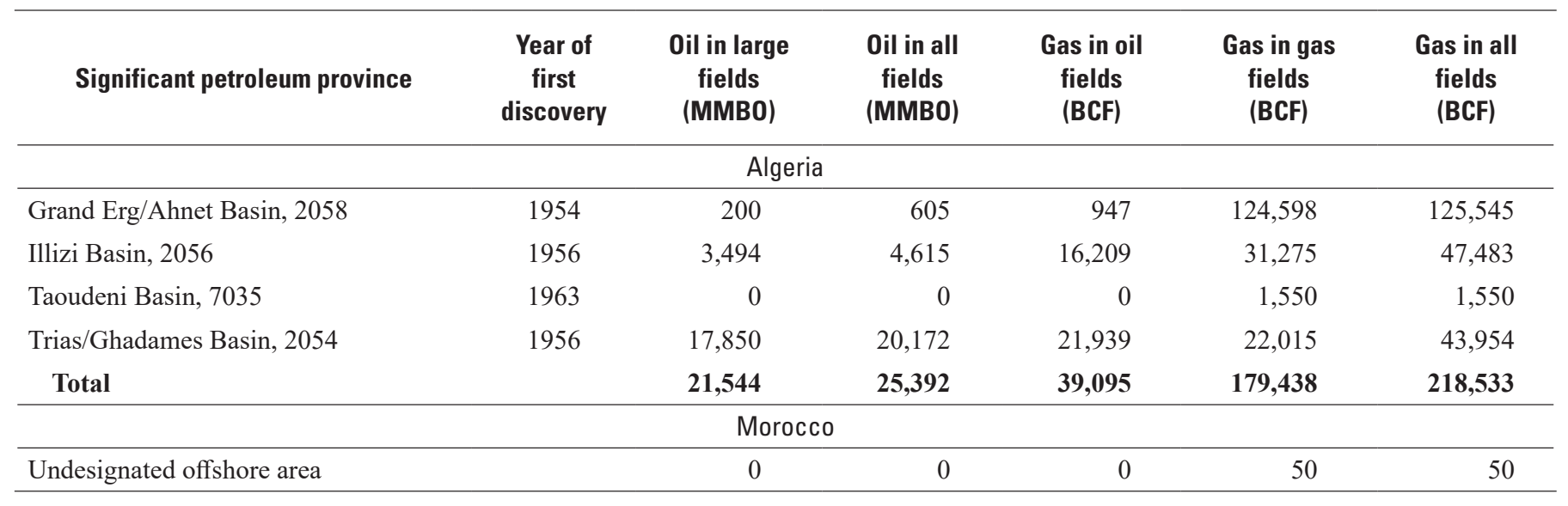

Figure 36. Continued. 


\section{Exploration data}

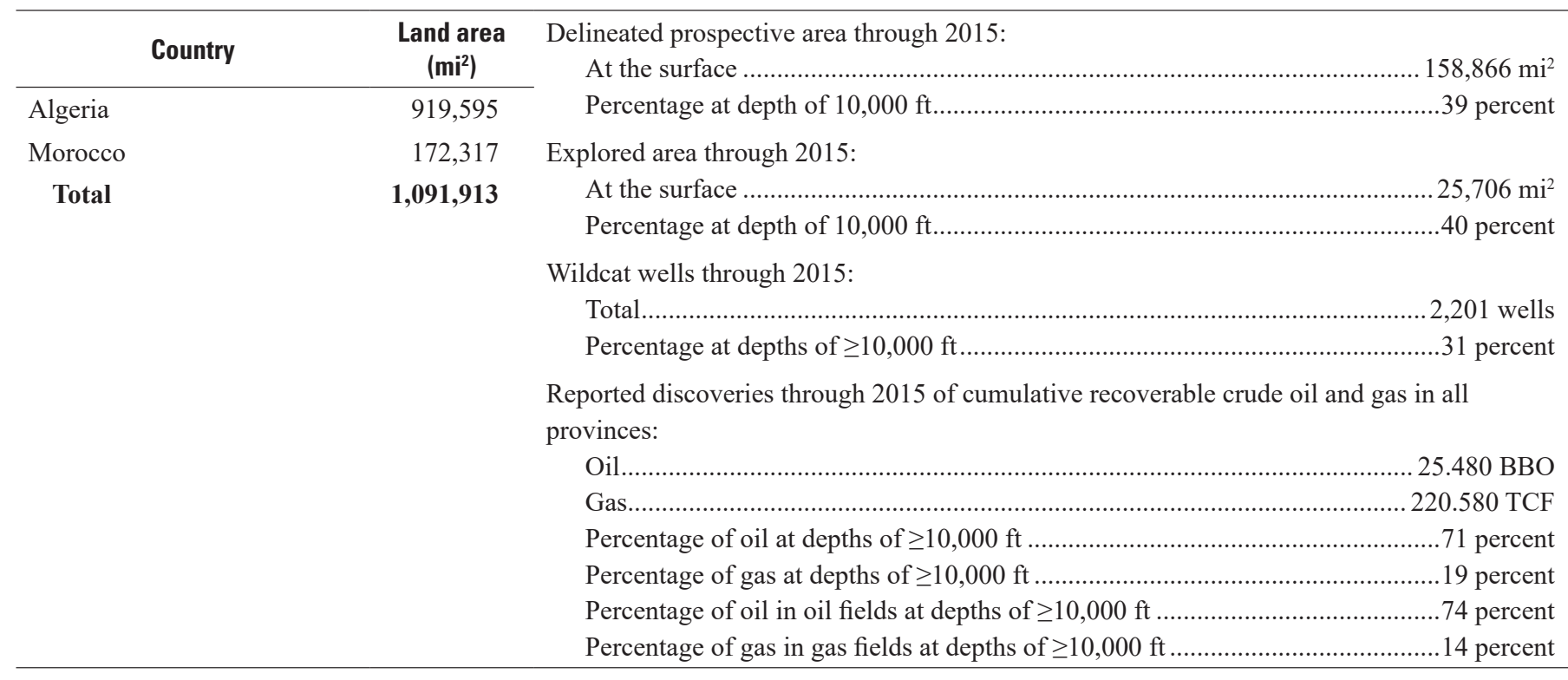

Figure 36. Continued. 


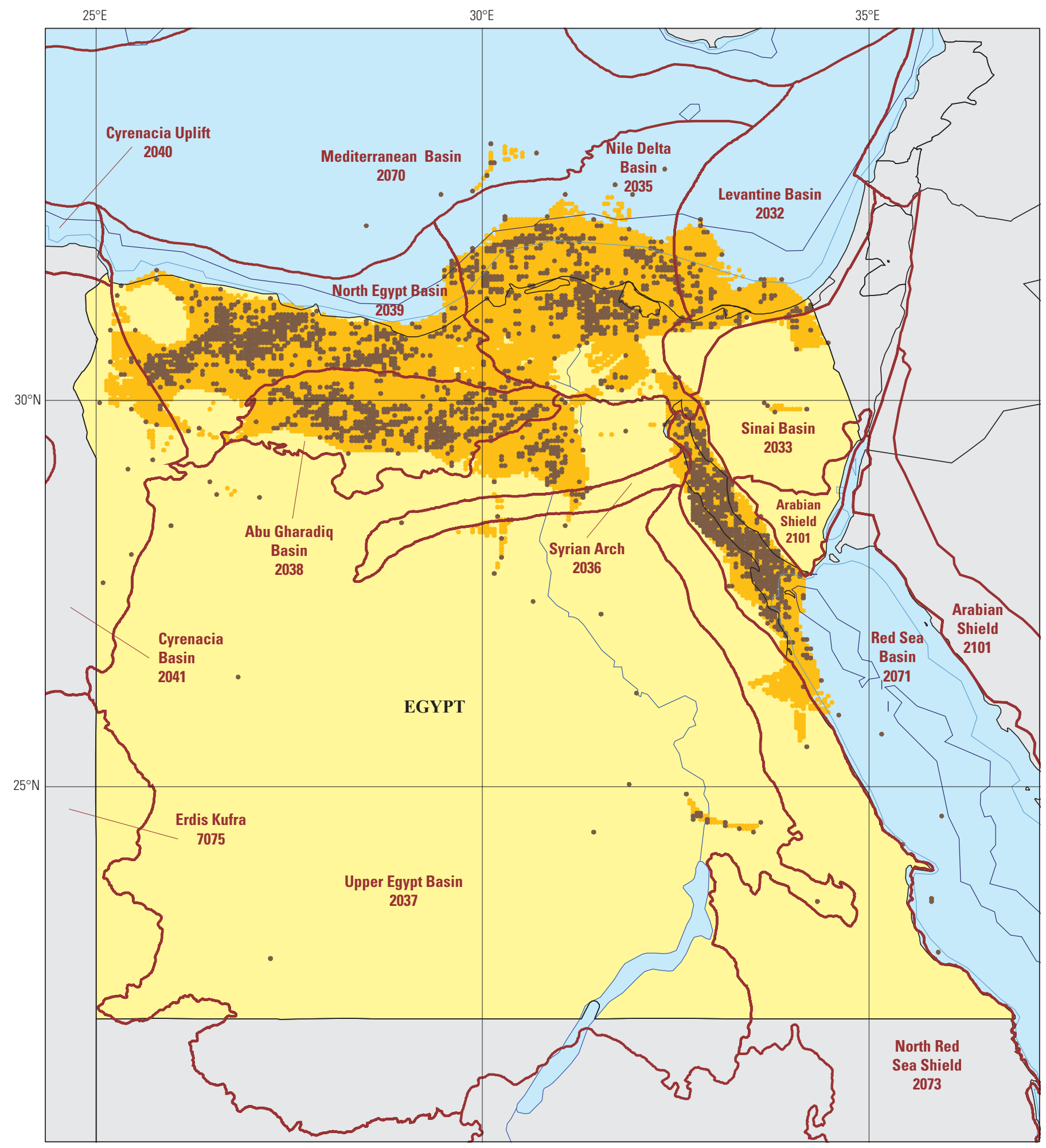

Figure 37. Map, graphs, and tables of data for oil and gas exploration through 2015 in Egypt. 
Growth in delineated prospective area and explored area through 2015, graphed by the year the areas became prospective or explored

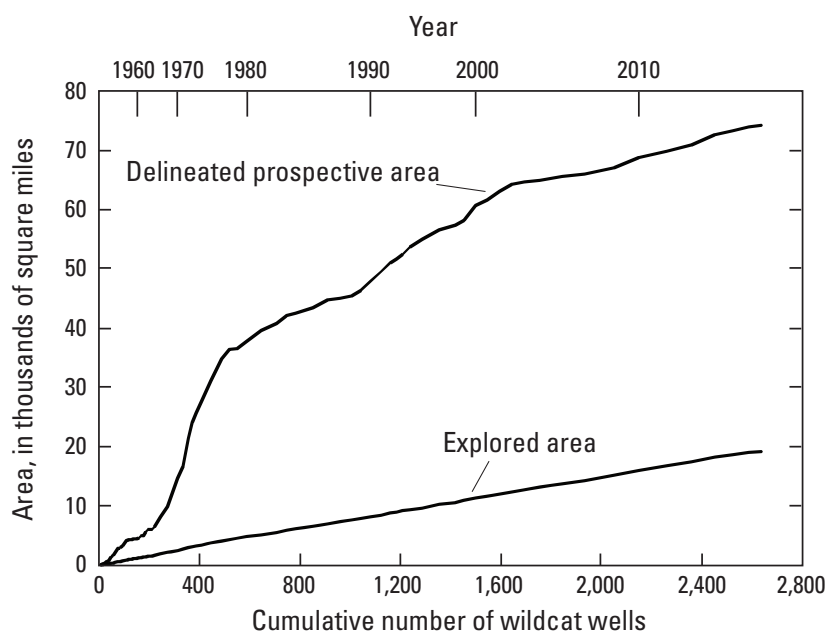

Cumulative recoverable oil and gas discoveries in all provinces through 2015, graphed by the year the field location became part of the delineated prospective area

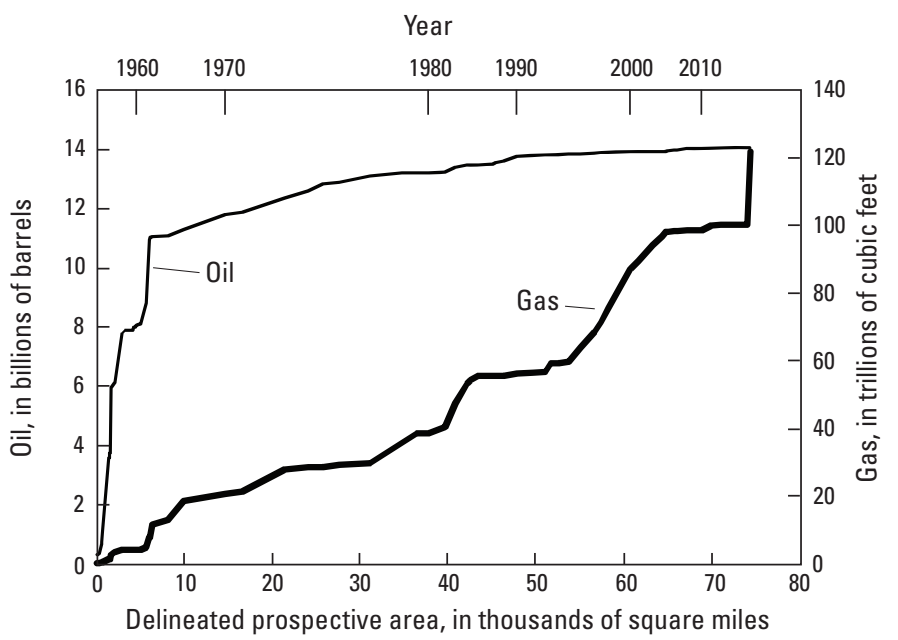

Figure 37. Continued. 
Significant petroleum provinces-Year of first discovery and cumulative recoverable oil and gas discovered through 2015

\begin{tabular}{lccrrrr}
\hline \multicolumn{1}{c}{ Significant petroleum province } & $\begin{array}{c}\text { Year of } \\
\text { first } \\
\text { discovery }\end{array}$ & $\begin{array}{c}\text { 0il in large } \\
\text { fields } \\
\text { (MMBO) }\end{array}$ & $\begin{array}{c}\text { Oil in all } \\
\text { fields } \\
\text { (MMB0) }\end{array}$ & $\begin{array}{c}\text { Gas in oil } \\
\text { fields } \\
\text { (BCF) }\end{array}$ & $\begin{array}{c}\text { Gas in gas } \\
\text { fields } \\
\text { (BCF) }\end{array}$ & $\begin{array}{c}\text { Gas in all } \\
\text { fields } \\
\text { (BCF) }\end{array}$ \\
\hline Abu Gharadiq Basin, 2038 & \multicolumn{7}{c}{ Egypt } \\
Levantine Basin, 2032 & 1968 & 222 & 1,190 & 1,831 & 3,606 & 5,437 \\
Mediterranean Basin, 2070 & 1967 & 0 & 19 & 13 & 3,956 & 3,969 \\
Nile Delta Basin, 2035 & 2003 & 0 & 0 & 0 & 1,222 & 1,222 \\
North Egypt Basin, 2039 & 1966 & 0 & 32 & 241 & 88,858 & 89,099 \\
Red Sea Basin, 2071 & 1966 & 0 & 1,514 & 2,134 & 11,780 & 13,914 \\
$\quad$ Total & 1907 & 8,931 & 11,280 & 7,059 & 1,133 & 8,192 \\
\hline
\end{tabular}

Figure 37. Continued. 


\section{Exploration data}

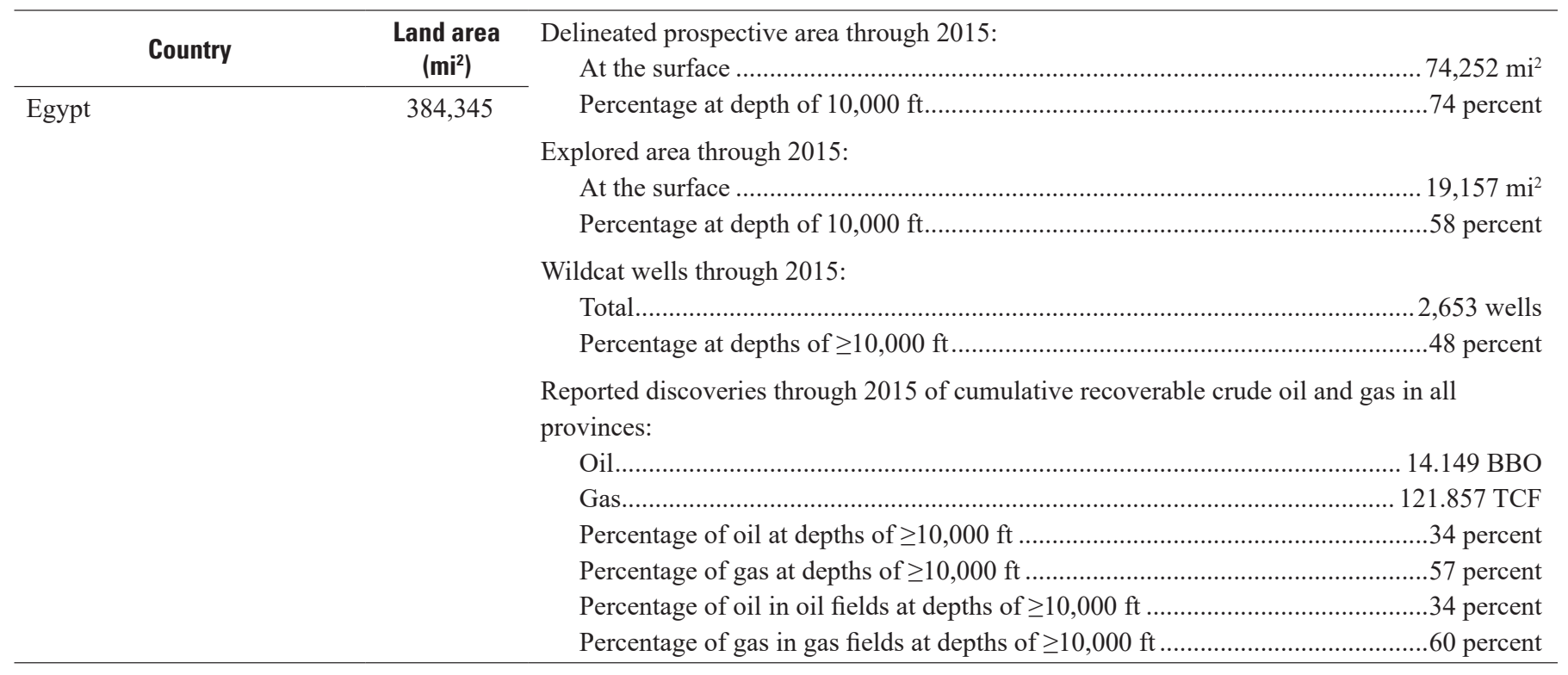

Figure 37. Continued. 


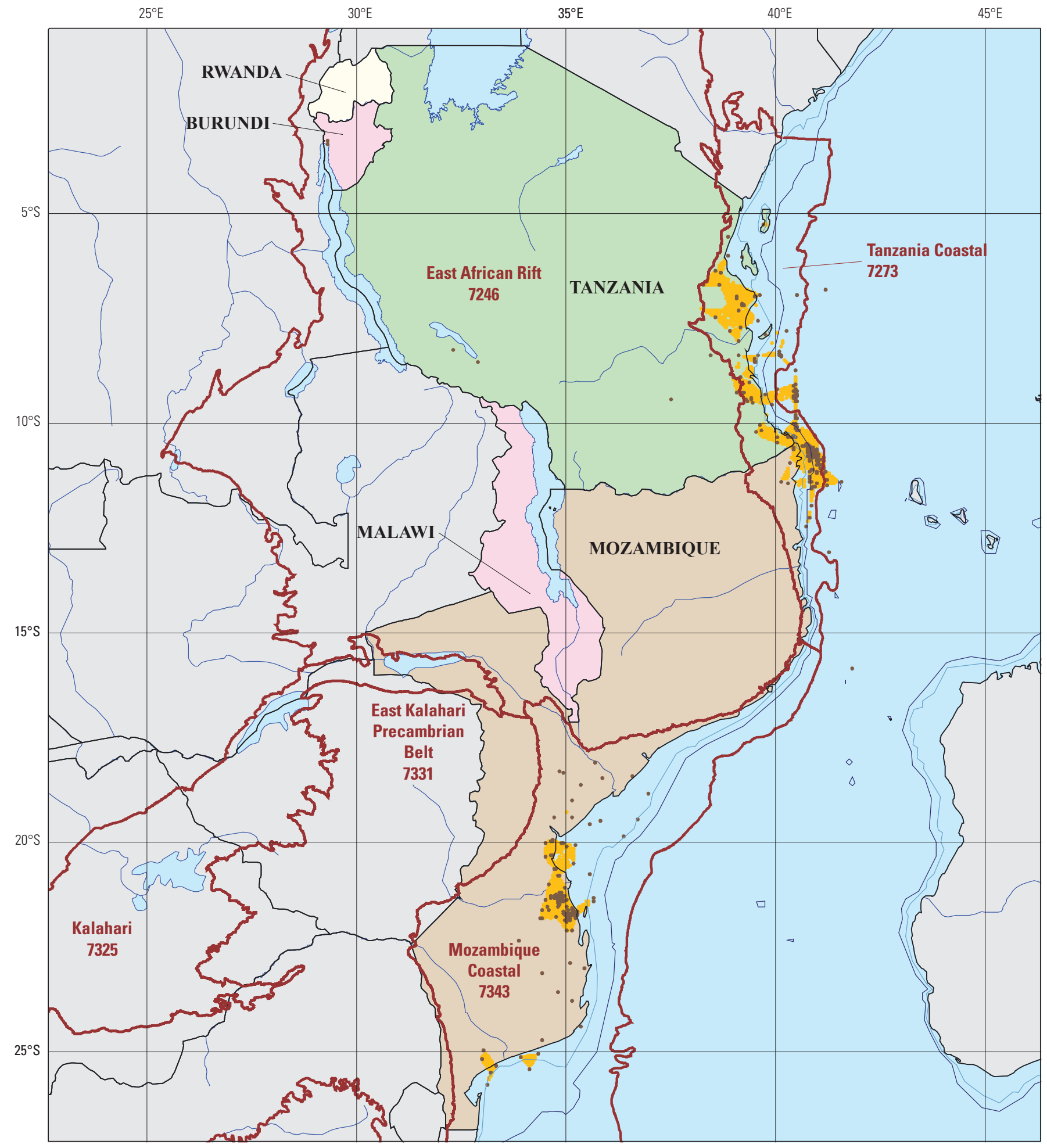

Figure 38. Map, graphs, and tables of data for oil and gas exploration through 2015 in Mozambique, Tanzania, Burundi, Malawi, and Rwanda. 
Growth in delineated prospective area and explored area through 2015, graphed by the year the areas became prospective or explored

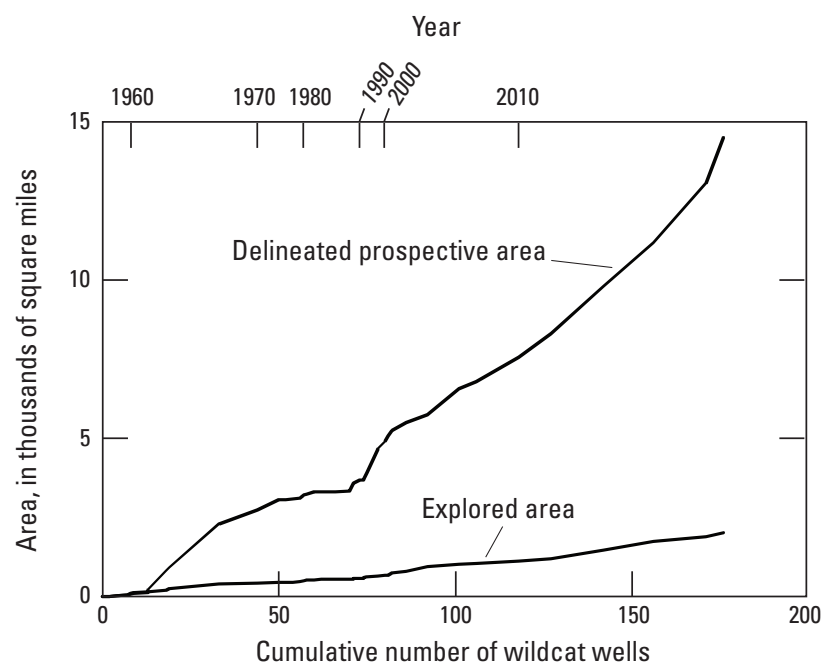

Cumulative recoverable oil and gas discoveries in all provinces through 2015, graphed by the year the field location became part of the delineated prospective area

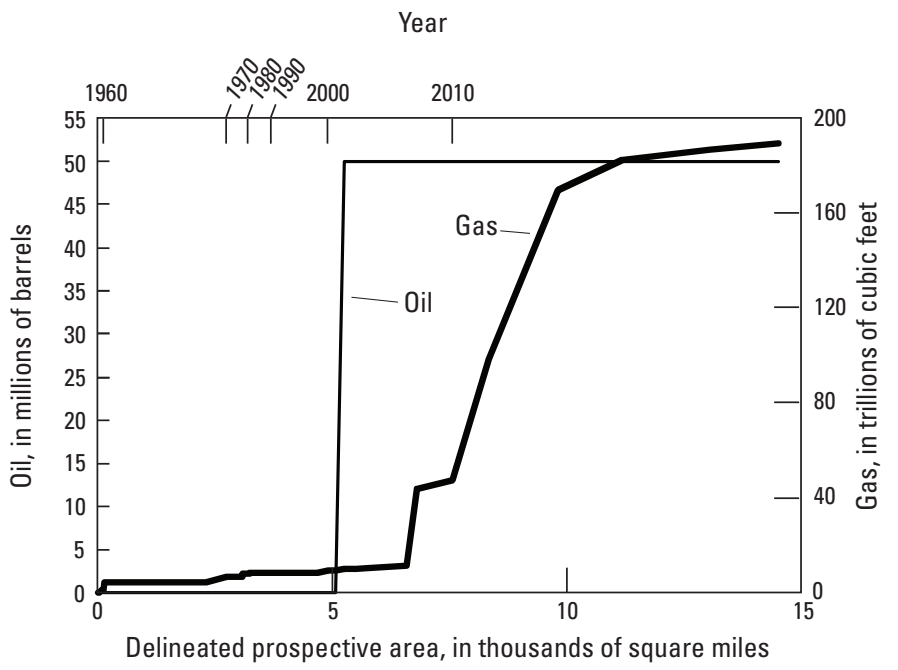

Figure 38. Continued. 
Significant petroleum provinces-Year of first discovery and cumulative recoverable oil and gas discovered through 2015

\begin{tabular}{|c|c|c|c|c|c|c|}
\hline Significant petroleum province & $\begin{array}{c}\text { Year of } \\
\text { first } \\
\text { discovery }\end{array}$ & $\begin{array}{l}\text { Oil in large } \\
\text { fields } \\
\text { (MMBO) }\end{array}$ & $\begin{array}{l}\text { Oil in all } \\
\text { fields } \\
\text { (MMBO) }\end{array}$ & $\begin{array}{c}\text { Gas in oil } \\
\text { fields } \\
\text { (BCF) }\end{array}$ & $\begin{array}{l}\text { Gas in gas } \\
\text { fields } \\
\text { (BCF) }\end{array}$ & $\begin{array}{l}\text { Gas in all } \\
\text { fields } \\
\text { (BCF) }\end{array}$ \\
\hline \multicolumn{7}{|c|}{ Mozambique } \\
\hline Mozambique Coastal, 7343 & 1953 & 0 & 50 & 625 & 9,011 & 9,636 \\
\hline Tanzania Coastal, 7273 & 2010 & 0 & 0 & 0 & 125,130 & 125,130 \\
\hline Undesignated offshore area & & 0 & 0 & 0 & 16,500 & 16,500 \\
\hline Total & & $\mathbf{0}$ & 50 & 625 & 150,641 & 151,266 \\
\hline \multicolumn{7}{|c|}{ Tanzania } \\
\hline Tanzania Coastal, 7273 & 1974 & 0 & 0 & 0 & 19,935 & 19,935 \\
\hline Undesignated offshore area & & 0 & 0 & 0 & 18,100 & 18,100 \\
\hline Total & & 0 & 0 & 0 & $\mathbf{3 8 , 0 3 5}$ & 38,035 \\
\hline
\end{tabular}

Figure 38. Continued. 


\section{Exploration data}

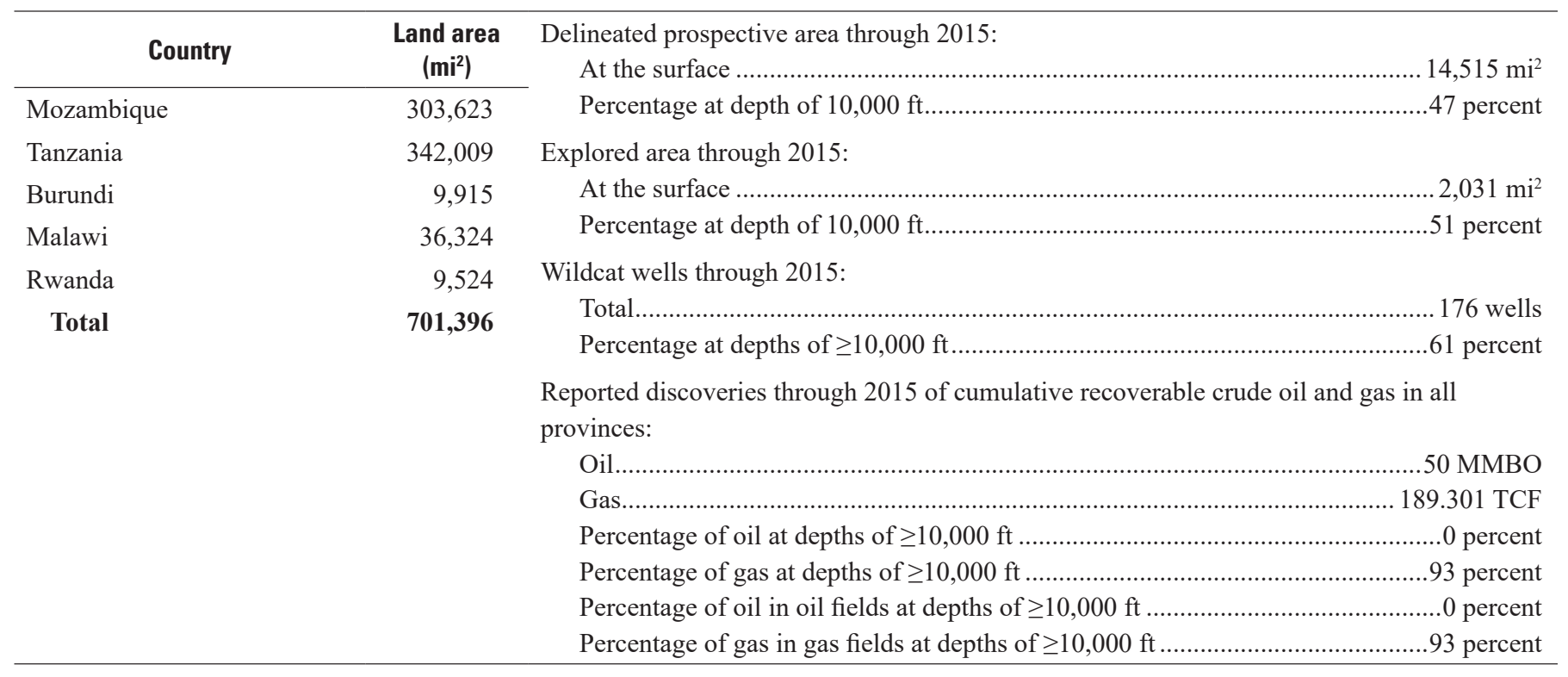

Figure 38. Continued. 


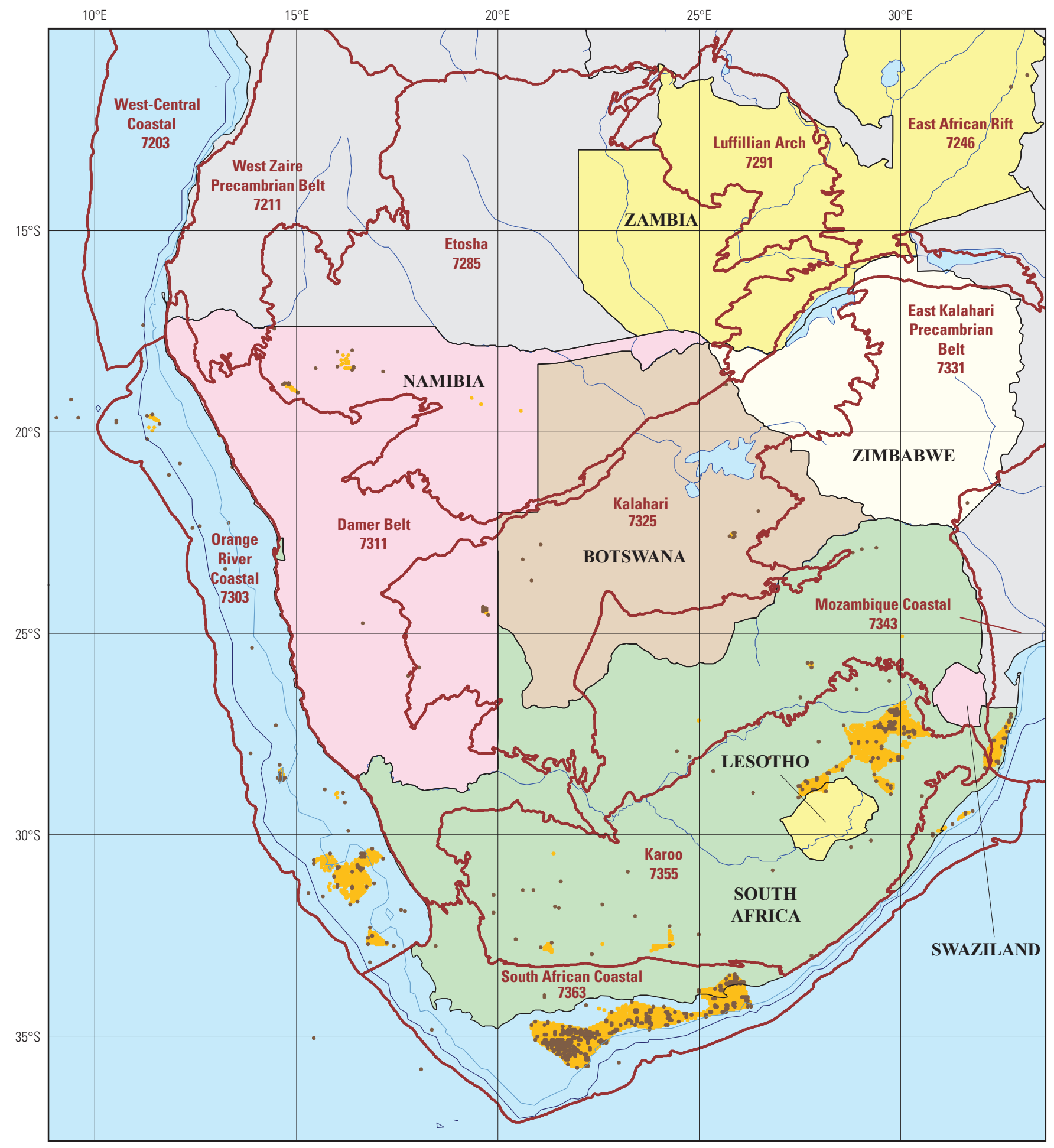

Figure 39. Map, graphs, and tables of data for oil and gas exploration through 2015 in South Africa, Namibia, Botswana, Lesotho, Swaziland, Zambia, and Zimbabwe. 
Growth in delineated prospective area and explored area through 2015, graphed by the year the areas became prospective or explored

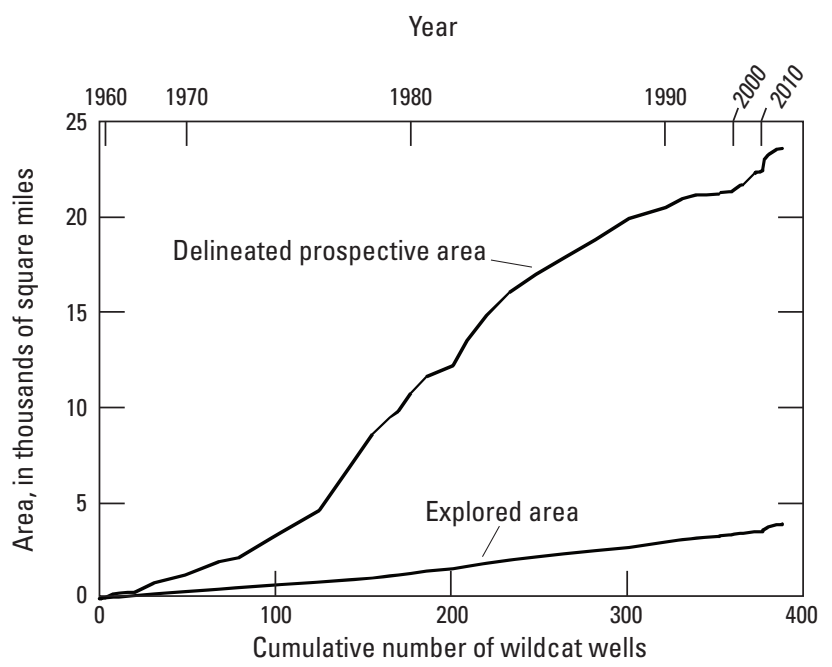

Cumulative recoverable oil and gas discoveries in all provinces through 2015, graphed by the year the field location became part of the delineated prospective area

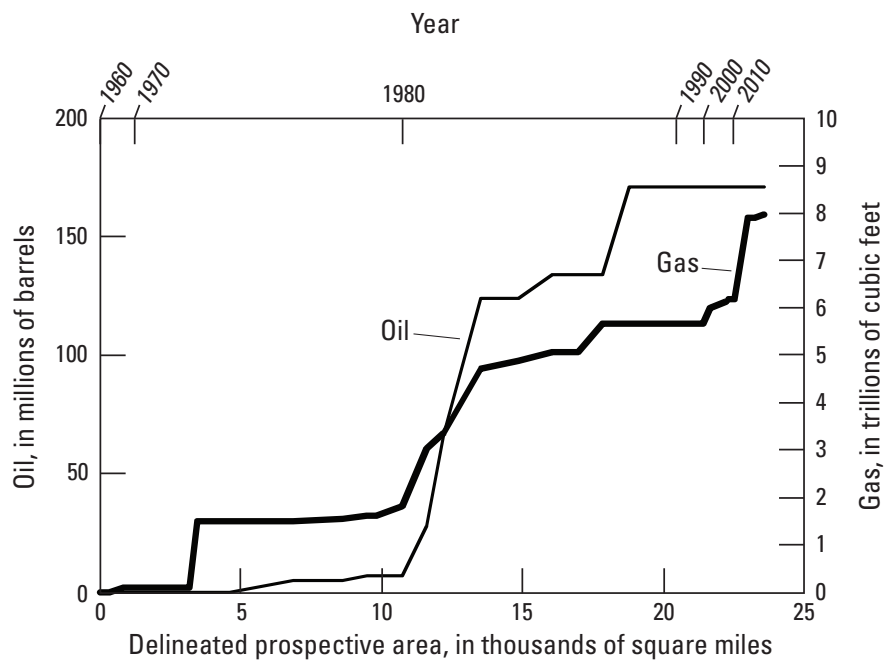

Figure 39. Continued. 
Significant petroleum provinces-Year of first discovery and cumulative recoverable oil and gas discovered through 2015

\begin{tabular}{|c|c|c|c|c|c|c|}
\hline Significant petroleum province & $\begin{array}{c}\text { Year of } \\
\text { first } \\
\text { discovery }\end{array}$ & $\begin{array}{c}\text { Oil in large } \\
\text { fields } \\
\text { (MMBO) }\end{array}$ & $\begin{array}{l}\text { Oil in all } \\
\text { fields } \\
\text { (MMBO) }\end{array}$ & $\begin{array}{l}\text { Gas in oil } \\
\text { fields } \\
\text { (BCF) }\end{array}$ & $\begin{array}{l}\text { Gas in gas } \\
\text { fields } \\
\text { (BCF) }\end{array}$ & $\begin{array}{c}\text { Gas in all } \\
\text { fields } \\
\text { (BCF) }\end{array}$ \\
\hline \multicolumn{7}{|c|}{ South Africa } \\
\hline Karoo, 7355 & 1969 & 0 & 0 & 0 & 1,483 & 1,483 \\
\hline Orange River Coastal, 7303 & 1987 & 0 & 37 & 4 & 1,099 & 1,103 \\
\hline Total & & $\mathbf{0}$ & 173 & 412 & 5,853 & 6,266 \\
\hline \multicolumn{7}{|c|}{ Namibia } \\
\hline Orange River Coastal, 7303 & 1974 & 0 & 0 & 0 & 1,400 & 1,400 \\
\hline
\end{tabular}

Figure 39. Continued. 


\section{Exploration data}

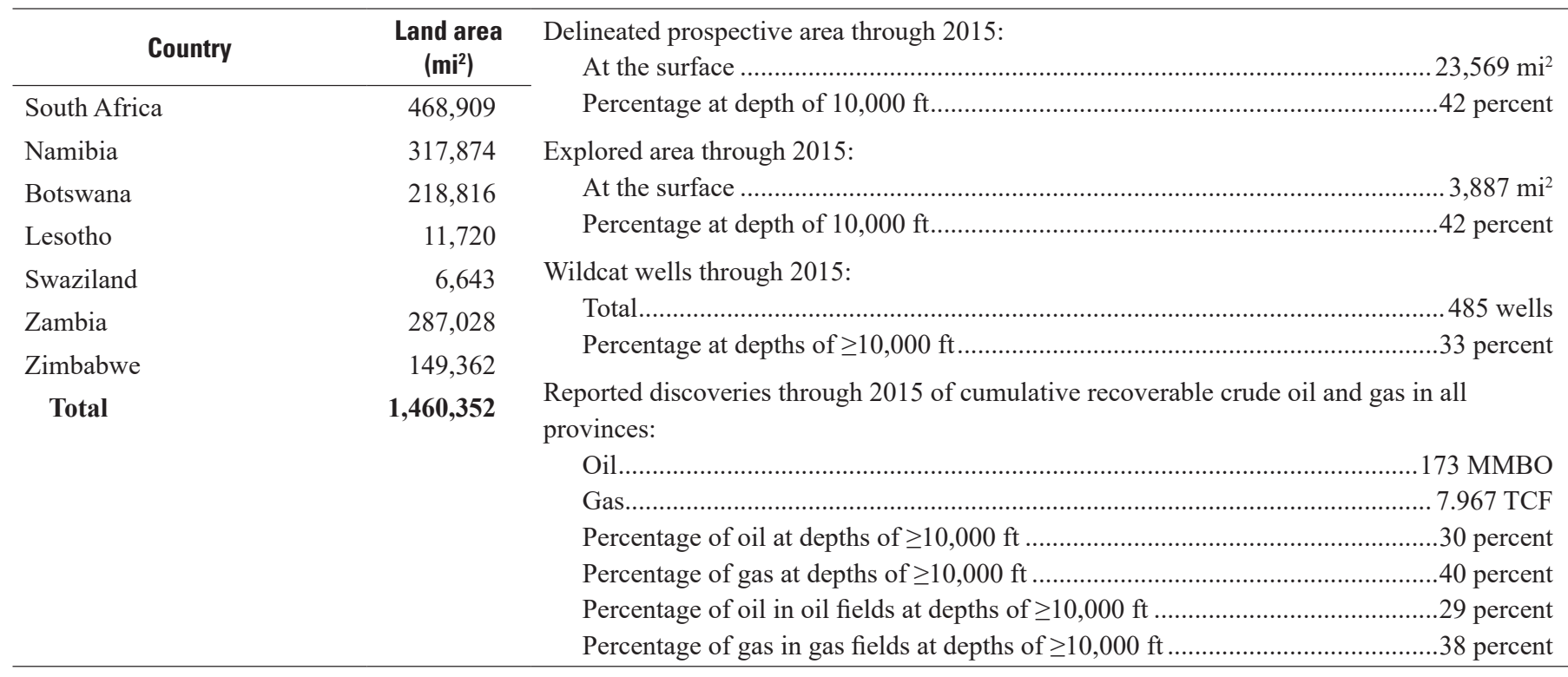

Figure 39. Continued. 




Figure 40. Map, graphs, and tables of data for oil and gas exploration through 2015 in Gabon, Republic of the Congo (Brazzaville), Cameroon, Equatorial Guinea, Democratic Republic of the Congo (Kinshasa), Central African Republic, and Sao Tome and Principe. 
Growth in delineated prospective area and explored area through 2015, graphed by the year the areas became prospective or explored

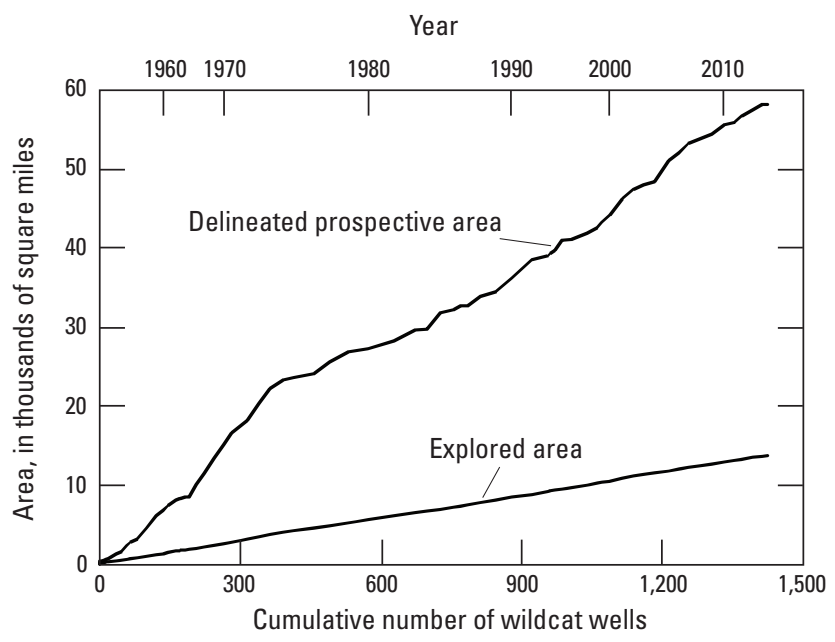

Figure 40. Continued.
Cumulative recoverable oil and gas discoveries in all provinces through 2015, graphed by the year the field location became part of the delineated prospective area

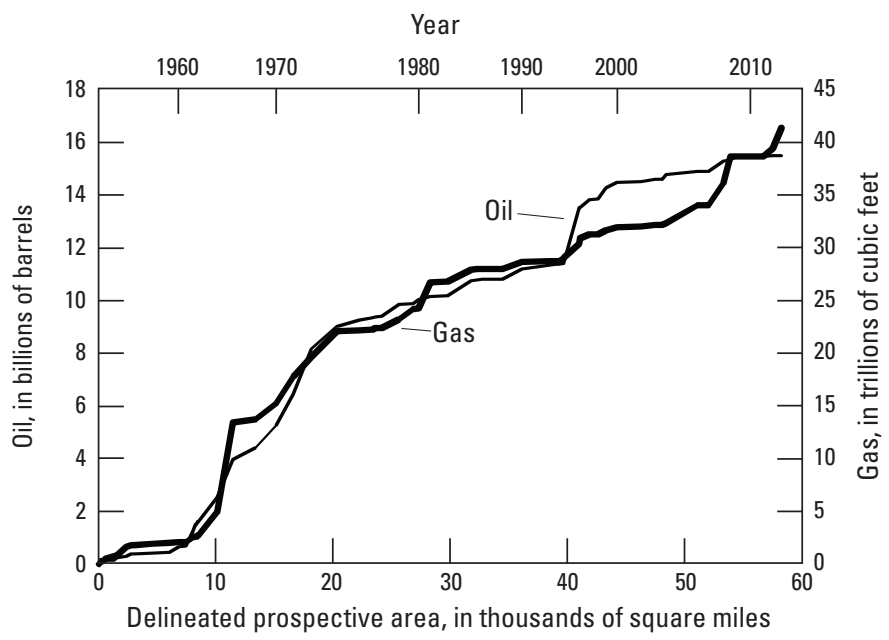


Significant petroleum provinces-Year of first discovery and cumulative recoverable oil and gas discovered through 2015

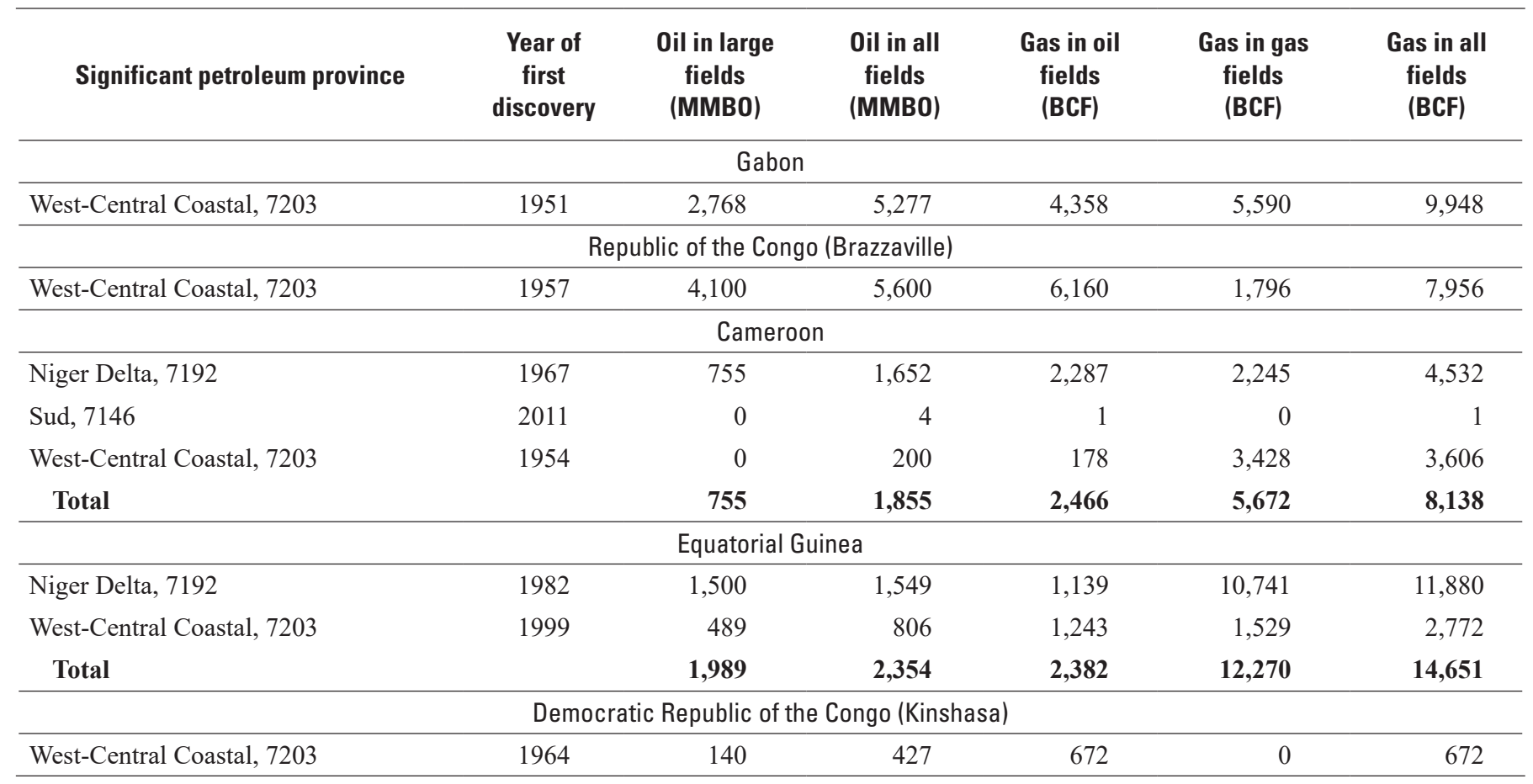

Figure 40. Continued. 


\section{Exploration data}

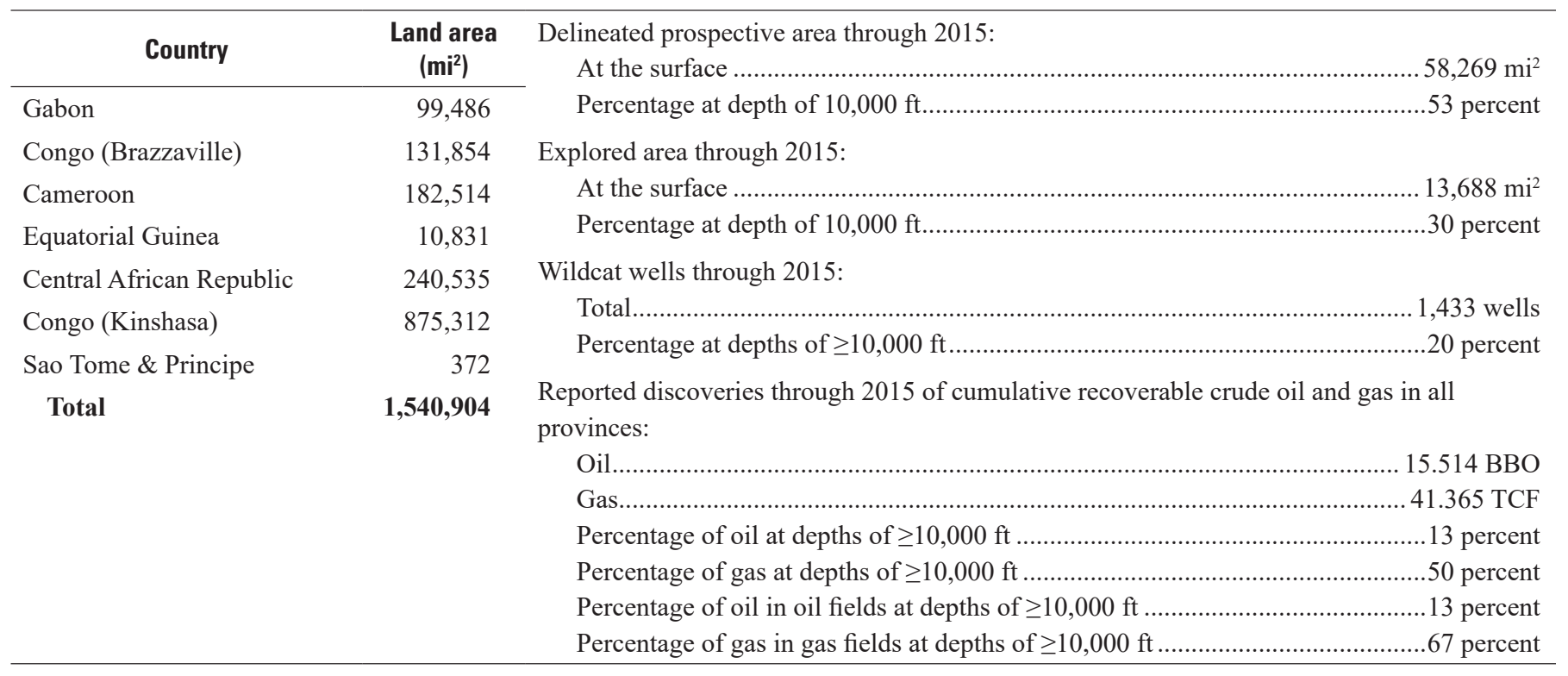

Figure 40. Continued. 


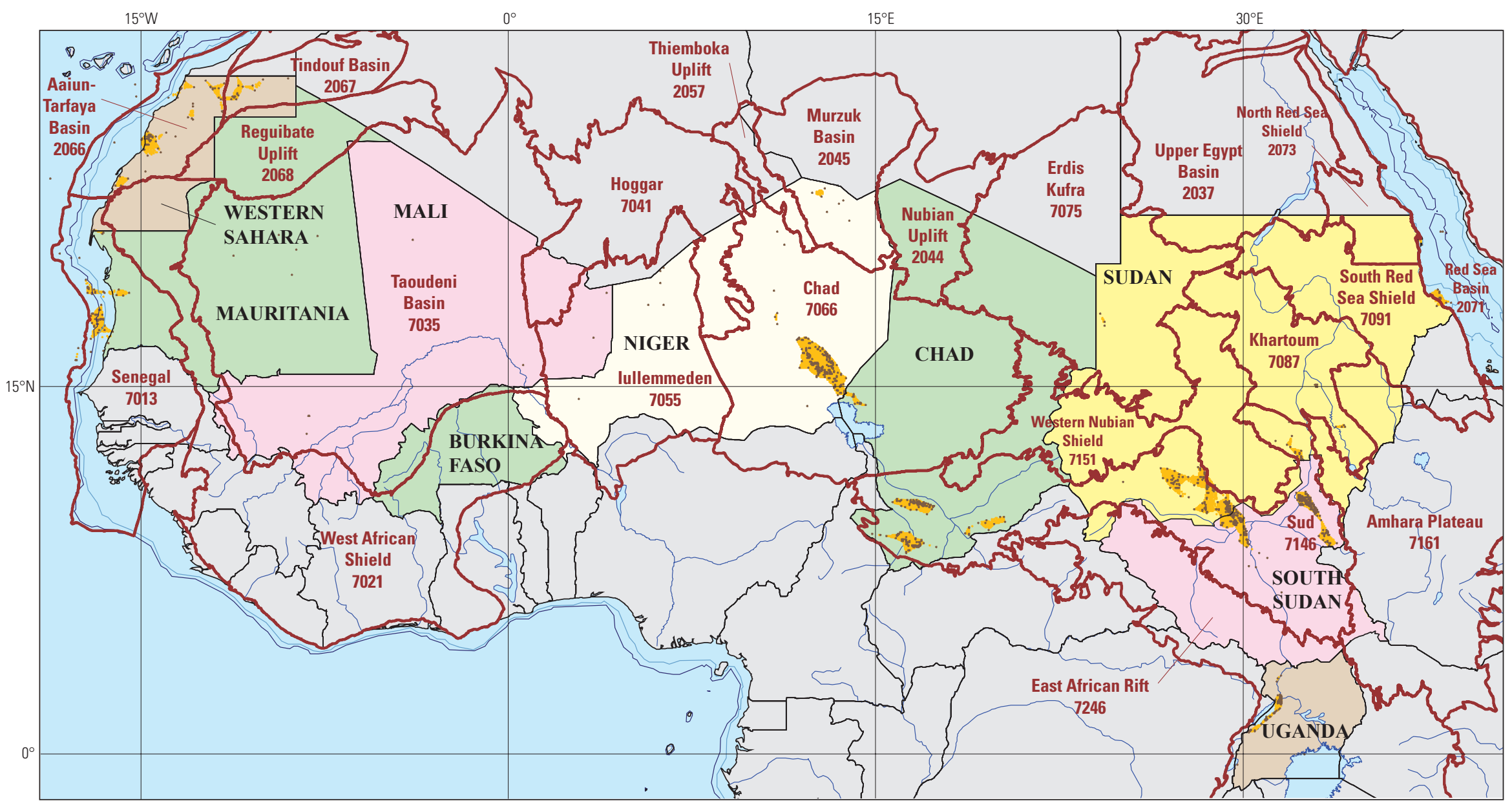

Figure 41. Map, graphs, and tables of data for oil and gas exploration through 2015 in Sudan, South Sudan, Chad, Mauritania, Niger, Burkina Faso, Mali, Uganda, and Western Sahara. 
Growth in delineated prospective area and explored

area through 2015, graphed by the year the areas became

prospective or explored

Year

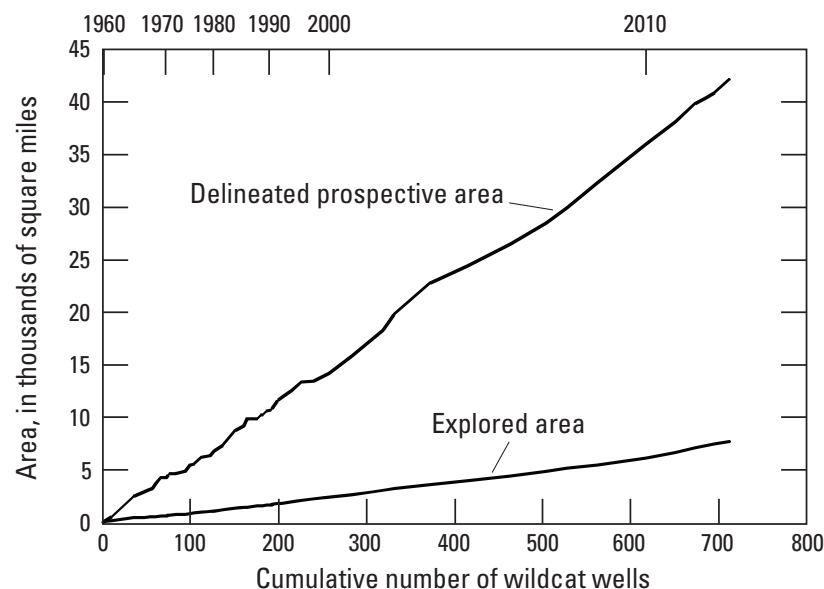

Cumulative recoverable oil and gas discoveries in all provinces

through 2015, graphed by the year the field location became part of

the delineated prospective area

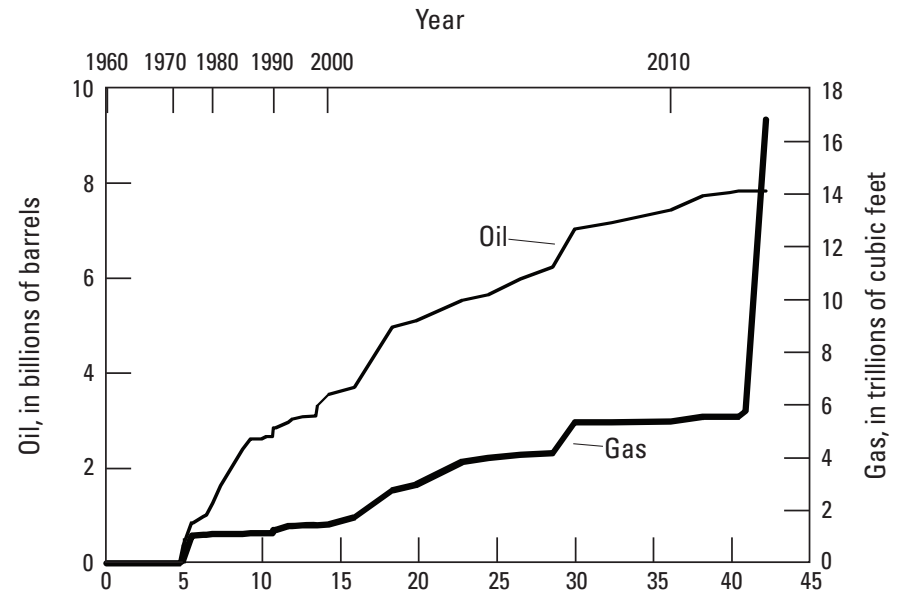

Delineated prospective area, in thousands of square miles

Figure 41. Continued. 


\begin{tabular}{|c|c|c|c|c|c|c|}
\hline $\begin{array}{l}\text { Significant petroleum } \\
\text { province }\end{array}$ & $\begin{array}{c}\text { Year of } \\
\text { first } \\
\text { discovery }\end{array}$ & $\begin{array}{l}\text { Oil in } \\
\text { large } \\
\text { fields } \\
\text { (MMBO) }\end{array}$ & $\begin{array}{l}\text { Oil in all } \\
\text { fields } \\
\text { (MMBO) }\end{array}$ & $\begin{array}{l}\text { Gas in oil } \\
\text { fields } \\
\text { (BCF) }\end{array}$ & $\begin{array}{l}\text { Gas in } \\
\text { gas fields } \\
\text { (BCF) }\end{array}$ & $\begin{array}{l}\text { Gas in all } \\
\text { fields } \\
\text { (BCF) }\end{array}$ \\
\hline \multicolumn{7}{|c|}{ South Sudan } \\
\hline Sud, 7146 & 1980 & 2,061 & 2,884 & 165 & 0 & 165 \\
\hline \multicolumn{7}{|c|}{ Sudan } \\
\hline Red Sea Basin, 2071 & 1963 & 0 & 0 & 0 & 850 & 850 \\
\hline Sud, 7146 & 1979 & 667 & 1,351 & 147 & 0 & 147 \\
\hline Total & & 667 & 1,351 & 147 & 850 & 997 \\
\hline \multicolumn{7}{|c|}{ Chad } \\
\hline Sud, 7146 & 1975 & 900 & 1,484 & 349 & 38 & 387 \\
\hline \multicolumn{7}{|c|}{ Mauritania } \\
\hline Senegal, 7013 & 2001 & 0 & 149 & 457 & 3,059 & 3,516 \\
\hline Taoudeni Basin, 7035 & 1974 & 0 & 0 & 0 & 159 & 159 \\
\hline Undesignated offshore area & & 0 & 0 & 0 & 11,050 & 11,050 \\
\hline Total & & $\mathbf{0}$ & 149 & 457 & 14,268 & 14,725 \\
\hline \multicolumn{7}{|c|}{ Mali } \\
\hline Taoudeni Basin, 7035 & 1987 & 0 & 0 & 0 & 2 & 2 \\
\hline \multicolumn{7}{|c|}{ Uganda } \\
\hline East African Rift, 7246 & 2006 & 924 & 1,392 & 252 & 0 & 252 \\
\hline
\end{tabular}

Figure 41. Continued. 


\section{Exploration data}

\begin{tabular}{|c|c|c|}
\hline Country & $\begin{array}{l}\text { Land area } \\
\qquad\left(\mathrm{mi}^{2}\right)\end{array}$ & 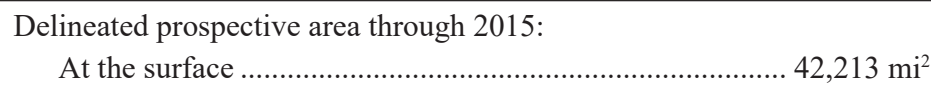 \\
\hline South Sudan & 248,777 & 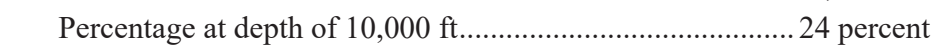 \\
\hline Sudan & 718,723 & Explored area through 2015: \\
\hline Chad & 486,180 & At the surface \\
\hline Mauritania & 397,955 & 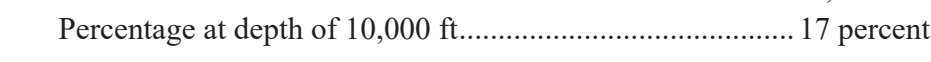 \\
\hline Niger & 489,076 & Wildcat wells through 2015: \\
\hline Burkina Faso & 105,715 & Total \\
\hline $\begin{array}{l}\text { Mali } \\
\text { Uganda }\end{array}$ & $\begin{array}{r}471,118 \\
76,101\end{array}$ & Reported discoveries through 2015 of cumulative recoverable crude oil \\
\hline Western Sahara & 102,703 & and gas in all provinces: \\
\hline Total & $3,096,347$ & 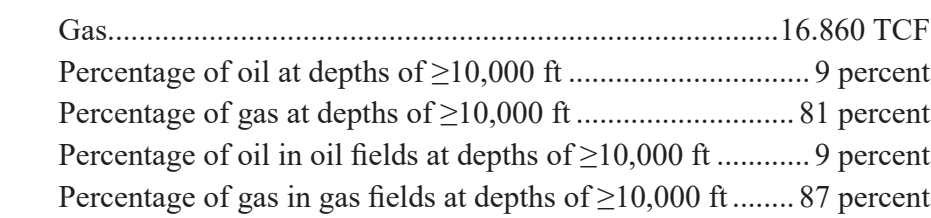 \\
\hline
\end{tabular}

Figure 41. Continued. 


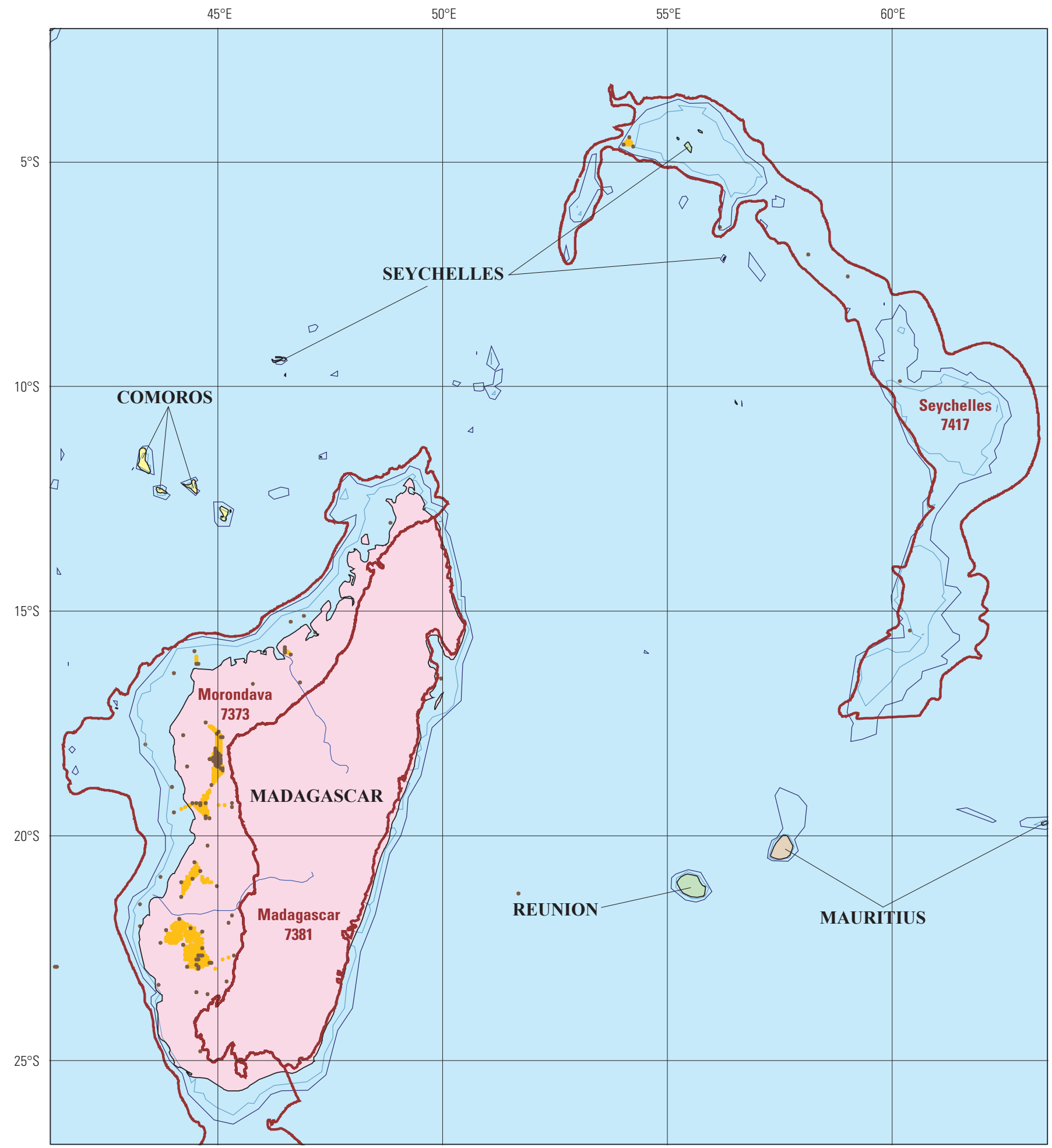

Figure 42. Map, graphs, and tables of data for oil and gas exploration through 2015 in Madagascar, Comoros, Mauritius, Seychelles, and Reunion (an overseas department of France). 
Growth in delineated prospective area and explored area through 2015, graphed by the year the areas became prospective or explored

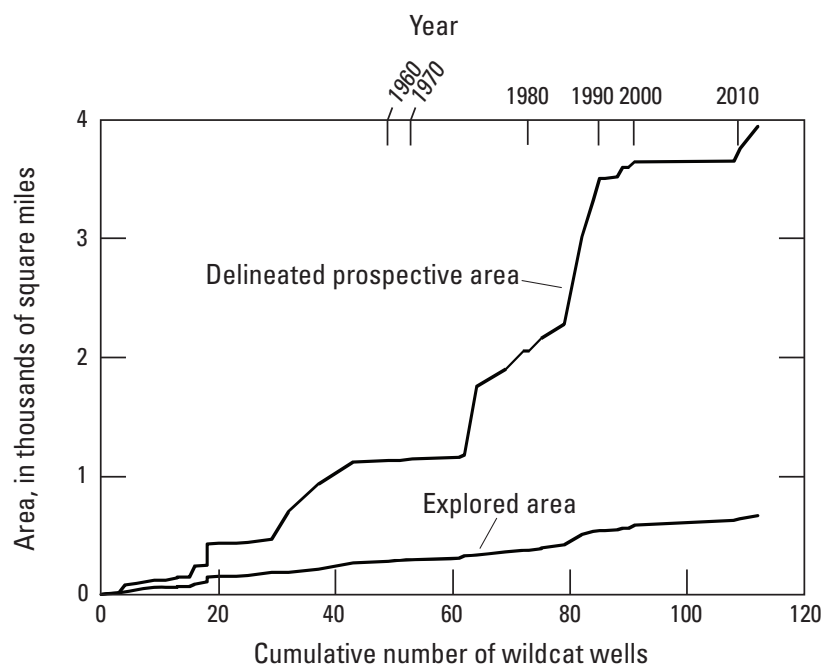

Cumulative recoverable oil and gas discoveries in all provinces through 2015, graphed by the year the field location became part of the delineated prospective area

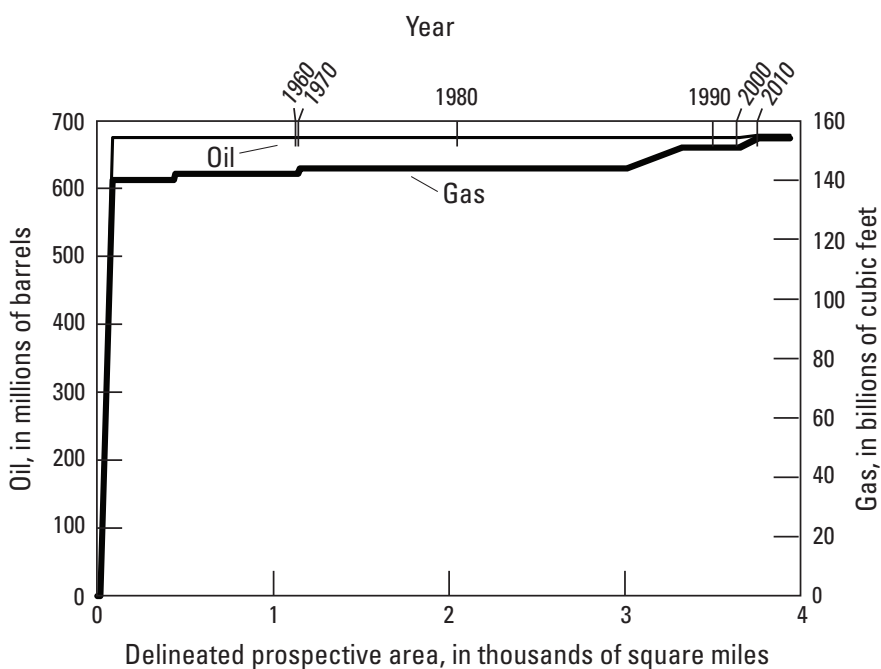

Significant petroleum province-Year of first discovery and cumulative recoverable oil and gas discovered through 2015

\begin{tabular}{lcccccc}
\hline Significant petroleum province & $\begin{array}{c}\text { Year of } \\
\text { first } \\
\text { discovery }\end{array}$ & $\begin{array}{c}\text { 0il in large } \\
\text { fields } \\
\text { (MMB0) }\end{array}$ & $\begin{array}{c}\text { Oil in all } \\
\text { fields } \\
\text { (MMBO) }\end{array}$ & $\begin{array}{c}\text { Gas in oil } \\
\text { fields } \\
\text { (BCF) }\end{array}$ & $\begin{array}{c}\text { Gas in gas } \\
\text { fields } \\
\text { (BCF) }\end{array}$ & $\begin{array}{c}\text { Gas in all } \\
\text { fields } \\
\text { (BCF) }\end{array}$ \\
\hline Morondava, 7373 & \multicolumn{7}{c}{ Madagascar } \\
\hline
\end{tabular}

\section{Exploration data}

\begin{tabular}{|c|c|c|}
\hline Country & $\begin{array}{c}\text { Land area } \\
\left(\mathrm{mi}^{2}\right)\end{array}$ & $\begin{array}{l}\text { Delineated prospective area through 2015: } \\
\text { At the surface }\end{array}$ \\
\hline Madagascar & 224,534 & Percentage at depth of $10,000 \mathrm{ft}$ \\
\hline Comoros & 863 & Explored area through 2015: \\
\hline Mauritius & 784 & 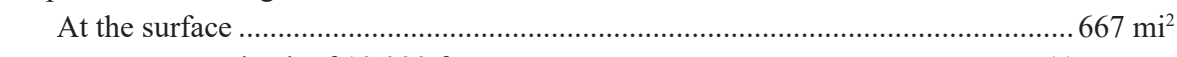 \\
\hline Seychelles & 176 & 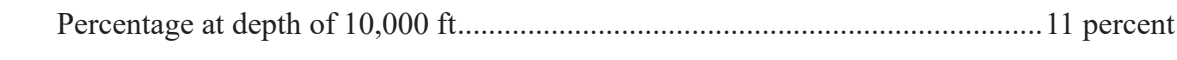 \\
\hline Reunion & 972 & Wildcat wells through 2015: \\
\hline \multirow[t]{8}{*}{ Total } & 227,328 & 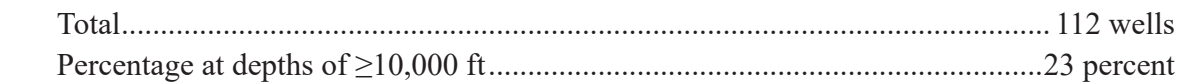 \\
\hline & & $\begin{array}{l}\text { Reported discoveries through } 2015 \text { of cumulative recoverable crude oil and gas in all } \\
\text { provinces: }\end{array}$ \\
\hline & & Oil. \\
\hline & & Gas. \\
\hline & & Percentage of oil at depths of $\geq 10,000 \mathrm{ft}$ \\
\hline & & 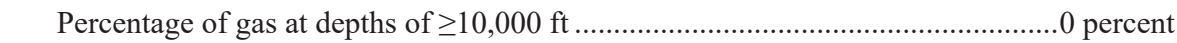 \\
\hline & & 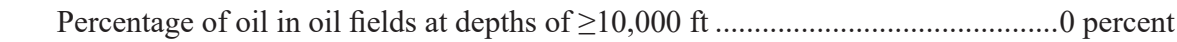 \\
\hline & & 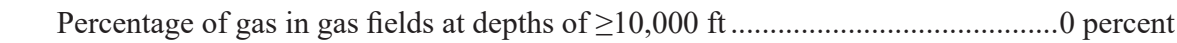 \\
\hline
\end{tabular}

Figure 42. Continued. 


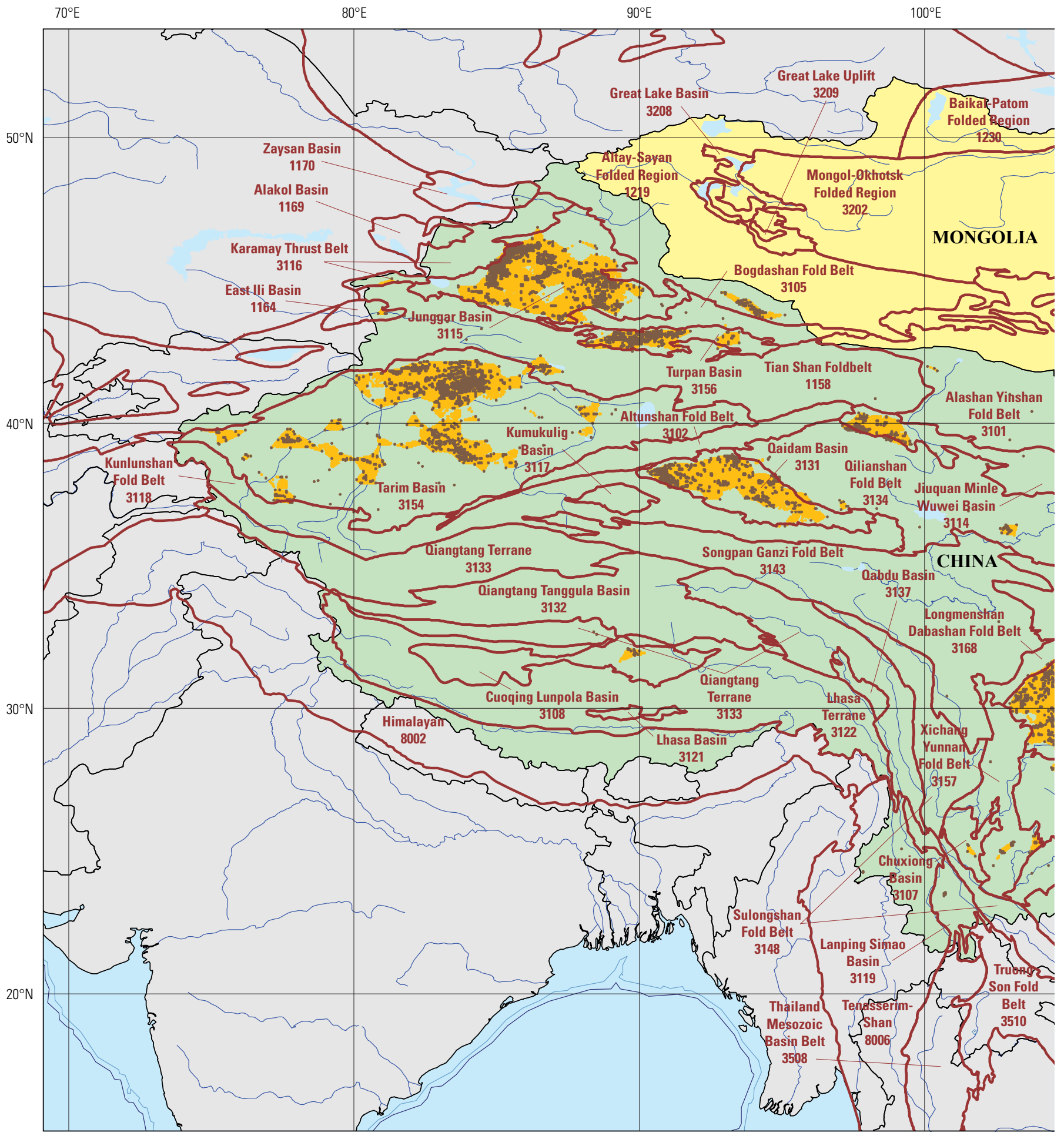

Figure 43. Map, graphs, and tables of data for oil and gas exploration through 2015 in China and Mongolia. 
$110^{\circ} \mathrm{E}$

$120^{\circ} \mathrm{E}$

$130^{\circ} \mathrm{E}$

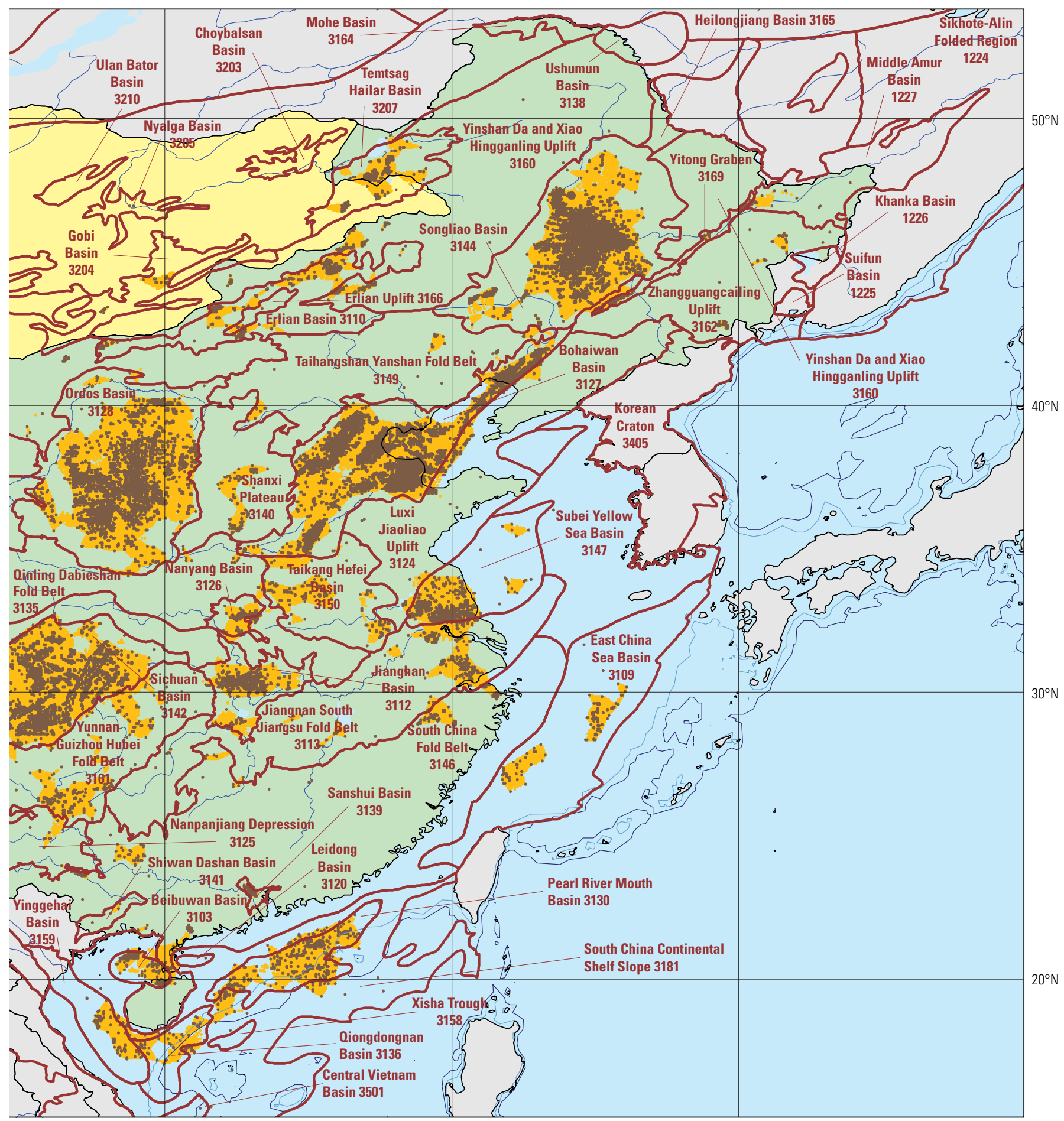

Figure 43. Continued. 
Growth in delineated prospective area and explored area through 2015 , graphed by the year the areas became prospective or explored

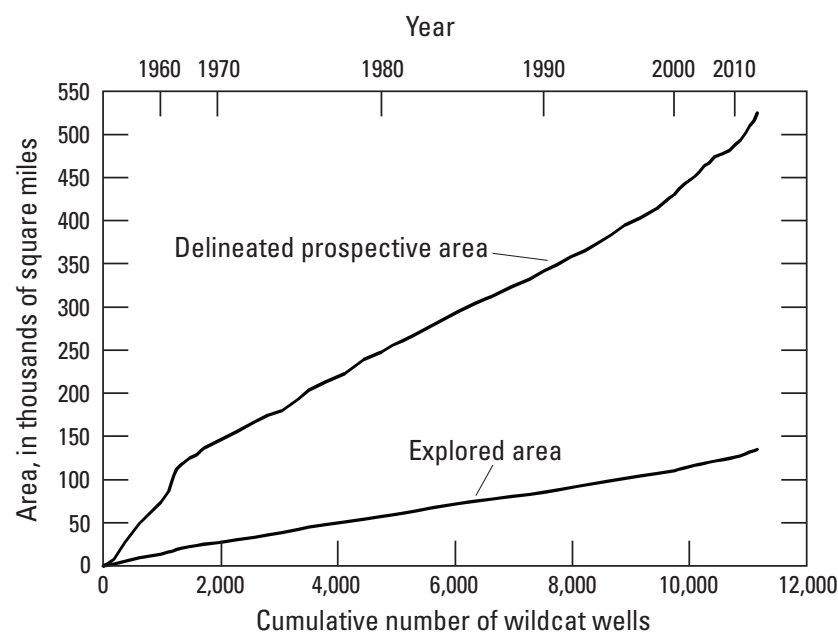

Cumulative recoverable oil and gas discoveries in all provinces through 2015, graphed by the year the field location became part of the delineated prospective area

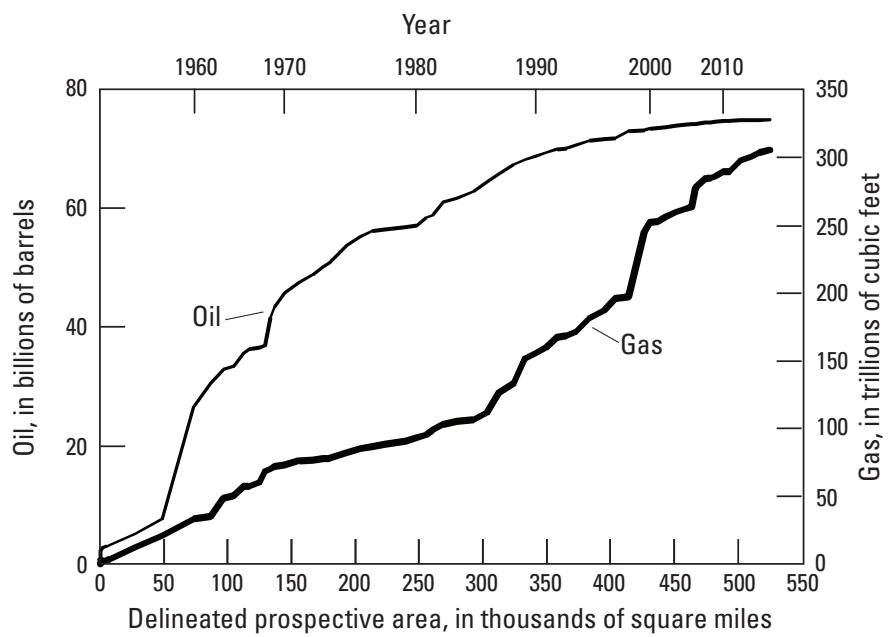

Significant petroleum provinces-Year of first discovery and cumulative recoverable oil and gas discovered through 2015

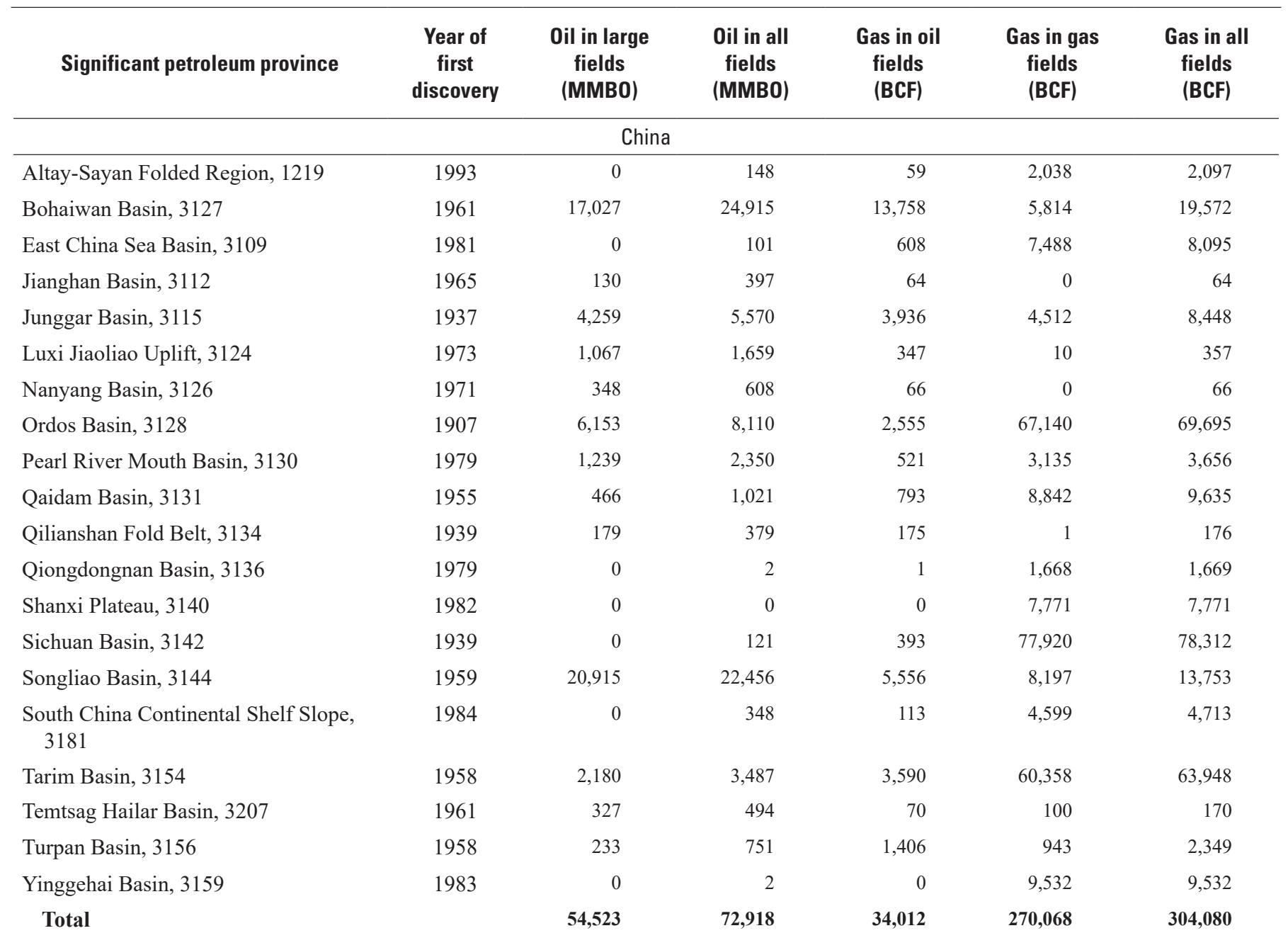

Figure 43. Continued. 
Significant petroleum provinces-Year of first discovery and cumulative recoverable oil and gas discovered through 2015. Continued

\begin{tabular}{lcccccc}
\hline Significant petroleum province & $\begin{array}{c}\text { Year of } \\
\text { first } \\
\text { discovery }\end{array}$ & $\begin{array}{c}\text { 0il in large } \\
\text { fields } \\
\text { (MMB0) }\end{array}$ & $\begin{array}{c}\text { Oil in all } \\
\text { fields } \\
\text { (MMB0) }\end{array}$ & $\begin{array}{c}\text { Gas in oil } \\
\text { fields } \\
\text { (BCF) }\end{array}$ & $\begin{array}{c}\text { Gas in gas } \\
\text { fields } \\
\text { (BCF) }\end{array}$ & $\begin{array}{c}\text { Gas in all } \\
\text { fields } \\
\text { (BCF) }\end{array}$ \\
\hline Temtsag Hailar Basin, 3207 & Mongolia \\
\hline
\end{tabular}

\section{Exploration data}

\begin{tabular}{|c|c|c|}
\hline Country & $\begin{array}{l}\text { Land area } \\
\left(\mathrm{mi}^{2}\right)\end{array}$ & 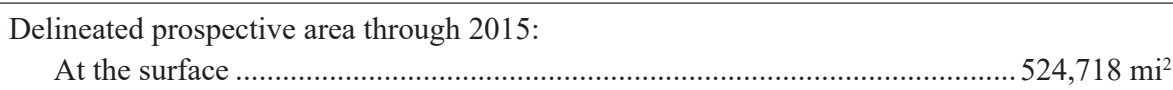 \\
\hline China & $3,600,947$ & 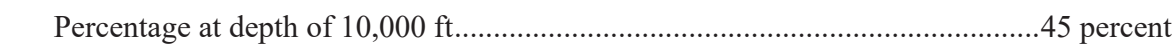 \\
\hline Mongolia & 599,831 & Explored area through 2015: \\
\hline \multirow[t]{12}{*}{ Total } & $4,200,778$ & At the surface ...................... \\
\hline & & 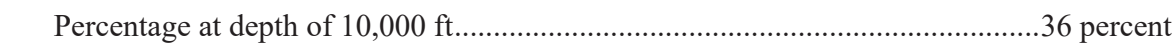 \\
\hline & & Wildcat wells through 2015: \\
\hline & & 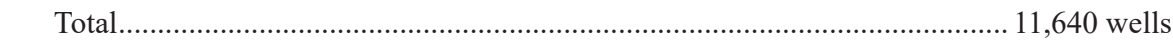 \\
\hline & & 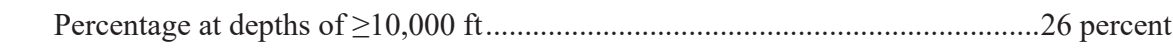 \\
\hline & & $\begin{array}{l}\text { Reported discoveries through } 2015 \text { of cumulative recoverable crude oil and gas in all } \\
\text { provinces: }\end{array}$ \\
\hline & & 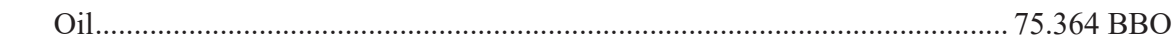 \\
\hline & & 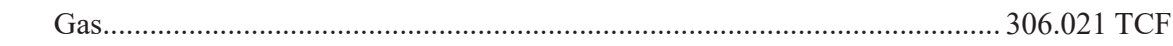 \\
\hline & & 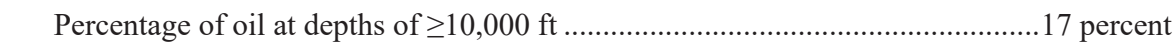 \\
\hline & & 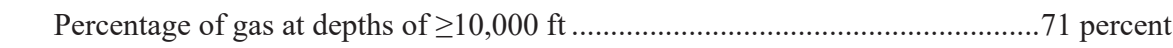 \\
\hline & & 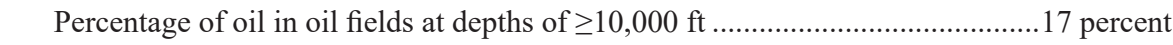 \\
\hline & & 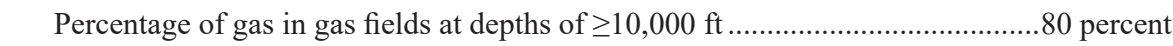 \\
\hline
\end{tabular}

Figure 43. Continued. 


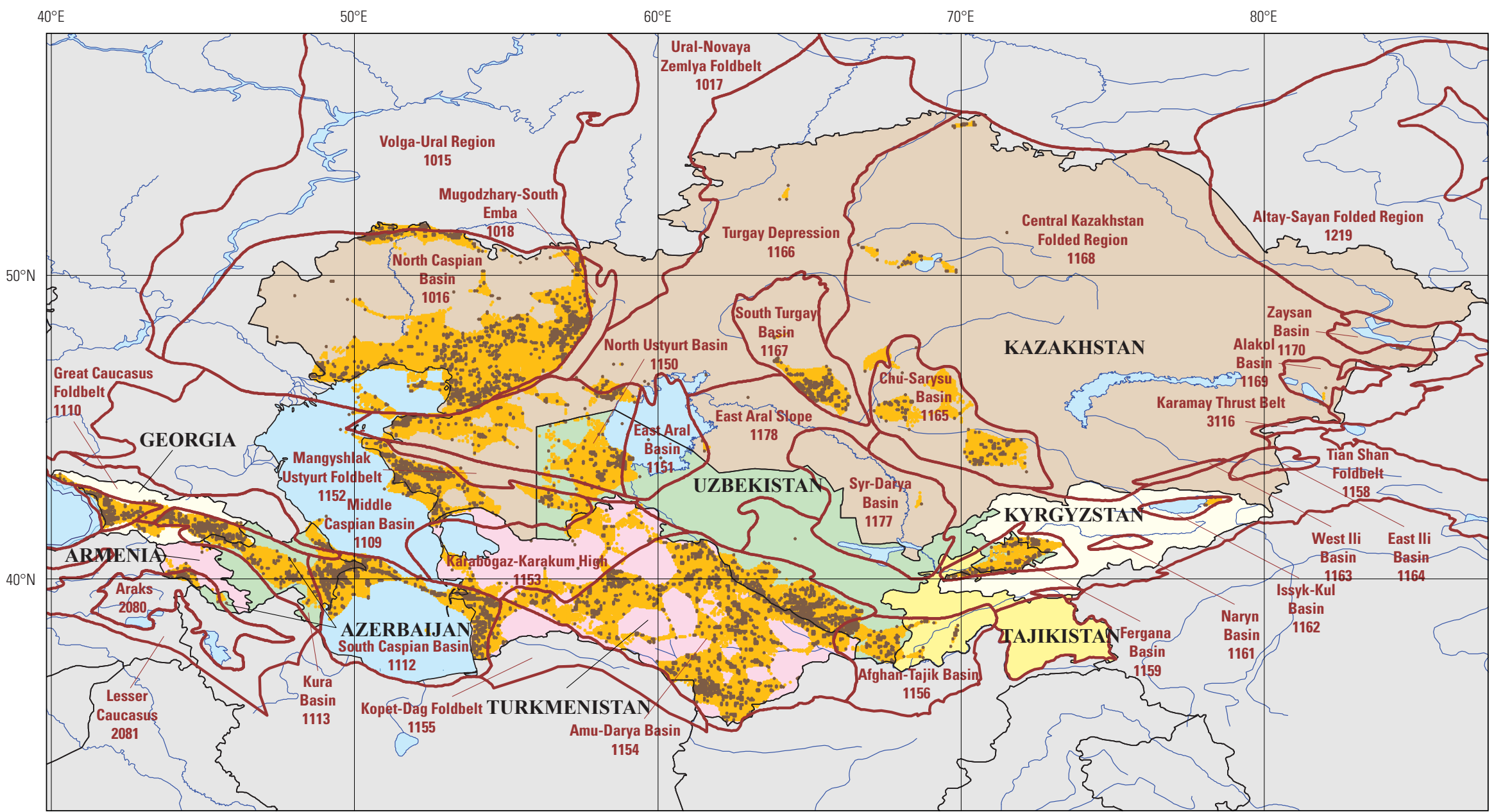

Figure 44. Map, graphs, and tables of data for oil and gas exploration through 2015 in Kazakhstan, Azerbaijan, Turkmenistan, Uzbekistan, Georgia, Kyrgyzstan, Tajikistan, and Armenia. 
Growth in delineated prospective area and explored

area through 2015, graphed by the year the areas became

prospective or explored

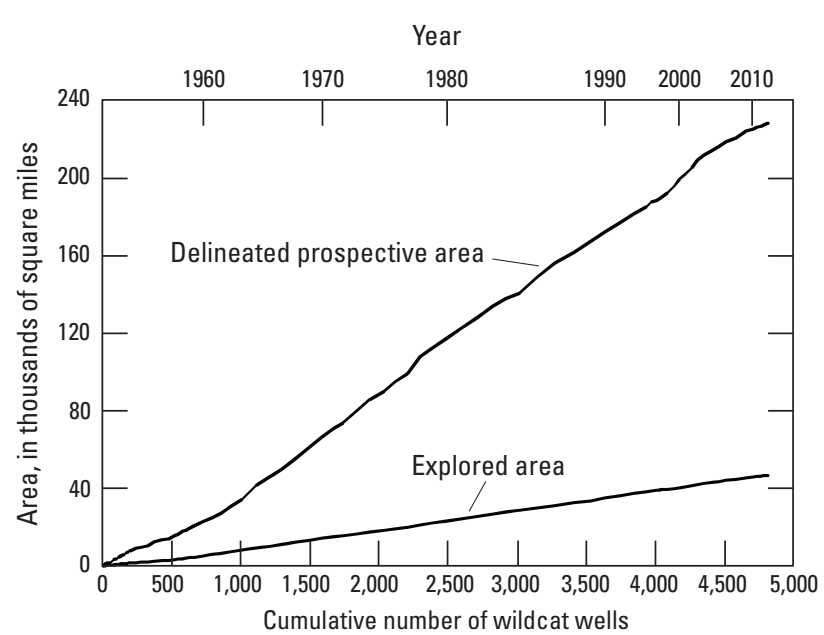

Cumulative recoverable oil and gas discoveries in all provinces through 2015, graphed by the year the field location became part of the delineated prospective area

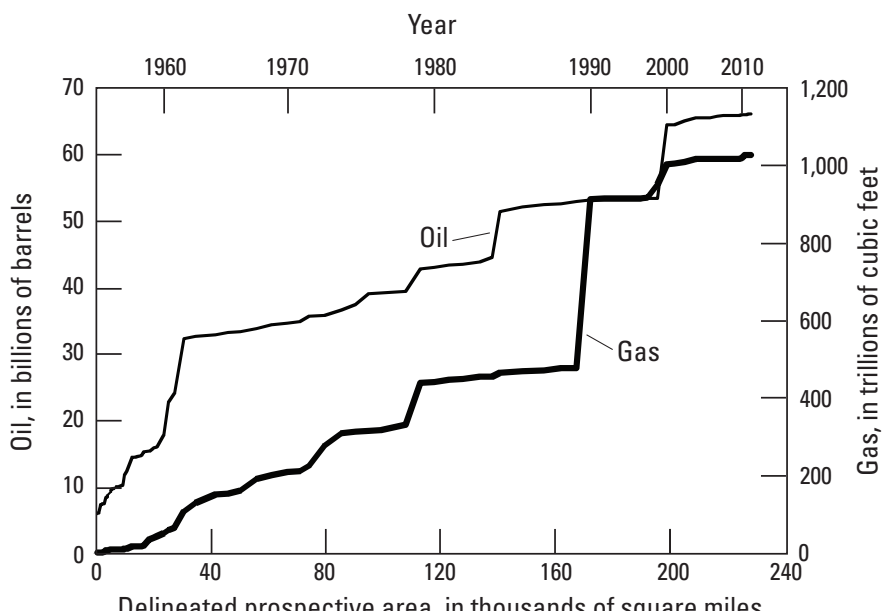

Delineated prospective area, in thousands of square miles

Figure 44. Continued. 


\begin{tabular}{|c|c|c|c|c|c|c|}
\hline $\begin{array}{l}\text { Significant petroleum } \\
\text { province }\end{array}$ & $\begin{array}{c}\text { Year of } \\
\text { first } \\
\text { discovery }\end{array}$ & $\begin{array}{l}\text { Oil in } \\
\text { large } \\
\text { fields } \\
\text { (MMBO) }\end{array}$ & $\begin{array}{l}\text { Oil in all } \\
\text { fields } \\
\text { (MMBO) }\end{array}$ & $\begin{array}{l}\text { Gas in oil } \\
\text { fields } \\
\text { (BCF) }\end{array}$ & $\begin{array}{l}\text { Gas in } \\
\text { gas fields } \\
\text { (BCF) }\end{array}$ & $\begin{array}{l}\text { Gas in all } \\
\text { fields } \\
\text { (BCF) }\end{array}$ \\
\hline \multicolumn{7}{|c|}{ Kazakhstan } \\
\hline $\begin{array}{l}\text { Central Kazakhstan Folded } \\
\text { Region, } 1168\end{array}$ & 2003 & 150 & 150 & 121 & 0 & 121 \\
\hline Middle Caspian Basin, 1109 & 1952 & 4,740 & 5,384 & 4,476 & 3,576 & 8,052 \\
\hline North Caspian Basin, 1016 & 1892 & 23,972 & 28,217 & 85,210 & 49,048 & 134,258 \\
\hline North Ustyurt Basin, 1150 & 1964 & 2,463 & 2,708 & 1,071 & 1,667 & 2,737 \\
\hline South Turgay Basin, 1167 & 1984 & 1,240 & 1,936 & 1,388 & 55 & 1,443 \\
\hline Volga-Ural Region, 1015 & 1979 & 122 & 202 & 2,613 & 2 & 2,615 \\
\hline Total & & 32,687 & $\mathbf{3 8 , 5 9 7}$ & 94,878 & 54,348 & 149,225 \\
\hline \multicolumn{7}{|c|}{ Azerbaijan } \\
\hline Kura Basin, 1113 & 1873 & 0 & 170 & 23 & 0 & 23 \\
\hline Middle Caspian Basin, 1109 & 1939 & 128 & 135 & 196 & 47 & 243 \\
\hline South Caspian Basin, 1112 & 1869 & 18,789 & 19,743 & 23,987 & 56,658 & 80,645 \\
\hline Total & & 18,918 & 20,049 & 24,206 & 56,705 & 80,910 \\
\hline \multicolumn{7}{|c|}{ Turkmenistan } \\
\hline Afghan-Tajik Basin, 1156 & 1988 & 0 & 0 & 0 & 240 & 240 \\
\hline Amu-Darya Basin, 1154 & 1959 & 0 & 119 & 722 & 645,731 & 646,452 \\
\hline Middle Caspian Basin, 1109 & 1973 & 0 & 0 & 0 & 29 & 29 \\
\hline South Caspian Basin, 1112 & 1933 & 4,503 & 5,127 & 13,783 & 13,723 & 27,506 \\
\hline Total & & 4,503 & 5,246 & 14,505 & 659,723 & 674,227 \\
\hline \multicolumn{7}{|c|}{ Uzbekistan } \\
\hline Afghan-Tajik Basin, 1156 & 1934 & 0 & 125 & 128 & 8,191 & 8,319 \\
\hline Amu-Darya Basin, 1154 & 1953 & 584 & 1,011 & 7,137 & 97,228 & 104,365 \\
\hline Fergana Basin, 1159 & 1901 & 219 & 561 & 280 & 232 & 512 \\
\hline Middle Caspian Basin, 1109 & 1964 & 0 & 0 & 0 & 1,777 & 1,777 \\
\hline North Ustyurt Basin, 1150 & 1968 & 0 & 1 & 0 & 7,179 & 7,179 \\
\hline Total & & 803 & 1,698 & 7,545 & 114,606 & 122,152 \\
\hline \multicolumn{7}{|c|}{ Georgia } \\
\hline Kura Basin, 1113 & 1869 & 226 & 368 & 222 & 63 & 285 \\
\hline
\end{tabular}

Figure 44. Continued. 
Significant petroleum provinces-Year of first discovery and cumulative recoverable oil and gas discovered through 2015.-Continued

\begin{tabular}{|c|c|c|c|c|c|c|}
\hline $\begin{array}{c}\text { Significant petroleum } \\
\text { province }\end{array}$ & $\begin{array}{c}\text { Year of } \\
\text { first } \\
\text { discovery }\end{array}$ & $\begin{array}{l}\text { Oil in } \\
\text { large } \\
\text { fields } \\
\text { (MMBO) }\end{array}$ & $\begin{array}{l}\text { Oil in all } \\
\text { fields } \\
\text { (MMBO) }\end{array}$ & $\begin{array}{l}\text { Gas in oil } \\
\text { fields } \\
\text { (BCF) }\end{array}$ & $\begin{array}{c}\text { Gas in } \\
\text { gas fields } \\
\text { (BCF) }\end{array}$ & $\begin{array}{c}\text { Gas in all } \\
\text { fields } \\
\text { (BCF) }\end{array}$ \\
\hline \multicolumn{7}{|c|}{ Kyrgyzstan } \\
\hline Fergana Basin, 1159 & 1901 & 104 & 302 & 656 & 350 & 1,006 \\
\hline \multicolumn{7}{|c|}{ Tajikistan } \\
\hline Afghan-Tajik Basin, 1156 & 1949 & 0 & 49 & 41 & 156 & 198 \\
\hline Fergana Basin, 1159 & 1908 & 0 & 36 & 107 & 83 & 191 \\
\hline Total & & $\mathbf{0}$ & 85 & 149 & 240 & 388 \\
\hline
\end{tabular}

\section{Exploration data}

\begin{tabular}{|c|c|c|}
\hline Country & $\begin{array}{l}\text { Land area } \\
\qquad\left(\mathrm{mi}^{2}\right)\end{array}$ & $\begin{array}{l}\text { Delineated prospective area through 2015: } \\
\text { At the surface }\end{array}$ \\
\hline Kazakhstan & $1,042,360$ & Percentage at depth of $10,000 \mathrm{ft} \ldots \ldots \ldots \ldots \ldots . . . .$. \\
\hline Azerbaijan & 31,903 & Explored area through 2015: \\
\hline Turkmenistan & 181,441 & 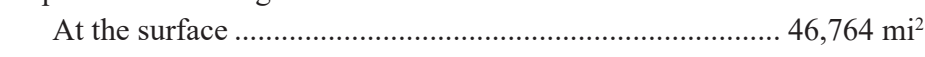 \\
\hline Uzbekistan & 164,248 & 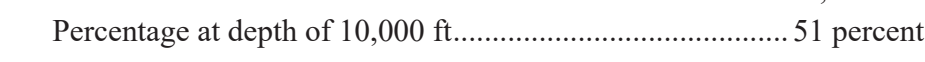 \\
\hline Georgia & 26,911 & Wildcat wells through 2015: \\
\hline Kyrgyzstan & 74,055 & 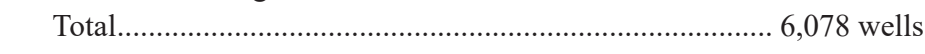 \\
\hline Tajikistan & 54,637 & Percentage at depths of $\geq 10,000 \mathrm{ft} \ldots \ldots$. \\
\hline Armenia & 10,889 & $\begin{array}{l}\text { Reported discoveries through } 2015 \text { of cumulative recoverable crude oil } \\
\text { and gas in all provinces: }\end{array}$ \\
\hline \multirow[t]{6}{*}{ Total } & $1,586,445$ & 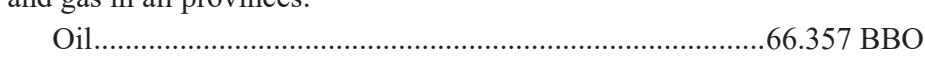 \\
\hline & & 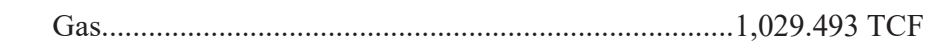 \\
\hline & & 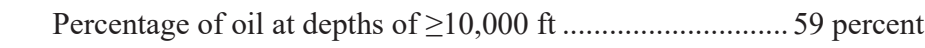 \\
\hline & & 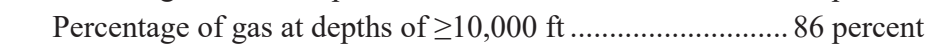 \\
\hline & & Percentage of oil in oil fields at depths of $\geq 10,000 \mathrm{ft} \ldots \ldots \ldots . .58$ percent \\
\hline & & Percentage of gas in gas fields at depths of $\geq 10,000 \mathrm{ft}$........86 percent \\
\hline
\end{tabular}

Figure 44. Continued. 


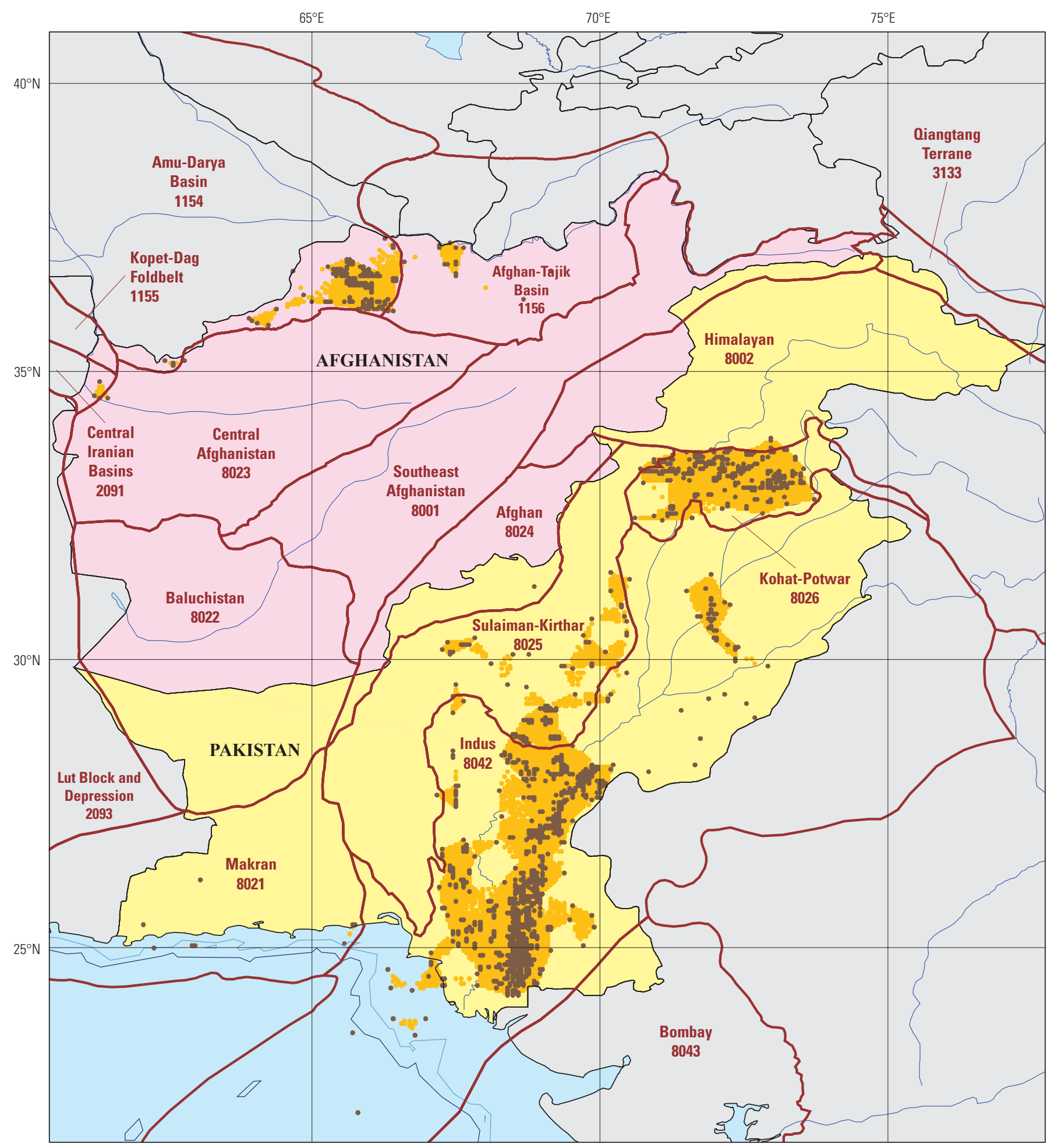

Figure 45. Map, graphs, and tables of data for oil and gas exploration through 2015 in Pakistan and Afghanistan. 
Growth in delineated prospective area and explored area through 2015, graphed by the year the areas became prospective or explored

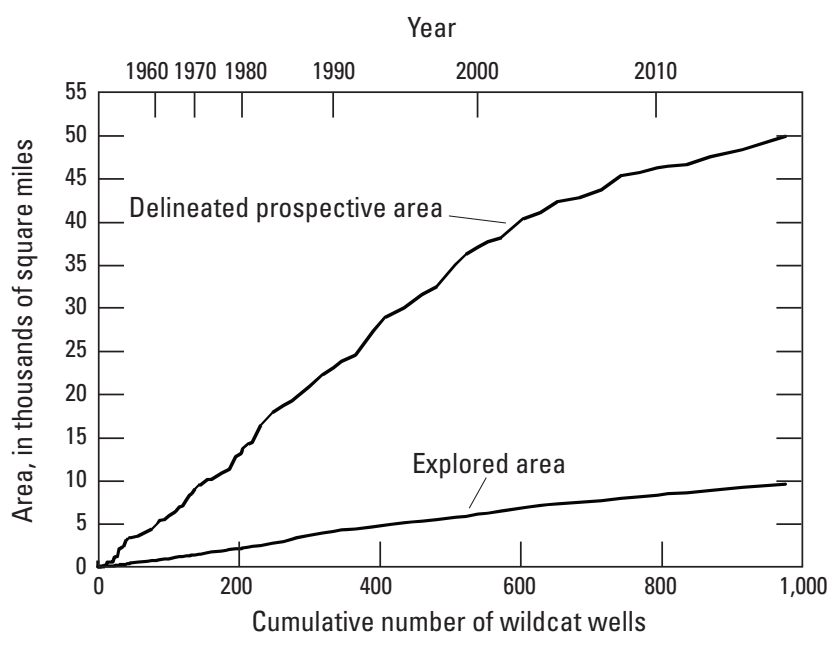

Cumulative recoverable oil and gas discoveries in all provinces through 2015, graphed by the year the field location became part of the delineated prospective area

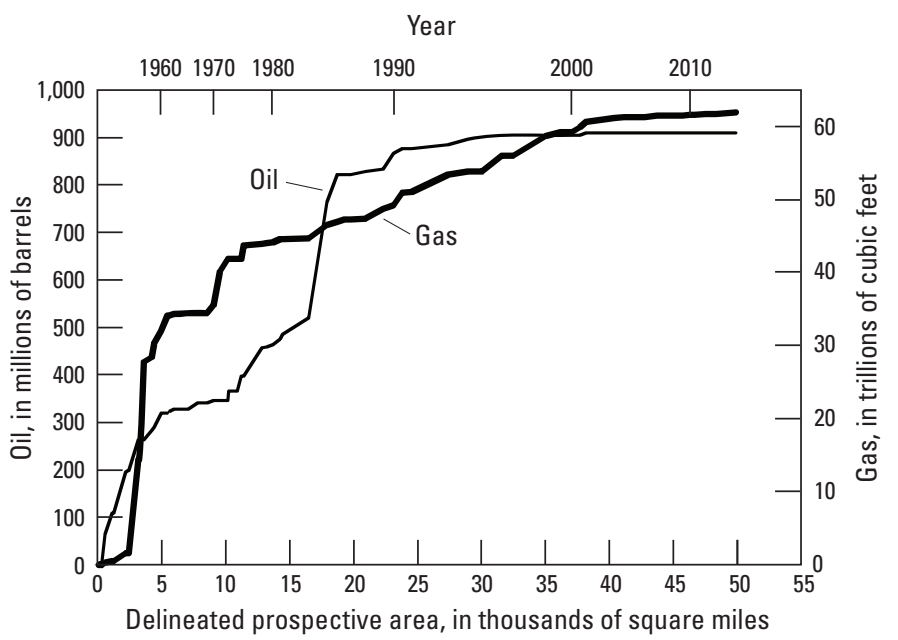

Figure 45. Continued. 
Significant petroleum provinces-Year of first discovery and cumulative recoverable oil and gas discovered through 2015

\begin{tabular}{|c|c|c|c|c|c|c|}
\hline Significant petroleum province & $\begin{array}{c}\text { Year of } \\
\text { first } \\
\text { discovery }\end{array}$ & $\begin{array}{l}\text { Oil in large } \\
\text { fields } \\
\text { (MMBO) }\end{array}$ & $\begin{array}{l}\text { Oil in all } \\
\text { fields } \\
\text { (MMBO) }\end{array}$ & $\begin{array}{l}\text { Gas in oil } \\
\text { fields } \\
\text { (BCF) }\end{array}$ & $\begin{array}{c}\text { Gas in gas } \\
\text { fields } \\
\text { (BCF) }\end{array}$ & $\begin{array}{c}\text { Gas in all } \\
\text { fields } \\
\text { (BCF) }\end{array}$ \\
\hline \multicolumn{7}{|c|}{ Pakistan } \\
\hline Indus, 8042 & 1957 & 0 & 405 & 476 & 29,816 & 30,292 \\
\hline Sulaiman-Kirthar, 8025 & 1883 & 0 & 5 & 0 & 20,683 & 20,683 \\
\hline \multicolumn{7}{|c|}{ Afghanistan } \\
\hline Afghan-Tajik Basin, 1156 & 1962 & 0 & 6 & 11 & 10 & 21 \\
\hline Amu-Darya Basin, 1154 & 1959 & 0 & 93 & 7 & 6,290 & 6,297 \\
\hline Total & & $\mathbf{0}$ & 99 & 17 & 6,300 & 6,317 \\
\hline
\end{tabular}

Figure 45. Continued. 


\section{Exploration data}

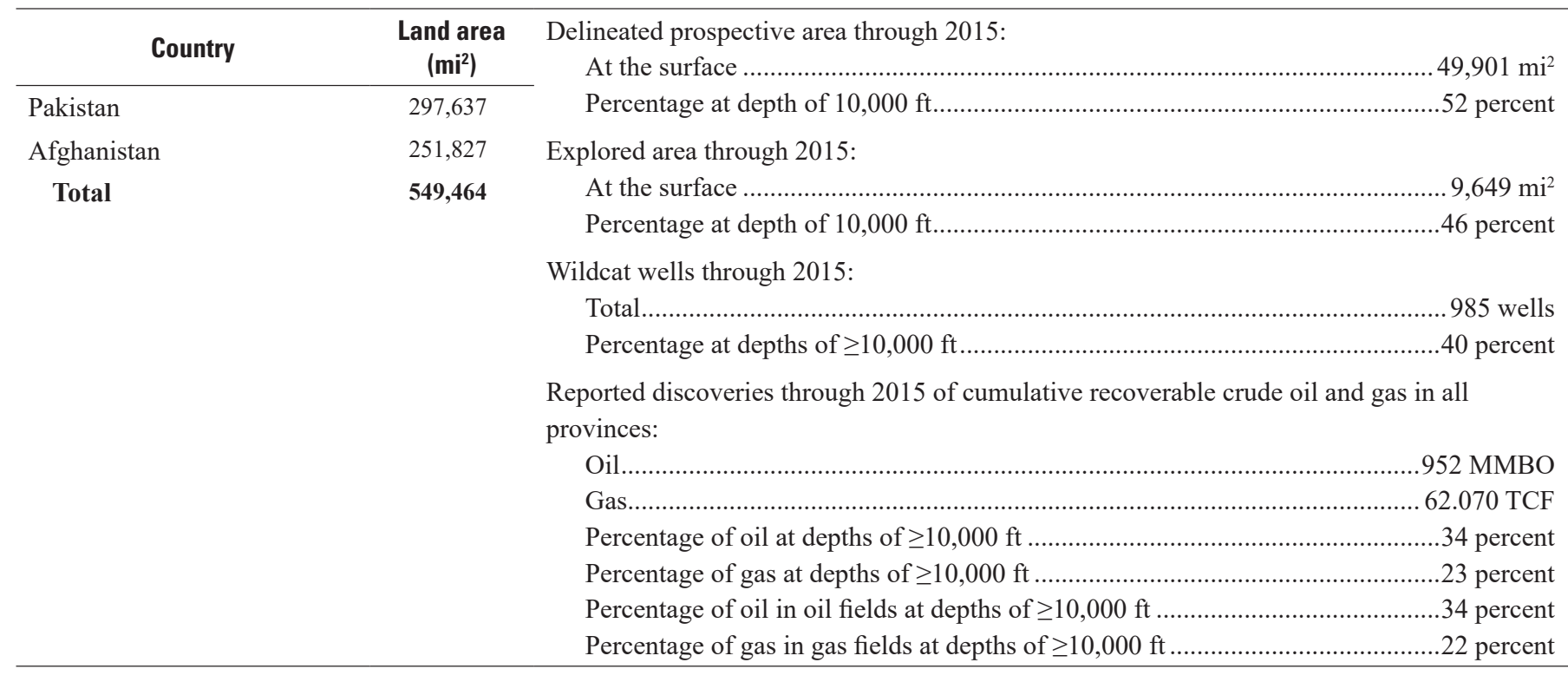

Figure 45. Continued. 


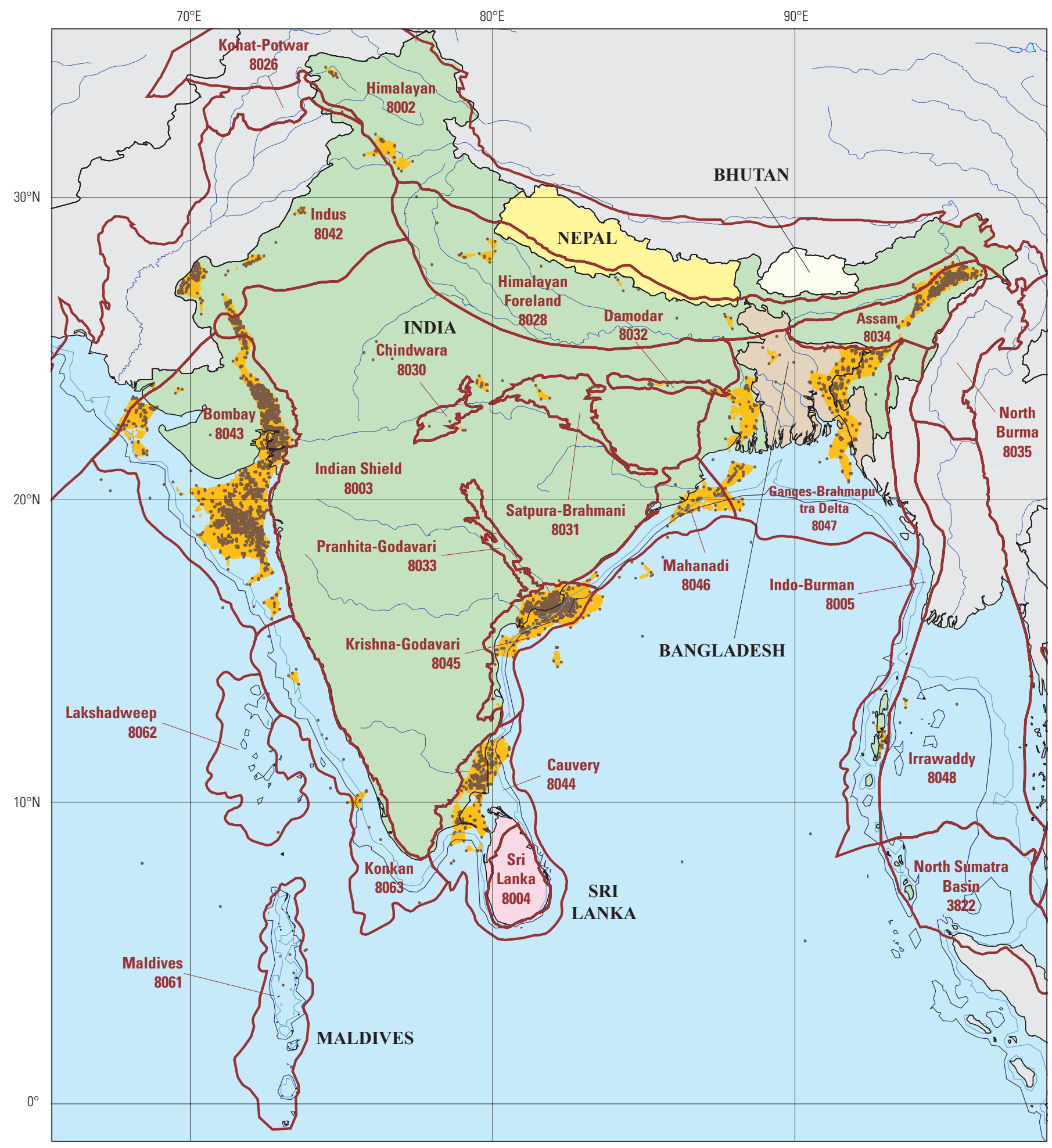

Figure 46. Map, graphs, and tables of data for oil and gas exploration through 2015 in India, Bangladesh, Bhutan, Maldives, Nepal, and Sri Lanka. 
Growth in delineated prospective area and explored area through 2015, graphed by the year the areas became prospective or explored

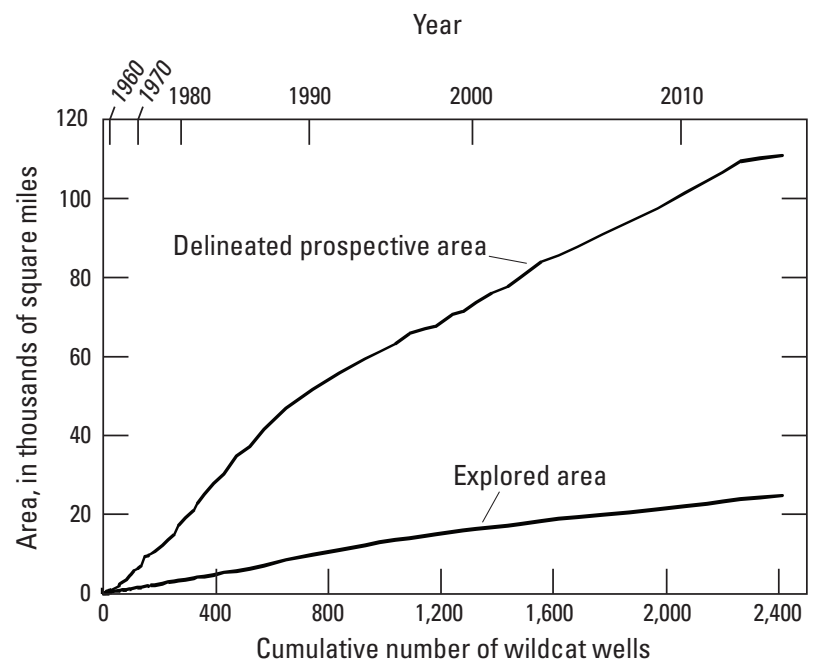

Cumulative recoverable oil and gas discoveries in all provinces through 2015, graphed by the year the field location became part of the delineated prospective area

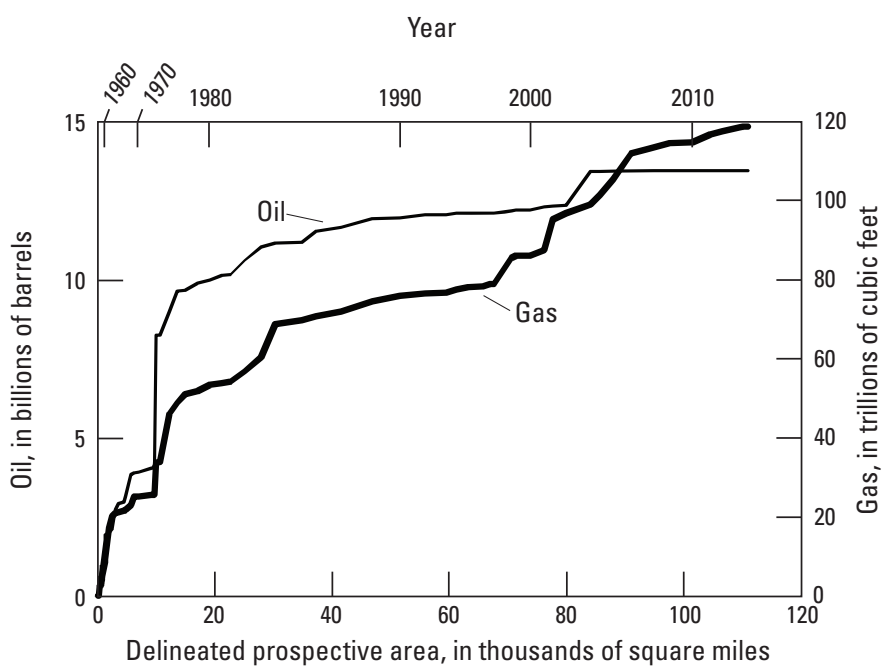

Figure 46. Continued. 
Significant petroleum provinces-Year of first discovery and cumulative recoverable oil and gas discovered through 2015

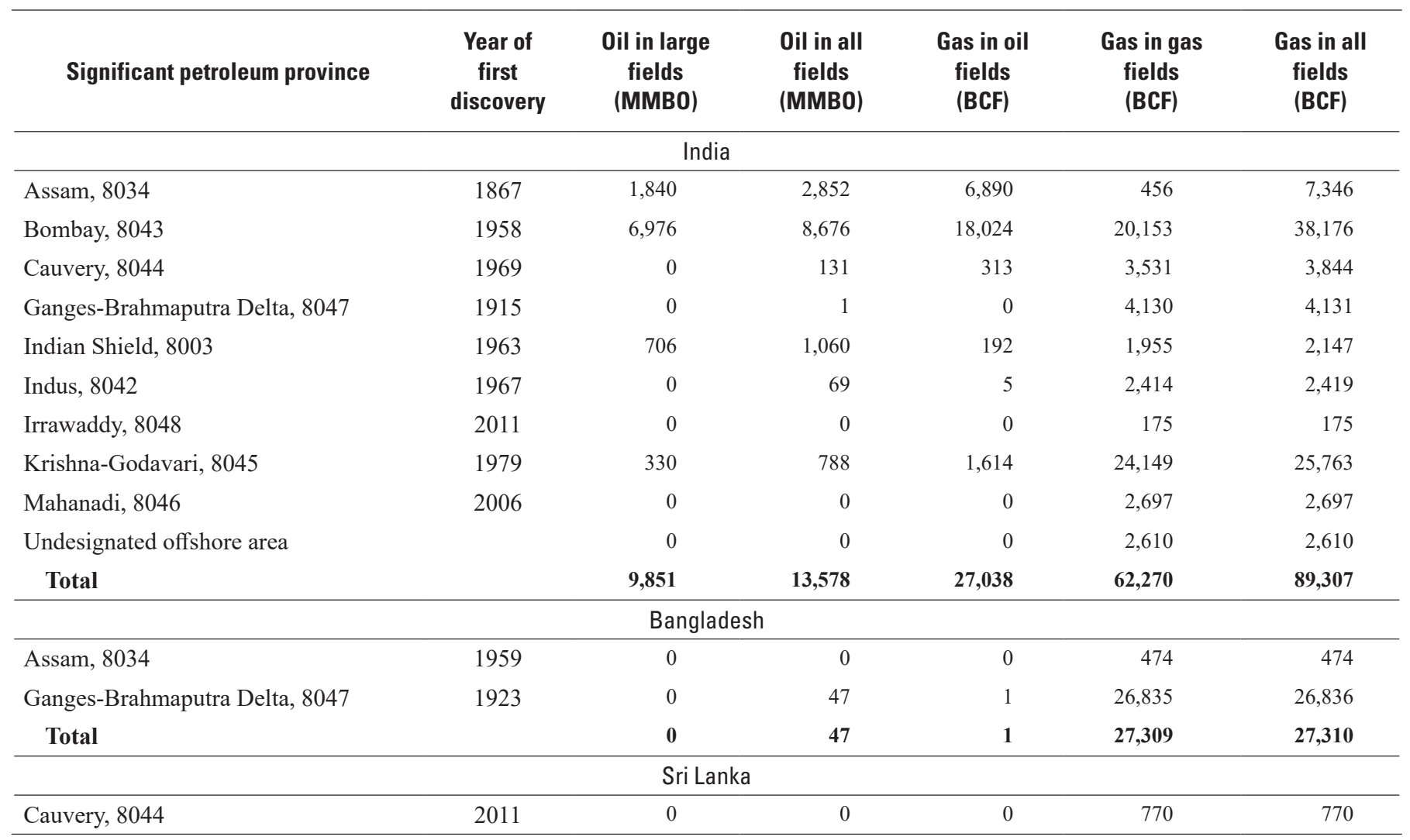

Figure 46. Continued. 


\section{Exploration data}

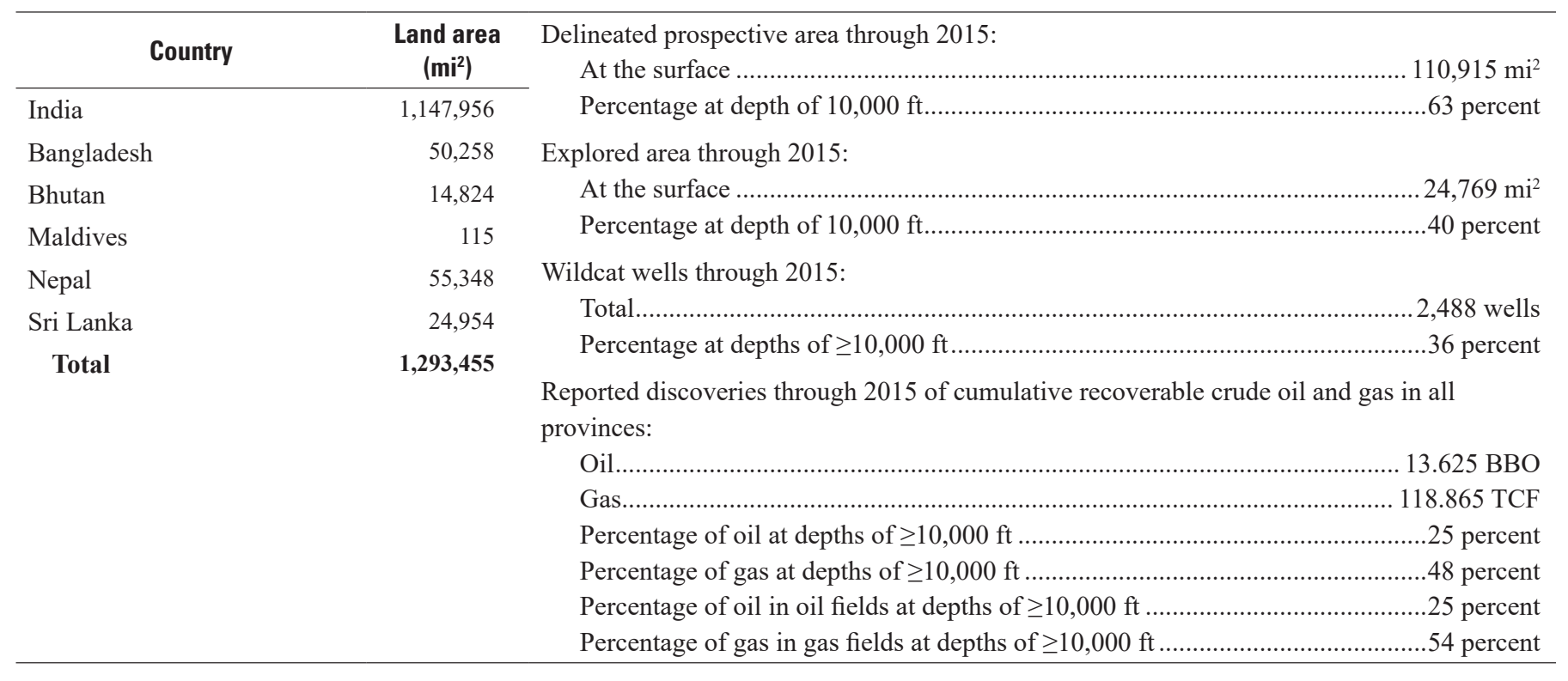

Figure 46. Continued. 


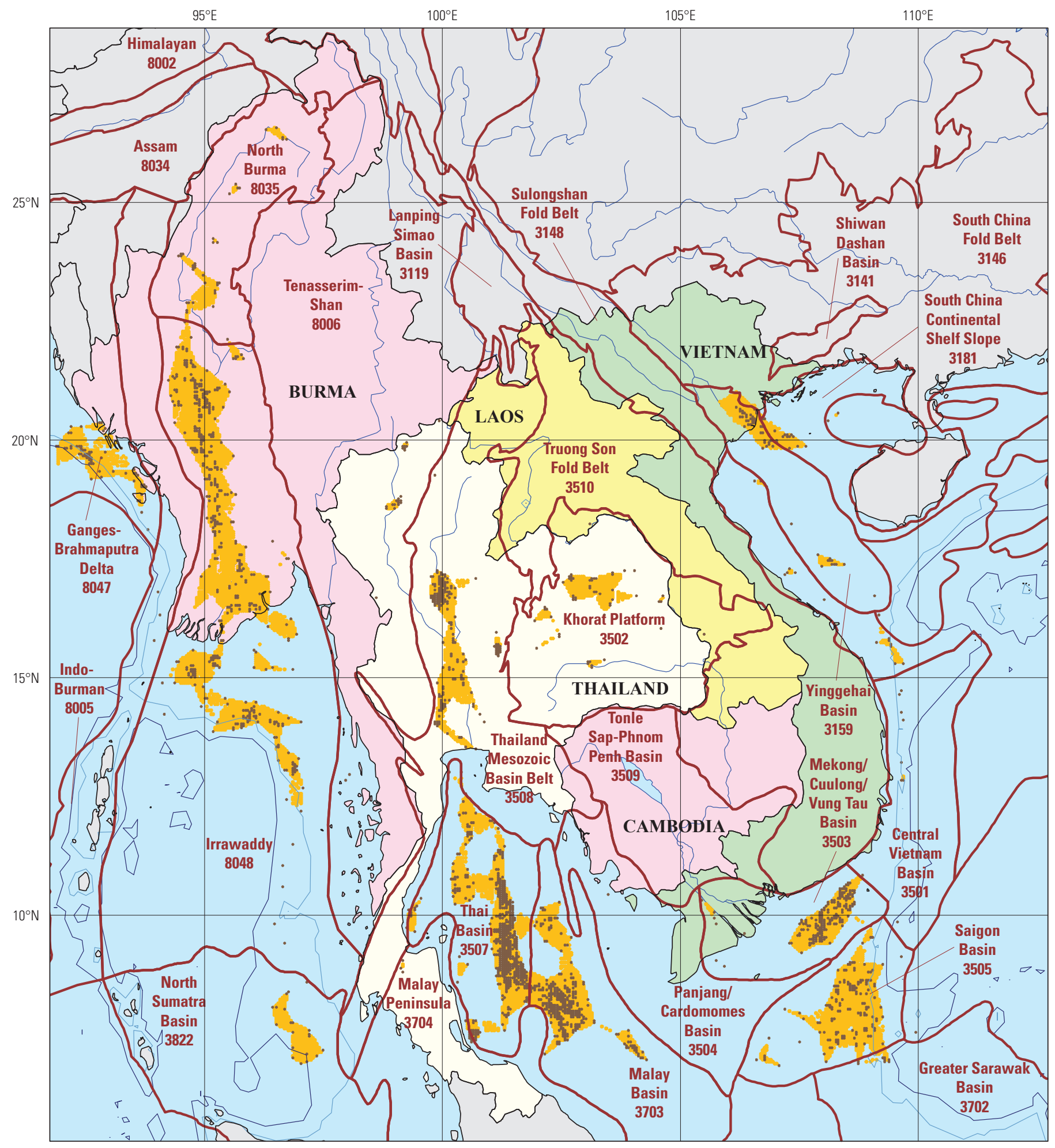

Figure 47. Map, graphs, and tables of data for oil and gas exploration through 2015 in Vietnam, Burma, Thailand, Cambodia, and Laos. 
Growth in delineated prospective area and explored area through 2015, graphed by the year the areas became prospective or explored

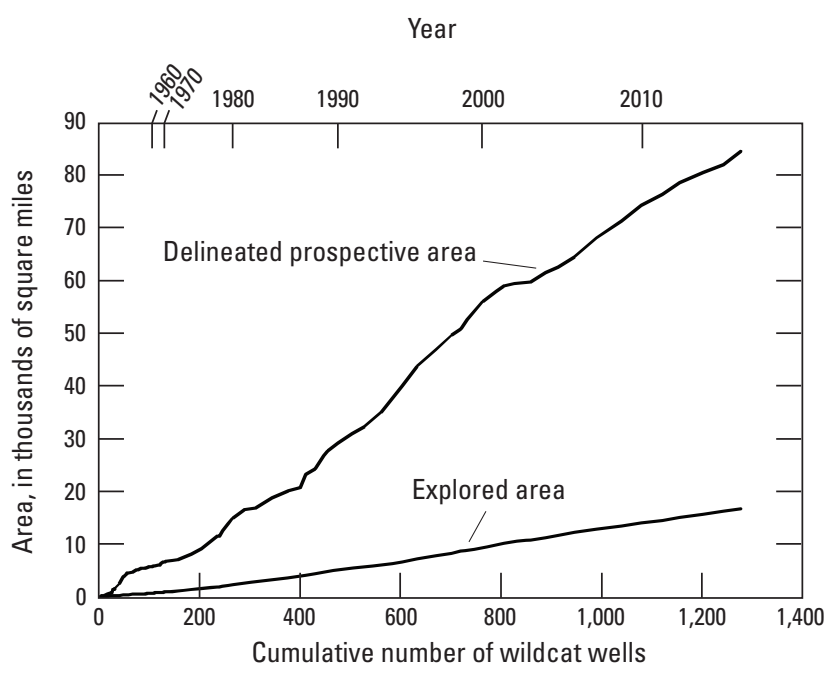

Cumulative recoverable oil and gas discoveries in all provinces through 2015, graphed by the year the field location became part of the delineated prospective area

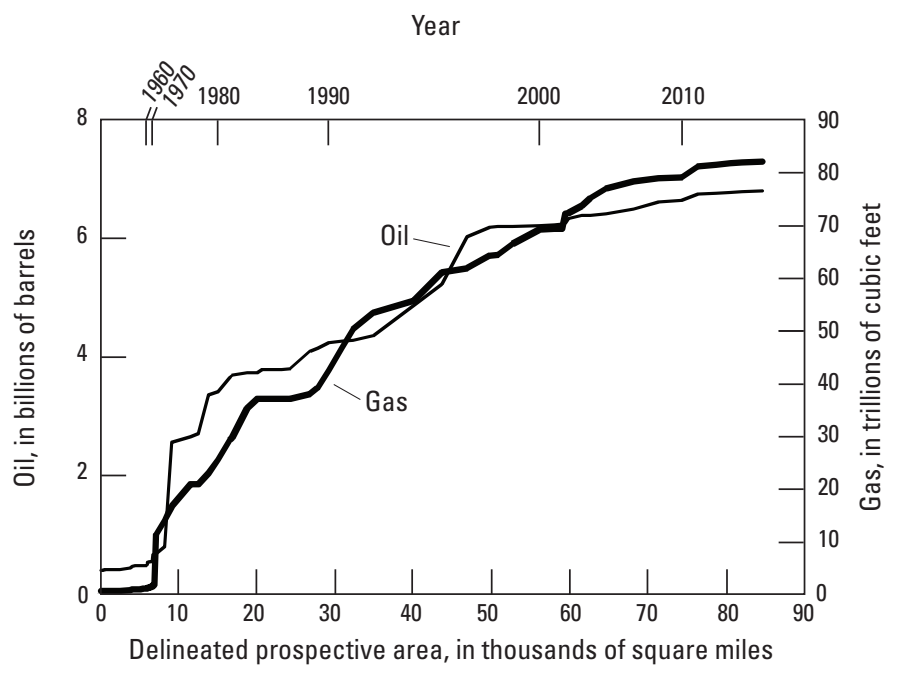

Figure 47. Continued. 
Significant petroleum provinces-Year of first discovery and cumulative recoverable oil and gas discovered through 2015

\begin{tabular}{|c|c|c|c|c|c|c|}
\hline Significant petroleum province & $\begin{array}{c}\text { Year of } \\
\text { first } \\
\text { discovery }\end{array}$ & $\begin{array}{l}\text { Oil in large } \\
\text { fields } \\
\text { (MMBO) }\end{array}$ & $\begin{array}{l}\text { Oil in all } \\
\text { fields } \\
\text { (MMBO) }\end{array}$ & $\begin{array}{c}\text { Gas in oil } \\
\text { fields } \\
\text { (BCF) }\end{array}$ & $\begin{array}{c}\text { Gas in gas } \\
\text { fields } \\
\text { (BCF) }\end{array}$ & $\begin{array}{c}\text { Gas in all } \\
\text { fields } \\
\text { (BCF) }\end{array}$ \\
\hline Greater Sarawak Basin, 3702 & 2009 & 0 & 42 & 244 & 143 & 387 \\
\hline Malay Basin, 3703 & 1991 & 0 & 231 & 1,009 & 5,152 & 6,161 \\
\hline Qiongdongnam Basin, 3136 & 1995 & 0 & 0 & 0 & 292 & 292 \\
\hline Saigon Basin, 3505 & 1974 & 111 & 356 & 828 & 6,944 & 7,771 \\
\hline $\begin{array}{l}\text { South China Continental Shelf Slope, } \\
\quad 3181\end{array}$ & 1990 & 0 & 61 & 155 & 2,833 & 2,987 \\
\hline Ganges-Brahmaputra Delta, 8047 & 1900 & 0 & $<1$ & 0 & 4,845 & 4,845 \\
\hline Irrawaddy, 8048 & 1864 & 518 & 673 & 1,049 & 14,709 & 15,758 \\
\hline Total & & 518 & 673 & 1,049 & 19,554 & 20,603 \\
\hline \multicolumn{7}{|c|}{ Thailand } \\
\hline Khorat Platform, 3502 & 1982 & 0 & 0 & 0 & 2,322 & 2,322 \\
\hline Malay Basin, 3703 & 1973 & 0 & 15 & 0 & 8,822 & 8,822 \\
\hline North Sumatra Basin, 3822 & 1976 & 0 & 0 & 0 & 875 & 875 \\
\hline Thai Basin, 3507 & 1973 & 308 & 971 & 3,715 & 17,703 & 21,417 \\
\hline Thailand Mesozoic Basin Belt, 3508 & 1981 & 221 & 374 & 649 & 126 & 775 \\
\hline \multicolumn{7}{|c|}{ Cambodia } \\
\hline
\end{tabular}

Figure 47. Continued. 


\section{Exploration data}

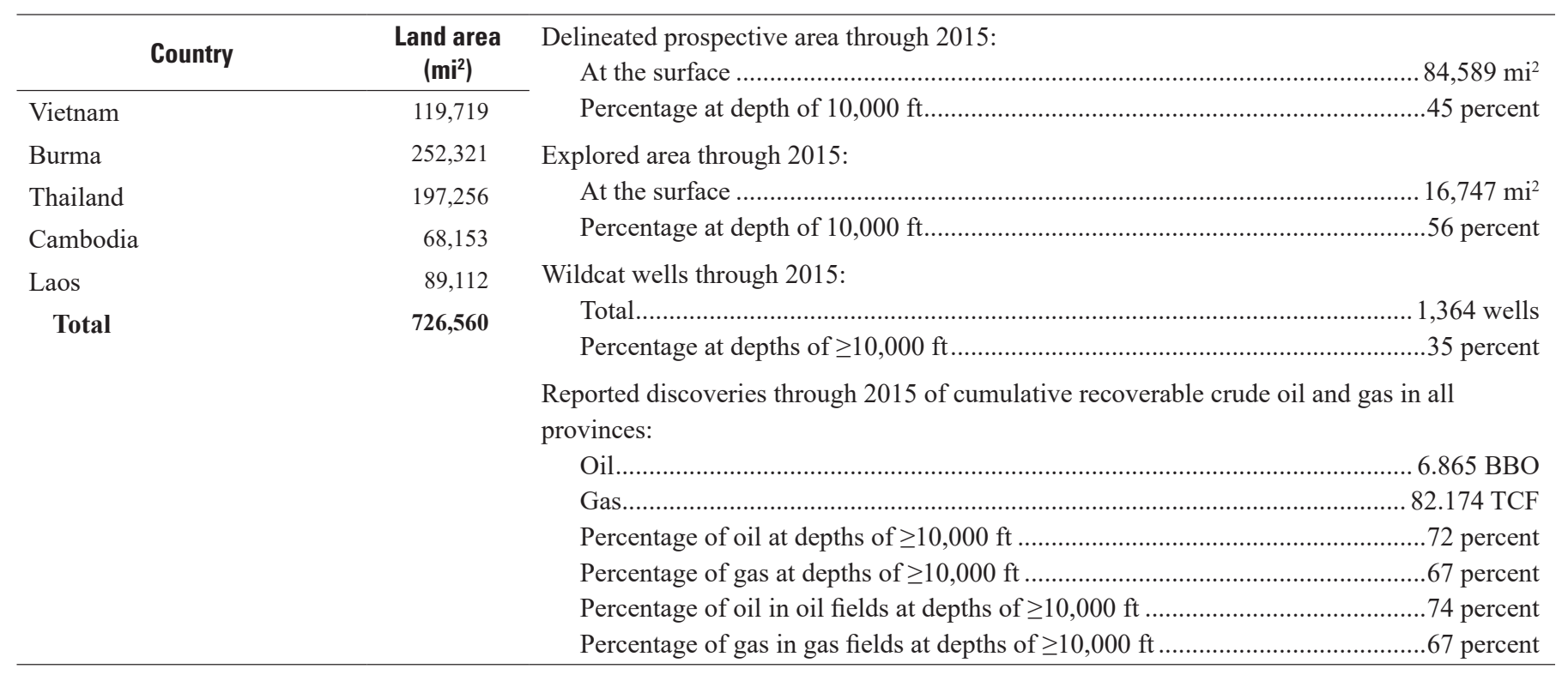

Figure 47. Continued. 


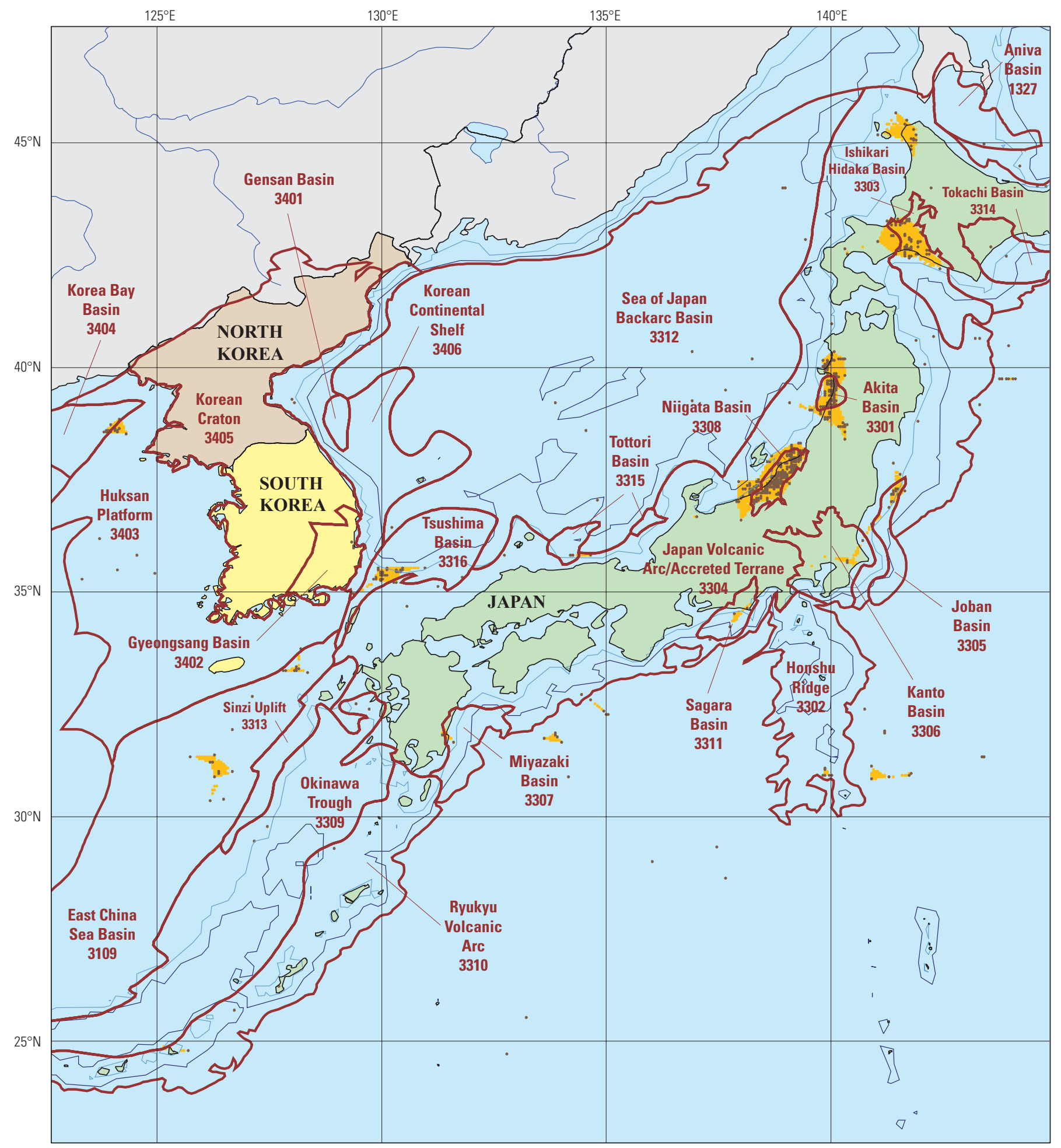

Figure 48. Map, graphs, and tables of data for oil and gas exploration through 2015 in Japan, South Korea, and North Korea. The Japan/South Korea Joint Development Area (JDA) is not delineated on the map because a standard boundary was not available. 
Growth in delineated prospective area and explored area through 2015, graphed by the year the areas became prospective or explored

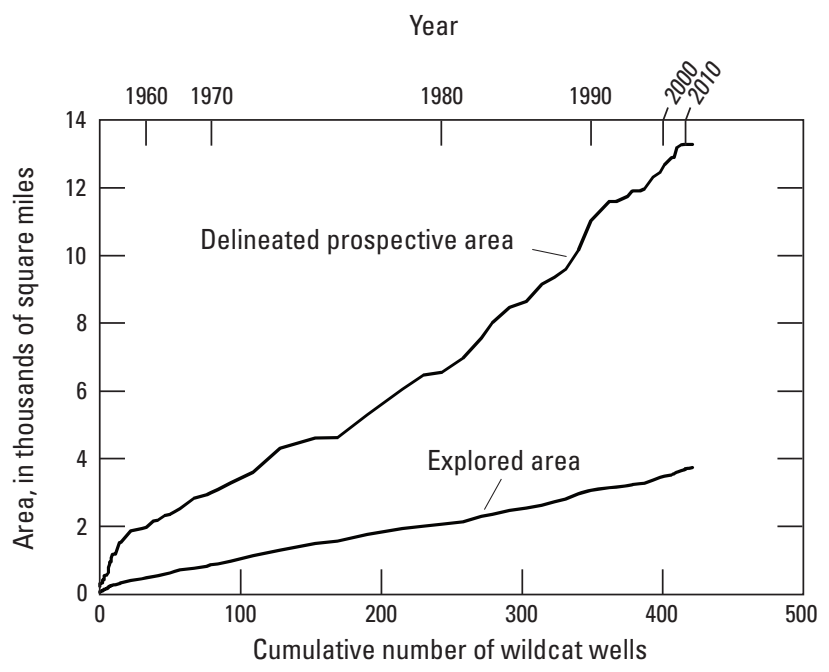

Cumulative recoverable oil and gas discoveries in all provinces through 2015, graphed by the year the field location became part of the delineated prospective area

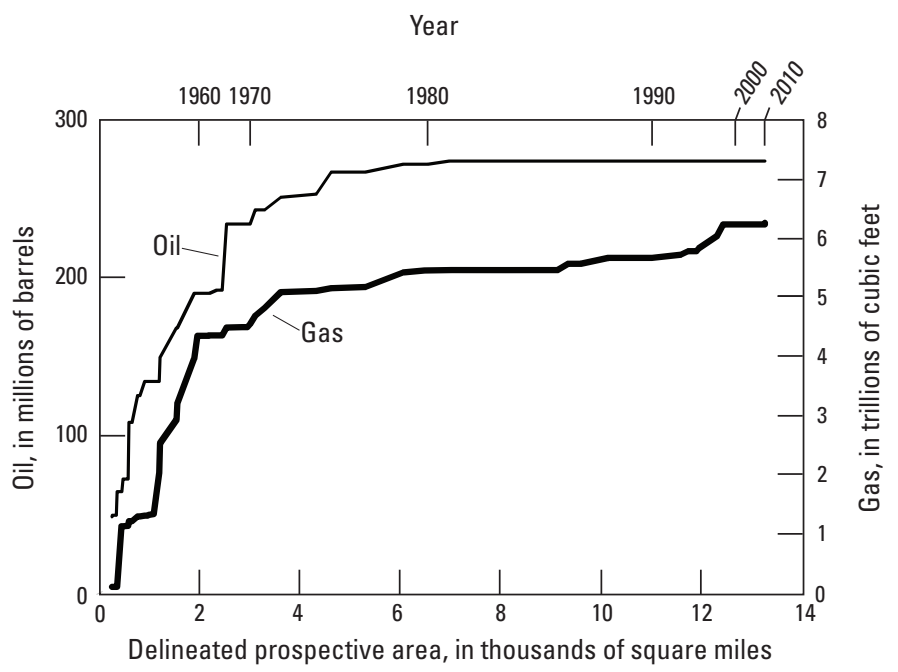

Figure 48. Continued. 
Significant petroleum provinces-Year of first discovery and cumulative recoverable oil and gas discovered through 2015

\begin{tabular}{|c|c|c|c|c|c|c|}
\hline Significant petroleum province & $\begin{array}{c}\text { Year of } \\
\text { first } \\
\text { discovery }\end{array}$ & $\begin{array}{c}\text { Oil in large } \\
\text { fields } \\
\text { (MMBO) }\end{array}$ & $\begin{array}{l}\text { Oil in all } \\
\text { fields } \\
\text { (MMBO) }\end{array}$ & $\begin{array}{l}\text { Gas in oil } \\
\text { fields } \\
\text { (BCF) }\end{array}$ & $\begin{array}{l}\text { Gas in gas } \\
\text { fields } \\
\text { (BCF) }\end{array}$ & $\begin{array}{c}\text { Gas in all } \\
\text { fields } \\
\text { (BCF) }\end{array}$ \\
\hline \multicolumn{7}{|c|}{ Japan } \\
\hline $\begin{array}{l}\text { Japan Volcanic Arc/Accreted Terrane, } \\
3304\end{array}$ & 1903 & 0 & 100 & 221 & 1,011 & 1,232 \\
\hline Total & & $\mathbf{0}$ & 228 & 495 & 4,488 & 4,983 \\
\hline \multicolumn{7}{|c|}{ South Korea } \\
\hline $\begin{array}{l}\text { Japan Volcanic Arc/Accreted Terrane, } \\
3304\end{array}$ & 1987 & 0 & 0 & 0 & 50 & 50 \\
\hline
\end{tabular}

Figure 48. Continued. 


\section{Exploration data}

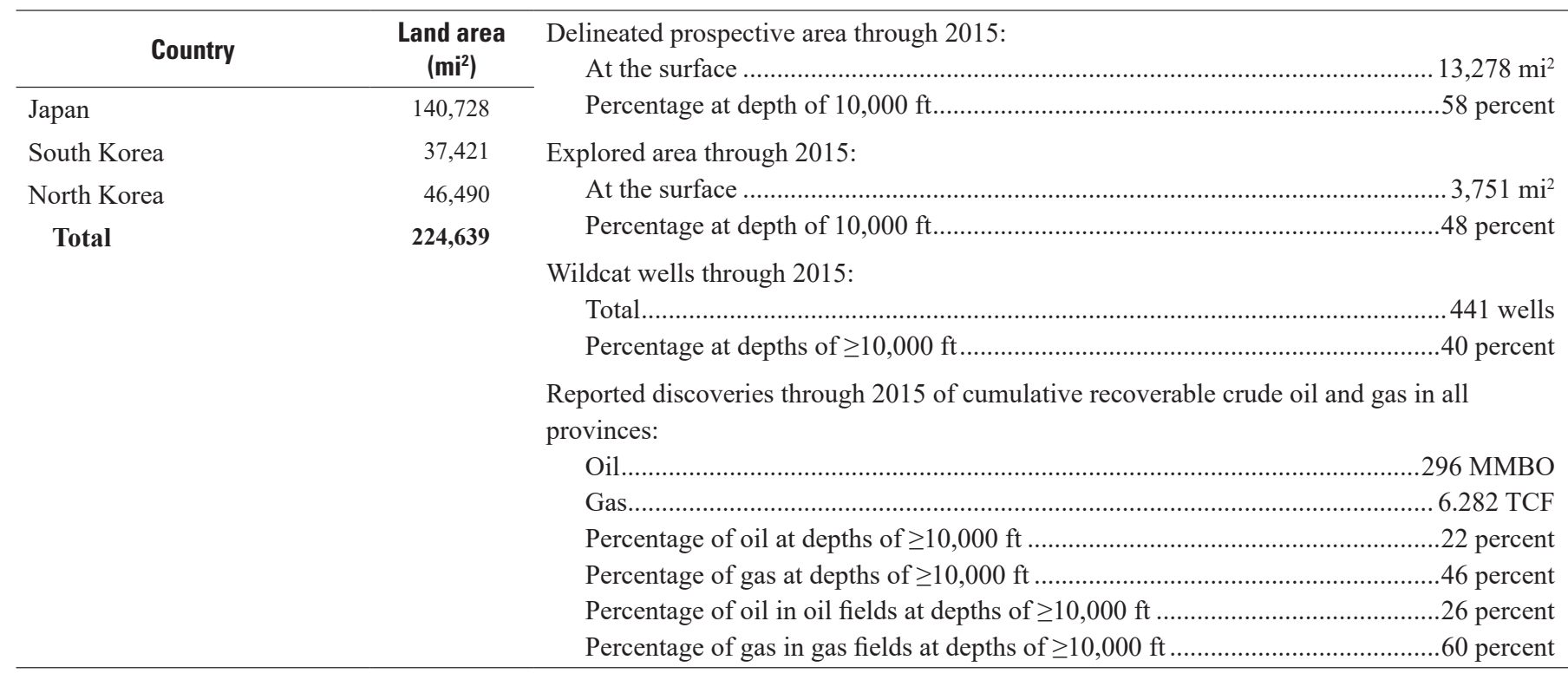

Figure 48. Continued. 


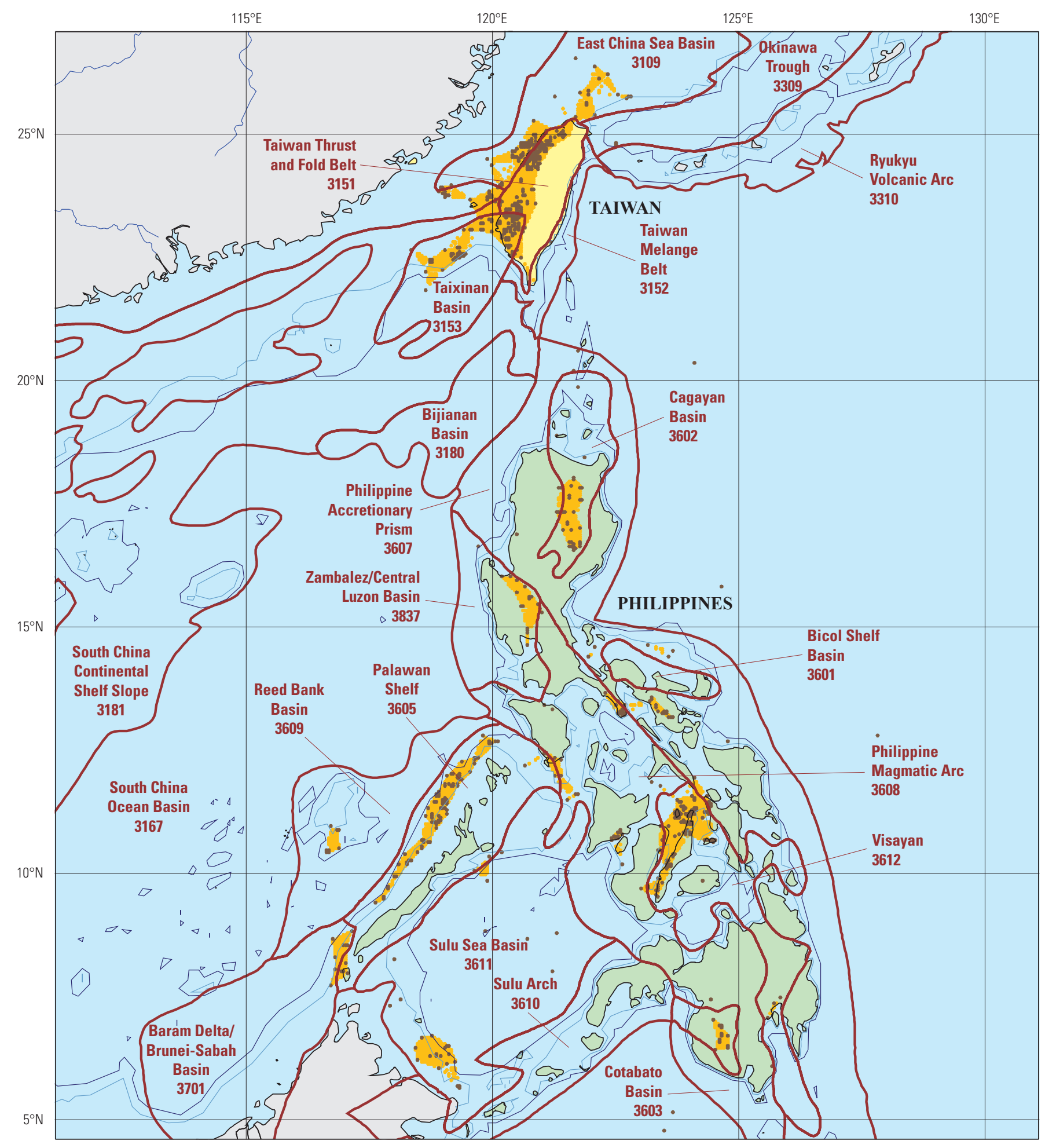

Figure 49. Map, graphs, and tables of data for oil and gas exploration through 2015 in the Philippines and Taiwan. 
Growth in delineated prospective area and explored area through 2015, graphed by the year the areas became prospective or explored

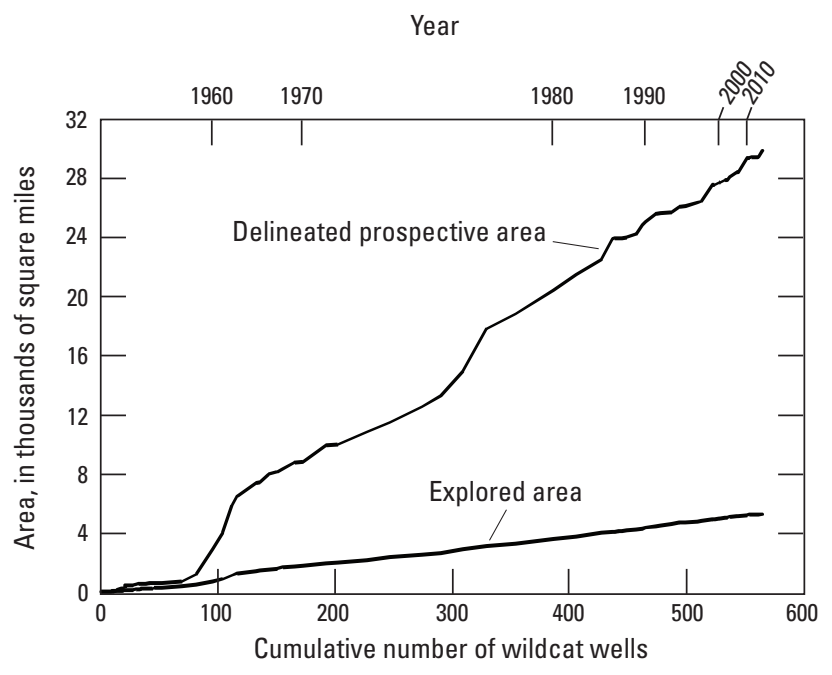

Cumulative recoverable oil and gas discoveries in all provinces through 2015, graphed by the year the field location became part of the delineated prospective area

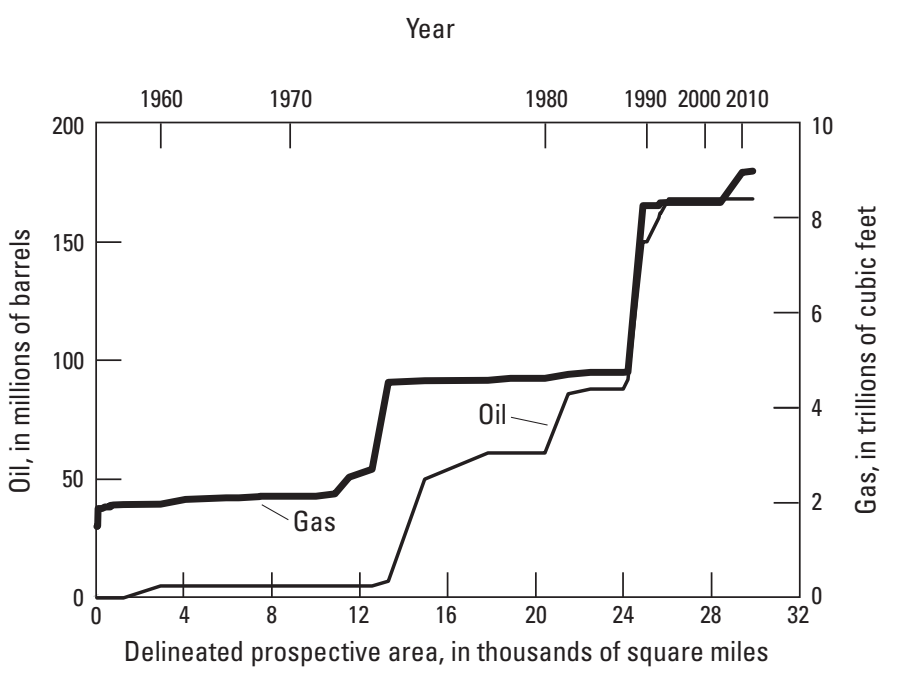

Figure 49. Continued. 
Significant petroleum provinces-Year of first discovery and cumulative recoverable oil and gas discovered through 2015

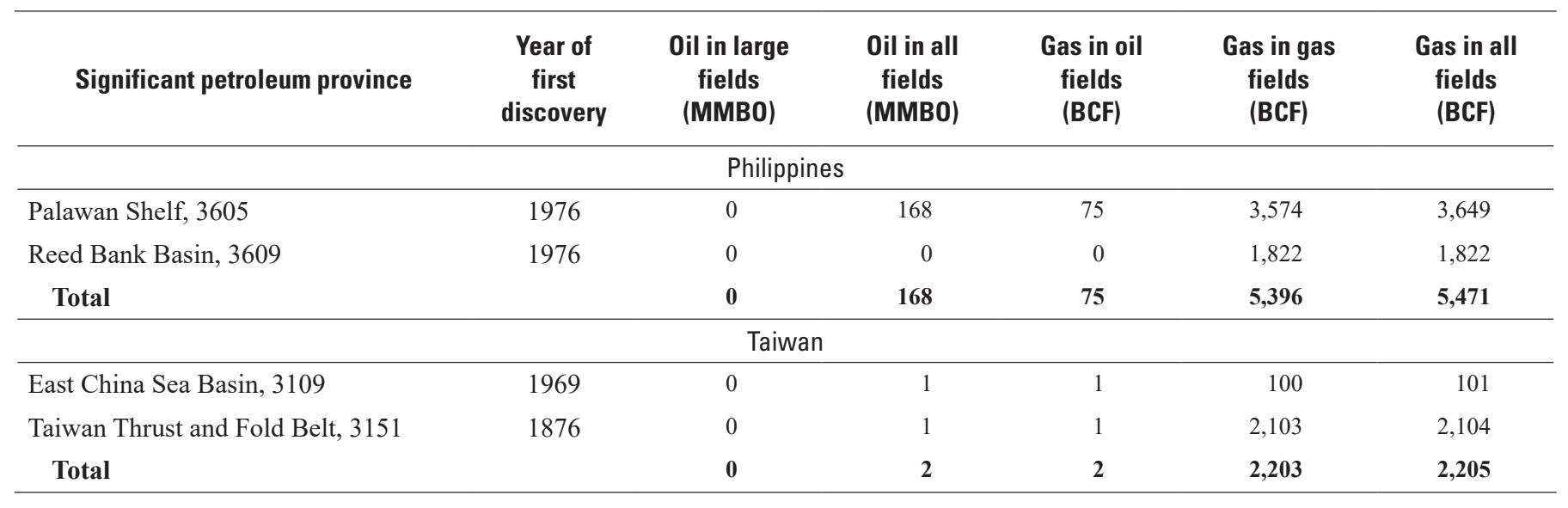

Figure 49. Continued. 


\section{Exploration data}

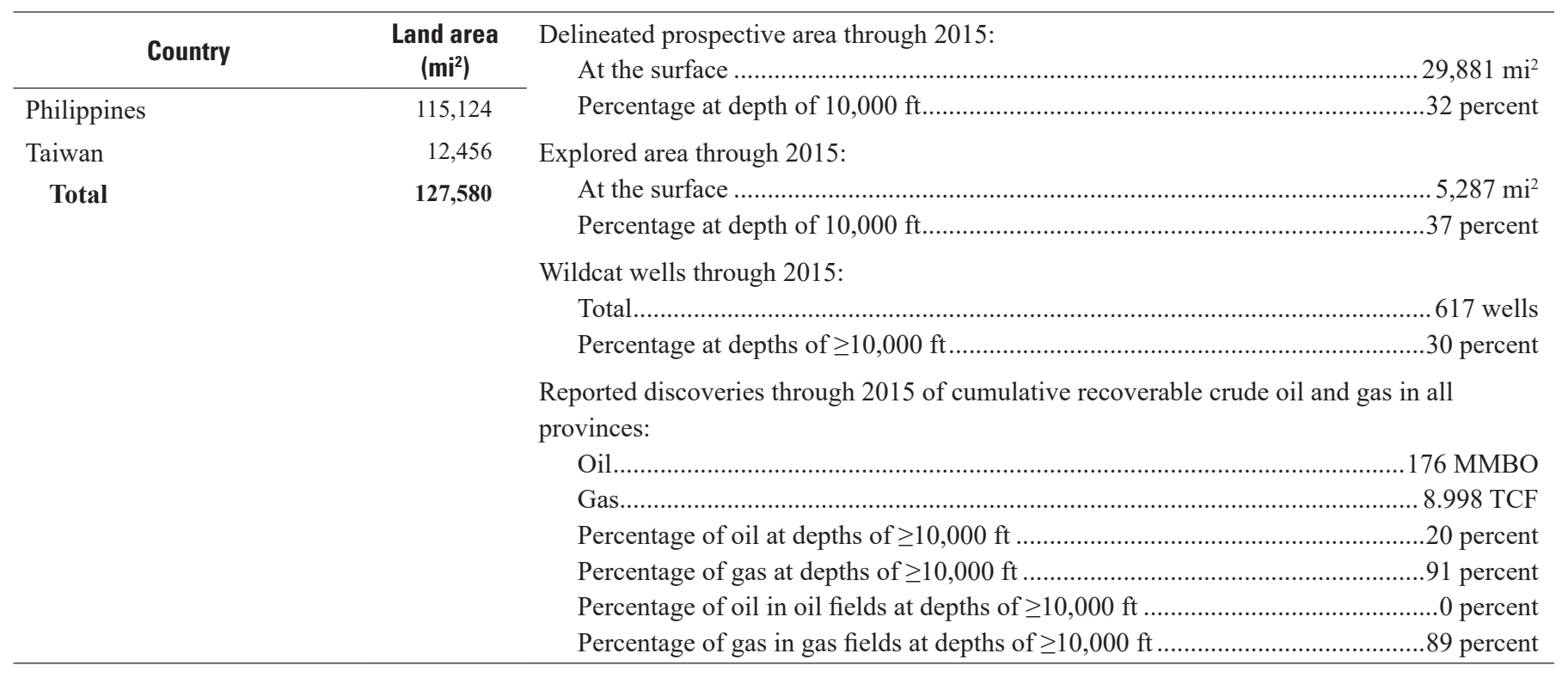

Figure 49. Continued. 


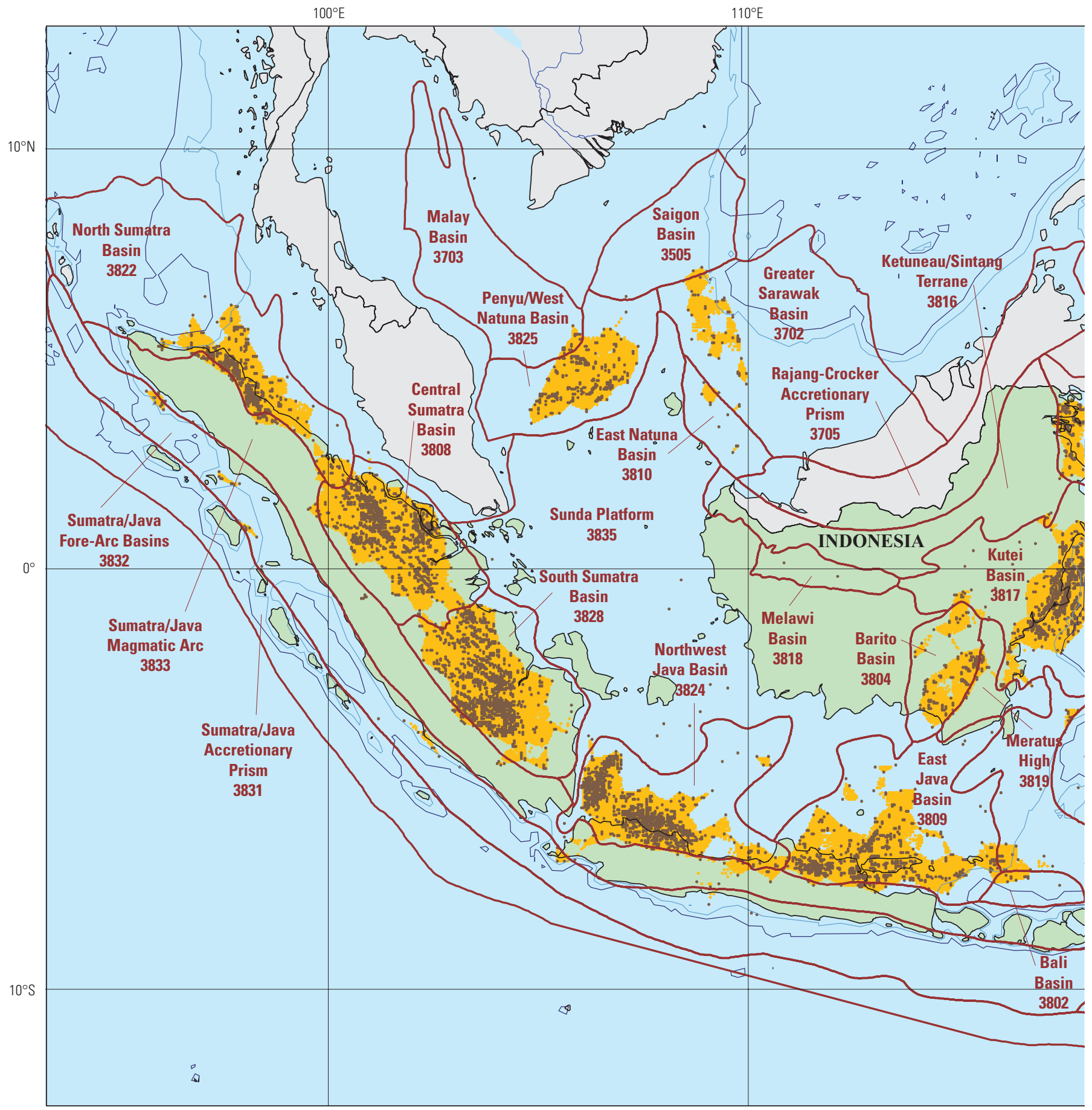

Figure 50. Map, graphs, and tables of data for oil and gas exploration through 2015 in Indonesia. 


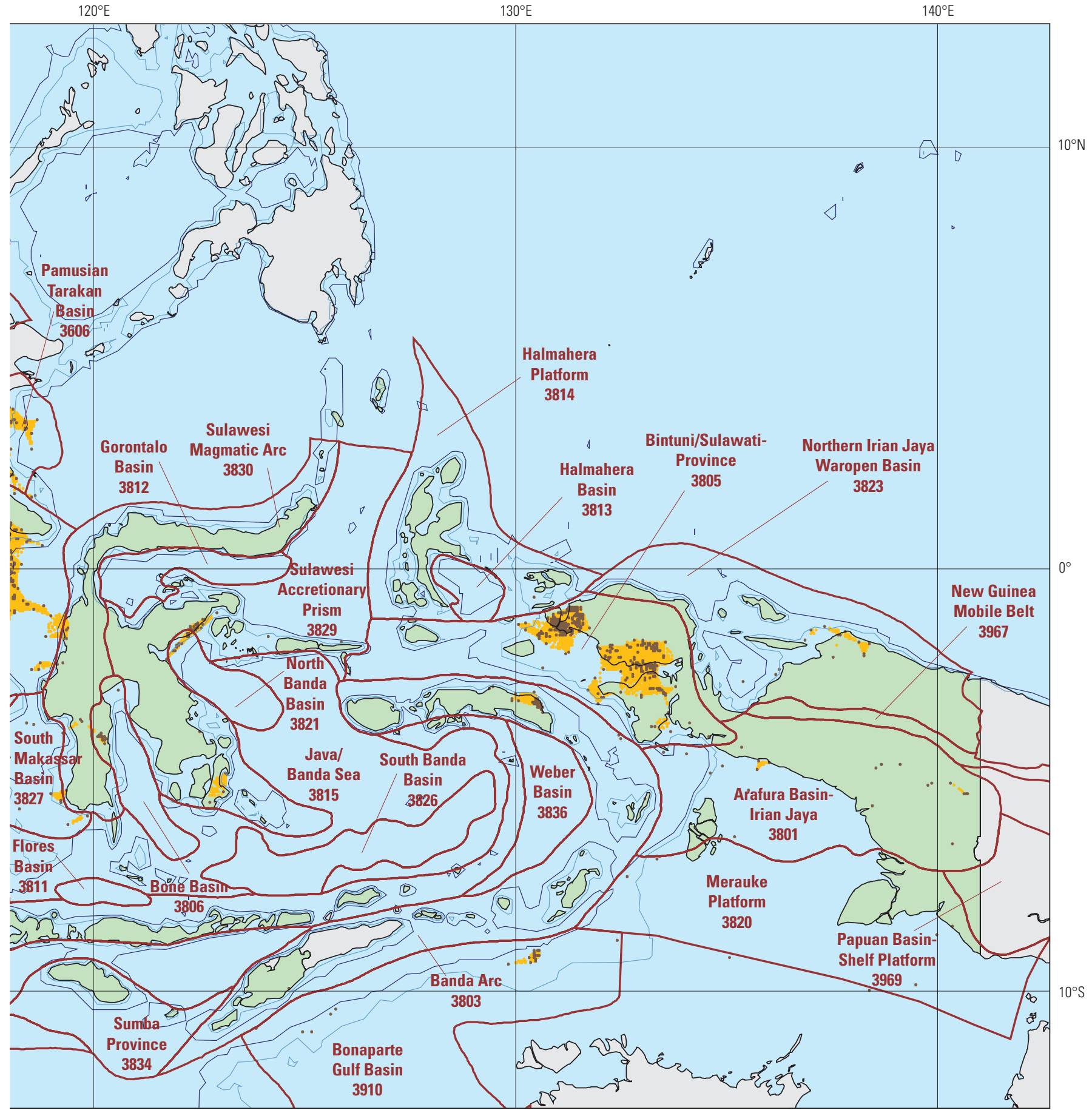

Figure 50. Continued. 
Growth in delineated prospective area and explored area through 2015 , graphed by the year the areas became prospective or explored

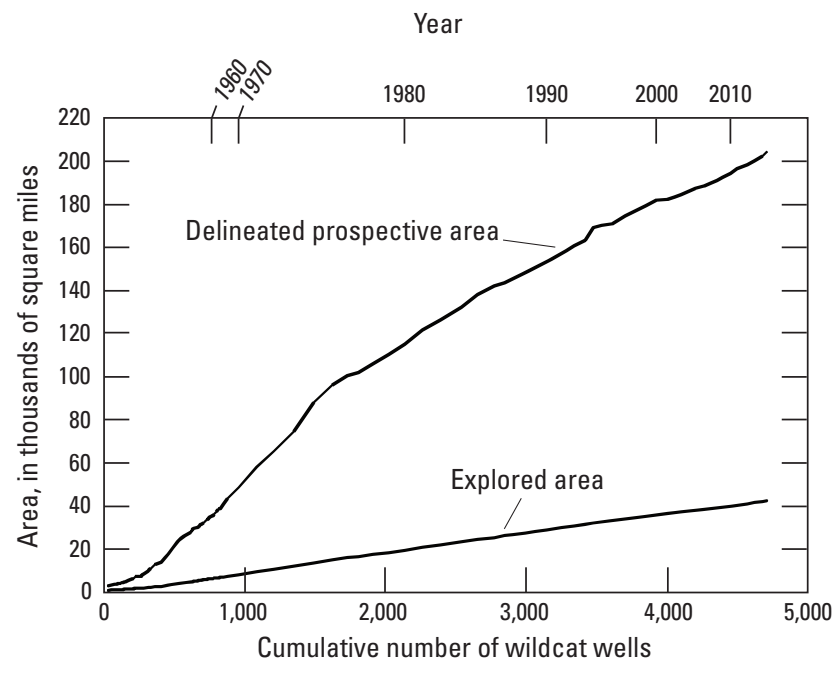

Cumulative recoverable oil and gas discoveries in all provinces through 2015, graphed by the year the field location became part of the delineated prospective area

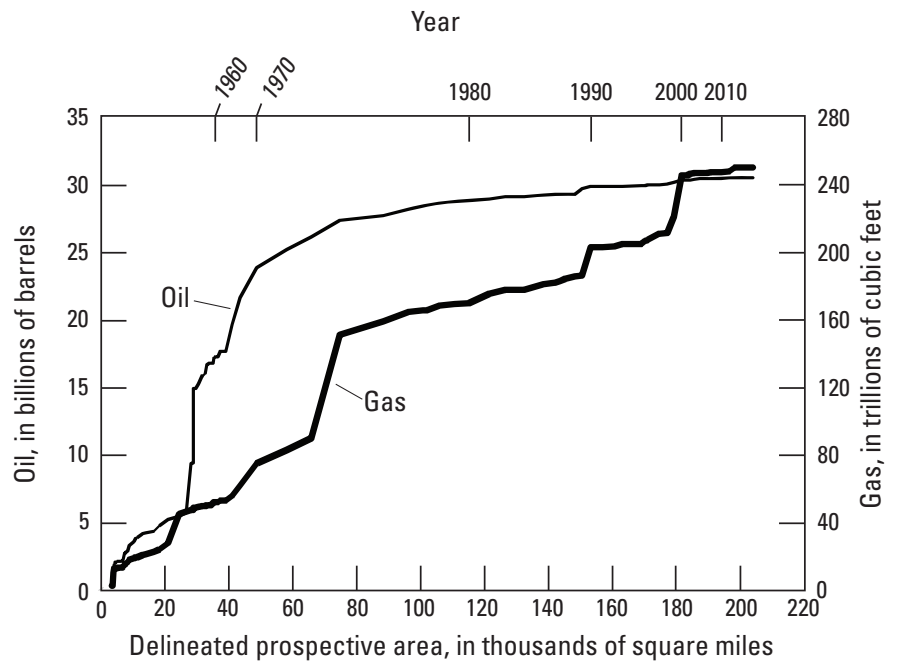

Figure 50. Continued. 
Significant petroleum provinces-Year of first discovery and cumulative recoverable oil and gas discovered through 2015

\begin{tabular}{|c|c|c|c|c|c|c|}
\hline Significant petroleum province & $\begin{array}{c}\text { Year of } \\
\text { first } \\
\text { discovery }\end{array}$ & $\begin{array}{c}\text { Oil in large } \\
\text { fields } \\
\text { (MMBO) }\end{array}$ & $\begin{array}{l}\text { Oil in all } \\
\text { fields } \\
\text { (MMBO) }\end{array}$ & $\begin{array}{l}\text { Gas in oil } \\
\text { fields } \\
\text { (BCF) }\end{array}$ & $\begin{array}{l}\text { Gas in gas } \\
\text { fields } \\
\text { (BCF) }\end{array}$ & $\begin{array}{c}\text { Gas in all } \\
\text { fields } \\
\text { (BCF) }\end{array}$ \\
\hline Banda Arc, 3803 & 1897 & 0 & 54 & 25 & 2,023 & 2,048 \\
\hline Barito Basin, 3804 & 1938 & 152 & 186 & 226 & 80 & 306 \\
\hline Bonaparte Gulf Basin, 3910 & 2000 & 0 & 0 & 0 & 18,470 & 18,470 \\
\hline Central Sumatra Basin, 3808 & 1939 & 12,872 & 15,117 & 2,552 & 1,123 & 3,675 \\
\hline East Java Basin, 3809 & 1888 & 723 & 1,485 & 2,915 & 10,104 & 13,019 \\
\hline Greater Sarawak Basin, 3702 & 1970 & 0 & 58 & 299 & 47,293 & 47,593 \\
\hline Kutei Basin, 3817 & 1897 & 2,617 & 3,664 & 8,392 & 48,345 & 56,737 \\
\hline $\begin{array}{l}\text { Northern Irian Jaya Waropen Basin, } \\
3823\end{array}$ & 1958 & 0 & 0 & 0 & 1,100 & 1,100 \\
\hline Northwest Java Basin, 3824 & 1897 & 1,888 & 3,878 & 6,989 & 7,124 & 14,112 \\
\hline Pamusian Tarakan Basin, 3606 & 1900 & 611 & 795 & 2,732 & 1,534 & 4,265 \\
\hline Penyu/West Natuna Basin, 3825 & 1972 & 390 & 847 & 2,102 & 3,644 & 5,746 \\
\hline South Sumatra Basin, 3828 & 1896 & 1,236 & 3,111 & 6,459 & 21,265 & 27,724 \\
\hline Sulawesi Accretionary Prism, 3829 & 1986 & 0 & 21 & 1 & 2,679 & 2,680 \\
\hline Total & & 21,138 & 30,725 & 34,283 & 213,162 & 247,445 \\
\hline
\end{tabular}

\section{Exploration data}

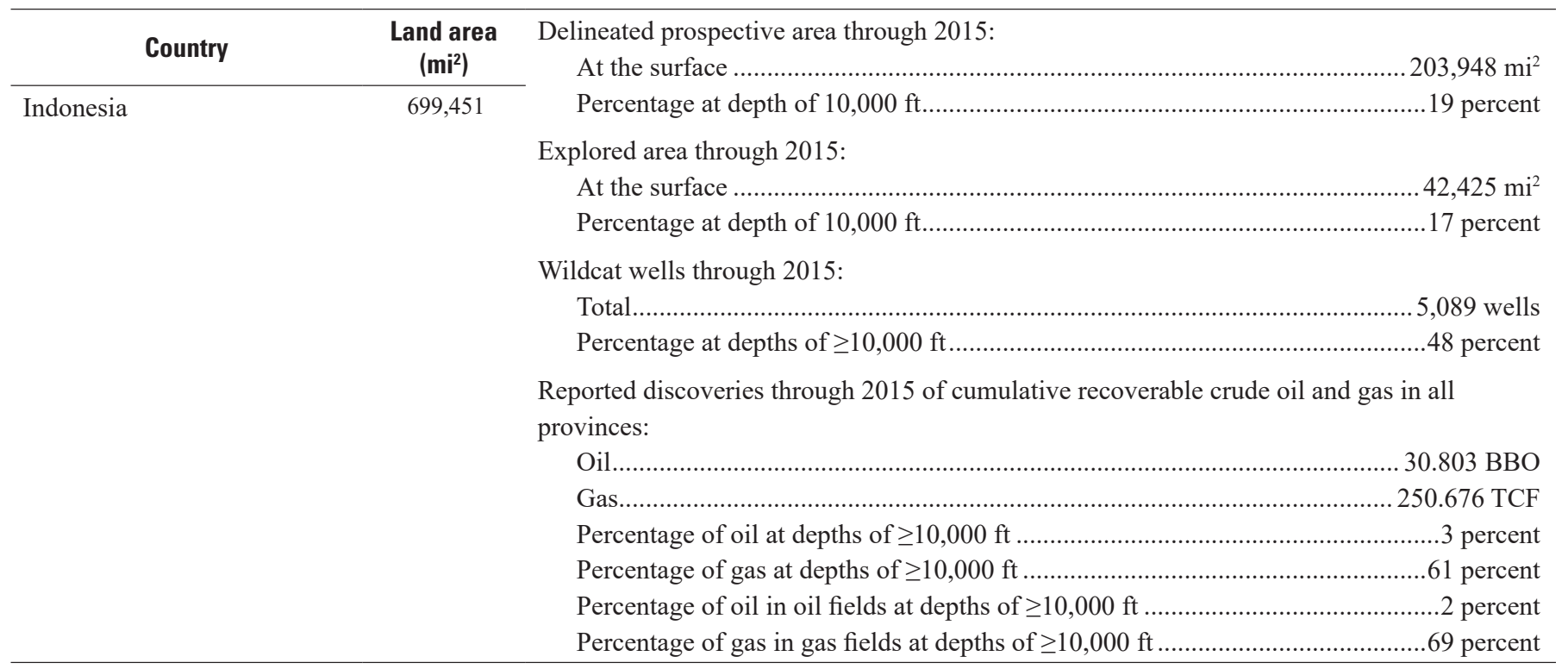

Figure 50. Continued. 


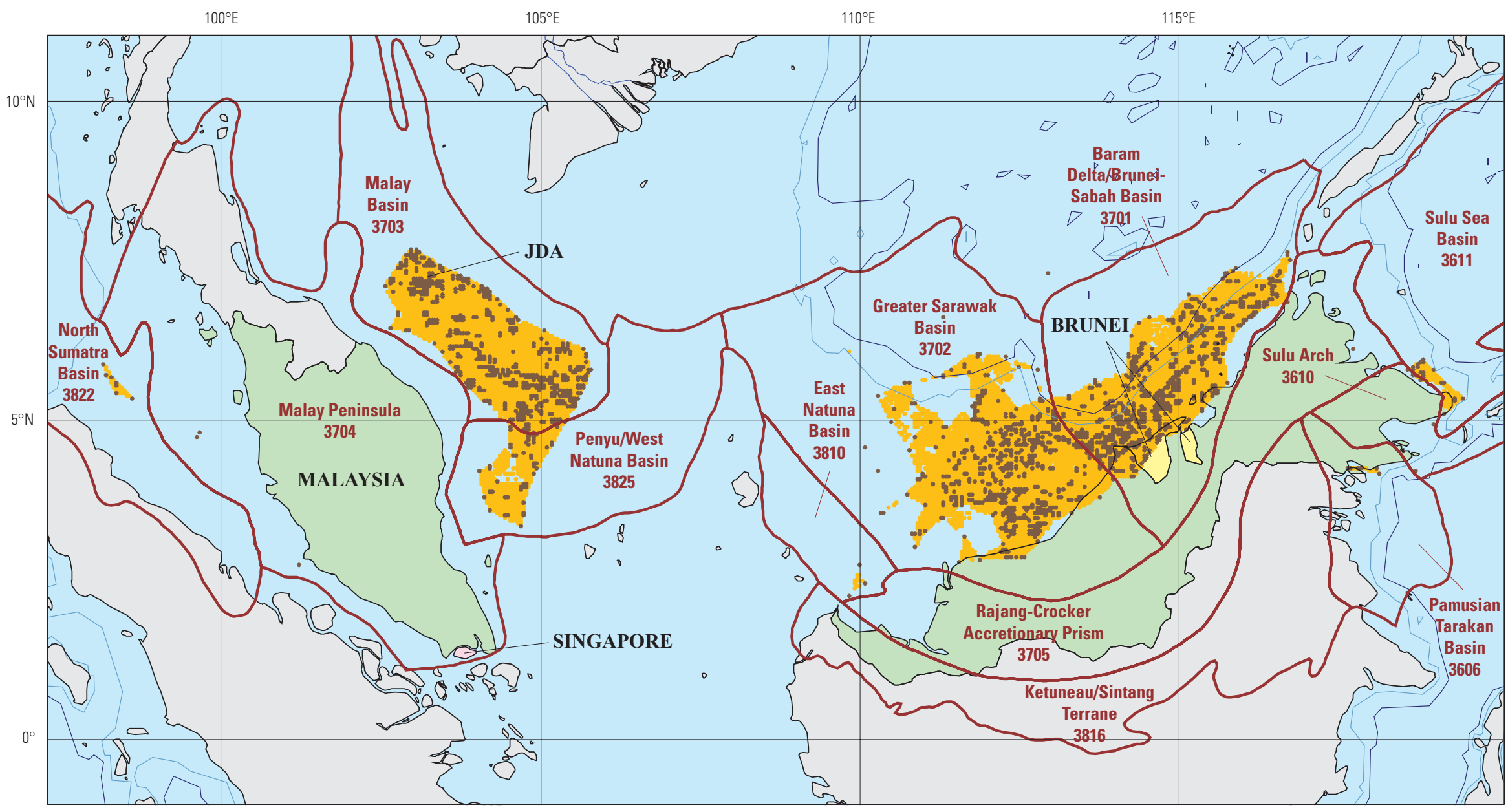

Figure 51. Map, graphs, and tables of data for oil and gas exploration through 2015 in Malaysia, Brunei, and Singapore. The Malaysia/Thailand Joint Development Area (JDA) is not delineated on the map because a standard boundary was not available. 
Growth in delineated prospective area and explored

area through 2015, graphed by the year the areas became

prospective or explored

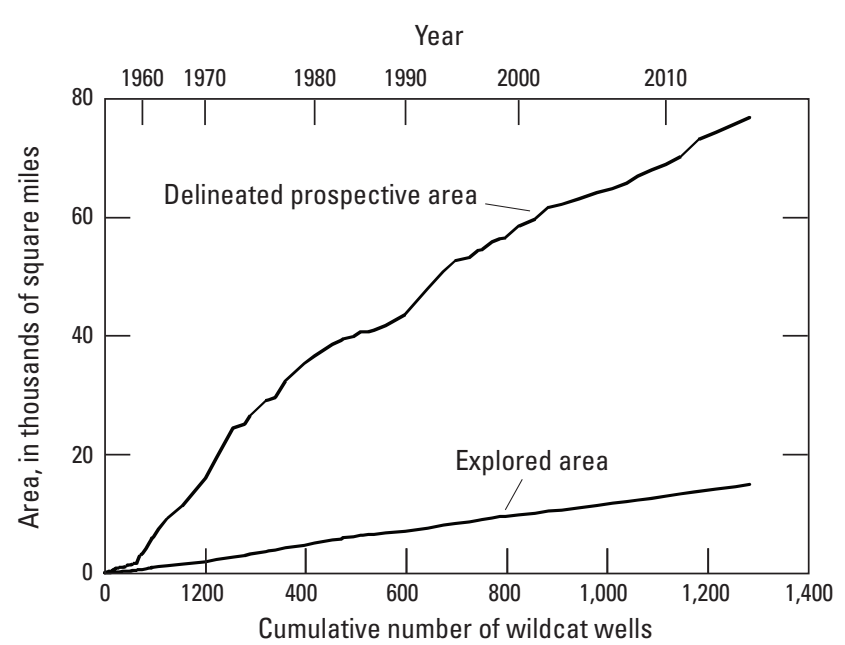

Cumulative recoverable oil and gas discoveries in all provinces through 2015, graphed by the year the field location became part of the delineated prospective area

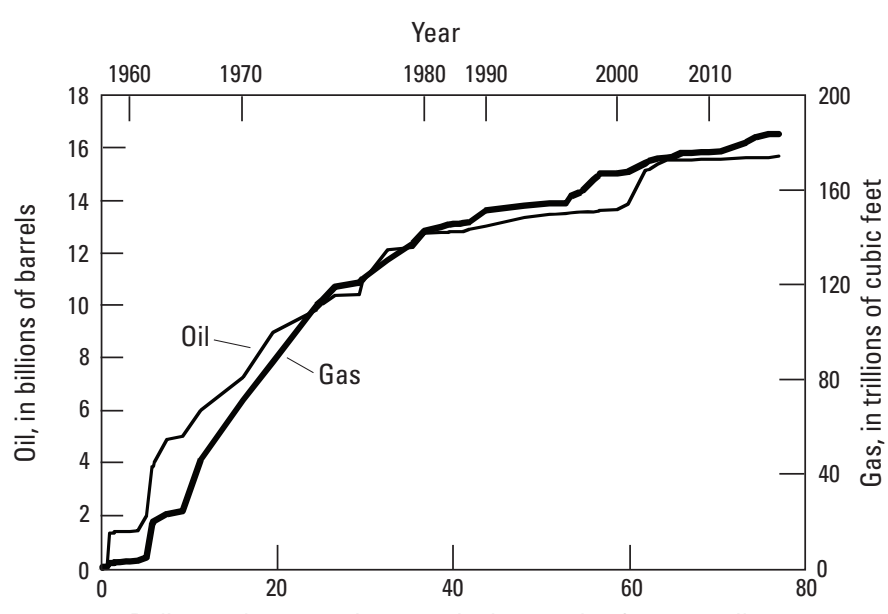

Figure 51. Continued. 

discovered through 2015

\begin{tabular}{|c|c|c|c|c|c|c|}
\hline $\begin{array}{l}\text { Significant petroleum } \\
\text { province }\end{array}$ & $\begin{array}{c}\text { Year of } \\
\text { first } \\
\text { discovery }\end{array}$ & $\begin{array}{c}\text { Oil in } \\
\text { large } \\
\text { fields } \\
\text { (MMBO) }\end{array}$ & $\begin{array}{l}\text { Oil in all } \\
\text { fields } \\
\text { (MMBO) }\end{array}$ & $\begin{array}{c}\text { Gas in oil } \\
\text { fields } \\
\text { (BCF) }\end{array}$ & $\begin{array}{c}\text { Gas in } \\
\text { gas fields } \\
\text { (BCF) }\end{array}$ & $\begin{array}{c}\text { Gas in all } \\
\text { fields } \\
\text { (BCF) }\end{array}$ \\
\hline \multicolumn{7}{|c|}{ Malaysia } \\
\hline $\begin{array}{l}\text { Baram Delta/Brunei-Sabah } \\
\text { Basin, } 3701\end{array}$ & 1910 & 3,806 & 5,255 & 12,888 & 14,873 & 27,761 \\
\hline Greater Sarawak Basin, 3702 & 1953 & 442 & 1,303 & 2,850 & 72,480 & 75,330 \\
\hline Malay Basin, 3703 & 1969 & 3,200 & 4,750 & 13,646 & 23,969 & 37,615 \\
\hline North Sumatra Basin, 3822 & 1989 & 0 & 0 & 0 & 110 & 110 \\
\hline $\begin{array}{l}\text { Penyu/West Natuna Basin, } \\
3825\end{array}$ & 1973 & 0 & 137 & 52 & 581 & 632 \\
\hline Total & & 7,449 & 11,444 & 29,436 & 112,013 & 141,449 \\
\hline \multicolumn{7}{|c|}{ Brunei } \\
\hline $\begin{array}{l}\text { Baram Delta/Brunei-Sabah } \\
\text { Basin, } 3701\end{array}$ & 1914 & 3,743 & 4,233 & 21,900 & 7,751 & 29,651 \\
\hline \multicolumn{7}{|c|}{ Malaysia-Thailand JDA } \\
\hline Malay Basin, 3703 & 1971 & 0 & 10 & 0 & 12,023 & 12,023 \\
\hline
\end{tabular}

Figure 51. Continued. 


\section{Exploration data}

\begin{tabular}{|c|c|c|}
\hline Country & $\begin{array}{l}\text { Land } \\
\text { area } \\
\left(\mathrm{mi}^{2}\right)\end{array}$ & 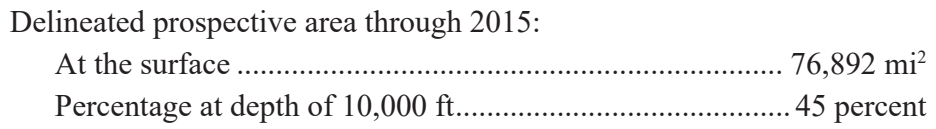 \\
\hline Malaysia & 126,895 & Explored area through 2015: \\
\hline Brunei & 2,033 & At the surface \\
\hline Singapore & 265 & 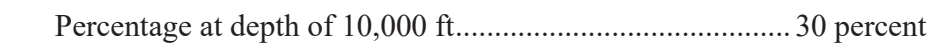 \\
\hline \multirow[t]{8}{*}{ Total } & 129,193 & 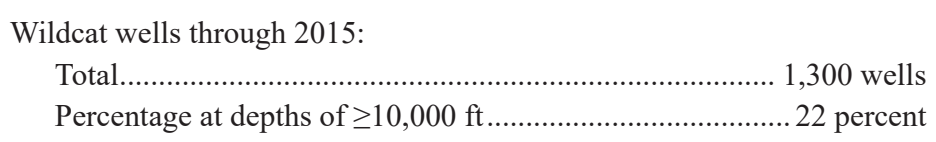 \\
\hline & & $\begin{array}{l}\text { Reported discoveries through } 2015 \text { of cumulative recoverable crude oil } \\
\text { and gas in all provinces: }\end{array}$ \\
\hline & & 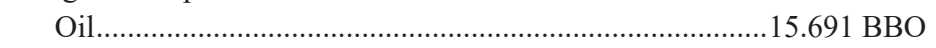 \\
\hline & & 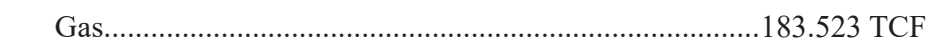 \\
\hline & & 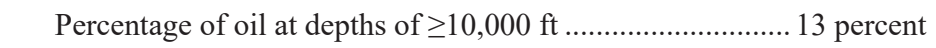 \\
\hline & & Percentage of gas at depths of $\geq 10,000 \mathrm{ft}$..........................20 percent \\
\hline & & Percentage of oil in oil fields at depths of $\geq 10,000 \mathrm{ft} \ldots \ldots \ldots .14$ percent \\
\hline & & Percentage of gas in gas fields at depths of $\geq 10,000 \mathrm{ft} \ldots \ldots . .24$ percent \\
\hline
\end{tabular}

Figure 51. Continued. 


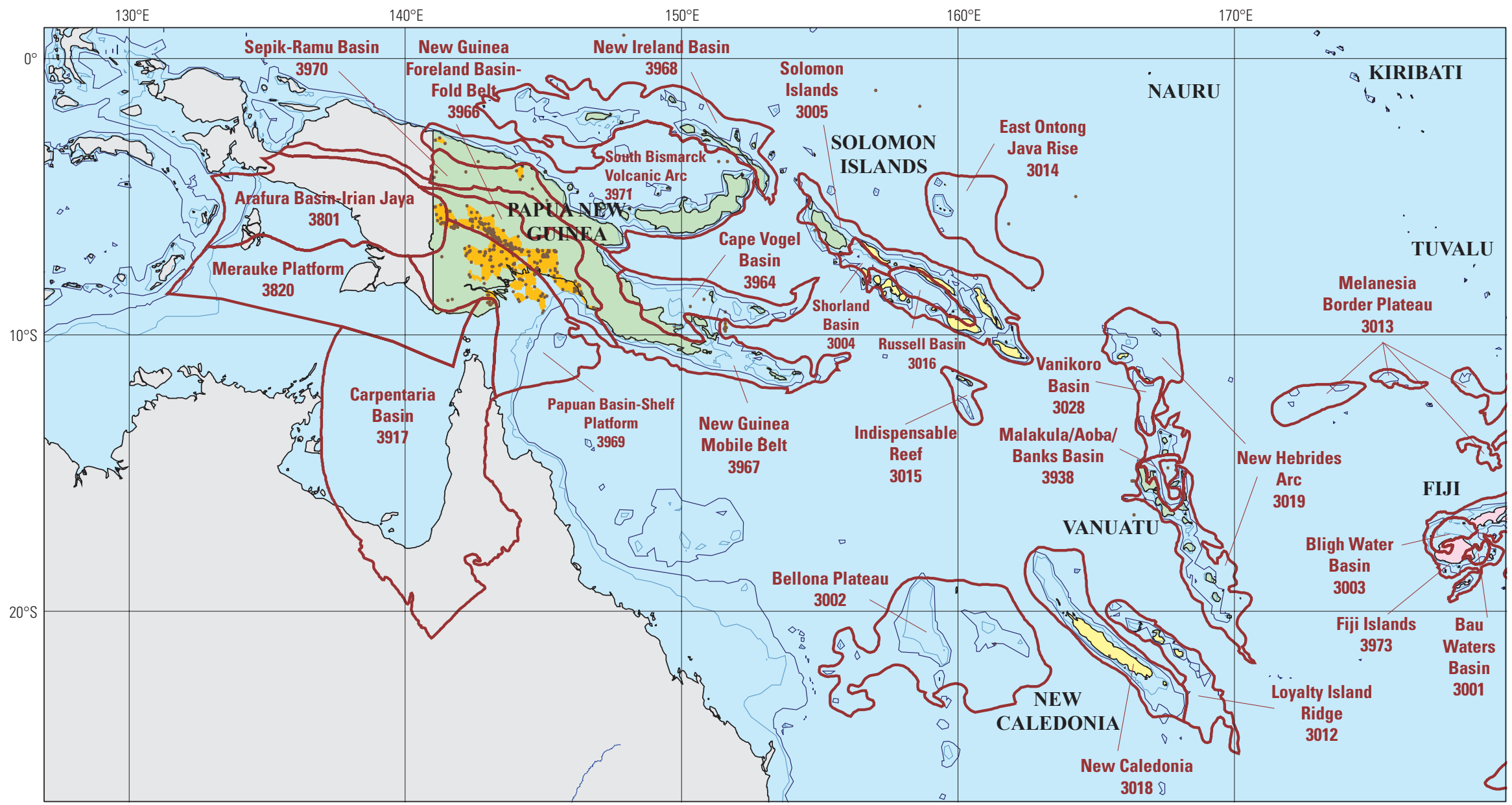

Figure 52. Map, graphs, and tables of data for oil and gas exploration through 2015 in Papua New Guinea, Fiji, New Caledonia (an overseas territory of France), Solomon Islands, Vanuatu, French Polynesia, Guam, Marshall Islands, Micronesia, Northern Mariana Islands, and Tonga. Six of these areas have delineated prospective areas and no discoveries but are outside the limits of the map: French Polynesia, Guam, Marshall Islands, Micronesia, Northern Mariana Islands, and Tonga. For completeness, three areas are labeled on the map, although they lack petroleum exploration: Nauru, Kiribati, and Tuvalu. 
Growth in delineated prospective area and explored area through 2015, graphed by the year the areas became prospective or explored

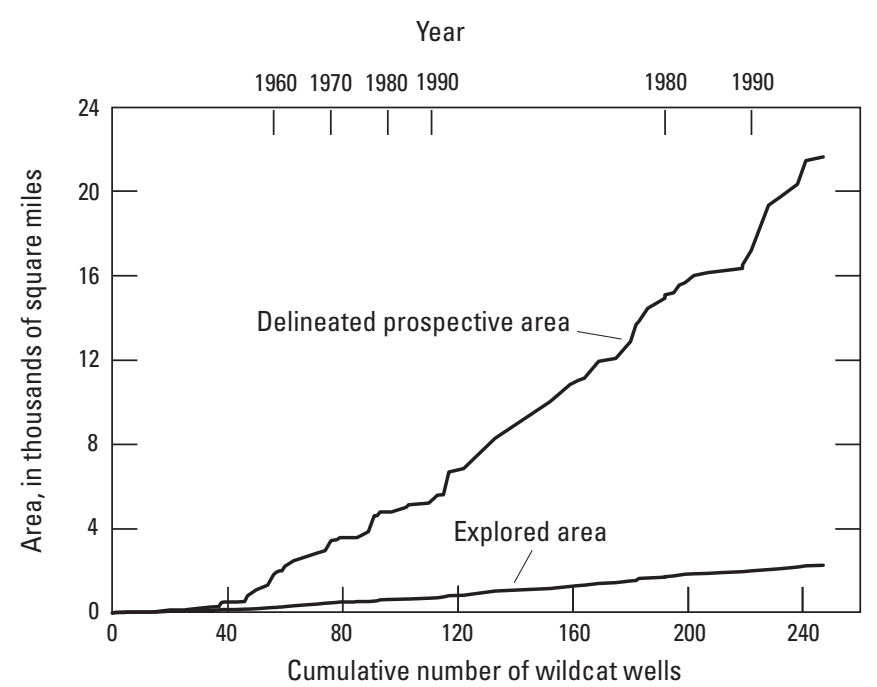

Cumulative recoverable oil and gas discoveries in all provinces through 2015, graphed by the year the field location became part of the delineated prospective area

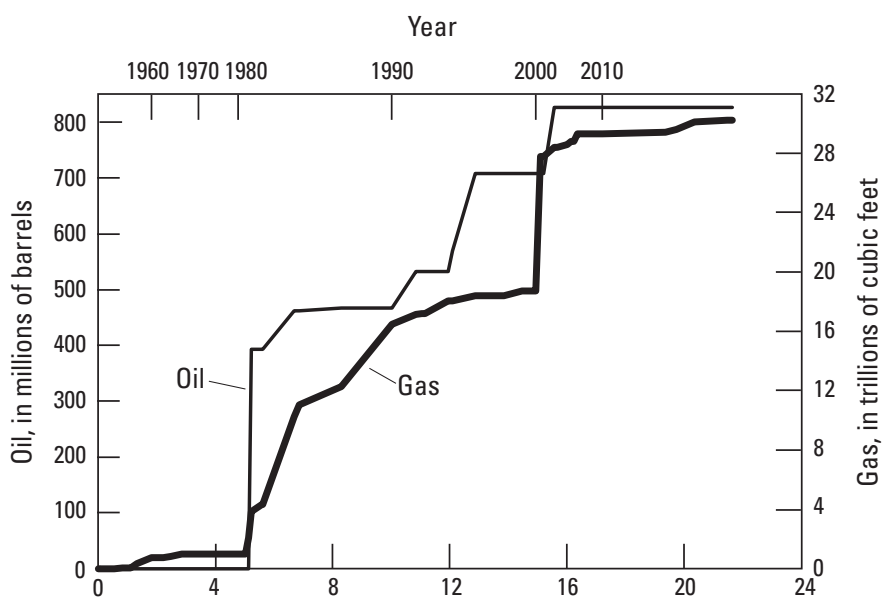

Delineated prospective area, in thousands of square miles
Significant petroleum provinces-Year of first discovery and cumulative recoverable oil and gas discovered through 2015

\begin{tabular}{lcccccc}
\hline $\begin{array}{c}\text { Significant petroleum } \\
\text { province }\end{array}$ & $\begin{array}{c}\text { Year of } \\
\text { first } \\
\text { discovery }\end{array}$ & $\begin{array}{c}\text { Oil in } \\
\text { large } \\
\text { fields } \\
\text { (MMBO) }\end{array}$ & $\begin{array}{c}\text { Oil in all } \\
\text { fields } \\
\text { (MMBO) }\end{array}$ & $\begin{array}{c}\text { Gas in oil } \\
\text { fields } \\
\text { (BCF) }\end{array}$ & $\begin{array}{c}\text { Gas in } \\
\text { gas fields } \\
\text { (BCF) }\end{array}$ & $\begin{array}{c}\text { Gas in all } \\
\text { fields } \\
\text { (BCF) }\end{array}$ \\
\hline $\begin{array}{c}\text { Papua New Guinea } \\
\text { New Guinea Foreland Basin- } \\
\text { Fold Belt, 3966 }\end{array}$ & 1949 & 581 & 829 & 2,810 & 22,154 & 24,965 \\
$\begin{array}{l}\text { Papuan Basin-Shelf Platform, } \\
\text { 3969 }\end{array}$ & 1958 & 0 & $<1$ & 0 & 4,928 & 4,928 \\
Total & & $\mathbf{5 8 1}$ & $\mathbf{8 2 9}$ & $\mathbf{2 , 8 1 0}$ & $\mathbf{2 7 , 0 8 2}$ & $\mathbf{2 9 , 8 9 3}$ \\
\hline
\end{tabular}

\section{Exploration data}

\begin{tabular}{|c|c|c|}
\hline & Land & Delineated prospective area through 2015 : \\
\hline Country & $\begin{array}{l}\text { area } \\
\left(\mathrm{mi}^{2}\right)\end{array}$ & $\begin{array}{l}\text { At the surface } \ldots \ldots \ldots \ldots \ldots \ldots \ldots \ldots \ldots \ldots \\
\text { Percentage at depth of } 10,000 \mathrm{ft}\end{array}$ \\
\hline
\end{tabular}

Papua New Guinea $\quad 174,850$ Explored area through 2015:

Fiji

At the surface ….......................................................... 2,263 $\mathrm{mi}^{2}$

New Caledonia $\quad 7,056 \quad$ Percentage at depth of $10,000 \mathrm{ft}$........................................... 38 percent

Solomon Islands $\quad 10,805$ Wildcat wells through 2015:

Vanuatu

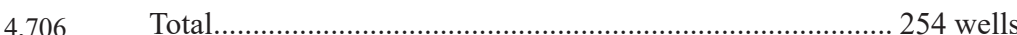

French Polynesia* $\quad 1,478 \quad$ Percentage at depths of $\geq 10,000 \mathrm{ft}$.....................................2 27 percent

Guam* 210 Reported discoveries through 2015 of cumulative recoverable crude oil

Marshall Islands*

Micronesia*

Northern Mariana

Islands* and gas in all provinces:

$271 \quad$ Oil....................................................................... 829 MMB

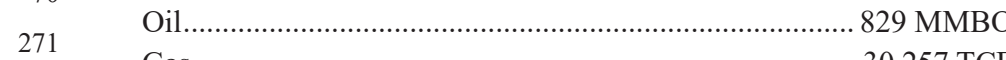

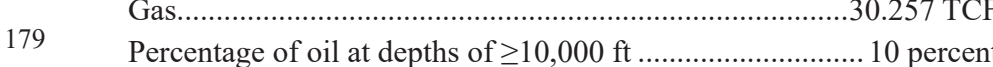

Tonga*

Percentage of gas at depths of $>10,000 \mathrm{ft}$.m.n. 36 percent

277 Percentage of oil in oil fields at depths of $\geq 10,000 \mathrm{ft}$......... 10 percent

"Not shown on map.

Figure 52. Continued. 


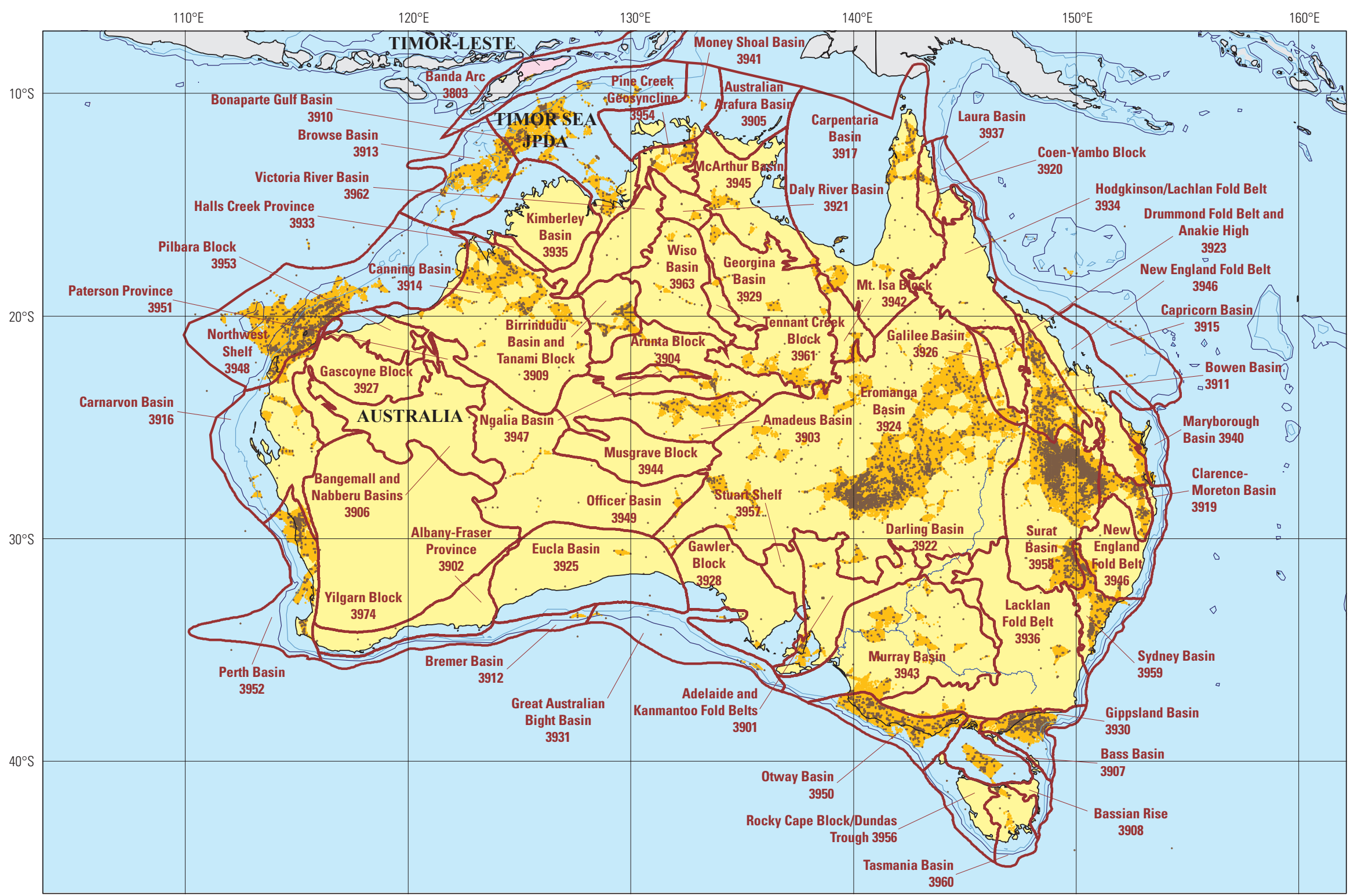

Figure 53. Map, graphs, and tables of data for oil and gas exploration through 2015 in Australia and Timor-Leste. The countries shared the Timor Sea Joint Petroleum Development Area (JPDA). The Timor Sea JPDA is not delineated on the map because a standard boundary was not available. 
Growth in delineated prospective area and explored

area through 2015 , graphed by the year the areas became

prospective or explored

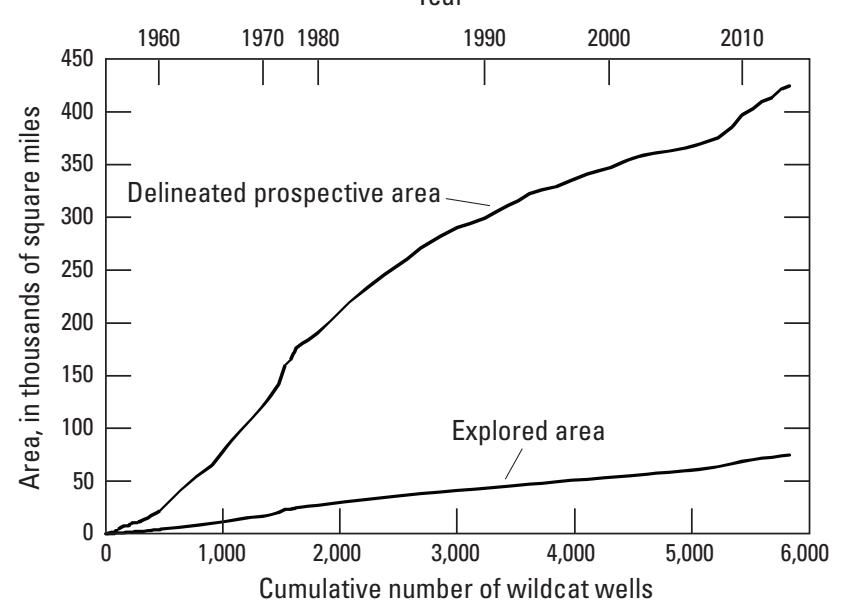

Cumulative recoverable oil and gas discoveries in all provinces through 2015, graphed by the year the field location became part of the delineated prospective area

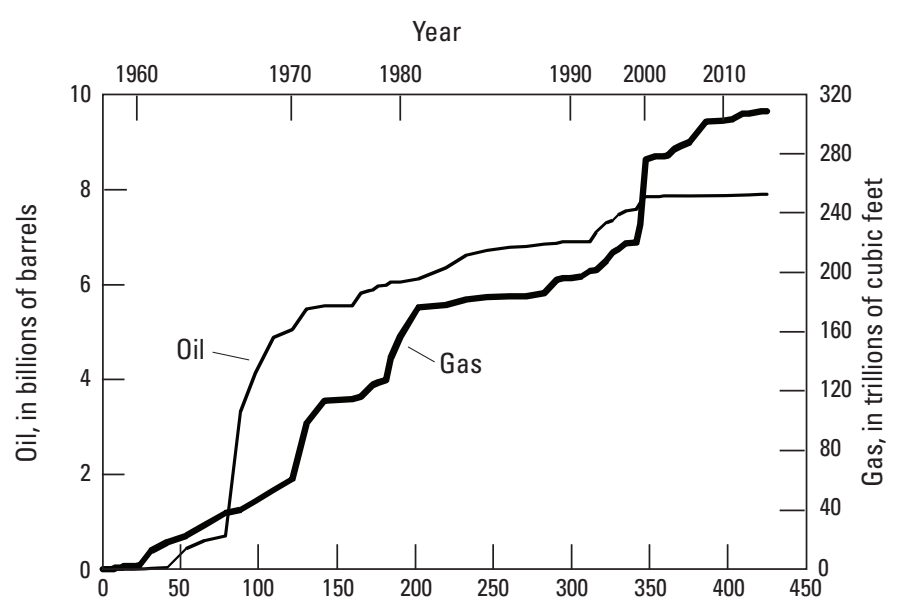

Delineated prospective area, in thousands of square miles

Figure 53. Continued. 

discovered through 2015

\begin{tabular}{|c|c|c|c|c|c|c|}
\hline $\begin{array}{l}\text { Significant petroleum } \\
\text { province }\end{array}$ & $\begin{array}{c}\text { Year of } \\
\text { first } \\
\text { discovery }\end{array}$ & $\begin{array}{c}\text { Oil in } \\
\text { large } \\
\text { fields } \\
\text { (MMBO) }\end{array}$ & $\begin{array}{l}\text { Oil in all } \\
\text { fields } \\
\text { (MMBO) }\end{array}$ & $\begin{array}{l}\text { Gas in oil } \\
\text { fields } \\
\text { (BCF) }\end{array}$ & $\begin{array}{c}\text { Gas in } \\
\text { gas fields } \\
\text { (BCF) }\end{array}$ & $\begin{array}{c}\text { Gas in all } \\
\text { fields } \\
\text { (BCF) }\end{array}$ \\
\hline \multicolumn{7}{|c|}{ Australia } \\
\hline Bonaparte Gulf Basin, 3910 & 1964 & 227 & 495 & 172 & 28,091 & 28,263 \\
\hline Bowen Basin, 3911 & 1955 & 0 & 0 & 0 & 7,570 & 7,570 \\
\hline Browse Basin, 3913 & 1971 & 0 & 169 & 217 & 48,874 & 49,092 \\
\hline Clarence-Moreton Basin, 3919 & 1968 & 0 & 0 & 0 & 2,675 & 2,675 \\
\hline Eromanga Basin, 3924 & 1964 & 0 & 497 & 1,361 & 19,769 & 21,129 \\
\hline Gippsland Basin, 3930 & 1924 & 3,805 & 4,181 & 2,178 & 12,159 & 14,337 \\
\hline Northwest Shelf, 3948 & 1954 & 895 & 2,462 & 2,569 & 144,249 & 146,818 \\
\hline Perth Basin, 3952 & 1964 & 0 & 49 & 38 & 4,295 & 4,333 \\
\hline Surat Basin, 3958 & 1900 & 0 & 39 & 126 & 26,076 & 26,201 \\
\hline Total & & 4,927 & 7,892 & 6,660 & 293,757 & 300,418 \\
\hline \multicolumn{7}{|c|}{ Timor-Leste } \\
\hline Banda Arc, 3803 & 1961 & 0 & $<1$ & 0 & 0 & 0 \\
\hline \multicolumn{7}{|c|}{ Timor Sea JPDA } \\
\hline Bonaparte Gulf Basin, 3910 & 1974 & 0 & 93 & 29 & 4,518 & 4,547 \\
\hline
\end{tabular}

Figure 53. Continued. 


\section{Exploration data}

\begin{tabular}{|c|c|c|}
\hline Country & $\begin{array}{l}\text { Land area } \\
\qquad\left(\mathrm{mi}^{2}\right)\end{array}$ & $\begin{array}{l}\text { Delineated prospective area through 2015: } \\
\text { At the surface ........................................................... 424,835 } \mathrm{mi}^{2}\end{array}$ \\
\hline Australia & $2,966,153$ & 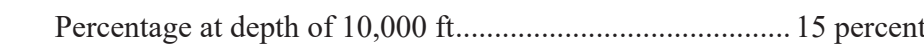 \\
\hline Timor-Leste & 5,743 & Explored area through 2015: \\
\hline \multirow[t]{12}{*}{ Total } & $2,971,895$ & At the surface \\
\hline & & 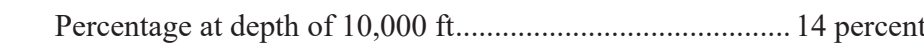 \\
\hline & & Wildcat wells through 2015: \\
\hline & & 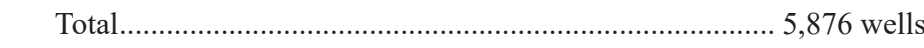 \\
\hline & & 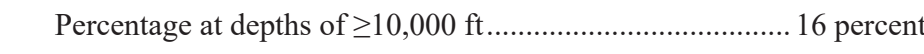 \\
\hline & & $\begin{array}{l}\text { Reported discoveries through } 2015 \text { of cumulative recoverable crude oil } \\
\text { and gas in all provinces: }\end{array}$ \\
\hline & & 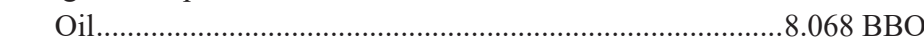 \\
\hline & & 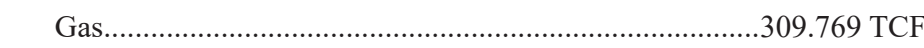 \\
\hline & & 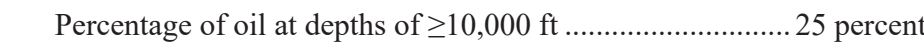 \\
\hline & & Percentage of gas at depths of $\geq 10,000 \mathrm{ft}$ \\
\hline & & Percentage of oil in oil fields at depths of $\geq 10,000 \mathrm{ft}$..........24 percent \\
\hline & & Percentage of gas in gas fields at depths of $\geq 10,000 \mathrm{ft} \ldots \ldots .64$ percent \\
\hline
\end{tabular}

Figure 53. Continued. 


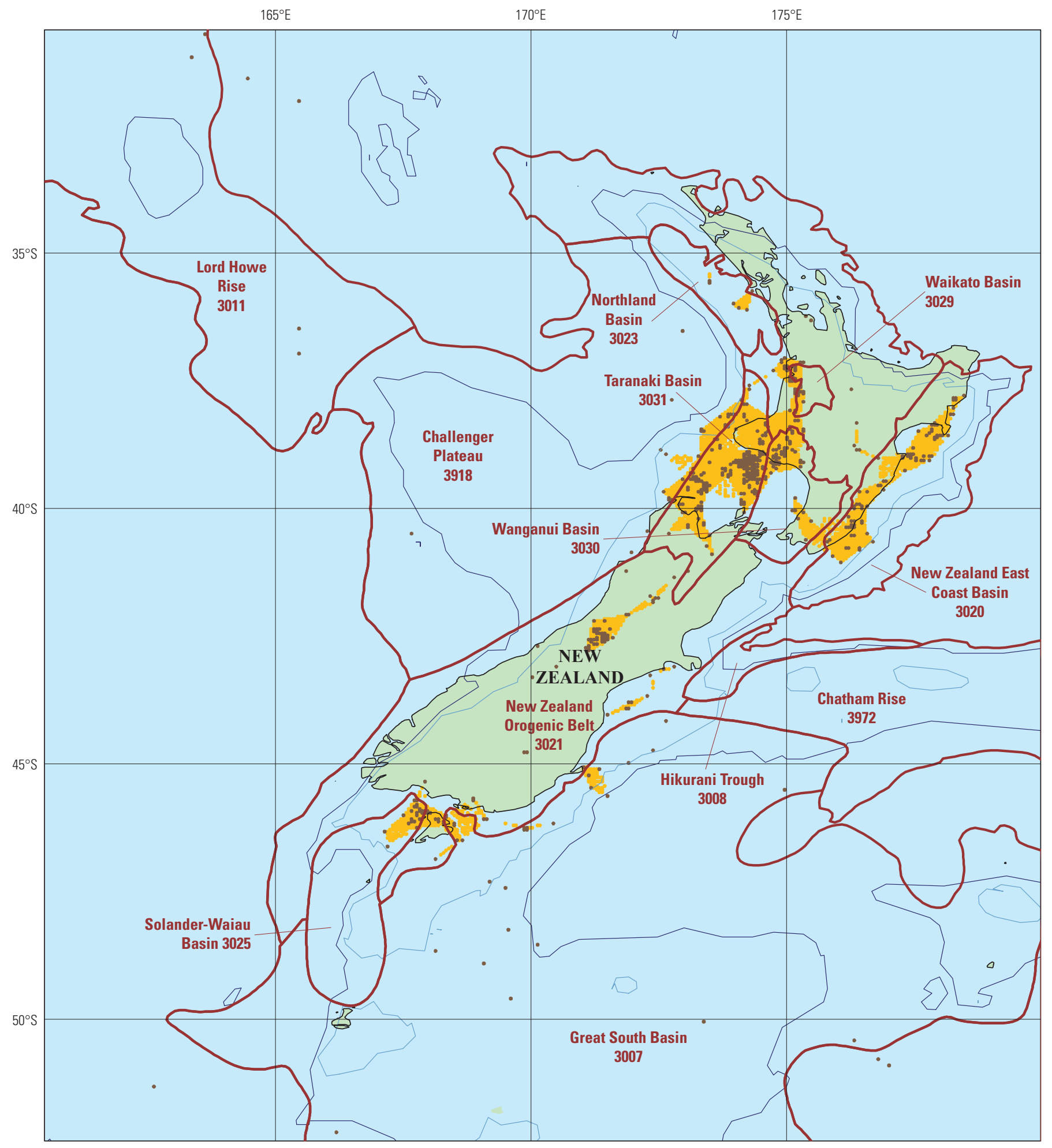

Figure 54. Map, graphs, and tables of data for oil and gas exploration through 2015 in New Zealand. 
Growth in delineated prospective area and explored area through 2015, graphed by the year the areas became prospective or explored

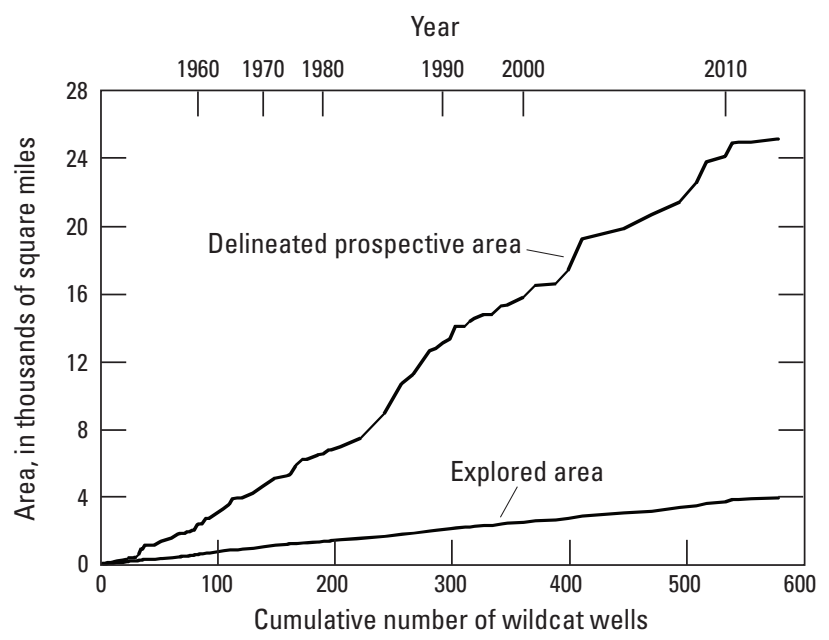

Cumulative recoverable oil and gas discoveries in all provinces through 2015, graphed by the year the field location became part of the delineated prospective area

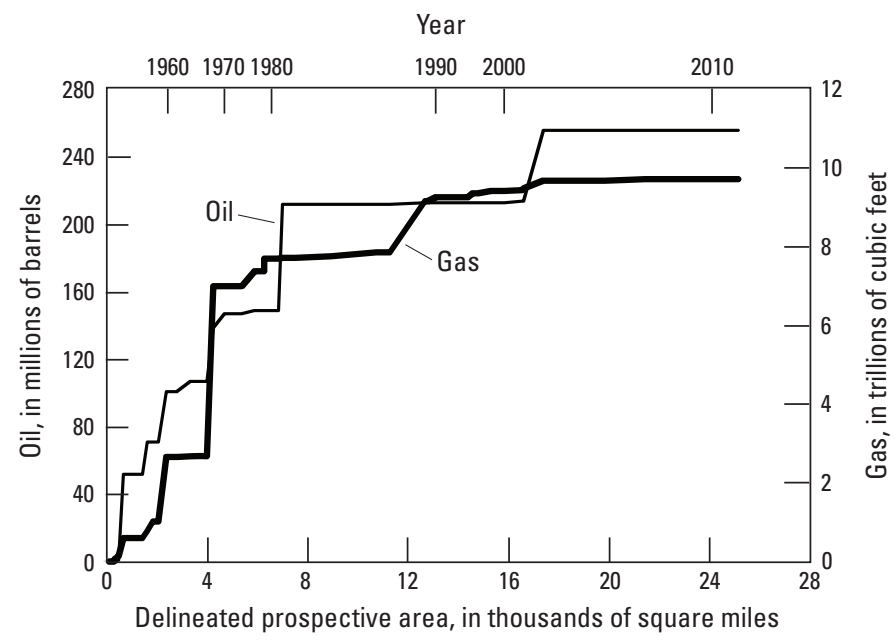

Significant petroleum province-Year of first discovery and cumulative recoverable oil and gas discovered through 2015

\begin{tabular}{lcccccc}
\hline Significant petroleum province & $\begin{array}{c}\text { Year of } \\
\text { first } \\
\text { discovery }\end{array}$ & $\begin{array}{c}\text { 0il in large } \\
\text { fields } \\
\text { (MMBO) }\end{array}$ & $\begin{array}{c}\text { Oil in all } \\
\text { fields } \\
\text { (MMB0) }\end{array}$ & $\begin{array}{c}\text { Gas in oil } \\
\text { fields } \\
\text { (BCF) }\end{array}$ & $\begin{array}{c}\text { Gas in gas } \\
\text { fields } \\
\text { (BCF) }\end{array}$ & $\begin{array}{c}\text { Gas in all } \\
\text { fields } \\
\text { (BCF) }\end{array}$ \\
\hline Taranaki Basin, 3031 & New Zealand \\
\hline
\end{tabular}

\section{Exploration data}

\begin{tabular}{|c|c|c|}
\hline Country & $\begin{array}{l}\text { Land area } \\
\quad\left(\mathrm{mi}^{2}\right)\end{array}$ & $\begin{array}{l}\text { Delineated prospective area through 2015: } \\
\text { At the surface }\end{array}$ \\
\hline \multirow[t]{12}{*}{ New Zealand } & 103,363 & 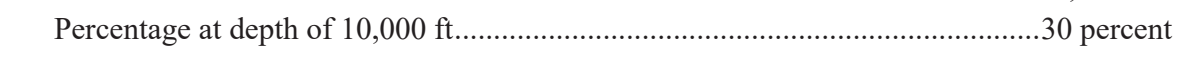 \\
\hline & & Explored area through 2015: \\
\hline & & 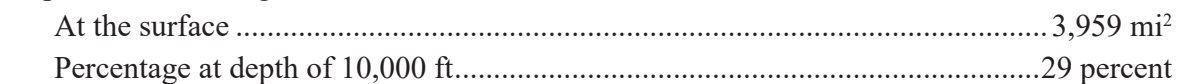 \\
\hline & & Wildcat wells through 2015: \\
\hline & & $\begin{array}{l}\text { Total } \\
\text { Percentage at depths of } \geq 10,000 \mathrm{ft}\end{array}$ \\
\hline & & $\begin{array}{l}\text { Reported discoveries through } 2015 \text { of cumulative recoverable crude oil and gas in all } \\
\text { provinces: }\end{array}$ \\
\hline & & 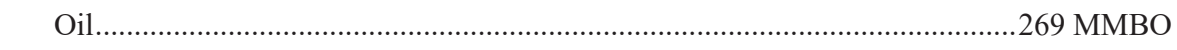 \\
\hline & & Gas. \\
\hline & & 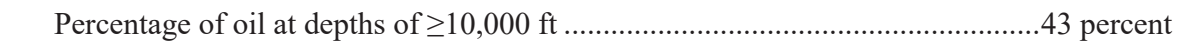 \\
\hline & & 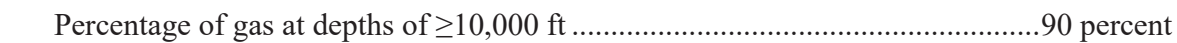 \\
\hline & & Percentage of oil in oil fields at depths of $\geq 10,000 \mathrm{ft} \ldots \ldots \ldots \ldots . . . . .$. \\
\hline & & Percentage of gas in gas fields at depths of $\geq 10,000 \mathrm{ft} \ldots . .$. \\
\hline
\end{tabular}

Figure 54. Continued. 


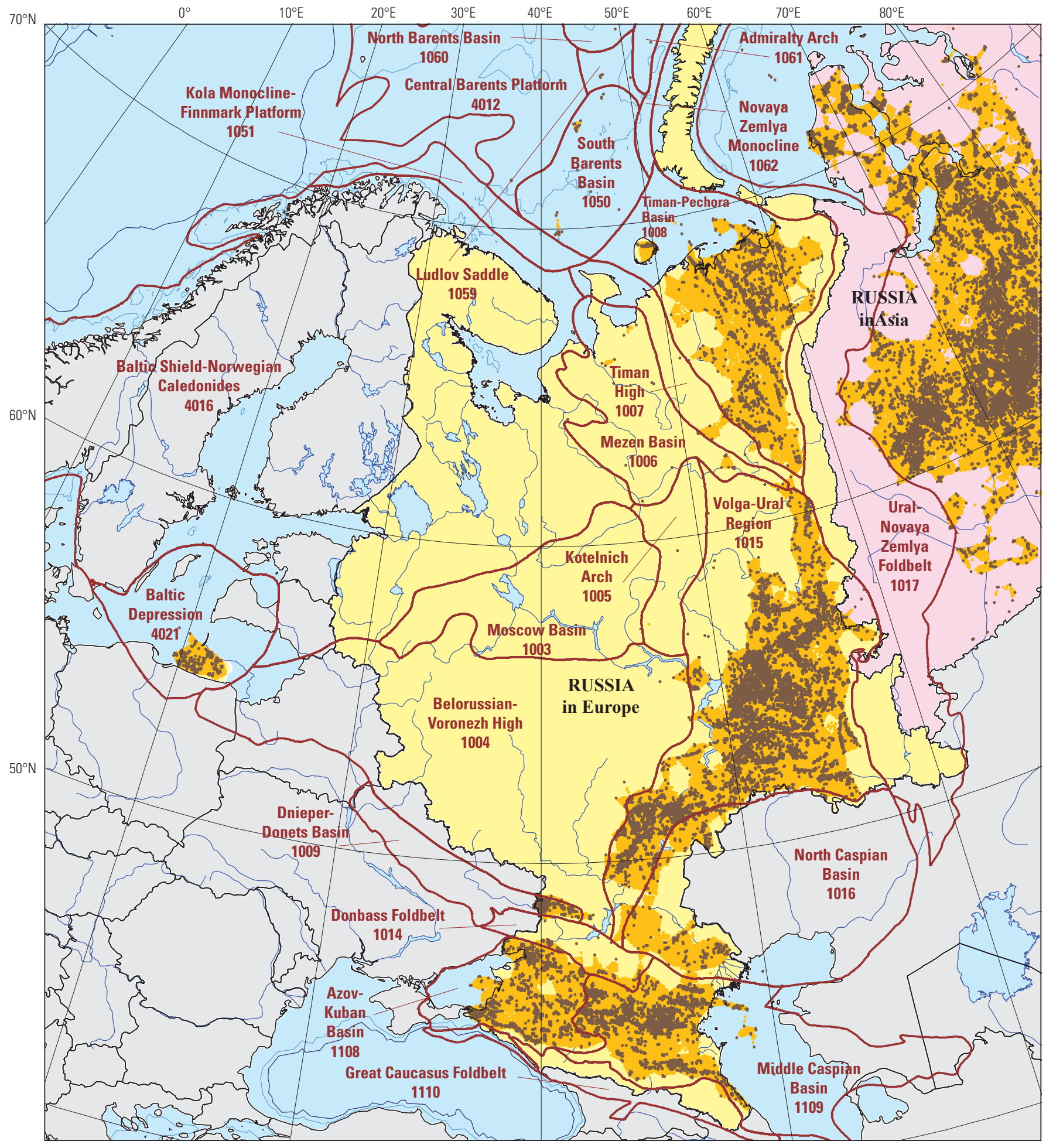

Figure 55. Maps, graphs, and tables of data for oil and gas exploration through 2015 in Russia. Separate maps show exploration in the part of Russia in Europe and the part of Russia in Asia. The graphs and data tables in this figure show data for all of Russia. 
Growth in delineated prospective area and explored area through 2015, graphed by the year the areas became prospective or explored

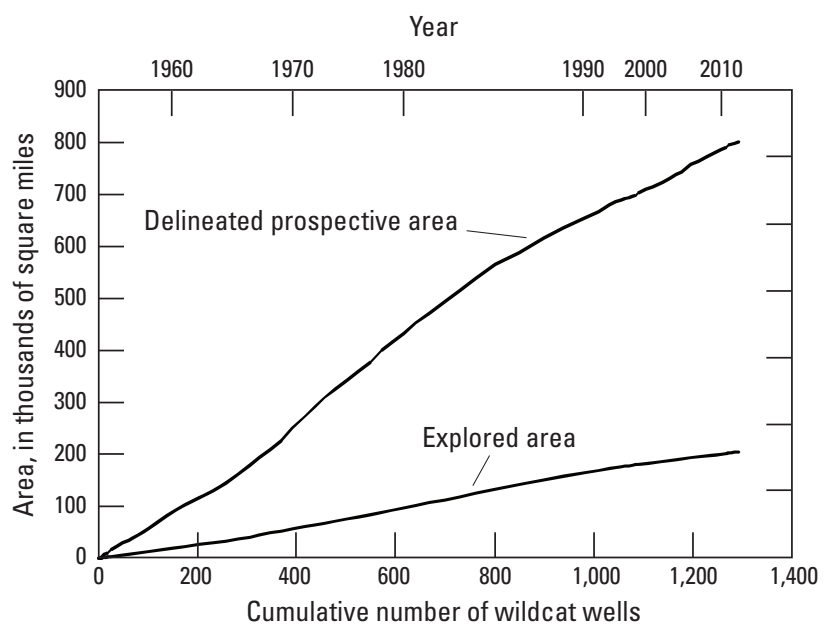

Cumulative recoverable oil and gas discoveries in all provinces through 2015, graphed by the year the field location became part of the delineated prospective area

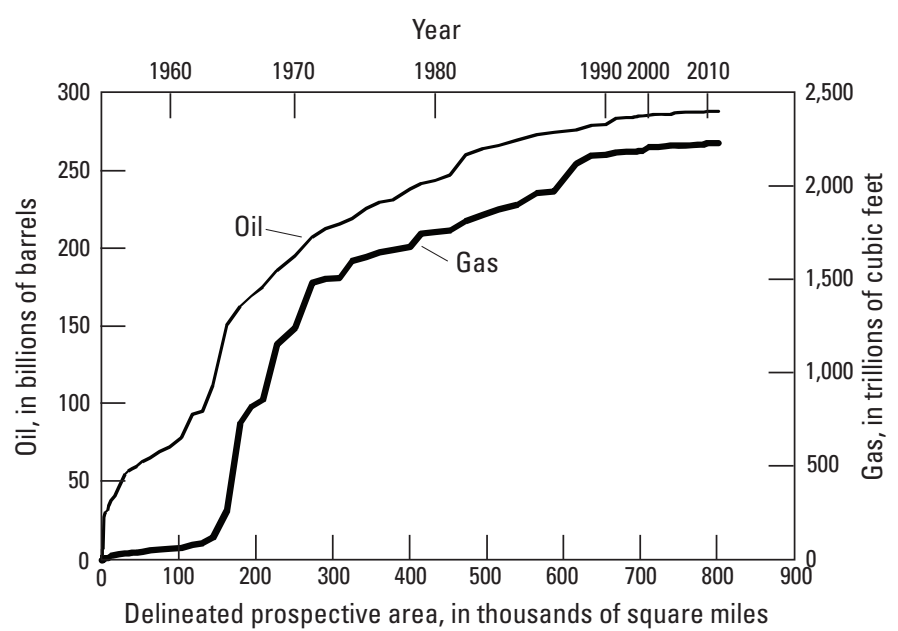

Figure 55. Continued. 
Significant petroleum provinces-Year of first discovery and cumulative recoverable oil and gas discovered through 2015

\begin{tabular}{|c|c|c|c|c|c|c|}
\hline Significant petroleum province & $\begin{array}{c}\text { Year of } \\
\text { first } \\
\text { discovery }\end{array}$ & $\begin{array}{c}\text { Oil in large } \\
\text { fields } \\
\text { (MMBO) }\end{array}$ & $\begin{array}{l}\text { Oil in all } \\
\text { fields } \\
\text { (MMBO) }\end{array}$ & $\begin{array}{l}\text { Gas in oil } \\
\text { fields } \\
\text { (BCF) }\end{array}$ & $\begin{array}{c}\text { Gas in gas } \\
\text { fields } \\
\text { (BCF) }\end{array}$ & $\begin{array}{c}\text { Gas in all } \\
\text { fields } \\
\text { (BCF) }\end{array}$ \\
\hline Angara-Lena Terrace, 1209 & 1954 & 0 & 2 & $<1$ & 50,680 & 50,680 \\
\hline Azov-Kuban Basin, 1108 & 1864 & 1,223 & 2,222 & 5,293 & 14,924 & 20,217 \\
\hline Central Barents Platform, 4012 & 1984 & 0 & 0 & 0 & 156 & 156 \\
\hline Deryugin Basin, 1321 & 2006 & 113 & 133 & 615 & 4,978 & 5,593 \\
\hline Dnieper-Donets Basin, 1009 & 1963 & 0 & 6 & 9 & 787 & 796 \\
\hline Kempendiay Region, 1212 & 2009 & 0 & 0 & 0 & 700 & 700 \\
\hline Nepa-Botuoba Arch, 1210 & 1962 & 2,937 & 3,754 & 11,472 & 35,668 & 47,140 \\
\hline North Caspian Basin, 1016 & 1963 & 0 & 143 & 123 & 65,495 & 65,618 \\
\hline North Sakhalin Basin, 1322 & 1923 & 2,930 & 3,721 & 20,684 & 21,274 & 41,958 \\
\hline South Barents Basin, 1050 & 1983 & 0 & 0 & 0 & 126,034 & 126,034 \\
\hline Timan-Pechora Basin, 1008 & 1916 & 11,917 & 15,757 & 8,108 & 31,859 & 39,967 \\
\hline Volga-Ural Region, 1015 & 1929 & 61,094 & 80,354 & 28,891 & 70,347 & 99,238 \\
\hline West Siberian Basin, 1174 & 1953 & 157,293 & 172,142 & 177,166 & $1,469,899$ & $1,647,065$ \\
\hline Yenisey-Khatanga Basin, 1175 & 1965 & 0 & 38 & 2 & 18,546 & 18,549 \\
\hline Total & & 244,485 & 287,501 & 271,365 & $1,957,539$ & $2,228,904$ \\
\hline
\end{tabular}

Figure 55. Continued. 


\section{Exploration data}

\begin{tabular}{|c|c|c|}
\hline & $\begin{array}{l}\text { Land area } \\
\qquad\left(\mathrm{mi}^{2}\right)\end{array}$ & 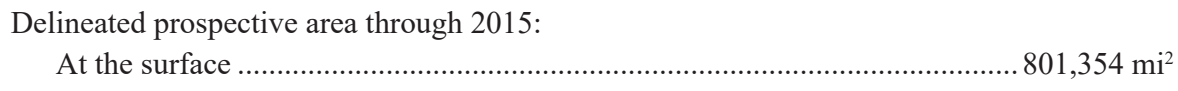 \\
\hline \multirow[t]{8}{*}{ Russia } & $6,323,482$ & 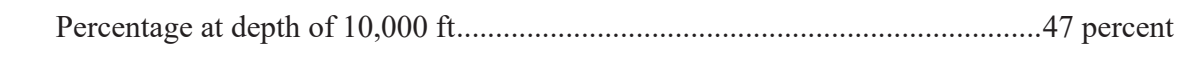 \\
\hline & & At the surface \\
\hline & & 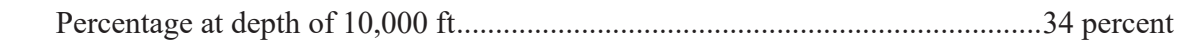 \\
\hline & & 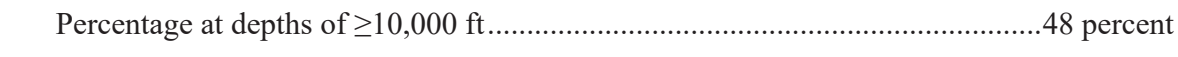 \\
\hline & & $\begin{array}{l}\text { Reported discoveries through } 2015 \text { of cumulative recoverable crude oil and gas in all } \\
\text { provinces: }\end{array}$ \\
\hline & & Oil \\
\hline & & 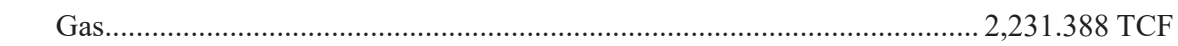 \\
\hline & & 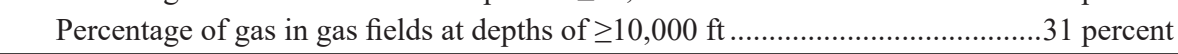 \\
\hline
\end{tabular}

Figure 55. Continued. 


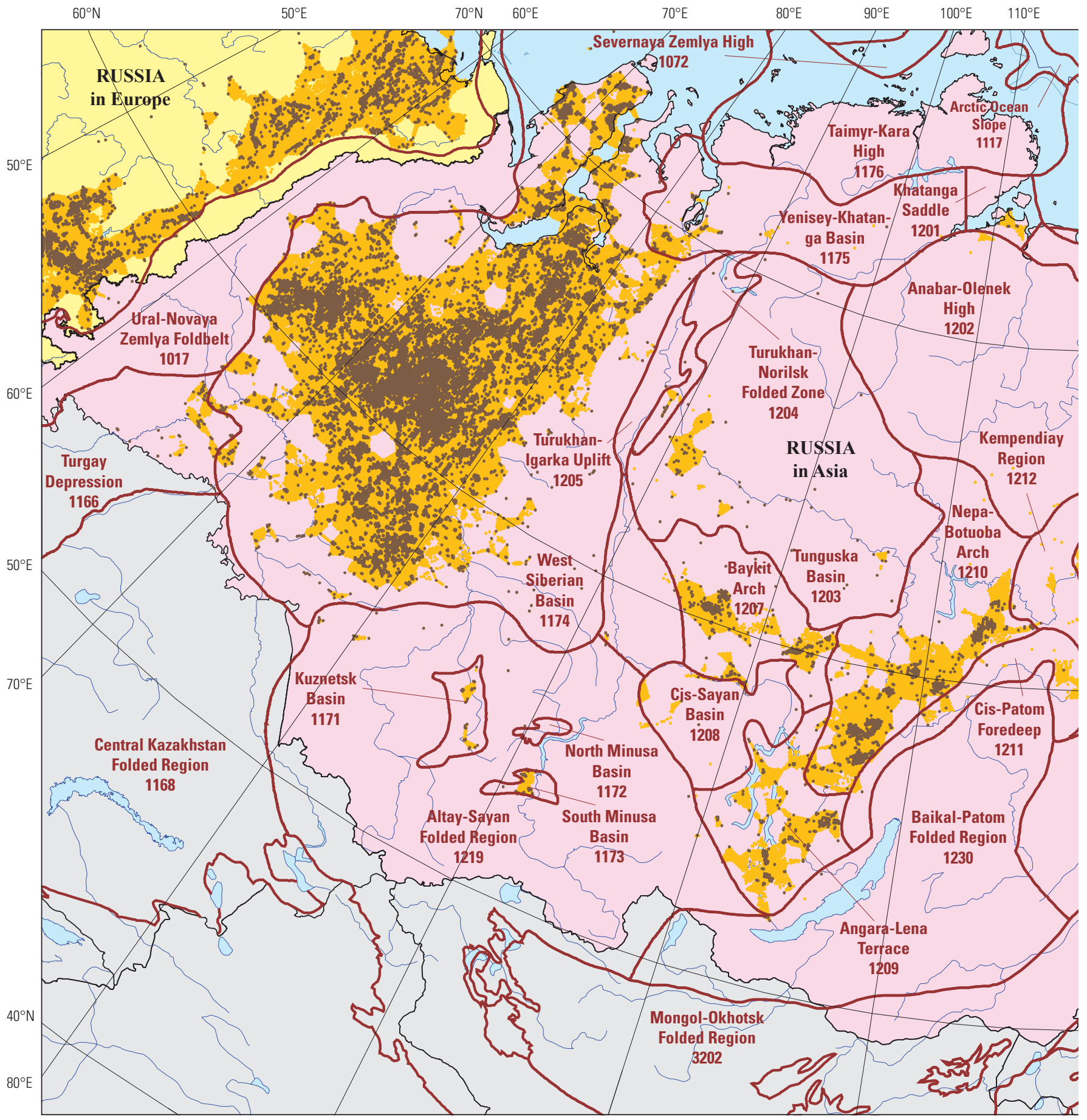

Figure 55. Continued. 


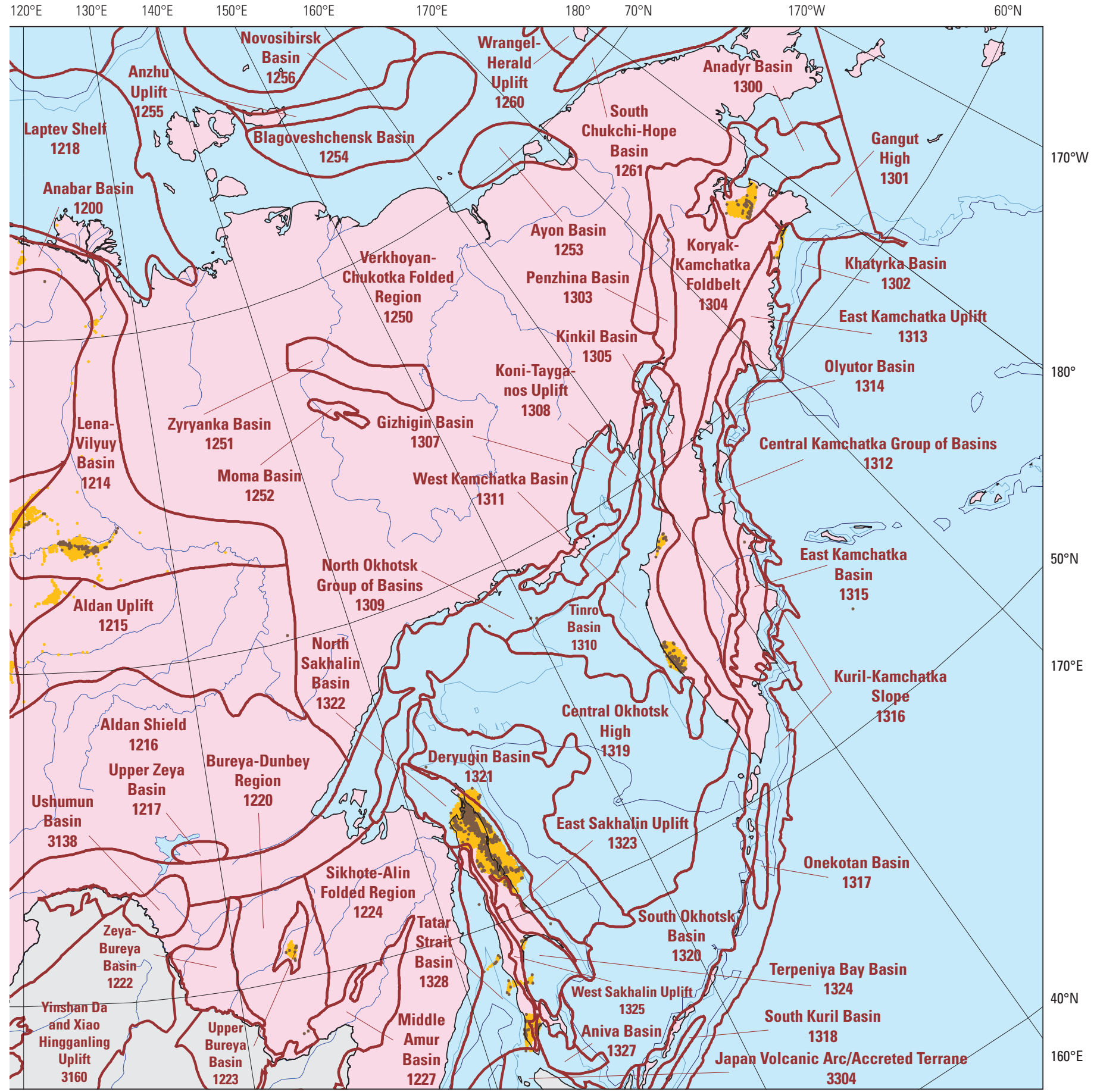

Figure 55. Continued. 




\section{$\frac{\mathbb{2}}{3}$}

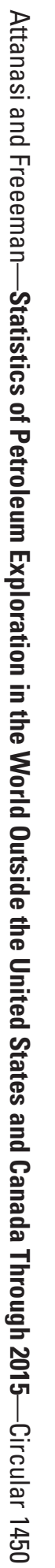

